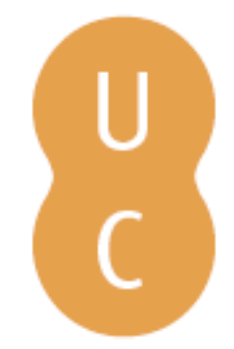

\title{
nommalina
}

\section{A Versão Latina por Pascásio de Dume dos Apophthegmata Patrvm: tomo I: introdução cultural, Pascásio como tradutor, texto crítico}

\author{
Autor(es): $\quad$ Freire, José Geraldes \\ Publicado por: Centro de Estudos Clássicos e Humanísticos; Imprensa da Universidade \\ de Coimbra \\ URL $\quad$ URI:http://hdl.handle.net/10316.2/2321 \\ DOI: $\quad$ DOI:http://dx.doi.org/10.14195/978-989-8281-82-1 \\ Accessed : $\quad$ 26-Apr-2023 14:56:26
}

A navegação consulta e descarregamento dos títulos inseridos nas Bibliotecas Digitais UC Digitalis, UC Pombalina e UC Impactum, pressupõem a aceitação plena e sem reservas dos Termos e Condições de Uso destas Bibliotecas Digitais, disponíveis em https://digitalis.uc.pt/pt-pt/termos.

Conforme exposto nos referidos Termos e Condições de Uso, o descarregamento de títulos de acesso restrito requer uma licença válida de autorização devendo o utilizador aceder ao(s) documento(s) a partir de um endereço de IP da instituição detentora da supramencionada licença.

Ao utilizador é apenas permitido o descarregamento para uso pessoal, pelo que o emprego do(s) título(s) descarregado(s) para outro fim, designadamente comercial, carece de autorização do respetivo autor ou editor da obra.

Na medida em que todas as obras da UC Digitalis se encontram protegidas pelo Código do Direito de Autor e Direitos Conexos e demais legislação aplicável, toda a cópia, parcial ou total, deste documento, nos casos em que é legalmente admitida, deverá conter ou fazer-se acompanhar por este aviso.

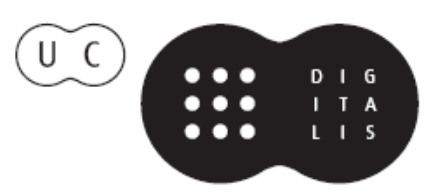




\title{
José Geraldes Freire
}

\section{A Versão Latina por Pascásio de Dume dos APOPHThegmata PATRVM}

\author{
Томо I \\ Introdução Cultural \\ Pascásio como Tradutor \\ Texto Crítico
}

Com Notas Introdutórias de Paula Barata Dias 
Autor: José Geraldes Freire

Notas Introdutórias: Paula Barata Dias

Título: A Versão Latina por Pascásio de Dume dos Apophthegmata Patrum. Tomo I

Editor: Centro de Estudos Clássicos e Humanísticos

Imprensa da Universidade de Coimbra

Edição: 2a/2011 [reimpressão da $1^{\text {a }}$ edição/1971 pelo Centro de Estudos Clássicos e Humanísticos]

Coordenador Científico do Plano de Edição: Maria do Céu Fialho

Conselho Editorial: José Ribeiro Ferreira, Maria de Fátima Silva, Francisco de Oliveira e Nair

Castro Soares

Director Técnico da Colecção: Delfim F. Leão

Concepção Gráfica e Paginação: Elisabete Cação e Rodolfo Lopes

Impressão: Simões \& Linhares, Lda. Av. Fernando Namora, no 83 - Loja 43000 Coimbra Obra

Realizada no âmbito das Actividades da UI\&D Centro de Estudos Clássicos e

Humanísticos

Universidade de Coimbra Faculdade de Letras Tel.: 239859981 | Fax: 239836733

ISBN: 978-989-8281-81-4

ISBN Digital: 978-989-8281-82-1

Depósito Legal: 325994/11

DOI: http://dx.doi.org/10.14195/978-989-8281-82-1

C IMPRENSA DA UNIVERSIDADE DE COIMBRA

(C) Centro de Estudos Clássicos e Humanísticos da Universidade de Coimbra

(c) Classica Digitalia Vniversitatis Conimbrigensis (www.classicadigitalia.uc.pt)

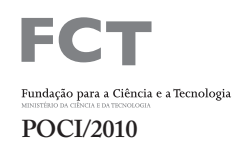

Reservados todos os direitos. Nos termos legais fi a expressamente proibida a reprodução total ou parcial por qualquer meio, em papel ou em edição electrónica, sem autorização expressa dos titulares dos direitos. É desde já excepcionada a utilização em circuitos académicos fechados para apoio a leccionação ou extensão cultural via $e$-learning. 


\title{
José Geraldes Freire
}

Universidade de Coimbra

\section{A Versão Latina por Pascásio de Dume dos APOPHTHEGMATA PATRVM}

\author{
Tomo I \\ Introdução Cultural \\ Pascásio como Tradutor \\ Texto Crítico
}

Com Notas Introdutórias de Paula Barata Dias

Coimbra

2011 - 2a edição 


\section{Notas InTRodutóRIAS}

A vinte e seis de Janeiro de 959, a condessa D. Mummadona Dias legou uma copiosa doação ao mosteiro de G uimarães ${ }^{1}$. Entre os uiginti libros ecclesiasticos deixados, figu am umas uitas patrum cum gerenticon. Trata-se de um testemunho que confi ma a extraordinária recepção da primeira literatura monástica no Ocidente latino e, em especial, da manutenção do interesse pelas biografias e pelas sentenças dos padres do deserto enquanto fontes de inspiração que o eram para as comunidades monásticas. Não é possível ter a certeza quanto aos textos referidos sob a titulação indicada, mas estamos em crer que seguramente se tratava de representantes da obra encetada por S. Martinho de D ume, A póstolo dos Suevos na Galécia precisamente a partir de 550 .

S. Martinho, que em 556 foi consagrado bispo de Dume e auxiliar de Braga, foi também o introdutor da vida monástica no Noroeste hispânico, tendo fundado o mosteiro de Dume por 550. Entre as suas realizações, traduziu do grego uma colecção das Sententiae Patrum Aegyptiorum ${ }^{2}$. Encomendou também a um seu discípulo, Pascásio, monge em Dume, a tradução para latim de uma colecção, em grego, de Apotegmas dos Padres que, segundo o prefácio do dito volume, justamente se inicia por Vitas patrum Graecorum ut cetera, facundia studiose conscriptas, iussus

${ }^{1} \mathrm{PMH}, \mathrm{DC}$, doc. 76: 44-48, 47.

${ }^{2} \mathrm{O}$ título completo, apurado por Freire, José Geraldes, (vide infra: 8-11) será Sententiae Patrum Aegyptiorum quas de graeco in latinum transtulit Martinus Dumiensis episcopus. 
a te, sanctissime pater, in latinum transferre sermonem.... Liber Geronticon de octo principalibus uitiis é exactamente o título da tradução de Pascásio de Dume, segundo a edição realizada por José Geraldes Freire ${ }^{3}$.

É este um exemplo evidente do modo como a difusão dos ideais monásticos se apoiava na circulação dos seus textos primordiais e emblemáticos, chamados "Ditos" ou "Sentenças" dos primeiros monges, e do modo como os discípulos eram integrados na rotina espiritual do dia-a-dia, enquanto pedagogia, como exemplos e inspiração para as novas gerações de monges e mesmo as novas fundações.

Do grego para o latim: assim aconteceu na maioria dos casos conhecidos no Ocidente, em que um protagonista, um leigo, pelo menos a princípio, e por vezes também consagrado, após ter empreendido uma peregrinação pelos lugares santos do Oriente, a saber, os da Palestina (os lugares da história da salvação), os santuários dos mártires cristãos e os mosteiros do Oriente (os assentamentos monásticos da Palestina, da Síria, do Egipto), e depois de terem, inclusivamente, prolongado a sua estadia junto destas comunidades para melhor aprenderem a disciplina do deserto, regressavam animados pela intenção de dar a conhecer e divulgar a vida consagrada entre os seus concidadãos.

A história das origens da implantação monástica no Ocidente foi essencialmente uma história de transmissão e de tradução de algo que era entendido como heróico e inteiramente novo iniciado nos finais do séc. III, uma experiência que, estando já escrita em grego, era já, ela própria, resultado de transmissão, síntese e adaptação, a partir da realidade original que a havia suscitado, reproduzindo na escrita uma tradição cultural oralizante, ou escrita em copta, siríaco, etc. Assim, consideram os maiores especialistas no género apoftegmático que as colecções gregas destes pequenos textos, representantes da primeira expressão literária suscitada pelo ascetismo cristão, são já elas próprias reelaborações faseadas de uma tradição ancestral, de âmbito regional, que era o de recolher para a escrita, de modo diverso, assistemático, e de modo progressivo (isto é, nunca dando a obra

${ }^{3}$ Freire, José Geraldes (vide infra: 1; 157). 
por terminada, sempre juntando mais algumas sentenças) os ditos dos líderes monásticos, instados pelos discípulos a dizerem algo que lhes servisse de ensinamento ${ }^{4}$.

Estas colecções diversas foram seguidamente coligidas de modo sistemático para o serviço de cada comunidade monástica e assim foram depois sendo traduzidas nas várias línguas do L este cristão: copta, siríaco, arménio, e etíope ${ }^{5}$. Versões sobrepostas, reescritas do mesmo núcleo temático, ou de um núcleo atribuído a um só autor, rápida transmissão dos testemunhos, rearranjos de colecções primitivas, até ao resultado final de um livro de edifi ação, amplifi ações hagiográfi as, tudo isto e muito mais contribuiu para tornar a questão textual e a edição crítica do género apoftegmático um dos mais complexos e intrincados domínios de trabalho de um filólo o.

A história das traduções latinas dos Apophtegmata Patrum, e o número de eruditos que a elas consagraram os seus estudos contam-se, por isso, em poucas linhas. Pelas coincidências de personagens e de relatos, é possível afi mar que João Cassiano, (370-435) um dos mais importantes divulgadores do monaquismo no Ocidente e sobretudo na Gália, ter-se-ia servido da tradição apoftegmática grega e e tê-la-ia integrado de modo assistemático e elaborado nas suas Collationes ${ }^{6}$. Mas Cassiano não transferiu para latim a estrutura compositiva que caracteriza o género apoftegmático, pelo que somos levados a pensar que este autor contactou com uma fase ainda instável da fix ção do género, ou

${ }^{4}$ Guy, J. Cl. (1984) Recherches sur la tradition Grecque des Apophtegmata Patrum, 2e ed., Bruxelles. Id (1993; 2003; 2005) Les Apophtegmes des Pères. Collection systématique, Cap. I-IX; X-XVI; XVII-XXI Sources Chrétiennes 387, 474, 498 Paris. Regnault, L. Les Sentences des Pères du desert: série des Anonymes, Solesmes. Gould, Graham, (1993) The Desert Fathers on Monastic Community, Oxford; Harmless W. (2000) "Remembering Poemen Remembering: The Desert Fathers and the Spirituality of Memory", Church History, 69: 483518.

${ }^{5}$ Nau, F., (1913) "Notes sur le texte originel des apophtegmes des Pères", Revue de l'Orient Chrétien 23,: 28-212. Guy, J. Cl. (1984) Recherches : 249-252 apresenta uma lista bibliográfi a dos estudos até então conhecidos acerca da tradição apoftegmática nas mais diversas línguas.

${ }^{6}$ Jean Cassien, Collationes, E. Pichery ed. e trad., (1955-1959), Sources Chrétiennes 42, 54, 64, Paris. 
seja, ter-se-ia deparado com objectos literários que eram, de facto, sentenças breves, ditos isolados, episódios entendidos como um todo, quanto muito coligidos segundo os seus autores.

De facto, o final do séc. V corresponde ao apogeu do género, quando proliferavam várias colecções, organizadas segundo critérios distintos: umas, as nominais, reunindo primeiramente as sentenças atribuídas a cada Padre, deram origem à série alfabética na qual, conforme o nome indica, os apotegmas eram ordenados pelo nome dos seus autores segundo a ordem do alfabeto grego.

Outras, as temáticas, agrupam-se de acordo com determinados tópicos relevantes para a vida espiritual, embora estas se perfilem de modo justapost .

Por fim os grandes livros de edifi ação resultaram de uma reelaboração dos dois critérios anteriores, produzindo-se então as chamadas colecções sistemáticas. Resultam de uma reflex o posterior sobre material diverso, colhido nas duas primeiras ordens de textos, e foram já preparadas a pensar num destinatário colectivo e alargado.

As traduções latinas, entre as quais são nominalmente conhecidas as do diácono romano Pelágio e a do subdiácono romano João, e, mais perto de nós, as do monge Pascásio, discípulo de S. Martinho, e deste mesmo, ainda abade de Dume, todos de meados do séc. VI, foram feitas sobre representantes distintos de colecções sistemáticas. Pelágio veio a ser papa (556-561), assim como João, que lhe veio a suceder na cátedra (561-574), o que é um sinal claro da receptividade do género literário entre a ordem secular da Igreja.

Em 1615, o jesuíta Heribertus Rosweidus publicou, na sua grande obra, as traduções latinas das colecções gregas de Apophtegmata nos livros III, V, VI e VII da sua Vitae Patrum (PL 73-74), uma reunião de textos de tema monástico de classifi ação diversa (inclui, por exemplo, a tradução latina de Rufino da Historia Monachorum in Aegypto e a Historia Lausiaca de Paládio, respectivamente no livro II e no livro VIII) ${ }^{7}$.

7 H. Rosweydus, Vitae Patrum siue Historiae eremiticae libri decem, Antuerpiae $1615\left(1628^{2}\right)$, PL 73-74. Verba Seniorum de Pelágio e João PL 73, 851-1022. A tradução atribuída a Pascásio na obra de Rosweydus, livro 
A colecção latina de Pelágio e João foi utilizada como testemunho indirecto por J. Claude Guy na sua investigação sobre a tradição grega dos Apophtegmata Patrum e na edição que realizou da mesma para as Sources Chrétiennes (ver nota 4), porque as traduções latinas foram realizadas sobre manuscritos mais próximos do arquétipo. De facto, a partir do séc. VI, a tradição manuscrita directa da literatura apoftegmática, em Grego e em Latim, continuou a multiplicar-se, posta ao serviço das instituições monásticas, enquanto fonte de edifi ação, sujeitandose às modifi ações, cortes e acrescentos suscitados localmente.

Esta transmissão viva faz sobressair com mais destaque o valor científico dos estudos que metodologicamente recorrem à comparação entre as versões gregas e latinas, na medida em que estas últimas podem ajudar a clarifi ar as versões mais antigas do texto grego, bem como fornecer pistas quanto a colecções que permanecem enquanto conjecturas. Mesmo assim, J. Cl. Guy estava convencido, ao apresentar o trabalho preliminar de investigação da transmissão miscelânea dos apotegmas gregos, que era impossível, actualmente, escrever a história do texto de todos os Apophtegmata Patrum, pelo que o máximo que seria conseguido era estabelecer "a economia geral das colecções".

Também a transmissão dos apotegmas em latim se fez por vias autónomas, ganhando complexidade, e não têm sido abundantes os estudos que a tomassem como objecto principal' Por todas estas razões o trabalho desenvolvido por José Geraldes

VII, cap. I-XL IV, reproduzida na PL 73 1025-1062. Guy, J. Cl., Recherches: $10,124$.

${ }^{8}$ G uy, J. C., Recherches: 11. Esta f ormulação é de D raguet, R., (1950) "Le Paterikon de l'Add. 22508 du British Museum”, Le Muséon 63: 27. Ainda, da introdução ao volume das Recherches..., não resistimos a citar as palavras com que abre o volume: "le problème philologique des Apophtegmata Patrum est l'un des plus complexes que pose l'édition des textes patristiques". O trabalho de J. Cl. G uy culminou na edição das Sources Chrétiennes indicada na n. 4.

9 Wilmart, A.(1922) "Le Recueil latin des apophtegmes", Revue Bénedictine, 34: 185-198; Battle, C. M. (1959) "De suscepta editio latinae uersionis “verba seniorum” communiter adpellatae" Studia Monastica 1: 115120; Philippart, G. (1975) “Vitae partum. Trois travaux récents sur d'anciennes traductions latines", Analecta Bollandiana 92: 353-365; também 93, 1975: 28. 
Freire, que neste volume se apresenta, é obra de grande mérito e impossível de ignorar por todos os que se interessam ou estudam a tradição literária apoftegmática latina.

A Versão Latina por Pascásio de Dume dos Apophtegmata Patrum publicada pela primeira vez em 1971, veio disponibilizar para a comunidade científi a a verdadeira obra de Pascásio, porque de facto o texto que na edição de Rosweydus havia sido apresentado resultou como uma colecção resumida e imperfeita dos apotegmas de Pascásio, sob o título Exhortationes Sanctorum Patrum tam Graecorum quam Aegyptiorum (PL 73: 68).

O texto completo, traduzido por Pascásio, só foi dado pela primeira vez a ler na editio princeps, tem mais do dobro dos capítulos e com o texto original muito aperfeiçoado, apresentado na Universidade de Coimbra em Novembro de 1971 de 1971, com o seu verdadeiro título que é Liber Geronticon. De Octo Principalibus Vitiis, de graeco in latinum translatum a Paschasio ${ }^{10}$.

Trazer à luz a autêntica obra de Pascásio constituiu um avanço notável para o conhecimento da tradição apoftegmática em latim. Tendo esta tradução sido elaborada entre 550 e 556, data da chegada de Martinho à Galécia e da sua elevação a bispo, verifica-se que Pascásio é praticamente contemporâneo de Pelágio e João, os outros principais tradutores latinos dos Apotegmas gregos. Além disso, a obra emerge como uma representante das colecções sistemáticas, neste caso organizadas sobre os tópicos das virtudes e dos vícios, ou seja, traduz uma colecção grega da fase de maturidade que seria próxima, mas não exactamente a mesma da que serviu de sustentáculo à obra de Pelágio e de João.

Não se conhece, até agora, nenhum manuscrito grego ordenado, isto é, em que os apotegmas assumam a mesma ordem e número que Pascásio apresenta na sua tradução latina, pelo que a obra de Pascásio faz eco de um Geronticon perdido, entre muitos

${ }^{10}$ J. G. Freire omite os atributivos Diacono dado por Rosweydus, assim como o título honorífico de Beato que se encontra nos principais manuscritos, por não se encontrarem fundamentos históricos que o justifiquem (vide infra: 40). 
os que teriam circulado nos séculos V e VI, ávidos do contacto com o "espírito do deserto" proporcionado pelos ensinamentos dos Padres.

Isso não quer dizer que não seja possível encontrar os paralelos, quer em versões gregas, quer nas traduções latinas, sobretudo de Pelágio e João. De facto, dos 358 apotegmas traduzidos por Pascásio, o editor identificou o equivalente grego para 309 , obtendo-se a elevada proporção de $86,3 \%{ }^{11}$. A identifi ação do mesmo apotegma em testemunhos diferentes não é, nesta tipologia de textos, tarefa fácil, exigindo grande persistência, exercício de memória e domínio do vocabulário em ambas as línguas, na medida em que os testemunhos existentes representam pontos de chegada, porvias diversase não simultâneas, de textos que primitivamente existiram enquanto peças isoladas (um apotegma) ou agrupados em conjuntos menores segundo uma organização onomástica, temática, ou mesmo nenhuma referência ou remissão.

Assim, o mesmo texto pode apresentar diferenças substanciais em dois testemunhos distintos, diferenças estas introduzidas também no contexto da recepção intermédia do apotegma ${ }^{12}$. Acresce à dificuld de da tarefa o facto de boa parte da obra de Pascásio ser, enquanto tal, publicada na edição de José Geraldes Freire pela primeira vez, ou seja, tratando-se de traduções latinas conhecidas que circulassem pelas fundações monásticas medievais, eram encontradas sob atribuições diversas ou mesmo nenhumas, ou se encontravam numa versão abreviada em comparação com o texto dado por Pascásio.

${ }^{11}$ Freire, J. G. (vide infra: 40). Os quadros dos lugares paralelos, e as remissões para as respectivas edições, encontram-se em 43-53. Também a edição de Bousset, W. (1923) Apophtegmata. Studien zur Geschichte des ältesten Mönchtums, Tübingen apresentou quadros paralelos que facilitaram o confronto entre a tradição grega e a latina.

${ }^{12}$ Cotelier, J. B. Ecclesiae Graecae monumenta, I, 1677, também em PL 65: 71-440 edita uma colecção alfabética de 120 padres a que se atribuíram 946 apotegmas. Nau, F. (1907-1913) "Histoires des solitaires égyptiens" Revue de l'Orient Chrétien 12: 48-69; 171-189; 393-413. 13: 47-66; 266-297. 14: 357379; 17: 204-211; 294-301; 18: 137-146. Nau publica uma colecção de 400 apotegmas anónimos. 
Assim temos de concluir que a edição de Pascásio dada por Rosweydus foi elaborada sobre uma recensão muito abreviada e alterada em relação ao texto original. O trabalho que aqui se apresenta só pôde ser conduzido porque foi opção de José Geraldes Freire fazer um levantamento e estudo exaustivo de manuscritos, desde o que se apurou ser a região de origem, com testemunhos de uma transmissão apoftegmática contínua, que pôde remontar ao séc. VIII, em escrita visigótica, e vai até ao séc. XXVII, com exame de mais de 200 manuscritos, dos quais 147 se revelaram interdependentes. Este trabalho permitiu ultrapassar incomparavelmente o texto de Rosweydus. Basta dizer que, enquanto o texto crítico autêntico de Pascásio tem 101 capítulos, a edição de Rosweydus tem apenas 44, entre os quais mais de uma dezena de apotegmas não foram traduzidos por Pascásio!

Desta pesquisa aprofundada de fontes resultou ainda uma inesperada compensação: no meio de um manuscrito todo ele de 10 textos de Vitas Patrum da Biblioteca de D resden, do séc. XIII, surgiu, perfeitamente definida uma colecção de apotegmas com um título bem nítido: Commonitiones Sanctorum Patrum. Tem 6 capítulos, com um total de 61 apotegmas, no geral todos de maior extensão que o habitual. Cerca de um quarto destes apotegmas eram já conhecidos, por se encontrarem a abrir o livro III das Vitas Patrum de Rosweydus (PL 73). Uma nova busca pelos catálogos de Manuscritos das principais bibliotecas europeias (Vaticano, Paris, L ondres, Bruxelas, L ovaina), permitiu encontrar, totalmente ou em parte, esta colecção até então desconhecida.

Desta investigação resultou também uma edição crítica, acompanhada de um estudofilológicoe paleográfico aprofundados, apresentada à discussão na Universidade de Coimbra, em 1974, com o título de Commonitiones Sanctorum Patrum. Uma nova colecção de apotegmas, cuja edição também se retoma, agora na colecção dos Classica Digitalia. Desde então, ficou completamente desmantelado o livro III das Vitas Patrum de Rosweydus, pois se tornou evidente que ele era uma compilação de apotegmas das Commonitiones (de tradutor desconhecido) e do trabalho de Pelágio e João (Rosweydus, livros V e VI), com poucos apotegmas 
finais de out a proveniência ${ }^{13}$.

A obra de Pascásio prolongou afinal na sua transmissão, as vicissitudes e a complexidade que caracterizou este género literário desde a sua fase mais criativa e produtiva até à sua difusão pela cristandade monástica do mundo tardio e medieval, desde o Noroeste hispânico à Saxónia, da Grã-Bretanha a Viena e ao Vaticano, pelo que o Autor procedeu a um levantamento aturado, descrição e avaliação dos testemunhos manuscritos que permitissem sustentar a edição crítica da mesma. A análise e crítica efectuada sobre estes materiais (cento e quarenta e sete manuscritos identifi ados e incluídos no stemma codicum) é dada a conhecer no volume II da edição.

A abundância,a dispersão e a adulteração dos testemunhos manuscritos são indícios quer da extraordinária recepção da obra de Pascásio entre os destinatários cristãos, quer da pervivência e utilidade do específico género literário na cultura espiritual da história da Europa desde o séc. VI até ao séc. XVII, mas também de alguma cristalização no seu uso: assim, o que chegou à edição impressa de Rosweydus foi um exemplar das versões abreviadas, mais simples e depuradas das suas características genuínas, mais afastadas do seu original. É neste trabalho de crítica que a comparação com o paralelo grego desempenha um critério de qualifi ação, e esse foi seguido por J.G. Freire.

O Editor fez ainda acompanhara sua editio princeps da obra de Pascásio de D ume com uma aprofundada análise linguística e literária do texto, bem como uma avaliação das características de Pascásio enquanto tradutor. No nosso entender, esta tarefa, além de ter reforçado os argumentos de identidade do corpus textual de Pascásio de Dume, tem por si só validade informativa para a hermenêutica e estudo literário do apotegma enquanto género literário. $\mathrm{O}$ método de análise, a organização da informação, o escrutínio dos pormenores relevantes para o estudo filológico demonstrados nas edições preparadas pelo investigador ( $A$ versão latina, 1971, 2 vols; e Commonitiones, 1974) constituíram um modelo de investigação em filologia precioso, no nosso entender

${ }^{13}$ Freire, J. G. (1974) Commonitiones Santorum Patrum, Uma Nova Colecção de Apotegmas, Coimbra. 
incontornável para todos os que encetam trabalhos de crítica textual e de edição em textos medievais.

Passados quarenta anos da edição da obra de José Geraldes Freire, tem havido, como revelámos, dificuld de em aceder a uma obra cujos exemplares disponíveis depressa se esgotaram. Valeu-lhe ter sido publicada na revista Humanitas, de ampla difusão (vols. XXI-XXII, 1969-1970; e XXIII-XXIV, 1971-1972). Ela é pois reeditada porque assim o demanda a comunidade científi a e académica, na medida em que continua a ser a única edição que apresenta com rigor científico a edição crítica da tradução latina dos A potegmas por Pascásio de D ume. É, por isso, da mais elementar justiça que a Academia a que José Geraldes Freire entregou o seu talento, trabalho e dedicação traga novamente à luz uma obra que tanto a ilustra.

Tivemos o privilégio de ter sido aluna do Professor José Geraldes Freire desde a licenciatura em Línguas e Literaturas Clássicas e Portuguesa, em 1989, de Mestrado, em 1996, até ao doutoramento, em 2005. Após essa data, por várias vezes, em congressos internacionais, fomos abordada por estudiosos que, ouvindo que éramos de Coimbra, logo nos perguntavam como deviam fazer para aceder à edição de Pascásio de Dume de José Geraldes Freire. Lá íamos fazendo circular os escassos exemplares que tínhamos disponíveis a título pessoal, ou dávamosa morada do $\mathrm{CECH}$, e até mesmo a do Autor. Acrescente-se ainda, como nota de curiosidade, que, ao que saibamos, até agora é a única edição completa de uma tradução latina dos Apophtegmata Patrum, já que as obras de Pelágio e João só podem encontrar-se apenas na edição de Rosweydus (PL 73-74) ${ }^{14}$.

Acolhendo os desafios do nosso Professor José Geraldes Freire, dedicámos toda a nossa formação pós-graduada aos autores cristãos, em especial ao estudo da tradição monástica frutuosiana.

14 Batlle, C. M., (1972) Die Adhortationes sanctorum partum ("Verba seniorum") in lateinishchen Mittelalter, Münster. O autor, então monge beneditino de Montserrat (Catalunha), apresenta as primeiras referências literárias às Vitae Patrum e a recepção das mesmas ao longo da Idade Média, procedendo ao levantamento da transmissão manuscrita das obras de Pelágio e João, sem contudo apresentar uma proposta de revisão da edição de Rosw eydus. 
É, por isso, com extremada comoção que acompanhamos com as nossas palavras uma obra que nos habituámos a compulsar, não só pela informação contida, como pelo rigor metodológico, que tem por autor alguém a quem tanto devemos como professora e estudiosa dos assuntostão atraentes e importantes do monaquismo antigo.

A obra do Professor José Geraldes Freire vale por si, não carecendo de qualquer intervenção de terceiros. Nestas circunstâncias,com alguma reserva acolhemos a sugestão de fazer acompanhar a mesma com um estudo introdutório, que nos foi formulada pelo $\mathrm{CECH}$ enquanto promotor desta edição, na pessoa da sua coordenadora, a Doutora Maria do Céu Zambujo Fialho, e da directora da linha de estudos medievais e renascentistas, Doutora Naír de Castro Soares. Nada há a acrescentar quanto ao objecto de estudo definido e apresentado pelo Doutor Freire, foi a nossa primeira reacção. $\mathrm{O}$ que nã o está feito, afinal

Reconhecendo haver no nosso país uma grande lacuna nos estudos acerca dos textos monásticos antigos, gregos e latinos, assim como uma escassez de debate acerca da história do movimento monástico, mesmo acerca dos nossos monges, história que despoletou uma imensa tipologia de textos de que os apotegmas são, porventura, os pioneiros, ousámos acompanhar a edição da versão latina dos Apophtegmata Patrum com um breve estudo, de índole panorâmica, que procura actualizar a informação, de acordo com a bibliografia mais recente, acerca dos tópicos que considerámos mais relevantes para o conhecimento das origens e características do movimento monástico, sobretudo aqueles que, no nosso entender, mais se destacam para entender o género literário apoftegmático como a literatura primordial das origens do monaquismo.

É com esse espírito de contribuição, de acolhimento do que fomos sentindo como uma aposta estratégica do Centro de Estudos Clássicos e Humanísticos no estudo dos autores cristãos, investigação que, desde as origens bíblicas até à riqueza da Patrologia em grego, latim e outras línguas do Próximo Oriente, necessariamente entre nós só beneficia da aliança entre a filologia clássica e a filologia c istã. 
Não menos relevante é o sentido de homenagem a um mestre que implantou na Academia conimbricense o estudo dos autores cristãos como área de interesse da filologia clássica, dizendo-lhe com humildade, afinal que aqui estamos empenhados em não deixar apagar a lucerna e, Deo iuuante, a passá-la a outros que esperamos continuem a trilhar caminhos por ele abertos. Possa esta obra para tal contribuir. 


\section{O Egipto como lugar de origem dos primeiros monges}

O Egipto romano teve uma enorme importância enquanto pioneiro depois da Ásia Menor, do desenvolvimentoe da afi mação do cristianismo no mundo antigo, tendo nele despontado alguns aspectos característicos da nova religião. Entre eles figu a com enorme destaque a emergência do monaquismo enquanto modo organizado de vida ascética, e movimento espiritual sistemático que animou o cristianismo desde o mundo antigo até à actualidade. Antão e Pacómio são apontados tradicionalmente como os precursores dos dois principais paradigmas da vida monástica, respectivamente a solitária ou eremítica, e a comunitária ou cenobítica. Os dois santos viveram no Egipto romano e cristianizado, Santo Antão nascido em 251 e S. Pacómio em 292, tendo os dois benefici do de vidas extraordinariamente longas, segundo as suas biografias que naturalmente incorporam elementos lendários ${ }^{15}$. Antão teria morrido centenário, em 356, Pacómio precedera-o em dez anos.

$\mathrm{Na}$ verdade, a origem do monaquismo cristão não é assim tão linear, e não devemos fi ar com a impressão de que os patronos apontados inauguraram algo sem precedentes na vida cristã, e que foi no Egipto, e numa data precisa, que do nada nasceu esta forma de vida inspirada. De facto, na Síria, na Palestina, na Mesopotâmia, na Capadócia a sua inspiração e imitação, algumas décadas depois, também no Ocidente latino surgiram, numa baliza temporal que decorre entre os últimos anos do séc. III e o séc. IV, em versão comunitária ou anacorética, mais independentes da iniciativa episcopal ou em estreito contacto

${ }^{15}$ Atanase d'Alexandrie, Vie d'Antoine, ( 1994 ) texto grego e trad. francesa por Bartelink, G. J., S ouces Chrétiennes. A tradição literária sobre S. Pacómio é muito complexa, mas, para a recepção de S. Pacómio no mundo greco-romano, sobressaem Paládio, num dos capítulos da Historia Lausiaca (Butler, C., (1898; 1904) Paladio, La Historia Lausiaca, Una discusión crítica; II. El texto griego en Textos y Estudios, VI, Cambridge, 2 vols; Halkin, F. (1932) Sancti Pachomii Vitae Graecae, Societé des Bollandistes, S ubsidia Hagiographica 19. 
com as dioceses e as comunidades cristãs organizadas, indivíduos ou grupos de indivíduos que se destacavam da comunidade e reivindicavam para si um estatuto e um modo especial de viver o apelo cristão, marcado por um maior rigor, disciplina, renúncia e despojamento.

Sem que estivesse ainda disponível o termo monachos, entre as comunidades cristãs, desde o Oriente ao Ocidente, existiam grupos de continentes, puellae, uiduae, perfecti, que constituíram um prenúncio de sociedades monásticas organizadas, entendidas como um grupo particular entre a comunidade cristã ${ }^{16}$. Mesmo assim, documentosescritos não originários da literatura monástica, e portanto insuspeitos de qualquer efabulação ficci nada, confi mam a utilização do termo monachos em Grego, no Egipto, em 324, e em L atim, (monachi) na Hispânia, logo em $380^{17}$.

Também não é exacto que Antão e Pacómio fossem precursores do monaquismo no Egipto, pois as suas hagiografias não mencionam a vida monástica adoptada por estas figu as como uma novidade. Pelo contrário, Antão e Pacómio aderiram à vida solitária como se esta já constituísse uma escolha conhecida e possível de ser feita, inspirados e ensinados por outros anciãos

${ }^{16}$ G uarrigues, J.-M., L egrez, J. (1990) Moines dans l'Assemblée des Fidèles a l'époque des Pères, Lyon: 41 Nesta obra, os autores estudam as origens da vida monástica nas comunidades eclesiais urbanas do Oriente, Síria, Capadócia, Palestina e na Gália "plutôt que de tout ramener a une seule racine, il faut reconnaître que le monachisme s'est formé spontanément en de nombreux points, au sein de l'église locale".

${ }^{17}$ Judge E. (1977) "The Earliest use of Monachos for 'monk' and the origins of Monasticism”, Jabrbuch fur Antike und Christentum 20: 72-89. Tratase de uma petição legal, em que um Aurelius Isidorus se queixa de ter sido agredido no campo, e que fora salvo da morte pela intervenção de um diácono de nome Antonino, e de um "monachos", de nome Isaac. No Ocidente, Conc. de Saragoça, em 380, c. 6, tit: "ut clericus qui propter licentiam monacus uult esse excommunicetur" (Vives, J. (1963) Concilios Visigoticos e hispano-romanos, Madrid, p. 17. Esta disposição canónica pretende limitar as "deserções" do estado clerical por causa do prestígio da condição de monge "propter luxum uanitatemque praesumptam". Trata-se de um texto muito interessante, na medida em que o estatuto de monge parece presumir uma promoção social, o que suscita uma reacção do episcopado no sentido de reduzir a fuga dos clérigos em busca dessa condição mais apelativa. 
que teriam sido seus mestres. A Vida de Antão refere mesmo o contacto do anacoreta com outros padres do deserto, como Amoun (Vit. Ant. 3, 60).

No entanto, não foi por acaso que os ascetas se converteram em símbolos primordiais da religiosidade e da vida monásticas enquanto expressões de um modo especial de viver o chamamento cristão, tal como não é irrelevante o facto de estas duas figu as serem originárias do Egipto. De facto, A África romana, e em particular o Egipto, constituiu a região de império romano onde mais rapidamente o cristianismo granjeou o estatuto de religião de massas, apresentando as mais sólidas e populosas comunidades cristãs, facto que pode ser facilmente atestado pelas manifestações, literárias, culturais e sociológicas decorrentes desta expressão religiosa.

Deste modo, as primeiras traduções latinas dos textos bíblicos usados por cristãos, ou seja, os mais antigos testemunhos da Vetus Latina, procedem de África, e destinaram-se ao uso de comunidades cristãs de língua latina sedeadas nas metrópoles da Cirenaica e da África Proconsular. A África romana foi também pioneira na composição dosActaMartyrum, relatos de martíriosque se contam entre as primeiras produções literárias do cristianismo posteriores à geração apostólica ${ }^{18}$. Historicamente, a hostilidade

${ }^{18}$ Burton, Ph., (2000) The old latin gospels. A study of their texts and language, Oxford: 14-18, veja-se a importância do cristianismo africano na produção das primeiras versões latinas do NT : "The african tradition is universally agreed to be the earliest identifiable continuous translation of the Gospels",.Q uasten, J. (1953), Patrologia, I, cap. V "Las primeras Actas de los Martires": 177-181 (trad. esp. BAC, Madrid, 2001) Os Actos dos Mártires Escilitanos em África e os Actos Proconsulares de S. Cipriano contam-se entre os mais antigos documentos literários cristãos em latim, e são relativos a acontecimentos dos finais do séc. II aos inícios do séc. III. Bagnall, R.; Worp, K. (2003) “The Era of Diocletian and of the Martyrs," The Chronological Systems of Byzantine Egypt, Leiden: 63-87. Marrou, H. -I. (1963) L'Eglise de l'Antiquité tardive, p. 19-22. "En Orient, la persécution a été beaucoup plus sévère et s'est prolongée, avec quelques periods de remission il est vrai, jusqu'au printemps 313, les souverains successifs qui ont régné sur l'Égypte, la Syrie et l'Asie Mineure n'ayant cessé d'être de plus en plus hostiles au christianisme". As perseguições no Egipto marcaram o carácter da Igreja alexandrina como uma igreja especialmente combativa, uma "igreja de mártires". Frankfurter, D. (1994) “The cult of the 
dos poderes públicos à nova religião e a violência das perseguições ao cristianismo atingiu com particular severidade o cristianismo africano, algo que pode ser explicado de vários modos, mas que apresenta a mais óbvia e primária justifi ação na disseminação e transversalidade do cristianismo entre as populações locais: ou seja, escrevia-se e era-se hostilizado, em primeiro lugar, porque se existia em número suficientemente visível para se ser considerado como um incómodo para a ordem estabelecida ${ }^{19}$.

O cristianismo egípcio apresentou também, com idêntica ou mesmo superior precocidade e solidez, uma face erudita e intelectual, fruto da riqueza civilizacional e complexidade multicultural da cidade de Alexandria. Logo nos alvores do séc. III, coube à escola catequética de Alexandria, com nomes como Clemente de Alexandria e Orígenes, o desenvolvimento sistemático de uma exegese cristã aos textos sagrados, absorvendo métodos de trabalho e conteúdos em continuidade com a erudição filosófica grega helenística, em especial as correntes filosóficas estóica e neo-platónica ${ }^{20}$.

martyrs in Egypt before Constantine: the evidence of coptic "Apocalypse of Elijah", Vigiliae Christianae 48: 25-47.

19 Para um conspecto sobre a especificid de do cristianismo egípcio, seu condicionamento pelas circunstâncias históricas das perseguições e sua influência no denvolvimento do monaquismo, Bagnall, Roger S. (1993) Egypt in Late Antiquity, Princeton University Press, pp. 278-303, s.v. "the Christianization of Eg ypt"; "the monasticism". O autor aponta ainda a presença da onomástica cristã nos documentos escritos, o aparecimento de referências às ordens consagradas do clero (bispos, presbíteros, diáconos e leitores como evidências da generalização do cristianismo. As características da administração política do Egipto romano e o tipo de sociedade aí desenvolvida, constituíram, segundo o autor, um factor de favorecimento da implantação do cristianismo. Assim, este ficou associado a um recrudescimento do "factor nacionalista", uma reacção do Egipto tr adicional aos ocupantes helénicos e romanos.

${ }^{20}$ Q uasten, J., op. cit.: 316-428 "los alexandrinos". (p. 317) "La escuela de Alejandría es el centro más antiguo de ciências sagradas en la historia del cristianismo. El médio ambiente en que se desarrrolló le imprimió sus rasgos característicos: marcado interés por la investigación metafísica del contenido de la fe, preferência por la filosofi de Platón y la interpretación alegórica de las Sagradas Escrituras". Sobre a continuidade entre a exegege platónica da bíblia operada em meio judaico, veja-se Van den Hoek, A. (1997) "The "Catechetical" School of Early Christian Alexandria and Its Philonic Heritage", The Harvard 
O judaísmo da diáspora no Egipto, de língua grega, também apresentou realizações em termos práticos e teóricos que, assemelhando-se aos propósitos do monaquismo cristão, podem ter fornecido a antecâmara que explica a vitalidade e a generalização do fenómeno monástico em terras egípcias. Neste aspecto, o testemunho de Fílon de Alexandria, no De Vita Contemplatiua, informa que havia comunidades judaicas no Egipto que teriam adoptado o ascetismo e que, por motivos espirituais, conduziam uma vida comunitária organizada separada da restante comunidade. Há semelhanças notáveis entre o modo de vida dos Terapeutas, estabelecidos no deserto a Sudoeste de Alexandria, e o das comunidades monásticas da Scétis e da Nítria, situadas precisamente no Baixo-Egipto, uma das com maior presença de comunidades monásticas populosas, com uma vida semi-anacorética (os monges viviam solitários em celas separadas umas das outras, juntando-se uma vez por semana para a eucaristia e as refeições comuns).

O testemunho de Fílon de Alexandria foi utilizado por Eusébio de Cesareia para justifi ar a antiguidade da presença cristã no Egipto. Por sua vez, S. Jerónimo (De Viris Illustribus, 11) e João Cassiano (De Institutis Coenobiorum 2, 5) elaboraram o testemunho de Eusébio para traçarem a origem apostólica do cristianismo egípcio (o próprio apóstolo $\mathrm{S}$. Marcos teria fundado a comunidade dos Terapeutas) e a continuidade entre este cristianismo ancestral e as experiências monásticas do Egipto. Trata-se, obviamente, de uma elaboração literária, que deixa por explicar os três séculos de distância entre as experiências de vida em comum nascidas da espiritualidade judeo-helénica dos Terapeutas documentada por Fílon e os assentamentosmonásticos nos desertos dos arredores de Alexandria.

Mas esta análise, afinal a primeira fenomenologia do monaquismo cristão, reflecte algumas evidências, como o facto de não ser possível atribuir ao monaquismo cristão a iniciativa de um conjunto de práticas ascéticas, que ele partilha com outras espiritualidades, e o facto de o Egipto romano ter reunido condições favoráveis a que não só o monaquismo se desenvolvesse

Theological Review, 90: 59-87. 
como fenómeno organizado, como também que fosse a experiência egípcia a mais documentada, a mais divulgada, em suma, a eleita como experiência a ser conhecida e imitada pelo mundo antigo, tanto na sua realização eremítica como na comunitária.

Deste modo, pensamos que o papel prestado pela língua de uso dominante em número e prestígio social dos falantes, foi decisivo. Reflectindo a diversidade geográfi a do fenómeno, os primeiros textos da cultura monástica foram produzidos nas mais variadas línguas, nelas figu ando com grande destaque o copta, o siríaco e o grego, e quase em simultâneo o latim. Numa primeira etapa, o grego e o latim foram também línguas de chegada, ou de tradução, de experiências que haviam sido vividas e descritas nas línguas particulares de regiões mais periféricas e menos urbanizadas do mundo antigo. Numa segunda fase, contudo, devido à popularidade e a divulgação do monaquismo, as línguas encetaram uma dinâmica de contacto que se concretizou na existência de versões em várias línguas do mesmo texto, produzidas com escassos anos de diferença, num fenómeno intenso de comunicação literária. Mas o grego não abandonou a primazia enquanto língua de chegada e língua de partida, em particular na tradução da experiência monástica oriental para o Ocidente latino.

Neste domínio, o Egipto vivia também condições privilegiadas, pelo seu multilinguismo. $\mathrm{O}$ grego era a língua de prestígio, das cidades e das classes sociais influentes e abastadas, e o copta era a língua do interior, dos habitantes locais e dos camponeses em particular. As duas línguas coexistiam no mesmo espaço, mas o grego era a língua de cultura, das cidades e dos cristãos cultivados, e a tradição literária cristã e monástica que usava o grego, ou que cedo trouxe para a escrita grega testemunhos coptas, foi sólida e abundante. As experiências egípcias, tal como estão documentadas nos escritos primitivos, podendo não ter sido vividas em grego, foram facilmente incorporadas e traduzidas por uma comunidade cristã helenófona sensível e aderente ao fenómeno monástico.

Assim, o corpus monástico em língua grega supera largamente o dos outros idiomas, descrevendo um mundo 
geografi amente localizado no Egipto e com protagonistas egípcios. Deste modo, o destaque concedido ao Egipto, enquanto lugar protagonista do monaquismo, resulta também do facto de se tratar de o melhor documentado, o mais disseminado enquanto experiência de massas, e aquele que reuniu melhores condições para ser conhecido pelo mundo latino ${ }^{21}$.

\section{A importância das viagens e das traduções para o aparecimento da primeira literatura monástica}

O contexto de composição dos primeiros textos que descrevem o fenómeno monástico resultou de relatos de viagens, reais ou ficci nadas, de leigos e consagrados que, numa espécie de turismo piedoso, buscavam nos lugares sagrados do Oriente, os associados à História da Salvação na Palestina, os santuários dos mártires e, não menos importantes, os lugares de santidade "em exercício" que constituíam as comunidades monásticas dos desertos nos arredores de Alexandria.

A Peregrinatio de Eg éria (381-384), relatando a viagem de uma aristocrata pelos lugares santos da Palestina e da Síria, na época teodosiana, acompanhada por um círculo de mulheres piedosas a quem trata por puellae e sorores, é um bom exemplo do fascínio exercido pelos lugares santos e heróicos do Oriente, e da curiosidade que pôde ser satisfeita graças à promoção do cristianismo a religião lícita e oficial do Estado romano, e à progressiva cristianização do espaço imperial22.

${ }^{21}$ Fomos sensíveis a um outro argumento para justifi ar a importância do Egipto nas origens do monaquismo, que é o do "privilégio topográfic " (Goehring, J. E. (2003) "The dark side of Landskape: Ideology and power in the christian myth of the desert" Journal of medieval and early modern studies 33: 437-451). Assim a paisagem egípcia, com uma topografia e uma ocupação humana que segregavam a zona habitada da zona desértica, fornecia o cenário perfeito para o contraste espiritual entre a cidade, o mundo habitado, e o deserto, o espaço de todos os desafios

${ }^{22}$ Eg éria, (1058) Itinerarium, Franceschini e Weber R. ed., CCSL , 175 176. A designada por Hélène Petré, Peregrinatio Aetheriae (SC 21, 1947) é tratada desde 1967 por Itinerarium Egeriae e correspondeu a uma viagem real, tendo sido datada com todo o rigor de Março de 381 à $2^{\text {a }}$ feira da Páscoa de 384 (25 de Março de 384) pelo Bolandista Paul Devos (Analecta Bollandiana 
A Historia Monachorum in Aegypto teria sido composta cerca de 400, relatando a viagem de um grupo de sete peregrinos, de Jerusalém pelo Egipto, realizada entre 394 e 395, que descreve o modo de vida dos monges "tal como os viram", a conduzir uma "uma vida angélica".

Paládio, um monge da Galácia, após uma estadia no Egipto, compôs, entre 419 e 420, um relato com testemunhos do modo de vida, ou episódios soltos, de mais de cem ascetas egípcios $^{23}$.

As duas obras, a primeira logo em 403, juntamente com o Asketicon de S. Basílio, foram traduzidas para o Ocidente, sob o título de Instituta Monachorum, pelo presbítero de Aquileia, Rufin .

O ofício incansável de S. Jerónimo, como tradutor de hebraico e de grego para latim, também disponibilizou para latim a Vida e as Regras de S. Pacómio, o que muito contribuiu para a elevação deste patriarca ao estatuto de líder do cenobitismo. Além disso, compôs entre 375 e 390, inspirado pela hagiografia dos monges que conhecera no Oriente, a Vida de Paulo de Tebas, no Egipto, a Vida de Hilarião de Gaza e a Vida de Malco (no deserto de Nisibe, na Síria), os três suplantando em rigor ascético o heróico Antão ${ }^{24}$.

Evágrio de Antioquia, companheiro e colega de juventude de Rufino e de S. Jerónimo, traduziu para latim a popular Vida de Santo Antão de A tanásio de Alexandria, a versão latina que $\mathrm{H}$. Rosweydus viria a recuperar para as suas Vitae Patrum ${ }^{25}$.

Finalmente João Cassiano, piedoso marselhês que

$\left.\mathrm{n}^{\circ} 1-2,1967\right)$

${ }^{23}$ Historia Monachorum in Aegypto, édition critique du texte grec et traduction annotée, (1971), A. J. Festugière ed. e trad, Bruxelles, prologus: 5-8. Palladius, (1898-1904) Historia Lausiaca, 2 vols, Cambridge.

${ }^{24}$ Boon, A. (1932) Pachomiana latina. Praecepta, Praecepta et instituta, Praecepta atque iudicia, praecepta et leges, Epistulae S. Pachomii, L ovaina. PL, 23: 17 ss. Kozik, I. S., (1968) The first Desert Hero "Vita Pauli with introduction, notes and vocabulary, Mount Vernon.

${ }^{25}$ Há uma tradução latina anónima anterior à de Evágrio (Bartelink, G.J., (1974) Vita di Antonio, Rome (texte critique, traduction italienne et commentaite). 
permaneceu entre 380 e 404 entre as comunidades monásticas da Palestina e do Egipto, no deserto de Scétis. Retornado à sua pátria devido à instabilidade provocada pelas investidas bárbaras no Oriente, tornou-se sacerdote e fundador de mosteiros. Instado pelo seu Bispo, compôs entre 420 e 430 duas obras fundamentais para o desenvolvimento do monaquismo à maneira egípcia no Ocidente, o De Institutis Coenobiorum e as Collationes ${ }^{26}$.

Podem ser tiradas algumas conclusões a partir deste inventário, que está longe de ser exaustivo: entre meados do séc. IV e meados do séc. V, ou seja, naquele período de relativa estabilidade conseguido entre a $\mathrm{Paz}$ da Igreja e as invasões bárbaras, que desestabilizaram o Oriente romano, a Palestina e o Egipto converteram-se em morada ou em lugar de passagem de personalidades oriundas das mais diversas paragens do império, mas com destaque para os latinófonos, sedentos de aderir a um movimento que eles percebiam como uma novidade e de auxiliarem, através de traduções, a disseminação dos ideais monásticos pelas suas terras de origem. Sobressai também, deste conspecto, a importância da Palestina e do Egipto enquanto lugares de culto entre esta nova "moda". A proximidade entre as duas metrópoles, Jerusalém e Alexandria, a facilidade de contactos via marítima, permitiu que se estabelecesse uma espécie de périplo entre os que visitavam o Oriente, escolhendo estes lugares.

Releve-se ainda o contraste existente entre a finalid de com que estes textos, em primeira mão ou em tradução, foram produzidos, e o perfil do herói monástico que neles se desenha. No caso de Cassiano, o destinatário é explicitamente a comunidade monástica dependente do bispo Castor, na região de Marselha. Mas todos presumem uma recepção colectiva, num quadro em que a ascese solitária e isolada dos monges retratados serve de exemplo para a edifi ação de um grupo. Encontraremos este contraste entre um processo criativo, valorizador do individual e do solitário, associado a uma leitura e a um destinatário essencialmente colectivo, ainda com maior contundência nos Apophtegmata Patrum, género em que este contraste foi evidente.

${ }^{26}$ Ver nota 6. Jean Cassien, De Institutis Coenobiorum J. Cl. Guy ed. e trad., (1965) S ources Chrétiennes 109, Paris. 
Esta é uma característica da literatura monástica antiga. Nasce fazendo a parenese do asceta que adopta, por escolha espiritual, um modo de vida separado e contrastante com a normalidade, cujas virtudes e carisma resultam dessa capacidade de conduzir cada vez mais longe o desafio físico e espiritual que o colocam no caminho da perfeição, mas tem como receptor o monaquismo comunitário e como propósito contribuir para a edifi ação harmónica da comunidade, numa estrutura social pouco tolerante à extravagância individual. Esta recepção está na base da abundância de testemunhos manuscritos deste género literário, uma vez que cada comunidade teria na sua biblioteca a sua própria colecção de "Sentenças dos Padres".

Além disso, repare-se na curta escala de tempo que decorre entre a produção do texto original e a sua disponibilização em latim. No nosso entender, o facto de a criação e a tradução existirem quase em simultâneo pode ser interpretado como a prova de que o monaquismo, enquanto realidade organizada, surgiu de um modo disseminado pela cristandade do império e de que o antecedente e a inspiração egípcia foram inicialmente um fenómeno de percepção por parte dos testemunhos antigos em peregrinação pelo fascinante Oriente. Acrescente-se ainda a importância que estes relatos atribuem ao valor presencial, enquanto elemento de credibilidade. O uvir os ensinamentos e ver as maravilhas conseguidas pelos campeões da ascese, buscar neles inspiração para uma conduta perfeita ganhou validade enquanto pedagogia cristã, mas, se reflecti mos bem, também continua ou prolonga um paradigma de transmissão de conhecimento filosófi , de formação de carácter e de aspiração e prática de santidade, entre mestre e discípulo, que já vinha do mundo antigo e da paideia greco-romana, em particular entre os estóicos e os cínicos.

\section{A Bíblia nas origens do ascetismo cristão}

O modo de vida ascético, como propósito a ser seguido pelo cristão não surge subitamente no cristianismo, na medida em que a Bíblia, em especial o NT, apresenta passagens que salvaguardam a transposição das consequências de adesão à nova 
fé para o quotidiano, modifi ando o comportamento do homem. Encontramos este apelo ascético explícito nas Cartas Apostólicas, mas tanto os Actos dos Apóstolos como os Evangelhos fornecem modelos a imitar.

Ser cristão implica modifi ar o comportamento, os propósitos, o agir quotidiano, ou seja, transportar a fili ção religiosa de uma dimensão teórica para uma dimensão prática ou ascética. Assim, o modelo teológico do ascetismo cristão tem como grande inspirador e impulsionador as Cartas Apostólicas. Ele apresenta com frequência uma disciplina do quotidiano humano que torna visível, para o próprio e para os outros, uma vivência e entusiasmo pela pertença a Cristo, assim como estabelece como objectivo do cristão o tornar-se progressivamente mais perfeito, na sequência do conselho instante e resumido de Jesus Cristo "-Sêde perfeitos como o Pai celestial é perfeito"(Mt. 5, 48).

Este conceito dinâmico de caminhada, associado à entrega a determinadas práticas, ou exercícios (ascese)de condicionamento físico e mental com o objectivo de atingir a perfeita união com Deus, salvaguarda o cristianismo como uma religião que reconhece o comportamento humano com instância de condicionamento metodológico ao serviço de uma finalid de metafísica ou teórica ${ }^{27}$. O u seja, para a teologia paulina, a caminhada humana não é um fim em si próprio, mas condiciona o fim último do cristianismo que só se cumpre plenamente no plano espiritual.

Assim, a prática da meditação e da prece contínua, a continência e a moderação no uso dos alimentos, a renúncia aos prazeres da carne, o abdicar de uma profiss o ou de uma carreira, o adoptar de um modo de vida parco e materialmente pouco

27 Krawiec, R. (2008) "Asceticism", The Oxford Handbook of Early Christianity, Harvey, A. S. e Hunter, David eds, Oxford: 764-779. (p. 767, cit.: "Scholars have agreed that asceticism is performance..." p. 768, cit: "Christian asceticism has its roots in the New Testament, and indeed ascetical passages in scripture have provided an area of historical investigation for earliest Christian asceticism". Não consideramos aqui, por razões de espaço, os textos das primeiras gerações apostólicas, como a Epistola de Barnabé, o Pastor de Hermas, o Evangelho de Tomás, os Actos de Paula e de Tecla, cujos contornos ascéticos foram apontados por extensa bibliografia (vide op. cit.: 781 ss, estudos acerca do ascetismo na literatura cristã até ao séc. IV. 
exigente, o prescindir da posse individual de bens, fazendo deles dádiva aos pobres, surgem como práticas ascéticas consagradas pelas Epístolas de Paulo como adequadas ao cristianismo, ou seja, modos de o cristão progredir no seu aperfeiçoamento interior, seguindo o modelo de $\mathrm{Cristo}^{28}$.

Por sua vez, os Actos dos Apóstolos fornecem a visão de uma comunidade cristã perfeita, a comunidade apostólica de Jerusalém após o Pentecostes. Sobressaem, como características positivas, a prática da oração e da Eucaristia, assim como a partilha fraterna dos bens e a unidade "um só coração e uma só alma" (Act. 5, 3). Destaca-se também a capacidade de realizar prodígios e milagres, ou seja, de os cristãos estarem revestidos por uma força que lhes permitia romper as limitações da sua condição humana ${ }^{29}$.

Surge, neste ultrapassar da condição humana, a memória e o exemplo de Cristo, capaz de realizar vários milagres para assombro dos que assistem, afinal a primeira fonte de inspiração para um modo de vida de características ascéticas que Paulo já interpretara nas suas cartas. Em Mt. 16, 22, Cristo apresenta ao jovem rico um programa de vida para ser "perfeito" que envolve, em última instância, o tomá-L o como modelo: "depois, vem e segue-Me ${ }^{{ }^{30}}$. S erá este, porventura, o excerto em que a dimensão

${ }^{28}$ O convite à imitação de Cristo (Ef. 5, 1-2 "Sêde, pois, imitadores de Deus, como filhos muito amados. Progredi na caridade, segundo o exemplo de Cristo “. A exortação paulina ao combate espiritual (Ef. 6, 18). Em Col. 3, 1-15, a finalid de do ascetismo cristão. A caminhada cristã apresentada como uma "corrida", ou uma "luta" (1Cor. 9, 24-26); ainda a temática ascética em S. Paulo 2Tim. 2,5; 4, 7-8.

${ }^{29}$ (Act. 2, 42-43) "eram assíduos ao ensino dos A póstolos, à união fraterna, à fracção do pão, às orações. Perante os inumeráveis prodígios e milagres realizados pelos apóstolos, o temor dominava todos os espíritos"; (Act. 4, 32-

35) "A multidão dos que haviam abraçado a fé tinha um só coração e uma só alma. Ninguém chamava seu ao que lhe pertencia, mas, entre eles, tudo era comum. E era com grande poder que os apóstolos davam testemunho da Ressurreição do Senhor Jesus, gozando todos de grande simpatia. Entre eles não havia ninguém necessitado, pois todos os que possuíam terras ou casas vendiam-nas, traziam o produto da venda e depositavam-no aos pés dos apóstolos. Distribuía-se então a cada um conforme a necessidade que tivesse".

${ }^{30} \mathrm{O}$ passo em causa, também em Lc. 18, 18-25, é fundamental para a noção de que ser-se cristão implica a adopção gradual de medidas que 
exemplar da vida de Cristo mais se torna evidente, embora outras passagens dos Evangelhos salientem a importância da imitação do agir de Cristo, como modelo para o comportamento dos que abraçam a nova religião ${ }^{31}$.

O fundamento bíblico do ascetismo cristão, enquanto realidade que pré-existe ao monaquismo, como fenómeno organizado, encontra-se também nos exemplos dos profetas do AT, e mesmo de João Baptista (que, embora integre o NT, apresenta muitas características que o permitem comparar aos patriarcas e profetas do Antigo testamento, a começar pelo facto de a sua acção se situar num momento preliminar ao da historia de Cristo).

Figuras como Abraão, Jacob, Moisés, João Baptista, apresentam-se como prefigu ações desse modelo de vida que implica a viagem, seja pela experiência do exílio, seja pela errância enquanto etapa de vida, ou pela procura deliberada do deserto como espaço de reflex o e de desafio interiores, mais tarde interpretadas pela exegese cristã como prefigu ações veterotestamentárias da vida do próprio Cristo na terra ${ }^{32}$. Os modelos veterotestamentários

modifi am a vida quotidiana. À pergunta "Mestre, que hei-de fazer de bom para alcançar a vida eterna?", Cristo responde-lhe primeiramente com os preceitos que já existiam na lei judaica, e que permitiam um primeiro estádio de adesão: "não matarás, não cometerás adultério, não roubarás, não cometerás falso testemunho, honra teu pai e tua mãe e ainda amarás o teu próximo como a ti mesmo". O jovem já cumpria tudo isso, o que faltava ainda? Mais duas etapas: a renúncia aos bens e depois o propósito de $\mathrm{O}$ seguir. "se queres ser perfeito, vai, vende tudo o que possuíres, e dá o dinheiro aos pobres, e terás um tesouro nos céus. Depois vem, e segue-me". A este mais exigente desafi , o jovem, que era riquíssimo, não pôde responder afi mativamente.

${ }^{31}$ Nas Bodas de Caná (Jo. 2, 5) o repto de Maria "fazei como Ele vos disser"; Mt. 16, 24 "Se alguém quiser vir após Mim, renegue-se a si mesmo, tome a sua cruz e siga-Me”. Também Mc. 8, 34; Lc. 9, 23. Também Jo. 14, 21, a conformação entre Jesus, o Pai e os que o seguem. Jo. 15, 12 "o Meu mandamento é este: Que vos ameis uns aos outros como Eu vos amei. Ainda em Jo. 15, 14: "Vós sereis Meus amigos se fi erdes o que vos mando". O instituir da prática cristã e da oração dominical acompanham o convite a que se imite, ou se reproduza o agir de Cristo: "rezai, pois, deste modo:..." (Mt. 6, 9-13). Em L c. 11, 1-4, “-S enhor, ensina-nos a orar como João ensinou aos seus discípulos. Disse-lhes ele:- Q uando orardes, dizei:..."

${ }^{32}$ L c. 4, 1-12, Cristo é tentado pelo demónio no deserto durante quarenta 
para o ascetismo foram valorizados pela exegese judeo-helenística de Fílon de Alexandria, e recuperados a partir de alguns dos seus comentários de ampla divulgação pela patrística grega, como modelos de ascese espiritual ${ }^{33}$.

Fílon, autordo séc.I, é ainda utilizado enquantotestemunha que confi ma a antiguidade da presença cristã no Egipto, e dos antecedentes do movimento monástico. No seu tratado De Vita Contemplativa, Fílon descreve a comunidade judaica dos essaioi, os essénios.

E embora se questione o propósito de Fílon em associaras práticas ascéticas dos essénios ao comportamento dos therapeutai, ascetas que, nos arredores de Alexandria do seu tempo, levavam uma vida em comunidade de contornos ascéticos, por inspiração religiosa, coube aos padres cristãos produzirem essa associação como modo de confi mar a continuidade entre a inspiração bíblica, e mesmo veterotestamentária, e o desenvolvimento do ascetismo cristão, ressaltar a antiguidade e a coerência do monaquismo para com a história precoce da revelação cristã ${ }^{34}$.

Os antecedentes bíblicos do ascetismo cristão, bem como todas as referências dos historiadores e dos biógrafos cristãos, quanto ao Egipto do séc. IV, como lugar do despontar monástico, foram, no entanto, explicações desenvolvidas já como resultado de uma reflex o especulativa e teórica que os autores antigos

dias. Mt. 8, 20 "o Filho do homem não tem onde descansar a cabeça".

${ }_{33}$ Estamos a pensar no De Abrahamo, no De Migrationi Abrahamo, no De Vita Moysis, no De Iosepho, e sobretudo no De Vita Contemplativa. Runia, D. (2003) Philo in Early Christian Literature, Minneapolis: 120-211 "Alexandria before Clement"; "Clement of Alexandria"; "Origen"; "In the alexandrinian tradition".

${ }^{34} \mathrm{O}$ valor testemunhal de Fílon e do De Vita Contemplativa surge em Eusébio de Cesareia, Historia Ecclesiastica 2, 16.2 - 18.8. Também na Praeparatio Euangelica 8.10.19-12.20, Eusébio cita os Hypothetica de Fílon para descrever o modo de vida ascético dos essénios. Também Sozómeno, Historia Ecclesiastica 1,12.9, Fílon é a fonte evocada para a descrição dos inícios do movimento monástico. Taylor, J. and Davies, Ph. (1998) "The So-Called Therapeutae of "De Vita Contemplativa", The Harvard Theological Review, 91: 3-24. De Vita Contemplativa 9.105-8. Também no tratado Quod omnis probus liber sit 75-91. Ver G uillaumont, A., (1979) Aux origines du monachisme chrétien, Bellefontaine. 
produziram num contexto em que o fenómeno monástico já se tinha sedimentado na Igreja.

De facto, Fílon dá testemunho de movimentos ético-religiosos do séc. I, tal como entre a composição dos textos bíblicos e o aparecimento dos primeiros monges no séc. IV decorreram muitas gerações. Permanecera o ascetismo cristão em estado larvar até encontrar as circunstâncias ideais para a sua evolução, enquanto modo de vida organizado e sistemático no séc. IV? Trata-se de uma questão complexa, a que é difícil, senão impossível, de ser aquietada de um modo linear. No entanto, os primeiros monges, de acordo com os testemunhos das biografias procedem do Egipto do séc. IV, e acompanham o fim da época das perseguições e a chegada da paz constantiniana.

\section{Fim da era dos mártires, início da era dos monges}

Dionísio de Alexandria deu-nos conta de que, por ocasião da terrível perseguição de Décio (250), muitos cristãos fugiram para o deserto e passaram a viver como solitários. Nada se sabe acerca da permanência deste tipo de vida após o fim da perseguição, mas não será errado pensar que, por motivos de fuga (aos impostos, à guerra, ao trabalho forçado) os habitantes do Egipto imaginavam o deserto como um lugar provável para a anachoresis, o afastamento do mundo ${ }^{35}$.

35 Eusébio de Cesareia, Historia Ecclesiastica 6, 40-42 (PG 21). O historiógrafo, citando Dioniso o Germano em carta dirigida a Fábio, Bispo de Antioquia, narra detalhadamente os efeitos da perseguição de Décio sobre os cristãos alexandrinos. Menciona explicitamente a "multidão" de cristãos que buscou refúgio no deserto e foi consumida pela fome, sede, doenças, bandidos, animais selvagens ou escravizada pelos bárbaros sarracenos. Mas os que lhes sobreviveram, no deserto, são chamados de "mártires", no sentido exacto da palavra, ou seja, "assistiram" à vitória dos que sacrifi aram a vida terrena à sua condição de cristãos, incompatível com a ordem de Décio. Também Cha eremon, Bispo de Nilo, fugiu para o deserto com a sua esposa e nunca mais foi visto. O termo "mártir", neste passo, não se aplica aos que pereceram, mas aos que sobreviveram à perseguição. Trata-se de um testemunho muito interessante, enquanto explicação plausível, não só para a presença circunstanciada de cristãos no deserto, como também da especial ligação entre o conceito de martírio e o de eremitismo. 
É também a Vida de S. Pacómio quem estabelece a ligação entre a era dos mártires e dos monges. A seguir às perseguições a fé cresceu extraordinariamente nos espaços sagrados de toda a parte, $e$ os mosteiros e lugares para os ascetas começaram a surgir, pois os primeiros monges foram testemunhas da coragem dos mártires". ${ }^{36}$

No momento em que a Igreja e os cristãos alcançam a tranquilidade e mesmo uma melhoria das condições de vida e do estatuto social que acompanha a progressiva cristianização dos poderes públicos, o monaquismo irrompe como tendência reformadora dentro da própria Igreja, apontando ao cristão a continuação de um martírio interior. O u seja, tendo o cristianismo, nos seus primeiros anos, flo escido apoiado na resistência e na provação dos mártires em combate contra um mundo hostil, alcançada a paz, como levar mais além o desafio de se ser cristão num mundo em que essa condição passou a ser maioritária e promotora de privilégios?

Sendo redutora a afi mação de que o monge substituiu o mártir nas vocações cristãs, na medida em que se encontram exemplos de ascetismo cristão anteriores ao séc. IV, o monaquismo apresenta uma dimensão crítica quanto ao status alcançado pela Igreja e à sua cada vez maior aliança com os poderes públicos. Quando o cristianismo emergiu para a legitimidade, com Constantino, o ascetismo, solidamente arreigado nas práticas de determinadas comunidades cristãs e fundamentado na mensagem evangélica, pôde também emergir e ganhar contornos organizados e institucionais. Neste sentido, o monaquismo constituiu uma forma histórica e concreta de enquadrar o ascetismo na Igreja e entre os cristãos.

Numa primeira fase, a expressão monástica desenvolveuse sem apoio formal, e até com alguma reserva, por parte dos poderes públicos, políticos e religiosos. As autoridades políticas e episcopais desenvolveram reacções de alguma reserva em relação ao fenómeno monástico, reacções que acompanharam, ou

${ }^{36}$ Chitt y, D. (1966) The Desert a City, Oxford: 7. Neste autor encontramos o testemunho citado, contido na versão copta da vida de Pacómio (Pachomian Koinonia: The lives, Rules and other writings of Saint Pachomius, Armand Veilleux ed. e trad. (1980) K alamazoo, Michigan, 1980, 1: 23-24. 
interpretaram uma opinião pública, mesmo cristã, hostil.

Assim, o piedoso Teodósio proibiu aos monges a entrada nas cidades, com o argumento de que "multa scelera faciunt" limitando-os aos deserta loca et uasta solitudines ${ }^{37}$. S. Jerónimo, um fervoroso admirador do monaquismo, deu conta, nas suas cartas, da antipatia suscitada em Roma pelos excessos de penitência, jejuns e orações, atribuídos aos monges, sendo descrito um cenário em que a ascese monástica perturbava a tranquilidade de uma cidade cristã ${ }^{38}$.

Nesta resistência,face a um grupo que advogavaa separação, física e comportamental, da comunidade em geral encontramos um sinal de que o monaquismo eclodiu como um movimento de bases, que pouco a pouco foi ocupando o espaço público e a adesão das elites cristãs cultivadas, o que foi fundamental para a sedimentação da cultura literária já referida, para a expressão em grego e latim, para o aparecimento de textos que interpretam já os fenómenos monásticos à luz da hermenêutica cristã.

Nessa medida, por um lado, ser monge permite assumir uma prática que se distingue, pela sua originalidade e rigor, da maioria dos cristãos em sociedade: procurar a solidão dos espaços isolados ou desertos, rejeitar a vida familiar, a propriedade, a obediência a uma hierarquia secular, orar, privar-se do conforto da alimentação e do sono, são modos de manter viva a postura de combate com o mundo e a procura da perfeição, assente no ultrapassar das dificuld des auto-impostas, espírito que animava a Igreja primitiva, tal como fora descrita nos Evang elhos ${ }^{39}$.

${ }^{37}$ CTh 9.40.16, 10.3.1-2 . Labriolle, P. de, (1934, reed. 2003) La Réaction païenne, Étude sur la polémique antichrétienne du Ier au VIe siècle, préface par Jean-Claude F redouille, Paris, 2006.

${ }^{38}$ S. Jerónimo Ep. 39, 6.

${ }^{39}$ Malone, E. (1950) The Monk and the Martyr: the Monk as the Successor of the Martyr. Washington, D.C.: Catholic University of America Press. Vööbus, A. (1960) The History of Asceticism in the Syrian Orient: A Contribution to the History of Culture in the Near East. Vol. I: The Origin of Asceticism, Eastern Monasticism in Persia. Louvain: 10-12; 69-90. Dias, P. Barata (1997) "A espiritualidade do monaquismo antigo: suas origens, suas características, sua evolução", Arquipélago 14: 211-230. Histoire de L'Église des Origines à nos jours, De la paix Constantinienne à la mort de Théodose, L abriolle, P. de et al. ed., Paris, 
Por outro lado, o monge, enquanto indivíduo isolado e destacado pelas suas atitudes, práticas e capacidades, tornase exemplo de heroismo e de santidade para as massas cristãs. Estas reconheceram os mártires uma condição excepcional pelo sacrifício extremo da própria vida, em circunstâncias dotadas de espectacularidade e de dramatismo, e construíram a sua galeria de modelos heróicos. Com o fim das perseguições, os paradigmas do heroismo cristão puderam transferir-se para os ascetas, aqueles que, por meio do sacrifício da vida quotidiana, também ofereciam às massas cristãs um testemunho de fé e exemplos de santidade, diante do vazio criado pelo fim das perseguições

Muitas explicações foram evocadas para as origens do movimento monástico no específico contexto em que ocorreu, e o assunto está longe de se esgotar. Considere-se, no entanto, que este assenta em fundamentos éticos e espirituais definidos já pela mensagem neo-testamentária, que abre caminho para a ascese enquanto via de aperfeiçoamento religioso. Esta realidade, específi a do cristianismo conjuga-se com as tendências filosóficas e morais do mundo antigo, também elas promotoras de um ideal de vida ascético, e que granjearam considerável popularidade no espaço greco-romano culto.

Neste sentido, pensamos que o que deve ser considerado na análise do fenómeno monástico no séc. IV será mais não o seu carácter pioneiro ou original, mas o do seu impacto e visibilidade, ou seja, o da conquista do espaço público enquanto voz dominante entre as comunidades cristãs. Esta conquista de centralidade traduziu-se fatalmente na aparência de que se estava a assistir a uma realidade completamente nova, concepção que foi habilmente explorada pelos compositores das primeiras biografias de monges.

Os anciãos de vida admirável são descritos como figu as humildes e avessas ao contacto humano, em busca da tranquilidade e do isolamento que lhes permite a entrega absoluta a Deus. São ainda apresentados como figu as pouco dotadas na cultura do mundo,analfabetosaté,cujasabedoriabrotavade modocarismático, graças ao seu percurso de fortalecimento através da ascese, e não

"l'état chrétien et les moines", t. III. 
como resultado de um processo de educação convencional, escolar ou filosófica, versada na cultura do mundo ${ }^{40}$.

Evidencia-se um desenvolvimento do paradigma do sábio ou do mestre: aquele que ensina e promove modelos de vida mais perfeitos não é o filóso o, versado na erudição humana, mas sim o simples que se deixa levar pela radicalidade do apelo evangélico, que em vários passos apresenta este novo homem como aquele que assume rupturas com as convenções (e. g. Mt. 10, 39: Quem achar a sua vida perdê-la-á; e quem perder a sua vida, por amor de Mim, achá-la-â).

$\mathrm{Na}$ verdade, trata-se de uma solidão que existe para ser vista e admirada pelos cristãos em redor, pois o asceta mais perfeito era não só aquele capaz das maiores renúncias como aquele que, alcançado um grau elevado de perfeição, derramava as suas graças e maravilhas como benefícios sobre a comunidade ${ }^{41}$. Entre estes benefícios estava o da palavra inspirada, convertida em ensinamento para os que buscavam orientação, para outros monges, para quem o visitasse. "Pater, eipe moi rhema" pediam os discípulos aos padres do deserto. E os anciãos acediam a encadear uma breve e lapidar sentença, que podia ter já sido colhida de outro ancião, porventura enquanto o próprio era ainda discípulo ${ }^{42}$.

\section{Os Apophtegmata Patrum. Algumas características do género literário}

Os investigadores são unânimes em considerar os

${ }^{40}$ Festugière A. J. (1960) Les Moines de l'Orient. I Culture ou sainteté introduction au monachisme oriental, Le Cerf. (Cf. 1Cor 3,19: "a sabedoria do mundo é loucura aos olhos de Deus". Festugière estuda, a partir dos primeiros documentos que relatam as experiências monásticas, a atitude crítica em relação à cultura e ao racionalismo, característicos do mundo antigo, bem como a apologia que a cultura monástica faz do anti-intelectualismo.

${ }^{41}$ Brown, P. (1971) The rise and function of the Holy Man in Late Antiquity", Journal of Religious Studies 61: 80-101; id. (1983) “The saint as Exemplar in Late Antiquity" Representations, 1-2: 1-25.

${ }^{42}$ Regnaut, L. "Aux origines des Apophtegmes", Les pères du desert à travers leurs Apophtegmes, Solesmes: 57-58. Burton- Christie, D. (1993) The Word in the desert, scripture and the quest for holiness in early christian monasticism, Oxford, s.v. "The s yings of the desert fathers": 76-103 
Apophtegmata Patrum o mais ancestral, espontâneo e autêntico dos géneros literários, cultivados pelo movimento monástico antigo. A designação de apophtegma era já utilizada pela literatura grega antiga para designar ditos breves, de carácter sentencioso ou opinativo, assim também simples episódios e exemplos, atribuídos a personalidades célebres e distintas (e. g. os Apophtegmata regum et Imperatorum de Plutarco). Estes apotegmas tornaram-se alvo de colecção primeiramente em suportes ligeiros, e depois em colecções, ora nominais e até alfabéticas, ora anónimas e desordenadas, ora ainda por temas espirituais, e o seu propósito era claramente pedagógico e pragmático: serviam o portador do livrinho de "máximas", em volumes de mão (cf. O tipo de obras conhecidas como Enchiridion "sempre à mão", ou seja "manual").

A adopção pelo monaquismo cristão desta designação resulta também de um processo de tradução que aproxima um objecto e realidade nova a algo que lhe é próximo na cultura dos tradutores. Assim, os termos Logos, Logion e Rhema teriam sido os primeiros usados para designar esta especial forma de transmissão de conhecimentos e estão mais de acordo com o texto produzido. Em latim, vulgarizou-se a adopção de Sententiae, tal como se adoptou a transliteração destes vocábulos por Apotegmas e sentenças, como género literário próprio e característico das origens do monaquismo.

Pedir uma "palavra" a um eremita era pedir um conselho, um ensinamento que beneficiava aquele que pedia, um discípulo, um monge em formação, um viajante, um companheiro de ascese em dificuld des, restaurando-se portanto uma relação pedagógica em que os presentes no acto comunicativo desempenham papéis distintos e não comutáveis entre si: há um que sabe, e é tido como mestre, e outro que recolhe o ensinamento, que é o discípulo.

A leitura dos Apophtegmata fornece pistas valiosas, quanto ao modo de vida no deserto, e ajudam a pôr em perspectiva o tópico do monge solitário, o "eremita". A escolha pelo deserto, o recolhimento na cela, o silêncio e o isolamento não eram um fim em si, mas meios para alcançar, gradualmente, a perfeição. Assim, os monges tinham consciência de ir pertencendo a uma sociedade crescente, constituída por homens com o mesmo 
propósito de vida, que estabeleciam relações entre si, se visitavam, e se orientavam uns aos outros, sendo um encontro programado a celebração dominical da liturgia Eucarística. Uma das relações privilegiadas suscitadas era a que se estabelecia entre o abade, ou seja, o pai espiritual, e seu discípulo, a qual está na génese da produção do apotegma ${ }^{43}$. A ascese é, portanto, um caminho que deve aprender-se, num modo particular de socialização.

Originalmente, este processo de transmissão é exclusivamente oral. Dizer, ouvir dizer, memorizar no âmbito de uma cultura que não utilizava a escrita, e depois, eventualmente, aquele que ouviutornar-se ele próprio transmissordo ensinamento que lhe foi legado, teria sido o processo que despoletou estas peças, autênticos quadros vivos da experiência dos primeiros ascetas no deserto.

A economia de palavras faz parte do seu processo de composição: em primeiro lugar, porque o monge assume o silêncio, a renúncia à parrhesia ou loquacitas, como uma das práticas ascéticas, ou seja, as palavras devem ser poucas, e quando ditas, devem ser ponderadas e exactas. Em segundo lugar, a palavra breve oferece melhores condições de memorização, pelo que se adequa à forma de circulação privilegiada destes discursos, no seu início exclusivamente oral.

Isso, naturalmente, levanta dificuld des quanto à primeira fase de agregação dos apotegmas em colecções, pelo que o que se afi ma a seguir resulta, essencialmente, de conjecturas: alguns discípulos retinham na memória os ditos inspirados dos seus mestres, outros talvez, escolarizados, por ventura até os que vinham das cidades, ou de outros lugares do Oriente, que não o Egipto,

${ }^{43}$ Gould, Graham, (1993) The Desert Fathers on Monastic Community, O xford. Gould estuda os elementos que, nos apotegmas, denunciama existência de relações interpessoais que reclamam a expressão de regras de conduta social e a defini ão de uma moral que regule as relações entre os monges que vivem em vários desertos, sendo os mais célebres as nas colónias monásticas de Scétis (um monaquismo de realização muito diversifi ada). Os ascetas devem assim evitar as falhas que o prejudicam na sua relação com o outro: a ira, a inveja, a maledicência. Guy, J. -Cl. (1961) "L es Apophtegmata Patrum”, Théologie de la Vie Monastique, Paris: 73-83. Também Burton Christie (1993) The Word in the desert...: 5) fala da "charismatic relationship between master and disciple". 
teriam começado por passar à escrita, numa versão semelhante a um "caderno de apontamentos", para uso pessoal, as palavras que os haviam sensibilizado ${ }^{44}$. Daqui resultou um modelo de colecção muito primitivo: desconexo, em que as peças se ajustavam sem ordem aparente ou, quando muito, dispostas pelo nome do autor da sentença.

Agora, consideremos que o mesmo ancião teve mais do que um discípulo e ouvintes, em diferentes momentos, e a vários legou o mesmo discurso, na sua lapidar sabedoria. Surgem portanto, muito próximo da sua criação, vários factores de divergência nos textos recebidos.

E, de facto, um dos aspectos mais interessantes nos estudos dos apotegmas é o de encontrar traços plausíveis de uma vivência real, tarefa possível de levar a cabo quando se comparam testemunhos diversos do mesmo núcleo textual, exibindo essas diferenças acidentais, de pormenor, que resultam de um processo de transmissão múltiplo; ou quando se analisam como um todo os apotegmas atribuídos a um padre, dispersos em vários depoimentos, e daí emergem elementos para a caracterização da identidade da figu $\mathrm{a}^{45}$.

Os apotegmas dão testemunho de personalidades reais. Antão, Macário, Pambo, Poemen, Arsénio, Orsiésio, Nilo, Amoun, e tantos outros, autores das sentenças inspiradas, são figu as cujas vidas também aparecem ilustradas nos relatos dos visitantes do deserto que mencionámos antes. A obra anónima Historia Monachorum in Aegypto, a de Paládio e de Cassiano, compostas na $1^{\text {a }}$ metade do séc. $V$, teriam conhecido estas colecções primitivas e teriam utilizado partes destas pequenas recolhas como modo de ilustrar a sabedoria dos seus autores. Estes autores deverão, portanto, ser considerados não só enquanto

\footnotetext{
${ }^{44}$ G uy, J. -CL. (1993) Les Apophtegmes..., S ources Chrétiennes $387: 20$

${ }^{45}$ Folliet, G. (1996) "La tradition latine des Septem capitula "Abbatis Moysi" Vigiliae Christianae, 50: 200-209. Cf. infra também, Paschasius, Liber Geronticon Freire, J.G. ed. cap. VI). W. Harmless (n. ss.: p. 486-503) estuda os ditos atribuídos ao abade Poemen. (p. 487) "many figu es in the Apophtegmata are cross-listed, so to speak in other Works of early monasticism", refere o investigador como argumento de reforço para a autenticidade destas personalidades.
} 
instância de confi mação, mas também enquanto testemunhos do processo de recepção e de funcionalidade dos apotegmas, e até como testemunhas de uma fase intermédia da fix ção da tradição apoftegmática.

Segundo L ucien Regnault e mais recentemente William Harmless, os apotegmas foram coligidos e passados à forma escrita na Palestina, onde os monges vindos das profundas distâncias de Scétis e de outros retiros no Norte de África buscaram refúgio após os ataques bárbaros de 407 ao Sudoeste Egípcio e às prósperas comunidades monásticas aí localizadas ${ }^{46}$. $\mathrm{O}$ acolhimento dos apotegmas por esta diáspora correspondeu também a um recuo da tradição oral, em benefício de diversas tradições escritas que já não pertencem ao género apoftegmático, mas a outras obras monásticas independentes, como a homilética, a hagiografia a hermenêutica bíblica, a teorização espiritual. A tradição é então organizada segundo os dois modelos principais conhecidos, ou seja, os nominativos ou a série alfabética, isto é, os apotegmas segundo o nome dos autores por ordem alfabética e segundo a unidade do tema, e, a partir desta organização surge uma outra ordem mais racional, que reúne o conjunto em torno de temas espirituais, e, descrevendo o progresso espiritual do monge, são fonte de edifi ação.

O Liber Geronticon De octo principalibus uitiis de Pascásio de Dume descende desta última tipologia, conhecida como a colecção sistemática ${ }^{47}$. Saliente-se, novamente, a extraordinária capacidade de estas colecções se difundirem pelo mundo tardio, nas mais diversas línguas, entre as quais o latim, sinal da popularidade e dinamismo da espiritualidade monástica nos sécs

46 Regnaut, L. (1981) "Les apophtegmes en Palestine aux V-VI siècles, Irénikon 54: 320-330. Harmless, W. (2000) "Remembering Poemen Remembering: the Desert Fathers and the Spirituality of Memory", Church History, 69: 483-518. Constitui este um dos primeiros estudos que, ao que sabemos, se debruçou sobre a hermenêutica da criação literária apoftegmática. Segundo Harmless (p. 484), este grupo de fugitivos eram sete monges. Também Bitton- Ashkelony and Kofsky A. (2000) "Gazan Monasticism in the fourthsixth Centuries: from Anchoritic to Cenobitic", Proche-Orient Chrétien 50: 14-62.

${ }^{47}$ G uy, J. C. (1984), Recherches...: 231-232. 
V e VI e depois, largamente, durante toda a Idade Média.

O tema da colecção, "os oito vícios principais" implicou uma teorização da espiritualidade monástica amadurecida, na medida em que apresenta de modo progressivo os vícios ou pecados que ameaçam o progresso espiritual do monge e, na segunda parte da colecção, acrescentam-se os capítulos sobre as virtudes opostas. É um tema caro e popular do ascetismo cristão, que foi cultivado antes e após a composição dos apotegmas, e que pela sua profundidade reflexiva é indício de que os apotegmas, sob uma superfície simples, ingénua e anti-intelectual, escondem uma complexidade filosófica que tem vindo a ser estudada, mas está longe de se ter esgotado ${ }^{48}$.

Muitos caminhos de investigação se abrem cada vez que um texto é restaurado e dado a conhecer. Este ve longe do nosso propósito, nesta introdução, desbravar qualquer um deles. Pretendemos, no entanto, apontar alguns caminhos para aspectos que porventura carecem de uma atenção mais aprofundada. Por exemplo, a tradução apoftegmática latina, desde S. Martinho, Pascásio, Pelágio e João permanece sem tradução em português. Também as relações de contaminação, ou seja os cruzamentos entre os textos monásticos de vários géneros, praticamente contemporâneos uns dos outros, e os apotegmas permanecem como área de trabalho profícua. Por fim interessa estudar a adaptação do género no Ocidente latino, de que Pascásio é um digno representante. Tendo chegado já como uma tipologia de textos não produtiva, as condições da sua resistência no Ocidente medieval, e em particular no Noroeste hispânico, podem e devem fazer pensar.

${ }^{48}$ Evágrio do Ponto, uma das vozes identifi adas nos Apotegmas como um dos padres do deserto, foi o primeiro asceta a teorizar sobre os "logismoi", os maus pensamentos que feriam a ascese monástica, e o modo de os combater (Évagre le Pontique Traité Practique ou le Moine, , A. Guillaumont ed. e trad. (1971) Sources Chrétiennes 170-171, L e Cerf. Guillaumont, A, "un philosophe au desert: Evagre le Pontique", Aux origines du Monachisme chrétien. Pour une phenomenologie du monachisme, SP 30, Ab. de Bellefontaine: 185-212. Sobre a difusão dos tratados de virtudes e vícios, Newhauser, R. (1993) The treatise on vices and virtues in latin and the vernacular, Turnhout. 


\section{POST SCRIPTUM}

Quando íamos entregar esta notas introdutórias, deparouse-me encontrar na Faculdade de L etras o Padre José Geraldes Freire, que continua a frequentar a Escola, na sequência de vários trabalhos. Ocorreu-me então a pergunta que deixei atrás: “- O que não está feito, afinal?” Com simplicidade e confian a, ousámos fazer-lhe esta pergunta a ele próprio.

Como de costume, não se furtou ao diálogo. E com naturalidade me respondeu mais ou menos o que se segue:

"Primeiro, há uma sugestão, e até um pedido, que me tem sido feito várias vezes, ao longo dos anos: - para divulgação junto de um público mais vasto, porque não apresenta a tradução dos Apotegmas, que publicou em primeira mão, através da obra de Pascásio de Dume, o Liber Geronticon, e da colecção por si descoberta das Commonitiones Sanctorum Patrum?

Devo responderque essa hipótese esteve sempre subjacente. Falaram-me até em colecções ideais para o fazer. A verdade é que nunca avancei eu com a proposta. Nunca me faltou que fazer...

Segundo, passo a contar-lhe um interesse meu muito mais antigo. Quando, no Instituto de Estudos Clássicos, de Coimbra, logo em 1963, me foi proposto pelos professores que me tinham convidado, em Julho anterior, que escolhesse um tema para um projecto de investigação, em ordem ao doutoramento, eu respondi: - Gostaria de estudar os autores latinos da Antiguidade Tardia, isto é, do final do Período Romano e do Suévico-Visigótico até à invasão árabe!

Responderam-me logo que, nesse caso, havia que consultar dois Mestres dessa época: o Prof. Díaz y Díaz, em Salamanca, e a Prof ${ }^{a}$ Christine Mohrmann, em Nimega, (Holanda). Assim se fez, logo desde as férias do Verão de 1963, por cartas. E assim entrei em contacto: primeiro, com os autores do Latim Tardio do Ocidente Hispânico, nomeadamente com Pascásio de D ume; depois, para adquirir uma especialização em Latim Vulgar (lá estava por detrás o professor de nós os três de Coimbra, que logo me recebeu também amavelmente, o Doutor Paiva Boléo) e em Latim e Grego dos Autores Cristãos, houve que frequentar a 
Escola de Nimega.

E daí arrancou um projecto que me tem ocupado até hoje, sempre com novas metas à frente. Além disso, nunca deixei de trabalhar com interesse na Filologia Clássica e na Linguística Histórica e de desenvolver os inícios do Latim Medieval, ministrados em Nimega, criando mesmo, a partir de 1978, o L atim Medie val em Portugal, tanto notarial (sécs. IX-XIV ) como literário (sécs XII-XV) um nunca mais acabar de textos, temas e autores.

E, aqui para nós, nunca me esqueci de aplicar a mim o conselho do Arcebispo de Braga, em 1948, ao Dr. Avelino de Jesus da Costa: “- Vai para Coimbra, mas nunca se esqueça de que é padre; e de Braga!" A mim, o meu Bispo não precisou de me lembrar de que eu era de Portalegre e Castelo Branco! O Sr. D. Agostinho, quando o Doutor Providência Costa e o Doutor Walter de Medeiros foram a Portalegre pedir-lhe para me ceder, a eles disse-lhes que sim; mas a mim, só me disse que ia pedir para mim uma audiência ao antigo Professor de Coimbra, então já há 30 anos Cardeal-Patriarca de Lisboa.

Perdoe aonde foi desembocar a resposta a uma pergunta sobre os apotegmas dos Padres do Deserto! Mas não consigo terminar ainda sem lhe contar que o Doutor Cerejeira se lembrava muito bem dos seus colegas de Faculdade; e me falou com intimidade dos Doutores Carlos Ventura (de Clássicas) e Joaquim de Carvalho (de Histórico-Filosófi as); e finalmente se comoveu, invocando o seu Padrinho de imposição de insígnias, Doutor António de Vasconcelos, que, tal como os quatro padres que mencionei, acabaram por ganhar também um especial vínculo à respectiva Sé Catedral. Q ue tudo seja dedicado a D. O. M.”

Por minha parte, terminei, agradecendo. 



\section{QVIBVSCVMQVE ME ADIVVARVNT}

En uobis pars apophthegmatis a Paschasio translati, cuius mirabile exemplum mihi facti estis.

IOANNES COLOBVS, 18 (212)

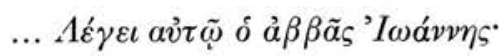

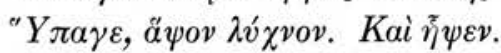

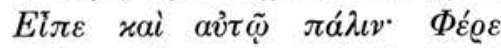

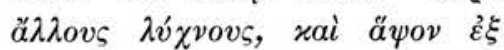

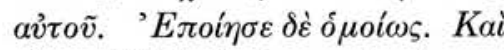

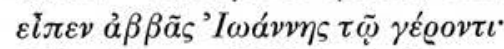

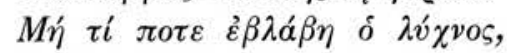

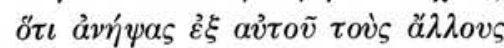

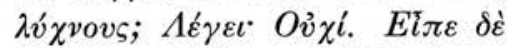
o $\gamma \varepsilon \dot{g} \omega v^{*}$ O

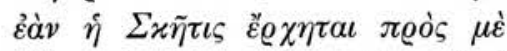

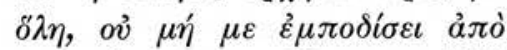

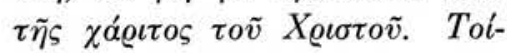

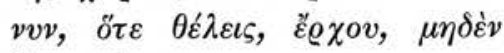

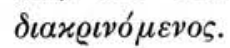

PASCHASIVS, LXXIII, 8 ... Cui abbas Ioannes: Vade et incende lucernam. Et cum incendisset, iterum dicit ei: Affer alias lucernas et incende ex ipsa. Cum autem ita fecisset, dicit ei: Numquid aliquid laesa est lucerna quia de illa alias incendisti? Cumque ille renueret, dicit: Et sic Ioannes: Etsi omnes qui in Sceti commanent ueniant requirere me, non mihi impediunt a gratia Christi. Quotienscumque ergo uis, ueni sine discretione. 

DISSERTAÇÃo APRESENTADA À FACULDADE DE LETRAS DA UNIVERSIDADE DE COIMBRA PARA OBTENÇÃO DO GRAU DE DOUTOR EM FILOLOGIA CLÁSSICA 



\section{$P R O ́ L O G O$}

Lembro-me como se fosse hoje. Poucos dias antes do Natal de 1962 os Profs. Doutor Américo da Costa Ramalho e Doutora Maria Helena da Rocha Pereira incitaram-me a apresentar alguns temas donde pudesse ser seleccionado um estudo que viria a servir de tese para as minhas provas de doutoramento. Percorrendo as Literaturas Grega e Latina, desde Homero ao desmoronar do Império Romano, mostrei timidamente depois uma gama de doze pontos, o último dos quais tinha por título:-o latim tardio no actual território português. Foi precisamente este que mereceu a preferência dos promotores do meu avanço nos estudos. E ocorreram logo as investigações levadas a cabo no domínio do latim tardio pela escola sueca do Prof. Löfstedt e no campo da «lingua especial dos cristãos» pela escola de Nimega, na Holanda.

Para delimitar mais o tema escolhido, aconselhou-me o Prof. Dr. Costa Ramalho a consultar o seu colega e amigo, então em Salamanca, Prof. Dr. Manuel Caetano Díaz y Díaz, sem dúvida o maior conhecedor da literatura latina medieval da Hispania. Assim surgiu no meu horizonte a figura de Pascásio, cuja obra, na opinião do Prof. Díaz y Diaz, era mal conhecida, mas susceptivel de fornecer material de interesse para uma investigação filológica. Quando, em vários encontros posteriores, comuniquei em Salamanca a marcha dos meus estudos, o Prof. Díaz y Díaz quase se escusou de me ter lançado para caminhos que nunca suspeitara fossem tão longos e acidentados. Mas as suas palavras decisivas foram para mim de orientação e grande estímulo.

Tendo começado pouco depois a recolha de documentação paleográfica, para fundamentar uma edição crítica, chegou a altura de me preparar para a apreciação linguística do texto. Pareceu então que o centro de investigação mais apropriado seria Nimega. Pedida a colaboração e direç̧ão dos meus estudos à Prof. ${ }^{a}$ Dr. ${ }^{a}$ Christine A. E. M. 
Mohrmann, prontamente veio resposta favorável. Estava decidida a minha ida para a Holanda nos anos lectivos de 1965-66 e 1966-67. $E$ Este o marco definitivo do arranque e avanço dos meus estudos.

$\mathrm{Na}$ Universidade de Nimega frequentei, durante os dois anos, o "Seminário» de Metodologia do Estudo do Grego e do Latim da Antiguidade Cristã, dirigido pela Prof. ${ }^{a}$ Ch. Mohrmann. Ao mesmo tempo segui também, nos dois anos lectivos, os seus cursos de Língua e Literatura Grega da Antiguidade Cristã, e de Lingua e Literatura Latina da Antiguidade Cristã. Atendendo à natureza do Autor que devia apreciar e aos objectivos globais da minha investigação, no ano lectivo de 1965-66 frequentei ainda o curso de Latim Vulgar, do Prof. B. E. Vidos, e de Latim Medieval, do Doutor L. J. Engels (que no ano seguinte passou a titular desta disciplina na Universidade de Gróninga). Vendo-me na necessidade de estudar longamente numerosos manuscritos, aproveitei o ano de 1966-67 para sistematizar conhecimentos sobre paleografia, seguindo as lições de Epigrafia e Paleografia Grega, do Prof. Dr. J. G. A. Ros, e de Paleografia Latina, do Prof. Dr. A. G. Weiler.

Sobre o que se conhecia até agora a respeito de Pascásio e o que nós conseguimos apurar, dará conhecimento o estudo que apresentamos. Vemo-nos na obrigação, no entanto, de deixar aqui uma advertência de carácter metodológico. A transmissão manuscrita da obra do monge de Dume revelou-se tão extensa e complicada que a sua análise não pôde limitar-se a um capítulo introdutório da edição crítica e da apreciação do texto. Como se verá, do escrito do súbdito de S. Martinho de Dume não só era mal conhecida a sua difusão, como sobre ele se têm emitido opiniões desprovidas de fundamento científico. Sendo assim, a descrição dos manuscritos e a prova filológica da evolução do texto alongaram-se 
tanto que tiveram de editar-se como segundo tomo do nosso trabalho. Em rigor, o nosso estudo deve ser apreciado como um conjunto. Procurámos, apesar disso, dar uma justificada unidade a cada um dos tomos. No primeiro, temos uma introdução cultural e literária sobre os problemas até agora suscitados por Pascásio, seguida duma análise das suas técnicas de tradução e particularidades do seu uso da língua latina. A edição do texto genuíno de Pascásio de Dume é o centro de toda a obra. $O$ segundo tomo é, como dissemos, todo ele consagrado às fases da transmissão manuscrita.

Quanto custou este trabalho, nem nós podemos já calcular a nossa parte, pois o tempo vai esbatendo a recordação de renovadas lutas $e$ canseiras. $O$ que não podemos esquecer é que ele seria impossível sem a ajuda, amparo e colaboração de muitas pessoas dedicadas e de instituições que se consagram à promoção da cultura e da investigação.

Em primeiro lugar devemos mencionar o Mecenas que patrocinou todo o nosso estudo, nomeadamente uma longa permanência no estrangeiro, vultuosas despesas de microfilmes e reproduções fotográficas de manuscritos, viagens a distantes bibliotecas, etc. - o Instituto de Alta Cultura, a cuja Direç̧ão nunca agradeceremos suficientemente as possibilidades que nos proporcionou. Dos centros de estudo-além dos de Nimega — não devemos omitir, pelo menos, o Institut de Recherches et d'Histoire des Textes, de Paris, e a Bibliotheca Bollandiana, de Bruxelas. A nossa gratidão vai também para diversos eruditos a quem recorremos várias vezes por correspondência, como por exemplo, o Prof. Dr. R. Draguet, de Lovaina; o Rev. P.e Jean-Claude Guy, de Toulouse; e Dom Columba Maria Batlle, monge de Monserrate, durante largo tempo a preparar o seu doutoramento em Munique, onde fez várias pesquisas a nosso pedido, antes e depois de nós próprio termos mergulhado 
também na riquíssima colecção de manuscritos da Biblioteca do Estado da Baviera.

A resenha da evolução do nosso estudo já deixou adivinhar o papel nele desempenhado pelo Prof. Dr. M. C. Díaz y Díaz. Mas não será possivel exprimir condignamente a nossa admiração e gratidão pelo modo com que a Prof. ${ }^{a}$ Dr. ${ }^{a}$ Ch. Mohrmann inúmeras vezes nos recebeu tanto no Instituto Clássico como na sua casa, em Nimega. A sua luz estende-se por todo o mundo da filologia clássica e românica. Lá procurámos também nós acender a nossa lucerna - para empregar a bela imagem de um dos apotegmas traduzidos por Pascásio.

Regresso de novo ao lar. Este longo trabalho é publicado na HVMANITAS. Só quem conhece bem a técnica difícil da composição de uma edição crítica - e aqui vai o nosso louvor para o esmero da Imprensa de Coimbra - pode apreciar a generosidade do Prof. Dr. A. da Costa Ramalho ao acolher esta tão dispendiosa publicação na revista que dirige. Mas no Director do Instituto de Estudos Clássicos de Coimbra eu vejo muito mais que um chefe: -é o orientador, o impulsionador, o amigo (permita-se-me a sinceridade do sentimento) que nos conquista pelo seu exemplo de trabalho, abnegação e estima. Retribuir-lhe só é possivel com uma inteira e leal dedicação.

Sempre que penso na minha preparação cientifica tenho que remontar às origens. O meu curso em Coimbra - de 1957 a 1962 - foi o único ao qual um conjunto de circunstâncias proporcionou que tivesse como professora, em nove cadeiras, a Doutora Maria Helena da Rocha Pereira. Quem seguiu um dos seus cursos fica a admirar para sempre a erudição, o rigor científico, a finura pedagógica das suas lições. Mas não pode fazer ainda ideia do que seja ser encaminhado do princípio 
até ao fim por uma Mestra que não se repete, não se esgota e não se cansa. Foi no seu «Seminário» que fui iniciado nos problemas de uma edição crítica; e a última directriz para a apresentação do aparato crítico do texto de Pascásio fica a dever-se-lhe também. A sua disponibilidade para auxiliar quem precisa de ajuda parece inspirada nesta frase vertida para latim por Pascásio: Quotienscumque ergo uis, ueni (LXXIII,8). Não há palavras para dizer quanto the devo.

Tenho obrigação de mencionar, finalmente, que este trabalho só pôde realizar-se graças também à dispensa de actividades pastorais correntes, que me foi concedida pela Autoridade eclesiástica a que estou ligado-livre, afectiva e juridicamente. Eu não esqueço nunca que, quando, em 1951, o então Bispo de Portalegre, Dom António Ferreira Gomes, me conferiu o sacramento da Ordem, me recebeu ad titulum seruitii Dioecesis. Se o seu sucessor e meu actual Venerando Prelado, Dom Agostinho Lopes de Moura, me permitiu dedicar-me ao ensino universitário e à investigação científica, apesar da escassez do clero de Portalegre e Castelo Branco, foi, certamente, porque entendeu que também esta pode ser uma forma de serviço da Igreja, à qual nunca foram indiferentes os problemas da cultura e do ensino. Eu nunca ousei pedir-lhe, no entanto, a isenção dos encargos diocesanos que deliberadamente assumira. Parece-me, pois, esta uma ocasião propícia para deixar aqui bem expresso que, embora longe, procurarei não vir a desmerecer da comunidade presbiteral a que pertenço. Sic me Deus adiuuet!

Coimbra, 11 de Fevereiro de 1971.

P. e José Geraldes Freire 

IN T R O D U ÇÃO 



\section{Cap. I-PASCÁSIO, SỨbito DE S. MARTINHO DE DUME}

\section{1 - O PREFÁCIO DE PASCÁSIO, DEDICADO A S. MARTINHO DE DUME}

Tudo o que até aqui se tem dito, de concreto, sobre Pascásio está baseado quase só numa fonte histórico-literária:-o prefácio da sua tradução dos apotegmas dos Padres do Deserto, dirigido a «Martinho, presbítero e abade». A obra de Pascásio é seguida imediatamente, na transmissão dos manuscritos, por outra tradução de apotegmas, feita por «Martinho, bispo de Dume». Da unidade íntima destas duas versões e da coincidência de S. Martinho ter sido o fundador do mosteiro de Dume, se tem concluído, e cremos que com razão, que Pascásio era monge em Dume e súbdito de S. Martinho, que primeiro ali seria simplesmente «presbítero e abade» e depois foi «bispo de Dume».

Dada a importância deste único documento original sobre Pascásio, vamos transcrevê-lo e traduzi-lo. Em seguida ordenaremos ideològicamente todas as conclusões que ele nos permite tirar.

Domino uenerabili patri Martino, presbytero et abbati, Paschasius.

Vitas patrum, Graecorum ut cetera, facundia studiose conscriptas, iussus a te, sanctissime pater, in latinum transferre sermonem,
Pascásio, ao venerável senhor e pai, Martinho, presbítero e abade.

As Vidas dos Padres, tal como as restantes obras dos gregos, escritas com todo o cuidado e elegância, tendo-me vós ordenado, santíssimo pai, que as vertesse para a língua latina, 
insolito si licuisset operi renituissem. Nec umquam quod scribi uel legi possit excludi, ingenii uecordis conscientia prohibente. Scire enim me quod nihil sciam non audeo dicere, ne uerbum hoc propter hoc uerbum, sapientissimo Socrati subripiam. Sed quia tuae me parere necesse est iussioni utar. Non gloriabor ingenio, fidemque quam tibi debeo etiam in opere iniuncto praestabo. Verum quia eloquentium uirorum sunt plurimae sermone latino conscriptae, quaram lectiones me expertem esse te etiam adstruente testificor, si quid de illis aut hic insertum forte repereris aut minus eleganter expressum, ne meae culpae reputetur exoro. Quia sicut in dato mihi codice reperi scripta sic transtuli, licet nec ea studiose posse profitear. Vnde restat ut quod te iubente coepi, te orante perficiam. Quae tamen si scribenda decreueris, ut tuo polire sermone digneris exposco. Neque enim mihi liquebit quaedam tibi placuisse, nisi et aliqua displicuisse cognouerim. se me fosse possível, negar-me-ia a este trabalho a que não estou habituado.

Porém, eu nunca excluí o que pudesse ser escrito ou lido, pois disso me impedia a consciência de ceder a uma insensata inclinação.

Com efeito, eu não ouso dizer que "sei que nada sei»; este dito, ao sapientíssimo Sócrates não o subtrairei, a propósito da ordem que me foi dada.

Antes me servirei dele, pois me sinto obrigado a obedecer a este vosso preceito: não me gloriarei do meu saber; e também nesta obra que me foi imposta mostrarei a fidelidade que vos devo.

Todavia, visto que há muitas obras de homens eloquentes redigidas em latim, nas quais me confesso versado graças também ao vosso amparo, peço-vos que não atribuais a culpa minha se delas algo ou ocasionalmente aqui encontrardes inserido ou expresso de modo menos elegante.

Pois, tal como encontrei escrito no códice que me foi dado assim traduzi, embora deva reconhecer que não o pude conseguir com arte.

Por conseguinte, resta-me a esperança de concluir pelo mérito das vossas orações o que comecei por mandado vosso.

E se determinardes que isto deve ser fixado por escrito, rogo vos digneis poli-lo com o vosso estilo. Pois não estarei certo de que algumas partes vos agradaram, se não puder verificar que também outras vos desagradaram. 
Não vamos dizer que todas as ideias expressas e cada um dos elementos do formulário utilizados por Pascásio são achados originais para este prefácio. Ninguém nos pode também forçar a concluir que se trata de um encadeamento de ideias e expressões que faziam parte da técnica dos prólogos, pelo que nada de especial nos seria lícito deduzir quanto aos reais sentimentos de Pascásio. Parece-nos oportuna aqui esta singela observação da Prof. ${ }^{a}$ Dr. $^{a}$ Christine Mohrmann: «Uma situação semelhante sugere palavras semelhantes, e as possibilidades do vocabulário de cada língua humana são limitadas: ao dizerem a mesma coisa, duas pessoas usarão provàvelmente mais ou menos as mesmas palavras» (1).

Cremos que apesar de certo convencionalismo dos prólogos, Pascásio seleccionou as ideias e expressões que melhor condiziam com a realidade dos seus sentimentos. Vamos, pois, ordenar sistemàticamente os pontos que traduzem a sua situação pessoal ao escrever o prefácio.

1 - Pascásio devia ser súbdito de Martinho. A dedicatória, apesar de respeitosa, não chega para o provar. Mais peso tem o facto de a tradução dos apotegmas ter sido um trabalho imposto por Martinho a Pascásio. Não há ideia tão acentuada como esta: iussus $a$ te, tuae iussioni, in opere iniuncto, te iubente, scribere decreueris. O cumprimento da ordem recebida é repetidamente encarado como um dever de obediência, virtude esta que exige uma submissão total, ligada, por certo, a um vínculo religioso: nec quod scribi uel legi potest excludi, me parere necesse est, fidemque quam tibi debeo etiam in opere iniuncto praestabo. Uma obediência que não exclui nada em relação a um abade, que vai até um trabalho antes não previsto, não pode ser entendida senão como expressão de um voto monástico.

(1) Ch. Mohrmann, The latin of Saint Patrick, Dublin, 1961, p. 8. Sobre o prólogo como género literário cf. T. JANSON, Latin prose prefaces, Studies in literary conventions (Acta Uniuersitatis Stockholmiensis, Studia Latina Stockholmiensia, XIII), Stockholm-Göteborg-Uppsala, 1964; A. A. R. BASTIAEnSEN, Le cérémonial épistolaire des chrétiens latins in Graecitas et Latinitas Christianorum Primaeua, Supplementa, Fasc. II, Nouiomagi, 1964, pp. 4-45; P. GiuffrIDA, Lanx Satura, Miscellanea Philologica, Università di Genova, 1963, pp. 113-216 (sobre os dois proémios do De inuentione de Cícero); J. MADOz, Citas y reminiscencias clásicas en los padres españoles in Sacris Erudiri V (1953) p. 115; J. LECLERCQ, Le genre epistolaire au Moyen Age, Lyon, 1946. 
2 - Pascásio foi discípulo de Martinho ou pelo menos deve-lhe muito da sua cultura nas letras clássicas. Logo no começo há uma referência ao brilho da Literatura Grega, o qual se revela também nos escritos sobre as Vitas Patrum. Mais adiante cita uma frase célebre, embora corrente, atribuída a Sócrates. Da Literatura Latina admira igualmente os eloquentes escritores. Neste ponto confessa a sua leitura frequente das obras em latim. Damos especial valor à expressão te etiam adstruente. Se adstruo não tem aqui o valor exacto de instruir, significa pelo menos que Martinho incitou e amparou Pascásio tanto nas letras gregas como nas latinas. $\mathrm{O}$ advérbio etiam não o interpretamos como referindo-se até ao apoio de Martinho no estudo das obras latinas, mas como uma ligação entre o conhecimento do grego e também o do latim, um e outro cultivados por Pascásio por incitamento de Martinho. Por fim refere-se a uma possível influência, certamente estilística, mais que vocabular, dos autores latinos preferidos.

3 - Pascásio menciona algumas das possíveis razões de escusa. É esta, talvez, a parte mais convencional: si licuisset renituissem, non gloriabor ingenio, minus eleganter expressum, insolito operi. Deveremos desta última expressão concluir que Pascásio não fizera até então quaisquer traduções, pelo menos de responsabilidade? Porque não acreditar na sua palavra? Lamentemos apenas que tal tenha acontecido, pois na obra que nos deixou revela-se um tradutor bem dotado.

4 - Pascásio deixa transparecer a delicadeza da sua consciência e dos seus sentimentos. Quando estudarmos as suas «técnicas de tradução", veremos até que ponto ele suprime palavras tidas como menos decentes, recorre a eufemismos e revela pureza de carácter (2). Podemos, pois, ver traços da sua psicologia quando fala da conscientia prohibente, ao manifestar a sua modéstia: licet nec ea studiose posse profitear, no pedido de orações ou quando no trecho final pede com tanta insistência e graça que o seu trabalho seja revisto pela mão do próprio Martinho. Teria ele feito essa revisão? Não sabemos.

5 - Pascásio garante-nos que fez uma tradução fiel do grego. A nossa «apreciação de Pascásio como tradutor» (3) vem confirmar esta asserção. Dando inteiro crédito às suas palavras, ficamos com

(2) Cf. cap. III, parágrafo III, nn. 1-9 e sobretudo nn. 11-13.

(3) Cf. todo o cap. III. 
a grata certeza de que se salvou através desta tradução latina um livro de apotegmas; ordenado por assuntos, cujo original grego parece estar irremediàvelmente perdido. Graças a Pascásio podemos reconstituir o seu título e conteúdo.

\section{2-AUTENTICIDADE DO PREFÁCIO E DA TRADUÇÃo DE PASCÁSIO}

Não encontrámos um só estudioso que pusesse em dúvida a autenticidade do prefácio e da obra atribuída a Pascásio. O problema não chega mesmo a ser posto a não ser por Salonius, o qual após um breve exame do prefácio escreve estas palavras: «Nós não temos nenhum motivo para duvidar desta apresentação de Pascásio, pois ela está em perfeito acordo com o que já sabíamos dele e da sua relação com Martinho, bispo de Braga» (1).

Todavia, ninguém até hoje tentou estabelecer um paralelo entre o estilo do prefácio e as características literárias da tradução de Pascásio. Cremos que é nossa obrigação fazer esse trabalho. Partindo, pois, das qualidades estilísticas que demonstramos serem típicas de Pascásio, vejamos agora até que ponto elas se reflectem e repetem no prefácio, o qual, evidentemente, nunca é considerado, no capítulo relativo ao valor da tradução.

Logo a primeira frase mostra uma das preocupações de Pascásio quando procura fazer estilo mais perfeito (2): a distribuição das palavras é algo artificiosa (III,2). O começo por Vitas Patrum, o complemento directo, é intencional e feliz, pois anuncia imediatamente o tema que vai ser versado. Note-se, porém, a distância a que é colocado o particípio atributivo conscriptas.

O grupo Graecorum ut cetera é tão rebuscado que Rosweydus não o compreendeu (3). Na sua edição escreve: Vitas Patrum Grae-

(1) A. H. SAlonius, Vitae Patrum. Kritische Untersuchungen über Text, Syntax und Wortschatz der spätlateinischen Vitae Patrum, Lund, 1920, p. 36.

(2) Os números romanos e árabes que vão entre parêntesis, depois de cada característica de estilo, remetem para os parágrafos e suas subdivisões do capitulo III, "Apreciação de Pascásio como tradutor».

(3). H. Rosweydus, Vitae Patrum, De uita et uerbis seniorum siue historiae eremiticae libri $X$. Antuerpiae, ex officina Plantiniana, 1628. Citaremos sempre 
corum (ut cetera) facundia studiose conscriptas... Esta pontuação, parecendo mais simples, tem o defeito de fazer pensar que vão ser descritas as Vidas dos padres Gregos... E já mais que um Autor se viu na necessidade de explicar que a maioria dos ascetas não eram sequer de língua grega, mas que Pascásio ter-se-ia deixado levar pelo facto de o seu original estar escrito em grego (4). Afinal perdia-se assim uma clara alusão ao brilho da Literatura Grega.

Perfeita é também a colocação das últimas palavras da primeira frase: insolito si licuisset operi renituissem.

Este artifício leva mesmo a jogos de palavras com clara intenção estilística (III,1). Repare-se na distribuição quiástica de ne uerbum hoc propter hoc uerbum, em que além da inversão da ordem do grupo uerbum hoc, a palavra uerbum é utilizada em sentido diferente, como fizemos ressaltar na nossa tradução. Igualmente o fecho do prefácio apresenta um paralelismo dos dois membros da frase, com realce para a antítese placuisse ... displicuisse.

Dos variados processos de negação utilizados por Pascásio há um aqui repetido: a sua preferência pela conjunção nec ... neque: nec enim umquam ... neque enim mihi liquebit (III,1).

Do seu gosto pela uariatio (III,4) encontramos aqui exemplo na atribuição da facundia aos gregos, da eloquentia aos latinos e em recear para si próprio que seja minus eleganter. Note-se ainda a preocupação de variar as conjunções coordenativas no princípio de frases ou membros de frase: sed, uerum, quia, unde, tamen. Só enim se encontra repetido.

A construção enfática de dignor seguido de infinitivo (III,6) aqui aparece também: ut tuo polire sermone digneris.

Rosweydus segundo a reprodução desta edição por J. P. Migne, Patrologia Latina, tt. LXXIII-LXXIV. A obra de Pascásio constitui o Livro VII e encontra-se na PL t. LXXIII, coll. 1025-1066.

Adoptaremos a grafia Heribertus Rosweydus que era a usada pelo grande estudioso, nascido em Utreque em 1569 , mesmo nas suas obras em latim e até, com uma pequena variante, nas obras em flamengo. Em Antuérpia, cidade onde viveu longos anos, publicou as Vitae Patrum em latim em 1615 e 1628 e aí veio a falecer em 1629. Nas traduções flamengas escrevia o seu nome com hífen: Ros-weydus. Achamos arbitrárias as grafias Rosweyd ou Rosweyde, esta última adoptada mesmo pelos Bolandistas. Sobre a figura de Rosweydus, cf. H. Delehaye, L'oeuvre des Bollandistes à travers trois siècles (1615-1915), Bruxelles, 1959, pp. 11-21.

(4) Cf. por exemplo, J. Perez de Urbel, San Martin y el monaquismo in Bracara Augusta VIII (1957), p. 53. 
De igual modo o relativo de ligação com valor demonstrativo (III, $1,7 \varepsilon, 8 \beta)$ aqui se encontra uma vez: quae tamen si scribenda decreueris...

Há processos que, embora mais comuns, Pascásio não deixou de sublinhar. Note-se a frequência dos verbos no fim do período ou dos respectivos membros de frase (II,5): renituissem, excludi, subripiam, utar, praestabo, testificor, exoro, transtuli, profitear, cognouerim. Não se perdeu também a oportunidade de apresentar um ablativo absoluto (III, $1,7 \varepsilon, 8 \beta, 8 \eta)$ : conscientia prohibente.

Anotemos ainda algumas manifestações de latim tardio: expertem tem aqui o mesmo valor de expertum; as formas excludi e renituissem serão objecto de um estudo especial (5).

Finalmente registemos a transposição do antecedente de quarum, que é lectiones, para dentro da oração relativa. Assim se compreende o caso e a concordância de plurimae conscriptae, à primeira vista sem substantivo de apoio. Trata-se de mais um rebuscado processo pelo qual Pascásio quis mostrar a sua capacidade na sintaxe latina.

$\mathrm{O}$ exame acabado de fazer mostra bem que as qualidades reveladas por Pascásio ao longo da sua tradução encontram um reflexo nas breves linhas do prefácio. Do ponto de vista estilístico podemos, pois, garantir a unidade do autor de toda a obra.

Não deixemos, no entanto, de confessar que no seu conjunto o prefácio não é uma peça de brilho literário. Falta-lhe ductilidade e clareza de expressão. Ao longo da sua tradução, Pascásio apresentará trechos mais simples e elegantes. Talvez que a preocupação de condensar em poucas frases um apreciável número de ideias e o desejo de apresentar provas da sua capacidade retórica contribuam para dar ao prefácio um aspecto geral de pouca fluidez, simplicidade e elegância. Já Mário Martins notara que o prólogo de Pascásio não abona muito a qualidade do seu latim, pois talvez por pretender fazer estilo caiu numa construção muito embrulhada (6).

(5) Cf. cap. III, parágrafo IV, n. 6.

(6) M. Martins, Pascásio dumiense, tradutor in Brotéria LI (1950) pp. 295-296. 


\section{3-O TRADUTOR DAS «SENTENTIAE PATRUM AEGYPTIO- RUM» NÃO É PASCÁSIO, MAS SIM MARTINHO, BISPO DE DUME}

A mais antiga referência literária a Pascásio encontra-se no livro De Scriptoribus Ecclesiasticis, de Sigeberto de Gembloux, terminado no ano de 1111. Aí se lê no "cap. CXVII. Martinus episcopus transtulit, per manum Paschasii diaconi, interrogationes et responsiones plurimas sanctorum Aegyptiorum Patrum in Dumiensi coenobio» (1).

Esta redacção é manifestamente ambígua. Rosweydus diz uma vez que a obra de Pascásio, isto é, o Livro VII, tem, segundo Sigeberto, o titulo de Interrogationes et responsiones SS. Aegyptiorum Patrum e noutro passo, embora atribua as Sententiae a S. Martinho, conclui que talvez a tradução destas também tivesse sido feita por Pascásio (2). Perez de Urbel, que não acha feliz para a obra de Pascásio o título de Vitas patrum Graecorum, acrescenta: «Com mais propriedade Sigeberto Gemblacense, aludindo a esta obra chama-lhe Interrogaciones $y$ responsiones dos padres egípcios» (3). A confusão chegou ao ponto supremo de Glorieux, para rectificar erros da Patrologia Latina ter escrito esta simples anotação: «vol. 73, 1025-1062. De uerbis seniorum $=$ Martin de Braga» (4).

(1) Cf. Patrologia Latina, t. CLX, col. 572. O simples número do capitulo de Sigeberto é objecto de discrepância entre os autores. Rosweydus, o primeiro a citá-lo, diz sempre que é o n. 118 (cf. PL LXXIII, coll. 16, 43 e 50). Garnefeld menciona também o cap. 118 (G. GARNEFELD, Elucidationes sacrae in quinque libros de imaginibus antiquorum eremitarum, Coloniae, 1621, p. 635). Florez e Caetano do Amaral, porém, referem-se ao cap. 117 (H. Florez, España Sagrada, t. XV, Madrid, 1759, p. 129; A. CaEtano do Amaral, Vida e opuisculos de S. Martinho Bracarense, Lisboa, 1803, p. 9). A nossa perplexidade aumentou quando vimos Luís Ribeiro Soares dizer primeiro que é no cap. CXVII e depois que no CXVIII (L. R. Soares, A linhagem cultural de S. Martinho de Dume, Lisboa, 1963, p. 169 e p. 196, com a agravante de nesta última página referir o cap. CXVI a Pelágio e o CXVII a João). Para evitar quaisquer dúvidas, conferimos o citado vol. CLX da PL e verificámos a seguinte ordem de atribuição: cap. CXV, Pelágio; CXVI, João; CXVII, Martinho e Pascásio; CXVIII, Smaragdus.

(2) PL LXXIII, coll. 43 e 86.

(3) J. P. DE URBeL, San Martin y el monaquismo in Bracara Augusta VIII (1957) p. 53.

(4) Mgr. P. Glonieux, Pour revalorizer Migne. Tables rectificatives, in Mélanges de Science Religieuse IX (1952), Cahier supplémentaire, Lille, p. 47. 
A frase de Sigeberto deu origem a um duplo erro: $10^{\circ}-$ julgar que a obra de Pascásio se intitula Interrogationes et responsiones e que pertence a Martinho;.$^{\circ}$ - atribuir a tradução das Sententiae Patrum Aegyptiorum, com probabilidade, a Pascásio.

$\mathrm{O}$ problema só pode ser resolvido com o recurso à transmissão manuscrita das duas obras. Ver-se-á então que a confusão foi provocada pelo facto de Sigeberto de Gembloux apenas conhecer a obra de Pascásio através de um manuscrito que erradamente a atribuía a Martinho.

A crítica textual revelou-nos que os manuscritos que nos transmitem cópia do texto autêntico de Pascásio e de Martinho são os da recensão longa, em melhor estado os do arquétipo $\alpha$ do que os de $\beta$ e seus derivados. Vamos resumir o testemunho dos códices (5).

Toda a série extensa, a verdadeira, tem no final da capitulatio de Pascásio com o n. CII (no arquétipo $\alpha$ ) ou CI (nos derivados do hiperarquétipo $\beta$ ) o seguinte título: Sententiae patrum Aegyptiorum quas de graeco in latinum transtulit Martinus Dumiensis episcopus.

Terminada a cópia do texto de Pascásio, o arquétipo $\alpha$ (representado só pelo Vaticanus latinus 4921 e Vat. Ottobon. lat. 942, visto que o códice de Madrid, Acad. Real da Hist., 80 está truncado) principia a tradução de Martinho repetindo exactamente o mesmo título.

Nos derivados de $\beta$ desenha-se uma divisão, sendo difícil de determinar onde teve a sua origem. Nos representantes de $\gamma$, o de Paris, Bibl. Nacional lat. 2768A mantém (só com omissão de Aegyptiorum) o título anterior; o do Porto, Bibl. Municipal 753, apresenta só o prin-

(5) A nossa exposição baseia-se no estudo directo da transmissão manuscrita. Os elementos paleográficos sobre os códices citados e as provas da autenticidade da recensão longa encontram-se descritos nos capítulos que lhes são destinados. Ver-se-á que chegámos à mesma conclusão de L. RiBeiro SOARes (op. cit., pp. 164-195) quanto ao erro provocado em Sigeberto por um manuscrito do tipo de Cambridge, Sidney Sussex College 47, mas fica completamente desfeita a sua suposição da prioridade duma não existente tradição "cantábrico-escótica" pela qual se provaria que o título original da versão de Martinho deveria ser Interrogationes et responsiones patrum Aegyptiorum quas de graeco in latinum transtulit Martinus episcopus in monasterio Dumiensi. 
cípio da redacção assim alterado: Item interrogationes et responsiones patrum..., mantendo-se o final Martinus Dumiensis episcopus.

Dos representantes de $\delta$ só Londres, Museu Brit. add. 30855 tem o texto de Martinho, reproduzindo exactamente o título de $\alpha$. O mesmo acontece aos derivados de $\varepsilon$ que têm o texto, isto é, Monte Cassino, Bibl. Abadia 50, e Salamanca, Bibl. Universitária 2537.

Dos restantes manuscritos da série longa só o de Seo de Urgel, anno 938, transmite a obra de Martinho, com o seguinte título, onde se nota uma omissão no princípio e a alteração do final: Item interrogationes patrum Aegyptiorum... transtulit Martinus episcopus in monasterio Dumiensi.

Conclui-se, portanto, que tanto em $\alpha$ como em $\beta$ o título era Sententiae patrum... Martinus Dumiensis episcopus. No entanto, copistas da Hispania devem ter mudado, não sabemos quando nem onde, o título para Interrogationes et responsiones ... Martinus episcopus in monasterio Dumiensi.

A recensão breve não tem capitulatio. Dá, todavia, após a tradução resumida de Pascásio uma versão também abreviada de Martinho. O seu mais antigo representante é o ms. de Estugarda, Bibl. Estadual, Theol. 303, com o título Interrogationes et responsiones Aegyptiorum patrum quas de graeco in latinum transtulit Martinus episcopus in monasterio Domense. O ms. de Bruxelas, Bibl. Real da Bélgica lat. 8216-18, de que dependerão todos os outros do tipo breve, apenas introduziu a substituição de et por uel.

Vamos entrar na parte decisiva para explicar a redacção de Sigeberto. A série média contaminada dispunha dum modelo do tipo $\varepsilon$ e de outro da recensão breve, A capitulatio foi reduzida a 79 títulos dos 101 de Pascásio. Após o último segue-se, sem numeração, no ms. de Winchester, Bibl. Catedral III. J. m., a seguinte redacção: Interrogationes et responsiones sanctorum patrum Aegyptiorum plurimae quas de graeco transtulit Martinus episcopus in monasterio Dumense. Como se poderá verificar o organizador deste modelo acrescentou sanctorum e plurimae, (tendo este copista omitido in latinum) e manteve a ordem primitiva de patrum Aegyptiorum. A introdução de plurimae é intencional, porque este modelo não transcreve o texto de Martinho, mas acrescenta sòmente várias das suas sentenças misturadas com os últimos capítulos de Pascásio.

Observe-se, porém, que este modelo faz preceder a capitulatio do prólogo de Pascásio. Os copistas resolveram o problema da falta 
de título anterior ao prefácio de diferentes modos. O de Winchester escreveu: In Christi nomine incipit prologus super uitas et consolationes sanctorum patrum. E segue-se a dedicatória e a carta de Pascásio a Martinho. Porém, o copista do manuscrito que se encontra em Cambridge, Sidney Sussex College 4.3.2. (47) recorreu a um processo original: suprimiu o último título da capitulatio que se referia à obra de Martinho, bem como a dedicatória de Pascásio, e antes do prefácio colocou esta redacção única (fl. 84v): Incipiunt collationes et uitae sanctorum patrum Aegyptiorum quas de graeco in latinum transtulit Martinus episcopus in monasterio Dumigense Pascasio. Cá está um título ambíguo que parece atribuir a obra a Martinho, não se percebendo bem qual a função de Pascasio.

Notemos ainda que este erro não é exclusivo do manuscrito de Cambridge. O códice de Paris, Bibl. Nacional, lat. 17632, que em parte lhe é aparentado, começa o resumo do texto de Pascásio com estes dizeres (fl. 146v): Incipit prologus quorundam interrogationum et responsionum sanctorum patrum Aegyptiorum quas transtulit de graeco in latinum Martinus episcopus in monasterio Dumensi.

Após este exame das fontes manuscritas podemos assegurar que o cap. CXVII do De Scriptoribus Ecclesiasticis de Sigeberto de Gembloux depende de um título do tipo que se lê no ms. de Cambridge. Lembremos que esta série média contaminada foi com muita probabilidade organizada na Gália e que os manuscritos actualmente existentes se encontram sobretudo no Norte da França, na Bélgica e na Inglaterra. Gembloux é a poucos quilómetros a Sudeste de Bruxelas e Sigeberto compulsou por certo um manuscrito com o incipit tão ambíguo como o de Cambridge. Sigeberto não conheceu senão uma coleç̧ão de apotegmas em que Pascásio e Martinho estavam envolvidos. Daí a sua ambígua redacção, em que o Pascasio do título foi desdobrado em per manum Paschasii diaconi.

Podemos pois concluir: $10^{\circ}$ - a obra cujo prefácio começa por Vitas Patrum é tradução de Pascásio; $2^{\circ}$ - Martinho, bispo de Dume, traduziu uma outra colecção cujo título inicial é Sententiae patrum Aegyptiorum quas de graeco in latinum transtulit Martinus Dumiensis episcopus. 


\section{4-OPINIÕES DIVERSAS SOBRE PASCÁSIO. APRECIAÇÃO}

A figura e a obra de Pascásio têm dado ocasião a diversas hipóteses, no geral expressas a propósito de estudos sobre S. Martinho de Dume (1). Vamos tentar resumir o essencial, guardando para o fim uma rápida apreciação.

O nome Pascásio é de origem hebraica e está documentado na área portuguesa desde a alta Idade Média. $\mathrm{Na}$ linguagem vulgar, com pronúncia espanhola, tornou-se um substantivo comum, «pascácio», com valor depreciativo (2).

(1) Que saibamos, só há dois artigos especialmente consagrados a Pascásio: Mário Martins, Pascásio dumiense, tradutor, in Brotéria LI (1950) Lisboa, pp. 295-304 e Columba M. Batlle, Contribució a l'estudi de Pascasi de Dumi i la seva versió de "Verba Seniorum» in Estudis Romànics, Instituto d' Estudis Catalans, Barcelona, VIII (1961) pp. 57-75. Como vamos sistematizar ideias, deixamos aqui a bibliografia a que recorremos e que consideramos expressiva da opinião tradicional: H. FloreZ, España Sagrada, t. XV, Madrid, 1759, pp. 111-133 e t. XVIII (1764) pp. 27-31; A. Caetano do Amaral, Vida e opúsculos de S. Martinho bracarense, Lisboa, 1803, pp. 1-138; Fr. J. Perez de Urbel, Los monjes españoles en la Edad Media, I, Madrid, 1945, pp. 183-193 e pp. 215-221; C. W. BARLow, Martini episcopi Bracarensis opera omnia, New Haven, 1950, pp. 1-10; J. MADoz, Martin de Braga, En el XIV centenario de su advenimiento a la Peninsula (550-1950), in Estudios Eclesiásticos (Revista das Faculdades de Teologia da Comp. de Jesus em Espanha) XXV (1951) pp. 219-242; e A. DE Jesus Da Costa, S. Martinho de Dume, Braga, 1950: citamos a separata de Bracara Augusta II (1950) n. 3, Outubro. Neste opúsculo o Rev. Prof. Dr. Avelino da Costa resume a opinião tradicional e junta a documentação antiga, desde as obras do próprio $\mathrm{S}$. Martinho e o prefácio de Pascásio, a Venâncio Fortunato, S. Gregório de Tours, Santo Isidoro de Sevilha, os Concílios de Toledo e as lições do Breviário de Soeiro. Um lugar à parte ocupa a tese do Dr. Luís Ribeiro Soares, A linhagem cultural de S. Martinho de Dume, I-Fundamentos, Lisboa, 1963. Esta obra merece cuidada atenção dos especialistas porque dá uma visão completamente diferente da tradicional, procurando situar o nascimento e toda a formação de S. Martinho na Itália, donde teria vindo directamente para a Galaecia. A par de elementos muito oportunos, que parecem realmente encaminhar-nos para a direcção apontada, tem, quanto a nós, o defeito de prescindir dos testemunhos tradicionais com os quais, afinal, se podia conciliar. Várias vezes teremos oportunidade de manifestar a nossa concordância ou discordância. As referências a Pascásio ocupam aí as pp. 163-231. Quando nos referirmos neste parágrafo aos autores acabados de citar, não mencionaremos mais a obra e a página.

(2) Cf. Neves ReIS, $A$ influência do povo na formação da linguagem in Boletim da Sociedade de Lingua Portuguesa V (1954), pp. 21-22. 
No geral pensa-se que Pascásio de Dume era de origem galaica. Todavia, C. M. Batlle atendendo ao conhecimento do grego e à intimidade com S. Martinho põe a hipótese de ele ser proveniente, como o seu abade, da Panónia ou de outra região oriental sob a influência do helenismo (3). L. Ribeiro Soares rejeita categòricamente a naturalidade galega de Pascásio e está convencido de que ele antes de vir para a Galiza era monge em Roma, com S. Martinho.

Quanto ao facto de Pascásio ser monge e súbdito de S. Martinho não há uma só discordância. A essa conclusão leva o prefácio que precede as Vitas Patrum e o género literário destas. Mário Martins vai ao ponto de desejar que um pintor nos mostrasse S. Martinho e Pascásio, em Dume, curvados sobre um códice grego, a procurar a palavra latina única e insubstituível que havia de salvar para a posteridade uma obra cujo original se perdeu.

Sigeberto de Gembloux é o primeiro escritor a dizer que Pascásio era diácono. A edição de Rosweydus apresenta, no título, o Livro VII como «traduzido por Pascásio, diácono da Santa Igreja Romana». A partir de então toda a tradição considerou como certa a qualidade de diácono. Foi Dom Columba, na esteira de outros, quem provou, com mais documentação, que Pascásio não era diácono nem da Igreja de Roma nem da de Braga. De facto nenhum manuscrito lhe atribui esse grau de ordens sacras. Dom Columba e L. R. Soares coincidem em imputar a responsabilidade desse erro a Sigeberto de Gembloux. Como este autor nos capp. CXV e CXVI do De Scriptoribus Ecclesiasticis, tratara de Pelágio e João, diácono e subdiácono, respectivamente, da

(3) Foi o sr. D. António Ferreira Gomes, bispo do Porto, quem em 1966, em Lourdes, nos chamou a atenção para a possibilidade de Pascásio ser, como S. Martinho, originário da Panónia, lembrando também que em Portugal, principalmente no Norte, há várias localidades com o nome de Panóias, uma delas muito célebre, perto de Vila Real. Poderá haver nestes topónimos uma relação remota com o apostolado missionário de $\mathrm{S}$. Martinho que assim veria homenageada a sua pátria. Por coincidência, também numa área linguística que engloba pelo menos a região de Vila Real, Felgueiras e Penafiel, o nome de Panóias pode ter dado origem ao substantivo comum "panão», com significado depreciativo.

A sugestão de que Panóias represente uma homenagem à Panónia de $\mathrm{S}$. Martinho foi sob outro ângulo posta por MANUEL DE BOAVENTURA (Subsidios e achegas para o estudo filológico de dois vocábulos da toponimia portuguesa: Dume e Panóias in Bracara Augusta VIII (1957) pp. 29-30) com o suposto de que todas as Panóias portuguesas, tal como a Panónia, são terras férteis. E panóia ou panaia é uma gramínea que pode ser farinada e dar pão! 
Igreja de Roma, é muito provável que ao tratar no cap. CXVII de novo tradutor de sentenças dos Padres do Deserto lhe tivesse atribuído, por mera suposição, o título de diácono. Se o foi, não há disso documento que resista à crítica. Dom Columba M. Batlle insiste, com razão, que Sigeberto pode também ter sido atraiçoado pela sua cultura, pois no princípio do séc. VI existiu em Roma um Pascásio, esse verdadeiramente diácono, autor de um tratado, hoje perdido, De Sancto Spiritu.

O que não está certo é L. R. Soares dizer que a expressão diácono "da Santa Igreja Romana» é invenção de Rosweydus. Ora este autor declara explìcitamente (cf. PL LXXIII, col. 51) que duvida que Pascásio de Dume tivesse sido diácono «da Santa Igreja Romana» e que apenas mantém esta expressão por assim encontrar escrito em edições anteriores das Vitae Patrum, não tendo coragem de suprimir este título.

Aliás, na descrição das edições anteriores, Rosweydus deixa rasto doutros títulos. A terceira edição das Vitae Patrum chamava-lhe «Pascásio, abade» (PL LXXIII, col. 71). Mas já Garnefelt rebatera este atributo, dizendo que se deve tratar de confusão com «Paschasius Rathbertus, abbas Corbeiensis» (4). De facto, S. Pascásio Radberto, abade beneditino de Corbie viveu de 785 a 860 .

Mais interessante é notar que a primeira edição das Vitae Patrum conhecida de Rosweydus «começa assim a quarta parte: Incipit prologus sancti Paschasii, ad exhortationes sanctorum patrum tam Graecorum quam Aegyptiorum» (PL LXXIII, col. 68). Poder-se-ia tratar também de confusão com S. Pascásio Radberto ou qualquer dos outros Pascásios a quem é concedida a honra da santidade. Lembremos que a tradição quer que por ocasião da fundação do convento de Santa Cruz de Coimbra tivesse existido um S. Pascásio natural desta cidade (5).

Aqui está um ponto em que os hagiógrafos bracarenses poderão deter-se. Os melhores manuscritos da obra de Pascásio, os do arquétipo $\alpha$, começam assim: Incipit Liber Geronticon, de octo principalibus uitiis, de graeco in latinum translatum a beato Paschasio. Este título é o que melhor condiz com a natureza da obra. Desde quando e até quando foi Pascásio de Dume considerado santo? Tem pelo menos

(4) G. GARNEFELT, Elucidationes sacrae in quinque libros de imaginibus antiquorum eremitarum, Coloniae, 1621, p. 635.

(5) Cf. Grande Enciclopédia Portuguesa e Brasileira, vol. XX, Lisboa, 1945, p. 510 . 
a seu favor o facto de não se tratar de personagem inventada e de os manuscritos em questão serem os que estão mais próximos do original dumiense.

H. Florez rejeita, com toda a razão, que Pascásio tenha traduzido também o Livro V, como pensavam Bivar e Nicolau António. Trata-se de confusão com Pelágio.

A opinião tradicional é que Pascásio aprendeu o grego em Dume, sob o magistério de S. Martinho. Os termos imprecisos do prefácio a este respeito não obstam a uma tirada de imaginação de Dom Justo Perez de Urbel, significativa da vivacidade espanhola. Vamos traduzi-la para dar um pouco de colorido a esta seca exposição. Depois de ter resumido o conteúdo das Sententiae de S. Martinho, continua Dom Justo: «Havia ali, sobretudo, um grande livro intitulado Vidas dos Padres que lhe havia servido a ele para tirar um grande número das suas sentenças. Tê-lo-ia traduzido ele mesmo, mas as suas actividades missionárias impediam-no. Afortunadamente tinha a seu lado um discípulo inteligente que tinha conseguido aprender o grego; era o diácono Pascásio. Martinho pôs em suas mãos o códice: -É preciso, disse-lhe, que os teus irmãos possam tirar também daqui edificação e ensinamento. Pascásio teria recusado»... Assim se mistura investigação com fantasia!

«Hinnebusch sugere que Pascásio aprendeu o grego no Oriente e veio para a Hispania com Martinho» (6). C. M. Batlle adere a esta hipótese e vai mais longe, dizendo que o prefácio-dedicatória não autoriza a dizer que Pascásio tenha aprendido o grego com S. Martinho. Mais apropriado lhe parece antes que Pascásio tivesse aprendido, como segunda língua, o latim e não o grego.

Quanto ao local e data da tradução, a opinião comum é que foi feita em Dume, quando Martinho ainda era «presbítero e abade». Ora a sua sagração episcopal foi a 5 de Abril de 556. Como a chegada a um porto da Galaecia foi por 550, conclui-se que a tradução, atendendo ainda ao tempo necessário para Pascásio aprender bem o grego, teria sido elaborada entre 550 e 556 , pendendo mais para as proximidades da segunda data.

Luís Ribeiro Soares dedica longo espaço (op. cit., pp. 211-223) a esta questão da determinação do local e data da tradução de Pascásio. Pensa que Pascásio traduziu primeiro as Vitas Patrum e que só poste-

(6) Traduzimos de BARLow, op. cit., p. 9, nota 14. 
riormente Martinho verteu os ditos dos Padres do Egipto «no mosteiro de Dume». Forçado a recuar a data do trabalho de Pascásio, acaba por concluir que a tradução já viera feita de Roma, onde Martinho e o discípulo viviam antes de se dirigirem para a Galaecia. Mais ainda, comparando quatro passos da Regra de S. Bento, que terá sido escrita entre 540 e 547, com os Livros III e VII de Rosweydus, conclui que a Regra já citou estas traduções das Vitae Patrum. Sendo assim, a tradução de Pascásio seria anterior pelo menos a 547, data da morte de S. Bento.

Não nos compete analisar as fontes da Regula Benedicti. Devemos, no entanto, avançar, sumàriamente o seguinte: $10^{\circ}-\mathrm{O}$ n. 6 de III Rosw. tem paralelo em Pelágio IV, 57. Aí poderia ter-se o santo inspirado, pois cita o cap. $\mathrm{V}$ de Pelágio várias vezes. $2 .^{\circ}-\mathrm{O}$ n. 206 de III Rosw. é na realidade um arranjo de parte de Martinho 108 (ed. Rosw.) como provamos na nossa identificação dos números do III Rosw. Sendo assim, haveríamos de concluir também que S. Bento utilizou a tradução de Martinho e portanto que esta era igualmente anterior a 547. Mas como, se L. R. Soares julga ter provado que Martinho traduziu em Dume, depois de 558?! $3 .^{\circ}$ - Restam dois passos (III Rosw. 170 e 196) que de facto só têm paralelo em Pascásio. Quanto a nós, os pontos da Regra que L. R. Soares julga dependerem de Pascásio (e de Martinho) constituem princípios gerais de ética e ascética que então, como hoje ainda, fazem parte do verdadeiro espírito religioso (7). Pascásio e Martinho não poderão constituir, portanto, baliza para a Regula Benedicti e muito menos para a Regula Magistri.

Após este encadeamento de opiniões por vezes contraditórias, o nosso parecer é que devemos limitar-nos aos conhecimentos que documentação segura nos fornece. Insistiremos em três pontos: $10^{\circ}-\mathrm{O}$ prefácio-dedicatória é o documento histórico fundamental que nos permite apurar alguns elementos sobre Pascásio: seria monge e súbdito de Martinho, a quem deveu incentivo para o conhecimento das línguas clássicas.

(7) Mart. 108 é uma longa sentença proferida por Silvano. Em III Rosw. 206 o apotegma é anónimo. Que estes pensamentos eram correntes pode provar-se, neste caso, pelo facto de as mesmas palavras também serem atribuídas a Santo Antão: Cf. F. Halkin, Bibliotheca Hagiographica Graeca, t. III, Bruxelles, 1957, p. 197, n. 5 ad. 
$2 .^{\circ}$ - A tradução que nos deixou revela-o um bom conhecedor do grego, capaz de verter para latim com fino gosto estilístico. Podemos também comprovar, por seu intermédio, que Pascásio possuía uma grande delicadeza de sentimentos. Do ponto de vista estritamente linguístico, não cremos que a tradução latina permita estabelecer qual a área geográfica onde foi elaborada. O vocabulário e a sintaxe são comuns aos meios literários de toda a Romania no século VI.

$3 .^{\circ}$ - A transmissão manuscrita garante-nos que o núcleo de expansão foi a Hispania visigótica. A recensão longa é a que melhor corresponde ao grego; os códices dela existentes ou foram copiados na Península Ibérica ou dependem de outros em escrita visigótica. Todas as outras recensões apresentam claros indícios de elaboração secundária. Cremos, por isso, lícito concluir que a tradução, se não foi feita na Hispania, aqui foi, por certo, primeiro utilizada. Atendendo à junção íntima dos trabalhos de Pascásio e de Martinho, o mosteiro de Dume deve ser considerado como originário ponto de partida.

Para além do que nos permitem vislumbrar o prefácio, a tradução e a transmissão manuscrita, cremos que tudo o mais que se diga de Pascásio não ultrapassará o plano das hipóteses ou das probabilidades.

Retomemos, para exemplo, algumas das questões tratadas. Seria Pascásio de origem galaica? Do fundo étnico ibero-romano ou de estirpe suévica ou de outros invasores que passaram pelo Noroeste Peninsular? Teria aprendido o grego com colonos ou missionários bizantinos? Faria uma peregrinação aos Lugares Santos? Teria vindo da Panónia, do Oriente ou de Roma - antes ou juntamente com S. Martinho? Considerando o ambiente político e cultural da época (8), poderíamos opinar:- tudo isto é possível. Mas para estas e outras interrogações só há uma resposta segura: - não sabemos.

(8) Sobre política geral da Galécia neste período, cf. História de Portugal, direç̧ão de Damião Peres, vol. I, O Dominio Germânico por F. NEWTON DE MACEDo, Barcelos, 1938, pp. 308-361; Historia de España, dirigida por R. MENENDEz PIDAL, tomo III, España Visigoda (414-711), Madrid, 1940, pp. LV + 666. Sobre os contactos com o Oriente, cf. P. GouBERT, Bizance et l'Espagne Wisigotique in Études Byzantines II (1944) pp. 5-78, III (1945) pp. 127-142, IV (1946) pp. 111-133; J. PerEZ DE URBel, Los monjes españoles en la Edad Media I, Madrid, 1945, pp. 351-376, M. Martins, Correntes de filosofia religiosa em Braga dos séc. IV a VII, Porto, 1950, pp. 23-40. 


\section{5-O TRADUTOR DA «VITA TAISIS» É PASCÁSIO E NÃO DIONÍSIO, O EXÍGUO}

A figura de Táisis tem sido objecto de muitos estudos e trabalhos nas letras e nas artes, desde a arqueologia, ao romance, à música, às investigações filológicas (1). H. Rosweydus ao publicar a Vita sanctae Thaisis (cf. PL LXXIII, coll. 661-662) declara que são desconhecidos o autor do original grego e da tradução latina (ibid., coll. 21,47,48-49).

O problema do tradutor começa a complicar-se quando os redactores dos Acta Sanctorum colocam ao lado da versão de Rosweydus uma outra que no manuscrito cotejado é atribuída a Dionísio. Das variantes destas versões concluíram que a Vita Taisis «fora traduzida em latim por dois escritores diversos» (2). Alguns anos mais tarde, ao descreverem os manuscritos de Milão, Bibl. Ambrosiana D. 525. Inf. e I. 145. Inf., os Bolandistas foram um pouco mais longe e disseram que o Dionísio a quem é atribuída a versão destes códices deveria ser o mesmo que traduziu a Vida de S. Pacómio, conhecido por Dionísio o Exíguo (3).

Ora aconteceu que, ao estabelecermos a edição crítica da obra de Pascásio de Dume, no cap. LVII,4 apareceu a história de Táisis numa versão quase idêntica à de Rosweydus. Forçado nos vimos,

(1) Damos uma breve amostra destes trabalhos: AL. GAIET, L'exploration des nécropoles gréco-bizantines d'Antinoë et les sarcophages de tombes pharaoniques de la ville antique e F. NAU, Histoire de Tais, Publication de textes grecs inédits et de divers autres textes et versions, ambos nos Annales du Musée Guimet, XXX (1903), Paris, pp. 27-40 e pp. 51-114 respectivamente; Anatole France, Thais, Paris, 1890; MASSENET, Thais, 1894, cf. apreciação desta ópera em Mário de SAMPaIo Ribeiro, Thais, Lisboa, 1951; O. R. Kuenne, A study of the Thais Legend, Philadelphia, 1922. A Vida de Tarsis faz parte dos textos arcaicos portugueses, cf. Revista Lusitana, XI (1908) pp. 211-212. Não confundir esta Táisis, penitente, com uma outra Taïs, cortesã ateniense, a que se refere DANTE, La Divina Comedia, Inferno, XVIII, 130-136, sobre a qual cf. A. DA Costa Ramalho, Humanitas XVII-XVIII (1965-66) pp. 262 e 365. Entre as várias grafias, preferimos Táisis que é a dos melhores manuscritos da obra de Pascásio.

(2) Acta Sanctorum, editio nouissima, curante Ioanne Carnandet, Octobris tomus quartus quo dies octauus et nonus continentur, Parisiis et Romae, 1866, pp. 223-224 (dia 8 de Out.).

(3) Catalogus codicum hagiographicorum latinorum bibliothecae Ambrosianae ciuitatis Mediolanensis, Bruxellis, 1892, pp. 86-97 e 144. 
pois, a estudar a questão da transmissão manuscrita deste edificante apotegma. Das investigações que fizemos, amplas e laboriosas, resumimos aqui o essencial para a questão que de momento nos interessa - a identificação do tradutor.

Temos actualmente conhecimento de 108 manuscritos que reproduzem a Vida de Táisis. Destes apenas 12 a fazem preceder do prefácio-dedicatória e da introdução atribuída a Dionísio. Os restantes apresentam um leque muito mais largo de variantes (embora todos baseados na simples redacção de Pascásio) do que deixa entrever a numeração da Bibliotheca Hagiographica Latina (4).

Estabelecemos o texto crítico da versão atribuída a Dionísio sobre os mais antigos manuscritos, que são do século xI: Milão, Bibl. Ambros. D. 525. inf. ff. $117^{\mathrm{r}}-118^{\mathrm{r}}$; Paris, Bibl. Nac. Nouv. acq. lat. 1491, ff. $804^{r}-806^{r}$; Roma, Bibl. Valliceliana, XII, ff. $280^{r}-282^{r}$ e Vaticano lat. 5411 , ff. $203^{\mathrm{v}}-205^{\mathrm{r}}$. Verifica-se então que ela se pode dividir em três partes:

1 - Domino carissimo mihi fratri Pastori abbati, Dionysius.

Sanctae Taisiae quondam meretricis mirabilem poenitentiam simplici sermone conscriptam, quam inter alios eximiae conuersationis uiros Aegyptios protulit talium fecunda uirtutum, de graeco me transferre iussisti. Sume igitur ... (= BHL 8014). É a carta-dedicatória.

2 - Salutis humanae aeterni regis aditus poenitentibus patet, etsi quicumque sit nexibus facinorum praegnatus... É uma introdução.

3 - Nam erat quaedam meretrix nomine Taisis tantae pulcritudinis... A segunda e a terceira partes são englobadas numa só numeração na BHL 8015.

Toda a terceira parte segue quase literalmente a tradução de Pascásio LVII,4. Perante tal observação, a atitude do crítico só pode ser esta: ou Pascásio introduziu na sua obra uma tradução já anterior-

(4) Bibliotheca Hagiographica Latina Antiquae et Mediae Aetatis ediderunt Socii Bollandiani, 2 voll., Bruxellis, 1898-1901. De futuro designaremos esta obra apenas por BHL. As variantes baseadas em Rosweydus (= Pascásio) ocupam os nn. 8012, 8013, 8017 e possìvelmente também as interpretações em verso dos nn. 8018 e 8019 . Falta dar um número às Epitomae de que também conhecemos vários manuscritos (cf. BHL, pp. 1160-1161). 
mente feita, libertando-a do prefácio e introdução; ou pelo contrário alguém, chamado ou fingindo chamar-se Dionísio, isolou o n. LVII,4 de Pascásio e enriqueceu-o com as duas primeiras partes. O problema só poderia resolver-se mediante a análise do texto crítico das duas «versões», comparando-o com o grego (5) e com a evolução da transmissão manuscrita. Vamos dar breves amostras dos resultados obtidos.

A maior variante encontra-se no passo seguinte:

\section{PASCÁSIO}

Cum autem, ostio plumbato, discederet, ait ad illum Taisis: Quo iubes, pater, ut aquam meam effundam? At ille respondit: In cella, sicut es digna. Cumque iterum quemadmodum deberet orare requireret, dixit ei: Non es digna nominare Deum...
DIONÍSIO

Cum autem, ostio plumbato, discederet, ait illi Taisis:

\section{Qualiter, pater}

mi, Dominum exorem, priusquam discedas, indica mihi. Dixitque ei senex: Non es digna nominare Deum...

Se atendermos a que se encontram nos textos gregos a pergunta e resposta omitidas por Dionísio, talvez possamos supor que este, por delicadeza ou decência, as eliminou. Mas estranhar-se-á logo a seguir que os elementos priusquam discedas e indica mihi faltem nos textos gregos. E começamos a suspeitar de um arranjo ... Para mais, a expressão: Cumque iterum quemadmodum deberet orare requireret é bem típica dos apotegmas traduzidos por Pascásio.

Fixemos agora um pormenor na continuação desta resposta do abade:

\begin{tabular}{|c|c|}
\hline PASCÁSIO & DIONÍSIO \\
\hline $\begin{array}{l}\ldots \text { quoniam et labia tua ini- } \\
\text { quitate plena sunt } \ldots\end{array}$ & $\begin{array}{c}\ldots \text { quoniam et labia tua }- \\
\text { plena sunt } \ldots\end{array}$ \\
\hline
\end{tabular}

(5) Não possuímos uma versão grega perfeitamente equivalente à tradução de Pascásio = Dionísio. Os textos que conhecemos são vários, reproduzidos por F. NAU, Histoire de Thais (cf. nota 1 deste parágrafo). Ver também F. HALKIN, Bibliotheca Hagiographica Graeca, II vol. Bruxellis, 1957, nn. 1695-1697 (pp. 261-262). 


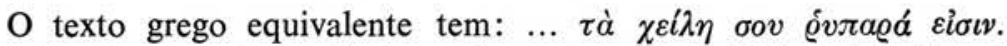

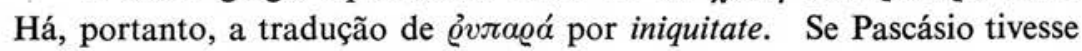
importado a tradução de Dionísio, como poderia ele acrescentar esta palavra coincidente com o grego? Pelo contrário, se supusermos um arquétipo, o de Dionísio, em que iniquitate foi omitida por descuido do copista (pois o membro da frase fica sem sentido) compreendemos por que nenhum manuscrito dele dependente possa ter reproduzido esta palavra.

Desçamos a alguns pormenores pelos quais se pıova que a «versão de Dionísio» depende exclusivamente da de Pascásio.

\section{PASCÁSIO}

Cumque locum illi abbas constituisset quo uenire deberet, illa discedens, collectis omnibus...
DIONÍSIO

Cumque locum illi $a b b a$ constituisset quo uenire deberet, illa descendens, collectis omnibus...

A quase igualdade constante da tradução não deixa admitir a hipótese de dois homens a trabalhar em locais diferentes. Neste extracto, a única diferença de monta é a oposição discedens: descendens. No texto grego correspondente, a forma verbal é ả $\tau \varepsilon \lambda \theta 0 \tilde{\sigma} \sigma \alpha$. É evidente que só discedens lhe corresponde. Pois bem: discedens é a lição típica do arquétipo $\alpha$; no hiperarquétipo $\beta$ deve ter-se dado a alteração, contra o grego, para descendens, como o provam os representantes de $\gamma$ e $\delta$. E assim o erro se propagou até $\varepsilon$, donde, como veremos, é tirada a «versão de Dionísio». Aqui está um pequeno exemplo já a provar também a genuinidade do arquétipo $\alpha$.

A frase que deixámos suspensa continua:

PASCÁSIO

... quaecumque ex peccato susceperat, perlatisque in medio ciuitatis ignem populo expectante adposuit, clamans...
DIONÍsIO

... quaecumque ex peccato susceperat, perlatisque in media ciuitate ignem populo expectante supposuit, clamans et dicens...

Nas três variantes assinaladas o grego não nos pode ajudar a reconhecer a primitiva redacção, porque o sentido não muda profundamente. Vejamos o que nos diz a transmissão manuscrita: supposuit 
aparece em todos os derivados de $\beta$ até $\varepsilon$; em $\gamma$ e $\delta$ temos mediam ciuitatem, sinal de que $\beta$ preferiu in com acusativo; media ciuitate, em ablativo, foi introduzido por $\varepsilon$ : é esta lição, já tão secundária, que Dionísio nos dá; o acrescento et dicens é um reforço da responsabilidade de Dionísio, que não se encontra em nenhuma outra recensão de Táisis. Temos aqui, pois, um indício de que a «versão de Dionísio» não é senão uma reprodução, adaptada, da recensão de $\varepsilon$.

Eis outro fragmento também significativo:

PASCÁSIO

Et profectus ad monasterium in quo fuerat reclusa...
DIONÍSIO

Et profectus ad monasterium in quo fuerat Taisis inclusa...

O nome de Táisis neste passo é uma inovação também exclusiva de Dionísio. A substituição de reclusa por inclusa deu-se em $\beta$, como o mostram os representantes de $\gamma$ e $\delta$. Porém, em $\varepsilon$, reclusa foi restabelecido pela contaminação que este subarquétipo tem $\operatorname{com} \alpha$. Como explicar então que Dionísio, por certo dependente de $\varepsilon$, volte à forma inclusa? Quem continuar a leitura do apotegma verá que precisamente doze palavras adiante aparece o particípio inclusa. A mesma tendência que se verificara em $\beta$ repetiu-se em Dionísio. Talvez que perante a uariatio, uma das características de Pascásio (cf. III,4) o vocábulo reclusa aparecesse como pejorativo... Uma observação devemos, todavia, fazer: o ms. de Paris, Bibl. Nac. nouv. acq. lat. 1491 matém, com $\varepsilon$, reclusa. Ao longo de todo o apotegma observam-se, de facto, dez casos em que este manuscrito de Paris se revela mais próximo de $\varepsilon$ do que os outros de Dionísio.

Um outro destes casos é precisamente a terminação:

\begin{tabular}{c|c} 
PASCÁSIO & DIONísIo \\
$\ldots$ et pausauit in pace. & $\begin{array}{l}\text { et pausauit in pace Domini protegente } \\
\text { pietate. }\end{array}$
\end{tabular}

O parisinus 1491 termina simplesmente: ...et sic quieuit in pace, sem conhecer ainda o acrescento piedoso atribuído a Dionísio, mas com duas pequenas variantes - sic e quieuit - que lhe são próprias. 
Pelo que acabamos de apresentar já se deve ter concluído que a chamada "versão de Dionísio» não é mais que uma reelaboração da tradução de Pascásio, feita tardiamente, pois o subarquétipo $\varepsilon$, de que depende, não poderá ser anterior à segunda metade do século VII.

Quanto a nós, o que se passou foi o seguinte: alguém que conhecia a tradução de Pascásio isolou a Vita Taisis e fê-la preceder de uma carta dedicatória e de uma introdução. Não sabemos se o autor desta suposta versão se chamava Dionísio. Somos de opinião que quem quer que fosse quis atribuí-la, de facto, a um tradutor de nomeada, e escolheu Dionísio, o Exíguo, que trabalhou em Roma durante toda a primeira parte do século vi. O modo como o falsário procedeu foi, porém, desajeitado.

Com efeito, das dez cartas-dedicatórias que se encontram em toda a obra de Dionísio, o Exíguo, nove delas terminam o endereço deste modo: Domino beatissimo patri ... Dionysius Exiguus. Entre as pessoas a quem consagrou trabalhos seus aparece uma dedicatória, mas uma só vez, a um Feliciano Pastori. É a carta que precede a tradução do sermão de Proclo sobre a Virgem. Só que o tradutor desta peça oratória parece ser Mário Mercator e não Dionísio... Não tivemos oportunidade de saber se a autenticidade da carta de Dionísio a Feliciano Pastor também é contestada. Nada nos admiraria, porque também só ela apresenta em posição inversa o nome do destinatário e só nela se lê o estranho atributo «romanus», pois Dionísio era da Cítia. Eis essa direcção: Dionysius Exiguus Romanus Feliciano Pastori (6).

A ninguém passará despercebido que a primeira frase da carta-prefácio atribuída a Dionísio lembra o começo de Pascásio a Martinho, só com diferença da apreciação do original.

(6) As observações que fazemos sobre as cartas-dedicatórias e trabalhos de Dionísio, o Exíguo, são baseadas no que dele está publicado na Patrologia Latina voll. LXVII e LXXIII. O sermão de Proclo está no vol. XLVIII com tradução atribuída a Mário Mercator, rebatendo-se, em nota, que seja obra de Dionísio, o Exíguo. 
PASCÁSIO

Vitas patrum, (...) studiose conscriptas iussus a te (...) in latinum transferre sermonem...
DIONísIO

Sanctae Taisiae (...) mirabilem poenitentiam simplici sermone conscriptam (...) de graeco me transferre iussisti...

Como poderia este Dionísio saber se o original grego estava escrito «com elegância» ou «em linguagem simples», se ele, por certo, não conhecia senão a tradução latina de Pascásio? Com razão notou Siegmund (7) que a tradução de Dionísio (e ele julgava tratar-se realmente de Dionísio, o Exíguo) se mantém estranha aos textos gregos publicados por F. Nau. De facto, os códices gregos apresentam já o apotegma transformado numa biografia precedida de um prefácio. Mas do teor deste prefácio grego não se encontra absolutamente nada no pseudo-Dionísio, o Exíguo - nem na carta-prefácio nem na introdução.

Ninguém se admirará de que uma tradução de Pascásio, um quase desconhecido, seja atribuída a Dionísio. Muito bem observou G. Bardy que os falsários não emprestam obras senão aos escritores ricos (8). Desta vez, porém, o êxito foi reduzido.

Perante a discussão sobre o tradutor da Vita Taisis não nos resta senão deixar aqui uma proposta:-quer saber-se se este apotegma foi traduzido por Pascásio ou não? Estudem-se as técnicas de Pascásio, deixando de fora o n. LVII,4, tal como nós fizemos. Depois, se se quiser um exemplo em que brilhem todas as qualidades de Pascásio, leia-se o n. LVII,4. Temos para nós que a tradução da Vita Taisis é porventura a obra-prima da arte de Pascásio de Dume.

(7) P. Albert Siegmund, Die Überlieferung der griechischen christlichen Literatur in der lateinischen Kirche bis zum zwölften Jahrhundert, München-Pasing, 1939 , p. 225.

(8) Gustave Bardy, La question des langues dans l'Église ancienne, I, Paris, 1948, p. 142. 


\section{6-O AUTOR DE UMA DAS TRADUÇÕES DAS «SETE} SENTENÇAS DO ABADE MOISÉS» É PASCÁSIO, E NÃO S. MARTINHO DE DUME

Como cap. CI da nossa edição crítica de Pascásio apresentamos o De sententiis septem quas locutus est abbas Moyses ad abbatem Poemenem. Embora sem querermos aprofundar aqui o tema, devemos expor sumàriamente os problemas levantados por este capítulo.

Dom Wilmart provou que esta pequena peça anda nos manuscritos gregos como apêndice ao grande livro de Pelágio-João e indicou alguns códices que contêm o seu texto grego (1). O P.e Guy acrescentou alguns manuscritos gregos e ampliou o quadro da sua posição, dizendo que é preferível considerar esta peça, bem como outras pequenas colecções de apotegmas, "como elementos subsidiários sòmente das colecções sistemáticas» (2). Não conhecemos, todavia, outro texto grego publicado, além dos números de Moisés que, na Patrologia Graeca, LXV, Moyses 14-16 e 18 (coll. 288-289), em boa parte correspondem a estas «sete sentenças».

Conhecemos três versões latinas das «sete sentenças do abade Moisés»: a primeira é a que foi publicada por Rosweydus no Livro VI das Vitae Patrum, cap. IV, nn. 1-3 e 7 (este último com uma contextura muito complexa); a segunda foi por Rosweydus incluída como n. 109 das Sententiae de S. Martinho de Dume (cf. PL LXXIV, col. 394); a terceira (e cremos ser o primeiro a dela dar conhecimento) encontra-se, inédita, só nos manuscritos do Vaticano, lat. 4921, fl. $73^{\mathrm{v}}$ e de Salamanca, Bibl. Universitária 2537, fl. 160va. Apenas a mencionada em segundo lugar passará a ocupar a nossa atenção.

Das várias dezenas de manuscritos que a seu tempo citaremos com a transmissão de Pascásio e Martinho, não há um só que termine a tradução do bispo dumiense com as "sete sentenças». Acontece, porém, que Rosweydus só tinha da obra de S. Martinho dois manuscritos: um que the fora enviado pelo P.e Cristóvão de Castro,

(1) A. WILmaRT, Le recueil latin des apophtegmes in Revue Bénédictine XXXIV (1922) pp. 194-195.

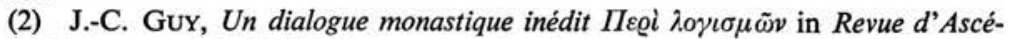
tique et de Mystique, XXXIII (1957), pp. 172-173. 
feito sobre um modelo da Biblioteca de Toledo, e o outro do mosteiro de S. Floriano (cf. PL LXXIII, col. 86). Podemos ainda hoje identificar estes seus modelos. O de S. Floriano é o actual de Bruxelas, Bibl. Real da Bélgica, lat. 8216-18; o de Toledo, ainda se encontra na Bibl. do Cabido, com o n. 27-24. Entre os dois, bem fez Rosweydus em ter preferido a versão do de Toledo, pois o do antigo mosteiro de S. Floriano contém apenas uma recensão abreviada.

Por estranho que pareça à primeira vista, o ms. de Toledo, Bibl. Capitular 27-24, é o único de que temos conhecimento em que as Sententiae de Martinho foram isoladas da obra de Pascásio. A explicação reside no facto de o copista do século XVI (trata-se, de facto, de uma cópia já tardia, mas muito útil para o nosso caso) ter juntado ali desde o fl. $7^{\mathrm{r}}$ a $35^{\mathrm{v}}$ nove opúsculos de $\mathrm{S}$. Martinho, ocupando as Sententiae os ff. $23^{\mathrm{r}}-30^{\mathrm{r}}$.

$\mathrm{O}$ texto crítico, que já estabelecemos, revela que o ms. de Toledo é do mesmo arquétipo que o do Vaticano, lat. 4921. Isto garante-nos que o copista de Toledo (ou um seu antecessor) trabalhou sobre um modelo do arquétipo $\alpha$, onde a obra de Pascásio é seguida das Sententiae de Martinho. Ora no ms. do Vaticano as «sete sentenças do abade Moisés» fazem parte da obra de Pascásio, como cap. CI. Só podemos concluir, pois, que o copista de Toledo (ou o seu antecessor) depois de isolar as Sententiae de Martinho acrescentou ao último número o capítulo de Pascásio que imediatamente as precedia.

Julgamos poder avançar um pouco mais. Quem observar o ms. de Toledo, Bibl. Capit. 27-24 notará que a última sentença de Martinho termina a meio do fl. $30^{\mathrm{r}}$. É muito possível que para preencher o resto da página, com matéria do mesmo teor, o copista de Toledo tenha recorrido a este pequeno capítulo das «sete sentenças de Moisés». Mais ainda: terminando as palavras do abade Moisés, com ponto final, em qui semper sua pecata et non proximi considerat, só no ms. de Toledo se lhe segue esta conclusão, provàvelmente da autoria do seu copista - opitulante gratia Domini nostri Jesu Christi qui cum Deo Patri et Spiritu Sancto uiuit et regnat per omnia saecula saeculorum. Amen.

Com razão observou Barlow que o último número de Martinho já possui uma conclusão apropriada nas palavras de benção sub gratia et uirtute Domini nostri Jesu Christi e que a tradição manuscrita é desfavorável a atribuir a S. Martinho a tradução das «sete sentenças 
do abade Moisés» (3). O que não compreendemos é que este investigador americano tenha, apesar de tudo, incluído a discutida peça no final das Sententiae de Martinho, «só porque Rosweydus também lá as imprimiu»... Igualmente de admirar é que Barlow faça conjecturas sobre o que teria o ms. de Toledo, baseado apenas nas edições, quando esse instrumento de trabalho está ao alcance dos investigadores, através do exame pessoal ou de microfilme.

Vimos assim que Rosweydus foi induzido em erro pelo único manuscrito em que as «sete sentenças de Moisés» vêm depois das de S. Martinho. Quem conhece a transmissão manuscrita sabe, porém, que elas fazem parte de manuscritos da recensão extensa de Pascásio, a autêntica, dos arquétipos $\alpha, \gamma$ e $\varepsilon$. Não deveria, pois, ser mais discutida a genuinidade do trabalho de Pascásio.

Por isso, deve ser inteiramente rejeitada a opinião de L. R. Soares que não só supõe não pertencerem as «sete sentenças» à primitiva versão de Pascásio, mas conclui até serem «um aditamento feito posteriormente», «talvez do autor do Geronticon», a situar «pelo menos, no período visigótico» (4). Tais suposições são totalmente afastadas pelo estudo da transmissão dos textos.

O P. e Mário Martins observou, com minúcia, que a última das «sete sentenças» termina no ms. do Porto, Bibl. Municipal 753, em considerat. Considerando, porém, que a edição de Rosweydus acrescenta opitulante gratia Domini..., julgou que a primitiva redacção poderia ser suspeita de «uma espécie de semipelagianismo larvar, com um certo esquecimento da graça de Deus, semipelagianismo esse que

(3) C. W. BARLow, Martini ... opera omnia, New Haven, 1950, p. 26.

(4) Luís Ribeiro Soares, A linhagem cultural de São Martinho de Dume, Lisboa, 1963, pp. 189-190, nota 42. Devem ser corrigidas as observações feitas nesta n. 42 sobre os mss. de Madrid e de Seo de Urgel. Com efeito, o de Madrid, Acad. R. Hist. 80 tem o texto do cap. VI, De tolleranda penuria, no fl. 127va. Este capítulo foi omitido por todos os derivados do hiperarquétipo $\beta$ na capitulatio. Por isso falta no índice e no texto do de Seo de Urgel. Para explicar que a capitulatio do ms. de Seo de Urgel tenha também as «sete sentenças» sob o n. CI deve reparar-se que o autêntico cap. C, Non loquendum de Scripturis sanctis nisi interrogatus (n. XCIX no índice de Urgel) foi desdobrado com novo título e número C: De curiositate Scripturarum euitanda (fl. $51^{\mathrm{r}}$ ). No texto, porém, este título artificial De curiositate Scripturarum euitanda não se encontra registado senão à margem, a par com o autêntico Non loquendum de Scripturis, sendo completa e ininterrupta a redacção dos apotegmas que o constituem (ff. $137^{\vee}-139^{r}$ ). 
alguns lançaram em rosto a alguns Padres do Deserto» (5). Sabemos agora que este apêndice é exclusivo do manuscrito de Toledo, Bibl. Capit. 27-24 e foi com toda a probabilidade acrescentado por um copista do século XVI que, por certo, estava longe de polémicas e cogitações semipelagianas.

Recordando que Pascásio prometeu traduzir tal como encontrou escrito no códice grego (cf. prefácio) e que as «sete sentenças do abade Moisés» eram uma pequena peça que os copistas gregos gostavam de juntar às coleç̧ões sistemáticas (Wilmart e Guy) aceitaremos, por certo sem relutância, que à coleç̧ão grega de Pascásio se tivesse também juntado este famoso conjunto de «sete sentenças», após os 100 capítulos em que a obra fora concebida.

Não há, pois, motivo para duvidar se esta tradução das «sete sentenças do abade Moisés» pertence ou não a Pascásio. A transmissão manuscrita afirma-o categòricamente.

\section{7-A TRADUÇÃO «DE MEDITATIONIBUS DUODECIM ANACHORETARUM» NÃO É DE PASCÁSIO}

Apesar de nenhum dos dois manuscritos de que Rosweydus se serviu para a sua edição do texto de Pascásio conter o De meditationibus duodecim anachoretarum, o douto hagiógrafo incluiu esta peça monástica como cap. XLIV (PL LXXIII, coll. 1060-1062), levado apenas pela influência de algumas edições anteriores das Vitae Patrum. O que é novo em Rosweydus é a publicação, em nota, do texto grego equivalente, segundo um manuscrito da Biblioteca Imperial, de que lhe fora fornecida cópia por David Hoesch (id. coll. 1062-1064).

Assim, graças à fama do trabalho de Rosweydus e à sua reprodução na Patrologia Latina, este capítulo foi considerado como o único da obra de Pascásio em que se podia confrontar o original grego com a tradução latina. Baseado neste suposto, Salonius fez até um minucioso estudo de colação do grego e do latim, sublinhando o extremo literalismo da tradução, apontando alguns erros devidos ao tradutor

(5) M. Martins, Pascásio dumiense, tradutor, in Brotéria LI (1950) p. 303. Esta hipótese, baseada no "pequeno apêndice acrescentado por algum devoto e escrupuloso copista", foi por L. R. Soares transformada no "aspecto nitidamente semipelagiano». (Cf. obra e pp. indicadas na nota anterior). 
ou ao editor e concluindo que se deve ser muito prudente ao tirarem-se conclusões linguísticas sobre o latim tardio, tendo como ponto de partida apenas textos deste género (1).

Em 1922, porém, Dom Wilmart provou que este capítulo aparece sistemàticamente como um complemento à tradução de Pelágio-João, sob o nome de Correctiones patrum, indicou alguns manuscritos gregos e latinos que o continham como elemento subsidiário da grande colecção sistemática daqueles dois tradutores e concluiu que, com as Sententiae patrum que então editou, a sua tradução deve ser obra de um continuador desconhecido que juntou no fim de João alguns elementos soltos (2).

Apesar disto, J. Perez de Urbel na sua famosa obra Los monjes españoles en la Edad Media continua a dizer que o cap. XLIV de Pascásio (ed. Rosweydus) nos deixa ver nele «um tradutor inteligente e fiel»! (3) E num congresso em Braga exprimiu mesmo a opinião de que o final do De meditationibus:- Haec sapientium et spiritualium responsa patrum. Et ueniat et in nos digna memoria... "é talvez uma exortação do diácono Pascásio aos seus irmãos de Dume ou mais provàvelmente uma adição do próprio $\mathrm{S}$. Martinho» (4).

Foi Dom Columba M. Batlle quem em 1961 rebateu com maior clareza a opinião tradicional, baseado não só no estudo de Wilmart mas ainda na observação de «que a forma extensa (de Pascásio) parece não ter conhecido o suposto cap. 44» (5). Nós acrescentamos desde já que nem sequer a recensão breve nunca o incluiu.

Mencionemos ainda que deste capítulo existe actualmente um texto grego estabelecido crìticamente sobre onze manuscritos, pelos quais se prova que a tradução falsamente atribuída a Pascásio não se baseia sobre as melhores lições (6).

(1) A. H. Salonius, Vitae Patrum. Kritische Untersuchungen über Text, Syntax und Wortschatz der spätlateinischen Vitae Patrum, Lund, 1920, pp. 34 e 36-38.

(2) A. WILMART, Le recueil latin des apophtegmes, in Revue Bénédictine, XXXIV (1922) pp. 185-198.

(3) Op. cit., vol. I, Madrid, 1945, pp. 220-221.

(4) Justo PeRez DE URBel, San Martin y el monaquismo in Bracara Augusta, VIII (1957) pp. 54-55.

(5) C. M. BAtlle, Contribució a l'estudi de Pascasi de Dumi i la seva versió de «Verba Seniorum» in Estudis Romànics, VIII (1961), p. 63 (n. 17) e p. 57 (n. 2).

(6) J.-C. GuY, La collation des douze anachoretes in Analecta Bollandiana, LXXVI (1958) pp. 419-427. 
No estudo que fizemos da transmissão manuscrita de Pascásio as Meditationes duodecim anachoretarum ou Correctiones patrum não se encontram nunca entre o texto de Pascásio, nem sequer imediatamente após qualquer das suas várias recensões. Não poderão, pois, ser consideradas, de modo algum, tradução sua.

Num só manuscrito elas vêm algumas páginas depois do final de Pascásio: é no de Basileia, Bibl. Universitária B. III.23, do séc. XIII. Pascásio termina no fl. $43(41)^{\mathrm{v}}$; depois vem Martinho; em seguida o cap. IV de João; e só depois, nos ff. $47(45)^{\mathrm{r}}-48(46)^{\mathrm{r}}$ temos o texto das Meditationes. Como se vê, ainda aqui, elas estão depois de João, como era de prever, de acordo com o plano apresentado por Wilmart.

Ao longo das nossas buscas sobre manuscritos encontrámos várias vezes as Correctiones patrum, dado que elas concluem muitas vezes o Livro VI de Rosweydus e que Pascásio (Livro VII) vem logo a seguir. Nestas condições, quem está em melhor situação para poder pronunciar-se sobre a posição das Meditationes ou Correctiones patrum, o seu presumível tradutor e a data em que foram anexas ao Livro VI é Dom Columba Maria Batlle que há longos anos se vem especializando na colecção sistemática geralmente atribuída a Pelágio-João.

\section{8 - NÃO PASSA DE UMA CONJECTURA SUGESTIVA DIZER-SE QUE A «VITA SANCTAE HELIAE» E O SEU PREFÁCIO SÃO UM ORIGINAL LATINO DE PASCÁSIO}

O P. e Guilherme Antolin, bibliotecário do Escurial e membro da Real Academia da História de Madrid, ao descrever, em 1909, o ms. do Escurial, Bibl. do Mosteiro a-II-9, do século x, lançou a hipótese de que a Vida de Santa Hélia, que se encontra nos ff. $72^{r}$ $-93^{\mathrm{r}}$, poderia ter sido escrita por Pascásio (1).

Ao fazer o inventário do códices de Pascásio, o Prof. Diaz y Diaz colocou à parte os manuscritos desta biografia, sob a designação de «falso adscriptum», acrescentando não encontrar razões para concordar

(1) Cf. Boletin de la Real Academia de la Historia, LIV (1909), pp. 55-67, 117-128, 204-246 e 265. A conjectura sobre Pascásio vem nas pp. 121-122; o prólogo que adiante analisaremos, nas pp. 122-123. 
com Antolin quer sobre um original latino quer sobre uma versão do grego da autoria de Pascásio (2).

Dom Columba Maria Batlle minimiza a argumentação de Antolin e diz que «enquanto não esteja provada com argumentos mais claros e mais decisivos uma tal atribuição, deve considerar-se, pelo menos, como sumamente duvidosa» (3).

Não conhecemos qualquer outra referência a Pascásio a propósito da Vita Sanctae Heliae. Porque julgamos merecer a hipótese de Antolin um estudo demorado, vamos dedicar-lhe aqui alguma atenção.

Começa o douto frade agostinho por confessar que tentou longamente identificar o autor desta biografia, mas sem qualquer resultado. Quanto ao original, inclina-se para que tenha sido o latim e não o grego. Indica então, como conjectura, «mas sem dar-lhe mais valor que o de uma simples conjectura», que o autor da Vida de Santa Hélia poderia ter sido «Pascásio diácono, discípulo de S. Martinho Dumiense».

As sugestões provêm de três pontos que enunciamos e aos quais fazemos logo a crítica pertinente.

1-A epístola dedicatória de Pascásio no Livro VII das Vitae Patrum é «muito parecida, na sua redacção, com o prólogo desta Vida de Santa Hélia». Ao estudarmos o prefácio de Pascásio indicámos bibliografia através da qual somos informados de que o prólogo, como género literário, obedecia já na Antiguidade a um certo número de tópicos. Não admira que os temas tratados sejam os mesmos. Quanto ao estilo parecem-nos bastante diferentes. O da Vita Sanctae Heliae é muito mais retórico e desenvolvido.

2 - «Nas palavras do prólogo - secundi ordinis sacerdotium administrans, poderia estar indicada a qualidade de diácono do autor, como o era Pascásio, e nas palavras sed pontifici probitate morum aequiperans, a qualidade de bispo de quem lha mandava escrever, como foi S. Martinho dumiense, bispo de Braga». Neste ponto pensamos que Antolin não compreendeu o que está escrito no prólogo. Transcrevemos: Mirari me fateor cur in me istud ordinem conmutaris,

(2) M. C. DIAZ y DIAZ, Index scriptorum latinorum Medii Aeui Hispanorum, Madrid, 1959, n. 32, p. 12.

(3) C. M. Batlle, Contribució a l' estudi de Pascasi de Dumi i la seva versió de «Verba Seniorum» in Estudis Romànics, VIII (1961), p. 63. Dom Columba reduz a argumentação de Antolin «ao facto de que a Vita Heliae parece ser versão de um diácono!». Não é tanto assim, como veremos. 
sanctorum eximie, Macedoni, secundi ordinis sacerdotium administrans, sed pontifici probitate morum aequiperans. Julgamos ser claro que administrans e aequiperans estão em vocativo, a concordar com Macedoni. Sendo assim, o autor do prefácio diz que o seu superior, o macedónio, exerce um sacerdócio de segundo grau, embora pelo brilho das suas virtudes seja igual a um pontífice. Não há aqui qualquer alusão a um diácono, mas sim a um presbítero (o segundo grau do sacerdócio) que igula um bispo em virtude. Se estas palavras tivessem sido escritas por Pascásio (que não se qualifica de diácono), só o poderiam ter sido antes de S. Martinho ser bispo, isto é, quando era simplesmente o «presbítero e abade» das Vitas Patrum.

3 - «S. Martinho de Dume e o seu discípulo Pascásio foram naturais da Panónia e daquela região era Santa Hélia, que nasceu em Irrácio, metrópole do Epiro». Como dissemos a seu tempo, nós nada sabemos de concreto sobre a origem de Pascásio.

Lendo toda a Vita Sanctae Heliae, verificamos que o seu estilo é retórico, com citações frequentes da Sagrada Escritura. Nada tem de comum com a simplicidade revelada por Pascásio na tradução dos apotegmas. Não esquecemos, no entanto, que quem traduz literalmente é menos livre na expansão dos seus sentimentos e na redundância do estilo.

Perante a exposição acabada de resumir e apreciar, concluímos que não há argumentos suficientes para se poder afirmar que Pascásio é o autor da Vita Sanctae Heliae.

Apesar de tudo, o prefácio continua a chamar a nossa atenção. Quem seria aquele macedónio, presbítero de exímia santidade? Também nos prende esta frase do autor, dirigida ao seu superior: Cur $a$ bilingui sermonem, a fatuo sapientiam, a caligante lumen desideras inpetrare? Quem seria este hagiógrafo que se considerava «bilíngue quanto ao modo de se exprimir»?

Se pudéssemos confirmar que este prólogo também era de Pascásio e igualmente dirigido a S. Martinho, na realidade exultariam os que imaginam para Pascásio uma proveniência oriental. Mas em vez de macedónio, não deveria antes escrever panónio, como S. Martinho diz de si mesmo?

Há, pois, várias questões em aberto. Poderão os orientalistas dizer-nos quem foi Santa Hélia e se os seus elementos biográficos condizem com os textos visigóticos? A data permitirá uma atribuição a Pascásio? Parece certo que esta biografia é de origem hispânica, pois só se lhe conhece outro manuscrito, procedente de Silos, hoje 
em Paris, Bibl. Nacional, n. acq. lat. 2178 , ff. $219^{\mathrm{v}}-240^{\mathrm{v}}$, do século XI. Os historiadores da Hispania poderão descobrir quem é este macedónio? Os críticos da hagiografia verão em tudo isto uma mistificação?

Finalmente, desejamos expressar a necessidade de uma edição crítica da Vita Sanctae Heliae. Nós apenas fizemos a do prefácio, baseada nos dois manuscritos até agora conhecidos. A busca de códices poderia revelar alguma rubrica com atribuição da obra. O ideal seria encontrar o endereço que precedia o prefácio. Então se ficaria a saber quem escreveu e a quem foi dedicada esta biografia. Com os elementos de que dispomos não podemos senão qualificar de sugestiva a "conjectura» de Antolin, mas sem argumentos decisivos. 


\section{Cap. II - PASCÁSIO E OS APOTEgMAS DOS PADRES DO DESERTO}

\section{1 - OS APOTEGMAS COMO GÉNERO LITERÁRIO}

Os «apotegmas, isto é, ditos breves e sentenciosos de varões ilustres», foram cultivados como género literário já nas Literaturas Clássicas e voltaram a ter grande voga no Renascimento (1).

Nas Literaturas Cristãs o apotegma apareceu como consequência da expansão do monaquismo, sobretudo nos desertos do Egipto. Crê-se que foi em Scétis que se começaram a fazer as primeiras colecções, como processo pedagógico de instruir os novos monges e forma de edificação geral (2).

(1) A definição que citámos é do P.e Manuel Bernardes, Nova Floresta, I, Porto, 1909, p. 2. O estudo mais completo sobre a origem e evolução do apotegma na Antiguidade e sua projeç̧ão na Idade Média e tempos modernos é o de WiLHeLM Gemoll, Das Apophthegma. Literarhistorische Studien, Wien, 1924. Plutarco e Valério Máximo foram os maiores cultores do género entre os gregos e os latinos, respectivamente. As mais famosas colecções feitas no Renascimento são as de Erasmo, Apophthegmatum opus, Parisiis, 1532 e as de Paulo Manúcio, Apophthegmatum ex optimis utriusque linguae scriptoribus libri VIII, Venetiis, 1590.

(2) Sobre as origens do monaquismo e do género apotegmático há literatura abundante. $\mathrm{O}$ interesse acendeu-se no último quartel do século XIX, após a obra extremamente crítica de H. WeINGarten, Der Ursprung des Mönchtums im nachconstantinischen Zeitalter, Gotha, 1877. Outras obras que fizeram época e levantaram polémica foram as de O. ZöcKLER, Askese und Mönchtum, Frankfurt a. M., 1897 e E. Amélineau, Saint Antoine et les commencements du monachisme chrétien en Égypte, Bibliothèque de la Propagande, Bruxelles, 1914. Prodígio de erudição é o trabalho de E. White, The monasteries of the Wâdi' $n$ Natrun. Part II. The history of the monasteries of Nitria and Scétis. New York, 1932. O tema foi reassumido sob perspectivas modernas por K. Heussi, Der Ursprung des Mönchtums, Tübingen, 1936. Um resumo do problema, enquadrado na época, pode ver-se 
O período de florescimento do género apotegmático, com poder criativo, vai de meados do século IV a meados do século v. Então se começaram a fazer as primeiras colecções. É natural que simultâneamente surgissem escritos em copta (língua materna dos monges

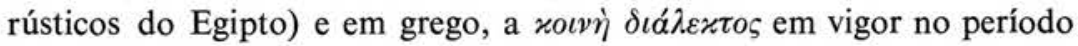
imperial e bizantino. Os filólogos descobrem, por vezes, em colecções tipicamente gregas, vestígios de coptismos. Com partes originàriamente escritas em grego e fragmentos traduzidos do copta, foram as colecções gregas que lograram maior divulgação e se espalharam por toda a Cristandade, através de traduções em aramaico, etíope, arménio, sírio, geórgio, eslavo, latim e árabe (3).

A simples leitura dos apotegmas revela imediatamente que eles apresentam variadas características. Segundo Bousset podem distinguir-se as seguintes classes: um instantâneo ou quadro vivo da vida do abade e seu discípulo; uma breve sentença ou resposta com valor pneumático ou de simples bom senso; um curto diálogo; o ensinamento através de uma parábola ou mesmo de uma alegoria. Observa ainda o mesmo estudioso que nos apotegmas são pouco abundantes as citações da Escritura, as discussões teológicas, os milagres, visões e homilias (4).

em A. Fliche-V. Martin, Histoire de l'Église, III, Paris, 1939: as pp. 297-369 sobre o monaquismo são de P. de Labriolle.

(3) Sobre a questão da língua original dos apotegmas damos a bibliografia que se lê com mais proveito: E. AméLineau, Monuments pour servir à l'histoire de l'Égipte chrétienne. Texte copte et traduction francaise in Annales du Musée Guimet, XXV (1894); M. ChaINe, Le texte originel des apophtegmes des Pères in Mélanges de la Faculté Orientale (Université Saint-Joseph, Beyrouth), V (1912), pp. 541-569; F. NAU, Notes sur le texte originel des apophtegmes des Pères, in Revue de l'Orient Chrétien, XVIII (1913), pp. 208-212; Th. HOPFNER, Über die koptisch-saidischen Apophthegmata Patrum Aegyptiorum und verwandte griechische, lateinische, koptisch-boharische und syrische Sammlungen in Akademie der Wissenschaften in Wien. Philosophisch-historische Klasse, Denkschriften, LXI (1919), Wien; R. DRAGUET, Les apophtegmes des moines d'Égypte. Problèmes littéraires in Bulletin de la Classe de Lettres et des Sciences Morales et Politiques, Académie Royale de Belgique, Bruxelles, XLVII (1961), pp. 134-149. Recordemos apenas, sobre as diversas versões, que o português F. M. Esteves Pereira publicou o texto etíope de $A$ vida de S. Paulo de Tebas (Lisboa, 1903) e da Vida de Santo Abunafre (Santo Onúphrio), Lisboa, 1905.

(4) Wilhelm Bousset, Apophthegmata. Studien zur Geschichte des ältesten Mönchtums, Tübingen, 1923. A obra de Bousset é indispensável para o estudo dos apotegmas. A descrição das características enunciadas encontra-se nas pp. 76-89. 


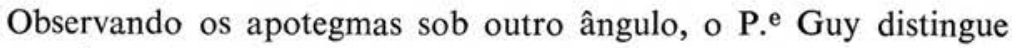
nas actuais colecções três tipos de formação: o primeiro é o de uma resposta existencial, um dom carismático do ancião que vai directamente dirigido ao discípulo que pergunta; depois, este dito passa de boca em boca, perde o carácter pessoal e é transformado de modo a melhor servir a comunidade; finalmente, o apotegma apresenta-se como simples narração edificante e torna-se um género convencional em que já nada subsiste do tipo originário (5).

Fàcilmente se compreende que após algum tempo em que os apotegmas se mantiveram apenas numa fase oral, alguém, movido por interesses espirituais, tentasse organizar pequenas colecções. Estas centravam-se a princípio sobre a sabedoria de um ancião em especial ou juntavam ditos de diversas procedências a propósito de uma virtude ou vício em particular. Depois as colecções foram-se avolumando e misturando até surgirem autênticos livros de edificação (6).

É nesta fase, que parece ter atingido o seu apogeu pelo final do século v, que deve situar-se a organização do original que serviu de base à tradução de Pascásio. Circulavam então diversas colecções: umas nominais, que dariam origem à série alfabética, segundo a letra inicial do nome de cada "padre»; outras de carácter desconexo, simples miscelânea de ditos de diversos anciãos e sobre assuntos variados (a este tipo pertence a tradução de S. Martinho de Dume, Sententiae Patrum Aegyptiorum); e outras sistemáticas, organizadas por virtudes e vícios (7).

(5) O P. e Jean-Claude Guy é actualmente o maior especialista dos apotegmas. As considerações que resumimos encontram-se no artigo Remarques sur le texte des apophthegmata patrum in Recherches de Science Religieuse, XLIII (1955), pp. 252-258. J.-C. Guy estuda a evolução de um apotegma concreto, sobre a Sunamítis em Note sur l'évolution du genre apophtegmatique in Revue d'Ascétique et de Mystique, XXXII (1956), pp. 63-68. O que aí se diz sobre Pascásio, cap. XXXVII, 4 (ed. Rosweydus) deve ser corrigido pelos resultados do nosso estudo, pois trata-se simplesmente de uma recensão diferente de Martinho, n. 16. O autêntico Pascásio não contém tal apotegma.

(6) Sobre a formação das colecções, cf. Cuthbert Butler, The Lausiac History of Paladius, I, Cambridge, 1898, pp. 208-215. Esta obra contribuiu para uma autêntica viragem nos estudos histórico-literários sobre os apotegmas. Útil tam-

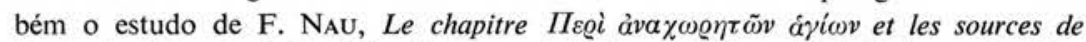
la vie de Saint Paul de Thèbes in Revue de l'Orient Chrétien, X (1905), pp. 387-391.

(7) O que subsiste de todo este material foi objecto do mais profundo estudo na obra de J.-C. GuY, Recherches sur la tradition grecque des «apophthegmata patrum», Bruxelles, 1962. 
Com frequência se tem dito que a única grande colecção sistemática é a que foi traduzida por Pelágio-João. A tradução de Pascásio era considerada de segunda ordem, dado que apenas se conhecia através da edição de Rosweydus. O nosso trabalho vem revelar que a autêntica versão de Pascásio constitui um livro de 101 capítulos, com o título De octo principalibus uitiis, contendo um total de 358 apotegmas.

Os estudiosos têm-se dividido extremamente sobre a natureza da colecção publicada no Livro III de Rosweydus. A maioria pensam que ela é desordenada, de tipo compilatório (Butler); outros vêem nela uma organização por temas, embora não muito nítidos na sua divisão (Hopfner e Bousset, v. g.). O nosso estudo vem mostrar também que do Livro III de Rosweydus apenas os primeiros 40 apotegmas são originais, obra de autor e tradutor desconhecidos. Além disso, os primeiros 40 apotegmas do III Rosw. não passam de uma antologia, sem títulos, do "autêntico Livro III das Vitae Patrum». Este, sim, é uma colecção sistemática dividida em seis capítulos, com um total de 61 apotegmas.

A nossa investigação colocou-nos assim, inesperadamente, perante duas obras em boa parte inéditas, das quais se perdeu o original grego. Por isso, só através do autêntico Pascásio e do tradutor do «autêntico Livro III" podemos voltar possivelmente ao final do século $\mathrm{v}$ e reconstituir duas colecções gregas que mais tarde foram utilizadas pelo organizador da colecção alfabética-anónima.

O fim primário que nos propusemos, e de que não nos desviámos, foi a elaboração de um texto crítico e de um estudo filológico da obra dc Pascásio. Não podemos, todavia, deixar de lembrar, ao menos uma vez, que a matéria, em si, é susceptível de despertar interesses de diversa ordem. Ao ler os apotegmas, entramos em contacto com um ambiente concreto, o do Próximo Oriente, meio-pagão meio-cristão, em que os monges procuravam a perfeição no isolamento. Temos quadros ao vivo, de interesse histórico, psicológico e ascético. A obra, em si, é um livro de edificação. Viria a propósito transcrever o prolegómeno XVI de Rosweydus, sobre «a utilidade destes livros» (PL LXXIII, coll. 61-63). Estamos perante um livro que foi abundantemente lido na Hispania a partir de meados do século VI e que se difundiu extraordinàriamente por toda a Europa Ocidental. Lê-lo é pormo-nos em contacto com gerações que moldaram o nosso passado, com uma espiritualidade que projectou a sua luz até ao presente. 


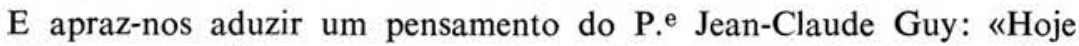
ainda, os apophthegmata patrum não terminaram a sua função educativa. Se eles não são já o livro do postulante à vida monástica, constituem sempre um insubstituível instrumento de formação» (8).

\section{2-EM BUSCA DO TEXTO GREGO DE PASCÁSIO}

Pascásio diz no seu prefácio que traduziu e que procurou ser inteiramente fiel ao original. Não há dúvida de que se tratava de um códice grego. O título das Sententiae Patrum Aegyptiorum é bem explícito: quas de graeco in latinum transtulit Martinus Dumiensis episcopus. S. Martinho possuía, por certo graças aos seus contactos com o Oriente, vários códices gregos, dois dos quais de apophthegmata patrum. O menor traduziu-o ele próprio; o maior entregou-o ao trabalho de Pascásio.

Embora haja apotegmas em várias línguas orientais, as traduções latinas existentes foram todas feitas sobre o grego. A redacção que veio a originar a série alfabética deve ter sido organizada entre 460-470 até final do século v, segundo o estudo de Wilhelm Bousset (1).

Do texto grego das grandes compilações primitivas, ordenadas segundo temas, apresentando as virtudes próprias dos monges, apenas de uma nos restam vários manuscritos, pela primeira vez estudados por Jean-Claude Guy, os quais continuam inéditos (2). Da pequena colecção traduzida por S. Martinho de Dume e do códice que foi entregue a Pascásio não se conhece até agora qualquer manuscrito ordenado.

O estudioso da obra de Pascásio sente, no entanto, com frequência, o desejo de recorrer ao texto grego para resolver certas dificuldades de ordem crítica. Salonius, que apenas conheceu a versão grega do capítulo De meditationibus duodecim anachoretarum (cf. PL LXXIII,

(8) J.-C. GuY, Les apophthegmata patrum in Théologie de la vie monastique, Paris, 1961, p. 83.

(1) W. Bousset, Apophthegmata. Studien zur Geschichte des ältesten Mönschtums, Tübingen, 1923, pp. 60-71.

(2) J.-C. GUY, Recherches sur la tradition grecque des apophthegmata patrum (Subsidia Hagiographica n. 36) Bruxelles, 1962, pp. 117-200. Todos os manuscritos se relacionam com a tradução latina de Pelágio-João (Livros V-VI das Vitae Patrum de Rosweydus). 
coll. 1060-1064), verificou imediatamente que a comparação com o grego tem grande importância não só para a reconstituição do texto latino, tal como ele nos é transmitido pelos manuscritos, como também para apreciar os métodos de trabalho do tradutor (3).

Restava-nos, pois, só o recurso às edições de apotegmas gregos, embora eles se encontrem numa ordem e com um texto que, em princípio, nada nos garante seja próximo do de Pascásio. O Prof. Dr. M. C. Díaz y Díaz já observara que o texto de que se serviu Pascásio se encontrava em parte em J. Cotelier e F. Nau. Não deixou, porém, bem explícito que estes editores não dispunham da colecção ideològicamente ordenada que Pascásio utilizou (4). Recorrendo, pois, aos textos gregos publicados, as edições de que nos servimos foram as seguintes:

1 - J. B. Cotelier, Ecclesiae Graecae monumenta, t. I, 1677, reeditada por Migne, Patrologia Graeca, t. LXV, coll. 71-440. Cotelier utilizou um manuscrito da família do Parisinus graecus 1599. Trata-se de uma compilação de apotegmas distribuídos segundo a ordem alfabética dos 120 «padres» a quem são atribuídos, num total de 946 peças.

2-F. Nau, Histoires des solitaires égyptiens, num total de 400 apotegmas, segundo o manuscrito de Paris, Coislin 126, publicados na Revue de l'Orient Chrétien, XII (1907) pp. 48-69, 171-189 e 393-413; XIII (1908) pp. 47-66 e 266-297 (sendo até aqui o texto grego seguido da tradução francesa); XIV (1909) pp. 357-379; XVII (1912) pp. 204-211 e 294-301; XVIII (1913) pp. 137-146. Após o n. 400 vem a indicação $A$ suivre, mas, de facto, a publicação do manuscrito nunca mais foi continuada. É uma série de apotegmas anónimos. As séries alfabética e anónima são fruto da elaboração de um compilador que se serviu de muitas colecções sistemáticas, miscelâneas e alfabéticas, fazendo uma distribuição que se tornou muito corrente.

3 - Os manuscritos que nos transmitem as duas séries anteriores foram estudados por Jean-Claude Guy, nas Recherches sur la tradition grecque des apophthegmata patrum (Bruxelles, 1962) que nos dão nas

(3) A. H. Salonius, Vitae Patrum. Kritische Untersuchungen über Text, Syntax und Wortschatz der spätlateinischen Vitae Patrum, Lund, 1920, pp. 36-38.

(4) M. C. Díaz y DíAZ, Index Scriptorum Latinorum Medii Aeui Hispanorum, Madrid, 1959, p. 11. 
pp. 13-115 não só o incipit dos apotegmas que constituem cada grupo, mas ainda pequenas peças completas que até então se encontravam inéditas.

Além destas, há pequenas publicações de apotegmas que consultámos, mas nas quais não encontrámos texto grego paralelo à tradução de Pascásio. Apenas para a Vita Taisis (= Pasc. LVII,4) devemos mencionar ainda as diversas recensões gregas que foram publicadas por F. Nau, nos Annales du Musée Guimet, XXX (1903), pp. 86-113 (Paris).

Em relação à parte de Pascásio já conhecida através do Livro III Rosw. (nn. 44-217) e do Livro VII (cap. I-XLII) o nosso trabalho de busca do texto grego estava facilitado pelos magníficos e minuciosos quadros de paralelos editados por W. Bousset, nas pp. 129-135 do seu estudo Apophthegmata (Tübingen, 1923). Mas não se esqueça que boa parte da obra de Pascásio é por nós publicada pela primeira vez. Para os apotegmas desconhecidos de Bousset tivemos nós que tentar descobrir o texto grego equivalente. É um trabalho difícil que exige não só o conhecimento, de memória, da tradução de Pascásio, mas ainda a organização de um bom índice remissivo da localização do seu vocabulário mais significativo. Lê-se um apotegma grego e fàcilmente a memória nos adverte se conhecemos ou não o seu correspondente latino. Mas será essa tradução de Pascásio? E qual o lugar, capítulo, número ou parágrafo em que se encontra? Eis a indagação crucial. Se mencionamos este aspecto do nosso trabalho é apenas para concluir que, apesar dos esforços empregados, é quase certo que vários paralelos gregos nos tenham escapado. Daqui apelamos para quem possa ajudar-nos a aperfeiçoar o quadro dos lugares paralelos.

A observação do quadro que damos a seguir mostra que entre os 358 apotegmas traduzidos por Pascásio conseguimos encontrar texto grego equivalente, no todo ou só em parte, para 309 apotegmas, o que dá uma proporção de 86,3 por cento. Esta percentagem é já suficientemente elevada para conseguir apreciar a fidelidade da tradução e comparar a técnica de Pascásio com a de outros tradutores latinos, sobretudo Pelágio-João. Deve, todavia, ter-se sempre presente que o texto grego que possuímos não representa sequer a melhor lição dos manuscritos do seu grupo (5) e que não temos qualquer garantia

(5) Cf. J.-C. GuY, Recherches sur la tradition grecque des apophthegmata patrum, Bruxelles, 1962, p. 57; R. DraGUET, Les apophtegmes des moines d'Égypte. Problèmes littéraires in Bulletin de la Classe de Lettres et des Sciences Morales et 
de quando o compilador preferiu a narração que se encontrava no texto grego de Pascásio ou no dos seus paralelos. Como veremos no capítulo seguinte, a comparação do grego que possuímos com a tradução do monge de Dume mostra que o seu original não andaria, na maior parte dos casos, muito longe da recensão grega por nós conhecida. A par de diferenças notáveis, verifica-se, para uma boa parte dos textos, a possibilidade de uma versão quase literal.

\section{EXPLICAÇÃO DOS SíMBOLOS DO QUADRO \\ E DO NOSSO PROCESSO DE CITAR OS PARALELOS}

Em primeiro lugar damos o capítulo, número de apotegma (e de parágrafo, se o houver) da nossa edição de Pascásio.

A segunda coluna é reservada para todo o texto grego de que obtivemos conhecimento. Abrange as seguintes remissões: 1-A série alfabética-nominal, publicada por Cotelier. As nossas citações fazem-se sempre, no entanto, segundo a sua reedição no volume LXV da Patrologia Graeca, entendendo-se que para este volume remetemos sempre que indicarmos o nome do autor do apotegma, o número que tem na colecção alfabética e a coluna em que se encontra na PG LXV. 2 - Os apotegmas gregos publicados por Nau (simplesmente representado por $N$ ) com indicação do número que têm no respectivo fascículo da Revue de l'Orient Chrétien. 3-Os lugares paralelos que se encontram só na obra há pouco citada de Guy (representado por $G$ ), dando o número que o apotegma tem na página que vai entre parêntesis. 4-Em dois casos o texto grego encontra-se só na Rosweydi notatio aos Livros V e VI das Vitae Patrum. Após o símbolo de $R$ not. segue o número da anotação e a coluna em que se encontra na Patrologia Latina, vol. LXXIII.

Vêm depois as equivalências nas restantes traduções latinas, sempre segundo a numeração das Vitae Patrum de H. Rosweydus na Patrologia Latina, voll. LXXIII ou LXXIV, conforme o tradutor.

O Livro V, ou tradução atribuída a Pelágio, é representado por $P g$, seguido do número do libellus (a que habitualmente damos a designação

Politiques (Académie Royale de Belgique), Bruxelles, XLVII (1961), p. 143; R. DrAGUET, $A$ la source de deux apophtegmes grecs (PG 65, Jean Colobus 24 et 32) in Byzantion, XXXII (1962), pp. 53-61. 
de capítulo) e da ordem do apotegma. O Livro VI, cuja tradução é atribuída a João, é indicado por Io, seguido do libellus e número de apotegma.

O Livro III precisa de especial atenção. Quando o paralelo se encontrar na edição de Rosweydus citaremos essa por $R$, acompanhado do número. Quando o lugar paralelo só se encontrar no "Autêntico Livro III» dar-se-ão o capítulo e o número do apotegma, precedidos de $A$, o que remete para a nossa descrição que se encontra, em lugar próprio, no segundo tomo deste estudo.

Por Livro VII entendemos o texto de Pascásio dado por Rosweydus, registando apenas o capítulo e número de apotegma.

$\mathrm{Na}$ última coluna vão indicados todos os outros paralelos latinos, no geral bastante raros.

As Sententiae Patrum Aegyptiorum de S. Martinho de Dume são representados por $M$ e número respectivo.

Por App. L. seguido de um número, entendemos o cap. $\mathrm{XX}$ da Palladii Lausiaca, o qual é de facto um apêndice que não pertence à obra de Paládio.

App. W. e um número indica o suplemento que A. Wilmart julga dever ser junto à tradução de João (Livro VI), publicado na Revue Bénédictine, XXXIV (1922) pp. 196-198.

O Heraclidis Paradisus será representado por $\mathrm{Hr}$ com indicação do capítulo, divisão em parágrafos (por vezes mais numerosos que a expressão gráfica da edição) e coluna, para facilitar a identificação.

A Palladii Lausiaca pròpriamente dita (até ao cap. XIX, inclusive) tem o símbolo $P d$ seguido de indicações iguais às da obra anterior.

O Livro IV de Rosweydus na parte tirada das Collationes de João Cassiano é designado só por $C s$ seguido do capítulo e coluna. Para os lugares paralelos aos trechos dados em Appendix à nossa edição são fornecidas indicações suficientes no lugar próprio.

Aparecem no quadro de paralelos algumas referências entre parêntesis. Podem reduzir-se a três classes: o tipo A I, 14 (=R 7) significa que o texto original é o do "Autêntico Livro III", o qual neste caso foi reproduzido na antologia que constitui os primeiros 40 números de III Rosw.; no Livro VII (Rosw.) o parêntesis ocorre quando a versāo exacta é a de Martinho, indicada na coluna ao lado, sendo a do Livro VII uma interpolação no geral retocada; finalmente o tipo (cf. Pg v, 37) indica que estes paralelos ou não são perfeitos ou se encontram em contexto diferente. 


\section{3-QUADRO DOS APOTEGMAS DE PASCÁSIO E DOS SEUS LUGARES PARALELOS}

\begin{tabular}{|c|c|c|c|c|c|}
\hline PASCÁSIO & TEXTO GREGO & PELÁGIO-JOÃo & LIVRO III & LIVRO VII & RESTANTES \\
\hline $\mathrm{I}, \mathrm{I}$ & - & - & R 44 & $\mathrm{I}, 1^{\mathrm{a}}$ & - \\
\hline 1,2 & Sisoes 23 (400) & - & A $1,3^{a}$ & $\mathrm{I}, 1^{\mathrm{b}}$ & - \\
\hline $\mathrm{I}, 3$ & Pambo 2 (368) & $\operatorname{Pg} X, 65$ & - & - & - \\
\hline $\mathrm{I}, 4$ & Poemen 31 (329) & $\operatorname{Pg} X, 44$ & $\begin{array}{ll}\text { A } & \text { I, } 1^{\text {b }} \\
\text { R } & 45\end{array}$ & - & - \\
\hline II, 1 & Siluanus 1 (408) & $\mathrm{Pg}$ IV, 40 & R 46 & - & - \\
\hline $\mathrm{II}, 2$ & Joseph 1 (228) & Pg XIII,I & $\begin{array}{ll}\text { A } & \text { I,16 } \\
\text { R } & 47\end{array}$ & - & - \\
\hline II,3 & N 18 & - & - & $\mathrm{I}, 2$ & App. L. 9 \\
\hline II,4 & N 231 & $\operatorname{Pg} \times, 99$ & R 48 & $\mathrm{I}, 3$ & - \\
\hline III,1 & - & - & R 49 & $\mathrm{I}, 4$ & - \\
\hline III, 2 & N 152 & Pg IV,60 & R 50 & - & - \\
\hline III,3 & Zeno 6 (177) & $\begin{array}{l}\text { Pg IV, } 17 \\
\text { (cf. Pg V,37 med.) }\end{array}$ & $\begin{array}{l}\text { A I,14 } \\
(=\mathrm{R} 7)\end{array}$ & - & - \\
\hline $\mathrm{III}, 4$ & Arsenius 19 (92) & Pg IV,6 & - & - & - \\
\hline III,5 & N 151 & Pg IV,59 & R 51 & - & - \\
\hline III,6 & $\begin{array}{l}\text { Sisoes } 2^{b}(392) \\
\text { (cf. Xoius } 1(312))\end{array}$ & $\begin{array}{l}\text { Pg IV, } 37^{\mathrm{b}} \\
\text { (cf. Pg IV, } 36^{\mathrm{c}}\end{array}$ & - & - & - \\
\hline III,7 & Poemen 16 (325) & Pg IV,29 & $\begin{array}{ll}\text { A } & \mathrm{I}, 8 \\
\text { R } & 52\end{array}$ & - & - \\
\hline IV, 1 & Sisoes 4 (392) & Pg IV,38 & - & - & - \\
\hline $\mathrm{V}, 1$ & Eulogius (169) & Pg VIII,4 & - & - & - \\
\hline $\mathrm{V}, 2$ & Macarius 10 (268) & Pg IV,26 & R 53 & - & - \\
\hline VI,1 & Theod. Pherm. 7 (189) & Pg VIII,7 & - & - & - \\
\hline VI,2 & N 256 & Pg VIII,21 & $\begin{array}{ll}\text { A } & \mathrm{I}, 7 \\
\text { R } & 54\end{array}$ & - & - \\
\hline VII,1 & Siluanus 5 (409) & $\operatorname{Pg} X, 69$ & R 55 & - & - \\
\hline VII, 2 & Joann. Col. 2 (204) & $\operatorname{Pg} \times, 27$ & R 56 & - & - \\
\hline VIII,1 & $\begin{array}{l}\text { Poemen } 93 \text { (344) } \\
\text { G } 730(96)\end{array}$ & - & R 57 & $\mathrm{I}, 5$ & - \\
\hline IX, 1 & - & - & R 58 & $\mathrm{I}, 6$ & - \\
\hline $\mathrm{IX}, 2$ & - & - & - & $\mathrm{I}, 7$ & - \\
\hline IX,3 & Poemen 14 (325) & Pg V,8 & R 59 & - & - \\
\hline $\mathrm{X}, 1$ & Synclet. 3 (421) & Pg IV,42 & R 60 & - & - \\
\hline $\mathrm{X}, 2^{\mathrm{a}}$ & $\mathrm{N} 184^{\mathrm{a}}$ & $\operatorname{Pg~V,32^{\mathrm {a}}}$ & - & - & - \\
\hline b & $\mathrm{N} 184^{\mathrm{b}}$ & $\operatorname{Pg} V, 32^{b}$ & $\begin{array}{l}\text { A VI,5 } \\
(=\mathrm{R} \mathrm{40)}\end{array}$ & - & - \\
\hline $\begin{array}{l}X, 3 \\
X, 4\end{array}$ & $\begin{array}{c}\text { N } 182 \\
\text { Macarius } 3 \text { (261) }\end{array}$ & $\begin{array}{l}\mathrm{Pg} \text { V,30 } \\
\mathrm{Pg} \text { XVIII.9 }\end{array}$ & $\mathrm{R} \overline{61}$ & $\overline{\mathrm{I}, 8}$ & - \\
\hline
\end{tabular}




\begin{tabular}{|c|c|c|c|c|c|}
\hline PASCÁSIO & TEXTO GREGO & PELÁGIO-JOÃo & LIVRO III & LIVRO VII & RESTANTES \\
\hline $\mathrm{XI}, 1$ & N 183 & $\operatorname{Pg} \mathrm{V}, 31$ & R 62 & - & - \\
\hline $\mathrm{XI}, 2$ & Poemen $62^{\mathrm{a}},{ }^{\mathrm{c}}(336)$ & $\begin{array}{l}\text { Pg V,9a, } \\
\text { (cf. Pg I,2) }\end{array}$ & R 63 & $\begin{array}{l}\mathrm{I}, 9 \\
v\end{array}$ & - \\
\hline $\mathrm{XI}, 3$ & - & - & $\mathrm{R} 64^{\mathrm{a}}$ & $\mathrm{I}, 10^{\mathrm{a}}$ & - \\
\hline $\mathrm{XI}, 4$ & - & - & $\mathrm{R} 64^{\mathrm{b}}$ & $1,10^{b}$ & - \\
\hline $\mathrm{XII}, 1$ & Arsenius 28 (96) & Pg II,7 & R 65 & - & - \\
\hline $\mathrm{XIII}, 1^{\mathrm{a}}$ & Joann. Col. 3 (205) & Pg IV,19 & $\begin{array}{l}\text { A } \quad \mathrm{I}, 3^{\mathrm{e}} \\
\mathrm{R} \quad 66^{\mathrm{a}}\end{array}$ & - & - \\
\hline b & Joann. Col. 28 (213) & - & $\begin{array}{l}\text { A } \quad I, 3^{b} \\
\text { R } 66^{b}\end{array}$ & - & - \\
\hline XIV,1 & N 51 & - & R 67 & II,1 & - \\
\hline XIV, 2 & Antonius $20(81)$ & $\begin{array}{l}\text { Pg VI,1 } \\
\text { (cf. Pg VI,10) }\end{array}$ & R 68 & - & - \\
\hline XIV,3 & Arsenius 29 (97) & Pg VI,2 & & - & - \\
\hline XIV, 4 & N 262 & Pg VI,22 & R 69 & - & - \\
\hline XIV,5 & Theod. Pherm. 1 (188) & Pg VI,6 & - & - & - \\
\hline XIV,6 & N 392 & $\mathrm{Pg}$ VI,5 & R 70 & - & - \\
\hline XIV,7 & Synclet. 5 (421) & $\mathrm{Pg}$ VI, $13^{\mathrm{a}}$ & R 169 & - & - \\
\hline $\mathrm{XIV}, 8$ & Arsenius 20 (92) & $\mathrm{Pg}$ VI,3 & - & - & - \\
\hline XIV,9 & N 258 & Pg VI,17 & R 71 & - & - \\
\hline $\mathrm{XIV}, 10$ & Paul. magn. 1 (381) & - & R $72^{\mathrm{a}}$ & $\mathrm{II}, 2^{\mathrm{a}}$ & - \\
\hline $\mathrm{XIV}, 11$ & Paul. magn. 3 (381) & - & $\mathrm{R} 72^{\mathrm{b}}$ & $\mathrm{II}, 2^{\mathrm{b}}$ & - \\
\hline $\mathrm{XIV}, 12$ & - & - & - & $\mathrm{II}, 3$ & - \\
\hline $\mathrm{XIV}, 13$ & - & - & - & $\mathrm{II}, 4$ & - \\
\hline $\mathrm{XV}, 1$ & Macarius 18 (269) & Pg XVI,6 & R 73 & III,1 & - \\
\hline $\mathrm{XV}, 2$ & N 339 & Pg XVI,19 & R 74 & III, 2 & - \\
\hline XVI,1 & N 376 & - & - & IV, 1 & - \\
\hline $\mathrm{XVI}, 2$ & G 651 (73) & - & - & IV, 2 & - \\
\hline $\mathrm{XVII}, 1^{\mathrm{a}}$ & N 282b & $\mathrm{Pg} \mathrm{XIII}, 14^{\mathrm{b}}$ & - & - & - \\
\hline b & $\mathrm{N} 282^{\mathrm{a}}$ & Pg XIII,14a & - & - & - \\
\hline XVIII,1 & Siluanus 8 (412) & - & - & $\mathrm{V}, 1$ & - \\
\hline XVIII, 2 & Poemen 169 (364) & - & R 170 & $\mathrm{~V}, 2$ & - \\
\hline XVIII,3 & Agathon 16 (113) & - & - & $\mathrm{V}, 3$ & - \\
\hline $\mathrm{XIX}, 1$ & - & - & R 75 & - & - \\
\hline $\mathrm{XIX}, 2$ & Arsenius 4 (88) & $\mathrm{Pg} X \mathrm{XV}, 6$ & $\begin{array}{l}\text { A VI, } 1^{\mathrm{b}} \\
\left(=\mathrm{R} 37^{\mathrm{b}}\right)\end{array}$ & - & - \\
\hline$X X, 1^{a}$ & - & - & R $76^{\mathrm{a}}$ & $\mathrm{VI}, 1^{\mathrm{a}}$ & - \\
\hline b & Poemen 34 (332) & Pg XVIII,18 & $\mathrm{R} 76^{\mathrm{b}}$ & $\mathrm{VI}, 1^{\mathrm{b}}$ & - \\
\hline${ }^{\mathrm{c}}$ & - & - & R $76^{\circ}$ & $\mathrm{VI}, 1^{\mathrm{c}}$ & - \\
\hline $\mathrm{XXI}, 1$ & Antonius 19 (81) & Io IV,11 & - & VI,2 & - \\
\hline $\mathrm{XXI}, 2$ & Sisoes 1 (392) & Pg XVI, 10 & R 77 & VII,1 & App. L. 14 ${ }^{\text {b }}$ \\
\hline $\mathrm{XXI}, 3^{\mathrm{a}}$ & - & - & R $78^{a}$ & $\mathrm{VII}, 2^{\mathrm{a}}$ & - \\
\hline b & Or $12(440)$ & $\mathrm{Pg} X \mathrm{XV}, 61$ & $\mathrm{R} 78^{\mathrm{b}}$ & $\mathrm{VII}, 2^{b}$ & App. L. $15^{b}$ \\
\hline XXII,1 & Poemen 177 (365) & $\mathrm{Pg} X, 53$ & R 79 & VII,3 & - \\
\hline
\end{tabular}




\begin{tabular}{|c|c|c|c|c|c|}
\hline PASCÁSIO & TEXTO GREGO & PELÁGIO-JOÃo & LIVRO III & LIVRO VII & RESTANTES \\
\hline XXII,2 & N 336 & Pg XVI,12 & R 80 & VII,4 & - \\
\hline XXII, 3 & - & - & R 81 & VII,5 & - \\
\hline XXIII,1 & Sisoes 34 (404) & - & R 82 & VIII,1 & - \\
\hline XXIII, 2 & Poemen 90 (344) & - & R 83 & VIII, 2 & - \\
\hline XXIV,1 & - & Io IV,12 & R 84 & - & - \\
\hline XXIV,2 & N 324 & $\operatorname{Pg} X V, 83$ & R 85 & - & - \\
\hline XXIV,3 & N 335 & Pg XVI,11 & - & IX,1 & - \\
\hline XXIV,4 & Zacharias $3^{\mathrm{a}}$, $^{\mathrm{c}}(180)$ & $\operatorname{Pg} X V, 17$ a , e & R 86 & $\mathrm{IX}, 2$ & - \\
\hline XXIV, $5^{\mathrm{a}}$ & Ammonas $8^{\mathrm{a}}(121)$ & - & - & $\mathrm{IX}, 3^{\mathrm{a}}$ & $\operatorname{Pd} 8^{\mathrm{a}}$ \\
\hline & Ammonas 3 (120) & Pg VII,3 & - & - & - \\
\hline XXIV,6 & Macarius 17 (269) & $\mathrm{Pg}$ IV, 28 & R 87 & - & App. L. 17a \\
\hline $\mathrm{XXV}, 1$ & Antonius 15 (80) & Pg VIII, 2 & R 88 & - & - \\
\hline$X X V, 2$ & Agathon 5 (109) & $\operatorname{Pg} \mathrm{X}, 10$ & $\begin{array}{l}\text { A IV,7 } \\
(=\mathrm{R} 21)\end{array}$ & - & - \\
\hline $\mathrm{XXV}, 3$ & Moyses 4 (284) & Pg XV,29 & - & - & - \\
\hline $\mathrm{XXV}, 4$ & Moyses 3 (284) & $\mathrm{Pg}$ XVI,7 & - & - & - \\
\hline XXVI,1 & Isidorus 2 (220) & $\mathrm{Pg}$ IV,22 & R 89 & - & - \\
\hline XXVI,2 & Achilas 4 (125) & Pg IV,9 & R 90 & - & - \\
\hline XXVI,3 & N 338 & Pg XVI,14 & R $91^{\mathrm{a}}$ & - & - \\
\hline XXVI,4 & Hyperech. 3 (429) & $\mathrm{Pg}$ IV, 49 & $\mathrm{R} 91^{\mathrm{b}}$ & - & - \\
\hline XXVII, $1^{\mathrm{a}}$ & Joann. Col. $8^{\mathrm{a}}$ (205) & $\mathrm{Pg}$ XVI, $3^{\mathrm{a}}$ & R $92^{\mathrm{a}}$ & - & - \\
\hline b & - & - & $\mathrm{R} 92^{\mathrm{b}}$ & - & - \\
\hline c & Joann. Col. $8^{\mathrm{b}}$ (205) & $\operatorname{Pg}$ XVI, $3^{\mathrm{b}}$ & $\mathrm{R} 92^{\mathrm{c}}$ & - & - \\
\hline d & - & - & R $92^{d}$ & - & - \\
\hline XXVII,2 & Poemen 4 (317) & $\mathrm{Pg}$ XVII,8 & R 93 & - & - \\
\hline XXVIII,1 & Motios 2 (300) & - & R 94 & $\mathrm{X}, 1$ & - \\
\hline XXVIII, 2 & - & - & - & $\mathrm{X}, 2$ & App. L. $14^{\mathrm{a}}$ \\
\hline XXVIII,3 & $\begin{array}{l}\text { Agathon } 4(109) \\
\text { (cf. Epiph. } 4^{\mathrm{b}}(164)\end{array}$ & $\begin{array}{l}\text { Pg XVII,6 } \\
\text { (cf. Pg IV, 15b }\end{array}$ & R 95 & - & - \\
\hline XXIX,1 & N 352 & $\mathrm{Pg}$ XVII, 22 & R 96 & - & - \\
\hline XXIX,2 & (cf. G 489 (67) ) & Io III,17 & R 97 & - & - \\
\hline XXIX,3 & N 201 & Pg VII,33 & R 98 & - & - \\
\hline $\mathrm{XXX}, 1$ & Macarius 1 (257) & $\mathrm{Pg} X \mathrm{XV}, 25$ & R 99 & - & - \\
\hline XXXI,1 & Orsisius $1^{\mathrm{a}}$ (316) & $\mathrm{Pg} X V, 51^{\mathrm{a}}$ & - & $\mathrm{XI}, 1$ & - \\
\hline $\mathrm{XXXI}, 2$ & & $\mathrm{Pg}$ IX, 8 & R 100 & $\left(\mathrm{XXXIX}, 2^{\mathrm{a}}\right)$ & M $39^{\mathrm{a}}$ \\
\hline XXXI,3 & Poemen 99 (345) & - & - & $\mathrm{XI}, 2$ & App. L. $5^{\text {b }}$ \\
\hline XXXI,4 & Isidorus 6 (221) & - & R 101 & $\mathrm{XI}, 3$ & - \\
\hline XXXI,5 & N $291^{\text {b }}$ & $\operatorname{Pg} X I V, 14^{b}$ & R 102 & $\mathrm{XI}, 4$ & - \\
\hline XXXI,6 & Sisoes $38(404)$ & - & R 103 & $\mathrm{XI}, 5$ & - \\
\hline XXXI,7 & N 210 & Pg VII,42 & R 104 & - & - \\
\hline XXXII,1 & Antonius 1 (76) & Pg VII,1 & R 105 & - & - \\
\hline XXXII,2 & N 202 & $\mathrm{Pg}$ VII, 34 & R 106 & - & - \\
\hline XXXII,3 & \begin{tabular}{|} 
Arsenius 11 (89) \\
$\mathrm{N} 195^{\mathrm{a}}$
\end{tabular} & Pg VII, $27^{\mathrm{a}}$ & - & - & - \\
\hline
\end{tabular}




\begin{tabular}{|c|c|c|c|c|c|}
\hline PASCÁSIO & TEXTO GREGO & PELÁGIO-JOÃo & LIVRO III & LIVRO VII & RESTANTES \\
\hline XXXII,4 & N 196 & Pg VII,28 & R 107 & - & - \\
\hline $\mathrm{XXXII,5^{ \textrm {a } }}$ & $\begin{array}{l}\text { N } 297 \\
\text { N } 400^{\mathrm{a}}\end{array}$ & Pg VII,23 & - & - & - \\
\hline b & $\mathrm{N} 400^{\mathrm{b}}$ & - & - & - & - \\
\hline e & - & - & - & - & - \\
\hline XXXII,6 & N 205 & Pg VII,37 & - & - & - \\
\hline $\mathrm{XXXII}, 7^{\mathrm{a}}$ & Moyses 6 (284) & Pg II,9 & R $109^{a}$ & - & - \\
\hline b & Antonius 10 (77) & $\mathrm{Pg} \mathrm{II} \mathrm{1}^{\mathrm{a}}$ & R $109^{b}$ & - & - \\
\hline c & - & - & - & - & - \\
\hline XXXII, 8 & Antonius 3 (76) & $\operatorname{Pg} \quad \mathrm{I}, 1$ & R 108 & - & - \\
\hline XXXIII,1 & - & - & R 110 & $\mathrm{XII}, 1$ & - \\
\hline XXXIII, 2 & Macarius 31 (273) & - & - & $\mathrm{XII}, 2$ & - \\
\hline XXXIII,3 & Zeno 3 (176) & - & R 111 & $\mathrm{XII}, 4$ & - \\
\hline XXXIII,4 & $\begin{array}{l}\text { Or } 10(440) \\
\text { N } 300\end{array}$ & $\operatorname{Pg} X V, 56$ & R 112 & $\mathrm{XIII}, 1$ & - \\
\hline XXXIII,5 & - & Pg VIII,20 & R 113 & $\mathrm{XIII}, 2$ & - \\
\hline XXXIII,6 & G $\quad$ S3 (34) & Pg VIII,19 & R 114 & - & - \\
\hline XXXIII,7 & $\begin{array}{l}\text { Or } 11(440) \\
\text { N } 299\end{array}$ & $\operatorname{Pg} X V, 54$ & R 115 & XIII,3 & - \\
\hline XXXIII, 8 & N 266 & $\mathrm{Pg} \times \mathrm{XI}, 38$ & R 116 & $\mathrm{XII}, 5$ & - \\
\hline XXXIII,9 & Abraham 1 (129) & $\operatorname{Pg} \times, 15$ & R 117 & - & - \\
\hline XXXIII,10 & Poemen 51 (333) & $\mathrm{Pg}$ XIII, 6 & - & - & - \\
\hline XXXIII, $11^{\mathrm{a}}$ & Tithoes 6 (428) & - & - & XII, $6^{a}$ & App. L. 19 \\
\hline b & Tithoes 1 (428) & $\operatorname{Pg}$ XII,11 & - & $\mathrm{XII}, 6^{\mathrm{b}}$ & - \\
\hline XXXIII,12 & N 61 & Io IV,35 & R 118 & $\mathrm{XII}, 7$ & - \\
\hline XXXIII,13 & Moyses 8 (285) & Pg VIII, 10 & R 119 & - & - \\
\hline XXXIII,14 & Simon 1 (412) & Pg VIII, 17 & - & - & - \\
\hline XXXIII,15 & Simon 2 (412) & Pg VIII, 18 & - & $\mathrm{XII}, 8$ & - \\
\hline XXXIV,1 & G 667 (74) & $\operatorname{Pg} \times V, 49$ & - & $\mathrm{XIII}, 8$ & - \\
\hline XXXIV,2 & G 656 (73) & $\mathrm{Pg} \times \mathrm{X}, 37$ & - & XIII,9 & - \\
\hline XXXIV, $3^{a}$ & N 107 & - & $\mathrm{R} 17 \mathrm{I}^{\mathrm{a}}$ & $\mathrm{XIII}, 10$ & $\begin{array}{l}\text { App. W. } 21 \\
\text { M } 58\end{array}$ \\
\hline b & N 381 & $\operatorname{Pg} \times V, 77$ & R $171^{b}$ & $\mathrm{XIII}, 5^{\mathrm{a}}$ & M 57 \\
\hline e & - & $x_{-}^{0}-$ & R $171^{\mathrm{c}}$ & $\mathrm{XIII}, 5^{\mathrm{b}}$ & - \\
\hline XXXIV,4 & Matoes 2 (289) & $\operatorname{Pg} X V, 28$ & $\mathrm{R} 123^{\mathrm{a}}$ & - & - \\
\hline XXXIV,5 & - & $\mathrm{Pg}$ XI,34 & $\mathrm{R} 123^{\mathrm{b}}$ & - & - \\
\hline XXXIV, 6 & N 115 & - & - & XIII,11 & App. W. 28 \\
\hline XXXIV,7 & N 304 & $\operatorname{Pg} X V, 60$ & - & $\mathrm{XIII}, 12$ & App. L. $15^{\mathrm{a}}$ \\
\hline $\mathrm{XXXV}, 1$ & Sisoes 18 (397) & Io II, 13 & R 120 & - & - \\
\hline $\mathrm{XXXV}, 2$ & Nisterous 1 (305) & Pg VIII,12 & - & $\mathrm{XII}, 3$ & - \\
\hline $\mathrm{XXXV}, 3$ & Besario 5 (141) & Io II, 4 & R 121 & $\mathrm{XIV}, 2$ & - \\
\hline $\mathrm{XXXV}, 4$ & Macarius 15 (269) & Io II,7 & R 122 & - & - \\
\hline XXXV,5 & - & - & - & - & - \\
\hline $\mathrm{XXXV}, 6$ & - & - & - & $\mathrm{XI}, 6$ & - \\
\hline
\end{tabular}




\begin{tabular}{|c|c|c|c|c|c|}
\hline PASCÁSIO & TEXTO GREGO & PELÁGIO-JOÃo & LIVRO III & LIVRO VII & RESTANTES \\
\hline XXXVI,1 & Macarius 11 (268) & $\operatorname{Pg} \mathrm{XV}, 26$ & R 124 & XIII,6 & - \\
\hline XXXVI,2 & N 298 & $\mathrm{Pg} X V, 53$ & R 125 & - & - \\
\hline XXXVI,3 & - & - & R 126 & XIII,7 & - \\
\hline XXXVI,4 & Theod. Pherm. 6 (188) & $\mathrm{Pg}$ XV,20 & - & - & - \\
\hline XXXVII,1 & Macarius $39(280)$ & - & R 127 & - & - \\
\hline XXXVIII,1 & Arsenius 16 (92) & $\operatorname{Pg} \mathrm{XV}, 8$ & - & - & - \\
\hline 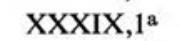 & $\mathrm{N} 322^{\mathrm{a}}$ & $\operatorname{Pg} X V, 80^{\mathrm{a}}$ & R $128^{a}$ & $X V, 1^{\mathrm{a}}$ & - \\
\hline b & (cf. G 759 (97)) & - & $\mathrm{R} 128^{\mathrm{b}}$ & $\mathrm{XV}, 1^{\mathrm{b}}$ & - \\
\hline c & $\mathrm{N} 322^{\mathrm{b}}$ & $\operatorname{Pg} X V, 80^{b}$ & $\mathrm{R} 128^{\mathrm{c}}$ & $\mathrm{XV}, 1^{\mathrm{c}}$ & - \\
\hline XXXIX,2 & Antonius 7 (77) & $\mathrm{Pg} X V, 3$ & R 129 & - & - \\
\hline XXXIX,3 & $\begin{array}{l}\text { N } 67 \\
\text { G } 490 \text { (67) }\end{array}$ & - & R 130 & $\mathrm{XV}, 2$ & - \\
\hline XXXIX,4 & Sisoes 13a (396) & $\operatorname{Pg} X V, 47^{\mathrm{a}}$ & - & - & - \\
\hline XXXIX,5 & Sisoes $13^{\mathrm{b}} \quad(396)$ & $\operatorname{Pg} X V, 47^{b}$ & - & - & - \\
\hline XXXIX, $6^{\mathrm{a}}$ & Poemen 97 (345) & - & R $131^{\mathrm{a}}$ & $\mathrm{XV}, 3^{\mathrm{a}}$ & - \\
\hline b & Poemen $98^{\mathrm{b}}$ & - & R $131^{b}$ & $\mathrm{XV}, 3^{\mathrm{b}}$ & - \\
\hline XXXIX,7 & - & - & - & $X V, 4$ & App. L. 12 \\
\hline XXXIX,8 & Dioscorus 2 (160) & - & - & $\mathrm{XV}, 5$ & App. L. $5^{\mathrm{b}}$ \\
\hline XXXIX,9 & Poemen 142 (357) & - & R 132 & - & $=$ \\
\hline $\mathrm{XL}, 1$ & Poemen 148 (357) & - & R 133 & XVI,1 & - \\
\hline $\mathrm{XL}, 2^{\mathrm{a}}$ & Hyperech. 4 (429) & Pg IV,51 & R 134 & $-i$ & - \\
\hline & Hyperech. 5 (429) & Pg IV,52 & - & - & - \\
\hline XLI,1 & N 254 & $\operatorname{Pg} 1 X, 11$ & - & - & - \\
\hline $\mathrm{XLI}, 2$ & Ioann. Col. 21 (212) & - & R 135 & - & - \\
\hline XLI,3 & $\begin{array}{l}\text { Pior } 3(373) \\
\text { (cf. Moyses } 2 \text { (281) }\end{array}$ & $\begin{array}{l}\text { Pg IX,9 } \\
\text { (cf. Pg IX,4) }\end{array}$ & R 136 & - & $\rightarrow$ \\
\hline XLI,4 & N $327\left(=\right.$ N $\left.396^{a}\right)$ & - & - & XVI,3 & (cf. App. L.10) \\
\hline $\mathrm{XLI}, 5$ & Theod. Pherm. 8 (189) & $\operatorname{Pg} X, 25$ & - & - & - \\
\hline XLI,6 & Isaac Theb. 1 (240) & Pg IX,3 & R 137 & - & - \\
\hline XLI,7 & Poemen 6 (320) & $\mathrm{Pg}$ IX,7 & - & - & 一 \\
\hline XLI, 8 & Antonius 21 (81) & Pg IX,1 & - & - & - \\
\hline XLI,9 & Antonius 29 (85) & - & R 138 & - & - \\
\hline XLI,10 & $\begin{array}{l}\text { Poemen } 23 \text { (328) } \\
\text { (cf. N 232 }\end{array}$ & $\operatorname{Pg~X,48}$ & - & - & - \\
\hline XLI,11 & - & - & R 139 & - & - \\
\hline XLI,12 & Poemen $70^{\mathrm{b}}(340)$ & - & R 140 & $\mathrm{XVI}, 4$ & - \\
\hline XLII,1 & Hyperech. 8 (432) & Pg XIV,11 & - & - & - \\
\hline XLII,2 & $\begin{array}{l}\text { Rufus } 2 \text { (389) } \\
\text { (cf. Ioseph Theb. (242)) }\end{array}$ & $\begin{array}{l}\text { Pg XIV,19 } \\
\text { (cf. Pg I,9) }\end{array}$ & R 141 & - & - \\
\hline XLII,3 & N 315 & $\mathrm{Pg} X V, 73$ & R 142 & - & - \\
\hline XLII,4 & Arsenius 35 (101) & - & - & - & - \\
\hline XLII,5 & Marcus 1 (293) & $\mathrm{Pg}$ XIV, 5 & R 143 & - & - \\
\hline XLII,6 & Marcus 2 (296) & - & - & - & - \\
\hline XLIII,1 & N 293 & Pg XIV,16 & R 144 & - & - \\
\hline
\end{tabular}




\begin{tabular}{|c|c|c|c|c|c|}
\hline PASCÁSIO & TEXTO GREGO & PELÁGIO-JOÃo & LIVRO III & LIVRO VII & RESTANTES \\
\hline XLIII, 2 & Ioan. disc. Paul. (240) & Pg XIV,4 & $\begin{array}{l}\text { A IV,13 } \\
(=\mathrm{R} \mathrm{27)}\end{array}$ & - & - \\
\hline XLIII,3 & N 294 & $\mathrm{Pg}$ XIV,17 & R 145 & - & - \\
\hline XLIV,1 & N 344 & - & R 146 & - & - \\
\hline XLIV,2 & N 347 & Pg XVII,16 & R 147 & - & - \\
\hline XLIV, 3 & Ioann. Pers. 2 (236) & Pg VI,7 & R 148 & - & - \\
\hline$X L V, 1$ & Poemen $69^{c}(337)$ & - & - & XVII,1 & - \\
\hline$X L V, 2$ & Theod.Pherm.11a (189) & - & - & XVII, 2 & - \\
\hline$X L V, 3$ & Apollo 1 (133) & - & - & XVII,3 & - \\
\hline XLVI,1 & Poemen $158(360)$ & - & R $149^{a}$ & - & - \\
\hline XLVI,2 & N 248 & $\mathrm{Pg} \times, 80$ & - & - & - \\
\hline XLVI,3 & Poemen 17 (325) & $\mathrm{Pg}$ IV, 30 & R $149^{b}$ & - & - \\
\hline XLVI,4 & N 284 & $\mathrm{Pg}$ XIII, 8 & R 150 & XVIII,1 & - \\
\hline XLVI,5 & Paphnutius 2 (377) & Pg XVII,12 & R 151 & - & - \\
\hline XLVI,6 & Arsenius 38 (104) & - & - & XVIII,2 & - \\
\hline XLVI, 7 & Poemen $70^{\mathrm{a}}$ (337) & $\operatorname{Pg}$ XVII,23 & R 140 & - & - \\
\hline XLVI, 8 & N 346 & Pg XVII,14 & R 152 & - & - \\
\hline XLVII,1 & N 253 & $\operatorname{Pg} I, 21$ & R 153 & $(\mathrm{XVI}, 2)$ & - \\
\hline XLVII, 2 & Isaac 4 (225) & $\mathrm{Pg}$ IV, 21 & - & - & - \\
\hline XLVII, 3 & Theod. Pherm. 22 (192) & - & - & - & - \\
\hline XLVII, 4 & Or $4(437)$ & - & - & - & - \\
\hline XLVIII,1 & Sisoes $30(401)$ & - & - & - & - \\
\hline XLIX,1 & Poemen 76 (340) & $\mathrm{Pg}$ IV,33 & R 154 & - & - \\
\hline XLIX,2 & Marcus 3 (296) & Pg XIV,6 & - & - & - \\
\hline XLIX, 3 & N 153 & $\mathrm{Pg}$ XIV,61 & $\begin{array}{l}\text { A V,5 } \\
(=\mathrm{R} 33)\end{array}$ & - & - \\
\hline XLIX,4 & Poemen 5 (320) & Pg VIII,13 & $\begin{array}{l}\text { A IV,4 } \\
(=\mathrm{R} 20)\end{array}$ & - & - \\
\hline XLIX, 5 & Poemen 7 (321) & Io II,10 & R 168 & $\mathrm{XIV}, 1$ & - \\
\hline XLIX, 6 & N 233 & $\operatorname{Pg} \mathrm{X}, 101$ & - & - & - \\
\hline XLIX, 7 & R. not. 4 (987) & $\mathrm{Pg}$ I,5 & - & - & - \\
\hline $\mathrm{L}, 1$ & - & - & - & - & - \\
\hline $\mathrm{L}, 2$ & N 355 & Pg XVII,18 & - & $\mathrm{XIX}, 1$ & - \\
\hline $\mathrm{L}, 3$ & Ioan. Theb. (240) & Pg XVI,4 & R 155 & $\mathrm{XIX}, 2$ & 一 \\
\hline $\mathrm{L}, 4$ & Agatho 27 (116) & - & R 156 & - & - \\
\hline $\mathrm{LI}, 1^{\mathrm{a}}$ & - & (cf. Pg VII, $17^{\mathrm{a}}$ ) & R $157^{\mathrm{a}}$ & $\mathrm{XX}, 1^{\mathrm{a}}$ & - \\
\hline b & (icf. Synclet. $7^{b}$ (424) & $\mathrm{Pg}$ VII, $16^{\mathrm{b}}$ & R $157^{\mathrm{b}}$ & $\mathrm{XX}, 1^{\mathrm{b}}$ & - \\
\hline c & - & Pg VII,45 & R $157^{c}$ & $\mathrm{XX}, 1^{\mathrm{c}}$ & - \\
\hline $\mathrm{LI}, 2$ & N 209 & $\begin{array}{l}\text { Pg VII,41 } \\
\text { (cf. Pg VII, } 16^{a}\end{array}$ & R 158 & $\mathrm{XX}, 2$ & - \\
\hline $\mathrm{LI}, 3$ & N 212 & $\mathrm{Pg}$ VII, 44 & - & - & - \\
\hline LII, 1 & N 279 & $\mathrm{Pg}$ XI,52 & R 159 & - & - \\
\hline LII, 2 & Pambo 8 (369) & Pg I,16 & R 160 & - & $\begin{array}{lll}\operatorname{Hr} & 2^{\mathrm{m}} & (261) \\
\operatorname{Pd} & 5^{\mathrm{d}} & (351)\end{array}$ \\
\hline
\end{tabular}




\begin{tabular}{|c|c|c|c|c|c|}
\hline PASCÁSIO & TEXTO GREGO & PELÁGIO-JOÃO & LIVRO III & LIVRO VII & RESTANTES \\
\hline LII,3 & Agatho $29^{\mathrm{b}}(117)$ & Pg XI,2 & R 161 & - & - \\
\hline LII,4 & Sisoes 14 (396) & Io III, 6 & R 162 & - & - \\
\hline LII, $5^{\text {a }}$ & Arsenius 39 (105) & $\operatorname{Pg} X, 9$ & R $163^{\mathrm{a}}$ & - & - \\
\hline D & Arsenius $40^{\mathrm{a}}(105)$ & $\operatorname{Pg} \times V, 9^{b}$ & R $163^{b}$ & - & - \\
\hline c & Arsenius $42^{\mathrm{d}}(108)$ & $\operatorname{Pg} X V, 10^{d}$ & $\mathrm{R} 163^{\mathrm{c}}$ & - & - \\
\hline d & Arsenius $41^{\mathrm{a}}(105)$ & $\mathrm{Pg}$ III, 1 & $\begin{array}{l}\text { R } 163^{\mathrm{d}} \\
\left(=\mathrm{R} 211^{\mathrm{c}}\right)\end{array}$ & - & - \\
\hline e & Arsenius $40^{\mathrm{c}}(105)$ & $\operatorname{Pg} X V, 9^{\mathrm{c}}$ & R $163^{\mathrm{e}}$ & - & - \\
\hline $\mathrm{f}$ & Arsenius $41^{b}(105)$ & $\mathrm{Pg} X \mathrm{X}, 9^{\mathrm{e}}$ & R $163^{f}$ & - & - \\
\hline LIII,1 & - & - & - & $\mathrm{XXI}, 1$ & - \\
\hline LIII, 2 & $\begin{array}{l}\text { Euprepius } 5 \text { (172) } \\
\text { N } 137\end{array}$ & $\operatorname{Pg}$ I,19 & - & $\mathrm{XXI}, 2$ & - \\
\hline LIII,3 & Poemen 65 (337) & $\mathrm{Pg} \mathrm{XI}, 23$ & - & - & - \\
\hline LIV,1 & N 142 & $\mathrm{Pg}$ III, 27 & - & - & - \\
\hline LIV, $2^{\mathrm{a}}$ & N 139 & $\mathrm{Pg}$ III, 23 & - & - & - \\
\hline b & N 140 & $\mathrm{Pg}$ III, 24 & - & - & - \\
\hline LIV, 3 & - & - & - & - & - \\
\hline LIV, $4^{a}$ & Pambo 4a (369) & Pg III,14a & R $164^{\mathrm{a}}$ & - & - \\
\hline b & Pambo 7 (369) & Pg XVII,11 & R $164^{b}$ & - & - \\
\hline c & Pambo $4^{\mathrm{b}}(369)$ & $\mathrm{Pg}$ III, $14^{\mathrm{b}}$ & R $164^{\mathrm{c}}$ & - & - \\
\hline $\mathrm{LV}, 1^{\mathrm{a}}$ & Poemen $120^{\mathrm{a}}(353)$ & - & - & $\mathrm{XXII}, 1^{\mathrm{a}}$ & - \\
\hline b & N 10 & - & - & XXII, $1^{b}$ & - \\
\hline $\mathrm{LV}, 2$ & N 271 & Pg XI,44 & R 165 & - & - \\
\hline$L V, 3^{a}$ & N 264 & $\mathrm{Pg}$ XI,39 & - & - & - \\
\hline b & - & $\mathrm{Pg}$ XI,42 & - & - & - \\
\hline $\mathrm{LV}, 4$ & Sarmata 1 (413) & - & - & 一 & - \\
\hline$L V, 5$ & Mios 3 (301) & Io IV,30 & - & - & - \\
\hline LV, 6 & Ioan. Col. 16 (209) & Io IV,13 & - & - & - \\
\hline LVI,1 & - & - & - & - & - \\
\hline LVI, 2 & - & Io I,16 & R 166 & XXIII,1 & - \\
\hline LVI,3 & Paul. Simpl. (381) & Pg XVIII,20 & R 167 & XXIII,2 & - \\
\hline LVII, 1 & - & - & - & XXIV,1 & App. L. 2 \\
\hline LVII, 2 & N 43 & - & R 217 & XXIV,2 & - \\
\hline LVII, 3 & N 135 & Pg III,20 & R 216 & - & - \\
\hline LVII, 4 & $\begin{array}{l}\text { (cf. An. Mus. Guim. } \\
30(1903) \text { p. } 86 \text { ss.) }\end{array}$ & - & - & - & - \\
\hline LVIII,1 & Macarius 19 (269) & Pg XII,10 & R 207 & - & - \\
\hline LVIII, 2 & - & - & - & - & - \\
\hline LVIII,3 & Ioann. Col. 12 (208) & - & R 208 & - & - \\
\hline LVIII,4 & Poemen 146 (357) & - & R 209 & - & - \\
\hline LIX, 1 & - & - & - & - & - \\
\hline LX,1 & Achilas $5^{b}(125)$ & - & - & - & - \\
\hline LXI, $1^{\text {a }}$ & Agatho 9 (112) & Pg XII,2 & - & - & - \\
\hline b & - & - & - & - & - \\
\hline
\end{tabular}




\begin{tabular}{|c|c|c|c|c|c|}
\hline PASCÁSIO & TEXTO GREGO & PELÁGIO-JOÃo & LIVRO III & LIVRO VII & RESTANTES \\
\hline LXII,1 & Zeno 5 (177) & Pg XVIII,7 & R 210 & - & - \\
\hline LXIII,1 & - & - & - & - & - \\
\hline LXIII, 2 & Epiphanius 3 (164) & $\mathrm{Pg}$ XII, 6 & - & - & - \\
\hline LXIV,1 & G 409 (65) & Io II,12 & - & - & - \\
\hline $\mathrm{LXIV}, 2^{\mathrm{a}}$ & Arsenius 30 (97) & Pg XII,1 & R $211^{\mathrm{a}}$ & - & - \\
\hline b & Arsenius 14 (92) & Pg IV, 2 & R $211^{\mathrm{b}}$ & - & - \\
\hline $\mathrm{LXV}, 1$ & Esaias 4 (181) & $\mathrm{Pg}$ XII,7 & - & - & - \\
\hline $\mathrm{LXV}, 2$ & Ioan. Col. 9 (205) & Pg III,6 & - & - & - \\
\hline LXVI,1 & Lucius (253) & $\mathrm{Pg}$ XII,9 & R 212 & - & - \\
\hline LXVII,1 & Siluanus 4 (409) & $\mathrm{Pg}$ XI, 28 & - & - & - \\
\hline LXVIII,1 & Macarius 14 (269) & Io II,6 & R 213 & - & - \\
\hline LXVIII,2 & Sisoes 12 (396) & Io II,14 & - & - & - \\
\hline LXVIII,3 & Ammonas 2 (120) & - & R 214 & - & - \\
\hline LXVIII,4 & Besario 1 (137) & Io II, 1 & R 215 & - & - \\
\hline LXIX,1 & Macarius 38 (280) & Io III,16 & R 172 & - & - \\
\hline LXX,1 & N 332 & Pg XV,87 & - & - & - \\
\hline LXX,2 & Antonius 12 (77) & $\operatorname{Pg} X, 2^{\mathrm{a}}$ & - & - & - \\
\hline LXXI,1 & N 302 & $\operatorname{Pg} X V, 58$ & R 173 & $\mathrm{XXV}, 1$ & - \\
\hline $\mathrm{LXXI}, 2^{\mathrm{a}}$ & Sisoes 11 (396) & $\operatorname{Pg} \mathrm{XV}, 45$ & R $174^{\mathrm{a}}$ & $X X V, 2^{a}$ & - \\
\hline & - & - & R $174^{\mathrm{b}}$ & $X X V, 2^{b}$ & - \\
\hline LXXI,3 & Poemen 67 (337) & $\operatorname{Pg} \times, 62$ & - & $X X V, 3$ & - \\
\hline LXXI,4 & - & - & - & $\mathrm{XXV}, 4$ & - \\
\hline LXXII,1 & N 218 & $\operatorname{Pg} X, 86$ & - & - & - \\
\hline LXXII, 2 & N 57 (= N 270) & $\mathrm{Pg} \mathrm{XI}, 43$ & - & - & - \\
\hline $\mathrm{LXXII}, 3^{\mathrm{a}}$ & N 219 & $\operatorname{Pg~X,88}$ & - & - & - \\
\hline & - & - & - & - & - \\
\hline LXXII,4 & Ioseph 3 (228) & Pg X,29 & - & - & - \\
\hline LXXII,5 & N 56 & - & - & - & - \\
\hline LXXII,6 & Sisoes $22(400)$ & - & - & $(\mathrm{XXXIX}, 1)$ & M 26 \\
\hline LXXII,7 & Siluanus 6 (409) & $\operatorname{Pg} \mathrm{XI}, 30$ & R 175 & - & - \\
\hline LXXII,8 & N 211 & Pg VII,43 & - & - & - \\
\hline LXXIII, $1^{\mathrm{a}}$ & Antonius 38 (88) & - & R 176 & - & - \\
\hline b & Antonius 37 (88) & - & - & - & - \\
\hline LXXIII, 2 & N 370 & - & - & - & - \\
\hline LXXIII,3 & Poemen $101^{\mathrm{b}}(345)$ & $\operatorname{Pg}$ IV, $25^{\mathrm{b}}$ & R 177 & - & - \\
\hline LXXIII,4 & N 164 & $\mathrm{Pg} \mathrm{V}, 13^{\mathrm{a}}$ & $\begin{array}{l}\text { A II, } 2 \\
(=\mathrm{R} \quad 9)\end{array}$ & - & - \\
\hline LXXIII,5 & Poemen 1 (317) & Pg XI,19 & - & - & - \\
\hline LXXIII,6 & - & - & - & - & - \\
\hline LXXIII, 7 & N 223 & $\mathrm{Pg} X, 92$ & R 178 & - & - \\
\hline LXXIII, 8 & Ioan. Col. 18 (209) & $\mathrm{Pg} \mathrm{XI}, 15$ & - & - & - \\
\hline LXXIV,1 & N 276 & $\mathrm{Pg}$ XI,49 & - & - & - \\
\hline LXXIV,2 & Poemen 52 (333) & $\operatorname{Pg} X, 59$ & - & - & - \\
\hline
\end{tabular}




\begin{tabular}{|c|c|c|c|c|c|}
\hline PASCÁSIO & TEXTO GREGO & PELÁGIO-JOÃo & LIVRO III & LIVRO VII & RESTANTES \\
\hline $\mathrm{LXXV}, 1^{\mathrm{a}}$ & Poemen 184 (368) & - & - & - & App. L. $4^{c}$ \\
\hline & Poemen 107 (348) & - & - & - & - \\
\hline LXXVI,1 & Moyses 12 (285) & $\mathrm{Pg} X, 63$ & - & XXVI,1 & - \\
\hline LXXVI,2 & Poemen 66 (337) & $\mathrm{Pg} \mathrm{I}, 15$ & - & XXVI,2 & - \\
\hline LXXVI, $3^{\mathrm{a}}$ & $\mathrm{N} 241^{\mathrm{a}}$ & $\mathrm{Pg} X, 108^{\mathrm{a}}$ & - & XXVI, $3^{\mathrm{a}}$ & - \\
\hline b & N $241^{b}$ & $\mathrm{Pg} \mathrm{X}, 108^{\mathrm{b}}$ & R 179 & XXVI, $3^{b}$ & - \\
\hline LXXVI,4 & - & - & - & XXVI,4 & - \\
\hline LXXVI,5 & 一 & - & - & - & - \\
\hline LXXVII, 1 & - & - & - & XXVII,1 & - \\
\hline LXXVII, 2 & Matoes 1 (289) & Pg VII,11 & - & - & - \\
\hline LXXVII, 3 & N 203 & $\mathrm{Pg}$ VII, 35 & - & - & - \\
\hline LXXVIII, 1 & - & - & R 180 & XXVIII,1 & - \\
\hline LXXVIII, 2 & - & - & - & XXVIII, 2 & App. L. 6 \\
\hline LXXVIII, 3 & N 235 & - & - & XXVIII,3 & - \\
\hline LXXIX,1 & N 349 & Pg XVII,19 & R 181 & XXVIII, 4 & $\left(\operatorname{cfCs} 51^{a}(845)\right.$ \\
\hline LXXX,1 & - & - & R 182 & - & - \\
\hline LXXX,2 & - & - & - & - & - \\
\hline LXXXI,1 & Poemen 183 (365) & Pg XVIII,16 & - & XXIX,1 & - \\
\hline LXXXI,2 & - & $\mathrm{Pg} X, 67^{\mathrm{a}}$ & - & - & $\mathrm{Hr}_{\text {prold }}{ }^{\mathrm{d}}(251)$ \\
\hline LXXXI,3 & - & - & - & - & - \\
\hline LXXXI,4 & Poemen 25 (328) & $\operatorname{Pg} \times, 50$ & R $183^{\mathrm{a}}$ & - & - \\
\hline LXXXI, 5 & $\begin{array}{l}\text { G } 1 \text { (29) } \\
\text { (cf. Poemen } 63 \text { et } 164)\end{array}$ & $\mathrm{Pg}$ VIII, 14a & R $183^{b}$ & - & - \\
\hline LXXXII,1 & Isaac $2(224)$ & - & - & - & - \\
\hline LXXXIII, $1^{\mathrm{a}}$ & Arsenius $6^{\mathrm{a}}(89)$ & $\operatorname{Pg} X V, 7^{a}$ & A VI, $3^{\mathrm{a}}$ & - & - \\
\hline $\mathrm{b}$ & $\begin{array}{l}\text { Arsenius } 6^{\mathrm{b}}(89) \\
\left.\text { (cf. Euprepius } 7^{\mathrm{b}}(172)\right)\end{array}$ & $\operatorname{Pg} X V, 7^{b}$ & A VI, $3^{b}$ & - & - \\
\hline LXXXIII, 2 & Arsenius 5 (88) & $\operatorname{Pg} X, 5$ & - & - & - \\
\hline LXXXIV, 1 & Arsenius $42^{\mathrm{a}}(105)$ & $\mathrm{Pg}$ XV,10 & - & - & $\left(\right.$ cf. $\left.\mathrm{Hr} 2^{\mathrm{n}}\right)$ \\
\hline LXXXIV, 2 & Ammun Nitr. $2^{b}(128)$ & $\mathrm{Pg}$ XI,20 & - & - & - \\
\hline LXXXIV, 3 & R. not. 14 (1024) & Io IV, 26 & - & - & - \\
\hline LXXXV,1 & Poemen $8^{\mathrm{b}}(321)$ & $\operatorname{Pg} \times, 39^{b}$ & R 184 & - & - \\
\hline LXXXV, 2 & Theod. Pherm. 3 (188) & Pg VIII,6 & - & - & - \\
\hline LXXXVI, 1 & - & - & - & $\mathrm{XXX}, 1$ & App. L. 11 \\
\hline LXXXVI,2 & N 303 & Pg XV,59 & - & $\mathrm{XXX}, 2$ & - \\
\hline LXXXVII, $1^{\mathrm{a}}$ & Matoes $11^{\mathrm{b}}(293)$ & $\mathrm{Pg} \mathrm{I}, 23^{\mathrm{b}}$ & R $185^{\mathrm{a}}$ & XXXI, $1^{\mathrm{a}}$ & - \\
\hline b & - & - & R $185^{b}$ & $\mathrm{XXXI}, 1^{\mathrm{b}}$ & - \\
\hline LXXXVII, 2 & Poemen 47 (333) & - & - & - & - \\
\hline LXXXVIII, 1 & Agatho 15 (113) & $\operatorname{Pg}$ IV,7 & - & - & - \\
\hline LXXXVIII, 2 & - & - & R 186 & XXXII,3 & - \\
\hline LXXXVIII, $3^{\mathrm{a}}$ & Euprepius $7^{\mathrm{a}}(172)$ & $\operatorname{Pg} X, 19^{\mathrm{a}}$ & - & - & - \\
\hline & - & - & - & $\mathrm{XXXI,1 \textrm {c }}$ & - \\
\hline LXXXVIII,4 & Euagrius 7 (176) & $\mathrm{Pg}$ XVI,2 & - & - & - \\
\hline LXXXVIII,5 & Arsenius $40^{\mathrm{b}}$ (105) & - & - & - & - \\
\hline
\end{tabular}




\begin{tabular}{|c|c|c|c|c|c|}
\hline PASCÁSIO & TEXTO GREGO & PELÁGIO-JOÃo & LIVRO III & LIVRO VII & RESTANTES \\
\hline LXXXVIII,6 & N 321 & Pg XV,79 & - & XXXII,1 & - \\
\hline LXXXVIII,7 & Tithoes 3 (428) & Pg XI,27 & - & XXXII,2 & - \\
\hline LXXXVIII,8 & Antonius 18 (81) & Pg IV,1 & - & - & - \\
\hline LXXXVIII,9 & Poemen 27 (329) & $\mathrm{Pg} X, 51^{\mathrm{b}}$ & - & - & - \\
\hline LXXXIX,1 & (cf. Tithoes 2 (428)) & $(\mathrm{cf} . \mathrm{Pg}$ IV, 44$)$ & - & XXXII,4 & (cf. M 72) \\
\hline LXXXIX,2 & Arsenius 12 (89) & $\operatorname{Pg} \mathrm{X}, 6$ & - & XXXII,6 & - \\
\hline LXXXIX,3 & - & - & R 187 & XXXII,7 & - \\
\hline LXXXIX,4 & Megethius 1 (300) & - & - & - & - \\
\hline $\mathrm{XC}, 1$ & Theod. Pherm. 25 (193) & $\mathrm{Pg} X \mathrm{XV}, 21$ & - & XXXIII,1 & - \\
\hline $\mathrm{XC}, 2$ & Isaac 1 (224) & - & $\begin{array}{l}\text { A IV,8 } \\
(=\mathrm{R} 22)\end{array}$ & XXXIII,2 & - \\
\hline $\mathrm{XC}, 3$ & Matoes 9 (292) & Pg XV,27 & R 188 & XXXIII,3 & - \\
\hline $\mathrm{XCI}, 1$ & Ammonas 9 (121) & $\mathrm{Pg} X \mathrm{XV}, 12$ & - & - & - \\
\hline XCII,1 & Poemen 59 (336) & $\mathrm{Pg}$ II, $12^{\mathrm{b}}$ & - & - & - \\
\hline $\mathrm{XCII}, 2$ & - & - & - & - & - \\
\hline XCII,3 & Poemen 9 (324) & Io IV,32 & A IV,6 & - & - \\
\hline XCIII,1 & Antonius 11 (77) & Pg II,2 & - & - & - \\
\hline XCIII,2 & $\begin{array}{ll}\text { Macarius } 41 & (281) \\
\text { Macarius } 27 & (273)\end{array}$ & - & R 189 & - & - \\
\hline $\mathrm{XCIII}, 3^{\mathrm{a}}$ & Arsenius 1 (88) & $\operatorname{Pg}$ II, $3^{\mathrm{a}}$ & R $190^{\mathrm{a}}$ & - & - \\
\hline & Arsenius 2 (88) & $\mathrm{Pg}$ II, $3^{\mathrm{b}}$ & R $190^{b}$ & - & - \\
\hline XCIII,4 & Arsenius 13 (92) & Pg XVII,5 & - & XXXIV,1 & - \\
\hline XCIII,5 & Arsenius 26 (96) & - & R 192 & XXXIV,2 & - \\
\hline XCIII,6 & Arsenius 37 (104) & - & R $193^{\mathrm{a}}$ & - & - \\
\hline $\mathrm{XCIII}, 7$ & Arsenius $42^{b}(105)$ & $\operatorname{Pg} X V, 10^{b}$ & R $193^{b}$ & - & - \\
\hline XCIII, 8 & Arsenius 7 (89) & $\mathrm{Pg}$ II, $4^{\mathrm{a}}$ & R $191^{\mathrm{a}}$ & - & - \\
\hline XCIII,9 & Arsenius 8 (89) & $\mathrm{Pg}$ II, $4^{\mathrm{b}}$ & R $191^{\mathrm{b}}$ & - & - \\
\hline XCIII,10 & Besario $4^{b}(140)$ & Io III,1 & R 194 & XXXIV,3 & - \\
\hline XCIII,11 & Macarius 33 (273) & Io III,2 & R 195 & - & - \\
\hline XCIV,1 & Arsenius 25 (96) & Pg II,5 & - & - & - \\
\hline $\mathrm{XCV}, 1$ & - & - & R 196 & $\mathrm{XXXV}, 1$ & - \\
\hline $\mathrm{XCV}, 2$ & - & - & - & $X X X V, 2$ & - \\
\hline $\mathrm{XCV}, 3$ & Ischyrio (241) & Io I,14 & R 197 & - & - \\
\hline XCVI,I & Agathon $1^{a}(108)$ & $\operatorname{Pg} X, 8^{\mathrm{a}}$ & R 198 & XLII,1 & - \\
\hline XCVI, $2^{a}$ & - & - & - & - & - \\
\hline b & Agathon 1c (109) & $\mathrm{Pg} \mathrm{X}, 8^{\mathrm{c}}$ & - & - & - \\
\hline c & N 118 & - & - & - & App. W. 31 \\
\hline XCVI,3 & Nisterous 2 (308) & $\operatorname{Pg} X V, 30^{b}$ & - & XLII,3 & - \\
\hline $\mathrm{XCVI}, 4^{\mathrm{a}}$ & Anub 1 (129) & $\operatorname{Pg} X V, 11$ & $\begin{array}{l}\text { R } 199^{\mathrm{a}} \\
\text { (cf. A IV,19) }\end{array}$ & $\mathrm{XLII}, 4^{\mathrm{a}}$ & - \\
\hline b & - & - & R $199^{\mathrm{b}}$ & XLII, $4^{b}$ & - \\
\hline $\mathrm{XCVII}, 1^{\mathrm{a}}$ & Synclet. 6 (421) & $\mathrm{Pg}$ VII,15 & - & - & - \\
\hline & N 204 & Pg VII,36 & - & - & - \\
\hline XCVIII,1 & Poemen 29 (329) & |Pg X,52 & - & XXXVI,1 & - \\
\hline
\end{tabular}




\begin{tabular}{|c|c|c|c|c|c|}
\hline PASCÁSIO & TEXTO GREGO & PELÁGIO-JOÃo & LIVRO III & LIVRO VII & RESTANTES \\
\hline $\mathrm{XCIX}, 1^{\mathrm{a}}$ & Poemen 53 (333) & $\operatorname{Pg} \mathrm{I}, 13$ & - & - & - \\
\hline & - & - & - & XXXVI, $2^{\mathrm{a}}$ & - \\
\hline c & (cf. N 125) & (cf. Pg XV,85a) & - & XXXVI, $2^{b}$ & - \\
\hline XCIX,2 & Arsenius 33 (100) & Pg XVIII,2 & $\begin{array}{l}\text { A VI,2 } \\
(=\mathrm{R} 38)\end{array}$ & XXXVI,3 & - \\
\hline $\mathrm{C}, 1$ & Poemen 45 (332) & $\mathrm{Pg} \mathrm{X}, 58$ & - & - & - \\
\hline $\mathrm{C}, 2$ & Poemen 55 (336) & $\operatorname{Pg} \times \mathrm{XV}, 39$ & - & - & - \\
\hline $\mathrm{C}, 3$ & Copres 3 (252) & $\mathrm{Pg} X \mathrm{XV}, 24$ & - & - & - \\
\hline$C, 4^{\mathrm{a}}$ & N 124 & $\mathrm{Pg}$ XI,25 & - & - & - \\
\hline b & - & - & - & - & - \\
\hline $\mathrm{C}, 5$ & Antonius 17 (80) & $\operatorname{Pg} \mathrm{XV}, 80$ & - & - & - \\
\hline $\mathrm{C}, 6$ & - & - & - & - & - \\
\hline $\mathrm{C}, 7$ & N $385^{\mathrm{a}}$ & $\begin{array}{l}\mathrm{Pg} \mathrm{X}, 94^{\mathrm{a}} \\
\text { (cf. Pg VI,12) }\end{array}$ & - & XLI, 2 & - \\
\hline $\mathrm{CI}, 1$ & $\begin{array}{l}\text { (cf. Moyses } 14-16,18 \\
(288))\end{array}$ & (cf. Io IV $, 1,2,3,7$ ) & - & - & (M 109) \\
\hline App. 1 & - & - & - & - & - \\
\hline App. 2 & - & - & - & - & $\begin{array}{l}\text { (cf. Vita Hilar. } \\
\text { PL } 23 \text { (37) }\end{array}$ \\
\hline App. 3 & - & - & - & - & - \\
\hline App. 4 & - & - & - & - & - \\
\hline App. 5 & - & - & - & - & - \\
\hline App. 6 & - & - & - & - & - \\
\hline App. 7 & - & - & - & - & $\begin{array}{l}\text { (cf. Vita Hilar. } \\
\text { PL } 23 \text { (43)) }\end{array}$ \\
\hline App. 8 & - & - & - & - & $\begin{array}{l}\text { (cf. Hr. P. PL } \\
74 \text { (286-287) ) } \\
\text { et II Rosw. } 31 \\
\text { (459) }\end{array}$ \\
\hline App. 9 & - & - & - & - & - \\
\hline
\end{tabular}




\section{Cap. III-APRECIAÇÃO DE PASCÁSIO COMO TRADUTOR}

\section{I - NOTAS PRÉVIAS}

Para ajuizar com segurança das qualidades de Pascásio como tradutor do grego para latim precisávamos de estar certos de que possuíamos o original grego sobre que trabalhou. Já vimos que a grande maioria do apotegmas gregos publicados se encontra na edição da série nominal (de J. B. Cotelier $=$ PG LXV) e na da chamada colecção anónima, só em parte editada por F. Nau (de 1907 a 1913).

Como não dispomos de outro material, fizemos um estudo comparativo da tradução de Pascásio com todos os apotegmas gregos que lhe são paralelos. Após essa análise, parece-nos necessário deixar aqui duas observações preliminares.

1 - Está fora do âmbito do nosso estudo discutir a natureza do texto grego que possuímos. Da sua comparação com Pascásio e outras traduções paralelas ressalta, à evidência, que a série nominal e anónima é fruto de uma compilação de várias fontes. Daí resultam aparentes contradições em relação ao texto de Pascásio e de Pelágio-João, pois uma vezes o grego parece corresponder-lhes satisfatòriamente, enquanto outras nos deixa a impressão ora de parecer anterior ora posterior. A constituição do seu conteúdo revela-se também complicada, havendo apotegmas que caminham perfeitamente a par, outros em que há novos elementos no grego e outros em que, pelo contrário, é o latim que se mostra mais extenso e bem informado.

Igualmente se poderiam citar casos em que o latim de Pascásio e Pelágio-João supõe, em ambos, um texto grego comum bastante diferente do que possuímos. Em contrapartida, há apotegmas muito 
semelhantes no grego e traduções latinas, verificando-se variantes apenas de pormenor. Neste caso, quando Pascásio e Pelágio-João são concordantes, poderíamos até, com bastante aproximação, reconstituir os elementos gregos que ambos possuíam e que faltam no texto publicado. Mas se nos detivéssemos nestes aspectos estaríamos a tentar restituir as colecções gregas que serviram de base à compilação actualmente existente. E esse não é agora o nosso objectivo.

2 - Apesar das divergências verificadas, em muitos pontos, entre os apotegmas gregos e as traduções latinas, devemos deixar também bem vincado que em muitos outros passos o grego existente e as traduções que conhecemos se correspondem suficientemente. É na base desta verificação que podemos apreciar as qualidades e as técnicas dos diversos tradutores latinos.

A nossa análise fixar-se-á primàriamente em Pascásio. Não deixaremos, no entanto, com alguma frequência, de chamar a atenção para o trabalho de outros tradutores.

Cremos chegado o momento de provar que o texto grego publicado, em muitos casos, corresponde bem às traduções latinas existentes.

\section{II - ASPECTOS DO TEXTO GREGO E DA TRADUÇÃO DE PASCÁSIO}

1-APOTEGMAS QUE PODERIAM PASSAR DE PASCÁSIO PARA AS COLECÇÕES GREGAS. Anotemos três apotegmas (LXXII,2; LXXXIX,4; e XCIII,6) que poderiam ter passado do texto grego de Pascásio para a compilação grega publicada. Dos dois últimos só conhecemos a tradução de Pascásio. Examinemos, pois, o único destes exemplos de que temos duas traduções latinas.

$$
\text { NAU, } 270
$$

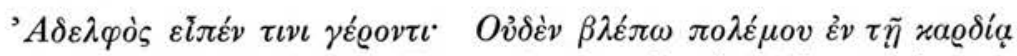

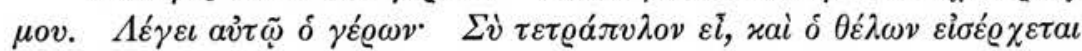

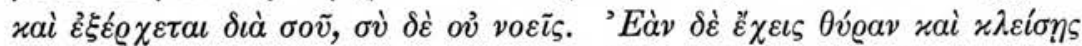

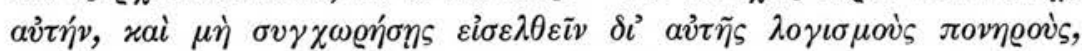

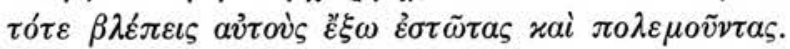


PASC. LXXII, 2

Quidam frater dixit seni: Nihil uideo pugnae in corde meo. Cui senex: Tu quadriportium es et qui uult ingreditur et egreditur per te; tu autem non sentis. Si autem habes ostium et clauseris illum et non permiseris per eum ingredi malas cogitationes, tunc uides eas de foris stantes et pugnantes.
PLG. XI, 43

Frater dixit cuidam seni: Nihil pugnae uideo in corde meo. Et dixit ei senex: Tu sic es uelut quadrigemina porta ut quicumque uoluerit intret unde uoluerit in te et unde uoluerit exeat, et tu non intelligis quae aguntur. Nam si haberes ianuam et clauderes eam, nec permitteres intrare per eam cogitationes malas, tunc uideres stantes foris, et pugnantes aduersum te.

Note-se, em primeiro lugar, que o texto grego é literalmente repetido atrás, em Nau 57, apenas com o acrescento, no fim de $\sigma \varepsilon$, a que corresponde em Pelágio aduersum te. O compilador grego deve ter encontrado o apotegma em duas colecções diferentes e não advertiu que se repetia.

Quanto às traduções latinas, ambas são literais, o que leva a breves coincidências de palavras. Todavia, Pelágio parece ter diante de si um texto grego com mais os dois pequenos acrescentos que sublinhámos no latim. Observe-se desde já um traço da técnica de Pascásio:

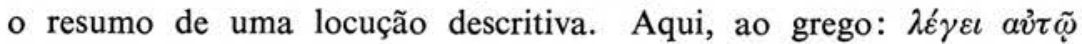

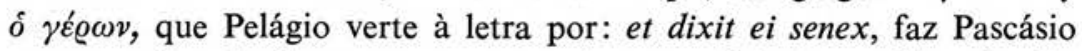
corresponder simplesmente, e com mais arte: Cui senex. Na selecção do vocabulário, Pascásio é menos «vulgar», preferindo ingredior ao intro de Pelágio.

2 - HÁ CASOS EM QUE PASCÁSIO É MAIS LITERAL QUE PELÁGIO-JOÃo. Embora raramente, Pascásio é por vezes mais literal na tradução do que Pelágio. No exemplo que damos a seguir, comecemos por notar que o apotegma se apresenta anónimo em Pascásio, ao passo que em Pelágio é atribuído a Hyperechius, tal como no grego, onde tem, na série alfabética nominal o n. 8 das sentenças que vêm sob este nome. 
HYPERECHIUS, 8 (432)

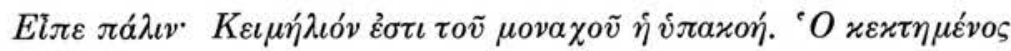

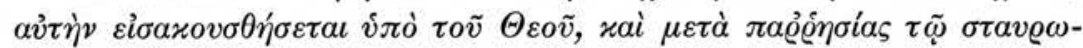

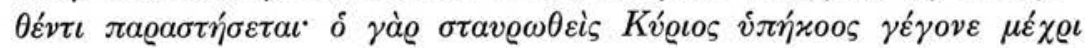

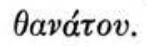

PASC. XLII,1

Dixit quidam senex: Grande ornamentum est monachis oboedientia. Nam quicumque eam possederit et ipse audietur et crucifixo cum fiducia adstabit, quia Dominus noster oboediens fuit usque ad mortem.
PLG. XIV,11

Dixit abbas Hyperichius: Quia ministerium monachi est oboedientia, quam qui possidet, quod poscit exaudietur et cum fiducia crucifixo adstabit; etenim Dominus sic uenit ad crucem, factus scilicet oboediens usque ad mortem.

Ambos os tradutores omitem o inciso vijò $\tau o \tilde{v} \Theta \varepsilon o \tilde{v}$, que deve ter sido posteriormente introduzido. No trabalho de Pascásio é de

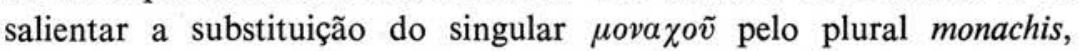
processo que adopta com frequência. As palavras sublinhadas em Pelágio não correspondem ao grego. Se de facto tinha $x \varepsilon \iota \mu \eta_{\lambda} \lambda_{\iota} \nu$ ('bem, tesouro') - como Pascásio deixa supor - Pelágio não entendeu o seu sentido. Além do acrescento quod poscit, registe-se a deficiente tradução de $\sigma \tau \alpha v \varrho \omega \theta \varepsilon i ́$ s por sic uenit ad crucem, como forma de uariatio. Pascásio cuja técnica de tradução leva a evitar repetições, omitiu a palavra, substituindo-a por noster, formando assim o grupo Dominus noster de frequente uso religioso e litúrgico.

Exemplos deste tipo, em que dois tradutores caminham a par, têm o mérito de nos garantir que o organizador da respectiva colectânea grega utilizava fontes comuns. Observemos, no entanto, desde já, que na maioria dos casos Pelágio e João são mais literais na sua tradução, com frequentes sinais de autêntica escravidão ao grego, o que raramente acontece em Pascásio.

3-COINCIDÊNCIAS LITERAIS ENTRE PASCÁSIO E PELÁgIO-JoÃo. A fonte comum de Pascásio e Pelágio-João é tão certa que poderíamos apresentar uma meia dúzia de exemplos em que, em pequenos passos, os 
dois tradutores coincidem literalmente. No entanto, alguns pormenores garantem-nos que, mesmo então, um tradutor não copiou do outro, mas se trata de fidelidade a um texto grego comum e de fácil interpretação. No exemplo que vamos apresentar sublinhamos, em Pascásio, as palavras iguais a Pelágio e, em Pelágio, os pormenores diferentes.

РАмBO, 7 (369)

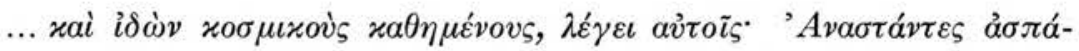

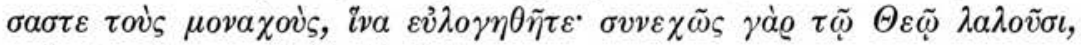

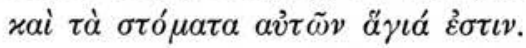

PASC. LIV, $4^{\text {b }}$

... cum uidisset saeculares dicit eis: Surgite et salutate monachos ut benedicamini; frequenter enim isti cum Deo loquuntur et os illorum sanctum est.
PLG. XVII,11

...et uidens quosdam saeculares sedentes dixit eis: Surgite et salutate et osculamini monachos ut benedicamini, frequenter enim cum Deo loquuntur et sancta sunt ora eorum.

É evidente que o grego sobre que ambos os tradutores trabalhavam devia ser muito semelhante ao que deixamos acima. A coincidência entre Pascásio e Pelágio dá-se, porém, apenas no passo transcrito. Com efeito, enquanto Pelágio XVII,11 corresponde a todo o apotegma grego Pambo, 7 (369), Pascásio LIV,4 é composto por elementos tirados de dois episódios diferentes.

Além disso, apesar do literalismo e da coincidência dos dois tradutores, há características próprias de cada um deles. Limitemo-nos a Pascásio. Note-se o gosto pela subordinação em cum uidisset, em

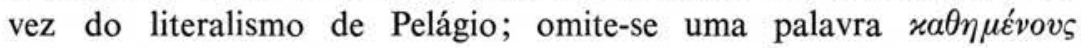
porque se pode subentender no surgite seguinte; acrescenta-se isti para pôr em evidência o sujeito; substitui-se o plural pelo singular em os...sanctum. Veremos que todos estes processos são frequentes em Pascásio.

Em Pelágio acrescenta-se et osculamini. Apesar de o grego que possuímos não ter o correspondente a este inciso, é natural que o texto grego de Pelágio o tivesse. Se o de Pascásio o apresentasse também 
é quase certo que apesar disso o omitiria, pois, como veremos, a sua tradução é muito comedida na efusão de sentimentos deste género... O pudor é uma das características seguras da tradução de Pascásio (1).

4 - COMParaÇão do Grego com três traduÇões latinas. Em certos casos é possível comparar o grego publicado com três traduções diferentes. Analisemos um apotegma complexo de Pascásio, o n. XXXIV,3. Está dividido em três partes. Eis o grego e as traduções da primeira:

$$
\text { NAU, } 107
$$

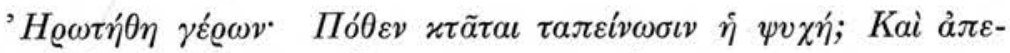

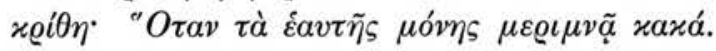

\begin{tabular}{|c|c|c|}
\hline PASC. XXXIV, $3^{\mathrm{a}}$ & APP. WILMART, 21 & MART. 58 \\
\hline $\begin{array}{l}\text { Requisitus quidam } \\
\text { senex quomodo po- } \\
\text { test humilitatem ani- } \\
\text { ma adipisci, respon- } \\
\text { dit: Si sua tantum- } \\
\text { modo mala conside- } \\
\text { ret. }\end{array}$ & $\begin{array}{l}\text { Inquisitus senex } \\
\text { unde anima pos- } \\
\text { sessionem humilitatis } \\
\text { adquireret, respon- } \\
\text { dit: Sua tantum solli- } \\
\text { cite cogitando mala. }\end{array}$ & $\begin{array}{l}\text { Requisiuit frater } \\
\text { senem dicens: Quo- } \\
\text { modo anima susci- } \\
\text { pere potest humilita- } \\
\text { tem? Respondit: Si } \\
\text { sua semper scrutetur } \\
\text { mala. }\end{array}$ \\
\hline
\end{tabular}

Só Martinho conservou o estilo primitivo de pergunta directa e resposta. Pascásio e o tradutor das Sententiae Patrum editadas por Wilmart subsituem o discurso directo por uma interrogativa indirecta. Este sistema é frequente em Pascásio, mas não em Pelágio-João. Quanto ao mais, as três traduções, embora fiéis, apresentam claros sinais de terem sido feitas por tradutores diferentes, apesar de o grego poder ter sido o mesmo para todos.

A segunda parte de Pascásio XXXIV,3 tem equivalente completo em Pelágio XV,77 e em Martinho 57, mas não no grego mais semelhante que encontrámos.

(1) Cf. infra III, nn. 11-12. 


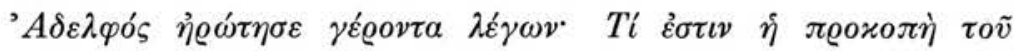

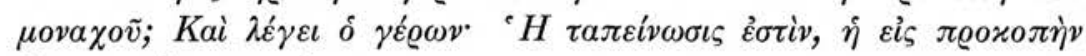

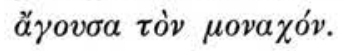

PASC. XXXIV, $3^{b}$

Dicebat autem: Quia profectio hominis humilitas est; qua ntumcumque enim se deposuerit homo in humilitate, tantum prouehetur in honore.

PLG. Xv, 77
Frater quidam in-
terrogauit senem di-
cens: Quid est pro-
fectus hominis? Et
respondit ei senex:
Profectus hominis est
humilitas. Quantum
enim quis ad humi-
litatem inclinatus fue-
rit, tantum eleuabi-
tur ad profectum.

MART. 57

Frater requisiuit senem dicens: Quid est profectus monachi? Respondit senex : Hu militas. Quantum enim quis in humilitate inclinatur, tantum proficit in excelso.

Da comparação destas três traduções conclui-se que devia existir um texto grego para a parte final comum aos tradutores latinos. Ou não o identificámos, ou não está publicado, ou perdeu-se. Podemos, porém, garantir que existiu.

Quanto ao princípio, Pelágio e Martinho traduzem à letra; Pascásio (ou o seu modelo grego) resumiu, adaptando à primeira parte do apotegma. Observe-se, no entanto, uma concordância entre Pascásio e Pelágio: ambos têm hominis (como talvez o seu texto grego), enquanto a versão de Martinho, monachi, corresponde à palavra da edição de Nau.

Para a terceira parte de Pascásio XXXIV,3 não conhecemos texto grego nem paralelos latinos. O pensamento liga-se, no entanto, com perfeição, ao teor geral do apotegma. O organizador grego do texto de Pascásio encontrou-o, por certo, numa colectânea então existente. W. Bousset, no seu quadro de lugares paralelos, remete para Longinus $203 \mathrm{~d}$.

5 - POSSÍVEIS RETOQUES DO ORIGINAL GREGo DE PASCÁSIO PARA COINCIDIR COM o título do CAPÍtulo. Há na tradução de Pascásio 
um bom número de pequenos acrescentos em relação ao grego que possuímos. É-nos difícil saber, em cada caso, se se trata de adições do organizador grego ou do tradutor latino. Em certas circunstâncias podemos, quase com certeza, assegurar que se trata de breves retoques do organizador, para melhor fazer coincidir o texto do apotegma com o título escolhido para o capítulo.

Assim, o cap. XCVIII diz: Qui sunt similes unius meriti fratres. $\mathrm{O}$ apotegma correspondente tem em grego a seguinte redacção:

POEMEN 29 (329)

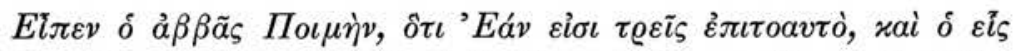

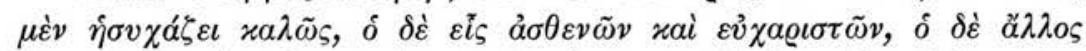

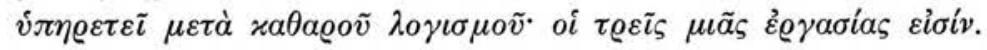

PASC. XCVIII, 1

Quidam frater requisiuit abbatem Poemenem dicens: Qui sunt unius meriti fratres? Respondit senex: $\mathrm{Si}$ fuerint tres simul, unus quidem in omni uerbo uel opere quiescens, alter autem infirmans et gratias agens, tertius uero cum munda conscientia obsequium faciens, hii tres unius operis sunt.
PLG. $\mathrm{x}, 52$

Iterum

dixit: Quia si sunt tres in unum, ex quibus unus bene quiescat, alius infirmetur et gratias agat, tertius uero ministret eis ex sincera uoluntate, hi tres similes sunt, uelut etiam si unius sint operis.

Pelágio parece ter diante de si um texto muito semelhante ao grego que damos acima, visto que o iterum dixit se refere, de facto

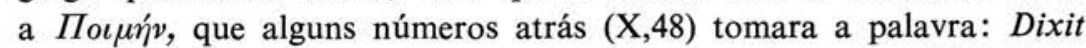
abbas Pastor. Já aqui temos uma oposição nítida entre Pelágio-João e Pascásio-Martinho, que se repetirá constantemente. Aqueles traduzem o nome do abade; estes transliteram-no apenas. Sendo assim, quando num manuscrito com apotegmas lemos o nome Pastor é de suspeitar que estejamos perante o texto de Pelágio-João. Apenas no fim se revela que o grego de que Pelágio se servia é de outra recensão, 
porque só então insere os elementos que dão o título ao capítulo de Pascásio: similes sunt uelut etiam si...

Quanto a Pascásio, parece, à primeira vista, que nos transmite uma recensão grega mais antiga do apotegma, visto que o apresenta no sistema perfeito de pergunta do discípulo e resposta do abade. Neste caso, poderíamos perguntar-nos por que não foi esta versão preferida pelo compilador da série alfabética... Supomos antes que, partindo de um texto grego igual ao que tinha Pelágio (e como já vimos isto é frequente), o organizador grego de Pascásio formulou no princípio uma pergunta de acordo com o título que pôs a este capítulo de uma só peça.

As traduções são ambas literais. Mas não é difícil de verificar a superioridade da de Pascásio. Não vemos aqui traços do ö $\iota$ que introduz a resposta; o período hipotético eventual foi expresso pelo perfeito do conjuntivo fuerint, em vez do servilismo (sunt) de Pelágio; o advérbio $\alpha \alpha \lambda \tilde{\omega} \varsigma$ é desdobrado numa expressão mais longa, o que é típico de Pascásio (2); as três modalidades do trabalho são mantidas

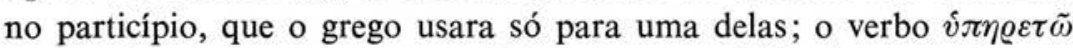
é traduzido por uma locução mais longa, vaga e delicada, o que é outra característica de Pascásio (3); na parte final, Pascásio continua a manter o sistema de colocar o verbo a terminar cada cólon.

6 - APOTEGMAS PASSADOS DO DISCURSO DIRECTO PARA O INDIRECTO. Ao discurso directo no grego existente corresponde com frequência, em Pascásio, a narração na terceira pessoa. Esta mudança poderia ter sido feita já pelo organizador da colectânea grega de Pascásio. Noutros casos é certo que se trata de um processo estilístico do monge de Dume. Eis um exemplo que poderá documentar diversas fases desta evolução literária.

MACARIVS $38(280)$

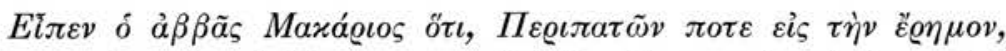

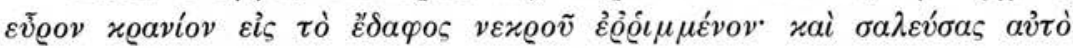

(2) Cf. Técnicas de tradução, n. 7.

(3) Cf. ibidem, nn. 1, 4, $7 \varepsilon$. 
$\tau \tilde{\eta} \beta a \hat{i} \eta \eta \eta$

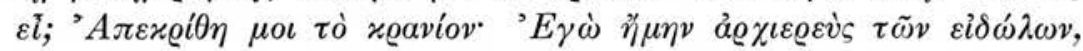

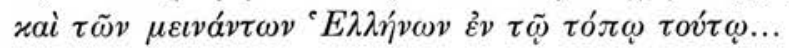

PASC. LXIX, 1

Abbas Macarius dum ambularet in deserto caput mortui cuiusdam pronum inuenit in terra. Quod postquam cum baculo suo conuertit, uocem uisum est emittere. Quod senex quisnam esset interrogat. At ille respondit: Ego quidem princeps eram sacerdotum idolorum ex gentibus quae hoc loco habitant...
JOÃo III, 16

Dicebant de eodem abbate Macario maiore, quia dum ambularet aliquando in eremum, inuenit caput hominis mortui in terra iacens; quod cum moueret de uirga palmae, quam in manu habebat, locutum est caput illud ad eum. Cui dixit senex: Quis es tu? Respondit caput illud ad senem: Ego eram sacerdos gentilium qui commanebant in loco hoc...

Todo o apotegma grego se encontra no discurso directo, com a narração na primeira pessoa. É muito provável que este processo represente a primeira fase da redacção. A tradução de João parece documentar um segundo estádio em que só o primeiro período foi transferido para o discurso indirecto. Há vários apotegmas gregos

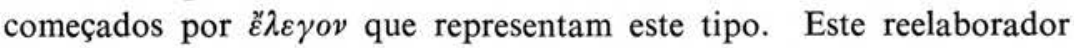
identificou melhor Macário, maiore, e incluiu uma explicação quase inútil sobre a vara quam in manu habebat. Depois passou a copiar literalmente quase até ao fim.

A tradução de Pascásio deixa entrever uma redacção grega que devia ser próxima da de João. É muito natural que o prolongamento do discurso indirecto até ao período seguinte seja obra de Pascásio, pois esse é um dos seus processos preferidos. Enquanto João é literal: Cui dixit senex: Quis es tu?, Pascásio, tenta manter por um pouco mais o estilo anterior, traduzindo com perfeita equivalência: Quod senex quisnam esset interrogat. Notem-se outras qualidades do trabalho de Pascásio. $\mathrm{O}$ indefinido de tempo ( $\pi \circ \tau \varepsilon$ ) passou para o indeterminado inicial do indivíduo (cuiusdam). Pronum é perfeita tradução, mas mais literária. Um sentido de indefinido é expresso por uocem uisum est emittere, como que para atenuar a estranheza 
do acontecimento, tendência esta que se observa noutros passos.

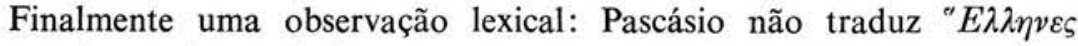
por 'gregos', ou 'helenos', mas por pagani (XXXVII,1) e "gentios» (aqui, LXIX,1), valor que a palavra tinha no grego cristão (4).

7 - SELECÇÃo Só DE ELEMENTOS DE INTERESSE MORAL. Finalmente vamos apresentar um exemplo em que, da redacção primitiva, o elaborador da colecção grega de Pascásio apenas seleccionou os elementos com interesse moral. O apotegma foi reduzido ao essencial, perdendo-se vários pormenores cheios de realismo, bem significativos da redacção original. Neste caso é evidente que o texto de Pascásio, apesar de mais resumido, é uma construção secundária (5).

\section{POEMEN $183(365,368)$}

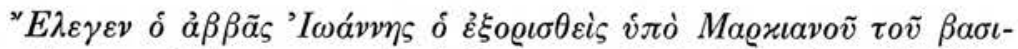

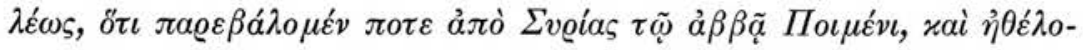

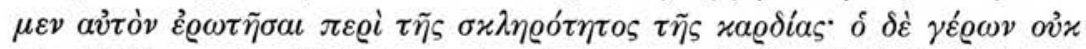

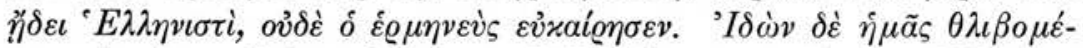

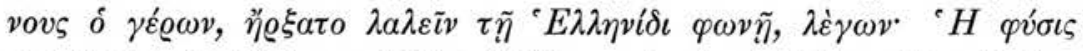

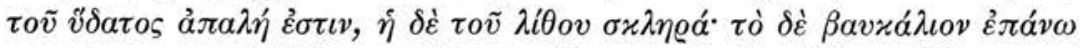

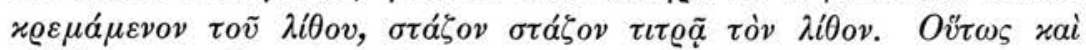

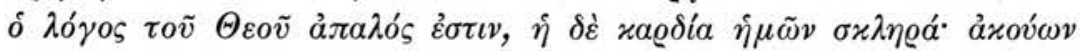

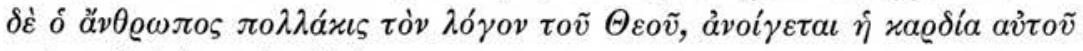

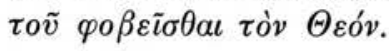

PASC. LXXXI, 1

Interroganti cuidamabbatem Poemenem de duritia cordis
PLG. XVIII, 16

Dicebat abbas Ioannes qui exiliatus est a Marciano: Quia uenimus aliquando de Syria ad abbatem Pastorem, et uolebamus interrogare eum de duritia cordis. Senex autem Graece ne-

(4) G. H. LAMPE, A patristic greek lexicon, Oxford, 1968, s.u.

(5) J.-C. GuY, Note sur l'évolution du genre apophtegmatique, in Revue d'Ascétique et de Mystique, XXXII (1956), pp. 63-68. 
sciebat, neque interpres inueniebatur. Videns ergo nos senex tribulantes, coepit Graeca lingua loqui, dicens: Natura aquae mollis est, lapidis autem dura est; et si uas aquae plenum pendeat supra lapidem, ex quo assidue stillans gutta cadat in lapidem, perforat eum; ita et sermo diuinus lenis est, cor autem nostrum durum; audiens ergo homo frequenter diuinum sermonem, aperitur cor eius ad timendum Deum.

A tradução de Pelágio corresponde bem ao grego existente. O compilador da colectânea grega traduzida por Pascásio não acrescentou nada para valorizar a lição moral. Mas eliminou tudo o que não era necessário ao seu objectivo edificante. Perdemos assim, em Pascásio, elementos interessantes sobre o uso da língua grega; desapareceu também o aspecto sobrenatural da solução do caso; ficou só o estritamente essencial ao capítulo De exhortatione et doctrina.

\section{III - TÉCNICAS DE TRADUÇÃO DE PASCÁSIO (1)}

1 - TRAdUÇÃo literal artística. A primeira qualidade que se exige do tradutor é que ele seja fiel ao pensamento expresso na língua original. Uma das características gerais dos antigos tradutores cristãos

(1) Indicamos aqui a bibliografia que nos orientou na elaboração desta parte do nosso trabalho: SvEN LUNDSTRÖM, Übersetzungstechnische Untersuchungen auf dem Gebiete der christlichen Latinität, Lund, 1955; F. BLATT, Remarques sur l'histoire des traductions latines in Classica et Mediaeualia I (1938), pp. 217-242; G. BARDY, La question des langues dans l'Église ancienne, I, Paris, 1948, pp. 247-289; G. Q. A. MEERSHOEK Le latin biblique d'aprés Saint Jérôme Nijmegen-Utrecht, 1966, pp. 21-30. Entre os autênticos modelos de investigação de técnicas de tradução do grego para o latim citamos: H. MøRLAND, Die lateinischen Oribasiusübersetzung, Oslo, 1932; H. DörRIE, Passio SS. Machabaeorum. Die antike lateinische Úbersetzung des IV Makkabäerbuches, Göttingen, 1938, pp. 24-31; MONICA WAGNER, Rufinus, the translator, Washington, 1945; H. W. F. M. HOPPENBRouwers, La plus ancienne version de la Vie de S. Antoine par S. Athanase, Utrecht-Nijmegen, 1960, pp. 20-49. 
é o seu literalismo. Há, no entanto, que distinguir entre uma tradução literal servil, que traduz palavra por palavra, procurando uma equivalência perfeita de vocabulário e até de sintaxe, e uma tradução literal, sim, mas cuidada, artística, com preocupação de selecção do vocabulário e de adaptação ao gosto estilístico da nova língua.

Pascásio é também um tradutor com consciência da necessidade de traduzir literalmente. Raramente, porém, se torna escravo do grego. O seu latim apresenta com frequência uma agradável ductilidade, gosto na distribuição das palavras, cuidado na arrumação dos membros da frase.

Vamos dar um primeiro exemplo em que o texto grego corresponde suficientemente ao latim que nos deram Pascásio e João. Após a leitura do original grego, aprecie-se o trabalho de cada um dos tradutores, lendo com atenção, do princípio ao fim, e em separado, cada um deles. A superioridade de Pascásio ressaltará logo à primeira leitura.

\section{SISOES 18 (397)}

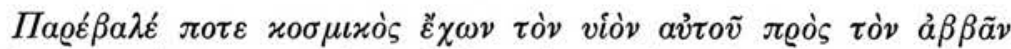

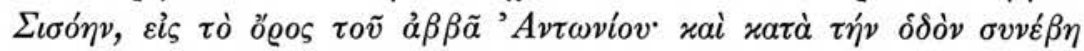

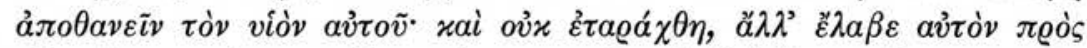

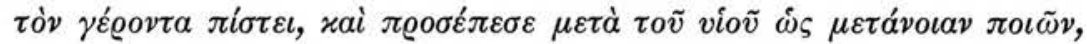

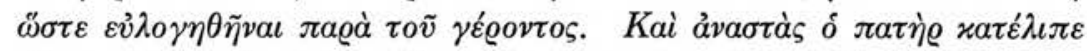

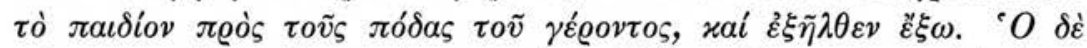

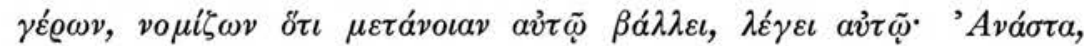

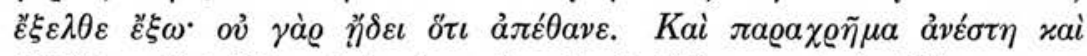

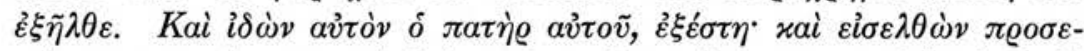

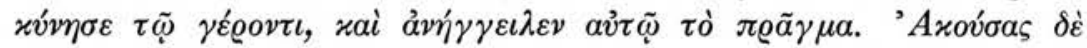

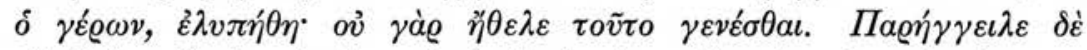

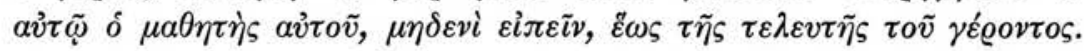

PASC. $x x x v, 1$

Abbas Sisoius cum habitaret in monte in quo erat beatus reclusus Antonius, quidam saecularis ad eum cum paruulo
JOÃO II,13

Venit aliquando quidam saecularis ad abbatem Sisoi in montem abbatis Antonii, habens filium suum secum; et in itinere 
filio percipiendae benedictionis gratia properauit. Contigit autem ut infans ille moreretur in uia; quem pater sine ulla mentis perturbatione sublatum, cum fide portauit ad senem. Ingressusque cellam tam se quam infantem proiecit in terram ut est moris postulantium benedictionem. Oratione autem facta, exurgens pater egressus est, filii corpusculo derelicto ante pedes abbatis. Quem cum senex adhuc orandi causa iacere speraret: Surge, inquit, fili, et egredere. Defunctum enim esse nesciebat. Confestimque puer exurgens egressus est. Quem cum pater uidisset obstipuit. Regressusque in cellam adorauit senem: tam causam filii quam luctum cum fide proprium enarrauit. Sed senex ualde maestus effectus (nec enim a se quicquam tale factum uolebat audiri) per discipulum suum illi homini ne cui usque ad suum transitum hoc diceret imperauit. mortuus est filius eius, et non est conturbatus, sed cum fide tulit eum ad illum senem, et procidit cum filio suo tamquam poenitentiam faciens, ut benediceretur $a b$ eodem sene. Et surgens pater pueri reliquit filium suum ante pedes ipsius senis, et egressus est foras cellam. Porro senex putans, quia poenitentiam ageret ante pedes ipsius puer ille, dixit ei: Surge, uade foras. Non enim sciebat quia mortuus erat. Et statim surgens egressus est. Et uidens eum pater eius, expauit, et intrans, adorauit senem, et dixit ei causam. Audiens autem hoc senex, contristatus est; non enim uolebat hoc fieri. Praecipit itaque ei discipulus senis ut nemini nuntiaret haec usque ad obitum ipsius senis.

Pode dizer-se que todos os elementos que se encontram no grego foram traduzidos tanto por Pelágio como por Pascásio, embora neste ocupem por vezes um lugar um pouco diferente. Sendo, pois, literal, a tradução de Pascásio encontra-se, no entanto, exornada de pequenos elementos que lhe dão mais harmonia. Assim devem ser apreciados os breves incisos reclusus, oratione autem facta e fili.

O final do primeiro período tem delicadeza (cum paruulo filio) e nobreza (antecipando $\varepsilon \dot{\jmath} \lambda o \gamma \eta \theta \tilde{\eta} v a \iota$ que foi traduzido pela bela perífrase percipiendae benedictionis gratia). Mas, no lugar próprio, o mesmo verbo volta a aparecer envolvido em nova perífrase: ut est 
moris postulantium benedictionem. O sentido de ternura paterna é reforçado pelo diminutivo filii corpusculo, já atrás pré-anunciado. A mesma expressão de afecto transparece nas palavras do abade: Surge, inquit, fili, et egredere, de tonalidade tão diferente do literalismo seco de João: dixit ei: Surge, uade foras. Igual diferença de sensibilidade estilística se nota na frase seguinte. Pascásio: Defunctum enim esse nesciebat; João: Non enim sciebat quia mortuus erat, transcrição

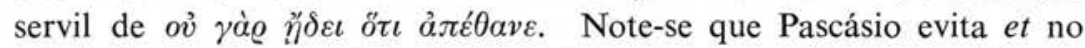
princípio de frase, substituindo-o elegantemente conforme as circunstâncias. É o que se verifica por diversas vezes logo a seguir. Pascásio: confestimque; João: et statim; Pascásio: quem cum pater uidisset; João: et uidens eum pater eius; Pascásio: regressusque in cellam (o que justifica o acrescento, atrás, de ingressus cellam); João: et intrans. Em vez da tradução literal servil de João: et dixit ei causam, Pascásio interpreta com perfeição o $\pi \varrho \tilde{a} \gamma \mu \alpha$ : tam causam filii quam luctum cum fide proprium enarrauit. Note-se o protelar de proprium, pois veremos que Pascásio estuda a ordenação das palavras.

A última frase de Pascásio é uma artística elaboração dos três últimos períodos do grego e de João. Além desta nova organização sintáctica e da selecção do vocabulário, anote-se ainda uma tradução

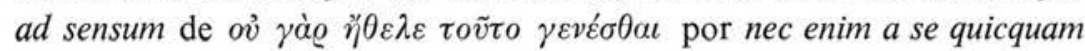
tale factum uolebat audiri. Com este expediente Pascásio enriquece a psicologia do abade Sisoio, não pondo a descoberto que ele ignorava o seu poder taumatúrgico e preparando o aviso de que o facto não fosse divulgado.

Há ainda pormenores estilísticos que realçam a técnica de Pascásio: o tríplice uso de quem, no princípio de frase, como simples pronome de ligação, com valor de eum; o uso de ablativos absolutos, resumindo uma situação; a preferência de nec ... uolebat em vez do monótono non de João; a intencional colocação do verbo no final de membro ou de frase, sobretudo na segunda parte da narrativa.

Lendo agora, lado a lado, por pequenas secções, o trabalho de Pascásio e de João ao traduzirem este apotegma, outros aspectos ainda poderão realçar a superioridade técnica e artística de Pascásio.

Acrescentemos um exemplo menor, onde, a par de qualidades já delineadas, se encontra documentado outro processo que adiante analisaremos. 


$$
\text { NAU, } 303
$$

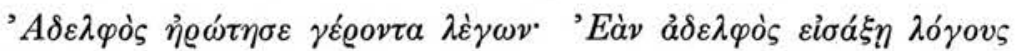

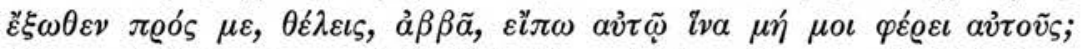

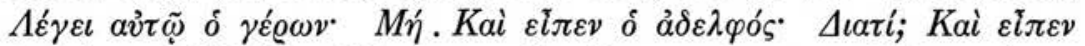

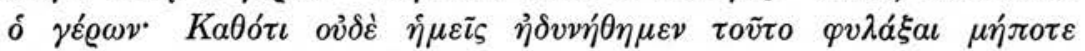

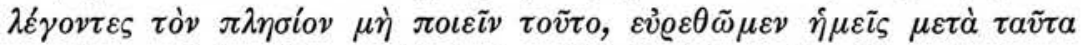

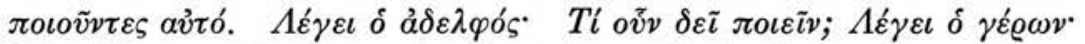

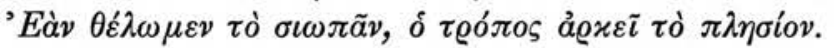

PASC. LXXXVI,2

Quidam frater requisiuit a sene dicens: $\mathrm{Si}$ uenerit aliquis frater sermones mihi de foris inferens alienos, iubes ut dicam illi quatenus mihi illos non afferat? Respondit senex: -

Nihil

dicas illi quia nec nos potuimus obseruare. Cauendum ergo ne forte dicentes proximo «hoc ne facias», nos idem postea faciamus. Cui frater: Quid ergo oportet facere? At senex: $\mathrm{Si}$ uoluerimus, inquit, tacere exemplum sufficit proximo.
PLG. $\mathrm{XV}, 59$

Frater quidam interrogauit senem dicens. $\mathrm{Si}$ quis fratrum adtulerit ad me de foris cogitationes, uis, abba, dicam ei ut non eas afferat ad me? Et respondit ei senex. Noli. Et dixit frater: Quare? Respondit ei senex: Quia nec nos hoc possumus custodire; et ne forte cum dicimus proximo «ne facias illud», inueniamus nos postea idipsum facientes. Et dixit frater: Quid ergo debet fieri? Et respondit ei senex: Si uoluerimus taciturnitatem seruare, sufficit proximo modus ipse.

Aparentemente, ambas as traduções são literais. Examinemos, porém, com cuidado, a segunda parte do apotegma. Mas antes notemos que Pascásio evita a multiplicação de perguntas e respostas na primeira parte, resumindo o conteúdo de duas perguntas numa só resposta.

A introdução de cauendum ergo exigido pelo sentido proibitivo da frase dá possibilidade de formar um período mais harmónico, colocando primeiro um particípio e depois o verbo no modo finito. Sobretudo Pascásio teve o cuidado de evitar a sintaxe grega $\varepsilon \dot{\varrho} \varepsilon \theta \tilde{\omega} \mu \varepsilon v .$. $\pi \circ \iota \tilde{v} \tau \varepsilon \varsigma$ em que Pelágio caiu. Note-se depois (contra Pelágio) a 
exclusão de qualquer et a introduzir a pergunta e resposta seguinte.

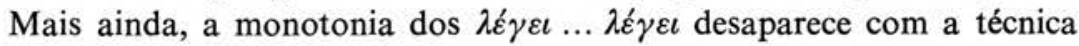
de Pascásio: Cui frater ... At senex. Além disso, observe-se o hábito bem latino de lançar um inquit após as primeiras palavras da resposta seguinte. As técnicas de Pascásio hão-de repetir-se, mas elas revelam já, só por si, uma arte que Pelágio e João não souberam criar.

2-ARTIFÍCIO NA DISTRIBUIÇÃo DAS PALAVRAS. O literalismo da tradução, mesmo quando artística, faz com que numa obra destinada à leitura corrente não haja uma excessivamente rebuscada inversão da ordem normal das palavras. Em casos especiais, porém, Pascásio recorreu a este artifício, que obriga a reler e meditar a frase.

O n. XXXII,3 de Pascásio é uma tradução fiel, tal como a de Pelágio VII,27a. Aproveitemos a oportunidade para registar que este apotegma «nominal», vem incluído também entre os "anónimos» na primeira parte de Nau, 195, apenas com a variante, na frase que vamos transcrever, a última, de $\not ̉ \delta \varepsilon \iota ~ \gamma a ́ \varrho$ por $\varepsilon i \delta \omega ́ s$.

\section{ARSENIVS $11(89)$}

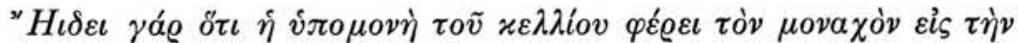

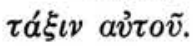

PASC. XXXII, 3

Continentia enim cellae monachum ad ordinem solet bonum uitae deducere.
PLG. VII, $27^{\mathrm{a}}$

Sciens quia perseuerantia cellae perducit monachum in ordinem suum.

O abade Arsénio exortara o discípulo a que não saísse da sua cela. A frase que temos acima é a conclusão do pensamento. Aqui importa-nos, em primeiro lugar, a disposição das palavras a partir de monachum. Em ordem directa teríamos: Continentia enim cellae solet deducere monachum ad bonum ordinem uitae. A colocação feita por Pascásio não pode deixar de ser fruto de um estudo com intenção artística. Veja-se a despreocupação revelada pela versão de Pelágio... Aproveitamos a oportunidade para sublinhar o gosto de Pascásio pelas 
expressões mais longas e enfáticas. Repare-se em Pelágio: perducit; Pascásio: solet deducere; Pelágio: in ordinem suum; Pascásio: ad ordinem bonum uitae.

Eis agora a elaboração do princípio de Pascásio XXXVIII,1. $\mathrm{O}$ texto grego não devia ser aqui igual ao que possuímos hoje. Mas o paralelo de Pelágio ajuda-nos a garantir a palavra patribus. (O ms. do Porto tem partibus). Adiante-se desde já que as cáricas são figos (da Cária) oferecidos por um quinteiro (a quodam uineae).

$$
\text { ARSENIVS, } 16 \text { (92) }
$$

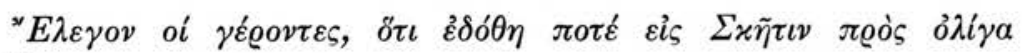
i $\chi \alpha a ́ \delta \iota \alpha .$.

PASC. XXXVIII, 1

Cum in Sceti patribus semel a quodam uineae fuissent caricae erogatae...
PLG. $\mathrm{XV}, 8$

Dicebant senes quia dederint quidam aliquando in Sceti fratribus paucas caricas...

É provável que o grego de Pascásio apresentasse aqui uma recensão mais antiga que a de Pelágio, dado que lhe falta o trabalho de reelaboração: " $E \lambda \varepsilon \gamma o v$... ö $\tau$, e menciona um pormenor que o reelaborador teria desprezado: o homem da vinha.

A tradução de Pelágio apresenta as palavras numa ordem cuidada, mas inteligível à primeira leitura. Já não é bem assim em Pascásio. Examine-se o trabalho de colocação das palavras, em comparação com a ordem directa: Cum in Sceti semel caricae erogatae fuissent patribus a quodam uineae... É evidente que a ordem preferida por Pascásio obedeceu a uma intenção artística para o princípio da narração.

Demos um terceiro exemplo, este sem paralelo latino. Trata-se do final de XLVI,6.

\begin{tabular}{|c|c|}
\hline ARSENIVS 38 (105) & PASC. XLVI, 6 \\
\hline 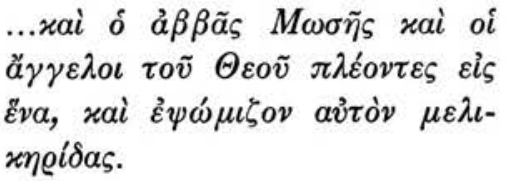 & $\begin{array}{l}\text {...in altera uero uidit abbatem } \\
\text { Moysen et angelos mellis ei } \\
\text { fauos in ore et dentibus inse- } \\
\text { rentes. }\end{array}$ \\
\hline
\end{tabular}


As últimas palavras exigem a seguinte ordem directa: angelos inserentes ei fauos mellis in ore et dentibus. A distribuição de Pascásio não pode deixar de ser considerada como fruto de um artifício estilístico conscientemente procurado.

A falta de paralelos latinos que nos possam elucidar melhor sobre o texto grego e o facto de isolarmos aqui o segundo membro de uma alternativa desaconselham outros comentários literários. Mas quase podemos assegurar que o alargamento expressivo in ore et dentibus é uma introdução da técnica de Pascásio.

3 - USO E POSPOSIÇÃO DE INQVIT. Num texto em que as perguntas e respostas são muito frequentes, os verbos declarativos, sobretudo dico, respondeo, aparecem contìnuamente. Pascásio procurou evitar a monotonia das frases introdutórias da resposta, reduzindo-as ao menor número possível de elementos e lançando para depois dos dois pontos (:) o bem característico verbo latino inquit. Que se trata de um processo estilístico intencional, provam-no inumeráveis exemplos em que podemos colacionar o grego e outras traduções latinas.

ARSENIVS 28 (97)

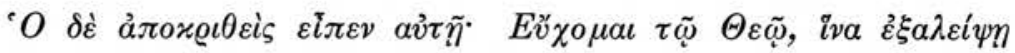

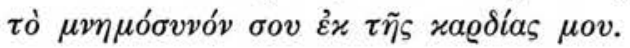

PASC. XII, 1

Cui Arsenius: Oro Deum meum, inquit, ut deleat tuam ex corde meo memoriam.
PLG. II, 7

Ille autem respondens dixit ei: Oro Deum ut deleat memoriam tui de corde meo.

Enquanto Pelágio é estritamente literal, Pascásio traduz com mais arte, reduzindo a oração declarativa inicial e introduzindo inquit no meio da resposta. Note-se ainda o cuidado na distribuição das palavras finais.

Só mais um exemplo aqui, pois o processo artístico está documentado em vários excertos comentados noutros lugares. 
SISOES, 1 (392)

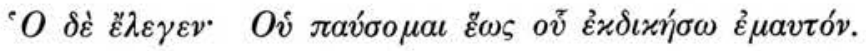

PASC. XXI,2

At ille: Non desistam, inquit, nisi me fortiter uindicauero.
PLG. XVI, 10

Ille autem dicebat: Non quiesco donec meipsum uindicauero.

Pelágio também conhece o inquit parentético, mas usa-o quando ele é pedido pelo grego. Eis um claro exemplo:

NAU, 392

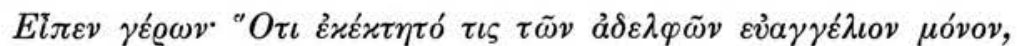

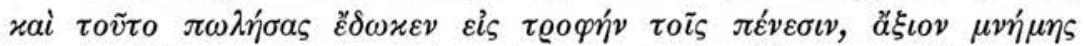

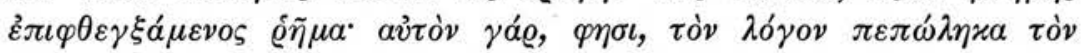

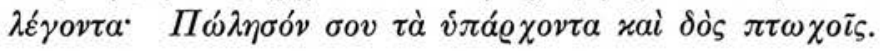

PASC. XIV, 6

Quidam monachus euangelium tantum possidens uendidit eum et esurientibus dedit, dignum quidem memoriae sermonem emittens: Ipsum, inquit, uerbum uenundaui qui mihi semper dicebat: «Vende quae possides et da pauperibus».
PLG. VI,5

Dixit abbas Euagrius fuisse quendam fratrem qui nihil habuit in substantia sua nisi tantum euangelium, et ipsum uendidit in pauperum nutrimento. Dicens quodam uerbo quod memoriae dignum est commendari: Ipsum etiam, inquit, uerbum uendidi quod iubet: «Vende omnia et da pauperibus».

Escolhemos o apotegma com o fim principal de mostrar que o inquit que se encontra agora em Pelágio e em Pascásio não é fruto de um achado estilístico. Ambos o traduziram do equivalente grego.

Quanto ao mais, o texto não se presta a comparações rigorosas porque Pelágio tinha, por certo, um grego diferente do de Pascásio. 
O proveito maior das duas versões latinas está em se poder atribuir a Evágrio, graças a Pelágio, o dito sentencioso que em Pascásio aparece como anónimo. E neste ponto o grego conservado na coleç̧ão de Nau é, por certo, anterior ao de Pelágio. Sabemos, com efeito, que

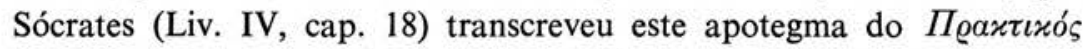
de Evágrio (2), o qual talvez tenha registado um facto com ele mesmo ocorrido. A atribuição a Serapião, em III Rosw. 70, é, pois, pura invenção do reelaborador tardio desta antologia latina.

4-O PROCESSO DA VARIATIO. Nota-se em Pascásio, com alguma frequência, a preocupação de evitar repetir o mesmo vocábulo, ainda quando este não varia no grego. Eis um exemplo magnífico em que uma vez mais se opõem os métodos de Pascásio e Pelágio.

SISOES 4 (392)

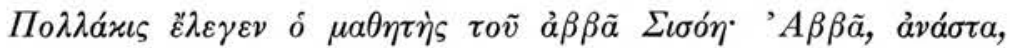

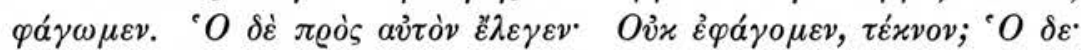

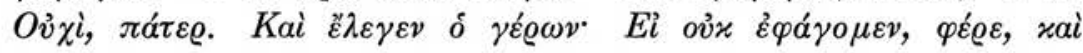
$\dot{\varepsilon} \sigma \theta i \omega \mu \varepsilon v$.

PASC. IV, 1

Abbati Sisoio frequenter suus dicebat discipulus: Tempus est, pater, ut reficiamus. At ille respondebat: Quidnam, fili, necdum comedimus? Ac discipulo renuente: Defer ergo, inquit senex, ut si necdum comedimus manducemus. Desiderium enim Dei obliuionem affert cibi.
PLG. IV,38

Frequenter dicebat abbati Sisoi discipulus: Surge, abba, manducemus. Ille autem dicebat: Quia adhuc non manducauimus, fili? Et ille respondebat: Non, pater. Dicebat autem senex: $\mathrm{Si}$ necdum manducauimus, affer, manducemus.

O grego usa três vezes o aoristo Ě qayov e varia uma vez para $\dot{\varepsilon} \sigma \theta i \omega$. Pelágio, cuja tradução é absolutamente literal, emprega as quatro vezes manduco. Em Pascásio, pelo contrário, há uma nítida intenção de variedade, servindo-se dos sinónimos reficio, comedo

(2) Cf. H. Rosweydus, Vitae Patrum, in PL. LXXIII, col. 989, nota 25. 
e manduco. A insistência em comedo, duas vezes, no centro do diálogo, poderá ela servir de pista para pré-anunciar uma diferenciação de zona linguística? Os elementos de que dispomos são escassos para responder.

Além deste precioso aspecto de uariatio, o pequeno apotegma tem outras características de Pascásio. A delicadeza da substituição do imperativo por uma sugestão convidativa: Tempus est, pater, ut reficiamus; o resumo do sentido de duas frases numa só: At illo renuente...; a inserção do inquit na resposta seguinte; a frase final, que não se encontra no grego, deve ter sido um acrescento do organizador da coleç̧ão original de Pascásio para adaptar o apotegma ao título do capítulo.

Seja outro exemplo o princípio de Pascásio XXIX,1. O texto grego tem:

$$
\text { NAU, } 352
$$

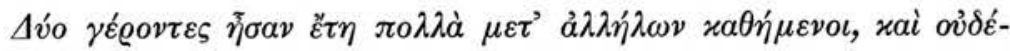

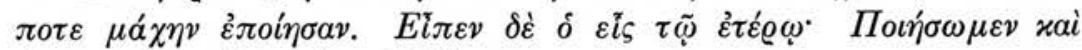

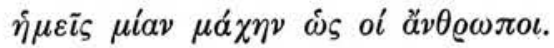

PASC. XXIX,1

Erant duo senes pariter sedentes in una cella et numquam inter se uel qualemcumque paruam contentionem habuerant. Dicit ergo unus ad alterum: Faciamus et nos unam litem sicut et alii homines.
PLG. XVII,22

Duo senes multis annis simul conuersati sunt, et numquam inter se litem habuerunt. Dixit autem unus alteri: Faciamus et nos unam litem, sicut homines faciunt.

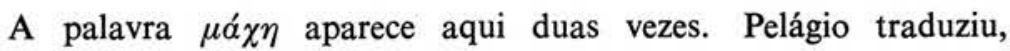
uniformemente, por lis. Pascásio, porém, teve a preocupação de variar o vocábulo, usando primeiro contentio e depois lis. Quem ler o resto do apotegma verificará que Pelágio usa ainda mais duas vezes lis, ao passo que Pascásio alternará de novo lis com contentio. Tal processo não é devido ao acaso, por certo.

Relevemos neste pequeno trecho de Pascásio mais algumas das suas características. Não sabemos se o acrescento in una cella estava no seu grego, mas tudo nos leva a crer que a introdução de uel qualemcumque paruam é mais uma traço da sua delicadeza e psicologia. 
Finalmente notemos a coincidência vocabular nas traduções de Pascásio e Pelágio: Faciamus et nos unam litem sicut que nos garantem o grego que possuímos, sem significarem dependência entre si.

Para o exemplo a seguir não temos paralelo latino. Aproveitamo-lo já para documentar outro aspecto da arte de Pascásio.

MACARIVS 39 (280-281)

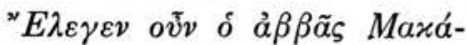

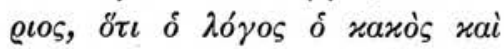

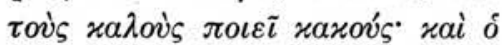

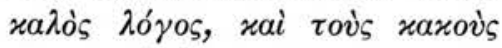

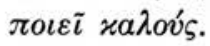

PASC. XXXVII,1

Dicebat ergo abbas Macarius: Sermo superbus et malus etiam bonos uiros conuertit ad malum; sermo autem humilis et bonus etiam malos mutat in melius.

Enquanto xaxós é traduzido três vezes por malus, embora em

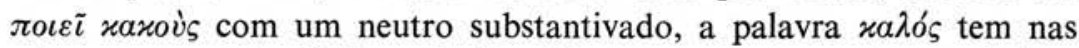
três representações latinas de Pascásio sempre uma versão variada e enriquecida: bonos uiros ... bonus ... mutat in melius, este final ( $\pi \circ \varepsilon \varepsilon \tilde{\imath}$

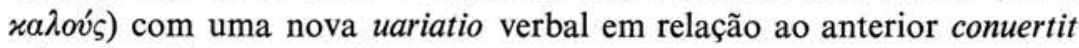

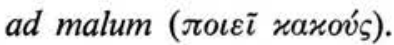

Além deste aspecto, tão pequena frase atesta a preocupação de Pascásio em realçar, em cada membro, a palavra fundamental, exprimindo-a por uma hendíades perfeitamente contrastante: xaxós - super-

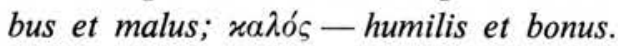

5 - CRIAÇÃo DE HENDíAdes. Pascásio possui o gosto latino da expressão alongada, que tem uma das suas formas de execução na hendíades. A uma palavra grega faz ele corresponder propositadamente duas latinas nem sempre sinónimas, mas que vêm reforçar o sentido profundo do vocábulo original.

Eis um exemplo bem expressivo:

$$
\text { NAU, } 324
$$

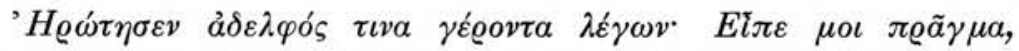

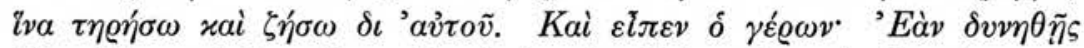

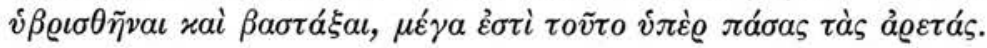


PASC. XXIV, 2

Quidam frater requisiuit senem dicens: Dic mihi unam rem quam custodiam et saluer per ipsam. Respondit ei: Si potueris iniuriari et affici conuiciis et portare ac tacere, magna est haec res super alia mandata.
PLG. $x V, 83$

Interrogauit quidam frater senem dicens: Dic mihi unam rem quam custodiam et uiuam per eam. Et dixit ei senex: $\mathrm{Si}$ potueris contumeliam pati et sustinere, magnum est hoc et super omnes uirtutes.

A comparação dos dois textos latinos e a sua correspondência perfeita com o grego garantem-nos que Pascásio e Pelágio tinham perante si um original da mesma recensão de Nau. Note-se o literalismo de Pelágio: contumeliam pati et sustinere. Pascásio, porém, a $\dot{\beta} \varrho \iota \sigma \theta \tilde{\eta} v a \iota$ faz corresponder iniuriari et affici conuiciis, e traduz $\beta \alpha \sigma \tau \tilde{\alpha} \xi \alpha \iota$ por portare ac tacere. O processo estilístico é o do desdobramento do conceito numa forma de gradação expressiva que não pode deixar de se considerar rebuscada, mas perfeita. Do ponto de vista linguístico repare-se que a $\pi \varrho \tilde{\alpha} \gamma \mu \alpha$, sem artigo e portanto indefinido, ambos os tradutores dão o valor de unam rem. Aqui temos um sinal de que pelo menos no século v, quando Pelágio e Pascásio traduziam, unum já era sentido como artigo indefinido.

Outro exemplo:

NAU, 253

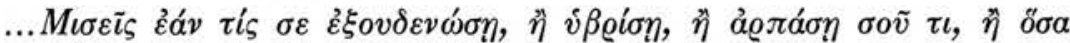

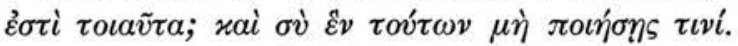

PASC. XLVII, 1

Horres si quis tibi calumniam fecerit, si quis contempserit uel iniuriatus fuerit, uel aliquid tibi abstulerit? Et tu siue haec siue alia his similia ne facias alicui.
PLG. 1,21

Si odio habes qui te in calumniam ducit, aut iniuriis appetit, aut aufert quod tuum est, aut aliquid tale facit, tu nihil horum facias cuiquam.

Importa aqui realçar a tradução de vßß@ín por iniuriis appetit em Pelágio e por uma expressão dupla em Pascásio: contempserit uel iniuriatus fuerit. $\mathrm{O}$ grego que temos acima devia ser o mesmo de 
Pascásio e Pelágio. Antes da interrogação tem o original uma quádrupla alternativa. Pelágio conservou-a, apesar de ter desprezado o vigor da interrogação. Pascásio, que manteve a interrogativa, aper-

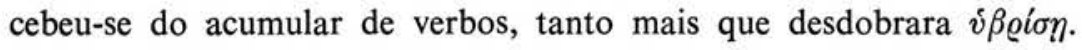
Valeu-se, pois, de outro expediente: passou a última alternativa para a frase seguinte, restabelecendo assim todo o conteúdo do original.

6 - PERÍfRASES COM DIGNOR. Uma das formas usadas por Pascásio para dar à frase um aspecto de polidez e de ênfase comedida é a construção de perífrases em que entra o verbo dignor seguido de infinitivo. A construção reveste-se de nobreza subjectiva, talvez por estarmos habituados a vê-la utilizada pela liturgia romana (3).

ARSENIVS 28 (96)

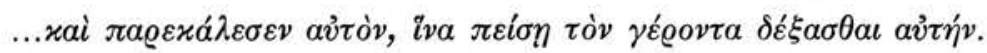

PASC. XII, 1

...rogauit eum quatenus beato persuaderet Arsenio ut eam suscipere dignaretur.
PLG. II, 7

...rogauit eum ut ageret cum sene ut uideret eam.

Trata-se de uma matrona romana que recorre à intercessão do arcebispo de Alexandria para conseguir que o abade Arsénio a receba. Pelágio, «diácono da Igreja de Roma» constrói a frase como se se tratasse de um negócio... Pascásio, porém, interpreta respeitosamente

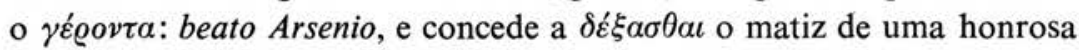
deferência: suscipere dignaretur.

Mais adiante é a própria matrona que se dirige a Arsénio nestes termos, segundo o grego:

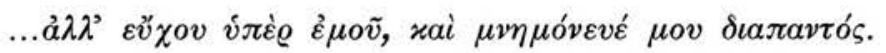

(3) M. P. Ellebracht, Remarks on the vocabulary of the ancient orations in the Missale Romanum, Nijmegen-Utrecht, 1963, p. 199. 
PASCÁSIO

...sed ut pro me ores et in memoriam me habere digneris exoro.
PELÁGIO

...sed ora pro me et memor esto mei semper.

Não há dúvida de que o "curial» Pelágio não adoça os imperativos.

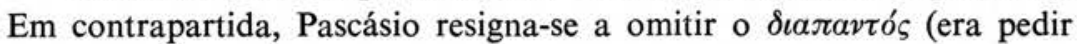
demais!) e introduz um reverente exoro reforçado por habere digneris. Esta interpretação da técnica respeitosa de Pascásio não é invenção nossa. Os textos aí estão e falam por si.

O mesmo sentido de mesura se nota no modo como Pascásio interpreta o pedido de uns noviços a Santo Antão:

ANTONIVS 19 (81)

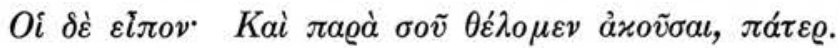

PASC. XXI,1

At illi ut ipse quoque aliquid dicere dignaretur instabant.
JoÃo IV,11

Qui dixerunt: Et a te uolumus audire, pater.

Este apotegma fornece-nos vários exemplos de como Pascásio sabe reduzir o número de intervenções dos interlocutores num diálogo, sem empobrecer o sentido. Aqui, enquanto agora é o "subdiácono» João que se mostra fiel seguidor do literalismo do seu predecessor no trabalho de tradução, Pelágio, novamente Pascásio sabe dar vigor à frase com um instabant e ao mesmo tempo atenua com a introdução de um aliquid antes do já apreciado dicere dignaretur.

Dentre vários outros exemplos, vamos colher mais dois num só apotegma, em que é figura primordial outro grande abade.

\section{MACARIVS 33 (276)}

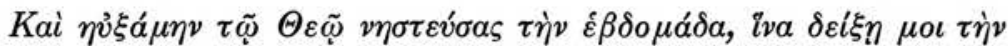

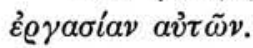


PASC. XCIII, 11

Desiderans ergo scire conuersationem eorum, septimana integra ieiunans, rogaui Deum ut mihi opera eorum dignaretur ostendere.
JOÃO III,2

Igitur oraui ego Deum ieiunans una septimana, ut demonstraret mihi operationem istorum.

Não sabemos se o primeiro membro da frase de Pascásio depende de um texto grego diferente do nosso ou se, como julgamos provável, se trata de uma interpretação do tradutor para arredondar o pensa-

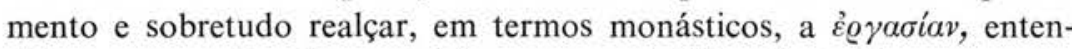
dida como a rica de conteúdo conuersatio (4). Certo é que a parte final tem em Pascásio um sabor diferente, o de quem suplica humildemente a Deus uma graça: opera eorum dignaretur ostendere. O istorum de João, dado o valor depreciativo desta palavra, não nos parece feliz. No aspecto linguístico, notamos a preferência em ambos os tradutores pela forma bem latina septimana. O que não garantimos é se una, em João, deve ser entendida como artigo indefinido. Pascásio substituiu o $\tau \dot{\eta} v$, definido, por integra que dá o mesmo valor concreto àquela semana inteira de jejum.

Quase ao terminar a edificante narração sobre os dois jovens irmãos, conta Macário:

Kai $\dot{\varepsilon} \xi \varepsilon \lambda \theta \dot{\omega} v, \lambda \varepsilon \dot{\varepsilon} \omega^{*} \quad E \ddot{v} \xi \alpha \sigma \theta \varepsilon \pi \varepsilon \varrho i \dot{\varepsilon}_{\mu o \tilde{v}}$

PASCÁSIO

Et egrediens ut pro me orare dignarentur expetii.
JOÃO

Exiens autem dixi: Orate pro me.

A par do esperado literalismo de João temos a delicadeza de Pascásio a dar uma tonalidade suave ao pedido de orações. Registe-se desde já a capacidade de evitar os dois pontos (:) por meio da subordinação.

(4) Cf. H. Hoppenbrouwers, Conuersatio. Une étude sémasiologique in Graecitas et Latinitas Christianorum Primaeua, Supplementa, Fasc. I, Nouiomagi, 1964, pp. 45-95. 
7 - EXPRESSÕES ALONGADAS COM VALOR ENFÁTICO. O processo que acabamos de estudar (dignor seguido de infinitivo) aparece um número considerável de vezes. Embora menos frequentes, há outras expressões do mesmo tipo. Para não alongar demasiado, vamos limitar ao mínimo a confrontação com os lugares paralelos.

a) - Mereor + infinitivo - Em XII,1 conta Pascásio que a matrona romana veio a Alexandria com a finalidade de visitar o abade Arsénio.

Arsenius 28 (96): $\quad \tilde{\eta} \lambda \theta \varepsilon \ldots i \delta \varepsilon \tilde{\imath} v$ av่นóv.

PASC. XII,1

...ut eum uidere mereretur aduenit.
PLG. II, 7

uenit $\ldots$ ut uideret eum.

A locução mais alongada dá solenidade ao estilo. O mesmo se nota no passo seguinte:

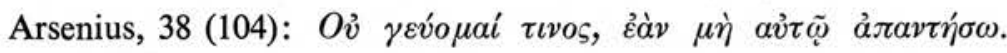

Pasc. XLVI,6 traduz: Non gustabo panem nisi illum uidere meruero.

Não há outra tradução latina deste apotegma, a não ser a que

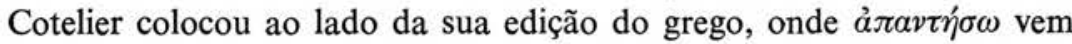
traduzido por occurrero. Também aqui Pascásio leva a palma, pela delicadeza da sua versão.

B) - Possvm + infinitivo - Eis uma breve sentença de Hyperechius, 3 (429):

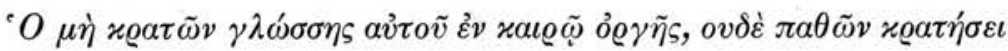

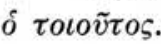

\section{PASC. XXVI, 4}

Qui linguam suam non tenuerit in tempore irae, nec passiones carnis suae aliquando poterit continere.
PLG. IV,49

Monachus qui non retinet linguam in tempore furoris, neque passionum corporalium retentor erit aliquando. 
É natural que o grego de Pascásio e de Pelágio, iguais entre si, tivesse no fim o equivalente a carnis suae (Pasc.) = corporalium (Plg.) e a aliquando (em ambos). O que importa agora é sublinhar a maior uariatio e amplidão de Pascásio: non tenuerit... nec poterit continere.

Evágrio e Arsénio haviam recebido antes de irem para o deserto boa formação retórica. Por isso Evágrio se intrigava como era possível que, sendo ambos tão letrados, os camponeses egípcios lhes fossem superiores em virtudes. E o companheiro responde:

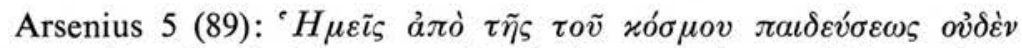

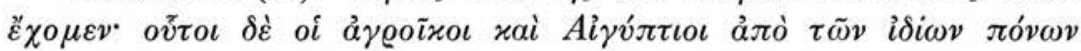

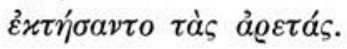

PASC. LXXXIII, 2

Nos ex saeculari scientia nihil potuimus adipisci, hii uero uirtutum scientiam ex propriis laboribus didicerunt.
PLG. $x, 5$

Nos quia mundanae eruditionis disciplinis intenti sumus, nihil habemus; hi autem rustici Aegyptii ex propriis laboribus acquisierunt uirtutes.

Temos aqui um elogio da natureza como mestra; as letras nem sempre levam à virtude. O potuimus adipisci de Pascásio é mais expressivo que o simples habemus de Pelágio.

Um último exemplo, dum breve conselho do abade Arsénio, 12 (89):

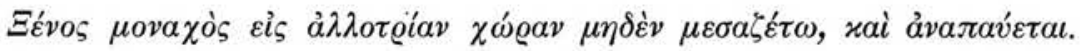

PASC. LXXXIX,2

Peregrinus monachus in aliena terra nullius causae mediator accedat et quietem poterit adipisci.
PLG. $\mathrm{x}, 6$

Peregrinus monachus in aliena prouincia habitans, nullis rebus se medium faciat, et quietus erit.

Aqui temos àvajav́o $\mu \alpha \iota$ traduzido em Pelágio por quiescor e em Pascásio pela locução quietem possum adipisci. Note-se o valor de mediator como «aquele que não se deve meter no meio de questões 
alheias». Trata-se, como veremos, de um ä $\pi \alpha \xi$ semântico de Pascásio.

r) - CONFITEOR + infinitivo - Não menos expressiva é esta construção que encontramos num dito que Pascásio atribui a Santo Antão, mas que o grego e Pelágio têm como anónimo.

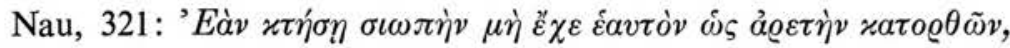

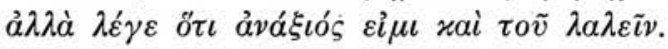

PASC. LXXXVIII,6

Si affectaueris silentium non arbitreris te exercere uirtutem sed indignum te proloqui confitere.
PLG. XV,79

$\mathrm{Si}$ acquisieris taciturnitatem, non habeas apud temetipsum quasi aliquam uirtutem, etiamsi obtinueris, sed dic: Quia indignus sum loqui.

Mais uma vez temos, em contraposição, o literalismo servil de Pelágio precisamente onde Pascásio soube criar uma expressão mais rica (proloqui confitere), a qual teve também o mérito de evitar o fastidiante quia.

O mesmo sistema se encontra numa longa narração de que extraímos este pensamento:

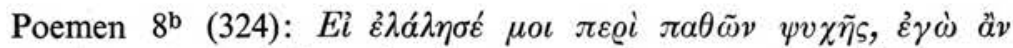

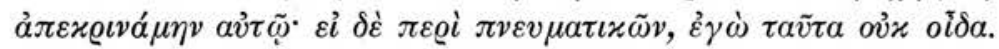

PASC. $\operatorname{LXXXV}, 1$

Si mihi locutus fuisset aliquid de passionibus animae, forsitan et ego respondissem illi; si autem de caelestibus, ego me nescire confiteor.
PLG. $x, 39^{b}$

Si ergo mihi locutus fuisset de passionibus animae, ego utique responderem ei; si autem de spiritualibus, ego haec ignoro.

Aqui os tradutores chegam a coincidir entre si, mas o final revela a superioridade do gosto de Pascásio. 


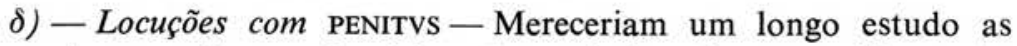
formas de negação em Pascásio, tão variadas elas são. Umas das mais eficazes consiste em reforçar a negativa com o advérbio penitus, 'inteiramente', 'absolutamente'.

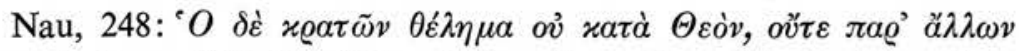

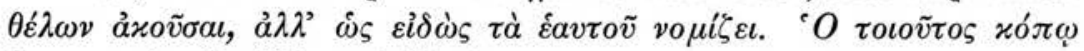

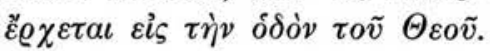

PASC. XLVI,2

Qui autem ita propriam tenuerit uoluntatem ut ab altero nihil penitus audire delectet, hic difficile ad uiam Dei peruenit.
PLG. $\mathrm{x}, 80$

Qui autem tenet uoluntatem suam, non secundum Deum, et neque ab aliis uult audire, sed uelut scitum se putat; qui huiusmodi est, uix perueniet ad uiam Domini.

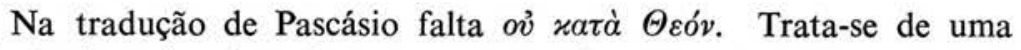
omissão intencional, pois esta expressão já aparecera na frase anterior do texto. Aqui importa a força da negação em Pascásio, sublinhada pelo delectet de tipo mais selecto: $u$ t ab altero nihil penitus audire delectet, de longe superior ao automatismo da tradução de Pelágio.

Noutro passo temos em grego, Macarius 31 (273): "E $E \varepsilon \gamma o v$

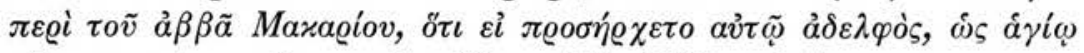

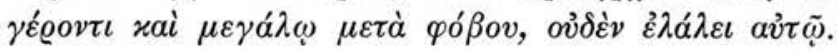

Não há outra tradução antiga senão a de Pascásio, XXXIII,2: Abbas Macarius si quis illum cum timore uelut sanctum uirum uoluisset adire, suscipiens nullum penitus a sene percipiebat responsum.

Apesar de não haver paralelo latino, verificamos que em Pascásio se encontra bem traduzido o pensamento do grego que possuímos.

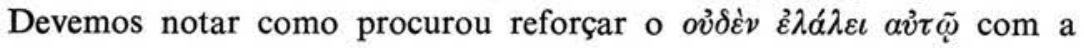
introdução de um suscipiens, com valor concessivo, e do intransigente penitus. A edição de Cotelier fez acompanhar o final desta versão fiel: nihil ei loquebatur. Como tem outro vigor a ampliada tradução de Pascásio que interpreta por duas palavras expressivas o verbo $\dot{\varepsilon} \lambda a ́ \lambda \varepsilon \iota$ ! 
$\varepsilon)$ - Outras perifrases expressivas - Para não alongar esta secção vamos recortar só três exemplos.

Os irmãos encontravam-se à mesa e um deles quis dar público testemunho da sua abstinência. Tal atitude mereceu-lhe depois grave repreensão. Damos a parte essencial.

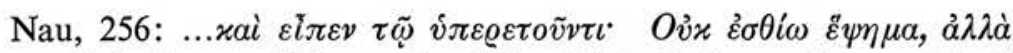

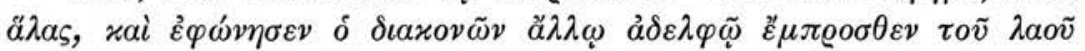

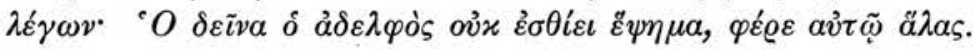

PASC. VI,2

...unus ministranti dicit: Quia nihil coctum comedo, sal mihi deferri praecipito. Quo uerbo minister audito, cum clamore audientibus ceteris cunctis, alii imperauit dicens: Quoniam coctum frater ille nihil comedit, parum illi salis afferto.
PLG. VIII,21

...qui dixit ministranti: Ego non manduco coctum aliquid, sed sal. Et uocauit minister alium fratrem coram multitudine, dicens: Ille frater non comedit coctum, affer ei sal.

Neste fragmento sublinhamos o circunlóquio sal mihi deferri praecipito por ser mais enfático e por usar o imperativo futuro, forma rara no latim, mesmo de bons autores. E Pascásio emprega-o de novo, com propriedade, mais adiante, por sua iniciativa: parum illi salis afferto. Repare-se também no arranjo perfeito do princípio da segunda frase, em que se congraçam dois ablativos absolutos.

$\mathrm{Na}$ tradução de Pelágio falta todo este sal do estilo... Note-se, uma vez mais, em Pascásio, a presença do relativo de ligação quo. A preferência, aqui, pelo vocábulo comedere não deve levar-nos a pensar numa definição de zona linguística, pois já observámos a sua variedade para traduzir este conceito (5). Registemos, neste caso, um ponto a favor de Pelágio com a uariatio: manducare ... comedere.

Para o segundo exemplo não dispomos ainda de texto grego, embora saibamos por J.-C. Guy e W. Bousset que ele se encontra nos manuscritos. Mas os paralelos latinos são suficientes.

(5) Cf. supra pp. $74-75$. 
Ao abade Macário fora revelado que, apesar de eremita, não atingira ainda a perfeição de duas mulheres da cidade. Ei-lo que vai, desejoso de aprender, e diz-lhes:

PASC. XXIX,2

Propter uos tantum laborem ueniens ex solitudine longinqua sustinui, ut opera uestra cognoscerem, quae mihi uos condecet enarrare. Cui illae sic responderunt: Crede nobis, sanctissime pater, quia nec praesente nocte a maritorum lectulis fuimus separatae.
JOÃO III, 17

Propter uos laborem tantum pertuli;

dicite mihi

nunc operationem uestram, quae uel quomodo est. At illae dixerunt: Crede nobis, quia hac nocte non fuimus sine uiris nostris.

Pensamos que os elementos omissos em João são fruto do gosto pela amplitude da frase, próprio de Pascásio. Além disso, ao imperativo indiscreto de João, dicite..., corresponde uma locução, em Pascásio, cheia de delicadeza, a terminar com uma construção - condecet enarrare - do tipo das que estudámos nas primeiras alíneas deste título.

Do mesmo modo, a resposta das mulheres, apesar de coincidente, denota em Pascásio um pouco mais de recato, além de ser mais ampla e ornada.

Temos, finalmente, oportunidade de comparar Pascásio só com o seu superior, Martinho, "presbítero e abade». Transcrevemos todo o apotegma.

SISOES $22(400)$

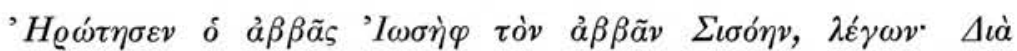

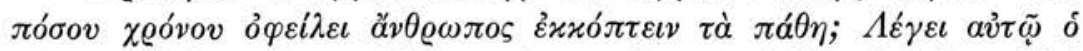

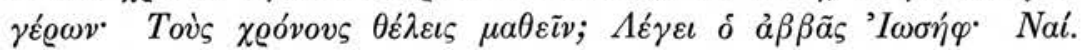

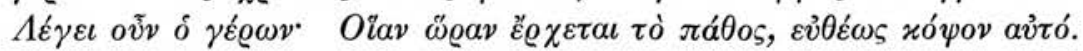


PASC. LXXII, 6

Abbas Joseph requisiuit abbatem Sisoium dicens: Per quantum tempus debet homo passiones cordis excidere? Respondit senex: Tempora uis huius rei cognoscere? Cum autem ille annuisset, respondit: Quacumque hora in corde tuo ingressae fuerint passiones, eadem hora illas si potueris abscide.
MART. 26

Requisiuit frater abbatem Sisoium: Post quantum tempus debet homo a se abscidere passiones? Respondit senex:

In quacumque hora uenerit passio, abscide illam, quia fragilis est anima; ante armetur, quam inquinetur.

Os paralelos entre Pascásio e Martinho são relativamente escassos para delimitarmos com segurança os seus cambiantes. Para mais, ainda não está feito o estudo de Martinho como tradutor grego das Sententiae. Acresce, além disso, que a recensão de Martinho tem aspecto de ser, na redacção original, posterior ao grego de Pascásio. A quem fez a colectânea primitiva de Martinho só interessava já a lição moral. Por isso foi omitida uma parte do diálogo e esse também o motivo do acrescento da consideração final, certamente já no grego: quia fragilis est anima; ante armetur, quam inquinetur.

Limitando-nos ao grego que ambos tinham em comum observamos: 1) Pascásio cometeu um lapso traduzindo, aqui, $\delta \iota \alpha ́$ por per; Martinho não hesitou e escreveu o justo post. 2) Martinho explicitou melhor abscidere juntando-lhe $a$ se. 3) O que nos trouxe a examinar este apotegma foi a tendência de Pascásio para a amplitude estilística. Só para ele a palavra $\pi a ́ \theta o \varsigma$ faz incluir sempre uma referência ao coração; E้ $\chi \varepsilon \tau \alpha \iota$ é traduzida por uma forma perifrástica (e não o simples uenerit de Martinho); sobretudo é denunciadora do seu sentido psicológico, a inserção de si potueris. Comparando, pois, só a última frase grega, a tradução de Pascásio resulta estilìsticamente mais perfeita. Reveja-se:

PASCÁSIO

Quacumque hora in corde tuo ingressae fuerint passiones, eadem hora illas si potueris abscide.

\section{MARTINHO}

In quacumque hora uenerit passio, abscide illam. 
Não podemos perder esta oportunidade para demonstrarmos que este apotegma, tal como se encontra no Livro VII de Rosweydus, embora aí seja atribuído a Pascásio, na realidade o que se nos dá é uma recensão (feita pelos organizadores dos subarquétipos $\mu$ e $\chi$ de Pascásio) da tradução de Martinho. Com efeito faltam lá os elementos típicos de Pascásio:- a menção do abade José, as referências ao coração, o diálogo sobre o tempo e a ênfase da frase final. Pelo contrário, os elementos próprios de Martinho aí estão todos, embora no fim um pouco deturpados. O elaborador do hiperarquétipo $\lambda$ deixou, além disso, a marca inconfundível das suas interpolações escriturísticas. É tempo de ler a contrafacção que, até aqui, incompreensìvelmente, ninguém suspeitou fosse feita deturpando o texto de Martinho. Sublinhamos os acrescentos do falsário.

\section{Rosw., XXXIX,1}

Abbatem Sisoium requisiuit frater: Post quantum tempus debet homo a se abscindere passiones? Respondit: Scriptum est in Euangelio: Quia peccatores Deus non audit, sed qui cultor Dei est, et uoluntatem eius facit. Ideo cum uenerit impugnatio, abscide illam, quia fragilis est anima; ante armetur quam a peccatis inquinetur.

8 - FORMAS DE CONCISÃo NARRATIVA. O gosto pela amplitude da expressão combina-se perfeitamente, na língua latina, com a tendência para fórmulas curtas, para a concisão dos conceitos, o encadeamento de frases entre si por meio da subordinação. Pascásio demonstra um apurado conhecimento das técnicas capazes de reduzir a feição narrativa redundante da língua grega a fórmulas mais simples e resumidas em latim. Serviu-se, para isso, de vários processos.

a) - Elipse do verbo ao introduzir uma resposta - A este tipo pertencem frases frequentemente começadas por: cui senex; at ille. Por simples que pareça o processo, o certo é que outros tradutores latinos não o utilizam, mantendo-se escravos do verbo declarativo grego.

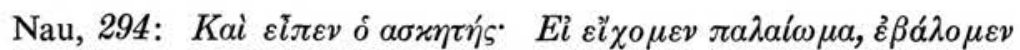

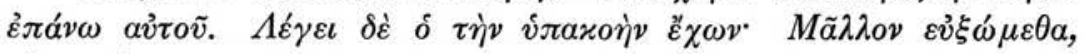

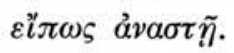


PASC. XLIII,3

Et dicit ille religiosus: $\mathrm{Si}$ haberemus aliquid ex ueteramentis mitteremus super illud. Cui frater: Oremus potius ne forte suscitet illum Deus.
PLG. XIV, 17

Et dixit abstinens ille ad fratrem suum: Si habuissemus aliquid uetustum, iactaremus super corpus illud. Et respondens ille oboediens frater, dixit: Magis oremus et forsitan resurget.

Parece claro que ambos os tradutores têm o mesmo grego. Todavia, só Pascásio omitiu na resposta o $\lambda \dot{\varepsilon} \gamma \varepsilon$. Note-se ainda que só o nosso tradutor se julga obrigado a acrescentar quem pode ser o autor da ressurreição. Julgamos que se deve registar também que o artigo definido em $\delta \dot{\alpha} \sigma \varkappa \eta \tau \eta \dot{s}$ foi expresso pelo pronome ille. Estaria já debilitado o valor demonstrativo do pronome ille, a caminho de se transformar em artigo? Outros exemplos de Pascásio parecem confirmá-lo.

O abade Lúcio perguntou a uns irmãos que o foram visitar:

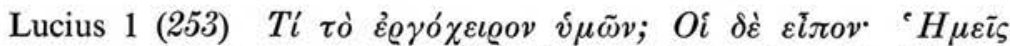

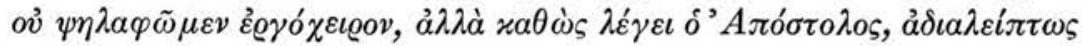

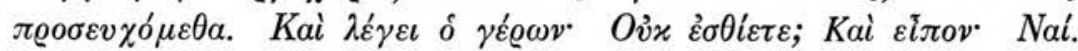

PASC. LXVI, 1

Quod soletis manibus uestris operari? At illi dixerunt: Nos nihil manibus operamur, sed secundum quod dicit Apostolus sine cessatione oramus. Quibus senex: Non manducatis? At illi professi sunt.
PLG. XII,9

Quod est opus manuum uestrarum? Et illi dixerunt: Nos non contingimus aliquod opus manuum, sed sicut dicit Apostolus sine intermissione oramus. Dicit eis senex: Et non manducatis? Illi autem dixerunt: Etiam manducamus.

O trecho completo donde extraímos este passo contém quatro perguntas e três respostas. Em Pelágio a introdução a cada uma delas é sempre feita com o verbo dico, usado sete vezes, portanto. Em Pascásio há uma busca intencional de uariatio e concisão, donde resultou a supressão três vezes do verbo dico. A primeira consistiu no 
processo que estamos apreciando: a elipse do verbo, ficando a parte inicial da frase reduzida a quibus senex. As duas outras resultaram da supressão do discurso directo com a resposta: Sim. No caso que temos presente, a introdução e a resposta foram substituídas pela frase: At illi professi sunt. A segunda frase afirmativa foi reduzida a uma simples oração temporal-causal: Cumque illi se dormire dixissent..., enquanto Pelágio traduz à letra: Et illi dixerunt: Dormimus. Este processo de evitar frase curtas só para dizer sim será apreciado adiante (cf. alínea $\gamma$ ).

No fragmento que acabamos de transcrever observe-se, a corresponder ao est inicial de Pelágio, a locução mais rebuscada soletis operari (cf. n. 7).

Eis outro exemplo de elipses consecutivas do verbo. Um irmão consulta o abade Teodoro sobre o jejum. Em certo passo, lemos:

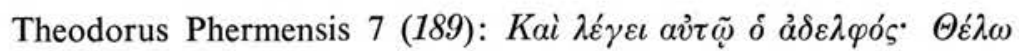

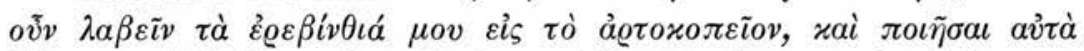

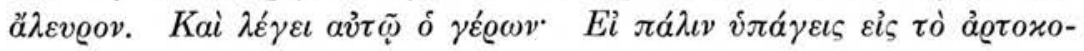

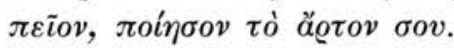

PASC. VI, 1

At ille: Volo ire ad pistrinum et de cicercula farinam facere. Cui beatus Theodorus: $\mathrm{Si}$ ad pistrinum semel ire desideras, fac panem tuum et comede.
PLG. VIII,7

Et dixit ei frater: Volo portare modicum cicer ad pistrinum, et facere inde farinam. Et dixit ei abbas Theodorus: Iam si ad pistrinum uadis, fac tibi panem.

Note-se que enquanto Pelágio, monòtonamente, emprega duas vezes dixit, Pascásio conseguiu eliminar completamente este verbo tão frequente no género dialogal dos apotegmas.

B) - Mudança do discurso directo para o indirecto - Um processo que Pascásio utiliza, com muita frequência e arte, é a eliminação de uma oração declarativa seguida de uma interrogação ou de uma resposta, substituindo-as por uma só frase no discurso indirecto.

Eis um diálogo entre o abade Antão e alguns irmãos, no qual as perguntas e respostas dos consulentes foram todas reduzidas a expressões narrativas, na linguagem indirecta. 
ANTONIVS $19(81)$

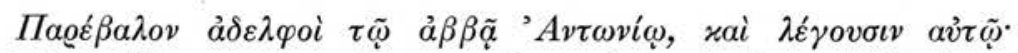

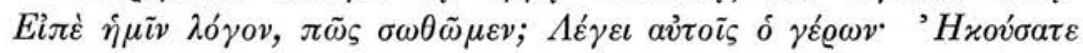

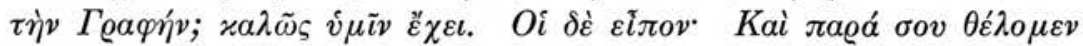

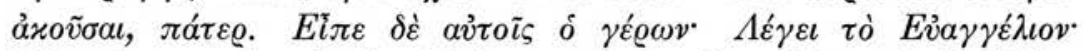

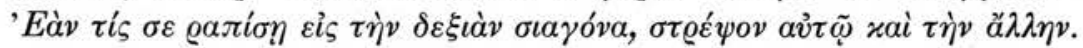

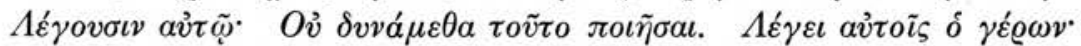

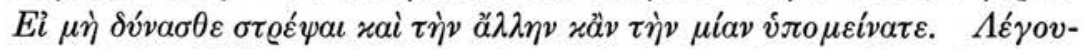

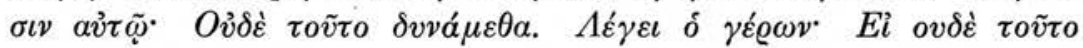

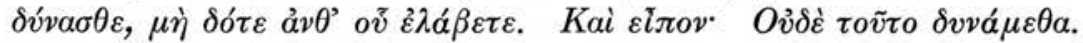

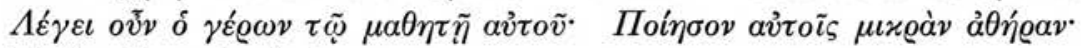

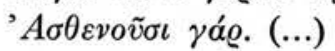

PASC. XXI,1

Quidam fratres uenientes ad abbatem Antonium postulabant per quem saluarentur audire sermonem. Quibus ille ait: Scripturas audistis? Quae uobis sufficiant scitis. At illi ut ipse quoque aliquid dicere dignaretur instabant. Tunc dicit eis: Dicit Euangelium: Si te percusserit aliquis in dextera maxilla praebe illi et alteram. At illi hoc se facere non posse dixerunt. Respondit eis: Si praebere alteram non potestis, uel in illa una iterum si uoluerit feriat. Sed cum nec hoc se posse facere testarentur, dicit eis: $\mathrm{Si}$ ergo nec hoc potestis, ne reddatis pro quod accepistis. Et cum illi idem uerbum quod superius dixerant repetissent, dicit Antonius discipulo suo: Vade, fac illis escas ut comedant; uides enim quod ualde infirmi sunt.

\section{JOÃO IV,11}

Dixerunt quidam fratres abbati Antonio: Volumus a te audire uerbum, quo saluari possimus. Tunc senex ait: Ecce Scripturas audistis, sufficiat uobis. Qui dixerunt: Et a te uolumus audire, pater. Respondit eis senex: Audistis Dominum dicentem: Si quis te percusserit in maxilla sinistra, praebe ei et alteram. Dicunt ei: Hoc implere non possumus. Dicit eis: Si ergo praebere ei et alteram non potestis, saltem de una ferte patienter. Responderunt ei: $\mathrm{Nec}$ hoc possumus. Dicit eis: $\mathrm{Si}$ neque hoc potestis, ne uelitis percutere magis quam percuti. Dicunt ei: Nec hoc possumus. Tunc senior ait discipulo suo: Succos praepara fratribus istis, quia nimis infirmati sunt. 
A comparação das traduções de Pascásio e João, postas lado a lado, permite apreciar o modo diferente como Pascásio tratou as intervenções dos irmãos. Logo a primeira, com a introdução de postulabant dá origem a uma bela frase com artística distribuição de palavras (cf. n. 2). Na segunda chama a nossa atenção a perífrase dicere dignaretur (cf. n. 6). Mais adiante é o próprio sentido do texto grego que Pascásio esclarece com uma tradução mais alargada e interpre-

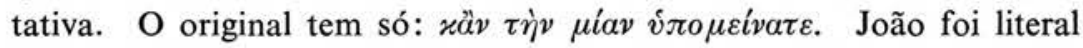
e quase obscuro: saltem de una ferte patienter. Mas Pascásio interpretou justamente: uel in illa una iterum si uoluerit feriat-onde devemos realçar o valor de uel, 'pelo menos', tão frequente no estilo de Pascásio. Igualmente no fim há em Pascásio um alargamento da tradução, sem modificar o sentido, mas antes reforçando-o. João também tentou compor aqui melhor a frase. Sublinhamos os elementos de um e outro tradutor que não estão explícitos no grego:

PASCÁSIO

Vade, fac illis escas ut comedant; uides enim quod ualde infirmi sunt.
JOÃO

Succos praepara fratribus istis quia nimis infirmati sunt.

Este último paralelo sugere-nos que o grego de Pascásio e João deveria ter um advérbio equivalente ao comum ualde: nimis.

Eis outro exemplo bem elucidativo do esforço para evitar o discurso directo, a fim de tornar a narrativa menos monótona.

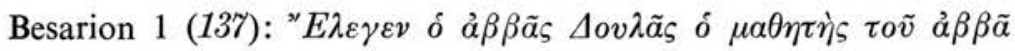

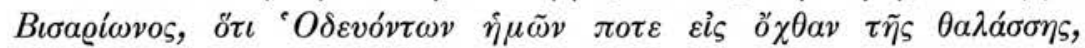

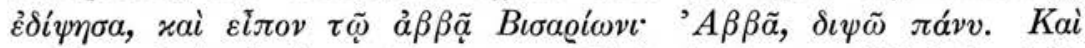

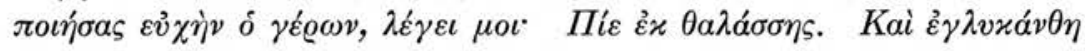

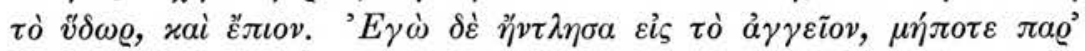

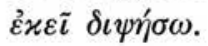

PASC. LXVIII, 4

Discipulus abbatis Besarionis nomine Dulas referebat eo quod dum pariter ambularemus per
JOÃO II,1

Dixit abbas Dulas discipulus abbatis Besarionis: Quia ambulantibus nobis secus litus maris, 
uiam iuxta litus maris contigit me sitire. Et dixi seni: Sitis me macerat. Qui facta oratione iussit me de mari aquam tollere et bibere. Quam cum bibissem et dulcissimam reperissem, uasellum quod mecum fortasse portabam impleui. sitiui; et dixi abbati Besarioni: Abba, sitio ualde. Et cum fecisset senex orationem dixit mihi: Bibe de mari. Et dulcis facta est aqua, et bibi; ego autem hausi modicam in uase ne forte iterum sitirem.

Observando ambas as traduções, verificamos que, tal como no grego, João introduz três vezes o discurso directo, empregando sempre dixit. Em Pascásio só a segunda intervenção permanece claramente no discurso directo. O princípio merece-nos especial atenção porque Pascásio, que quis fugir à narrativa directa pelo emprego de referebat eo quod, acabou por deixar vestígios da descrição na primeira pessoa, escrevendo ainda ambularemus (em vez de ambularent) e me (em vez de $s$ ). Perfeita é a versão da intervenção do abade: ablativo absoluto (em vez da oração temporal de João) e o verbo iubeo seguido de infinitivo, com o acrescento tollere, implícito na ordem de beber. O final que transcrevemos é um claro exemplo de como Pascásio prefere o encadeamento de orações subordinadas (uma das preferências dos bons autores) em vez da simples parataxe (cf. a seguir alínea $\eta$ ). Note-se ainda o duplo uso do relativo qui ... quam, em princípio de frase, como elemento de ligação.

Não resistimos a apresentar um terceiro exemplo, não só para se verificar que em Pascásio a expressão referebat eo quod é seguida de uma narrativa na terceira pessoa, mas ainda por podermos comparar ao mesmo tempo três traduções latinas, uma das quais do ainda não identificado tradutor do «autêntico Livro III».

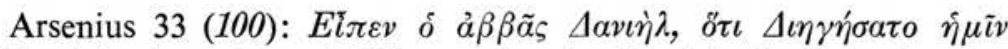

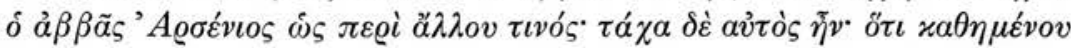

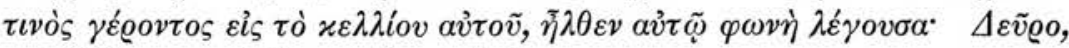

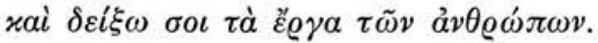


PASC. XCIX,2

Beatus Arsenius referebat eo quod dum propria resideret in cellula uocem sibi dicentem audiuit ut egrederetur foris propter opera hominum contemplanda.
PLG. XVIII, 2

Dixit abbas Daniel, qui erat discipulus abbatis Arsenii, quia narrauit ei abbas Arsenius, tamquam de alio aliquo dicens (puto tamen quod de eo dicebatur), quia cum sederet in cella sua quidam senum, uenit uox dicens ei: Veni, ostendam tibi opera hominum.
III AUT. VI,2

(= III ROSW. 38)

Dicebat etiam abbas Daniel quomodo sanctus Arsenius referebat fratribus dicens quasi de alio audisset, sed ut quantum datur intelligi, ipse talem uidit uisionem: Quia sedebat, inquit, quidam de senioribus in cellula sua et subito uenit uox ad eum dicens: Egredere foras et ostendam tibi opera hominum.

Torna-se evidente que Pelágio e o tradutor do «autêntico Livro III" tinham um texto grego de uma recensão semelhante à que transcrevemos. Entre ambos apenas se nota que o segundo dá, talvez por sua iniciativa, um pouco mais de desenvolvimento à narrativa.

Pascásio possuía, por certo, um texto grego de uma adaptação posterior donde foram suprimidos os elementos iniciais que não interessavam à moralidade do apotegma. Precisamente a partir do momento em que as três versões são concordantes com o grego que possuímos, nos importa observar a técnica de tradução de Pascásio. E esta distingue-se logo, em primeiro lugar, pela eliminação do discurso directo, que os outros tradutores introduzem por dicens. Pascásio resolve o problema com perfeição, dando relevo à ideia subjacente representada por audiuit, do qual faz depender a oração final que exprime o convite a sair (pleonàsticamente reforçado em Pasc. e III Aut. por foris: foras) e depois substitui a parataxe por uma oração gerundiva, de aspecto mais solene, regida por propter (quando se esperaria o clássico ad). Como vemos, os processos estilísticos de Pascásio são bem definidos e constantes. 
$\gamma$ ) - Supressão da afirmativa Naí- Uma das ocasiões mais características em que Pascásio substitui o discurso directo pelo indirecto é quando, a uma pergunta, o interlocutor responde simplesmente: Naí 'sim'. O caso chega a ser intrigante, porque o latim tinha várias maneiras de expressar a afirmativa, não sobrevivendo nas línguas românicas nenhum dos advérbios do período clássico. E nós mal podemos saber como é que Pascásio dizia «sim», cuja nasal também é enigmática em português.

Comparemos o grego com várias traduções latinas. Vejamos o primeiro aparecimento de vaí no texto de Pascásio. Dois irmãos foram consultar o abade Pambo, mas ele não lhes respondia. Pensavam em retirar-se, quando uns clérigos os aconselharam a insistir. Vem então uma pergunta:

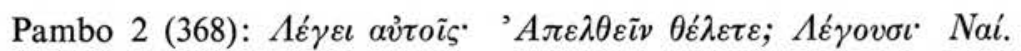

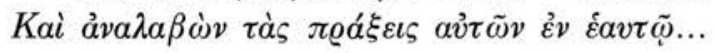

PASC. $\mathrm{I}, 3$

At ille percunctactus est eos si abire uellent. Quibus annuentibus recordatus opera eorum in semetipsum...
PLG. $\mathrm{x}, 65$

Et ille dixit eis: Ambulare uultis? Et dixerunt: Etiam. Et intuens eos, in semetipso accipiens opera eorum...

Todas as perguntas e respostas passaram ao discurso indirecto. O vaí foi transformado num ablativo absoluto com o particípio do português anuir, que bem o interpreta. Note-se a interrogativa indirecta introduzida pelo vulgar percunctatus ... si (cf. adiante, alínea $\delta$ ).

Pouco depois é o abade José que pergunta, e Pascásio resolve o problema do mesmo modo.

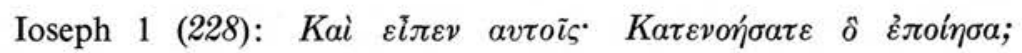

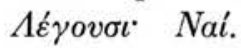

PASC. II, 2

Et dicit eis: Sensistis quod feci? Cum autem illi annuissent...
PLG. XIII,1

Et dixit eis: Vidistis quid feci? Dixerunt: Etiam. 
Na terceira vez que vaí aparece a solução é já outra. Um peregrino, que estava recebendo do abade Silvano uma lição prática, pergunta-lhe a certa altura:

Siluanus 5 (409): Ỏ̉x ह̌́q

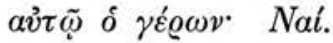

PASC. VII, 1

Numquid hodie fratres non comederunt? Cumque șenex fateretur...
PLG. $\mathrm{X}, 69$

Abba, hodie fratres non comederunt? Et dixit ei senex: Etiam iam comederunt.

Aqui, enquanto Pelágio reforça o seu etiam com a repetição do verbo, Pascásio recorre a uma oração temporal-causal de cum, seguida do verbo fateor, que reproduz igualmente bem o sentido afirmativo.

O sistema de supressão de vaí pode servir-se de outros verbos, desde que o sentido seja salvaguardado. Assim acontece num passo em que dois irmãos dialogam sobre a possibilidade de emenda. Naí.

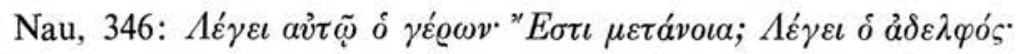

PASC. XLVI,8

Et dicit senex: Et uis poeniteri? Cum autem promisisset...
PLG. XVII, 14

Et dixit ei senex: Estne poenitentia? Et dixit frater: Etiam.

Aqui Pascásio interpreta a vontade de fazer penitência como uma promessa. Entre outros verbos utilizados recordem-se os que se encontram em Pascásio LXVI,1 (professi sunt...; se dormire dixissent...) já colacionados na alínea $\alpha$.

ס) - Passagem de interrogativas directas a indirectas - As orações interrogativas directas, tal como muitas outras construções no discurso directo, tendem em Pascásio, para evitar a série monótona de perguntas, a passar para interrogativas indirectas. Este processo nem sempre é, no entanto, fácil de descobrir. 
Assim, em Pasc. X,4 quando Macário se interessa por saber, junto do demónio, se há monges que cedem à tentação e tendo verificado que há só um, continua:

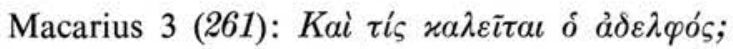

PASC. $\mathrm{x}, 4$

Cumque nomen ab eo requi-
PLG. XVIII, 9

Et quid uocatur frater ille? sisset...

Aqui a interrogativa directa foi transformada numa oração temporal-causal onde o valor interrogativo só é denunciado pelo verbo requiro.

No geral, porém, a transformação é fàcilmente reconhecível. Já atrás (6) examinámos o começo de Pascásio LXIX,1, onde se lê esta frase: Quod senex quisnam esset interrogat. O pronome interrogativo manteve-se aqui, tal como no princípio do seguinte apotegma:

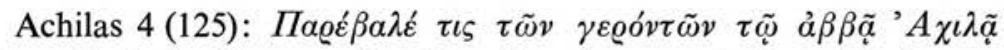

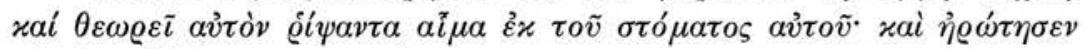

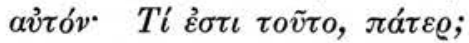

PASC. XXVI,2

Cum uenisset quidam de patribus ad abbatem Achilam, uidit eum sanguinem expuentem et requisiuit quid esset.
PLG. IV,9

Venit aliquando quidam senum ad abbatem Achillem, et uidit eum iactantem sanguinem de ore suo, et interrogauit eum, dicens: Quid est hoc, pater?

Como se vê, Pascásio resume a narração numa só frase. Mas a interrogação, embora indirecta, é nìtidamente marcada por quid.

Mais frequente é, porém, em Pascásio, outro processo. A interrogativa indirecta é apenas enunciada por um verbo apropriado, seguido de um $s i$, a conjunção que servia de interrogativa no latim vulgar e tardio. Vejamos só um exemplo.

(6) Cf. n. II, 6, p. 63. 


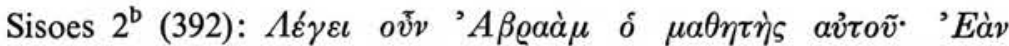

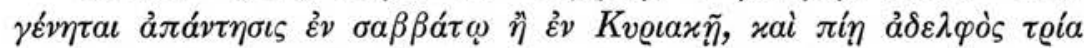

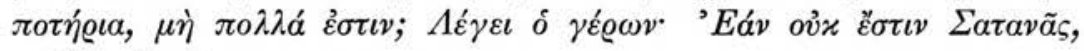

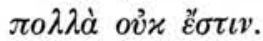

PASC. III, 6

Requirebat abbatem Sisoium discipulus suus Abraham si sabbatorum die, facta caritate in ecclesia, tres calices uini monachus debet haurire. Respondit: Si non est ibi Satanas non sunt multi tres calices (...).
PLG. IV, 37b

Dicit ergo Abraham discipulus eius: $\mathrm{Si}$ occurritur in sabbato et dominica ad ecclesiam, et biberit frater tres calices, ne multum est? Et dixit senex: $\mathrm{Si}$ non esset Satanas, non esset multum.

É possível que o grego de Pascásio tivesse aqui uma pequena diferença em relação ao que ficou acima. Mas o que nos importa está bem patente no grego e em Pelágio. Abraão dirige-se a Sisoio

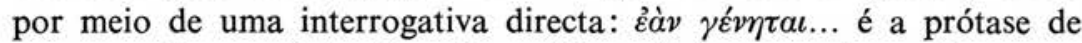
uma oração condicional, cuja apódose é interrogativa. O mesmo se passa em Pelágio com o si occurritur..., condicional, seguido da interrogativa directa ne multum est? Não assim em Pascásio. A primeira frase foi toda reduzida ao discurso indirecto, marcando, desde o princípio, o verbo requirebat que o si sabbatorum die... é aqui, de facto, uma oração interrogativa indirecta.

Já vimos atrás (alínea $\gamma$ ) que a Pasc. I,3: At ille percunctatus est eos si abire uellent corresponde em $\mathrm{Plg}$. $\mathrm{X}, 65$, de acordo com o grego: Et ille dixit eis: Ambulare uultis? A interrogativa indirecta é obra da arte de Pascásio. Não devemos deixar-nos sugestionar pela semelhança com o português: perguntar se... O verbo percunctor já é frequente em Plauto, é usado por Cícero e na idade argêntea e tem representantes românicos fora da Península Ibérica...

$\varepsilon)$ - Omissão de palavras repetidas no grego - Uma das práticas utilizadas por Pascásio para tornar a narração mais concisa é a omissão de palavras que o texto grego repete, mas que fàcilmente se podem subentender, com uma tradução adequada. 


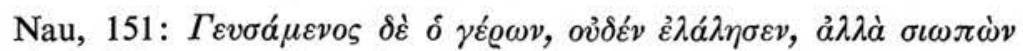

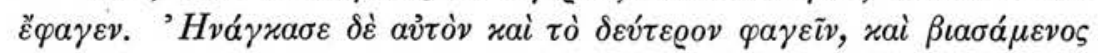

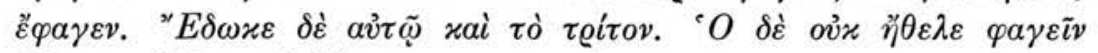

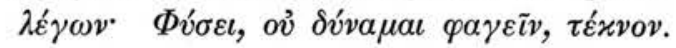

PASC. III, 5

Cum autem gustasset senex nihil locutus est, sed tacens comedit. Item secunda uice, cum eum conpelleret, comedit. Tertia uero uice cum ei daret dicit: Non possum comedere, fili.
PLG. IV, 59

Senex uero cum gustasset, nihil locutus est, sed tacitus manducauit. Conpellebat autem eum adhuc manducare. Et extorquens sibi manducauit, et dabat ei tertio. Ille autem nolebat manducare, dicens: Vere non possum, fili.

Neste trecho, o grego emprega cinco vezes formas de ě́payov. Pelágio traduziu sempre à letra, excepto no final, onde achou dispensável um novo manducare. Pascásio tem, por certo, o mesmo grego que Pelágio, a ponto de por vezes coincidirem as palavras da tradução. Soube, porém, variar um pouco a narrativa. Assim se deve interpretar o item secunda uice, donde resultou evitar já um $p a \gamma \varepsilon \tilde{\imath}$. E mais

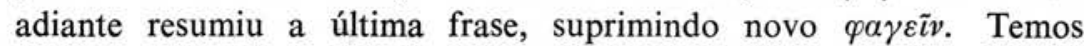
assim que, com uma tradução perfeita, Pascásio conseguiu cortar duas vezes o monótono verbo comedere. Curioso notar que, neste caso, a oposição entre Pascásio, com comedere, e Pelágio, com manducare, é constante.

Vejamos agora um extracto do primeiro apotegma da colecção alfabética-nominal.

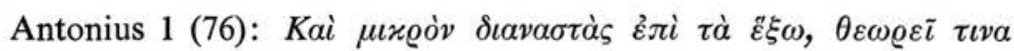

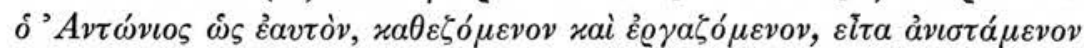

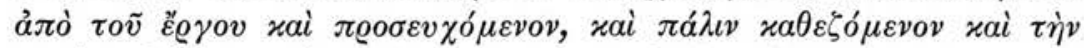

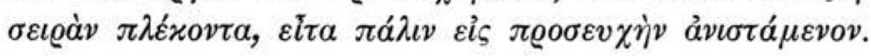

PASC. XXXII, 1

Et post paululum surgens quendam sibi similem conspicatur se-
PLG. VII,1

Et modice assurgens, coepit foras exire. Et uidit quendam, 
dentem torquere funiculum et surgentem ex opere et orantem. tamquam seipsum, sedentem atque operantem; deinde surgentem $a b$ operibus et orantem; et iterum sedentem, et plectam de palmis facientem, et inde rursus ad orationem surgentem.

Mais uma vez a tradução de Pelágio corresponde literalmente ao grego. Em ambos se vê que a figura aparecida por duas vezes se senta a trabalhar e em seguida se levanta para orar. Pascásio conservou todos os elementos essenciais à narração e à lição moral, mas eliminou a duplicação verbal das atitudes. Poderá pôr-se a hipótese de tal simplificação da acção ter já sido feita pelo organizador grego da colectânea traduzida por Pascásio. O seu processo de resumo, tal como veremos também na alínea seguinte, permite-nos supor que a redução poderá ter sido feita pelo próprio tradutor.

Com efeito, logo no apotegma seguinte se verifica, em Pascásio, a omissão de outro elemento repetido.

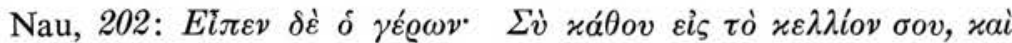

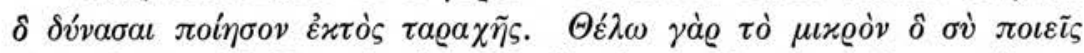

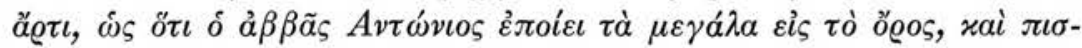

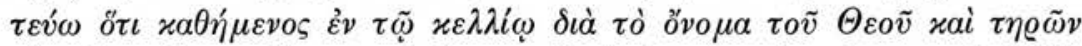

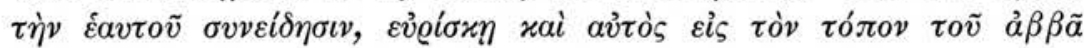

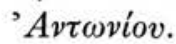

PASC. XXXII, 2

Cui senex dixit: $\mathrm{Tu}$ sede in cella tua et quod potes fac sine turbatione animi

et confido in Deum quoniam qui sedet in cella sua propter Deum inuenitur in locum ubi est abbas Antonius.
PLG. VII,34

Dixit autem ei senex: Tu sede in cella tua et fac quod potes sine perturbatione; ita est enim parum quod tu modo facis, sicut quando abbas Antonius magna et plurima faciebat in eremo. Credo enim in Deo, quia quicumque sedet in cella propter nomen eius et custodit conscientiam suam, inueniatur et ipse in Antonii loco. 
Pelágio traduz todo o texto grego e considera também o apotegma anónimo. Em Pascásio é um irmão que vai consultar o abade Áquila. É este que lhe dá o conselho que transcrevemos, do qual Pascásio eliminou a dupla referência ao abade Antão, reduzindo-a ao essencial: o trabalho solitário na cela, por amor de Deus, é recompensado como as famosas actividades de Santo Antão. Vê-se aqui uma clara intenção de resumo e de evitar repetições.

ל) - Redução de hendíades a uma só palavra - $\mathrm{O}$ desejo de concisão leva, por vezes, Pascásio a evitar uma expressão dupla no grego, vertendo-a por uma só palavra que lhe parece suficientemente significativa. Anotamos dois exemplos.

NAU, 135

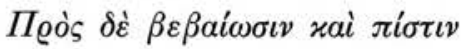
$\tau \tilde{\omega} \nu \lambda \varepsilon \gamma o \mu \varepsilon \dot{v} \omega \nu \ldots$
PASC. LVII, 3

Ad confirmationem sane uerborum suorum...

$\mathrm{O}$ apotegma tem paralelo em Plg. III, 20, mas neste passo é certo que a recensão de Pelágio é diferente, pois está encurtada de um episódio completo que Pascásio traduziu com fidelidade. Precisamente nesse episódio se encontra a expressão que transcrevemos, em que o grego usa dois substantivos quase sinónimos, vertendo Pascásio só o primeiro.

Também numa narrativa contada pelo discípulo do abade Teodoro, em que aquele se não mostrara generoso, se lê este passo:

THEODORVS 22 (192)

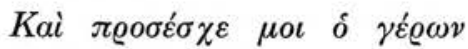

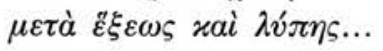

PASC. XLVII, 3

Quo uiso senex cum trucido eum uultu respexisset...

Falta outra tradução latina antiga paralela deste apotegma. Talvez que a dificuldade de traduzir ${ }^{\natural} \xi \iota \varsigma$ 'hábito, natural, faculdade' tenha feito com que Pascásio julgasse melhor condensar o sentido

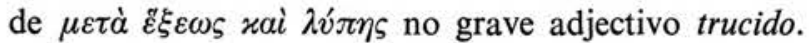

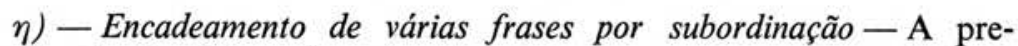
ferência de Pascásio pela subordinação em vez da parataxe ficou já 
impiìicitamente demonstrada quando vimos que passa o discurso directo para o indirecto (alíneas $\beta, \gamma, \delta$ ). Por isso, apresentaremos aqui apenas exemplos em que, por intermédio da subordinação, duas ou mais frases são reunidas numa só.

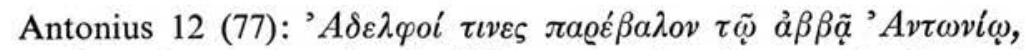

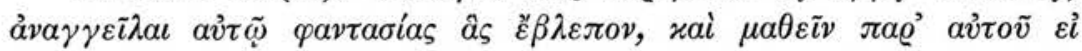

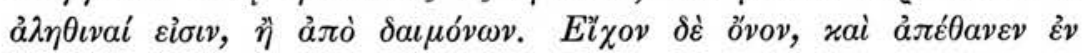
$\tau \tilde{\eta} \delta \delta \tilde{\omega}$.

PASC. LXX,2

Cum quidam fratres ad beatum Antonium pergerent, uolentes ab eo inquirere si phantasmata quae uidebant inpulsu daemonum cernerentur, habebant secum asinum quem in uia contigit mori.
PLG. $\mathrm{x}, 2^{\mathrm{a}}$

Fratres quidam uenerunt ad abbatem Antonium, ut nuntiarent ei phantasias quas uidebant, et cognoscerent ab eo utrum uerae essent, an a daemonibus illuderentur. Habebant autem asinum secum, et mortuus est eis in uia.

Tanto no grego como em Pelágio temos dois períodos independentes entre si, cada um deles ainda dividido por uma conjunção copulativa, em parataxe, portanto. Observando agora o texto de Pascásio, verificamos que os dois períodos foram fundidos num só e que ambas as conjunções copulativas desapareceram. Este maior poder de concisão narrativa conseguiu-o Pascásio recorrendo à subordinação. Apenas um pormenor não foi traduzido: a interrogativa indirecta dupla foi transformada em simples, mediante o corte da primeira

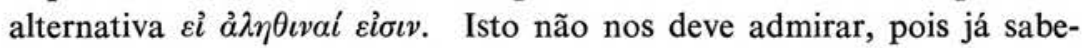
mos que Pascásio tem o gosto da síntese e este inciso fàcilmente se subentende. Com efeito, se Santo Antão respondesse que as visões não eram obra do demónio, concluir-se-ia que eram verdadeiras.

Mais elucidativo é ainda o exemplo seguinte. Devemos apenas lembrar que se trata dum apotegma em que à narração grega na primeira pessoa corresponde em Pascásio uma descrição na terceira pessoa (7).

(7) Cf. Aspectos do texto grego e da tradução de Pascásio, n. 6, pp. 62-63. 


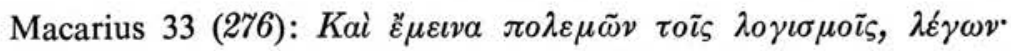

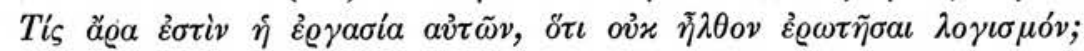

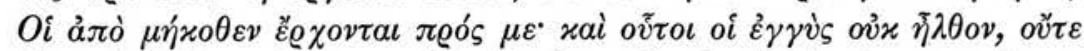

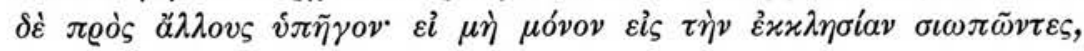

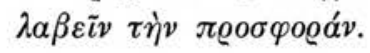

PASC. XCIII,11

Et quia alii de longinquis regionibus uenirent ad me, illi uero nec a me aliquid requirerent nec ad alios propinquarent, non leuiter admirabar, uidens eos tantum in ecclesia oblationem cum silentio in oratione percipere.
JoÃo III, 2

Sustinui autem et ego luctando cum animo meo, dicens: Putas quae est horum operatio, quia non uenerunt interrogare me de cogitationibus suis? Qui enim de longinquo sunt, ueniunt ad me; isti autem de proximo mihi non uenerunt ad me: nam nec ad alium abierunt, nisi solum ad ecclesiam cum silentio accipere oblationem.

Também aqui o grego e João têm duas frases, a segunda das quais com duas conjunções coordenativas e uma subordinativa. Em Pascásio tudo isto se reduziu a um período, no qual se mantêm apenas as duas conjunções coordenativas. E note-se que todos os elementos essenciais ao pensamento se encontram condensados na única frase de Pascásio.

O período que vem a seguir já o transcrevemos e analisámos ao estudar as perífrases com dignor (cf. n. 6). Vamos dar a continuação imediata, pois o processo da síntese narrativa verifica-se também aqui.

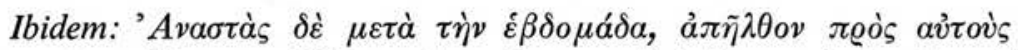

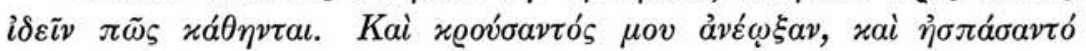

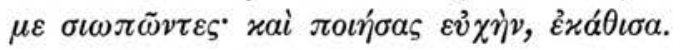

PASCÁSIO

Et post hoc, profectus ad eos pulsaui ad ostium, quo aperto
JOÃO

Surgens autem post illam septimanam abii ad eos uidere 
tacentes adorauerunt utrique; et postquam facta ex more oratione, consedi. quomodo sederent. Et cum pulsassem aperuerunt mihi, et salutauerunt me tacentes; faciensque orationem, sedi.

Novamente temos no grego e em João dois períodos independentes, contendo o segundo duas conjunções copulativas. A todo este sistema de parataxe corresponde em Pascásio uma só frase, onde apenas se encontra em correspondência a última conjunção copulativa. E o pensamento não foi alterado nem falta sequer nenhum dos membros do texto grego original.

Note-se, na parte final, que postquam fica pendente, sem que se Ihe siga uma oração temporal do tipo: postquam facta est ex more oratio. Esta anomalia foi provocada pela forte sugestão de um inesperado ablativo absoluto, facta ... oratione, invariável na transmissão manuscrita.

Revendo este processo de Pascásio verificamos que a síntese é conseguida mediante o recurso a orações subordinadas, sobretudo temporais, ao ablativo absoluto e aos particípios. Dá-nos assim um texto mais denso e de sabor mais latino que o do literalismo extreme de Pelágio-João.

9 - INTRODUÇÃo Do DISCURSO DIRECTO. Embora a tendência dominante em Pascásio seja a de passar uma narrativa do discurso directo para o indirecto, num pequeno número de casos nota-se que, para dar maior vivacidade à descrição, quando nela não há diálogo ele o introduz. Damos três exemplos.

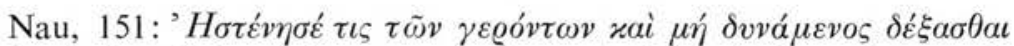

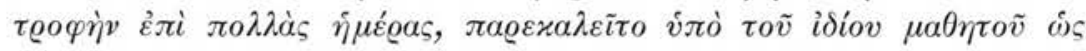

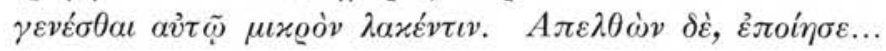

PASC. III, 5

Quidam ex senibus factus est infirmus et per multos dies non poterat escam ullam suscipere. Conpulit autem eum discipulus suus, dicens: Iubes facio tibi paruam placentam? Et iit et fecit.
PLG. IV, 59

Infirmatus est quidam senum; et cum non posset sumere cibum multis diebus, rogabatur a discipulo suo ut fieret ei aliquid, et reficeretur. Abiit autem et fecit... 
Julgamos que o texto grego que temos seria o mesmo de Pelágio e Pascásio. Perante a alongada introdução descritiva, Pascásio resolveu transformar uma interrogativa indirecta num interpelação pessoal do discípulo, com certo tom de carinho e dedicação. O estilo beneficiou com isso.

Um pouco diferente é o caso de Nau, 209: $\Gamma c^{\prime} \varrho \omega \nu \tau \iota \varsigma$ j̃v xai

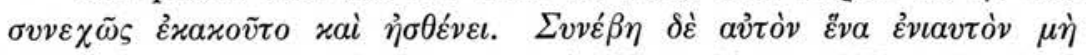

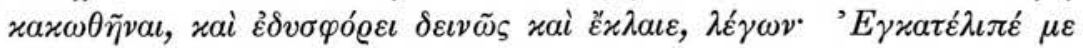

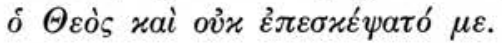

PASC. LI, 2

Quidam senex cum frequenter infirmaretur et langueret, contigit ut uno anno nulla ei inualitudo contingeret et propterea flebat et grauiter ferebat dicens: Reliquisti me, Domine, et noluisti me praesenti hoc anno uisitare.
PLG. VII,41

Senex quidam erat qui frequenter aegrotabat. Contigit autem eum uno anno non aegrotare; qui affligebatur grauiter et plorabat, dicens: Dereliquit me Deus, et non uisitauit me.

Aqui tanto o grego como Pelágio têm também as palavras do ancião, mas dirigidas a uma terceira pessoa. Pascásio criou um processo de maior vivacidade, fazendo com que a queixa se dirija directamente a Deus. A expressão ei inualitudo é uma correcção nossa, de acordo com o grego e Pelágio. Os manuscritos, certamente devido à antiga scriptio continua têm: eum ualitudo MVPSCA eum inualido L ualitudo $\mathrm{E}$, omitindo este manuscrito ei.

Outro exemplo seguro em que Pascásio passou para o discurso directo o que em grego está no indirecto encontra-se em

ACHILAS $5^{\text {b }}$ (125)

\section{" $E \lambda \varepsilon \gamma \varepsilon v \quad \delta \quad \dot{\alpha} \beta \beta \tilde{\alpha} \varsigma$ ' $A \mu \mu \omega \dot{m}$,}

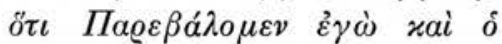

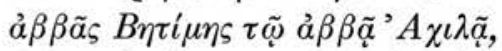

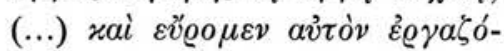

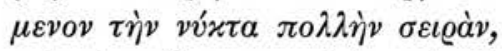

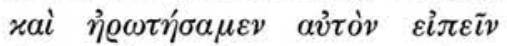
$\dot{\eta} \mu \tilde{\imath} \nu$ hó $\gamma o v$.
PASC. LX, 1

Abbas Ammon uenit ad abbatem Achilam

et inuenit eo quod per noctem grandem funiculum operatus esset et requisiuit eum: Pater, dic nobis sermonem aliquem. 
Não há para este apotegma outra tradução antiga. É certo que o princípio foi reelaborado pelo organizador da compilação grega de Pascásio. Na parte que nos interessa, porém, o reelaborador já estava seguindo à letra a sua fonte. E a prova está em que, tendo eliminado, no princípio, a referência ao abade Betimes e o plural $\varepsilon v ้ \varrho o \mu \varepsilon v$ (Pasc. inuenit), logo a seguir já mantém î $\mu \tilde{\imath} v$ (Pasc. nobis). Ora precisamente neste ponto o grego narra no discurso indirecto. É Pascásio quem, para estabelecer o equilíbrio com a única resposta directa que se segue, resolve fazer também a pergunta de modo directo.

Mas acentuemos que este processo é raro em Pascásio. Ao todo, temos anotados seis exemplos. O que se verifica com uma frequência quase sem número é a eliminação do discurso directo, substituindo-o pelo indirecto, como vimos (cf. n. 8, $\beta$ ).

10 - TRAdUÇÃo AD SENSVM. Em algumas dezenas de passos, a tradução de Pascásio não é literal, mas também não parece exigir necessàriamente outro texto grego. Supomos que o tradutor se conformou apenas com o sentido geral da frase, vertendo do modo que lhe pareceu mais adequado.

Poemen contava de um outro abade que, estando este a chorar os seus pecados, um discípulo lhe veio dizer: "Tu não tens pecados, pai». Eis a conclusão:

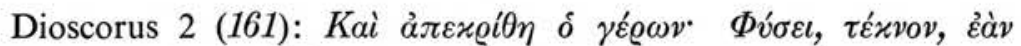

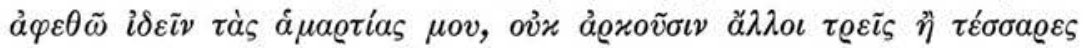

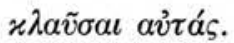

PASC. $\mathrm{XXXIX}, 8$

At senex: In ueritate, inquit, fili, si peccata mea Deus manifestaret omnibus non solum alii tres et quattuor sufficerent mecum plangere sed pluriores.
APP. LAUS. $\mathrm{xx}, 5^{\mathrm{b}}$

Respondit ei senior: Certe, fili, si permissum fuerit flere peccata mea, non uiderem aliorum; nec tamen sufficeret mihi flere peccata mea, etiam si alii tres uel quattuor plangerent mecum.

Cremos que ainda está por deslindar quem é o tradutor dos apotegmas que foram acrescentados, como cap. XX, à Palladii Lausiaca. Comparando o grego com as duas versões latinas, verificamos que se 
correspondem quanto ao sentido geral da resposta. $\mathrm{O}$ original grego de Pascásio, se não era o que demos acima, devia estar muito próximo dele. $\mathrm{O}$ inquit (cf. $\mathrm{n}$. 3) e o alargamento mecum plangere sed pluriores (cf. n. 7) estão dentro do estilo de Pascásio.

Repare-se como Pascásio trata o final da resposta de Arsénio ao arcebispo de Alexandria que lhe mandara recado de que desejava ir visitá-lo.

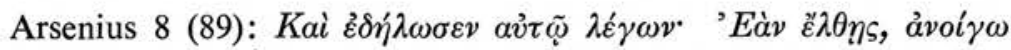

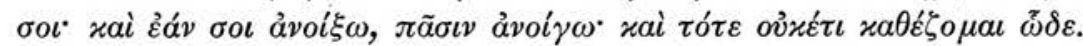

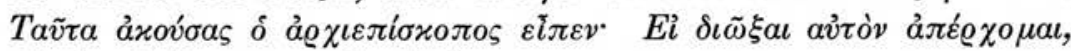

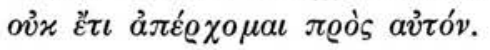

PASC. XCIII,9

...mandauit ei: Si ueneris aperio tibi, si autem tibi et omnibus, si autem omnibus ultra hic non sedebit Arsenius. Quod cum audisset episcopus incepto abstitit ne eum cogeret de loco ipso discedere.
PLG. II, $4^{\text {b }}$

Et mandauit ei, dicens: $\mathrm{Si}$ uenis aperio tibi. Sed si tibi aperuero, omnibus aperio, et tunc iam ultra hic non sedebo. Haec ergo audiens archiepiscopus, dixit: Si eum persecuturus uado, numquam uadam ad hominem sanctum.

Só a última frase está em causa. Enquanto Pelágio é literal, Pascásio faz uma tradução aqui nìtidamente ad sensum. No grego e em Pelágio está bem expresso que o arcebispo desistiu, por então, de ir visitar Arsénio, mas guardava a esperança de um dia o poder fazer. Pascásio, pelo contrário, põe em relevo outro aspecto implícito na atitude do arcebispo: desistiu da visita para não obrigar o eremita a recolher-se noutro lugar. E esta interpretação está de acordo com a resposta enviada por Arsénio.

Noutro apotegma, o mesmo abade Arsénio visitara uns irmãos e, ao ouvir o ruído de um canavial agitado pelo vento, perguntou que «terramoto» era aquele. E explicou:

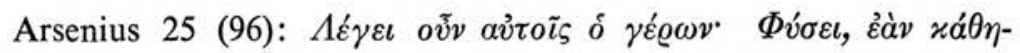

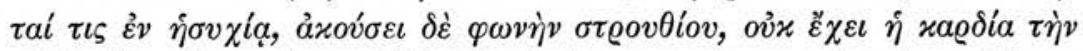

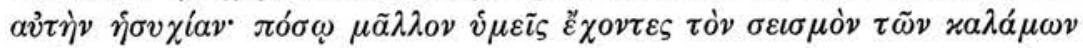

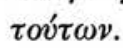


PASC. XCIV, 1

Quibus Arsenius ita respondit: $\mathrm{Si}$ quis in solitudine residens Deum orat cantante passere auscultat, iam non potest eandem intentionem mentis ad requiem custodire. Vos autem uicino terraemotu si potestis in requiem sedere satis admiror.
PLG. II, 5

Dicit eis senex: Vere, quia si quis sedet cum quiete, et audierit uocem auis, non habebit cor eius eandem quietem, quanto magis habentes sonum arundinum harum?

Uma vez mais se verifica ser a tradução de Pelágio perfeitamente literal. A de Pascásio é um pouco mais abundante, introduzindo os elementos explicativos que sublinhámos, os quais, no entanto, condizem maravilhosamente, ad sensum, com o pensamento de Arsénio. Quem ler só as duas versões latinas reconhecê-las-á paralelas, mas não deixará de notar a maior perfeição de estilo e amplidão de frase em Pascásio.

11 - SUPRESSÃO DE «PALAVRAS FEIAS». O leitor habituado à variedade dos temas nos apotegmas sabe que entre os monges e seus discípulos não floresciam só exemplos de virtude. Chegam a ser chocantes alguns episódios incluídos no capítulo $\mathrm{V}$ de Pelágio, intitulado De fornicatione. Na sua «introdução ao monaquismo oriental» (8), o P. e A.-J. Festugière ajuda-nos a compreender a situação destes homens recém-convertidos e vivendo ainda num ambiente pagão.

Quem ler todo o livro de Pascásio observará, no entanto, que os casos de «perigo moral» são raros e sobretudo que não há "quedas». Este aspecto deve-se, por certo, ao compilador desta colecção grega que eliminou as «cenas escabrosas».

Há, todavia, um outro aspecto que é, sem dúvida, fruto da delicadeza de consciência de Pascásio e do qual só se apercebe quem colacionar os lugares paralelos. Mesmo quando o texto grego conservou algumas "palavras feias», Pascásio evitou-as na tradução, reduzindo-as no geral a expressões vagas ou eufemísticas e até suprimindo-as, pura e simplesmente.

(8) A.-J. Festugière, Les moines d'Orient, I, Culture ou Sainteté, Paris, 1961.

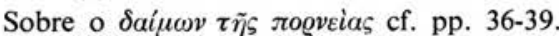


Comecemos por examinar o que se passa com a palavra $\pi$ ogvía, reduzida à simples cogitatio.

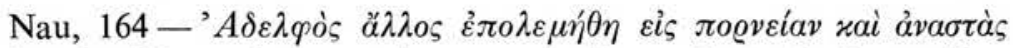

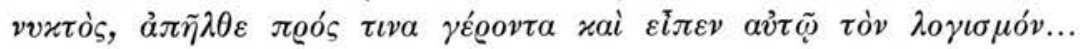

PASC. LXXIII, 4

Quidam frater inpugnatus est a cogitatione et exurgens per noctem profectus est ad quendam senem et dixit ei cogitationem suam.
PLG. V,13 $3^{a}$

Alius frater stimulatus est a fornicatione. Et surgens nocte perrexit ad senem et dixit ei cogitationem suam.
III AUT. II, 2 (= III R 9)

Et alius etiam frater uehementer inpugnabatur $a b$ inmundo spiritu fornicationis. Exurgens autem nocte abiit ad quendam sanctum probatum in uirtutibus seniorem, confessus est ei quam patiebatur inpugnationem a spiritu fornicationis.

Apesar da extensão do tradutor do «autêntico Livro III», para quem conhece os seus hábitos de tradução permanece claro que os três textos latinos dependem do grego que temos acima. Pelágio e

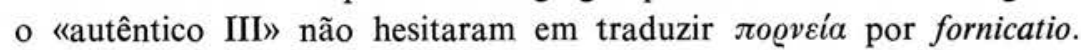
Só Pascásio, com recato, se ficou pela cogitatio.

Mais adiante o ancião aconselha o irmão e diz-lhe: Ibidem-Ỏ̉ $\dot{\varepsilon} v$

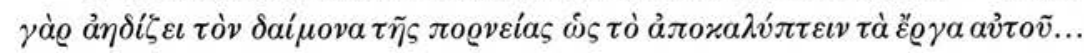

\begin{tabular}{c|c} 
PASCÁSIO & \multicolumn{1}{|c}{ PELÁGIO } \\
$\begin{array}{l}\text {..nihil sic daemonem } \\
\text { inpugnatorem con- } \\
\text { tristat quomodo ma- } \\
\text { nifestare opera eius... }\end{array}$ & $\begin{array}{l}\text { Nihil enim sic ex- } \\
\text { taediat daemonem } \\
\text { fornicationis quomo- } \\
\text { do si reuelentur sti- } \\
\text { mulationes eius. }\end{array}$
\end{tabular}

\section{AUTÊNTICO}

Nihil enim ita allidit uirtutem daemonum quomodo si quis secreta inmundarum cogitationum reuelauerit sanctis ac beatissimis patribus. 
Neste caso Pelágio e o "autêntico III» voltam a deixar expressa

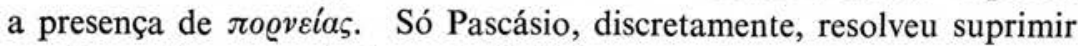
a palavra da sua tradução, substituindo-a por inpugnatorem.

Apenas anotámos uma ocasião em que Pascásio foi um pouco mais explícito. Havia dois monges, um dos quais já se sentia velho e pediu a um irmão mais novo para ir viver com ele. Mas este escusou-se porque era "pecador». O velho insistia e diz o apotegma:

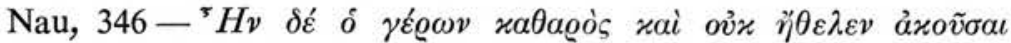

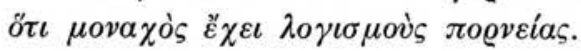

PASC. XLVI, 8

Erat autem ille senior mundus et nolebat audire quia monachus habet aliquando cogitationem prauam.
PLG. XVII, 14

Erat autem senex ille mundus et nolebat audire quia monachus haberet in cogitatu fornicationem.

As traduções são tão semelhantes que ficamos certos de que foi

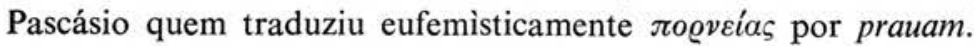

O mesmo sistema de eufemismo se verifica neste passo para o qual não há outro paralelo latino:

ANTONIVS 29 (85)

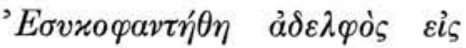

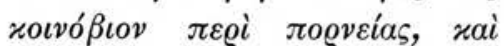

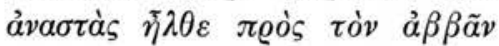

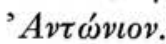

PASC. XLI,9

Contigit fratri culpa in coenobio et dum a ceteris increparetur ad abbatem est profectus Antonium.

A tradução é tão literal que não há dúvida de que foi Pascásio quem evitou especificar a natureza da acusação.

$\mathrm{O}$ aligeiramento do vício chega a exprimir-se por uma fórmula inteiramente anódina.

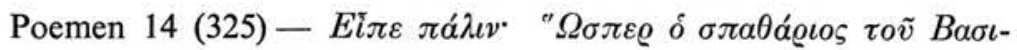

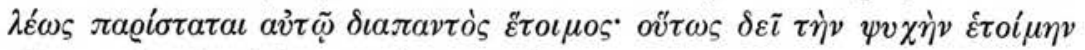

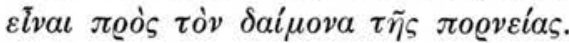


PASC. IX,3

Dixit abba Poemen: Quemadmodum imperatoris spatharius semper illi adstat armatus, ita et animam aduersus daemonem huiusmodi oportet esse semper armatam.
PLG. $V, 8$

Dixit abbas Pastor: Sicut spatharius principis assistit ei semper paratus, ita oportet et animam semper esse paratam aduersus daemonem fornicationis.

O escrúpulo de Pascásio chega a tal ponto que, estando o seu livro organizado segundo a ordem «de octo principalibus uitiis», não há nenhum capítulo que tenha o título De fornicatione. Ora basta a simples leitura do título dos capítulos da obra para se ver que, se os primeiros sete tratam da gula, desde o oitavo até ao décimo terceiro inclusive todos se ocupam da luxúria. Pois nem este vocábulo aparece a caracterizar a série.

Aproveitamos a oportunidade para corrigir, a propósito desta palavra, o texto grego do apotegma seguinte, baseando-nos na lição segura dos paralelos latinos. Numa série de capítulos dedicados ao silêncio interior, favorecido pela solidão do deserto, temos esta sentença.

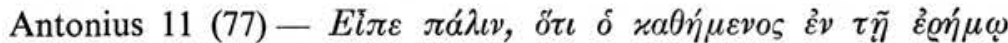

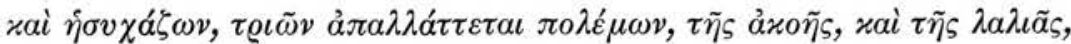

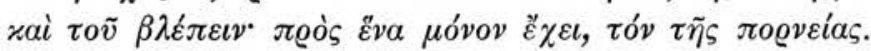

PASC. XCIII, 1

Beatus Antonius dicere solebat: Qui sedet in deserto tribus proeliis caret, id est, uisus, auditus et detractionis, et ad unum tantummodo opus cordis intentus est.
PLG. II, 2

Dixit iterum: Qui sedet in solitudine, et quiescit, a tribus bellis eripitur; id est, auditus, locutionis et uisus; et contra unum tantummodo habebit pugnam, id est, cordis.

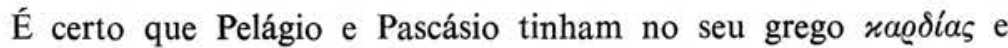

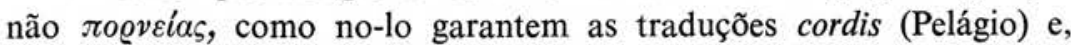
como é de esperar, em Pascásio, mais amplo, opus cordis. Acentuamos

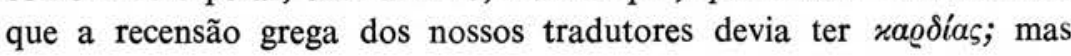




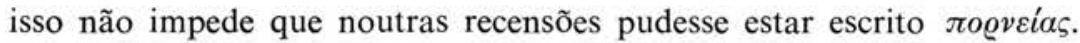
Com efeito, a "guarda do coração", como se diz em linguagem de ascética e mística, inclui necessàriamente o afastamento dos «maus pensamentos", incluindo os da ro@veía. Além dos passos já apontados, anotámos mais algumas circunstâncias em que a referência

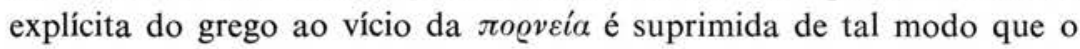
leitor não se apercebe do que está por debaixo da tradução de Pascásio. Assinalamo-los sumàriamente.

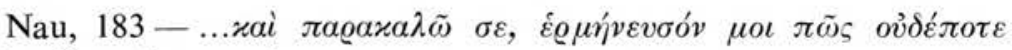

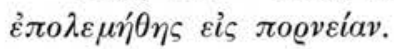

PASC. XI,1

Sed rogo te, explana mihi quemadmodum non es inpugnatus.

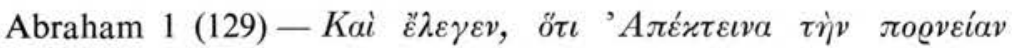

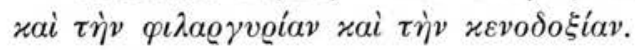

PASC. XXXIII, 9

Dicebat ipse: Quia occidi gloriam.
PLG. V,31

Sed obsecro te, ut interpreteris mihi quomodo nunquam sollicitatus sis a fornicatione. gloriam.

Neste apotegma Abraão pretende convencer um velho, que se vangloriava de ter vencido os três vícios acabados de indicar, de que eles permanecem sempre radicados na natureza. Para isso apresenta-lhe três casos concretos. Pascásio transcreve o segundo e o terceiro, mas omite totalmente o primeiro sobre a joøveía. Ei-lo no seu realismo:

IDEM (132)

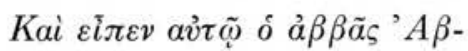

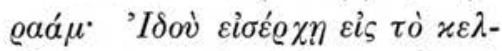

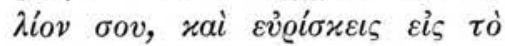

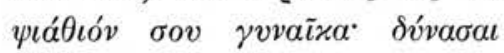

PLG. $\mathrm{X}, 15$

Et dicebat: Quia extinxi fornicationem et auaritiam et uanam gloriam. 


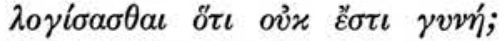
$\Lambda \hat{\varepsilon}^{\prime} \gamma \varepsilon v^{\circ} O \tilde{v} \cdot \dot{\alpha} \lambda \lambda \dot{\alpha} \pi 0 \lambda \varepsilon \mu \tilde{\omega} \tau \tilde{\omega}$ $\lambda о \gamma \iota \sigma \mu \tilde{\varphi} \mu \eta \dot{\eta} \ddot{\alpha} \psi \alpha \sigma \theta \alpha \iota \alpha \hat{\tau} \tau \tilde{\eta} s . \Lambda \dot{\varepsilon}-$

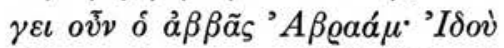

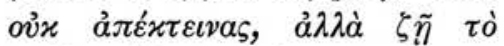
$\pi \alpha ́ \theta o \varsigma, \delta \varepsilon ́ \delta \varepsilon \tau \alpha \iota$ dé. mulier est? Et dixit: Non, sed inpugno cogitationem meam, ut non tangam mulierem illam. Dixit abbas Abraham: Ecce igitur non fornicationem interfecisti, quia uiuit passio ipsa, sed alligata est.

É depois disto que Abraão apresenta o achado do ouro entre pedras. Só nos podemos perguntar: teria este primeiro vício e exemplo sido eliminado pelo elaborador do grego ou só na tradução de Pascásio? Os paralelos levam-nos a pensar que o corte é obra do pudor de Pascásio.

O n. LV,6 de Pascásio segue literalmente o grego e Pelágio. Falta-lhe, porém, a conclusão, ou seja, a explicação concreta da parábola, que é a seguinte:

IOANNES COLOBVS 16 (209)

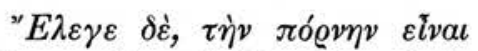

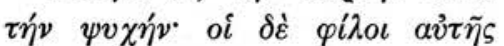

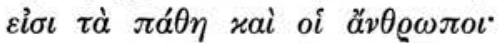

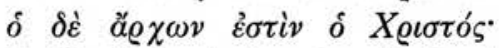

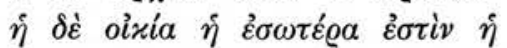

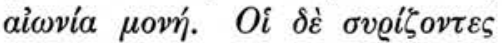

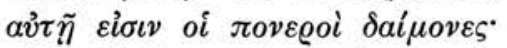

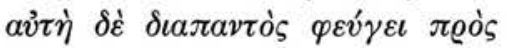

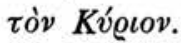

\section{JOÃO IV,13}

Haec ita locutus senior, dicebat meretricem esse animam, amatores ei esse uitia, ducem uero uel principem dicebat esse Christum, domumque eius caelorum perpetuam mansionem, sibilatores autem daemones sunt maligni. Haec ergo si casta fuerit et fidelis, semper currit ad Deum.

Devemos, no entanto, dizer que Pascásio conhece as palavras fornicatio e fornicator, mas só as usa em casos em que a responsabilidade lhe não pode ser atribuída.

Em IX,2 fornicatio uel inmunditia fazem parte de uma citação bíblica (S. Paulo aos Efésios V,3). Em XXV,2: Tu es, Agathon, superbus et fornicator? - é uma tentação de alguns que vieram com intenção de fazer irritar o abade Agatão. Finalmente, em LVI,3 um pecador arrependido confessa pùblicamente os seus pecados e diz: Ego homo sum peccator et in multis temporibus istis semper fornicationi fui deditus. E mais adiante explica como obteve o perdão de Deus: Ego autem fornicator, conpunctus in hoc sermone prophetae et ingemescens intra 
pectus meum... Este último apotegma é altamente edificante. Os monges terminam a narrativa com estas palavras: Quam magnificata sunt opera tua Domine! Omnia in sapientia fecisti!

Ao longo do confronto de todo o texto de Pascásio com o grego paralelo verificamos que ele evita outras «palavras feias». Estão

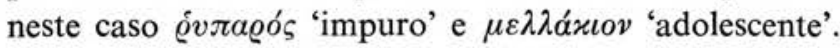

Assim em X,3 pergunta um irmão em Pascásio: Quid faciam quia inquietant me cogitationes? Mas os paralelos têm:

NAU, 182

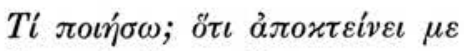

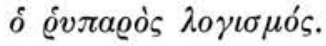

PLG. V,30

Quid facio quia occidit me sordida cogitatio?

E em XI,1 de novo em Pascásio se lê: Quid faciam quia non possum sufferre cogitationes?

\author{
NAU, 183

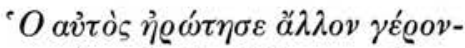

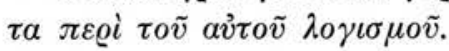

PLG. V,31

Frater quidam interrogauit senem de huiusmodi cogitatione.

Estes apotegmas encontram-se seguidos, como se vê, em Nau e

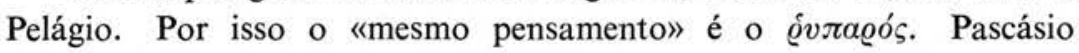
separou-os pela longa narração de $\mathrm{X}, 4$, mas nem por isso quis explicar melhor de que espécie de «pensamentos» se tratava. Aliás, já vimos que cogitatio em Pascásio significa muitas vezes $\lambda o \gamma \iota \sigma \mu o ̀ \varsigma ~ \tau \tilde{\eta} \varsigma$

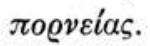

Em XXXII,2 um irmão, em Pascásio, queixa-se ao abade Áquila de que de opera in opera transgredior et de cogitatione in cogitatione. O que lá se não diz é que, segundo Nau, 202 e Pelágio VII,34 (onde o apotegma é anónimo) se faz referência também a

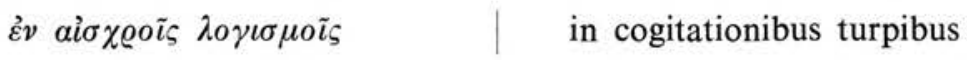

Finalmente, Pascásio, em XCIX,1, termina a última frase: et si quamcumque notitiam cum muliere habuerit. Ora todo o n. 125 de Nau está contido no último parágrafo deste apotegma de Pascásio. Mas 


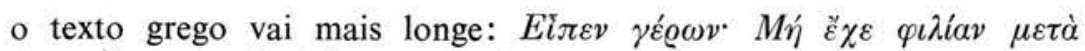

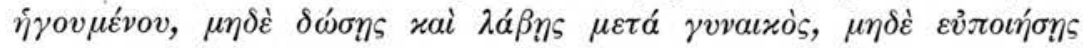
$\mu \varepsilon \tau \dot{\alpha} \mu \varepsilon \lambda \lambda \alpha x i o v$. A edição de Nau escreve na última palavra $\mu \varepsilon i \lambda \alpha x i o v$. Deve tratar-se de "gralha», pois tal vocábulo não existe. O que sabemos é ter sido um dos vícios da civilização helenística o abuso de $\mu \varepsilon \lambda \lambda \alpha x i ́ a$ 'jovens'. Pascásio (se não foi já o elaborador grego) eliminou a última referência. Mas ainda aqui propendemos a atribuir tal discrição a Pascásio, uma vez que em Pelágio se adverte mais que uma vez do perigo que constituem as crianças...

Para que estivemos nós a fornecer tantos elementos sobre estes aspectos que Pascásio propositadamente queria ocultar? O historiador da cultura e da espiritualidade dos séculos IV-VI desejará, ao ler a obra de Pascásio, enquadrá-lo em uma das várias correntes filosófico-teológicas em que se dividiu o monaquismo, sobretudo oriental. Ora o texto de Pascásio, só por si, não deixa suspeitar o que ele intencionalmente omitiu. Nós queremos dar um contributo à compreensão de Pascásio dentro da espiritualidade do seu tempo. E não temos a veleidade de supor que outrem, se não for advertido, vá fazer, sistemàticamente, o estudo paralelo de Pascásio com o grego e outras versões latinas. Por isso aqui deixamos todos estes elementos de referência.

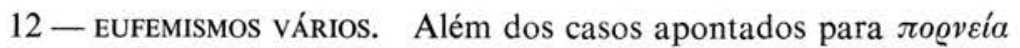
e outras "palavras feias», há vários passos em que Pascásio, por sua iniciativa, atenua a tradução da palavra grega, tornando assim a leitura menos ofensiva para as pessoas em causa ou evitando a exaltação da imaginação em matéria de moribus.

Um exemplo simples:

NAU, 184

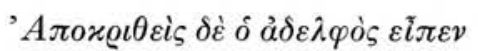

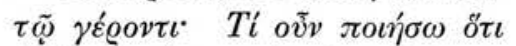

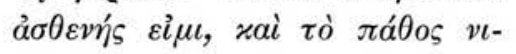
$x \tilde{\alpha} \mu \varepsilon$;
PASC. $\mathrm{x}, 2$

Et respondens frater: Quid ergo faciam quoniam infirmus sum et proeliare non ualeo?

$\mathrm{O}$ apotegma tem paralelo em $\mathrm{Plg}$. V,32, mas neste a narração cai mesmo na pornografia, sinal de que tinha uma recensão grega diferente da de Nau. Concretamente, em relação à pergunta do irmão, 


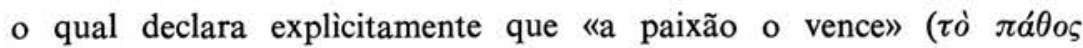
vıx $\tilde{a} \mu \varepsilon)$, ambos os tradutores usaram uma forma menos grave:

PASC. $x, 2$

proeliare non ualeo.
PLG. v,32

et superat me passio haec.

Mais claro é o trecho seguinte:

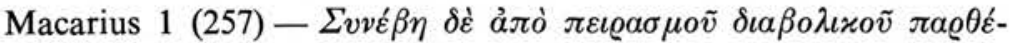

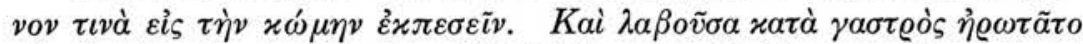

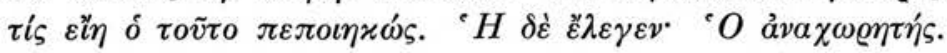

PASC. $\mathrm{XXX}, 1$

...contigit quandam uirginem per stuprum uentris onus accipere. Quae dum a quo fuisset conprehensa requiritur: Anachoreta, inquit, ille uester hoc facinus in me perpetrauit.
PLG. $\mathrm{XV}, 25$

Contigit autem, tentante diabolo, ut quaedam uirgo in uico illo uitiata lapsum faceret. Et cum in utero habere coepisset, interrogatur quis esset de quo in utero haberet; illa autem dixit: Quia hic solitarius est, qui mecum dormiuit.

O grego de Pascásio e Pelágio deveria ter a resposta da jovem mais alongada que o nosso. O que é de assinalar é a discrição com que Pascásio só refere o hoc facinus, enquanto Pelágio é muito mais realista.

A oposição dos dois tradutores nesta matéria é mais evidente ainda no trecho seguinte, em que um irmão foi enviado a uma aldeia vizinha em busca de um auxiliar do ancião. Ao chegar lá, bateu à porta e apareceu só uma filha do ajudante, dizendo que seu pai tinha saído. E prosseguem as versões:

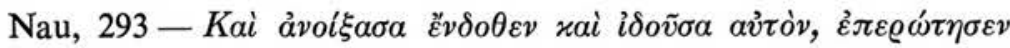

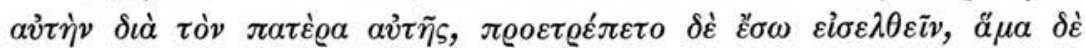

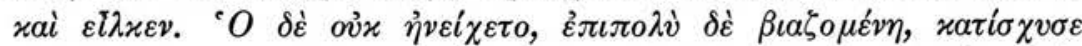

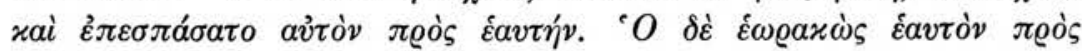

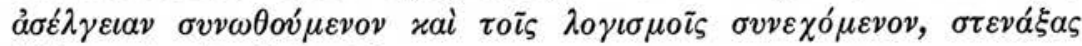

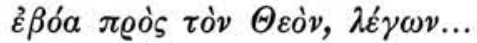


PASC. XLIII, 1

Quae cum aperuisset ostium et frater eam de patre eius requireret cur tot diebus tardasset, illa hortabatur eum ingredi in domum, simul et trahebat. Cum autem ille non adquiesceret, illa inualuit et adtraxit eum ad se. Cum autem uidisset ille quia ad peccatum trahebatur et urguebant eum cogitationes ingemuit et clamauit dicens ad Dominum...
PLG. XIV, 16

Quae pulsantem fratrem ut audiuit, uenit ad ostium et aperuit ei. Et cum interrogaret eam de patre suo, illa hortata est eum ut intraret hospitium, simul etiam et trahebat eum. Ille uero non acquiescebat intrare. Sed cum diu eum cogeret, praeualuit introducere eum ad se. Et conplexa eum, coepit eum illicere ad conmistionem corporis sui; ille autem uidens trahi se ad luxuriam, et cogitationibus confundi, ingemiscens clamabat ad Deum dicens...

A recensão grega e as versões latinas são muito próximas entre si. Apesar da ocasião próxima de pecado que Pascásio não pôde deixar de descrever, as suas palavras são ainda mais recatadas que as do grego. Em Pelágio, pelo contrário, parece que há a preocupação de desenvolver toda a evolução da tentação e a paixão desregrada da rapariga. Felizmente que, graças à oração do irmão, Deus o libertou sùbitamente do perigo.

O irmão "pecador» de que já falámos (9) para experimentar o velho que com ele desejava viver, depois de alguns dias de experiência veio dizer-lhe:

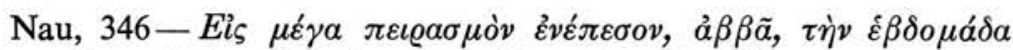

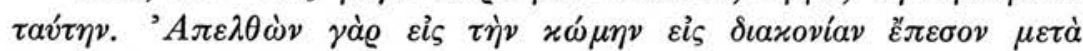
rvvaıxós.

(9) Cf. Supressão de «palavras feias» n. 11, p. 110. 
PASC. XLVI, 8

In grandi tentatione incidi septimana hac, abba. Profectus enim in uico, propter necessitatem meam, peccaui.
PLG. XVII, 14

In magna tentatione incurri hebdomada ista, abba; pergens enim pro ministerio quodam in uicum, incidi in mulierem.

Mais uma vez é patente que Pascásio evita expressões duras, ao passo que Pelágio não receia ferir susceptibilidades.

Se no caso anterior Pascásio deixou velada a natureza do pecado, no seguinte elimina por completo a queda na tentação:

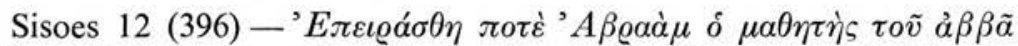

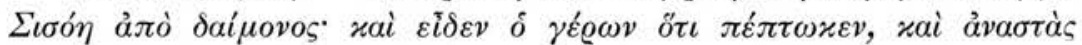

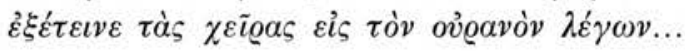

PASC. LXVIII, 2

Abbas Sisoius cum quodam tempore discipulus eius Abraham tentatus fuisset ab spiritu,

dit ad caelum, dicens...
JOÃO II,14

Tentatus est aliquando Abraham discipulus eiusdem abbatis Sisoi a daemonio; et uidens eum idem senex, quia cecidit, surrexit et expandit manus suas ad Deum, dicens...

De facto, só por Pascásio não chegaríamos a aperceber-nos de tudo o que realmente se passou. Para além de traduções eufemísticas, neste caso o escrúpulo de Pascásio vai ao ponto de cortar do texto o que lhe parece impróprio de um monge.

13 - Delicadeza de sentimentos. Queremos ainda relevar um outro aspecto do carácter de Pascásio, manifestado nas suas traduções: - a delicadeza dos seus sentimentos, que o leva a atenuar expressões que poderiam ser consideradas menos respeitosas para com outras pessoas.

Quando os irmãos Anub e Poemen se retiraram para o deserto, sua mãe foi uma vez para os visitar, mas eles recolheram-se na sua cela. Ela, cá fora, começou a chorar. E continua a narração:

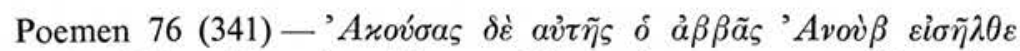

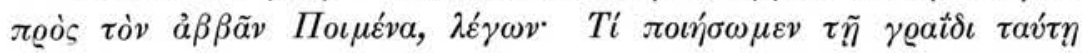




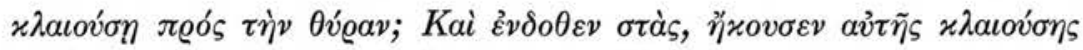

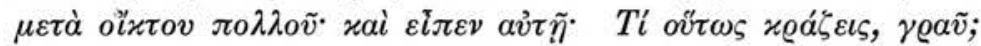

PASC. XLIX,1

Abbas uero Anub ad beatum Poemenem ingressus ait: Quid faciamus de hac anu quae plangit ad ostium? Tunc exurgens abba Poemen uenit ad ostium. Quo non aperto, audiens eam lamentari iugiter, dicit: Cur tantos clamores, cum iam aetate defessa sis, et planctus effundis?
PLG. IV,33

Audiens autem eam abbas Anub, intrauit ad abbatem Pastorem, dicens: Quid faciemus uetulae isti, ita ante ostium flenti? Surgens autem abbas Pastor, uenit ad ostium et intro stans, audiuit eam plorantem miserabiliter nimis; et dixit: Quid sic clamas, uetula?

Os textos gregos de Pelágio e Pascásio deviam ser mais próximos entre si do que com a redacção transcrita acima, pois ambos têm um inciso que nela falta: Tunc exurgens abba Poemen (Pasc.): Surgens autem abbas Pastor (Plg.). O que choca, do ponto de vista psicológico, é a maneira rude como Poemen se dirigiu à mãe. Pelágio traduziu à letra. Pascásio, porém, ornamentou a frase e substituiu o desprezível uetula, por cum iam aetate defessa sis. Este final é bem expressivo da diferença de temperamento e de técnica dos dois tradutores. Aliás, já antes Pascásio evitara uetula, escolhendo uma palavra mais literária: anu.

Logo no apotegma seguinte podemos ver outra marca da delicadeza de Pascásio. Também a mãe de Marcos foi visitar o filho. Por ordem do abade este saiu, mas passou tão disfarçado que nem a mãe o reconheceu. Tendo ela insistido com o abade na súplica de lhe deixar ver o filho, Silvano intervém:

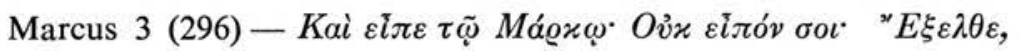

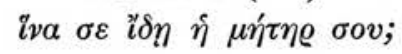

PASC. XLIX,2

Tunc senex dicit Marco: Iam antea dixi tibi ut egredereris et uideret te mater tua.
PLG. XIV, 6

Et dixit Marco: Non dixi tibi, «Egredere ut uideat te mater tua»? 
No grego e em Pelágio a intervenção do abade tem aqui um claro tom de repreensão. Em Pascásio a frase apresenta-se de modo mais benevolente. Para isso pode ter contribuído a redacção que faz da repetição do primeiro aviso uma oração subordinada. Quando muito o que dela pode transparecer é um certo ar de impaciência...

Vejamos agora como Pascásio contorna uma imprecação. Depois de ouvir a descrição da caveira do sacerdote dos ídolos sobre as penas da outra vida, Macário admira-se.

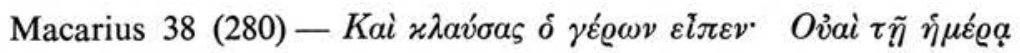

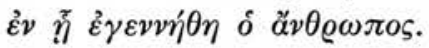

PASC. LXIX,1

His auditis lacrimas senex effudit dicens: Vae die illa in qua homo mandatum Dei transgressus est.
JOÃO III, 16

Ait ergo senex cum fletu: Vae illi diei, in qua natus est homo...

Enquanto o grego e João lamentam o facto de o homem ter vindo à existência, Pascásio evita esse pessimismo, lançando a causa dos castigos sobre o facto de o homem transgredir os mandamentos de Deus. É mais teológico, além de não dar ideia de desespero.

Vamos finalmente apresentar dois exemplos nítidos de atenuação de responsabilidades, pelo uso de paene 'quase'.

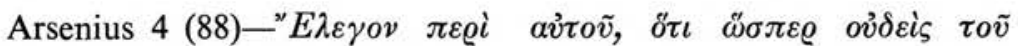

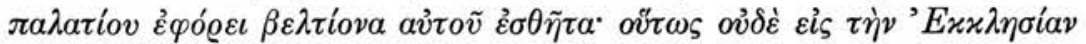

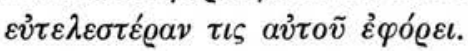

PASC. XIX,2

Abbas Arsenius, sic ut paene super omnes homines, dum saecularis esset et pretiosis uestibus utebatur; ita constitutus in
PLG. XV,6

Dicebant autem de eo qui supra, quia sicut dum in palatio esset, nemo melioribus uestibus eo utebatur; ita et dum in
III AUT. VI, $1^{\text {b }}$

(= III R 37b)

Dicebant ergo de eo sancti seniores, quia sicut cum in saeculi conuersatione esset, nimis pretiosa uestimenta prae om- 
eremo uiliora uestimenta uti prae ceteris festinabat. conuersatione moraretur, nemo eo uilius tegebatur. nibus utebatur; ita postmodum in eremo Sceti degens, studebat ut ab omnibus monachis uiliora et despecta uestimenta haberet.

As três traduções latinas garantem-nos que o apotegma se conservou em grego, ao longo de diversas recensões, sempre com as mesmas palavras ou apenas com leves retoques. Ainda aqui Pelágio é o mais literal e o "autêntico Livro III» o mais abundante. Em Pascásio apenas as palavras sic ut paene super omnes homines chamam a nossa atenção. À primeira vista elas parecem um acrescento do tradutor a desculpar Arsénio de também usar rico vestuário quando vivia no palácio de Teodósio, tal como acontecia com quase todos os cidadãos. Depois de madura reflexão julgamos ver nelas o segundo termo de comparação de et pretiosis uestibus utebatur... sic ut paene super omnes homines: ... a ponto de serem melhores do que as de quase todos os homens. Em qualquer caso, o advérbio de limitação paene vem sempre estabelecer uma certa moderação. Arsénio não seria, mesmo no mundo, o mais preocupado com os requintes do vestuário...

A confirmar a segunda hipótese está a variedade de processos dos tradutores para exprimir o segundo termo de comparação. Pelágio nos dois membros da frase usa o esperado ablativo: melioribus... eo; eo uilius. O tradutor do "autêntico III" varia o sistema: nimis petiosa... prae omnibus; uiliora et despecta ... ab omnibus monachis. Em Pascásio no primeiro membro ou não há segundo termo de comparação ou, como supomos melhor, é sic ut paene super omnes homines; ao passo que na segunda parte é claro que está representado por prae ceteris.

A composição de Pascásio XCVI,2 levanta complicados problemas sobre as recensões dos lugares paralelos. Estamos, no entanto, em boas condições para apreciar a introdução de dois paene só por Pascásio.

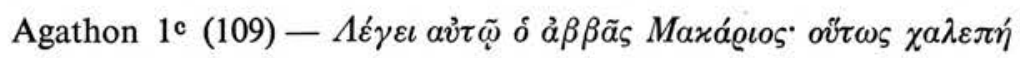

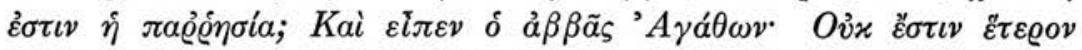

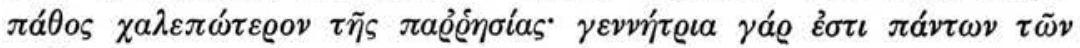
$\pi \alpha \theta \tilde{\omega} \nu$. 
PASC. XCVI, $2^{\mathrm{b}}$

Graue enim ma-

lum est et paene omnibus peius fiducia, quae genitrix est omnium paene malorum.
PLG. $\mathrm{x}, 8^{\mathrm{c}}$

Dixit abbas Macarius: Sic mala fiducia est? Respondit abbas Agathon: Non est peior altera passio quam fiducia; genitrix est enim omnium passionum.

Como o apotegma XCVI,2 de Pascásio é constituído fundamentalmente por uma resposta de Agatão a Macário, estamos quase certo de que a frase grega que estaria aqui deveria corresponder muito pròximamente à recensão que actualmente possuímos. Tudo nos leva, pois, a crer que as duas atenuantes com paene são obra de Pascásio,

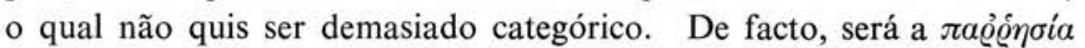
a pior das paixões? A tradução por fiducia é quase constante na antiguidade cristã (10), mas o seu sentido é aqui, nìtidamente, 'liberdade de falar'.

\section{IV - RESERVAS À TRADUÇÃO DE PASCÁSIO}

Numa obra tão extensa como a que Pascásio traduziu, é impossível supor que em todos os pontos achemos o seu labor perfeito. Apesar das técnicas aperfeiçoadas que nele observámos - superiores até às de outros tradutores paralelos - também ele cai no literalismo e chega mesmo a ter passos que nos parecem infelizes, pouco claros e quase incompreensíveis. Deixamos aqui alguns apontamentos de defeitos anotados. Em seguida examinaremos outros aspectos da língua de Pascásio.

1 - Dificuldade DE COMPREensão. Há um apotegma cuja primeira parte nos deixa hesitantes na justa interpretação.

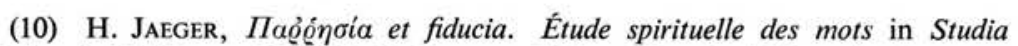
Patristica, I (1957), pp. 221-239; L. ENGELS Fiducia dans la Vulgate in Graecitas et Latinitas Christianorum Primaeua. Supplementa. Fasc. I (1964). Nouiomagi, pp. 97-141; Idem, ibid., Fasc. III (1970), pp. 61-118: Fiducia. Influence de l'usage juridique sur l'emploi commun et chrétien. 


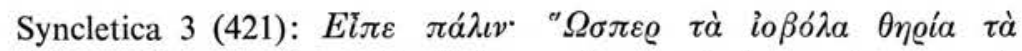

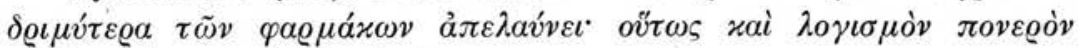

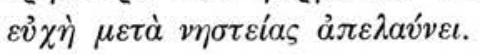

PASC. $\mathrm{x}, 1$

Dixit quidam senex: Sicut uenenata animalia fortiores herbae uel pigmenta expellunt ita et cogitationes sordidas oratio cum ieiunio pellit.
PLG. IV, 42

Dixit iterum quae supra: Quia sicut uenenosa animalia acriora medicamenta a se expellunt, ita cogitationem sordidam ieiunium cum oratione depellit ab anima.

O que torna difícil a tradução é o facto de o sujeito e o comple-

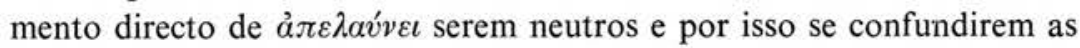
formas de nominativo e acusativo. Pelágio parece entender assim, segundo a ordem das palavras preferida: "Assim como os animais venenosos expelem de si os 'medicamentos' mais nocivos, assim...». Em Pascásio, é certo que o sujeito é fortiores herbae uel pigmenta, mas a expressão uenenata animalia torna a frase menos clara. Nós interpretamo-la deste modo: "Assim como as ervas mais activas ou os medicamentos de cor expelem o veneno dos animais envenenados, assim...». Cremos que Pascásio viu melhor qual era o sujeito, mas não foi feliz na expressão do complemento directo, escravizado como ficou ao texto grego.

Um pouco mais adiante, para traduzir a versatilidade do vento, Pascásio preferiu uma perífrase que faz perder a imagem. Trata-se de um irmão que cedia às sugestões do demónio, o qual se vangloria:

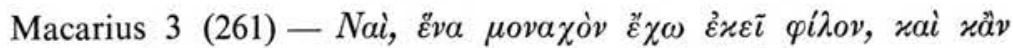

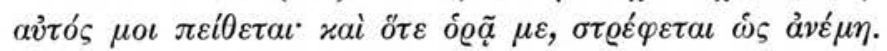

PASC. $x, 4$

Unum habeo amicum uel ipse mihi consentit et quotiens me uiderit huc atque illuc cito conuertitur.
PLG. XVIII,9

Unum tantummodo habeo fratrem illic, uel ipse solus mihi acquiescit; et quando uidet me, conuertitur uelut uentus.

Ambas as traduções são literais, mas preferíamos que Pascásio tivesse mantido o símile $\dot{\omega} \varsigma$ àvé $\mu \eta$, em vez de o interpretar por huc 
atque illuc. Note-se ảvé $\mu \eta$, singular, feminino, só abonado por este passo em Lampe (1).

Mais difícil de compreender é o passo seguinte em que um irmão que era negligente se viu, em êxtase, chamado a juízo diante de sua mãe e por ela foi repreendido. Pelágio, ou porque não tivesse o texto integral ou para evitar dificuldades, omite a parte mais complicada.

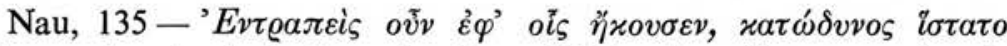

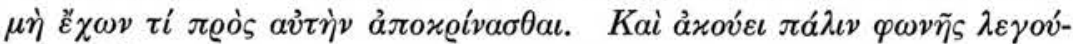

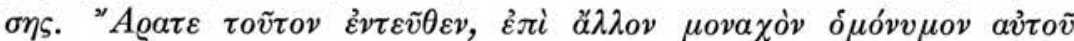

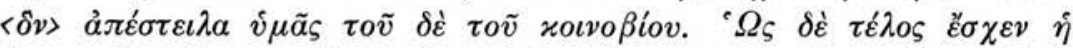

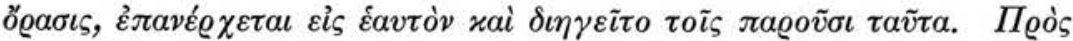

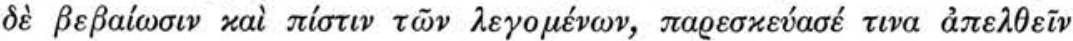

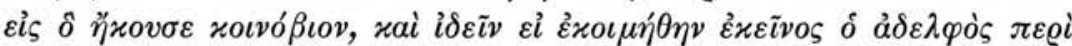

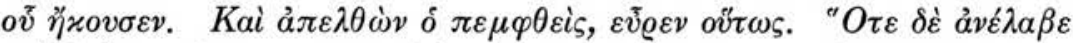

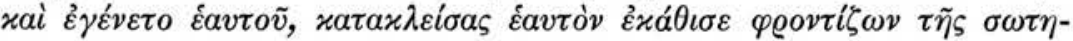

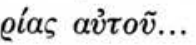

PASC. LVII, 3

Erubescens ergo in quibus audierat nihil habebat quid responderet. Et ecce uoce facta ut hic reuocaretur, tamquam altero iussu ex coenobio frater transiret, reuersus ad se haec ipsa quae cognouerat adstantibus nuntiabat. Ad confirmationem sane uerborum suorum conpulit ut aliquis de adstantibus ad coenobium iret et uideret si transiret frater eiusdem nominis de quo audierat. Et qui profectus est inuenit ita. Ipse uero postquam sanus effectus est, reclusit se et sedit cogitans de salute sua...
PLG. III,20

Confusus autem in his quae audierat, ipso dolore stupidus factus est et stabat non habens quid matri suae respondere posset.

Iuxta dispensationem autem misericordiae Dei, posteaquam haec uidit, contigit ut repararetur et euaderet $a b$ instanti infirmitate. Et cogitans apud se, diuinitus factam esse huiusmodi uisionem, includens se de cetero sedebat et cogitabat de salute sua...

(1) Cf. G. W. H. LAMPE, A patristic greek lexicon, Oxford, 1968, s.u. 
O princípio e o fim do extracto que damos são bem claros no grego, em Pascásio e Pelágio. A parte que sublinhámos da redacção de Pelágio faz boa ligação com o sentido anterior, mas, perante o grego que temos e Pascásio, ou representa uma recensão grega posterior (o mais provável) ou foi Pelágio que simplificou um trecho que the pareceu confuso. Os dois longos períodos centrais de Pascásio, apesar do cuidado que pusemos na reconstituição do seu texto (com muitas variantes nos manuscritos) não resultam claros. Quanto a nós, a

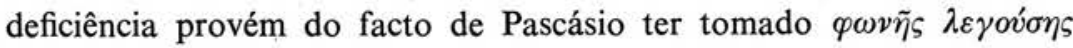
como um genitivo absoluto, de não ter traduzido no discurso directo

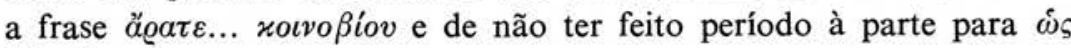
$\delta \dot{\varepsilon} \tau \dot{\varepsilon} \lambda o \varsigma \ldots \tau \alpha \tilde{v} \tau \alpha$.

Eis a nossa tradução directa do grego e do latim de Pascásio, no passo mais complicado.

DO GREGO

E ouviu então uma voz que dizia: "Retirai este daqui e substituí-o por outro monge com o mesmo nome, que eu vos enviei de um determinado mosteiro». Quando a visão terminou, voltou a si e contou aos circunstantes o sucedido.
DE PASCÁSIO

E eis que tendo-se ouvido uma voz para este voltar à vida, como se, por uma ordem, um irmão de outro mosteiro tivesse morrido, voltando a si contou aos circunstantes tudo o que lhe fora revelado.

Esclarecido agora o sentido desta primeira grande frase de Pascásio, já é mais fácil de compreender a alusão da segunda a que alguém fosse ao outro mosteiro e verificasse se tinha morrido um irmão com o mesmo nome do que tivera a visão. Esta dificuldade de interpretação resultou, afinal, do excesso de três qualidades que apreciámos em Pascásio (cf. III,8): a concisão narrativa, a introdução do discurso indirecto e a omissão de elementos repetidos.

Vamos terminar com um exemplo em que o leitor de Pascásio se não pode aperceber do que está realmente escrito no grego.

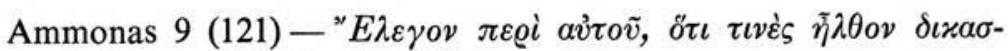

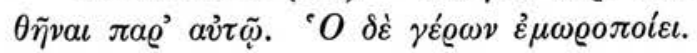


PASC. XCI,1

Cum quidam praesente Ammone episcopo negotium dicerent, ille non intendit in uerbis eorum.
PLG. XV,12

Dicebant de abbate Ammone quia uenerunt ad eum quidam petentes ut iudicaret inter eos; senex autem dissimulabat.

A tradução de Pelágio traduz perfeitamente o sentido do grego. Pascásio, pelo já conhecido processo de subordinação, reduz as duas frases a uma só. O pior é que deixa o caso em expressões muito vagas: dos que "vieram pedir para ele servir de juiz entre eles», diz-se apenas que «expuseram um negócio»; em vez de deixar expresso que Ámon "fez de louco», como se não pudesse perceber do que se tratava, refere sòmente que «não prestou atenção às suas palavras». Mas assim mal se compreende a sequência tal como a dá o próprio Pascásio: «uma mulher disse para a sua vizinha: este velho está doido». Teria Pascásio um começo grego diferente? Ou tratar-se-á antes da sua delicadeza de sentimentos, que não quer deixar expresso que o bispo propositadamente, «fez parte de louco»? (cf. III, n. 13).

2 - automatismos de traduÇão. Pascásio ganhou certos hábitos de tradução ao longo do seu trabalho e tende a usar os mesmos sistemas em casos idênticos. Está nestas condições o uso de quia, quod ou quoniam depois de verbos declarativos que em grego são seguidos de $\delta ̋ \iota$, mas em latim seria preferível substituir simplesmente por dois pontos (:), a introduzir o discurso directo. É abuso usar quia quando o grego omite ö $\tau$.

$$
\text { NAU, } 315
$$

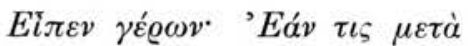

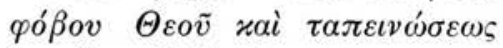

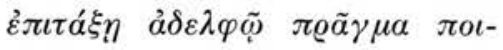
$\tilde{\eta} \sigma \alpha \ldots$.
PASC. XLII, 3

Quidam senex dixit: Quia si quis fratri suo iniunxerit causam cum timore Dei et cum humilitate...

Não seria de esperar quia, visto que pelo menos esta recensão grega não apresenta ö $\iota$. Pascásio, porém, levado talvez por hábitos de tradução, procedeu como em tantos outros casos.

O mesmo se verifica até sem que haja paralelo grego, mas pela simples confrontação com outra tradução latina. 
PASC. LXXVIII, 2

Et dixit senex: Quoniam qui adhuc laborant postulantes de remissione peccatorum...
APP. LAVS. $\mathrm{XX}, 6$

Et dixit: Quicumque laborant et deprecantur ueniam peccatorum...

A tradução que vem no final da Palladii Lausiaca dá a impressão de que o grego omitia aqui ö $\iota$. Pascásio introduziu um quoniam ou por força do hábito ou talvez porque o seu grego fosse diferente.

Só mais um caso, mas doutro género. A história do irmão que quis dar público testemunho de só tomar um pouco de sal, termina com esta repreensão:

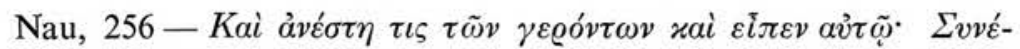

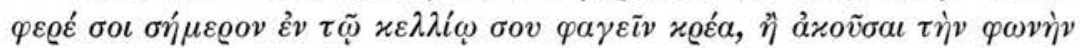

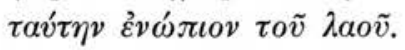

PASC. VI, 2

Tunc beatus Theodorus dixit: Oportuit te, inquit, carnes in cella tua comedere quam hunc praesentibus omnibus audire sermonem.
PLG. VIII, 21

Surrexit autem quidam senum et dixit ei: Expedierat tibi hodie in cella tua comedere carnes, quam audiri hanc uocem coram tantis fratribus.
III AUT. I,7

Tunc surrexit a mensa unus ex senioribus et dixit ei: Oportebat te, frater, in cella tua hodie carnem comedere quam istam talem uocem de tua abstinentia praesentibus cunctis dicere fratribus.

Como habitualmente, a versão do tradutor do «autêntico Livro III» é a mais desenvolvida. No entanto, é claro que os três tradutores têm um grego muito semelhante. Apenas Pascásio nos permite tirar este apotegma da classe dos «anónimos» para o podermos atribuir a Teodoro. Do ponto de vista de técnica, Pascásio deixou-se levar pelo seu gosto de pospor inquit no princípio da resposta (cf. III, n. 3). Ora neste caso trata-se de um vício, uma vez que o verbo declarativo 
dixit já tinha sido colocado no seu lugar exacto, de acordo com o grego e os outros tradutores.

3- Pleonasmos. O caso acabado de apresentar da repetição do verbo declarativo, poder-se-ia considerar como uma insistência pleonástica.

De facto Pascásio não escapa também a repetições desnecessárias. Veja-se este exemplo evidente:

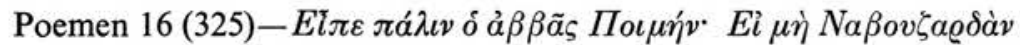

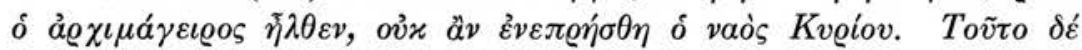

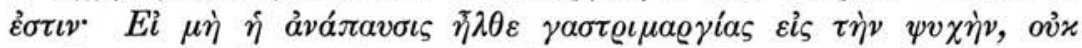

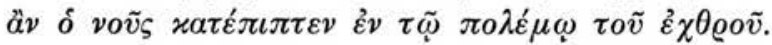

PASC. III, 7

Dixit abba Poemen: Nisi Nabuzardan princeps cocorum uenisset in Hierusalem, templum Domini non arsisset igne. Hoc autem est: quia nisi desiderium gastrimargiae in anima uenerit sensus hominis non succenditur in pugna diaboli.
PLG. IV,29

Dixit abbas Pastor: Nisi Nabuzardan archimagirus uenisset, non concrematum fuerat templum Domini igne; ita et nisi quies gulae et uentris uenerit in animam, nequaquam mens corruit pugnans contra inimicum.
III AUT. I, 8 (=APP. LAVS. XX,1)

Solebat beatus abbas Poemen exponere fratribus de Scripturis Prophetarum ubi dicit: Quia nisi princeps cocorum Nabuchodonosor regis uenisset in Hierusalem utique non fuisset igne incensum templum Domini. Hanc autem parabolam ex hoc exemplo ita exponebat spiritualiter dicens: Quia et nos cum pulsauerit spiritus gastrimargiae, id est, gulae concupiscentia in aliquas delectationes ac saturitatem uentris si qui sint obaudientes atque explentes uoluptates ac desideria gulae, tunc incendetur igne libidinis templum Domini, id est, corpora nostra, sicut dicit Apostolus: Nescitis quia corpora uestra templum Dei sunt? $\mathrm{Si}$ quis ergo uiolauerit templum Dei, disperdet illum Dominus. 
Qualquer de nós traduziria o verbo $\dot{\varepsilon} \mu \pi \varrho \eta \dot{\theta} \omega$ simplesmente por «queimar» ou «incendiar». Verificamos, porém, que Pascásio junta imediatamente «queimar pelo fogo». Verdade seja que os outros tradutores caem no mesmo pleonasmo, variando apenas o verbo. Para isso pode ter contribuído qualquer versão bíblica do IV Livro dos Reis, XXV,8-9, donde a imagem é tirada.

$\mathrm{O}$ apotegma que acabamos de apresentar é um explêndido documento da natureza moralizante e homilética do «autêntico Livro III». Tudo leva a crer que a sua recensão grega seja mais tardia. Note-se até a confusão de Nabuzárdan com Nabucodonosor...

Aproveitemos a oportunidade para observar o tratamento de duas palavras gregas:

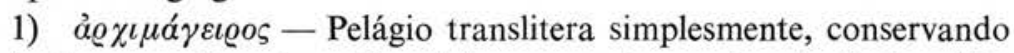
o helenismo archimagirus; Pascásio e o tradutor do "Autêntico III» coincidiram em dar-lhe o valor de «chefe de cozinheiros». Este é, de facto, o seu significado original. A palavra passou, no entanto, a ter também valor militar de 'chefe de escolta' ou de exército e neste sentido foi usada pela versão dos Setenta e pela Vulgata (2). Os tradutores latinos do apotegma parecem ignorar o contexto bíblico.

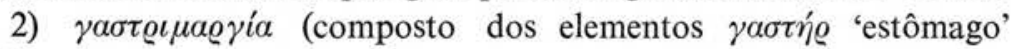
e $\mu \alpha$ á $\gamma o \varsigma$ 'desregrado') é a glutonaria ou gula. Neste caso é Pascásio que conserva o grecismo gastrimargia, enquanto Pelágio interpreta com hendíades por gula et uenter. O tradutor do "autêntico Livro III» serviu-se do seu habitual desenvolvimento para transcrever primeiro o helenismo gastrimargia e depois o explicar no próprio texto como gulae concupiscentia.

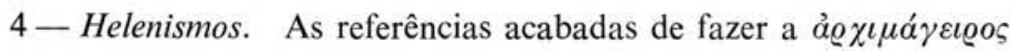

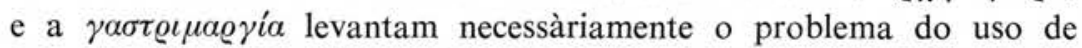
helenismos em Pascásio. Não é nosso intento apreciar demoradamente os aspectos lexicológicos do nosso Autor. Apesar disso, vamos atentar, por momentos, no seu comportamento perante determinadas palavras gregas (3).

(2) Septuaginta, id est Vetus Testamentum graece (...) edidit Alfred Rahlfs,

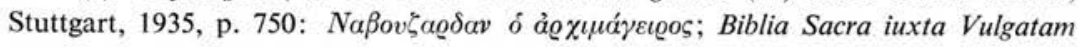
Clementinam (...) a A. Colunga-L. Turrado, Matriti, 1946, p. 437: Nabuzardan

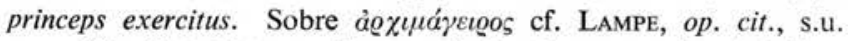

(3) O tradutor melhor estudado, do ponto de vista linguístico, dentro das Vitae Patrum é Paládio. Lembrar, por exemplo, Sture Linnér, Syntaktische und 
M. Martins observou, de passagem, que a tradução de Pascásio «revela, ainda, um certo gosto pelas palavras de origem grega» e cita, como exemplos, gastrimargia e philargyria (4). Nós diríamos que Pascásio se conformou, dum modo geral, com os hábitos linguísticos da época, observando-se até nele a preocupação de verter para latim palavras que já estavam consagradas na sua transliteração do grego. Vamos dar breves exemplos.

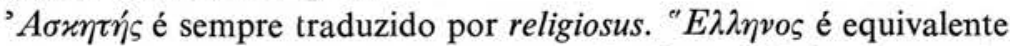

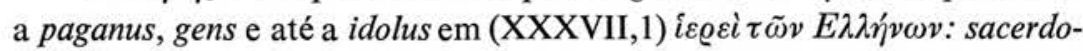

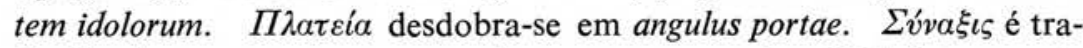
duzido duas vezes por congregatio e uma por oratio. Mais interessante é o que se passa em Pasc. XXIV,1: temos aí a transliteração philosophus por três vezes, enquanto no fim vem a sua tradução, sapientiae studiosus; em contrapartida, enquanto o paralelo João IV,12 usa philosophia, Pascásio prefere o termo latino sapientia.

Aliás, o problema da importação do grego para o latim é constante ao longo de toda a língua de Roma, apesar das tentativas de repressão orientadas pelos puristas (5). A liberdade no uso de estran-

lexikalische Studien zur Historia Lausiaca des Palladios, Upsala, 1943 e R. T. MeYeR, Lexical problems in Palladius' Historia Lausiaca in Studia Patristica I (1957), pp. 44-52. Sobre Rufino conhecemos também um estudo de HeInRICH Hoppe, Griechisches bei Rufinus in Glotta, XXVI (1938), pp. 132-144. Sobre o vocabulário grego para a vida monástica, citamos alguns estudos parciais: Dom JeAN LeCLercQ, Études sur le vocabulaire monastique du Moyen Age, Roma, 1961 (= Studia Anselmiana, 48), em que são examinadas as palavras monachus, philosophia e theoria. No t. 51 de Studia Anselmiana, Roma, 1963, sob o título Otia monastica. Études sur le vocabulaire de la contemplation au Moyen Age, J. LeCLERCQ examina as palavras quies, otium, uacatio e sabbatum - que aparecem também, todas elas, em Pascásio. Indicamos ainda pela relação com o nosso texto: R. Joly, Le vocabulaire chrétien de l'amour est-il original? pideĩv et àyajãv dans le grec antique, Bruxelles, 1968; A. J. Vermeulen, Le développement sémasiologique d'ė̃upáveıa et la fête de l'Epiphanie in Graecitas et Latinitas Christianorum Primaena, Supplementa, Fasc. I, Nouiomagi, 1964, pp. 7-44; J. LeClerCQ, Eremus et eremita. Pour l'histoire du vocabulaire de la vie solitaire in Collectanea Ordinis Cisterciensium Reformatorum, XXV (1963) pp. 8-30; Irenée Hausherr, Penthos. La doctrine de la componction dans l'Orient chrétien (= Orientalia Christiana Analecta, 132), Roma, 1944.

(4) Mário Martins, Correntes da Filosofia Religiosa em Braga dos séculos IV a VII, Porto, 1950, p. 35.

(5) Cf. um panorama geral sobre os helenismos em latim clássico em J. Marouzeau, Traité de stylistique latine, Paris, 1946, pp. 172-176 e em J. B. Hofmann-A. Szantyr, Lateinische Syntax und Stilistik, München, 1965, 
geirismos é mais acentuada nas camadas populares bilingues ou em contacto com novas formas de cultura. Por isso, quando o Cristianismo, pregado em grego, entrou em contacto com comunidades de língua latina, deu-se uma considerável entrada de termos gregos que se foi ampliando ao longo dos séculos (6).

Com o florescimento do monaquismo nos séculos IV e $\mathrm{v}$ e a sua expressão literária em grego originou-se nova corrente de importação para o Ocidente - que seguia com admiração os prodígios dos ascetas orientais. Lembre-se a impressão produzida em S. Agostinho pelo relato da vida de Santo Antão (7). Pela mesma época, ilustres homens de letras, como Rufino, S. Jerónimo e João Cassiano, tinham começado a empreender viagens de estudo e longas estadias pelos desertos e mosteiros do Próximo Oriente, traduziam biografias e regras monásticas e implantavam comunidades religiosas de língua latina. Basta perpassar os dez livros e os apêndices das Vitae Patrum editadas por Rosweydus para a cada passo se depararem vocábulos de origem grega.

Entre os tradutores, Pascásio não foi, como vimos, o que mais se deixou escravizar pela força do vocábulo original. Damos a seguir uma lista, por ordem alfabética, das transliterações gregas que ocorrem em Pascásio, tendo nós prestado especial atenção às palavras mais frequentes na linguagem monacal:

abbas, acedia, agape, amma, anachoreta, analabius, blasphemia, cauma, cenodoxia, coenobium, daemon, diabolus, eremita, eremus, extasis, eulogium, gastrimargia, haereticus, melotes, monachus, monasterium, mysterium, paximatia, philargyria, philosophia, propheta e scilla.

Muitas destas palavras tinham entrado desde há muito na língua corrente dos cristãos ou estavam especialmente consagradas pela vida monástica, mesmo no Ocidente. Nada há a estranhar que Pascásio as tivesse empregado. Algumas delas prestar-se-iam, todavia, a um atento estudo lexicológico.

pp. 759-765. Entre as «histórias da língua», cf. por exemplo, G. Devoto, Storia della lingua di Roma, Bologna, 1940, especialmente pp. 166-175 e 223-231.

(6) Sobre a influência do Cristianismo na introdução de helenismos em latim, cf. Christine Mohrmann, Études sur le latin des chrétiens, I, Roma, 1958, pp. 22$-25,41-46,61-63$ e $88-90$.

(7) S. Aureli Augustini Confessionum libri XIII (...) studio Iosephi Capello, Taurini, 1948, Lib. VIII, capp. 6-7, pp. 266-269. 
5 - vUlgarismos DE FEIÇÃo ROMANIZANTE. As técnicas aperfeiçoadas de tradução e a selecção de vocabulário que por vezes observámos em Pascásio não excluem que na sintaxe e no uso de certas palavras se revele um escritor de época tardia, sem preocupações de purismo estilístico.

Prestámos atenção ao conjunto do léxico de Pascásio e estudámo-lo sob vários aspectos. Aqui vamos deixar apenas algumas frases em que, pelo vocabulário, Pascásio se revela um escritor influenciado pela linguagem corrente, de uso vulgar, a ponto de nos sugerir a futura evolução do latim para as línguas românicas (8).

Notemos já que, apesar do cuidado que pusemos no exame do texto, não encontrámos elementos linguísticos convincentes que demonstrem ter a tradução de Pascásio sido feita em Dume ou em qualquer outra parte da Hispania. O vocabulário e as tendências semânticas de sabor romanizante são bastante genéricas para não se deixarem circunscrever a uma área determinada. Por vezes são comuns a toda a Romania; na maioria dos casos estão de acordo com a evolução que veio a realizar-se pelo menos no grupo que compreende o italiano, o francês, o castelhano, o português e outras línguas e dialectos românicos do Ocidente europeu.

Damos as frases segundo a ordem alfabética do vocábulo que desejamos acentuar, colocando ao lado a versão de Pelágio-João ou outros tradutores latinos antigos. Os comentários sobre o aspecto

(8) Devemos mencionar aqui um certo número de obras que, mesmo quando não explìcitamente referidas, estão subjacentes às nossas observações deste número e do seguinte. Os dicionários latinos foram utilizados para uma larga investigação lexicológica, de que deixamos apenas alguns exemplos. Os léxicos gregos foram-nos sobretudo necessários quando confrontámos a tradução de Pascásio com os textos editados por Cotelier e por Nau.

J. B. Hofmann, El latin familiar (trad. J. Corominas), Madrid, 1958; C. H. Grandgent, Introducción al latin vulgar, (trad. F. B. Moll), Madrid, 1952; V. VÄÄNÄNEN, Introduction au latin vulgaire, Paris, 1963; R. A. HAADSMA et J. Nuchelmans, Précis de latin vulgaire, Groningen, 1963; Th. H. Maurer, Gramática do latim vulgar, Rio de Janeiro, 1959; G. RoHLFs, Sermo uulgaris latinus, Tübingen, 1956; J. Herman, Le latin vulgaire, Paris, 1967.

J. J. Nunes, Compêndio de Gramática histórica, Lisboa, 1930; M. SAID AlI, Gramática histórica da lingua portuguesa, S. Paulo, 1966; I. Lima Coutrnho, Gramática histórica, Rio de Janeiro, 1968.

Thesaurus linguae latinae, Lipsiae, 1900 ss.; Aeg. ForcellinI, Totius latinitatis lexicon, Prati, 1858-1860; A. Ernout et A. Meillet, Dictionnaire étymologique 
romanizante insistirão sobre a tradução e tendências verificadas no português, mas observações semelhantes poderiam ser feitas, na maioria dos casos, sobre as outras línguas românicas.

1 - PASC. XXXIII, 12

Et exurgens ambulabat cum eo.
JOÃO IV,35

Surgens quoque senex abiit cum ipso.

Note-se a preferência de Pascásio por ambulare com o valor de andar. Temo-lo registado 14 vezes. $\mathrm{O}$ facto pode ter interesse para os romanistas que discutem ainda a evolução semântica e fonética de ambulare e não estão de acordo com o étimo de andar.

Mas este verbo, de uso românico geral, é também utilizado por Pelágio. Um exemplo:

PASC. XLVI, 5

Semel autem ambulans deuenit super latrones.
PLG. XVII,12

Ambulans autem aliquando iter, superuenit in conuentu latronum.

O mesmo uso conjunto se verifica nos paralelos Pasc. XCIII,10: João III,1 e Pasc. LVII,1: App. Laus. 2.

de la langue latine, Paris, 1959; Ch. T. LewIS and Ch. ShorT, A latin dictionary, Oxford, 1962; Ch. Dufresne (Du Cange), Glossarium mediae et infimae Latinitatis, Parisiis, 1840; J. F. NiermeYer, Mediae latinitatis lexicon minus, Leiden, 1965; A. Sleumer, Kirchenlateinisches Wörterbuch, Limburg a.d. Lahn, 1926; A. BLAISE, Dictionnaire latin-français des auteurs chrétiens, Turnhout, 1954; W. MEYER-LÜBKE, Romanisches etymologisches Wörterbuch, Heidelberg, 1968.

C. Figueiredo, Novo dicionário da lingua portuguesa, Lisboa, 1949; A. NASCENTES, Dicionário etimológico da lingua portuguesa, Rio de Janeiro, 1932; J. PeDro MACHADO, Dicionário etimológico da lingua portuguesa, com a mais antiga documentação..., Lisboa, 1957; J. CoRominas, Diccionario critico etimológico de la lengua castellana, Madrid, 1954.

Ch. Dufresne (Du Cange), Glossarium ad scriptores mediae et infimae Graecitatis, Lugduni, Anissonii, 1688; H. Stephano, Thesaurus graecae linguae, Parisiis, 1831 ss.; A. BaIlly, Dictionnaire grec-français, Paris, 1950; H. G. LIDDELL and R. SCOTt, new edition by H. S. JoNeS, A greek-english lexicon, Oxford, $1966+$ A Supplement, edit. by E. A. Barber, Oxford, 1968; G. W. H. LAmPE, A patristic greek lexicon, Oxford, 1968. 
In hoc capitulo ne mireris.

In hoc non admireris.

O que estranhamos em Pascásio é o tom coloquial resultante da introdução de capitulo, palavra que falta no grego: Theodorus Pher-

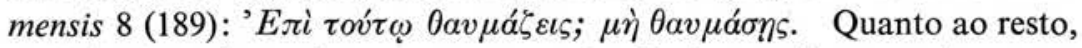
Pelágio é mais «vulgar» na construção do imperativo negativo e no próprio uso do verbo precedido de prevérbio: admiror.

A palavra capitulo com o sentido genérico de 'assunto, matéria' aparece outra vez em Pascásio, contra a corrente do grego.

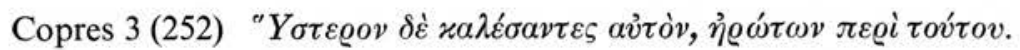

PASC. C, 3

Postea autem uocantes eum interrogauerunt pro eodem capitulo.
PLG. XV,24

Postea autem uocantes eum, interrogabant eum de eadem quaestione.

Nesta pequena frase os dois tradutores coincidem exactamente na oração subordinada; depois divergem levemente. O que nos importa

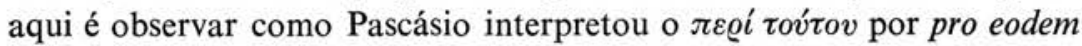
capitulo, enquanto Pelágio escolheu um termo mais adequado-de eadem quaestione.

Tratava-se de uma discussão sobre Melquisedeque, personagem bíblico de origem enigmática. O termo capitulo em Pascásio tem mais uma vez um significado muito genérico, que conservará também nas línguas românicas.

$$
3 \text { - PASC. } \mathrm{XV}, 1
$$

Et carricauit animalem cum eo.
PLG. XVI,6

Et adiuuabat eum ad animal carricandum.

Mário Martins (9), seguro da origem galaica de Pascásio, citou este passo para exemplificar que a sua linguagem «muito se aproxima

(9) M. Martins, Pascásio Dumiense, tradutor, in Brotéria, LI (1950) p. 297. 
da dos nossos dias». Mas não podemos fixar uma área geográfica. Com efeito, os sufixos em -icare são frequentes no latim tardio e, como ocasionalmente nota J. Herman (10), o verbo carricare «sobrevive em quase todas as línguas românicas». A prova está em que Pelágio, "diácono da Santa Igreja Romana» empregou o mesmo verbo. Se o acusatio animalem é de Pascásio - pois no-lo dão os melhores códices - temos aqui um sinal da tendência para o desaparecimento do neutro.

Pascásio volta a usar mais duas vezes carricare em XLIV,1, mas para este apotegma não temos paralelo latino.

$$
4 \text { - PASC. XIV, } 2
$$

Et conpara tibi carnes.
PLG. VI,1

Et eme carnes.

Pascásio usa 8 vezes o verbo conparare com o valor de 'comprar'. De todos estes passos só há outro com paralelo de Pelágio, o qual de novo volta a contrapor-lhe emere (Pasc. XLIV,3: Plg. VI,7). Sabemos que os autores «vulgares» da época imperial já usavam conparare como sinónimo de emere. Não admira, pois, a sua frequência em Pascásio. Quanto à área linguística, note-se que conparare tem representantes em línguas de toda a Romania...

5 - Embora sem paralelo doutro tradutor latino, não podemos deixar de saborear, sob o aspecto linguístico e etnológico, esta corrente tradução de Pascásio LVII,2: Erat enim discalceata. Nada custa a crer na existência do composto, uma vez que calceare era comum em toda a área latina. No conjunto do apotegma apetecia traduzir «ia descalça». Mas o grego lá estava a exigir (Nau, 43- ̃̃v $\gamma \grave{\alpha} \varrho$

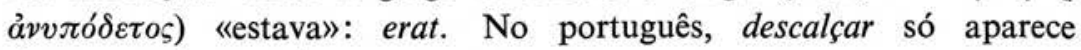
documentado no séc. Xv.

6 - O termo "ferramenta» aparece em Pascásio duas vezes, sem paralelo latino, mas ainda como neutro: XIV,7 - Nam tribulatio et paupertas haec sunt monachi ferramenta. Trata-se de um plural, numa

(10) Joseph Herman, Le latin vulgaire, Paris, 1967, p. 111 (Col. «Que sais-je?» n. ${ }^{\circ}$ 1247). 
conclusão que não vem em Pelágio VI,13a. O singular vem em Pascásio LXXI,4: Ligna Libani dixerunt: "Quam grandia et alta sumus et paruissimum ferramentum incidit nos!». O termo tem correspondentes desde o italiano ao português. Pelágio também o usa (cf. VI,21) num apotegma que não tem paralelo em Pascásio.

7 - Só encontrámos um passo em Pascásio em que fui serve de perfeito a ire. O apotegma tem paralelo em Pelágio X,29, mas, no trecho em questão, Pascásio é mais desenvolvido. Eis o que diz um irmão a Poemen, em LXXII,4: Fui ad senem Ioseph et interrogaui eum... Curiosa a coincidência com o sistema supletivo do português $i r$, que recorre ainda aos temas de uado e fui. Mas este uso não se desenvolveu só entre nós e, em latim, é muito anterior a Pascásio (11).

8 - Registamos a seguir habet associado num conjunto com valor de tempo: 'há muitos dias'.

PASC. XXVI,3

In ueritate, fratres, plurimos dies habet cogitatio mea uolens illis aliquid dicere.
PLG. XVI, 14

Credite mihi, fratres, dies habeo, ex quo uolo eis praecipere.

Em rigor ambos os tradutores foram impulsionados pelo grego:

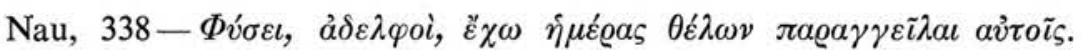
Mas note-se que Pelágio foi fiel: «tenho dias em que quero avisá-los». Só Pascásio adoptou uma perífrase em que se pode descortinar o processo de transição entre «ter» e «haver», este já numa expressão com valor temporal.

9 - O pronome ille apresenta em Pascásio, além do habitual matiz demonstrativo, construções em que o seu equivalente nas línguas românicas já é classificado de pronome pessoal e até de simples artigo definido.

Eis o prenúncio de várias formas do pronome pessoal.

Em Pasc. XLVI,8 lemos: Cum ergo post septimanam senex uenisset

(11) Du Cange, s.u. fuit e Corominas, s.u. ir. 
ad illum, ille uolens experire eum dicit... Em ille pode ver-se sem dificuldade o pronome da terceira pessoa ele, pois está ali quase apagado o valor demonstrativo. O lugar paralelo de Pelágio XVII,14 tem versão diferente.

Mais clara é a forma feminina de illa com valor de ela.

PASC. XLIX, 1

Illa autem uoce filii cognita amplius exclamauit...
PLG. IV,33

Illa autem cum uocem eius audisset, multo magis clamabat...

A concordância dos dois tradutores é sintomática, tanto mais que o grego tem aqui o simples artigo: Poemen 76 (341) - ${ }^{\circ} H \delta \dot{\varepsilon} \tau \tilde{\eta} \varsigma$

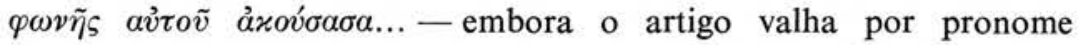
demonstrativo. O que ressalta bem das traduções latinas é como o pronome está a meio caminho entre o demonstrativo e o pessoal.

Outros casos de ille evoluem no mesmo sentido. No passo seguinte Pelágio devia ter um texto corrompido.

PASC. VII,1

Da illi codicem ut legat et mitte illum in cella...
PLG. $x, 69$

Voca Zachariam et mitte fratrem istum in cellam...

O grego que possuímos diz: Silvanus 5 (409) $-\Delta \grave{s} \tau \tilde{\omega}$ ả $\delta \varepsilon \phi \tilde{\omega}$

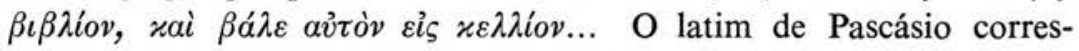
ponde à seguinte tradução portuguesa em que ambas as formas de ille são já pronomes pessoais: «Dá-lhe um códice para ler e mete-o na cela».

Registamos dois passos em que o artigo grego é traduzido em Pascásio por ille, sem que seja necessário dar-lhe valor demonstrativo.

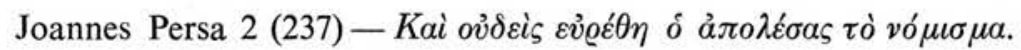

PASC. XLIV, 3

Et nemo inuentus est qui perdidisset illum solidum.
PLG. VI,7

Et nemo est inuentus qui perdidisset eum. 
Ao longo deste apotegma já, em Pascásio, várias vezes o artigo grego com um substantivo fora substituído, com elegância, simplesmente pelo pronome demonstrativo, evitando assim a repetição dos mesmos substantivos.

O outro caso apresenta-se semelhante em Pelágio e Pascásio, embora mais nítido neste.

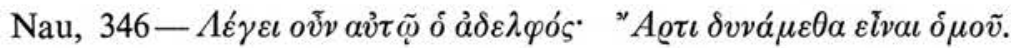

PASC. XLVI, 8

Tunc ille frater dixit: Modo possumus pariter permanere.
PLG. XVII, 14

Tunc dixit frater ille: Modo scio quia possumus simul manere.

Note-se que o apotegma trata de dois irmãos, um deles mais velho, a quem o mais novo dá o tratamento de abba. Por isso, quando no grego se escreve $\delta$ ả $\delta \varepsilon \lambda \varphi o ́ s$ refere-se sempre e só a ille iunior, como uma vez Pascásio também traduziu, sem que ille tivesse outro valor

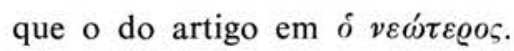

10 - Já anteriormente assinalámos (12) o aspecto romanizante que tem este passo em Pascásio:

PASC. I, 3

At ille percunctatus est eos si abire uellent.
PLG. $\mathrm{x}, 65$

Et ille dixit eis: Ambulare uultis?

Além de termos aqui mais uma abonação de ambulare em Pelágio (cf. n. 1) é o verbo percunctari que nos impressiona pela sua ligação com o português "perguntar». Se os dicionários nos dizem que percunctari é corrente em latim, registemos, todavia, que ele só aparece, em Pascásio, neste passo. No geral encontramos requirere, interrogare, etc.

(12) Cf. pp. 95 e 98. 
11 - Uma palavra que não pode deixar de nos fazer evocar o português "postigo» lê-se em

PASC. $\mathrm{XXV}, 1$

Tu quidem, frater, similis es aedificio quod quamuis habeat ingressum ornatum, per posticum tamen a latronibus expoliatur.
PLG. VIII, 2

Similis es domui quae a facie quidem ornata est, de retro uero a latronibus despoliata.

Meyer-Lübke apenas menciona como continuador de posticum o espanhol 'postigo'. A mesma palavra existe em português. Nem por isso, no entanto, nos julgamos no direito de reivindicar uma origem hispânica para a tradução de Pascásio. O latino posticum era da linguagem corrente e encontra-se documentado em Plauto, na época clássica e até na Vulgata. Lê-se no livro de Daniel XIII,18: Clauseruntque ostia pomarii et egressae sunt per posticum. Tratando-se de palavra divulgada, não podemos insistir no facto da sua sobrevivência só na Hispania. Aliás o vocábulo adquiriu entre nós valor semântico diferente, o de 'pequena porta cortada dentro duma porta maior' e não o sentido latino que ainda se verifica em Pascásio de 'porta detrás'.

12 - Encontrámos a preposição pro no sentido exacto do português 'por'.

PASC. $\mathrm{XC}, 3$

Cui senex, pro humilitate, ait: Et mea cogitatio parum uolebat.
PLG. XV,27

Dixit autem ei senex cum humilitate: Et animus meus modicum uolebat hoc.

O que está em causa é Pascásio ter preferido a preposição pro, com valor de modo, quando Pelágio traduziu com maior regularidade cum humilitate (Matoes 9 (292): $\mu \varepsilon \tau \dot{\alpha} \tau \alpha \pi \varepsilon \iota v \omega ́ \sigma \varepsilon \omega \varsigma)$. Em rigor, vertendo em português, "por humildade», poderemos dar-lhe sentido de causa, o que corresponde ao tom geral do carácter da pessoa que fala, Moisés, acabado de ser ordenado de presbítero. 
13 - Note-se o sabor de quietum neste passo:

PASC. XCII, 3

Nam non me dimittunt hic residere quietum.
JOÃo IV,32

Alioquin non me permittent homines sedere in loco isto.

O latim quietum, com valor de 'tranquilo' subsiste em todas as línguas românicas. Em português temos duas formas divergentes: 'quieto' e 'quedo'. É a escolha do vocábulo entre outros possíveis para designar «permanecer tranquilo, ficar na cela cum quiete» que nos seduz.

14 - Veja-se como quomodo, introduzido por Pascásio para subordinar orações independentes em grego, deixou de ter valor consecutivo para adquirir o matiz causal do português 'como', 'visto que'.

PASC. $x x x y, 3$

Sed faciamus taliter: Quomodo ante omnes solet uenire ad ecclesiam...
JOÃO II,4

Hoc ergo faciamus: Ecce uenturus est mane ante omnes in ecclesiam...

Pelágio, tendo traduzido literalmente, evitou este romanizante quomodo.

15 - Há dois casos em Pascásio em que o verbo relaxare, geralmente com o significado de 'distender', 'aliviar', aparece com o valor do simples laxare, donde proveio o português «deixar». Não há traduções paralelas latinas.

Pasc. LXXIII,2 - Um irmão encontrou um locum quietum. E pediu ao abade para o deixar ir para lá (ut illum dimitteret postularet). Mas o abade noluit eum penitus relaxare dicens...

Em português traduziríamos tanto dimittere como relaxare por 'deixar'. Em Pascásio há uma uariatio, mas o segundo termo é de carácter «vulgar».

Pasc. LXXVII,1 - Si monachus paucis diebus laborat et iterum relaxatur et rursus laborat et deinde negligit... 
Há nova uariatio em Pascásio. Aqui, porém, relaxare é sinónimo do seguinte negligere. Ocasionalmente notámos também em Pelágio IV,11 o uso de relaxare, mas no sentido comum de 'abrandar, negligenciar'.

Laxare tem representantes em toda a Romania.

16 - Há uma oposição à primeira vista significativa entre Pascásio e Pelágio. Aquele usa sempre septimana ao passo que este prefere hebdomada. Registámos seis vezes a palavra septimana em Pascásio. Eis as duas primeiras:

PASC. v,1

Eulogius (...) presbyter religiosus nimis, ieiunans semper biduana, frequenter autem et integram septimanam...

PASC. VII, 2

Factaque illic septimana regressus est ad fratrem suum.
PLG. VIII, 4

Eulogius presbyter erat et abstinens atque ieiunans biduanas leuando, aliquando etiam et usque hebdomadam trahebat ieiunium...

PLG. $x, 27$

Et facta ibi hebdomada una, reuersus est ad fratrem suum.

A preferência de Pascásio por septimana nada pode indicar sobre a zona onde foi feita a sua tradução, porque ela se mantém, evoluída, em todas as línguas românicas.

17 - Temos agora um exemplo dos mais interessantes do ponto de vista fraseológico: o emprego de teneo para indicar obrigação.

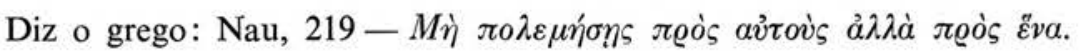

PASC. LXXII, 3

Aduersus omnes non teres pugnare, sed aduersus unam.
PLG. $\mathrm{x}, 88$

Non repugnes contra omnes, sed contra unam.

A frase tem equivalente literai em português, como perífrase a evitar um imperativo negativo: «não tens que lutar contra todas...». 
Se Pelágio nos não oferece este pitoresco tenes, nem por isso a sua construção do imperativo negativo e a preferência por contra são menos «vulgares»...

18 - Também a palavra terraemotus, como unidade, chamou a nossa atenção.

PASC. XCIV, 1

Quid est iste terraemotus?
PLG. II, 5

Quis est motus hic?

Ambos os tradutores tinham diante de si a palavra $\sigma \varepsilon \epsilon \mu o^{\prime} \varsigma$ (Arsenius 25 (96)). É precisamente a justaposição das duas palavras latinas, tal como hão-de subsistir desde a Itália, passando pela França, à Hispania, que revela o aspecto romanizante de Pascásio.

19 - Do abade Paulo Magno (3 [381]) conta-se a sua mortificação na Quaresma e o seu trabalho (Pasc. XIV,11): et unam mattam faciens eandem texebat et retexebat ne tantummodo foris exiret.

Não há outra tradução antiga deste apotegma. Cotelier dá na sua edição a seguinte versão: necnon cum una sportula, quam plectebat et dissoluebat usque ad festum inclusus.

A nossa atenção cai primeiro em "tecer e destecer» tão parecidos com o latim de Pascásio (e diferentes do de Cotelier...).

Quanto à palavra matta tem ela aqui o valor exacto de 'esteira de junco'. Os autores dividem-se quanto à origem e evolução semântica de matta. Meyer-Lübke apresenta como seu derivado, em português, mata, 'Wald, Holz', isto é, 'bosque, mata'. Não deixe de se registar, todavia, que Corominas considera o termo matta, do latim tardio, como proveniente do semítico, através do púnico, equivalente ao hebraico mittâh, que significa 'manta, cobertor', e que se espalhou na Romania meridional em virtude dos contactos com o Norte de África. Esta interpretação parece adaptar-se a outro passo de Pascásio, XCIII,11 (linha 40). Aí se diz que para S. Macário dormir, os dois irmãos mattam ergo mihi in uno angulo conlocauerunt. Aceita-se que em vez de colchão lhe dessem uma 'esteira'; mas para se cobrir não precisaria de uma manta?...

20 - Várias vezes a palavra unus aparece em Pascásio com o valor do grego $\varepsilon i \tilde{\zeta}$, o numeral, ou até para designar o ordinal primus. 
O que merece a nossa atenção é o uso já bem estabelecido de unus com valor de artigo indefinido, que não tinha no latim clássico.

O caso mais fácil de verificar é quando o grego apresenta o substantivo desprovido de artigo.

Joannes Persa 2 (237) - Kai ĩ $\lambda \theta \varepsilon v$ ả $\delta \varepsilon \lambda \varphi o ̀ \varsigma ~ \pi \alpha \varrho \alpha \varkappa \alpha \lambda \tilde{\omega} v \alpha v ่ \tau o ́ v . .$.

PASC. XLIV, 3

Venit unus frater petens ei...

Pelágio manteve-se fiel ao grego. Pascásio, porém, acentuou o indefinido com a forma unus. Reconheçamos, todavia, que Pelágio-João também várias vezes empregam unus como indefinido.

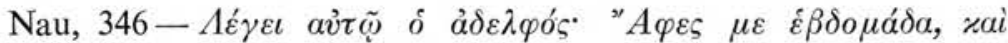
$\pi \alpha \dot{\lambda} \iota v \lambda \alpha \lambda o \tilde{v} \mu \varepsilon v$.

PASC. XLVI, 8

Et dicit ei ille iunior: Permitte me hac una septimana et iterum loquimur.
PLG. XVII,14

Et dicit ei frater: Dimitte mihi unam hebdomadam, et iterum loquemur.

Primeiro notemos, em Pascásio, ille no lugar do artigo definido, processo que Pelágio evita. De acentuar é que sendo $\varepsilon \beta \delta o \mu a ́ \delta \alpha$ indefinido, tanto Pelágio como Pascásio a fazem preceder de una $(\mathrm{m})$. Mas o nosso autor parece restringir logo a ideia de indeterminação, escrevendo hac una, isto é, só nesta...

O valor indefinido de unus é claro quando vem seguido do pronome alter. Tal significado também aparece em Pascásio mais que uma vez. Vamos dar um passo para o qual falta outra tradução latina antiga.

ARSENIVS 38 (105)

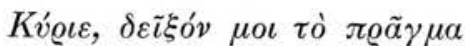

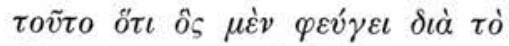

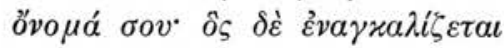

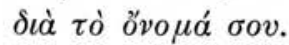

PASC. XLVI,6

Domine, hanc mihi rem precor ostende, quia unus propter nomen tuum omnes homines uidere aut conpellere refugit, alter uero omnibus idem propter nomen tuum communis est. 
Mais evidente se torna ainda quando unus traduz o próprio indefinido grego $\tau \iota$.

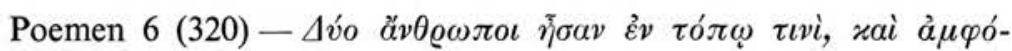

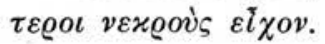

PASC. XLI, 7

Erant duo homines in uno loco et utrisque contigit ut haberent mortuos.
PLG. IX,7

Duo homines erant in loco uno, et ambo habebant mortuos suos.

Neste fragmento ressalta com toda a clareza que tanto para Pascásio como para Pelágio unus é equivalente perfeito do latino quidam, com valor indeterminado.

Ao terminar esta selecção de aspectos «vulgares» da língua de Pascásio queremos chamar a atenção para o contraste por vezes resultante do confronto com Pelágio e João. Estes dois últimos tradutores interessam-nos especialmente porque tudo leva a crer que escreveram em Roma.

Em certos casos parecia que Pascásio era mais «vulgar» no vocabulário empregado. Mas notemos, em primeiro lugar, que em muitos outros pontos Pascásio é seguramente mais artista e melhor seleccionador de vocabulário. Depois, não deixe de se ter em conta que nós não fizemos um estudo sobre os «vulgarismos» de Pelágio e João. Estes existem também, embora não precisamente nos mesmos lugares de Pascásio, o que só vem reforçar a inteira independência das duas traduções entre si.

Para mencionar apenas um exemplo que nos põe de sobreaviso, registemos o uso de applicare em Pelágio (X,39 - duas vezes; e XIV,14 - uma vez). Pois em Pascásio nunca o sentido de 'chegar' é expresso por applicare ou pelo simples plicare. Dir-se-ia que ignora estes verbos. E todavia eles eram de uso corrente em toda a Romania...

6 - INOVAÇÕES LINGUíSTICAS - Sob esta designação vamos indicar uma selecção de palavras e formas que se encontram até agora só

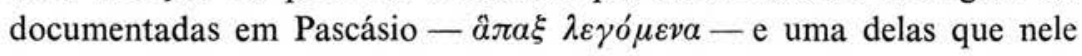
tem a mais antiga abonação. 
Propositadamente deixamos de lado questões de mudança de género, de número e de particularidades da flexão em substantivos, e de conjugação, sobretudo pondo de parte o frequente problema dos verbos «depoentes». Com efeito, temos em Pascásio numerosos exemplos de verbos activos que estão tratados como «depoentes» e vice-versa. A nossa atenção vai incidir sobre palavras novas ou sentidos novos de palavras já antes conhecidas. Seguiremos a ordem alfabética dos vocábulos.

1 - Cineratus, a, um - Em XXV,3 lemos:

Bene tibi fecerunt, cinerate, nigricori; cum enim non esses homo, quare ingressus es inter homines?

MOYSES 4 (284)

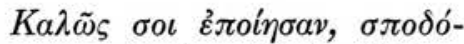

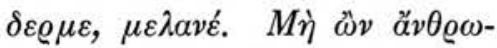

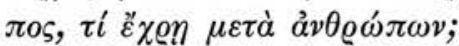

PLG. XV,29

Bene tibi fecerunt cinerente et caccabate. Qui cum homo non sis, quare te in medio hominum dare praesumpsisti?

A forma cinerate está bem documentada pelos melhores manuscritos da recensão longa: MVL. Os outros desta recensão que possuem o apotegma (PEUC) emendaram para cinerente (forma que $\mathrm{S}$ escreve erradamente cirenenti).

De facto o Thesaurus Linguae Latinae regista a forma cinerentus, só atestada pelo passo de João. (A remissão Vitae Patrum 5,29 está errada; deve ser 6,2,4). Diz que é o mesmo que cinereus.

A palavra cineratus tem em Pascásio o mesmo valor de cinereus e cinerentus, uma vez que traduz o grego $\sigma \pi о \delta o ́ \delta \varepsilon \varrho \mu \varepsilon$ 'de pele cor de cinza'. Realmente Moisés era tido como etíope e tinha pele escura.

Fora de Pascásio, cineratus só aparece documentado, em Du Cange (13), na Epistola Guiberti abbatis Gemblacensis ad Gertrudem uirginem (séc. XII-XIII). Temos, pois, um avanço de seis séculos.

(13) Du Cange s.u. cineratus. Cf. dados mais pormenorizados sobre Guiberto de Gembloux in Enciclopedia Cattolica, Città del Vaticano, 1951.

ro 
2-Excludi - Esta forma encontra-se no princípio do prefácio, neste contexto:

Nec enim umquam quod scribi uel legi possit excludi, ingenii uecordis conscientia prohibente.

A lição excludi é atestada por toda a recensão longa. O elaborador do subarquétipo $\iota$ teve dificuldade em compreender a frase e emendou para excudi, forma que se encontra na edição de Rosweydus. Mais ousado ainda, o organizador do modelo $\lambda$ perante a diferença dos seus paradigmas resolveu corrigir para abscondi. É certo que ambos os reelaboradores entendiam estas formas como a primeira pessoa do singular do perfeito do indicativo e não como um infinito passivo.

A tradução mais antiga que conhecemos do prefácio de Pascásio encontra-se nas Vitae Sanctorum, editadas em Sevilha a 16 de Maio de 1520 (Bibl. Publ. Évora, reservado 178, p. 200). O passo em questão é assim traduzido: "Vedando me lo ingenio y conociendo me no ser a ello bastante, fize cosa que leer o escrivir se pueda». Vê-se que traduz excudi por «fize cosa».

O nosso problema está em saber se excludi (a lição segura de Pascásio) poderá ser interpretado como perfeito do indicativo. Seria de esperar a forma «regular» exclusi. Em nenhum dicionário encontramos registada esta forma de modo seguro. Só o Thesaurus Linguae Latinae (s.u.) menciona excludi, mas com uma variante excluserat no Liber Genealogiae Chron. I p. 161 e na Passio Petri et Pauli, long. 1, mas nesta com a variante exclusit. Ora, em Pascásio, na única recensão autêntica, excludi não apresenta variantes. E a tradução não pode ser outra senão deste tipo: «Nem eu nunca excluí do dever de obediência o que possa escrever-se ou ler-se, pois mo proibe a consciência de que seria isso fruto de mau espírito». Temos, pois, aqui uma prova segura de que a morfologia de excludo estava já seguramente alterada no século vi, dando-lhe como perfeito normal excludi. Dele deriva o português excluí.

3 - Farinis - Este vocábulo é um äj $\alpha \xi$ de Pascásio e é típico do arquétipo $\alpha$. O hiperarquétipo $\beta$ substituiu-o pelo seu sinónimo panis, de uso corrente. Eis o grego e as traduções de Pascásio e João.

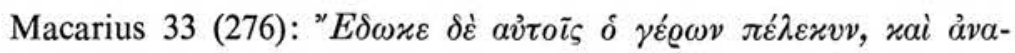

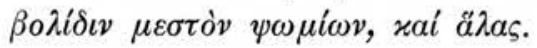


PASC. XCIII,11

Quibus ego alueolum cum secure et saccum plenum farinibus cum modico sale contradidi.
JOÃo III,2

Dedi autem eis securim et sportam plenam panibus, et salem.

Dos sete manuscritos da recensão extensa que nos transmitem este apotegma só o Vaticanus lat. 4921 e o Vrgellensis dão a lição farinibus. Aquele é um representante puro do arquétipo $\alpha$, o que julgamos mais próximo do original; o de Seo de Urgel, embora siga normalmente o subarquétipo $\varepsilon$ dispunha, por certo, de um modelo $\alpha$. Neste caso, perante a divergência dos seus modelos, o copista do Vrgellensis preferiu a lectio difficilior de $\alpha$. Com efeito, não encontrámos a palavra farinis registada em nenhum léxico.

Quanto ao seu significado, logo o revisor de $\beta$ o interpretou, correctamente, como panis. Resta-nos saber que espécie de pão era este. Em VI,1 traduziu Pascásio um apotegma em que o discípulo diz ao abade Teodoro: Volo ire ad pistrinum et de cicercula farinam facere. E Teodoro responde-lhe: Si ad pistrinum semel ire desideras, fac panem tuum et comede. Neste caso trata-se de pão feito com farinha, resultante da moagem de grão de bico. A palavra panem é aqui a tradução do corrente ă $\varrho \tau o v$. Em Pasc. XCIII,11, temos $\psi \omega \mu i \omega v$, que à letra significa 'pedaço, bocado', dado que já $\psi \omega \mu$ ó é 'bocado de pão'. Qual o cereal de que seriam feitos estes $\psi \omega \mu i \alpha$ - farines? Não temos elementos para responder.

4-Mediator - Esta palavra aparece duas vezes em Pascásio. A primeira em LXXXIX,2: Peregrinus monachus in aliena terra nullius causae mediator accedat. Já vimos (14) no confronto com o grego ( $\mu \varepsilon \sigma \alpha \zeta \varepsilon ́ \tau \omega)$ e com Pelágio (se medium faciat) que mediator não tem em Pascásio o valor de 'mediador' ou 'intermediário', mas o de 'intrometer-se no meio de questões'.

Este sentido é confirmado pela segunda abonação em Pascásio XCVI,3: Vnde adeptus es hanc uirtutem, frater, ut quotienscumque tribulatio contigit in coenobio ne loquaris neque mediator accedas?

(14) Cf. supra p. 82. 
NISTEROVS 2 (309)

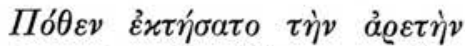

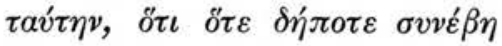

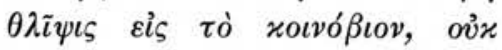

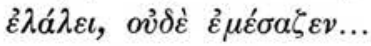

PLG. $\mathrm{XV}, 30^{\mathrm{b}}$

Quomodo acquisisti uirtutem hanc, ut quando emerserit tribulatio aliqua in monasterio, non loquaris neque te medium facias?

Aqui está um passo em que seríamos tentado a entender mediator como 'medianeiro, árbitro'. Porém, o grego e Pelágio garantem-nos que Nisteróo, em ocasiões de disputa, nem falava «nem se intrometia na questão». Punha-se de parte. Observemos que em Pelágio a expressão te medium é uma reconstituição nossa, pois a Patr. Lat. LXXIII, col. 960 escreve taedium, palavra inteiramente fora do contexto.

O sentido em que Pascásio usa mediator, 'o que se mete no meio de problemas suscitados', não o encontrámos registado em parte alguma.

5 - Necessarius, a, um - $\mathrm{O}$ adjectivo necessarius aparece quatro vezes em Pascásio. Em três delas (XXI,2; XLIII,1 e XLIII,3) tem o valor corrente de 'necessário, indispensável'. Há, porém, um caso à parte que merece estudo.

Em XV,2 conta-se que um irmão entrava na cela de outro, muito considerado e trabalhador, e tirava de lá o que encontrava. O que se sentia lesado não se queixava, mas antes trabalhava mais, dizendo, segundo Pascásio:

Puto frater ille necessarius est. Eis o grego e a versão de Pelágio:
NAU, 339
PLG. XVI,19

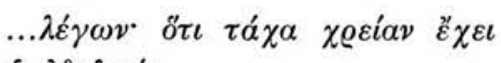

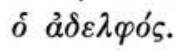
...dicens: Credo, opus habet frater iste.

O sentido de Pascásio é fácil de entender: «Julgo que aquele irmão se encontra em necessidade». Talvez fosse mais justo dizer simplesmente, como o grego, o irmão, fazendo de ille um pronome já com valor enfraquecido. Os dicionários de latim tardio e medieval não registam necessarius com este sentido. Apenas A. Blaise, no Dictionnaire Latin-Français des Auteurs Chrétiens, s.u., citando exclusivamente este passo de Pascásio, tirado de Vit. Patr. 7.3.2, isto é, VII Rosw., 
regista o significado que se adapta ao pensamento: qui est dans le besoin. Trata-se, quanto tudo deixa supor, de um å $\pi \alpha \xi$ semântico de Pascásio. A palavra era estranha, mesmo para os copistas da recensão longa, pois teve as seguintes substituições: necessatus PEU necessitatus p. corr. L ne satiatus $\mathrm{S}$. Isto significa que só o arquétipo $a$ manteve a forma primitiva. Por outro lado, verificamos, com supresa, que necessarius foi reconstituído em $\iota$, o qual achou estranha a forma necessatus, particípio inexistente do verbo necesso... E assim a boa lição, por conjectura, chegou até às edições!

6-Nigricorius, a, um-A propósito de cineratus (n. 1) transcrevemos o trecho em que Moisés era chamado também nigricori. O grego diz simplesmente $\mu \varepsilon \lambda \alpha \nu \varepsilon ́$ e João traduziu caccabate, 'negro como uma panela'.

A única palavra que os léxicos registam como um å $\pi \alpha \xi$ de Solinus (séc. III p. C.) é nigricolor, oris. Pascásio, porém, não usou sequer esta, mas uma outra que tem o mesmo significado e que não aparece em nenhum léxico: nigricorius. Os manuscritos da recensão longa dividem-se: nigricori $\mathrm{MVU}$ nigraecori $\mathrm{P}$ nigricore $\mathrm{E}$ nigriori $\mathrm{L}$ nigri coloris $\mathrm{S}$. $\mathrm{O}$ apotegma só é transcrito por outro subarquétipo, o $\mu$, que também guarda a forma nigricori, sinal de que era a que se encontrava em $\varepsilon$. Cremos nada mais haver a fazer que registar o å $\pi \alpha \xi$ de Pascásio nigricorius, a, um com o valor de 'de cor negra ou escura'.

7 - Quadriportium, $i$ - Em LXXII,2 de Pascásio um ancião diz a um discípulo em tom de censura: Tu quadriportium es et qui uult ingreditur et egreditur per te.

NAU, $57(=270)$

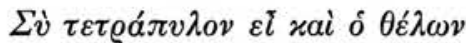

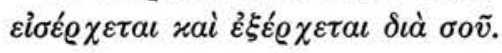

PLG. XI,43

Tu sic es uelut quadrigemina porta, ut quicumque uoluerit intret unde uoluerit in te et unde uoluerit exeat.

Ambas as traduções são literais. Pelágio desdobrou o composto grego em quadrigemina porta. Pascásio dá-nos um substantivo que não encontramos registado em nenhum dicionário. $\mathrm{O}$ que os léxicos 
conhecem é quadriporticus, como 'átrio rodeado de quatro portas'. Mas não há dúvida de que Pascásio escreveu quadriportium, lição de VL e Paris, Bib. Nac. lat. $2768 \mathrm{~A}$. As variantes na recensão longa são quadriportis $\mathrm{P}$ quadriportius UC quadripotius $\mathrm{S}$ (erro manifesto). $\mathrm{O}$ apotegma não vem em nenhuma das outras recensões.

8 - Renitui, perfeito de renito $(r)$ - As dificuldades linguísticas surgidas no prefácio de Pascásio revestem especial acuidade por falta de texto grego e de lugares paralelos. Repare-se para a última palavra da primeira frase:

Vitas patrum, Graecorum ut cetera, facundia studiose conscriptas iussus a te, sanctissime pater, in latinum transferre sermonem, insolito si licuisset operi renituissem.

Pascásio quer, sem dúvida, dizer que «se fosse lícito resistiria a fazer um trabalho a que não estou habituado». A dificuldade não está em entender o pensamento, mas sim em justificar a forma renituissem.

Tudo nos leva a crer que renituissem, forma só dada por $\mathrm{M}$ era a original de $\alpha$ e que o hiperarquétipo $\beta$ a substituiu por renuissem, por ser este verbo mais conhecido com o valor exigido pelo contexto. Esta última forma se encontra, de facto, em todos os outros arquétipos e subarquétipos que transmitem o prefácio. Lembremos, antes, que V, aparentemente divergente, com nituissem, deve remontar a renituissem. Com efeito, o grupo operi renituissem deveria estar em scriptio continua no modelo de V, donde resultou o duplo erro de V: aperire nituissem.

Como explicar então que o melhor arquétipo nos dê uma forma inexistente? Os dicionários registam renitor, $i$, renixus sum ou renisus sum, ou mesmo sem a série do perfeito. O valor que lhe é atribuído é o de 'fazer esforços contra, resistir'. O advérbio renitenter dá bem, à primeira vista, a impressão de «resistência», de «ser contrário".

Não dispomos ainda do estudo do Thesaurus Linguae Latinae para esta palavra. Quem melhor nos elucidou foi Forcellini, pois a certa altura informa que em Apuleio 3, Metamorfoses 9, alguns autores preferem ler renuentem em vez de renitentem. Depois, em renuo confirma que alguns editores trocam este verbo com renitor no citado passo de Apuleio.

Em parte alguma, porém, encontrámos que renitor tivesse deixado de ser «depoente» para ser substituído pelo activo renito. Nem a 
isso nos autoriza, com segurança, Pascásio. O que ele nos fornece, e julgamos que com certeza, é uma forma activa de perfeito renitui para o verbo renito $(r)$. Só assim se explica o mais-que-perfeito do conjuntivo renituissem.

Tal facto não deve, porém, causar-nos surpresa. Num estudo que fizemos sobre verbos «depoentes» em Pascásio, baseando-nos na observação das formas que damos no texto e nas variantes que vão no aparato crítico, verificámos que há verbos activos usados como «depoentes» e «depoentes» empregados como activos (ambos os casos só em lectiones uariantes) e ainda a existência de verbos ora utilizados como «depoentes» ora como activos. Só este caso nos interessa aqui.

Assim o verbo mutuo é sempre activo, excepto em XLIV,3 (linhas 23 e 27) onde está, por certo, usado como «depoente». Do mesmo modo a par de percunctor, escrito em 1,3 (linha 10) há o activo percuncto. Remuneror (cf. Pasc. XxII,3, linha 2) é clássico, enquanto remunero é tardio. Esta hesitação entre activos e «depoentes» e a tendência comprovada do latim tardio para fazer recuar o emprego dos dos «depoentes», a ponto de terem desaparecido nas línguas românicas, deve levar-nos a aceitar, sem estranheza, a forma renituissem como mais-que-perfeito do conjuntivo de renitor já evoluído para a forma activa renito. Cremos que Pascásio será, até agora, o único testemunho a apresentar.

9 -Veteramentum, $i$ - Dois irmãos, indo de viagem, encontraram um cadáver. Então, segundo Pascásio, XLIII,3: Et dicit ille religiosus: Si haberemus aliquid ex ueteramentis mitteremus super illud.

NAU, 294

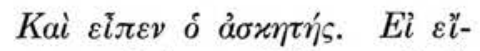

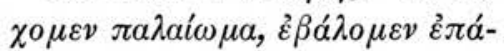

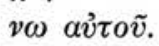

PLG. XIV,17

Et dixit abstinens ille ad fratrem suum: Si habuissemus aliquid uetustum, iactaremus super corpus illud.

Ao substantivo neutro $\pi \alpha \lambda \alpha i \omega \mu \alpha$ fez Pascásio corresponder ueteramentum que não encontramos em nenhum dicionário. O seu significado é 'pano velho'. A palavra mais semelhante em latim é uetera- 
mentarius, $a$, um, 'que diz respeito a coisas velhas'.-Veteramentum é, pois, outro ä $\pi \alpha \xi$ de Pascásio.

Não deixe de se anotar ille, com valor enfraquecido, a traduzir o artigo de $\delta$ ả $\sigma x \eta \tau \eta \dot{s .}$.

\section{V - NOTA FINAL}

O estudo acabado de fazer sobre as técnicas de tradução e a língua de Pascásio sabemos bem que não é exaustivo. Numa obra tão extensa como a deste autor tardio há necessàriamente muitos outros vocábulos, além dos mencionados, que merecem exame atento.

Uma consideração especial sobre aspectos morfológicos leva-nos a advertir que em Pascásio se verificam fenómenos já bem conhecidos do latim tardio: uso do masculino que tende a suplantar o neutro; grande hesitação na flexão dos temas nominais em -i-; tendência para a eliminação dos temas em -u- e em -e- («quarta e quinta declinação») em proveito dos temas em -o- e em -a-; o neutro do plural passa por vezes a singular feminino; variantes na flexão dos pronomes; anomalias na «regência» das preposições, etc.

O tratamento dos verbos requer uma atenção muito particular. Há mudanças de temas; tendência para incluir um -i- em alguns tempos; variantes na conjugação do perfeito, mais-que-perfeito e futuro perfeito - do indicativo, e ainda do presente e mais-que-perfeito - do conjuntivo. Os verbos «depoentes» e reflexos estão sujeitos a uma grande flutuação, no geral em proveito das formas activas.

Quanto acabamos de indicar poderia sugerir que o latim de Pascásio representa uma fase de profunda desagregação da língua. Devemos atenuar esta impressão, esclarecendo, em primeiro lugar, que as observações sobre as variantes morfológicas acabadas de enumerar são relativamente escassas, e ainda que elas são formuladas sobre as lectiones uariantes dos diversos códices da recensão extensa. Só através deles podemos aproximar-nos de Pascásio, mas este escritor não é responsável pelas dúvidas que nos surgem em virtude da acção pessoal dos copistas da sua obra.

Por exemplos citados oportunamente, vimos que a sintaxe de um escritor justifica só por si um estudo à parte, que no geral resulta muito longo. Embora tenhamos uma vez ou outra tocado em aspectos 
sintácticos e estilísticos, tivemos que pôr de parte uma análise circunstanciada da sintaxe de Pascásio.

Finalmente queremos chamar a atenção para a importância da obra de Pascásio em relação a estudos semasiológicos, sobretudo de índole monástica e espiritual. O conteúdo e evolução de conceito de certas palavras beneficiará em ser confrontado com autores anteriores, contemporâneos e posteriores.

Apesar de não termos feito um largo desenvolvimento dos pontos acabados de indicar, o nosso estudo aproveitou as características mais marcantes de quase todos eles. Cremos assim ter deixado uma imagem, tão delineada quanto possível, da arte, do estilo, da língua e da própria personalidade de Pascásio. 


\section{Cap. IV - OBSERVAÇÕES SOBRE A NOSSA EDIÇÃO DE PASCÁSIO}

O estudo minucioso de todos os códices que nos transmitem a tradução de Pascásio, e das numerosas famílias em que se subdividiu, levou-nos à conclusão, abundantemente documentada, de que a recensão extensa é a que corresponde ao trabalho original.

Acontece, porém, que a própria recensão extensa está subdividida em diversas famílias. Examinando atentamente cada uma delas, acabámos por seleccionar seis manuscritos de base que nos poderão dar uma ideia tão exacta quanto possível do que seria o texto primitivo. Ocasionalmente, recorremos à lição de outros manuscritos da mesma recensão extensa que nos pareceu poderem ajudar a reconstituir o texto.

Para a elaboração do texto e do aparato críticos procurámos informar-nos junto das melhores obras da especialidade e na medida em que pareceu possível e oportuno seguimos as suas lições e exemplos. $\mathrm{O}$ mesmo se diga no que respeita à organização e expressão gráfica do stemma codicum (1).

Problema complicado foi o da opção sobre normas ortográficas. Escudado na autoridade de Jacques Fontaine, professor da Sorbonne,

(1) As obras que nestes pontos mais úteis nos foram são: LouIs HAVET, Manuel de critique verbale appliquée aux textes latins, Paris, 1911; Oтто STÄHLIN, Editionstechnik, Leipzig, 1914; GIoRgio PASQUali, Storia della tradizione e critica del testo, Firenze, 1934; J. Bidez- A. B. Drachmann, Emploi des signes critiques (nouv. edit. par A. Delatte-A. Severyns), Bruxelles, 1938; PAul MAAS, Textkritik, Leipzig, 1960; B. A. VAN Groningen, Traité d'histoire et de critique des textes grecs, Amsterdam, 1963; A. DAIN, Les manuscrits, Paris, 1964. Como modelos concretos citamos: P. B. CORBEt, La regle du Maitre (Le probleme de l'édition), Bruxelles, 1953; E. Amand de Mendieta, Eustathius, Berlin, 1958; Manlius Simonetti, Tiranii Rufini opera, Turnholti, 1961; HeRMANN FrÄNKEL, Einleitung zur kritischen Ausgabe der Argonautika des Apollonius, Göttingen, 1964. 
estudioso e editor de textos visigóticos (2), resolvemos seguir as normas fundamentais que orientavam os copistas da Hispania dos séculos IX-XI, na medida em que elas são aceites pelos bons dicionaristas (3).

Seguimos assim, como princípio comum, a grafia dos prevérbios sem assimilação da consoante final ao grau de sonoridade da primeira consoante da sílaba seguinte. Por isso escrevemos: adgreditur, adpetere; conmisi, conparare; inluminati, inpeditus; obcumbas; subripiam; etc. Todavia há certas assimilações que são quase constantes nos manuscritos visigóticos. Nesse caso, tal como Fontaine, cedemos à tradição hispânica, como por exemplo em afferte, annuisset; collectis, commendatam, corrupta; imperata, impleo; occulte; sufferre; etc. Também devemos assinalar a preferência por hii no nominativo do plural, mas his no dativo. Cremos que estas pequenas divergências não deslustrarão o aspecto ortográfico geral. Aceitamo-las como homenagem a uma tradição bem firmada na Hispania da alta Idade Média.

Por vezes, antes do aparato crítico geral, abrimos um outro pequeno rodapé para assinalar os passos da Sagrada Escritura citados ou aludidos no texto. Há, porém, um pequeno número de alusões que não conseguimos identificar. Na opinião do Prof. Van Iersel, da Universidade de Nimega, pode tratar-se de traduções de uma versão grega da Bíblia diferente da que serviu de base para a versão da Vulgata.

Finalmente, após o texto de Pascásio damos a edição de alguns passos, inéditos na sua maioria, que se encontram em algumas recensões secundárias entre o texto de Pascásio, mas que na realidade lhe não pertencem, devendo por isso rejeitar-se como espúrios.

Assim cremos ter introduzido suficientemente o leitor na obra que vai abrir e que há vários séculos não é apreciada na sua versão integral e original.

(2) O melhor exemplo da técnica, neste domínio, de J. Fontaine é a edição de Isidore de Seville, Traité de la nature, Bordeaux, 1960.

(3) Tivemos como dicionário de base, para dirimir dúvidas ortográficas, pela sua validade tanto para o período clássico como para a época tardia e medieval, Ch. T. Lewis-Ch. Short, A latin dictionary, Oxford, 1962. 



\section{PASCHASII DVMIENSIS}

TRANSLATIO

\section{LIBER GERONTICON}

DE OCTO PRINCIPALIBVS VITIIS 


\section{SIGLA ET MANU SCRIPTI}

In edendo Paschasii textum his manu scriptis utimur:

M - Matritensis, Acad. Reg. Hist. 80, saec. Ix.

V - Vaticanus lat. 4921, saec. xIV-xv.

$\mathrm{P}$ - Portucalensis, Bibl. Municip. 753, saec. $\mathrm{xv}$.

E - Escorialensis, Bibl. Monast. I-III-13, saec. IX-X.

L - Londinensis, Brit. Mus. add. 30855, saec. XI. Textum Paschasii L diuidit in quattuor partes, sicut manu scripti descriptio monstrabit. Cum titulus capituli uel apophthegma iteratur in quauis serie, series ubi lectio uarians occurrit sic signabitur: $\mathrm{L}^{1}, \mathrm{~L}^{2}, \mathrm{~L}^{3}, \mathrm{~L}^{4}$

S-Salmanticensis, Bibl. Vniuersit. 2537, saec. XIII-XIv.

Rarius etiam horum mss. lectionem in lucem edimus:

U - Vrgellensis, Bibl. Capitularis, anno 938.

C-Cassinensis, Bibl. Monast. 50, saec. XI.

A - Olisipponensis, Bibl. Nat. 454 (olim Alcobat.), saec. XII-XIII.

G - Stutgartensis, Bibl. Region. Theol. 303, saec. VIII-IX (Germanus).

H - Bruxellensis, Bibl. Reg. Belg. 8216-18, saec. Ix (Hunus).

R - Rotomagensis, Bibl. Mun. 1375, saec. XI.

W-Wiesbaden, Bibl. Region. 8, saec. xv.

F-Vienensis, Bibl. Nat. Austriae 386, saec. XII (Francus).

B - Bruxellensis, Bibl. Reg. Belg. 8372, saec. xII. 


\title{
LIBER GERONTICON DE OCTO PRINCIPALIBVS VITIIS
}

\author{
DE GRAECO IN LATINVM \\ TRANSLATVM A BEATO PASCHASIO
}

Capitvlatio

I - Quomodo in propria cella solitarie uiuatur.

II - De inrumpendo ieiunio in aduentu fratrum.

III - De uincendo desiderio gulae.

IV - Quia perfectis memoria cibi subtrahatur.

$\mathrm{V}$ - De abstinentia occultanda.

VI - De toleranda penuria.

VII - Non manducare monachum sine opere aliquo.

VIII - Contra spiritum blasphemiae.

IX - De origine passionis corporis.

$\mathrm{X}-\mathrm{De}$ eo quod oportet contra daemonem orando resistere.

LIBER - MVLS om. PE 1 Incipit liber MVS in nomine Domini incipit liber L 2-4 de octo ... Paschasio om. LS 3 in latinum de graeco V CAPITVLATIO - MVPELS 5 capitulatio] eiusdem add. MV incipiunt rubricae istius libri de Vitis Patrum $P$ incipiunt capitula Geronticon E om. LS 6 in propria cella solitarie uiuatur] s. in p. c. u. S in p. c. solitarius uiuere (-itur P -at E) debeat (om. PE) PEL 7 de inrumpendo...fratrum om. E ieiunium LS 8 desiderium L 9 quia ... subtrahatur om. E perfectis] -us $\mathrm{S} o m$. V memoriae MVS cibi] nimio desiderio add. LS subtrahitur P 10 occultanda om. E 11 de toleranda penuria om. PS 12 opere aliquo] quacumque opera E qualicumque o. L aliquo o. PS 13 spiritus E 14 passionis corporis] fornicationis EL p. corporeae $\mathrm{P} \quad$-um caprorum $\mathrm{S} \quad 15$ de eo quod oportet contra daemonem orando resistere] de inpugnatione daemonum (-is $\mathrm{L}^{3}$ ) et usque ad uesperam (-um $\mathrm{L}^{3}$ ) ieiunare $\mathrm{EL}^{3}$ de eo quem o. orando c. d. $\mathrm{r}$. $\mathrm{S}$ de eo q. o. c. daemones orando r. P 
$\mathrm{XI}$ - De eo quod passiones per abstinentiam ieiunii uincantur uel uigiliis.

$\mathrm{XII}$ - De fugiendis mulieribus.

XIII - Passiones carnales fame et siti interiri.

XIV - Contra philargyriam: de perfecta abrenuntiatione diuitiarum.

$\mathrm{XV}$ - Nihil dolendum monacho si aliquid amiserit.

XVI - Quia tolerantia paupertatis in requiem aeternam perducit.

XVII - Non debere scrupulosum esse in largiendo.

XVIII - De reprimenda auaritia.

XIX - De uilitate uestis.

$\mathrm{XX}$ - De origine irae.

$\mathrm{XXI}$ - De non retribuendo malum pro malo.

XXII — De retribuendo bonum pro malo.

15 XXIII - De non resistendo inimicis.

XXIV - De perfecta patientia.

$\mathrm{XXV}$ - De tentatione patientiae.

XXVI - Non loquendum in ira.

XXVII - Quia inuidia per patientiam uincitur.

20 XXVIII - Quia oportet pro pace quoduis bonum contemni.

XXIX - De perfecta concordia.

$\mathrm{XXX}$ - De patientia in latis criminibus.

XXXI - Contra spiritum tristitiae qui desperationem facit.

XXXII - Contra spiritum acediae.

1 qui $\mathrm{S}$ per om. $\mathrm{S}$ abstinentiam] $-\mathrm{a} \mathrm{L}^{3}$ et add. $\mathrm{P} \quad$ om. $\mathrm{S}$ ieiunii] -um $\mathrm{P}$-is $\mathrm{E} \quad \mathrm{om}$. MV uincatur $\mathrm{S} 2$ uel uigiliis $o m$. EP 3 fugiendis] -as E $\quad-\circ$ L mulieres $E \quad 4$ quod passiones $P$ passiones carnales] de passionibus carnis cum $S$ interiri] -ire MV -eant $P$ in itinere $S \quad 5$ philargyriam] -a EL et add. $\mathrm{L}^{1}$-ae iram MV de perfecta abrenuntiatione diuitiarum] de p. abrenuntiatio $\mathrm{L}^{3}$ a.d. om. $\mathrm{L}^{1} \quad$ om. MV 7 dolendo $\mathrm{L}$ monacho] -um $\mathrm{ESL}^{1} \quad$-os $\mathrm{L}^{3}$ aliquid] quid ELS admiserit $\mathrm{S}$ inter $\mathrm{XV}$ et XVI inserit sub numero VII de pecuniis $\mathrm{L}^{3} \quad 8$ tolerantia] -ae MV $\quad$-am PE toleranda $\mathrm{L}$ aeternam om. $\mathrm{P}$ perducat $\mathrm{P} 9$ debere] monachum add. MV scrupulosum] -us VL scripulum E esse] monachum add. $\mathrm{S}$ in om. E 12 contra iram de PS 13 retribuendum E 14 retribuendum E 15 de om. ELS resistendo]-um E retribuendo PS inimicum L 17 patientiae] poenitentiae MV 18 de non $\mathrm{L}^{1}$ loquendo LS 19 uincatur PS 20 quia] quod $\mathrm{S}$ quamuis $\mathrm{S}$ bono $\mathrm{L} \quad 22$ latis criminibus] lati criminis $\mathrm{L}$ altis c. S lacrimis E 23-24 ordinem capitulorum XXXI et XXXII inuerit $\mathrm{M} 23$ desperationem] desperare $\mathrm{E}$ 
XXXIII - Contra spiritum uanae gloriae.

XXXIV - Contra spiritum superbiae.

XXXV - Quod perfecti nolint facere miracula ne extollantur.

XXXVI - Daemones humilitate uinci et effugari.

XXXVII - Quia sermo superbus etiam bonum hominem malum facit, sermo uero humilis etiam de malo bonum facit.

XXXVIII - Quia humilitate magnorum et parui iuuentur.

XXXIX - Quia utiliter aliquotiens in sordidis cogitationibus relinquimur ne extollamur.

$\mathrm{XL}$ - Quomodo uitetur detractio.

$\mathrm{XLI}$ - Non debere de quouis peccatore diiudicare neque quemquam condemnare.

XLII - De oboedientia monachorum.

XLIII - Quia oboedientia de quouis periculo liberat.

XLIV - De caritate: hoc faciendum alteri quod tibi fieri uis.

$\mathrm{XLV}$ - De mandatis Dei in proximo: ut quod tibi uis fieri facias illi.

XLVI - De uoluntate proximi facienda.

XLVII - Non faciendum alteri quod tibi non uis fieri.

XLVIII - Non debere fratri uerecundiam incutere.

XLIX - De non praeponendis Deo parentum affectibus.

1 uanae] inanis $\mathrm{V} \quad 2-3$ ordinem capitulorum $X X X I V$ et $X X X V$ inuertunt PELS 3 quod] quia $\mathrm{L}^{1}$ perfecti] quamuis possint tamen (tamen om. S) add. PELS nolint] -ent EL -unt PS (qui post facere traiecit) facere miracula] $\mathrm{m}$. f. PLS facere $o m$. E ne extollantur $o m$. EL1 4 quia daemones $S$ daemones] cum add. $\mathrm{P}$ humilitate] -em MV humilitas $\mathrm{E}$ uinci et effugari] $\mathrm{u}$. et fugiri $\mathrm{P}$ uincit fugari $\mathrm{E}$ fugantur et uincuntur $\mathrm{S} \quad 5$ quia] qua $\mathrm{L}$ etiam bonum hominem] de bono homine S 5-6 facit malum $\mathrm{L} \quad 6$ sermo uero] et sermo $\mathrm{S}$ humilis...facit om. E etiam] et $\mathrm{V}$ om. $\mathrm{S}$ malo] -um $\mathrm{M}$ homine $a d d$. S 7 magnorum] maiorum $M$ et] etiam $E$ parui] paruuli $E S$ iuuantur $P$ 8 quia utiliter] qualiter $\mathrm{L}^{1}$ utiliter $\mathrm{om} . \mathrm{L}^{3}$ aliquotiens $\mathrm{om} . \mathrm{L}^{3}$ sordidis] sordibus $\mathrm{E} \quad$ reliquimur $\mathrm{L} \quad 9$ ne extollamur $\mathrm{om} . \mathrm{L}^{3} \quad 10$ uitetur] uidetur $\mathrm{S}$ 11 peccatore] -um $\mathrm{E}$-i $\mathrm{S}$ diiudicare] iudicare $\mathrm{L}^{1}$ quemquam om. $\mathrm{L}^{1}$ 13 monachorum om. EL 14 quia] qui $\mathrm{E}$ periculo] peccato PS liberat] se periculo add. S 15 de caritate $\mathrm{om} . \mathrm{L}^{2}$ hoc $\mathrm{om}$. S facienda $\mathrm{S}$ alteri om. $\mathrm{P}$ fieri uis] u.f. EL alio ne feceris quod tibi fieri non uis add. E 16 proximo]-i E -um S 16-17 ut quod ... illi om. S 16 fieri uis E 17 facias] et add. E 19 de non $\mathrm{S}$ non faciendium ... fieri om. E faciendo $\mathrm{S}$ tibi non uis fieri] $t$. f. n. u. P n.t. u.f.S fieri om. M 20 non debere... incutere $o m$. E deberi $\mathrm{M}$ fratri] fieri $\mathrm{V} 21$ praeponendis] proponendis $\mathrm{M}$ posponendis $\mathrm{V}$ Deo om. $\mathrm{L}^{2}$ 
L - De obsequiis infirmantium uel ipsa infirmitate.

LI - Quia infirmitas corporis prosit.

LII - De transitu perfectorum.

LIII - De timore Dei.

LIV - De lacrimis uel luctu.

LV - De poenitentia.

LVI - Quomodo per poenitentiam uno die potest homo reconciliari Deo.

LVII - Quia et in proposito poenitentiae si transeat homo tamen suscipiatur.

LVIII - De oratione.

LIX - Oratio praeferenda operi.

$\mathrm{LX}-\mathrm{Ab}$ opere ad orationem tamquam ad requiem ueniendum.

LXI - Eo quod ex omnibus uirtutibus oratio maiorem laborem habeat.

LXII - Vbique oratio praemittenda propter insidias et secundo et tertio.

LXIII - De iugitate orandi.

20 LXIV - Quod iugitas orandi propositum inpediat diaboli.

LXV - Quia et manducando potest orare.

LXVI - Quomodo sine cessatione oretur.

LXVII - Constringenda uagatio oculorum ne abstrahatur sensus $\mathrm{ab}$ oratione.

25 LXVIII - De fiducia perfectorum in oratione.

1 uel] in S infirmitas $\mathrm{E} \quad 2$ corpori $\mathrm{S} \quad 4$ de timore Dei om. E 5 lacrimas $\mathrm{L}^{2} \quad$ uel] et $\mathrm{E}$ de $a d d . \mathrm{S} \quad 7$ uno] omni $\mathrm{E} 9$ quia] qui $\mathrm{S}$ et om. PS si om. S 10 tamen om. P suscipiatur] suscipiat Deus P a Deo add. L 12 oratio] quia oratio est $\mathrm{S}$ praeferenda] proferenda $\mathrm{EL}^{2}$ operis E $13 \mathrm{ab}$ opere ad orationem tamquam ad requiem ueniendum] ab o. t. ad r. ad o. ueniendo $\mathrm{P} \quad \mathrm{ab}$ o. ad o. t. ad r. ueniendam V de o. ad oratione t. ad r. uenire $\mathrm{L}^{2}$ est add. S om. E 16 habet EL 17 ubique] ubicumque E propter insidias] p. diaboli i. S diaboli add. MV secundo] bis PS 19 habet numerum XVII sed correspondentem titulum de iugitate orandi om. E 20 iugitas] in iugatis $\mathrm{E}$ orandi propositum inpediat diaboli] o. p. d. i. PEL d. p. i. o. S 21 et manducando] m. etiam S 22 quomodo ... oretur om. E 23 de constringenda $\mathrm{E}$ uagatione PE 23-24 abstrahatur sensus ab oratione] ab o. a. s. S abstrahat (abstrahantur E) s. a. o. PE ab oratione om. $\mathrm{L}^{2}$ 25 fiducia] perfidia $\mathrm{S}$ in oratione om. $\mathrm{E}$ 
LXIX - Quia oratio uiri perfecti etiam mortuis prosit.

LXX - De reuelationibus.

LXXI - De inpugnatione daemonum.

LXXII - De pugna cogitationum.

LXXIII - De reserandis cogitationibus cum omni opere.

LXXIV - De discretione.

LXXV - Quia non noceant quaedam his qui discretionem habent.

LXXVI - De mortificatione.

LXXVII - De perseuerantia.

LXXVIII - De labore sanctorum.

LXXIX - Quare modo laborantes talem gratiam non accipiunt sicut antiqui.

LXXX - Vtrum sciant uiri sancti quando uenit in eis gratia Dei.

LXXXI - De exhortatione et doctrina.

LXXXII - Quia doctrina et sine uerbo opere solo confertur.

LXXXIII - Fortiorem esse scientiam experimento operum quam lectionem.

LXXXIV - De Scripturis diuinis.

LXXXV - Nihil loquendum curiosis de Scripturarum quaestionibus.

LXXXVI - De curiositate uitanda.

LXXXVII - De contentionibus euitandis.

LXXXVIII - De silentio.

LXXXIX - De peregrinatione.

$\mathrm{XC}-\mathrm{De}$ fugiendo honore clericatus.

$\mathrm{XCI}$ - De stultitia perfectorum.

XCII - De quieta uita.

1 quia oratio ... prosit om. E uiri perfecti etiam] u. p. et $\mathrm{V}$ ueri et perfecti uel $\mathrm{S}$ prosit] prodest $\mathrm{P} 2$ de reuelationibus] de referationibus $\mathrm{M}$ de reserationibus $\mathrm{V} \quad \mathrm{om}$. $\mathrm{E} \quad 3$ inpugnatio $\mathrm{L}^{2} \quad 5$ reserandis] referendis $\mathrm{L}$ reserendis Deo $\mathrm{E}$ cum] uel PEL et $\mathrm{S}$ omni] in $\mathrm{S} \quad 7$ nocet $\mathrm{L}^{2}$ quaedam om. $\mathrm{E}$ 11 accipiunt] habent MV 12 sicut] qualem $\mathrm{S} \quad 13$ utrum] si add. $\mathrm{L}^{2} \quad$ sciunt $\mathrm{E}$ uiri om. P ueniat LS in eis om. E gratia] -ae M $\quad$-am L ${ }^{4}$ Dei om. PL ${ }^{4}$ 15 et $\mathrm{om}$. PS confertur] confirmat V confortetur L continetur PS post capitulum LXXXII sequitur titulus capitis LXXXVI, quod in loco proprio omittit $\mathrm{E}$ 16 scientia $\mathrm{L}^{2}$ opere $\mathrm{E} 17$ lectionem] -e E electionem $\mathrm{V} 19$ nihil] non $\mathrm{E}$ quaestionibus] testimoniis $\mathrm{E} \quad 21$ contentionis $\mathrm{E}$ euitandis] uitandis VP 25 de stultitia perfectorum om. E 26 de quieta uita om. E post capi-

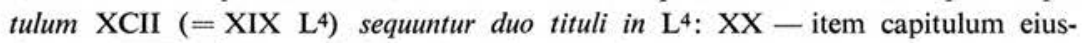
dem $\quad$ XXI - item capitulum de quiete quod oportet sect 〈et) ur. 
XCIII - De eremo et quare fugiant homines ad eremum uel in solitudinem.

XCIV - Quia in solitudine ab omni strepitu summum debeat esse silentium.

$\mathrm{XCV}$ - Quae sit obseruantia eremitae.

$\mathrm{XCVI}$ - De coenobio: quomodo in eo uiuendum sit.

XCVII - Non debere de coenobio in coenobio mutari.

XCVIII - Qui sunt similes unius meriti fratres.

XCIX - Qualis debet esse generalis omnium uita.

$\mathrm{C}$ - Non loquendum de Scripturis sanctis nisi interrogatus.

$\mathrm{CI}$ - De sententiis septem quas locutus est abbas Moyses ad abbatem Poemenem.

[CII - Sententiae patrum Aegyptiorum quas de graeco in latinum transtulit Martinus Dumiensis episcopus.]

1 fugiant homines] fugantur h. E fugiuntur h. $\mathrm{L}^{2} \quad$ h. fugiunt $\mathrm{S}$ ad eremum uel] ad eremo uel $\mathrm{M} \quad o m$. PESL$^{2} \quad 2$ solitudine $\mathrm{MEL}^{2} \quad 3-4$ quia... silentium om. E 3 summum] esse add. repetens postea $\mathrm{L}$ debet PLS 5 quae sit obseruantia eremitae om. E 6 eum E sit om. E 7 coenobio ${ }^{2}$ ] -um VPS mutare EL 8 qui sunt ... fratres om. E unius meriti similes $\mathrm{P}$ fratres $\mathrm{om}$. $\mathrm{PL}^{2} \quad 9$ debeat $\mathrm{E}$ omnium] hominum $\mathrm{E}$ omnis $\mathrm{S}$ 10 non loquendum ... interrogatus $\mathrm{om}$. E non loquendum]non loquendo $\mathrm{P}$ de n. loquendo $\mathrm{L}^{4}$ si loquendis $\mathrm{S}$ de $\mathrm{om}$. $\mathrm{SL}^{4}$ sanctis nisi] quis sit $\mathrm{S} \quad 11-12 \mathrm{de}$ sententiis ... Poemenem om. EL 11 de sententiis] sententiae PS quam MV abbas om. PS 12 Poemenem] Piminionem P Pemenonem S 13-14 sententiae ... episcopus om. PEL 14 dumiensis] cluniensis $\mathrm{V}$ duniensis $\mathrm{S}$ episcopus] expliciunt capitula add. M Finiunt rubricae huius libri dicti seu nominati uulgo Vitas Patrum add. $\mathrm{P} \quad$ expliciunt capitulationes add. $\mathrm{S}$ 


\section{PRAEFATIO}

DOMINO VENERABILI PATRI MARTINO, PRESBYTERO ET ABBATI, PASCHASIVS.

Vitas patrum, Graecorum ut cetera, facundia studiose conscriptas, iussus a te, sanctissime pater, in latinum transferre sermonem, insolito si licuisset operi renituissem. Nec enim umquam quod scribi uel legi possit excludi, ingenii uecordis conscientia prohibente. Scire enim me quod nihil sciam non audeo dicere, ne uerbum hoc, propter hoc uerbum, sapientissimo Socrati subripiam. Sed quia tuae me parere necesse est iussioni utar. Non gloriabor ingenio, fidemque quam tibi debeo etiam in opere iniuncto praestabo. Verum quia eloquentium uirorum sunt plurimae sermone latino conscriptae quarum lectiones me expertem esse te etiam adstruente testificor, si quid de illis aut hic

PRAEFATIO-In praefatione utimur manu scriptis MVPGHRWFB om. ELS 1 Praefatio] incipit p. GH incipit p. in libro Geronticon $\mathrm{P}$ incipit p. praecedentis libelli MV incipit p. Paschasii in uitam patrum B in Christi nomine incipit prologus in uita et collationibus sanctorum patrum F incipit prologus Paschasii in exhortationes monachorum W om. R 2 Domino...Paschasius om. R uenerabili] beatissimo WF patri] petri W om. F presbytero et abbati] episcopo W et om. P om. F Paschasio V 4 tranferre] transtulere $\mathrm{V}$ insolito] in solido $\mathrm{V}$ insolitum $\mathrm{R} \quad 5$ operi] -e GHWFB opus $\mathrm{R}$ aperire $\mathrm{V}$ renituissem] nituissem $\mathrm{V}$ renuissem PGHRWFB neque PGHB scripsi $P \quad 6$ potest GHRWFB excludi] excudi GHB abscondi RWF ingenii] ingenue $P$ in genu $W$ uecordis] cordis $P$ aut $\begin{array}{lllll}\text { cordis GHB uel cordis RWF scire] dicere W } 7 \text { enim om. W } & 7-8 \text { non }\end{array}$ audeo ... surripiam om. RWF 8 sapientissimo] -mos $\mathrm{P} \quad o m$. $\mathrm{H}$ Socrati] -is $\mathrm{H}$ Horatio $d u b$. $\mathrm{P}$ tuae] tu $\mathrm{G}$ tua $\mathrm{HB}$ tibi $\mathrm{W}$ parere] pariter GHB 9 iussioni] -e (tua add. W) GHWB non gloriabor om. W ingenio om. RWF fidem GHRWFB 10 uerum] utrum $F$ eloquentium] -a GRF -ae HW 11 plurimae] -i GHB -orum sup. lin. $\mathrm{R}$ sermone latino] 1. s. HB sermone om. P om. F conscriptae]-i GHB latine add. F quorum GHB lectionis PRWF 12 me expertem] meae (om. H) expertum HRF expertum me $B$ meae e. W adstruentem $P$ testifico $\mathrm{H}$ si quid] sed quia $\mathrm{H}$ hic om. RWF 
insertum forte repereris aut minus eleganter expressum, ne meae culpae reputetur exoro. Quia sicut in dato mihi codice reperi scripta sic 15 transtuli, licet nec ea studiose posse profitear. Vnde restat ut quod te iubente coepi, te orante perficiam. Quae tamen si scribenda decreueris, ut tuo polire sermone digneris exposco. Neque enim mihi liquebit quaedam tibi placuisse, nisi et aliqua displicuisse cognouerim.

\section{I - QVOMODO IN PROPRIA CELLA SOLITARIE VIVATVR}

1 - Quidam frater quemadmodum in cella propria degere debet abbatem Sisoium requisiuit. Cui ille: Comede, inquit, panem tuum et sal et non tibi sit necessitas aliquid excoquendi.

2-Altero quoque idem requirenti respondit: Daniel propheta dixit: «Panem desideriorum non comedi».

3 - Duo simul fratres ad abbatem Pambo uenerunt, ex quibus unus ait: Ego biduanam facio et duo paximatia comedo. Possum in hac continentia saluari an decipior?

13 reperis MV aut] ut $\mathrm{HB}$ eleganter] eliganter MVW eligantur $\mathrm{P}$ diligenter $\mathrm{B} \quad 14$ dato] dalatus $\mathrm{V}$ codice] quo die MV reperi] -is W ea add. HB sic] et add. $\mathrm{P} \quad 15 \mathrm{nec}$ post add. $\mathrm{H} \quad$ studiose] me proferre add. sup.lin. G posse] me proferre add. $\mathrm{H}$ proferre me add. B profiteor HRWB ut $\mathrm{om}$. W 16 qui GHB si $o m$. V scribenda] scrutanda RWF 17 polire] poli P pollere G exposco] exoro B 18 liquebit] libet RWF placuisse tibi HB aliqua] tibi add. RF 19 cognouerim] explicit add. M explicit praefatio add. GB explicit prologus add. F

I-MVPELS Ante quomodo: Incipit textum eiusdem libri MV Incipit liber Geronticon ES solitarie uiuatur] solitarius uiuere debeat EL solitarie $\mathrm{om}$. S 1-MVPELS 1 degere] eligere $\mathrm{V}$ agere $p$. corr. $\mathrm{E}$ deberet PEL 2 Sisoium] Siscarum $V \quad$ Sisonium $P$ comede inquit] i. cotidie $S \quad 3$ sit om. S aliquid om. VP

2-MVPELS 1 alteri PS quoque] quodam $L$ idem $o m$. $L$ requirenti]-di V -e EL respondit] sanctus $\mathrm{S}$ eras. $\mathrm{E} 2$ dixit $\mathrm{om} . \mathrm{V}$ non] nunquam $\mathrm{S}$

3-MVPS om. EL 1 Pambo RW (П $\alpha \mu \beta \omega)$ : Pammo MV Pannom S Pannio $P \quad 2$ biduanam] -num $P$ biduam $S$ paximatia] paxomatia MV papimatia $P$ possim MV 3 hac continentia] h. abstinentia $S$ hanc continentiam $\mathrm{P}$ 
Item alter: Ego quotidie opera mea duabus siliquis uendo, ex quibus parum mihi retineo uictum. Nam reliquum erogo eleemosynam. Possumne propter hoc saluari an decipior? Et his dictis cum ab eo responsum peterent nullatenus illis dabat. Cum autem uellent recedere, postulati a clericis atque audientes quod talis esset consuetudo senis non cito respondendi, restiterunt. Sed uenientes ut ei uale facerent dixerunt: Ora pro nobis, pater. At ille percunctatus est eos si abire uellent. Quibus annuentibus, recordatus opera eorum in semetipsum, scribebat in pauimento: «Pambo, biduanam facis et duo paximatia comedis; propter hoc factus es monachus? Nonne et Pambo operatur quotidie duas siliquas et erogat inde eleemosynam? propterea ergo factum te speras monachum?» Et addidit: Bona quidem opera, sed si sit conscientia cum operibus, tunc enim quis saluus efficitur.

4-Requisitus abba Poemen quemadmodum oporteat ieiunare, respondit: Ego uolo monachum ita quotidie parum comedentem ut non satietur. Nam biduana et triduana ieiunia uanae gloriae uacant. Haec enim omnia examinauerunt senes et inuenerunt quia bonum est sic quotidie parum comedere ut sit et quotidie esurire. Hanc enim uiam regiam leuem nobis esse demonstrauerunt.

4 item] idem $\mathrm{S}$ operam meam $\mathrm{S}$ duobus $\mathrm{S}$ quibus] mihi add. repetens $\mathrm{S}$ 6 -ne] me $\mathrm{S} \quad$ om. $\mathrm{P} \quad$ propter] pater $\mathrm{S}$ hoc om. $\mathrm{S} 7$ peterent] paterent $\mathrm{V}$ 8 postulanti $\mathrm{S}$ quid $\mathrm{S} 9$ restiterunt] restituerunt $\mathrm{V}$ sed] et PS 12 scribebat om. V pauimentum $\mathrm{S}$ biduanam]-a $\mathrm{S}$-um $\mathrm{P}$ duos $\mathrm{P}$ 13 comedes MV propter hoc] propterea $P$ nonne et] qui uero $S 14$ duobus siliquis $\mathrm{S}$ et $\mathrm{om} . \mathrm{M}$ inde] in $\mathrm{S} \quad 15$ ergo $\mathrm{om}$. S factum te speras monachum] s. te f. m. P m. te f. s. S addidit] dicens add. S 16 si om. V enim om. $\mathrm{S}$ saluus om. $\mathrm{S}$

$$
\text { 4-MVPELS } 1 \text { abbas VPS Pemon S } 2 \text { ita } \mathrm{om} . \mathrm{L} \text { comedere P }
$$

3 uanae gloriae] -a g. E -a gloria $P$ uacant] uactant $V$ est $P \quad 4$ enim] autem $\mathrm{E}$ quia] quod LS 5 sic om. ELS ut sit] ut sis Vom. L et $o m$. E 6 leuem] liberam L nobis om. L esse om. E monstrauerunt PELS 


\section{II - DE INRVMPENDO IEIVNIO IN ADVENTV FRATRVM}

1-Abbas Siluanus dum cum discipulo suo Zacharia ad quoddam monasterium peruenissent, fecerunt eos monachi antequam egrederentur parum comedere. Postquam ergo egressi sunt inuenit discipulus eius aquam et uolebat bibere. Cui abbas Siluanus: Zacharia, hodie 5 ieiunium est. At ille: Numquid hodie non comedimus, pater? Et dicit ei senex: Illa esca in caritate erat. Nos autem nostrum ieiunium teneamus.

2-Quidam de patribus ad abbatem Ioseph in Panepho perrexerunt ut eum requirerent de susceptione fratrum, si licet illo tempore uel fiduciam cum his uel laetitiam habere. Et antequam requirerent eum, dicit discipulo suo: Quod facturus sum hodie ne mireris. Et

5 posuit duo sedilia illis qui uenerunt et dicit eis: Sedete - unum a dextris suis et alterum a sinistris. Et ingressus in cella sua misit sibi uestimenta corrupta et egressus sedit in medio illorum. Et iterum ingressus misit alia meliora quae solebat in die festo uti et egressus transiit per ipsos. Et post haec iterum ingressus, quotidianum uesti-

10 mentum suum uestitus uenit et sedit inter eos. Illi autem mirati sunt et obstupuerunt propter hoc factum. Et dicit eis: Sensistis quod feci? Cum autem illi annuissent dicit eis: Et quid feci? Dicunt ei: Primo uestimenta corrupta usus es et postea alia meliora. Et dicit eis: Numquid mutatus sum ex illo inhonesto aut ex illo meliori? Dicunt ei: Non.

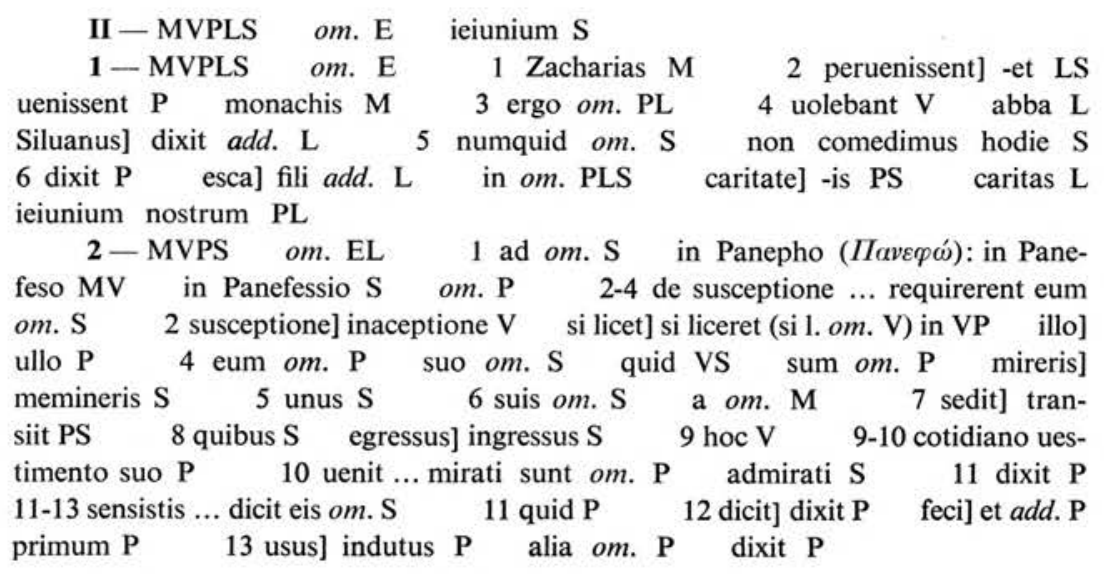


Quibus senex: Si ergo idem ego sum in utrisque et non sum mutatus sicut et illud primum non me nocuit ita nec secundum mutauit. Sic ergo debemus facere in occursione fratrum ut quando eorum praesentia est cum fiducia et laetitia suscipiamus eos. Quando autem soli sumus opus est ut luctus permaneat in nobis. Illi uero audientes quae in cordibus suis habebant, antequam requirerent, glorificauerunt Deum et laeti discesserunt.

3 - Dixit unus senex ad alterum senem habentem caritatem et suscipientem tam monachos multos quam saeculares: Lucerna quidem multis lucet, rostrum tamen proprium incendit.

4-Dicebat unus ex patribus quia inuenitur homo multum comedens et adhuc esuriens continet se. Alter autem parum comedit et satiatur. Qui ergo multum comedit et adhuc esuriens continet se maiorem mercedem habet quam ille qui parum comedit et satiatur.

\section{III - DE VINCENDO DESIDERIO GVLAE}

1 - Dixit quidam senex: Ne quod desideraueris aliquando, manduces. Comedens autem quod tibi transmissum a Domino, gratias ei age.

2-De quodam sene referebant quia desiderauit cucumerem. Quem cum tulisset suspendit ante oculos suos et ne uinceretur ex cupi-

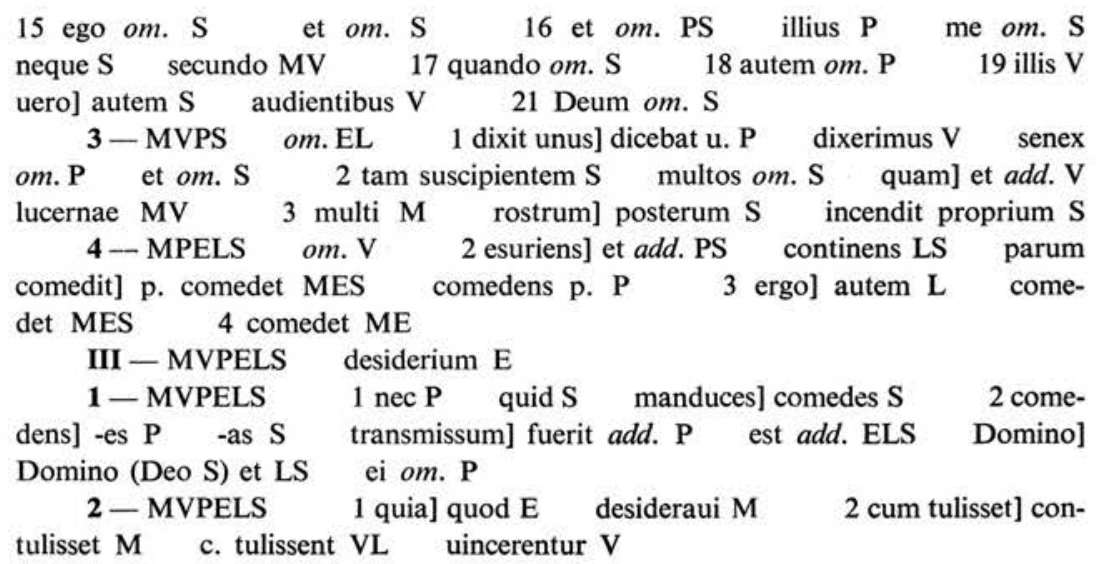


ditate non tetigit eum, sed magis agebat poenitentiam puniens semetipsum ob hoc ipsud quod desiderasset.

3-Abbas Zenon dum ambularet in Palestina fatigatus sedit iuxta eos qui cucumeres de horto leuabant et uolebat comedere ex ipsis. Dicebat autem intra se: «Tolle unum cucumerem et comede. Quid enim est?» At iterum ipse cogitationi propriae respondebat: 5 «Nescis quoniam fures ad poenam uadunt? Experire ergo temetipsum si potes tormenta portare.» Et surgens stetit in caumate dies quinque. Et frixit semetipsum dicens: Vere non possum tormenta portare. $\mathrm{Si}$ ergo non possum portare non debeo furare et comedere.

4-Abbas Arsenius quando poma nata fuissent ex omnibus sibi deferri praecipiens semel tantummodo de singulis agens gratias Deo gustabat.

5 - Quidam ex senibus factus est infirmus et per multos dies non poterat escam ullam suscipere. Conpulit autem eum discipulus suus dicens: Iubes facio tibi paruam placentam? Et iit et fecit. Erat autem uasculum paruum habens mel et alium uasculum simile habens oleum de lini semine expressum. Erat autem fetidum et in nulla re alia proficiebat nisi forte in lucerna. Et deceptus frater misit in escam senis de illo, sperans esse mel. Cum autem gustasset senex nihil locutus

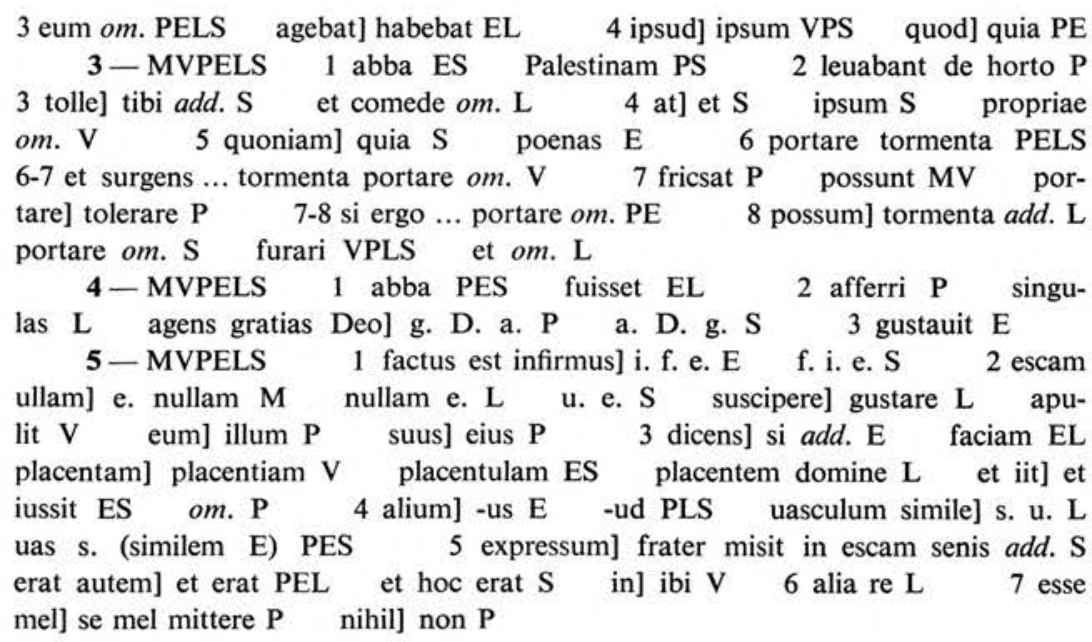


est, sed tacens comedit. Item secunda uice cum eum conpelleret, comedit. Tertia uero uice cum ei daret dicit: Non possum comedere, fili. Ille autem tamquam uolens adhortari eum dixit: Ecce, abba, bona sunt et ego comedo ex ipsis. Et postquam gustauit et sensit rem quam fecerat, cecidit in faciem suam dicens: Vae mihi, abba, quoniam occidi te et tu peccatum inposuisti super me quia locutus non es mihi. Dicit ei senex: Fili, ne contristeris; si enim uoluisset Deus ut mel comederem, mel misisses.

6-Requirebat abbatem Sisoium discipulus suus Abraham si sabbatorum die, facta caritate in ecclesia, tres calices uini monachus debet haurire. Respondit: Si non est ibi Satanas non sunt multi tres calices; si uero ibi Satanas, id est, concupiscentia, iam multi sunt.

7-Dixit abba Poemen: Nisi Nabuzardan princeps cocorum uenisset in Hierusalem, templum Domini non arsisset igne. Hoc autem est: quia nisi desiderium gastrimargiae in anima uenerit, sensus hominis non succenditur in pugna diaboli.

\section{IV - QVIA PERFECTIS MEMORIA CIBI NIMIO DESIDERIO SVBTRAHATVR}

1-Abbati Sisoio frequenter suus dicebat discipulus: Tempus est, pater, ut reficiamus. At ille respondebat: Quidnam, fili, necdum

III, 7 lin. 1-2: Nisi... igne - cf. IV Reg. XXV, 8-9

\footnotetext{
8 item] ita $\mathrm{E}$ iterum $\mathrm{L}$ in add. S eum om. L 10 tamquam om. S uolens adhortari eum dixit] u. optare e. d. S nolens coepit rogare eum et d. L bona $\mathrm{om}$. S 11 postquam] postea quam $\mathrm{L}$ quam rem $\mathrm{V} \quad 12$ suam $\mathrm{om}$. E dicens] et dixit $\mathrm{P}$ quoniam] quia $\mathrm{S} 13$ posuisti PELS mihi om. PELS dixit PL fili] mi add. S 14 ne] non $\mathrm{E}$ enim om. E Deus uoluisset S 6-MVPELS 1 Sisoium] Sisonium PS suus] eius $P \quad 3$ debet] -eret $P$ -eat S 3-4 non sunt ... Satanas om. VE 4 calices] uini add. S si uero] si u. (om. S) est PLS id est] adest L concupiscentiam E iam om. S 7-MVPELS 1 abbas PS Pemon S Nabuzardan] Abuzardan M 2 arsisset] in add. $\mathrm{P}$ igne] -em $\mathrm{P} \quad$-i $\mathrm{S} \quad 3$ est autem $\mathrm{P}$ quia om. E nisi $o m$. $\mathrm{S} 4$ hominis] ut $a d d . \mathrm{S}$ suscendatur $\mathrm{S}$ in pugna] inpugnatione $\mathrm{V}$ IV - MVPLS om. E memoriae $\mathrm{S}$ cibi] sibi $\mathrm{V}$ nimio desiderio] in uno d. S om. P subtrahitur PS 1-MVPLS om. E 1 Sisoio] Sisonio $\mathrm{S}$ frequenter] frater add. $\mathrm{P}$ suus dicebat discipulus] suo $d$. discipulo $M$ dicebat s.d. VS 2 reficiamur PS quidnam] quid autem PS filii LS
} 
comedimus? Ac discipulo renuente: Defer ergo, inquit senex, ut si necdum comedimus manducemus. Desiderium enim Dei obliuionem 5 affert cibi.

\section{V - DE ABSTINENTIA OCCVLTANDA}

1 - Eulogius quidam nomine, discipulus Ioannis episcopi Constantinopolitani, presbyter religiosus nimis, ieiunans semper biduana, frequenter autem et integram septimanam, et tantummodo panem et salem comedens ab hominibus glorificabatur. Hic ergo cum audisset

5 de his qui in Sceti sunt quia magna est uita eorum et sperans ab his aliquid amplius instrui, uenit usque ad Pelusium. Cumque ibi conperisset desertam factam Sceti a Mazicis, contristatus est. Dixerunt autem ei: Quia est magnus senex de Sceti in loco qui dicitur Panepho, Ioseph nomine, uade ad eum. Cum autem peruenisset ad abbatem

10 Ioseph, sperabat aliquid durius in eorum uictu inuenire. Suscepit ergo eum senex cum gaudio et dicit discipulo suo: Quicquid habes adpone nobis hodie propter peregrinos. Et cum sedissent ut comederent, hii qui erant cum presbytero Eulogio dixerunt: Afferte parum salis; presbyter enim res has non comedit. Abba autem Ioseph tacens

15 comedit et bibit. Cum autem tres dies ibi fecisset presbyter Eulogius, nec psallentem audiuit nec orantem uidit senem. Quicquid enim

3 ac discipulo renuente $\mathrm{om}$. S 4 manducemus] comedamus P $4-5$ desiderium ... cibi om. PL 5 cibi] tibi $\mathrm{V}$

V-MVPELS

1-MVPELS 1 Constantinopolitanus L 2 ieiunia E biduanas PLS 3 et $^{2}$ ] om. S tantummodo] tantum S 4 sal L hominibus] omnibus PEL glorificabatur] nimis add. L 5 in om. E magna] magnificata $\mathrm{L} \quad 6$ amplius om. PS Pelusium] Pelasium P cum V ibi] sibi S 7 desertam] -a S uitum $P$ factam] -a ES -um P Sceti a Mazicis] Scitim a m. L Scitimam a Mazinis $\mathrm{E} \quad \mathrm{S}$. amaniazicis $\mathrm{P}$ autem tristitia magis $\mathrm{S} 8$ est om. $\mathrm{S}$ de]

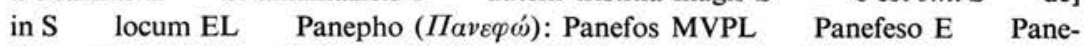
fesos S 10 uictu] -um MV uita $\mathrm{P} 11$ ergo] autem $\mathrm{P}$ om. E dixit PES 12 ut comederent] ubi c. V om. E 13 his M erant] uenerunt L 13-14 parum salis] panem et salem (sal L) EL 14 enim] noster add. $\mathrm{L}$ has res L comedit RW ( $\left.\varepsilon_{\sigma} \sigma i \varepsilon \iota\right)$ : comedet MVPELS abbas VPS tacens om. E 15 et bibit om. P autem om. V tres dies ibi] i. t. d. V add. moram s. scr. L fecisset] -ent $\mathrm{P}$ fuissent $\mathrm{S}$ Eulogius presbyter $\mathrm{P}$ $16 \mathrm{nec}^{1}$ ] neque $\mathrm{S}$ psallentem] eum add. $\mathrm{L}$ nec ${ }^{2}$ ] neque $\mathrm{S}$ uidit om. $\mathrm{P}$ 
faciebat omnia in absconso faciebat. Egressus est ergo inde in nullo iuuatus. Per dispensationem autem Dei facta est nebula in illa die et errantes iam prope uespere uenerunt iterum ad cellam senis. Et antequam pulsarent ostium, audierunt eos psallentes per multas horas. Cum autem pulsassent ostium, iterum tacuerunt. Ingressos autem eos suscepit senex cum magna laetitia iterum. Et quia aestus grauis fuerat, hii qui cum presbytero Eulogio uenerant, tulerunt uas aquae et porrexerunt presbytero ut biberet. Erat autem aqua ipsa mixta marina cum fluuiali. Quam cum gustasset presbyter Eulogius non potuit bibere. Recogitans ergo quae uidisset, ingressus ad senem cecidit ad pedes eius et rogabat eum ut cognosceret conuersationem eius dicens: Quid est hoc, abba, quia dum hic essemus numquam psallebas et post discessum nostrum tam diu uos audiuimus psallentes et iterum uolens bibere inueni aquam salsam? Et dicit ei senex: Frater iste qui mecum est nescio quantum stultus est et per errorem misit illic aquam marinam. Eulogius autem permanebat petens ut cognosceret ueritatem. Et dicit ei abba Ioseph: Illum paruum calicem uini quem bibimus propter caritatem Christi bibimus; hanc autem aquam semper utuntur fratres. Et docuit eum omnem discretionem cogitationum et ut in absconso operaretur si quid boni faciebat et non coram hominibus. Factus est ergo postea mirabilis et comedebat omnia quaecumque ei

17 omnia] omne L om. P est om. ES inde om. PS 18 iuuatus] adiutus L illa die] d. i. P illo die S et om. E 19 uesperam P iterum] itaque S ad] super ES fratres $P$ cellae E 20 pulsassent $L$ per om. E 21 pulsassent] -rent VP -ret E iterum om. L ingressos] -us V -i P -is $p$. corr. L eos] eis p. corr. L om. $\mathrm{P} \quad 22$ suscepit senex cum magna laetitia iterum] s. eos senex i. c. gaudio L $\quad$ s. i. eos (om. S) senex c. gaudio PS susceperunt eos c. gaudio E grauis fuerat] g. fuisset EL f. g. S 23 uenerant] erant ES tuleruntque E 24 ut biberet ... ipsa om. S biberent V ipsa $\mathrm{om}$. PL permixta P 25 quam] aqua S 26 recogitatus $\mathrm{V}$ ergo] autem $\mathrm{E} \quad 27$ et $\mathrm{om} . \mathrm{S} \quad 28$ est $\mathrm{om} . \mathrm{S}$ dum] cum V numquam] non S et $o m$. S 29 nostrum] meum V audiui PS uolui S 30 bibere] et add. $\mathrm{S}$ aquam inueni $\mathrm{E}$ dixit $\mathrm{P} \quad 31$ nescit $\mathrm{S}$ quantum] quam $\mathrm{E}$ stultus] tutus E per] propter E illic om. PLS 32 autem $\mathrm{om}$. S 33 dixit $\mathrm{P}$ ei] et dicit illi add. repetens $\mathrm{S}$ abbas $\mathrm{L}$ paruum] parum MVPEL quod L 34 hanc autem aquam] h. autem (ergo $\mathrm{E}$ om. V) a. VE hac a. aqua LS hac aqua a. P 35 et $^{1} \mathrm{om} . \mathrm{S}$ eum] Deum S om. MV omnem om. P ut om. P 36 operari P si] sic $\mathrm{E}$ quod $\mathrm{E}$ bonum PE hominibus] omnibus E 37 factum L postea om. S comedebat] manducauit $\mathrm{E}$ omnia om. L quaecumque] quae PS ei om. L 
adposita fuissent. Et didicit in absconso bonum opus operari. Et ita iuuatus discessit inde cum gaudio.

2-Abbas Macarius, quotiens cum fratribus facta caritate reficiebat, hoc in proprio corde statuerat ut quantos uini calices oblatos hausisset tantis diebus nec aquam gustaret omnino. Cum ergo fratres uinum ei porrigerent, cum gaudio sumebat ut se siti postea maceraret.

5 Quod cum discipulus eius uidisset, patefacto senis consilio ne ei uinum porrigerent coniurabat, tormenta illi ingeri potius quam pocula manifestans.

\section{VI - DE TOLLERANDA PENVRIA}

1-Abba Theodorus cuidam fratri dicenti: «Volo paucis diebus panem non manducare», respondit: Bene facis. Nam et ego hoc aliquando fecisse conmemini. At ille: Volo ire ad pistrinum et de cicercula farinam facere. Cui beatus Theodorus: $\mathrm{Si}$ ad pistrinum

5 semel ire desideras, fac panem tuum et comede. Quid enim opus est aliis quod panem non gustas agnoscere?

2 - Facta autem congregatione in ecclesia cum esset festiuitas et ceteri comederent, unus ministranti dicit: Quia nihil coctum comedo, sal mihi deferri praecipito. Quo uerbo minister audito, cum clamore

38 fuissent]-et E illi $a d d$. MV ei $a d d$. L et didicit... operari om. L didicit] dicit VE didiscit S operaris E et om. E 39 inde om. L

2-MVPS om. EL 1 abba $\mathrm{S}$ quotiescumque $\mathrm{S} 2$ calices uini S 2-3 oblatos hausisset] ablatos h. P h. o. S 3 tantos dies $\mathrm{P}$ neque $\mathrm{S} \quad$ ergo $\mathrm{om}$. S 3-4 ei uinum fratres $\mathrm{S} \quad 4$ siti se $\mathrm{P} \quad 5$ eiusdem $\mathrm{S}$ consilio senis $\mathrm{S} \quad 6$ porrigeretur $\mathrm{V} \quad$ illi $\mathrm{om}$. PS ingeri potius] p. ingerens $\mathrm{S}$ VI-MVEL om. PS

1 - MVPELS 1 abba Theodorus cuidam fratri dicenti] abba (-as VL) Th. quidam f. d. VEL abbati Theodoro quidam frater dicebat $P \quad 2$ manducare] gustare EL respondit om. S et om. S ego hoc] h. e. S hoc om. MV 3 aliquando] me add. PS at ille uolo ire] ait i. u. ire E agnoscere inquit uolo $\mathrm{S}$ et de $\mathrm{om}$. S 4 cicercula] cecircula $\mathrm{M}$ cercula V cerciculam E circula $\mathrm{L}$ circucola $\mathrm{S}$ si om. $\mathrm{S}$ semel om. $\mathrm{S}$ desiderans $\mathrm{S} 6$ alios PELS quod om. $\mathrm{P}$ panes $\mathrm{P}$ gustas] -ans $\mathrm{E}$ comedas PS agnoscere om. S

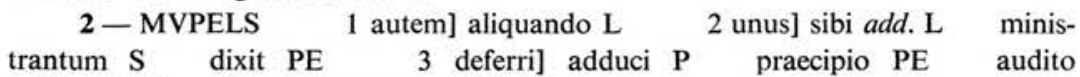
minister PS clamore] magno add. $\mathrm{S}$ 
audientibus ceteris cunctis, alii imperauit dicens: Quoniam coctum frater ille nihil comedit, parum illi salis afferto. Tunc beatus Theodorus dixit: Oportuit te, inquit, carnes in cella tua comedere quam hunc praesentibus omnibus audire sermonem.

\section{VII - NON MANDVCARE MONACHVM SINE QVALICVMQVE OPERE}

1-Quondam aliquis peregrinus uenit ad abbatem Siluanum in monte Sina et uidit quod fratres operabantur et dicit ei: Quare operamini escam quae perit? Maria ergo bonam partem elegit. Tunc senex dicit discipulo suo Zachariae: $\mathrm{Da}$ illi codicem ut legat et mitte illum in cella quae nihil habet. Hora autem nona circumspiciebat si forte uocaret eum senex ad comedendum. Postquam uero transiit hora, uenit ad senem et dicit ei: Numquid hodie fratres non comederunt? Cumque senex fateretur, ait ille: Et quare me non uocasti? Tunc

VII, 1 lin. 2-3: operamini ... perit-cf. Io. VI, 27.

lin. 3: Maria... elegit - cf. Luc. X, 42 .

4 cunctis om. PELS aliis VES imperáuit om. V 5 frater ille nihil] nihil frater $S$ f. i. non $P$ comedet MVPEL afferto] -te $L$ affero $S$ 5-6 beatus Theodorus dixit] b. Th. inquit $\mathrm{S}$ d. b. Th. $\mathrm{L}$ dixit om. PE 6 inquit om. PS in cella tua carnes P 7 hac E praesentibus omnibus audire sermonem] p. fratribus a. S. P praesentis o. a. s. E s. p. fratribus audiri $\mathrm{S}$

VII - MVPELS non manducare monachum sine qualicumque opere] non (s. scr. decet $\mathrm{L}^{1}$ ) manducare $\mathrm{m}$. $\mathrm{s}$. q. (aliquo $\mathrm{P}$ quacumque E) o. $\mathrm{PEL}^{1}$ sine aliquo o. n. manducare $\mathrm{m}$. S

1 -MVPELS 1 quondam] quidam MVPS die quadam $\mathrm{L}$ aliquis] autem $\mathrm{P}$ om. $\mathrm{S}$ peregrinus uenit] p. frater u. ES u. p. frater L 2 montem EL ei] eis $\mathrm{E}$ om. $\mathrm{P} \quad 2-3$ operamini escam quae perit (perit cf. Io. VI,27): o. escam (-a M) quae (qui E) periit MVPE ista o. q. mari pereiuit $\mathrm{S} 3$ Maria ... elegit $\mathrm{om} . \mathrm{S}$ ergo] enim PE autem $\mathrm{L} 4$ senex om. $\mathrm{S}$ dixit $\mathrm{P}$ Zacharia $\mathrm{E}$ illi] ei $\mathrm{S} \quad 5$ illum om. $\mathrm{P}$ cellam PL circumspiciebat] circuminspiciebat L add. uiam (-as E) PES 6 uero] enim L transit EL 7 et om. E dixit $\mathrm{P}$ non om. $\mathrm{S} \quad 8$ ait] at MVP p. corr. $\mathrm{L}$ et om. S uocastis $\mathrm{PE}$ 
ait ad eum abba Siluanus: Tu homo spiritualis es et non necesse habes

10 hanc escam; nos autem tamquam carnales opus habemus comedere et ideo operamur. Tu autem bonam partem elegisti, legis quotidie et non uis carnalem escam accipere. Quod cum audisset ille coepit poeniteri et dicere: Indulge mihi. Tunc respondit abbas Siluanus: Ergo necessaria est Martha Mariae; propter Martham enim Maria

15 laudatur.

2-Abbas Ioannes dicebat fratri suo maiori: Vellem securus esse sicut et angeli securi sunt; nihil operantes sed Deum tantummodo conlaudantes. Et proiecto pallio suo egressus est in eremum. Factaque illic septimana regressus est ad fratrem suum. Cum autem pul-

5 sasset ostium, non illi aperuit frater, dicens: Tu quis es? Et ille dixit: Ego sum Ioannes. Cui ille: Ioannes angelus factus est et non est iam inter homines. Ille autem rogabat eum dicens: Ego sum. Et noluit illi ostium aperire, sed reliquit eum usque dum lucesceret. Mane autem facto dicit ad eum: Homo es et necesse habes operari ut pascaris.

10 Tunc ille proiecit se ante pedes eius et dixit: Indulge mihi quia homo sum et cibum desidero.

\section{VIII - CONTRA SPIRITVM BLASPHEMIAE}

1-Quidam frater inpugnabatur ab spiritu blasphemiae et erubescebat dicere. Et quoscumque audisset magnos senes pergebat ad eos ut illis

9 ait $\mathrm{om}$. EL abbas P spiritalis E necesse habes] h. n. S h. necessariam $p$. corr. L es necessarii $\mathrm{E}$ necessaris $\mathrm{P} \quad 10$ hanc] istam $\mathrm{S}$ opus om. $\mathrm{S} \quad 11$ elegisti bonam partem $\mathrm{V}$ quotidie] codicem $\mathrm{P}$ omni die EL 13 poenitere PLS mihi] abba $a d d$. $\mathrm{P}$ respondit] dixit $\mathrm{P}$ abba LS Siluanus om. P 14 Martham] Martah E enim Maria] M. etiam S

2-MVPELS 1 abba S 2 essem L securi sunt om. S sed] et $\mathrm{P}$ Deum tantummodo] t. D. S Dominum semper t. L 3 laudantes ES pallio] palleto $\mathrm{V}$ est om. S 3-4 facta $\mathrm{S} 4$ septima $\mathrm{S}$ regressus] reuersus $P \quad 5$ qui $E$ et] at PELS 6 angelus om. $S$ est factus $\mathrm{P} \quad 7$ eum om. PELS ego sum om. $\mathrm{P} \quad 8$ illi] ei $\mathrm{S}$ sed] et $\mathrm{L}$ eum] illum $\mathrm{L} \quad \mathrm{om}$. PE usque dum] usquequo PS $9 \mathrm{es]}$ add. aut angelus? P et] an $\mathrm{P}$ sed $\mathrm{E}$ ut] te add. EL pascas $\mathrm{E} 10$ proiexit $\mathrm{L}$ ante] ad PELS $\quad 10-11$ quia .... desiderio om. ELS

VIII - MVPELS

1-MVPELS $\quad 1$ a VP 2 quoscum $\mathrm{E}$ illis] ei $\mathrm{S}$ om. $\mathrm{V}$ 
declararet. Et cum mox peruenisset, iterum uerecundiabatur dicere. Cum ergo frequenter ad abbatem Poemenem ueniret, uidit eum senex habentem cogitationes et dicit ei: Ecce frequenter uenis ad me habens cogitationes et sic iterum remeas tristis, tecum illas reportans. Dic ergo mihi, fili, quid est quod habes? At ille dixit: In blasphemiam inpugnabat me diabolus et erubescebam dicere. Et mox ut aperuit causam, leuior inpugnatio eius apparuit. Et dicit ei senex: Ne contristeris, fili. Quando enim haec ad te cogitatio uenit, dic: «Ego causam non habeo; blasphemiae tuae super te, Satanas; hanc enim causam anima non uult». Quamcumque autem causam anima non uoluerit, non diu permanebit. Et ita sanus frater ille discessit.

\section{IX - DE ORIGINE PASSIONIS CORPORIS}

1-Dixit abbas Moyses: Per has quattuor res passio gignitur: per abundantiam escae et potus, et per satietatem somnii, et per otium et iocum, et ornatis uestibus incedendo.

3 declararent $\mathrm{S}$ cum mox] dum $\mathrm{P} \quad \mathrm{m}$. ut $\mathrm{L}$ cum om. ME peruenisset iterum] i. p. S iterum om. PL uerecundiabatur]-diebatur ME -dabatur (rursus add. S) VPS 4 ergo] autem $\mathrm{L}$ frequenter $\mathrm{om} . \mathrm{V}$ ad abbatem Poemenem ueniret] u. ad a. P. E ad a. P. (Poemen VL om. S) ueniret (perueniret $\mathrm{L}$ peruenisset S) VLS 4-5 uidit eum senex om. S 5 habentem cogitationes] c. h. E habente c. L dixit P 6 tristis] et add. E tecum om. S illud P 7 reportans] -as VEL portans S filii VS habens L dixit om. S 8 blasphemia EL inpugnat PS me om. S erubesco S 8-9 et mox ... apparuit om. P 9 ut om. MES aperuit] illi add. S om. E dixit P 10 non E contristes $\mathrm{L}$ fillii $\mathrm{S}$ enim haec] h. etiam $S$ ad te cogitatio uenit] ad (a E) te cogitatio (om. S) u. ES c. impugnat et $u$. ad te $P \quad 11$ causa $E$ blasphemiae tuae] blaphemiae (-a PE -am S) tua PELS Satanas] -a S Satan E 12 causa E animam $\mathrm{M}$ quamcumque] qua- $\mathrm{EL}$ quae- $\mathrm{S}$ autem] quae $a d d . \mathrm{S} \quad \mathrm{om} . \mathrm{E}$ 13 causa $\mathrm{E}$ animam $\mathrm{L}$ non uoluerit] noluerit $\mathrm{S}$ 13-14 et ita... discessit om. P 14 frater ille sanus S

IX - MVPELS passionis corporis] p. corporeae $\mathrm{P}$ fornicationis uel generibus $\mathrm{E}$ fornicationis $\mathrm{L}$ passionum corporum $\mathrm{S}$

1-MVPELS 1 abba LS gignitur] ignitur $E \quad 2$ abundantia $L$ et potus] et potu $\mathrm{L} o m$. $\mathrm{V}$ et ${ }^{2} \mathrm{om}$. S per ${ }^{2} \mathrm{om}$. E et $^{3} \mathrm{om}$. S per $^{3} \mathrm{om}$. V 3 iocum] locum $\mathrm{V}$ incidendo $\mathrm{E}$ 
2-Item dixit: Corpore multae sunt passiones. Et dicit ei frater: Quae sunt? At ille respondit: Quas Paulus apostolus dicit: «Fornicatio uel inmunditia et omnis cupiditas nec nominetur in uobis sicut decet sanctos». Risus quoque et fiducia frequenter usque ad proe5 lium ueniunt.

3-Dixit abba Poemen: Quemadmodum imperatoris spatharius semper illi adstat armatus, ita et animam aduersus daemonem huiusmodi oportet esse semper armatam.

\section{$X$ - DE EO QVOD OPORTET CONTRA DAEMONES ORANDO RESISTERE}

1-Dixit quidam senex: Sicut uenenata animalia fortiores herbae uel pigmenta expellunt ita et cogitationes sordidas oratio cum ieiunio pellit.

2-Quidam frater requisiuit quendam ex patribus: Quid faciam quoniam cogitationes me inquietant et non me permittunt requiescere una hora et contristatur anima mea? Cui senex respondit: Quando

IX, 2 lin. 2-4: fornicatio... sanctos - cf. Eph. V, 3.

\footnotetext{
2-MVPELS 1 item] idem L corpore] -oreae PS meo add. L multae] mulieris $\mathrm{E}$ passiones] cogitationes $\mathrm{E}$ dixit $\mathrm{P} \quad 2$ at ille respondit om. S Paulus om. S apostolus dicit] d. a. PL a. dixit V a. ait E 3 et] uel E om. S ne VPS in uobis] inter uos E 3-5 sicut ... ueniunt om. E 4 risus] rursus $\mathrm{S}$ quoque $\mathrm{om} . \mathrm{V}$ frequenter fiducia $\mathrm{S}$ usque $\mathrm{om}$. S 5 uenit LS

3-MVPLS om. E 1 dixit abba Poemen] d. a. Pemon S abbas Pemen d. P imperatoris spatharius] s. i. L i. statarius $\mathrm{S} \quad 2$ anima $\mathrm{L}$ huiusmodi om. PS 3 esse semper] s. e. P semper om. LS

$\mathrm{X}$ - MVPLS om. E daemonem LS

1-MVPS om. EL 1 uenenata animalia] u. quaedam a. V uenenum ab animali $\mathrm{P} \quad 2$ sordidas $o m$. $\mathrm{P} \quad 3$ repellit $\mathrm{S}$

2-MVPLS om. E $\left.2 \mathrm{me}^{1}\right]$ meae MVS inquietant] me add. S 2-3 me permittunt requiescere una hora] me p. quiescere u. h. V p. me (om. S) r. u. h. PS p. me u. h. r. L
} 
ueniunt cogitationes in corde tuo ne loquaris cum ipsis. Illarum est enim semper suggerere et non elidunt; non tamen conpellunt. In tua est enim potestate si suscipias. Vides enim quid fecerunt Madianitae? Ornauerunt filias suas et praestiterunt; uim autem neminem conpulerunt; et qui uoluerunt ceciderunt cum ipsis; alii uero irati occiderunt eas. Sic ergo et de cogitationibus sit. Et respondens frater: Quid ergo faciam quoniam infirmus sum et proeliare non ualeo? Ait senex: Considera, et quando incipiunt loqui tecum ne respondeas illis, sed surge et ora et incipe meditari.

Dicit ei frater: Ecce meditor et non est conpunctio in corde meo quia uirtutem uerbi nescio. Cui senex: Tu tantummodo meditare. Audiui enim quod abbas Poemen diceret, sed et alii patres, hunc sermonem: Quoniam incantator nescit uirtutes uerborum quae dicit, sed tamen serpens audiens, intelligit uirtutem uerborum et obaudit et humiliatur. Sic et nos. Etsi uirtutem uerborum quae dicimus ignoramus, sed tamen daemones, audientes, ex timore discedunt.

3-Quidam frater dixit seni: Quid faciam quia inquietant me cogitationes? Cui senex: Quando uult mater ablactare infantem, scillam mittit circa mamillam suam. Et ueniens infans ex consuetudine ad escam ex amaritudine quam gustauerit fugit. Mitte ergo et tu scillam. Cui frater: Et quae est illa scilla quam debeo mittere? Cui senex: Memoriam mortis et tormentorum uenturi saeculi.

4 ueniunt] seminant $\mathrm{L} \quad$ ipsis] illis $\mathrm{P}$ eis $\mathrm{S} \quad$ 4-5 est enim semper] enim $\mathrm{e}$. semper (om. P) PL s. est $\mathrm{S} 5$ suggerere] surgere VL elidunt] negligunt PS 6 est enim] ergo est PS est $\mathrm{om}$. $\mathrm{V}$ enim $\mathrm{om}$. $\mathrm{L}$ potestas $\mathrm{L}$ uide $\mathrm{V}$ enim ${ }^{2}$ ] ergo $\mathrm{S}$ quod $\mathrm{P}$ Madianitae] Moabitae $p$. corr. $\mathrm{P} \quad 7$ praestiterunt] prostituerunt PLS uim] ui $\mathrm{P}$ ubi $\mathrm{S} \quad 8$ irati $\mathrm{om}$. PL 9 et $^{1} \mathrm{om}$. L sit] fit LS respondit $\mathrm{P} \quad 10 \mathrm{ergo} \mathrm{om} . \mathrm{S}$ proeliare] praeualere $\mathrm{S}$ ualeo] possum $\mathrm{P} \quad 11$ et $\mathrm{om}$. VS tecum] tamen $\mathrm{S}$ non $\mathrm{L}$ respondas $\mathrm{S}$ 12 illi $\mathrm{L} \quad 13$ ei] enim $\mathrm{P}$ ecce] ego $\mathrm{S} \quad 14$ uerbi] ubi sed p. corr. ibi $\mathrm{P}$ senex] dixit add. $\mathrm{P}$ tu om. P tantummodo] semper add. L 15 audiuit S enim om. S sed et alii] ad alios $\mathrm{P}$ patres] et add. $\mathrm{V} \quad 16$ quoniam] quem $\mathrm{S}$ cum L uirtutem PS dicunt S 17 audiet $\mathrm{L}$ intelleget $\mathrm{L}$ uirtutem uerborum] -es u. $V$ u. uirtutem $P$ et ${ }^{1}$ om. $S$ abaudit $P \quad 18$ sic] sed V uerborum] eorum PS om. L 19 ex timore discedunt] d. prae t. S 3-MVPELS 3 scillam] siculam $V$ stillam $S$ et] ut $S$ consuetudinem $\mathrm{E} 4$ esca $\mathrm{M}$ amaritudinem $\mathrm{M}$ fugit] -get $\mathrm{E}$ fuit $\mathrm{L}$ et om. P 5 scillam] iscillam $M \quad$ a $V$ illa om. $L$ quem $M L$ 6 memoria VPEL mortis] est add. P uenturi] futuri VPL 
4-Abbas Macarius dum maneret in illa solitudine, qua solus erat, inferius autem altera solitudo plena erat multis fratribus, sera per uiam circuminspiciebat et uidit daemonem uenientem in figuram hominis uestitum tunicam lineam perforatam. Et per singula foramina uascella

5 parua pendebant. Et dicit illi senex: Quo uadis magne? Et respondit ei: Vado commonere fratres hos qui sunt inferius. Cui senex: Et propter quid uascula tot tecum fers? At ille: Gustum fero fratribus; et ideo tanta fero ut si unum non placuerit, ostendam aliud. Si autem et illud displicuerit porrigo aliud; et fieri non potest nisi unum ex his

10 aliquod placeat eis. Et haec dicens discessit. Permansit autem senex iterum uiam circuminspiciens usquequo rediret. Et cum rediret dicit ei: Salueris. At ille: Quo mihi istud uerbum, quia omnes mihi contrarii facti sunt et nullus meis consiliis adquiescit? Et dicit ei senex: Ergo neminem habes amicum? At ille respondit: Vnum habeo amicum

15 uel ipse mihi consentit et quotiens me uiderit huc atque illuc cito conuertitur. Cumque nomen ab eo requisisset, respondit ei: Theopentus dicitur. Discedente illo mox surrexit abbas Macarius et descendit ad inferiorem eremum. Quod cum fratres audissent, egressi sunt illi in obuiam et unusquisque sperans ut apud eum maneret praeparabat 20 se. At ille requirens cellam Theopenti ad eum profectus est. Cumque

4-MVPELS Ante hanc sententiam habent titulum: De inpugnatione (inpugna L) daemonis et usque ad uesperam (-um L) ieiunare EL 1 abba S dum] cum EL maneret] sederet EL 2 altera] alia $P$ erat] est $P$ esset $S$ sero VPEL 3 circumspiciebat PELS uidit $o m$. S figura PES 4 tunica linea perforata PS uascella] uascula VE uasella PLS 5 parua pendebant] p. perpendebant $\mathrm{P}$ pendebat parua $\mathrm{S}$ illi]ei $\mathrm{V} \quad \mathrm{om}$. $\mathrm{P}$ quod $\mathrm{E}$ et $^{2}$ om. E respondit] dixit $\mathrm{P} \quad 6$ ei om. $\mathrm{V}$ admonere $\mathrm{P}$ inferius] interius MV 7 propter quid] p. quod ELS pro quo $P$ uascula tot] t. u. PS feres MEL 9 et ${ }^{1} \mathrm{om} . \mathrm{S}$ illud] aliud $\mathrm{S}$ porrigam ES et ${ }^{2}$ ] etsi L his] illis PELS 10 aliquod] -id S om. P hoc VP discessit] et add. E 11 circumspiciens PELS usquequo] usque $\mathrm{S}$ rediret ${ }^{2}$ ] -sset $\mathrm{P}$ uideret $\mathrm{E} 12$ quo] quod $\mathrm{EL}$ quomodo $\mathrm{V}$ istud] istic $\mathrm{P}$ mihi om. L 13 facti om. E nullis E consiliis meis $\mathrm{S}$ acquiescit] iam eos abbas Macharius admonerat add. $\mathrm{P} \quad$ dixit $\mathrm{P} \quad 15$ ipsum $\mathrm{S}$ mihi] mei $\mathrm{L} \quad 16$ requisisset respondit ei] requisiuisset $\mathrm{r}$. ei $\mathrm{V}$ requisisset et quia $\mathrm{E}$ req. quia PLS Theopentus] Theopintus PL Thepinctus S 17 diceretur PES discedente] discendente $\mathrm{E}$ surrexit] discessit $\mathrm{E}$ abba ES 18 quem $\mathrm{S}$ audissent] uidissent $\mathrm{S} \quad 19$ illi] ei $\mathrm{S}$ in om. $\mathrm{S}$ unusquisque] unusqui E ut] quod PS praeparabat] -ant L -uit E 20 Theopenti] Theopincti S 
cum gaudio illum suscepisset et essent utrique simul soli, dicit ei senex: Quemadmodum tecum, frater? At ille respondit: Orationibus tuis bene est. Et senex: Non nos inpugnant cogitationes? At ille: Interea bene sum. Erubescebat enim dicere. Et dicit ei senex: Ecce quot annis sum in solitudine et ab omnibus honoror; et in hac aetate, cum sim senex, molestae sunt mihi cogitationes. Respondit Theopentus: Crede, abba, quoniam et mihi. Et tunc senex singulas cogitationes quasi inpugnantes se fingebat, usquequo totum illi confiteretur Theopentus. Post haec dicit ei: Quemadmodum ieiunas? At ille dixit: Vsque ad nonam. Cui senex: Vsque ad uesperam ieiuna; et de euangelio uel de aliis Scripturis sine cessatione semper aliquid meditare; et quotiens tibi aliqua cogitatio superuenerit, numquam deorsum aspicias sed sursum; et mox Dominus adiutor tibi est. Et ita discessit in propriam solitudinem. Et iterum uiam circuminspiciens, uidit daemonem euntem et requirit eum: Quo uadis? At ille simili modo: Fratres uado admonere, respondit. Cum autem reuerteretur requisiuit eum: Quemadmodum fratres? At ille dixit: Male, quoniam omnes agrestes effecti sunt et quod de omnibus peius est, et unum quem habui amicum, oboedientem mihi, et ipse nescio unde conuersus est, et de omnibus amplius asperior mihi uisus est, et iuraui non ibi accedere nisi post multum tempus. Et haec dicens discessit daemon.

21 illum om. E utriusque E dixit $\mathrm{P} \quad 22$ tecum] est tibi sup. scrip. $\mathrm{S}$ fratri $\mathrm{S}$ respondit om. $\mathrm{S} 23$ est] esto $\mathrm{S}$ om. $\mathrm{P}$ senex] dixit add. $\mathrm{P}$ non] quam $S$ nos] te VE 24 enim] ei $E$ dicit ei senex] s. dixit $P$ quot] quod ME 25 annis] anni (sunt quibus add. S) VLS sunt V omnibus] hominibus ME 26 respondens E Theopinctus S 27 crede] mihi add. ELS quoniam] quia $\mathrm{S} 28$ quasi] quas $\mathrm{E}$ usquequo] atque $\mathrm{P}$ usque E totum illi confiteretur Theopentus] de toto confiteretur illi Teopintus $\mathrm{P}$ c. i. tantum Theopinctus $\mathrm{S} 29$ hoc $\mathrm{V}$ dicit ei] dixit ei senex $\mathrm{P}$ dixit] ei add. E 30 usque $^{2}$ om. S uesperum MVE 31 uel de aliis Scripturis] siue de alia Scriptura P semper om. S meditare aliquid V 32-33 respicias EL 33 tibi adiutor EL 34 propriam solitudinem] propriam (-a E) solitudine EL uia $\mathrm{E}$ circuminspiciens] circumspiciens $\mathrm{S}$ circumrespexit $\mathrm{V}$ circumspectans PEL 35 requisiuit $\mathrm{S}$ eum om. $\mathrm{S}$ quod $\mathrm{L}$ 35-36 simili modo fratres uado admonere respondit] respondens $\mathrm{s}$. $\mathrm{m}$. uisitare $\mathrm{f}$. $\mathbf{P}$ uado om. EL $\quad 37$ at ille dixit $\mathrm{om}$. S quoniam] quia ES 38 effecti] facti V 38-39 et unum quem habui amicum oboedientem] inueni a. o. q. inimicum ibi $h . S$ et om. PEL amicum om. V 40 mihi asperior V 40-41 non ibi accedere] i. n. a. $S$ ut i. n. -erem $P$ haec] hoc V sic PELS daemon om. PELS 


\section{XI - DE EO QVOD PASSIONES PER ABSTINENTIAM IEIVNII VINCANTVR VEL VIGILIIS}

1-Quidam frater requisiuit quendam senem dicens: Quid faciam quia non possum sufferre cogitationes? Cui senex: Ego in hanc causam numquam inpugnatus sum. Scandalizatus ergo frater ille uenit ad alterum senem et dixit ei: Ecce quid mihi dixit ille senex et scanda5 lizatus sum in ipso, quoniam super naturam humanam locutus est. Dicit ei ille senex secundus: Non simpliciter tibi dixit ille homo Dei hunc sermonem. Vade ergo et age poenitentiam apud ipsum, ut dicat tibi uirtutem uerbi huius. Reuersus ergo frater uenit ad senem et coepit ei dicere: Indulge mihi, abba, quoniam insipienter feci ut non 10 tibi uale dicerem et ita egrederer. Sed rogo te, explana mihi quemadmodum non es inpugnatus. Dicit ei senex: Ex quo factus sum monachus non sum satiatus neque pane neque aqua neque somno. Et horum omnium cogitatio cum mihi inmineret non me permisit sentire pugnam quam tu dixisti. Et egressus est iuuatus frater ab eo.

2-Interroganti iterum cuidam super cogitationes dixit abba Poemen: Monachus si uentrem suum et linguam suam tenuerit et uagationem non fuerit sectatus, confide quia non moritur.

XI - MVPELS qui $S$ passiones] -is quae $S$ abstinentiam] -a $E^{3}$ et add. $\mathrm{P}$ ieiunium $\mathrm{P}$ uincatur $\mathrm{S}$ uel uigiliis om. $\mathrm{P}$

$$
\text { 1-MVPELS } 1 \text { quaesiuit } S \text { quodam sene } E \quad 2 \text { hac causa } E
$$

3 sum] est $\mathrm{S}$ ergol autem PS ille] ipse PELS 4 mihi dixit] $\mathrm{d} . \mathrm{m}$. $\mathrm{V}$ $\mathrm{m}$. dixerit $\mathrm{S} \quad \mathrm{et}^{2} \mathrm{om}$. $\mathrm{E} \quad 5$ humanam om. $\mathrm{S} \quad$ est] et add. $\mathrm{E} \quad 6$ dixit $\mathrm{P}$ ei om. S ille'] illi $\mathrm{S}$ senex om. LS secundo $\mathrm{V}$ non] nunc $\mathrm{S}$ simpliciter tibi dixit] t. s. d. L $\quad$ s. d. t. S ille 2 om. S Dei] tibi sup. scr. L 7 ipsum] eum $P \quad$ ut] et $E \quad 8$ uirtutem] ueritatem MVP huius uerbi LS 9 ei dicere] d. ei $\mathrm{S}$ ei om. $\mathrm{L}$ quoniam] quia $\mathrm{S}$ feci] egi $\mathrm{S}$ 9-10 non tibi uale] t. n. u.S t. uale (ualenter L) non PL t. uel dicere n. E 10 dicerem] facerem $\mathrm{S}$ egrederem $\mathrm{E} \quad 11$ pugnatus $\mathrm{M}$ dicit] respondit $\mathrm{P} \quad 12$ pane neque aqua neque] de $\mathrm{p}$. $\mathrm{n}$. de a. $\mathrm{n}$. de $\mathrm{EL}$ somno] uino $\mathrm{P} \quad 13$ pugnam] respondit frater add. $\mathrm{P} \quad 14$ quam $\mathrm{om}$. $\mathrm{P} \quad$ tu $\mathrm{om} . \mathrm{S} \quad$ est $\mathrm{om} . \mathrm{S}$ iuuatus frater $a b$ eo] i. $a b$ eo f. $V$ f. i. ab eo PLS

2-MVPELS 1 interroganti iterum cuidam super] i. iterum quidam (quidem E) s. MVEL interrogatus i. quidam frater $P \quad 2$ suam om. PE 3 fuit $\mathrm{E}$ sectatus] secutus $\mathrm{E}$ confido MVLS quia] quod $\mathrm{V}$ morietur VES 
3-Duo fratres ad abbatem Eliam uenerunt inpugnati a cogitationibus et uidens eos senex quod corpulenti essent, tamquam ad discipulum suum subridens, ait: Vere, frater, ego erubesco pro te quia sic nutristi corpus tuum, cum certe profitearis te monachum. Pallor enim cum humilitate et macies decus est monachi.

4-Item dixit: Monachus edens multum et operans multum non confidat; qui autem parum edet etiam si parum operetur, confidat et uiriliter agat.

\section{XII - DE FVGIENDIS MVLIERIBVS}

1-Abbas Arsenius cum sederet in Canopo, quaedam mulier, uirgo et diues timensque Deum ac propterea abbatis Arsenii fama conperta de romana ciuitate ut eum uidere mereretur aduenit in Alexandria. Quae cum honorificenti a Theophilo suscepta fuisset, ipsius ciuitatis archiepiscopo, rogauit eum quatenus beato persuaderet Arsenio ut eam suscipere dignaretur. Ipse igitur prius ad eum est profectus episcopus dicens: Quaedam romana mulier, et dignitate et opibus et opinione ceteras antecellens, uidere te ac benedici desiderans de tam longinqua regione peruenit, cui ut occurras exposco. Sed cum non adquieuisset occurrere, illa cognoscens, animalia sua sterni praecepit

3-MVPELS 2 et] cum add. V 3 suum om. S sic] si E 4 enutristi P certe $o m$. S profitearis te] te p. S te $o m$. V

4-MVPELS 1 dixit] quia add. EL monachus om. $\mathrm{P}$ multum edens $\mathrm{S}$ multum operans $\mathrm{S} 2$ autem] aut $\mathrm{S}$ parum ${ }^{1}$ ] paruum $\mathrm{M}$ paucum PELS edit $\mathrm{S}$ operatur $\mathrm{E} 3$ et uiriliter] $u$. et $\mathrm{S}$

XII - MVPELS - fugiendo L

1 - MVPELS 1 abba LS Canopo] Canapo MP Canapeo V Campo $\mathrm{S} 2$ et diues om. $\mathrm{P}$ timens $\mathrm{P}$ ac] atque $\mathrm{S}$ om. $\mathrm{P}$ propter $P$ abbati L 2-3 fama conperta] -am compertam $P$ fama om. E 3 Roma P Alexandriam VLS 4 quam L honorificenti a] -tia V -tia a L honorifice a PES suscepta] accepta P 5 ciuitati E archiepiscopum $\mathrm{S}$ eum om. S persuaderet beato ES 6 ipse om. L igitur] autem $\mathrm{P} \quad \mathrm{om} . \mathrm{V}$ prius om. PELS profectus est $\mathrm{E} \quad 7$ dicens] confido in Deum meum quia uidebo eum add. $\mathrm{S}$ mulier romana $\mathrm{S}$ et ${ }^{1}$ om. $\mathrm{S}$ opibus] operibus $\mathrm{P} \quad 8$ antecellens] antecedens $\mathrm{P}$ te om. $\mathrm{P}$ atque $\mathrm{S}$ benedici] benedictionem $\mathrm{E}$ desiderat $\mathrm{L} \quad 9$ longinquam regionem L 10 agnoscens $\mathrm{E}$ 
dicens: Confido in Deum meum quia uidebo illum nec ab hac intentione fraudabor. Nec enim homines ueni conspicere qui et in nostra supersunt ciuitate, sed prophetam desideraui uidere. Cum ergo uenisset ad cellam beati Arsenii, contigit ut illum foris deambulantem cons15 piceret ac mox ante pedes eius in faciem prona prosternitur. Quam ille cum festinatione suscitans, ita conpellebat: Si faciem meam tantum praeuidere desideras, intuere. Illa uero prae uerecundia non ualebat oculos adtollere. Dicit ergo ei senex: Numquid non de meis actibus conperisti? Illos debueras intuere. Quomodo ergo et nauigare

20 tantum pelagum praesumpsisti? An ignoras te mulierem esse, quibus quocumque non licet exire? An ut Romam rediens, aliis te feminis glorieris uidisse Arsenium ut fiat mare peruium ad me uenientium feminarum? At illa respondit: Si uult Deus nullam huc permittam uenire; sed ut pro me ores et in memoriam me habere digneris exoro.

25 Cui Arsenius: Oro Deum meum, inquit, ut deleat tuam ex meo corde memoriam. Quo illa uerbo hoc recepto in ciuitate regrediens, aegritudine prae tribulatione percepta est. Quam cum uisitationis causa uidisset episcopus et quid rei esset inquireret, illa sermonem illius senis quem ultimum de memoria sui audierat enarrauit, ac propterea se

11 Deum] Dominum V illum] eum PS hac om. E intentione] mea add. E 12 nec om. S enim om. P qui]quia E 13 ciuitates $\mathrm{E}$ sed] et add. S 14 beati om. E illum] eum VL 15 atque S facie PE 16 ille om. L tantum] tanto $\mathrm{L}$ quam $\mathrm{S}$ tempore add. L om. P 17 praeuidere desideras] desiderans uidere $\mathrm{P}$ uidere d. ELS intuere $o m$. E uero] autem $\mathrm{L}$ prae] pro $\mathrm{L}$ ob $\mathrm{S}$ uerecundiam S 17-18 non ualebat oculos] oculos (suos add. L) n. u. PELS 18 ergo ei] ei e. V ergo om. PES non om. S 19 conperisti] coperis te S intueri $\mathrm{P} \quad$ et $\mathrm{om} . \mathrm{S} \quad 20$ tantum pelagum] t. pelagus $\mathrm{S}$-os pelagos $\mathrm{PE}$ pelagum om. L praesumisti $\mathrm{L}$ quibus om. $\mathrm{P} \quad 21$ quocumque non] n. q. $\mathrm{L}$ cuicumque $\mathrm{n}$. $\mathrm{P}$ an ut] aut $\mathrm{E}$ an uero ut $\mathrm{P}$ romanam $\mathrm{V}$ 21-22 aliis te feminis glorieris] glorificeris te a. f. E te om. PL 22 mare peruium] $\mathrm{m}$. prauum $\mathrm{S}$ per mare uiam $\mathrm{L}$ 22-23 feminarum uenientium $\mathrm{V}$ 23 respondit om. S Deus] meus add. L nulla M hic PL 23-24 uenire permittam PES 24 memoria E digneris habere L 25 oro] rogo $\mathrm{E}$ ut inquit $\mathrm{P} \quad 25-26$ tuam ex meo corde memoriam] tua ex c. m. memoriam $\mathrm{L}$ ex c. tuo tuam $\mathrm{m}$. S m. t. ex c. meo E 26 quod L hoc om. PES recepto] comperto $p$. corr. E percepto PS ciuitatem VLS regrediens] ab add. S 27 tribulatione] turbatione $\mathrm{L}$ percepta] correpta PE conperta $\mathrm{L}$ correcta $\mathrm{S}$ quem S 28 et $\mathrm{om} . \mathrm{S}$ rei $\mathrm{om} . \mathrm{S}$ illius] illi L huius E 29 sui] huius senis E sua LS propterea om. S 29-30 se uelle] euelle E 
uelle mori prae tristitia confitetur. Sed episcopus tali eam consolatur alloquio: Numquid nescis te esse mulierem et quia per feminas solet inimicus hominem inpugnare? Ideo uultum tuum ex corde suo deleri dixit; nam pro anima tua Dominum deprecatur. Quibus uerbis recreata discessit.

\section{XIII - PASSIONES CARNALES FAME ET SITI INTERIRI}

1 - Dicebat abbas Moyses: Si uoluerit imperator ciuitatem aliquam inimicorum expugnare, prius escam ipsorum et aquam interdicit et ita inimici eius fame conpulsi subiciunt se regno eius. Ita et passiones carnales: $\mathrm{Si}$ in ieiunio et fame uolueris uiuere, deterrescunt et non sunt fortes aduersus animam.

Quis enim est ita fortis ut leo? Et tamen propter uentrem suum intrat in caueam et omnis uirtus eius humiliatur.

\section{XIV - CONTRA PHILARGYRIAM: DE PERFECTA ABRENVNTIATIONE DIVITIARVM}

1-Quidam iuuenis uolebat renuntiare mundo et frequenter eum egressum de domo sua reuocabant eum cogitationes inuoluentes negotiis. Erat enim diues. Vno ergo die, egresso eo, circumdederunt eum et

30 pro $\mathrm{E}$ confiteretur $\mathrm{S}$ tali eam consolatur] t. e. consoletur $\mathrm{L}$ talia c. E ita ei consolationem tribuebat $P \quad 31$ eloquio $\mathrm{L}$ te nescis $\mathbf{P}$ esse mulierem] m. e. E esse om. L feminas] -a E -is L mulieres $\mathrm{S} 32$ suo om. $\mathbf{P}$ deleri om. $\mathrm{S} 33$ Dominum] Deum $\mathrm{S} 34$ recreata] secreta $\mathrm{P}$ XIII - MVPELS quod (de E) passiones PE interiri] -eant $P$-ire $S$ 1 -MVPELS 1 abba LS 2 prius] primus $\mathrm{E} \quad 3 \mathrm{ita}^{1} \mathrm{om}$. E eius om. EL conpulsi fame $\mathrm{S}$ et ${ }^{2}$ om. E 4 deterrescunt] detrescunt $\mathrm{V}$ 6 enim est] est etiam S est om. EL ita om. L et om. S 7 caueam] cauerna $\mathrm{E}$ omnes uirtutes $\mathrm{L}$ humiliantur $\mathrm{L}$

$$
\text { XIV - MVPELS filargiria (et add. } \mathrm{L}^{1} \text { ) EL }
$$

1-MVPELS 1 abrenuntiare L eum om. L 2 egressum de domo sua] de d. s. e. S semel et bis add. L eum] sup. scr. L om. PES inuoluentes] eum add. EL negotiis] et add. S 3 enim] ualde $a d d . \mathrm{L}$ ergo om. $\mathrm{S}$ eo] et $\mathrm{V}$ circumdauerunt ES eum om. E 
multum puluerem excitauerunt ante eum quatenus reuerteretur ad

5 domum. Ille uero confestim expolians se et iactans uestimenta sua, currebat nudus ad monasterium. Declarauit autem Deus uni seni dicens: Surge et suscipe athletam meum. Exurgens ergo senex obuiauit illi nudo et cognoscens causam admiratus est et dedit illi habitum monachilem. Quando ergo ueniebat aliquis ad senem requirere eum

10 de cogitationibus uariis, respondebat: De renuntiatione autem, dicebat, hunc fratrem requirite, quia ego ad mensuram renuntiationis istius necdum perueni.

2 - Quidam frater renuntiauit saeculo et cum dispersisset pauperibus quaedam sibi retinuit in propriam rationem et uenit ad abbatem Antonium. Quod cum senex conperisset dicit ei: $\mathrm{Si}$ uis monachus fieri, uade in uico et conpara tibi carnes et inpone corpori tuo nudo

5 et sic ueni ad me. Cum ergo hoc fecisset frater, tam canes quam aues omne corpus illius propter carnem rapiendam tam dentibus quam ungulis disrupuerunt. Cum autem uenisset ad senem, requisitus si fecisset quod ei praeceperat, illo autem demonstrante corpus suum laceratum, dicit ei sanctus Antonius: Quicumque renuntiant saeculo

10 et uolunt habere pecunias sic a daemonibus lacerantur.

4 excitauerunt ante eum] a. eum e. E e. daemones a. eum L 4-5 quatenus reuerteretur ad domum] q. euerteretur ad d. V om. $\mathrm{P} \quad 5$ spolians $\mathrm{E}$ 6 monasterio E 7 et $\mathrm{om}$. EL accipe $\mathrm{V}$ athletam] aletam $\mathrm{S} \quad 8 \mathrm{illi}^{\mathrm{I}]}$ ei $\mathrm{P}$ et cognoscens] c. enim L et ${ }^{1} \mathrm{om}$. EL est om. S 9 monachilem] monachalem VPS ergo ueniebat aliquis] e. u. aliqui M enim u. a. VPL a. etiam u. S perquirere PS 10 de renuntiatione autem dicebat] de -em a.d. sup. scr. $\mathrm{L} \quad$ ad renuntiationem $\mathrm{E} \quad$ autem $\mathrm{om} . \mathrm{S} \quad 11$ requirite] requirere $\mathrm{S}$ om. $\mathrm{P}$ ego om. $\mathrm{S}$ renuntiationis] renuntians $p$. corr. $\mathrm{E}$ istius] eius $\mathrm{L}$

2-MVPELS $1 \mathrm{cum}$ ] aliqua $a d d . \mathrm{P}$ aliquid add. $\mathrm{S}$ dispersisset] omnia sua add. $\mathrm{L} \quad 2$ quendam $\mathrm{L}$ retinuit] poenituit $\mathrm{S}$ abbatem] beatum EL 3 reperisset ELS 4 uade] et add. S in uico] ad uicum E carnes $d u b . \mathrm{P} \quad$ et $^{2} \mathrm{om}$. E imponi $\mathrm{L} \quad 5$ et sic ... canes] sic om. E om. $\mathrm{S}$ quem $\mathrm{S} 6$ illius] eius $\mathrm{S} \quad 7$ unguibus $\mathrm{ES}$ disrupuerunt] disruperunt $\mathrm{E}$ diruperunt PS si] quid $\mathrm{S} 8 \mathrm{ei} \mathrm{om} . \mathrm{E}$ ille VP demonstrante] -tem V -trans $\mathrm{P} 9$ ei $\mathrm{om}$. EL sanctum Antonium L renuntiant] -at $\mathrm{L}$-auerit $\mathrm{E} \quad 10$ uoluerit $\mathrm{E}$ pecunias] paciencias $\mathrm{V}$ a] ad $\mathrm{M}$ daemoniis $\mathrm{L}$ laceratur $\mathrm{E}$ 
3-Cum quidam magistrianus ad beatum uenisset Arsenium parentis eius afferens testamentum qui ei amplissimam haereditatem reliquerat, ille uero susceptum eulogium rumpere festinaret, ac magistriano pedibus eius prouoluto et postulante ne rumperet ne ipse caput amiteret, respondit Arsenius: Ego ante illum huic saeculo mortuus sum. Ille autem adhuc modo defunctus est. Ac mox reddidit testamentum, nolens uel quid in eo scriptum esset agnoscere.

4-Quidam frater requisiuit senem: Vis ut retineam mihi duos solidos propter infirmitatem corporis? Et uidens senex cogitationes eius, quod uellet retinere eos dixit ei: Retine. Reuersus ergo in cella frater, coepit cum cogitationibus propriis conluctari dicens: Putas uerum mihi dixit senex an non? Exurgens iterum uenit ad senem rogans et dicens: Propter Deum dic mihi ueritatem, quia conturbor a cogitationibus meis propter illos duos solidos. Dicit illi senex: Quia uidi cogitationem tuam uolentem tenere eos dixi tibi ut teneres. Nam non est bonum tenere plus quam necesse est corpori. Duo ergo solidi sunt spes tua etsi contigerit ut pereant. Numquid Deus non cogitat de nobis? Iacta ergo cogitatum tuum super Deum quoniam ipsi cura est de nobis.

XIV, 4 lin. 10-11: Deus... nobis - cf. I Pet. V, 7.

lin. 11: Iacta... Deum - cf. Ps. LIV, 23.

\footnotetext{
3-MVPELS Ante textum huius apophthegmatis habet titulum: De pecuniis L 2 parentis] -es MVE -ibus PS efferens $E$ qui] quia $P$ 2-6 qui ei ... testamentum] om. MV 2 ei $\mathrm{om}$. P amplissima hereditate L 3 reliquerat] -ant ei $($ om. S) PS relinquerant $\mathrm{L}$ elogium P atque $\mathrm{S} \quad 4$ aduoluto $\mathrm{E}$ et postulante] adpostulante $\mathrm{E}$ ac p. $\mathrm{L}$ atque p.S rumpere $\mathrm{L} \quad 5$ illum huic] illo huc $\mathrm{E}$ sum mortuus $\mathrm{S} \quad 6$ ac] ad $\mathrm{E}$ atque $\mathrm{S}$ reddit $\mathrm{P} \quad 7$ esset] esse $\mathrm{E}$ erat PL agnoscere] -et LS cognosceret $\mathrm{E}$

4-MVPELS 1 senem] dicens add. $\mathrm{S}$ ut] et $\mathrm{L} \quad 2$ et] sed $\mathrm{S}$ senem E cogitationem PELS 3 uollens EL cellam P 4 cum om. ES conluctare EL 5 dixit mihi E non] et add. PES 6 et dicens om. $\mathrm{P} \quad 7$ duos illos $\mathrm{V}$ illi] ei S 8 teneres] retineres PLS 9 corpore MV 10 tua om. S etsi] et $\mathrm{S}$ contigerit] -int ME contigit $\mathrm{S} 11 \mathrm{ergo}$ ] in Deum add. E cogitatum tuum] cogitationem tuam PELS super Deum] in D. S om. E quoniam ipsi] et ipse $\mathrm{S} 12$ est om. S
} 
5-Abbas Theodorus dum esset iuuenis et haberet tres codices bonos spirituales, ad beatum Macarium est profectus dicens: Quid faciam quoniam tres codices habeo? Iubes me illos ad legendum pro meo retinere iuuamine idemque aliis pro instructione praestare 5 an uendere et erogare pauperibus eleemosynam? Cui senex: Vtraque res quidem bonae sunt, sed magis est nihil habere. Quod audiens ille statim ipsos codices uenundauit et pretium illorum praestitit eleemosynam.

6-Quidam monachus euangelium tantum possidens, uendidit eum et esurientibus dedit, dignum quidem memoriae sermonem emittens: Ipsum, inquit, uerbum uenundaui qui mihi semper dicebat: «Vende quae possides et da pauperibus».

7-Requisitus quidam ex patribus si perfectum bonum esset egestas, respondit: Magna res est. Nam qui eam sustinet uoluntarie, tribulationem quidem habet carnis, animae uero requiem. Nam tribulatio et paupertas haec sunt monachi ferramenta.

8 - Aliquando abbatem Arsenium contigit infirmari et pro cura propria nummis paucissimis indigere et cum non haberet unde comederet, accepit ab altero eleemosynam et dixit: Gratias ago tibi, Domine, quia me fecisti dignum propter nomen tuum accipere eleemosynam.

XIV, 6 lin. 3-4: Vende... pauperibus - cf. Mat. XIX, 21; Marc. X, 21; Luc. XVIII, 22.

5-PELS om. MV 1 abba $\mathrm{S}$ dum] cum E 2 spirituales] spiritales $\mathrm{E}$ ad legendum add. $\mathrm{S}$ beatum] abbatem $\mathrm{S}$ est Macarium $\mathrm{L}$ 3 faciam] pater add. L me illos] mihi eos $\mathrm{P} \quad 4$ idemque] eosque PS 5 pauperibus] pretium pro $\mathbf{P}$ pretium $\mathrm{E}$ pretium eius $\mathrm{S}$ elemosina $\mathrm{P}$ 5-6 utraque res quidem] u. r. utique $\mathrm{S}$ uterque q. r. PE 6 magis] maius $\mathrm{E}$ melius $\mathrm{S}$ nihil] non $\mathrm{S} \quad 7$ ipsos] illos $\mathrm{S}$ praestitit] reddidit $\mathrm{E}$

6-MVPES om. L 1 monachorum S euangelium tantum] t. e. E euangeliorum t. codicem $\mathrm{P}$ tantum om. $\mathrm{S}$ uendit $\mathrm{E} 2$ eum] illum $\mathrm{P}$ illud $\mathrm{S} \quad \mathrm{om}$. E quidem $\mathrm{om}$. PES 3 ipsum] illud $\mathrm{P}$ uerbum inquit $\mathrm{P}$ uenundaui] -it $\mathrm{S}$ uenundam $\mathrm{V}$ qui] quid $\mathrm{E}$ quod $\mathrm{S}$ semper mihi $\mathrm{S}$ 7-MVPELS 1 requisitis $\mathrm{L}$ bonorum MV 2 egestans $\mathrm{S}$ magna res] magnum bonum $\mathrm{P}$ est] egestas add. E nam om. E 3 quidem] autem $L$ anima $E$ nam] animae $S$

8-MVPELS 1 Arsenio $\mathrm{E}$ et] cum add. $\mathrm{V}$ om. $\mathrm{S} \quad 2$ indigeret MV 3 ago om. P 4 quia] qui E fecisti dignum] dignum (me add. L) f. PELS eleemosynam om. MV 
9-Cum quidam rogaret abbatem Agathonem ut pecunias in propriam rationem acciperet nolebat dicens: Opera manuum mearum me pascit. Cum autem ille persisteret et diceret uel propter indigentes dignare suscipere, respondit: Duplex uerecundia est:- quia et non indigens suscipio et aliena praestans uanae gloriae subiacebo.

10 - Dicebat abba Paulus Galata: Si aliquas res uoluerit monachus in cella sua habere praeter eas sine quibus non potest uiuere, frequenter cogitur de cella egredi et ita a daemone decipitur.

11 - Hic autem ipse in una quadragesima cum sextario lentis et paruo aquae uasculo perdurauit et unam mattam faciens eandem texebat et retexebat ne tantummodo foris exiret.

12-Quidam frater requisiuit senem dicens: Fac caritatem, abba, et dic mihi sermonem quid debeam in iuuentute mea congregare ut habeam illud in senecta? Cui senex: Aut Christum adipiscere et cogita de te aut certe pecunias ne mendices.

XIV, 12 (cf. lin. 4, lect. uar. post mendices): Deum... mamona - cf. Luc. XVI, 13.

9-MVPELS 1 Agathon ML pecunias] -am $\mathrm{V}$ erogaret add. $\mathrm{E}$ 2 propria ratione $\mathrm{S}$ acciperet] susciperet ELS nolebat] uolebat V solebat $\mathrm{E} \quad 3$ pascent $\mathrm{PS}$ persisteret ille $\mathrm{P}$ et diceret] quid ederet MV om. E 4 quia] qui $\mathrm{E} \quad \mathrm{om}$. V et om. PLS 5 indiget V suscepit E et $o m$. S subiceo EL

10 -MVPELS 1 dicebat] enim add. E autem add. PLS abbas PL Galata] -tas EL galaa MV aliqua ME 2 eas] ea L has MV uiuere non potest $\mathrm{S} \quad 3$ cogitur] cogitat $\mathrm{L}$ egredi] exire EL et ita... decipitur om. L

11 -MVPELS 1 una quadragesima] unam -am $\mathrm{P}$ urna $\mathrm{q} . \mathrm{S}$ cum] tamen V lentis eras. nouissimam silabam E 2 paruae MV aquae] atque $\mathrm{S}$ et] ut $\mathrm{L}$ mattam] martam $\mathrm{V}$ eandem] tandem $\mathrm{P}$ eadem $\mathrm{E}$ 3 texebat] tegebat $\mathrm{P}$ et retexebat] et retegebat $\mathrm{P}$ om. $\mathrm{MV}$ ne] nec $\mathrm{L}$ neque $\mathrm{S}$ foris exiret] e. f. $\mathrm{P}$ foras e. $\mathrm{L}$

12 - MVPES om. L 2 sermonem om. $\mathrm{P}$ in] a $\mathrm{V}$ congregari $\mathrm{M} \quad 3$ illum $\mathrm{V}$ in om. V senecta] -am VP -ute $\mathrm{S}$ senex] ait add. PS aut] ad V om. P 3-4 adipiscere et cogita] aspice et cogitare V a. et (aut E ut P) cogita (-et P) EP $\quad$ c. a. S 4 aut] autem V non E mendices] ergo tuum est eligere: si (aut P) Deum, Deum; aut si (om. P) mamona, mamona add. PE ergo tuum est eligere: Deum aut mamona add. $\mathrm{S}$ 
13 - Frequenter abba Agathon suum discipulum commonebat dicens: Nequando aliquid tibi tale adquiras quod, fratre petente, dare te pigeat et per hoc inueniaris mandatum Dei transgredere.

\section{XV - NIHIL DOLENDVM MONACHO SI ALIQVID AMISERIT}

1-Abbas Macarius cum esset in Aegypto et egressus fuisset de cella sua, reuersus inuenit quendam furantem id quod in cella sua habebat. Stetit ergo et ipse tamquam peregrinus et carricauit animalem cum eo cum multa requie et produxit eum dicens: Nihil in hoc

5 mundo intulimus; Dominus dedit; sicut ipse uoluit et factum est. Benedictus Dominus in omnibus.

2-Quidam frater uicinus cuidam magno seni ingrediebatur cellam eius occulte et quicquid habebat senex furabatur. Cum autem uideret senex non illum arguebat, sed amplius operabatur dicens: Puto frater ille necessarius est. Habebat ergo grandem tribulationem

5 senex ex penuria panis. Cum autem moreretur et circumdedissent eum fratres, ille uidens eum fratrem qui solebat ei furari, dicit ei: Accede

XV, I lin. 4-5: Nihil... intulimus - cf. I Tim. VI, 7.

lin. 5-6: Dominus... omnibus - cf. Iob I, 21.

\footnotetext{
13-MVPES om. L 2 aliquid tibi tale] t. a. tale P tale a. t. S tale om. E fratri petenti PS 3 te om. P inueniaris] ingrediaris E Dei] Domini $S$ transgredere] -gredi $V$-diens PES XV - MVPELS dolendo $\mathrm{L}$ monachum $\mathrm{VL}^{1}$ aliquid] quid $\mathrm{EL}$ admiserit $\mathrm{L}^{3}$

1-MVPELS 1 abba PLS cum] dum PL et egressus] egressusque L et $o m$. E fuisset] est E 3 et $^{1} \mathrm{om}$. S peregrinus] cum eo add. L carregauit S animalem] animal PS et etiam p. corr. L 4 eo] illo PELS requie] patientia PS 5 intulimus] uerum (uere E) enim (om. E) nec auferre quid (om. E) possumus add. EL dedit] Dominus abstulit add. PES et] ita S 6 Dominus] Deus ES

2-MVPELS 1 uicinus] erat add. PELS seni] et add. $\mathrm{P}$ ingrediebatur] in add. PELS 2 cella EL autem] ergo P 3 uidebat E illum] eum $\mathrm{S}$ arguebat] urgebat $\mathrm{V} \quad 4$ ille frater $\mathrm{L}$ necessarius] necessatus $\mathrm{PE}$ necessitatus $p$. corr. $\mathrm{L}$ ne satiatus $\mathrm{S}$ habet $\mathrm{S}$ ergo] autem $\mathrm{P}$ etiam S 5 senex om. ELS et om. L circumdarent E $6 \mathrm{eum}^{2}$ ] illum PS fratrem] frater $\mathrm{L}$ ei ${ }^{1}$ ] eum VE furare EL accede] add. repetens accede $\mathrm{P}$
} 
huc ad me, frater. Et adprehendit manus eius et osculatus est dicens: Gratias ago manibus istis, frater, quia propter eas arbitror me iturum in regno caelorum. Ille autem conpunctus et agens poenitentiam factus est et ipse strenuus monachus ex actibus senis quos uidit.

\section{XVI - QVIA TOLERANTIA PAVPERTATIS IN REQVIEM AETERNAM PERDVCAT}

1-Dicebat unus ex senibus: Nihil inuenimus scriptum de Lazaro illo paupere quod aliquam uirtutem fecerit, nisi hoc tantum quia numquam aduersus diuitem murmurauit, quamuis ille nullam ei misericordiam inpenderet; sed cum gratiarum actione portauit laborem paupertatis suae et ideo in Abrahae sinu receptus est.

2-Item dicebat: Quia non oportet cogitare quemquam nisi de timore Dei. Nam et si coactus fuerit de corporali necessitate esse sollicitus, numquam de ea cogitet ante tempus.

XVI, 1 lin. 1-5: Lazaro... receptus est - cf. Luc. XVI, 20-31.

7 huc ad me] ad me huc L huc om. P aprehendens EL et ${ }^{2}$ om. L est] eum add. PS 8 istis] istius $\mathrm{S}$ hiis $\mathrm{P}$ fratris $\mathrm{S}$ arbitror me] me a. L iterum uel add. S me om. $\mathrm{P} 9$ regno] -um $\mathrm{P}$-a EL et om. MV poenitentiam] et add. E $\quad 10$ est om. S et om. EL

XVI-MVPEL tollerantiam E in] ad E requiem aeternam] -e aeterna MV aeternam om. P perducit ELS

1-MVPELS 1 Lazaro] Eleazaro MPEL 2 illo paupere] i. pauperte $\mathrm{S}$ om. $\mathrm{P}$ aliquam] aliquando $\mathrm{S}$ fecisset $\mathrm{L}$ hac $\mathrm{L}$ tantum] tamen $\mathrm{S}$ 3 illi S nullam ei misericordiam] nulla misericordia ei $\mathrm{E} \quad$ n. m. ei L ei $o m$. PS 4 actionem $\mathrm{L} \quad 5$ suae $\mathrm{om}$. $\mathrm{L}$ sinum $\mathrm{S}$ receptus] susceptus $\mathrm{S}$

2-MVPELS 1 item] idem EL om. S 2 et om. E corporali] temporali $\mathrm{E} \quad 3$ de ea $\mathrm{om} . \mathrm{S}$ 


\section{XVII - NON DEBERE SCRVPVLOSVM ESSE IN LARGIENDO}

1-Quidam presbyter multas eleemosynas faciebat et uenit ad eum quaedam uidua petens parum frumenti. Cui presbyter dixit: Vade et affer uas ut tibi dem. Illa autem cum adtulisset saccum, considerans illum presbyter dixit: Vere grandis est. Et fecit erubescere

5 uiduam mulierem. Cum autem dimisisset eam presbyter, dicit ei quidam senex: Ne uendidisti uiduae frumentum? Dicit illi: Non, sed eleemosynam illud dedi. Cui senex: Ergo qui totum illud eleemosynam dabas, quemadmodum illud paruum quod tibi supra uisum est scrupulosus fuisti et fecisti eam erubescere?

10 Aut nescis quia si aliquis faciat plurima bona et tamen in modico aliquo scrupulositatem illi inimicus inmiserit perdet mercedem operum bonorum quae fecit?

\section{XVIII - DE REPRIMENDA AVARITIA}

1 - Abbas Siluanus dum esset absens a cella sua, discipulus eius Zacharias cum aliis fratribus saepem horti disiecit et fecit hortum maiorem. Quod postquam regressus hoc senex agnouit, tulit melotem suam ut discederet. At illi proicientes se ad pedes eius, propter quod

\footnotetext{
XVII - MVPELS debere] labore $\mathrm{S}$ scripulosus $\mathrm{L}^{1}$ esse] monachum add. $\mathrm{S}$

1-MVPELS 2 paruum $\mathrm{L}$ frumentum $\mathrm{E}$ dixit presbyter $\mathrm{S}$ 3 ut] ubi PELS ille $\mathrm{P} \quad 4$ illum] illam $\mathrm{P}$ om. $\mathrm{S}$ dixit] dicens $\mathrm{V}$ d. (dicit E) ei PE uere] uade $\mathrm{S}$ erubescere] erubere $\mathrm{E} 5$ admisisset $\mathrm{V}$ eam] illam PELS 6 uidua $\mathrm{M}$ illi] ei PEL 7 sed] in add. S senex] si add. EL qui] si $\mathrm{S}$ om. EL tot $\mathrm{M}$ illud'2] illum $\mathrm{P}$ 8 quemadmodum] in add. $\mathrm{P}$ illum $\mathrm{PL}$ paruum correxi: parum codd. 9 et] om. E 10 aut] an $\mathrm{P}$ at $\mathrm{S}$ non scis $\mathrm{S}$ faciat] fecerit $\mathrm{P}$ faciens EL tamen in modico] tantum in modio $\mathrm{S} 11$ aliquo om. EL scrupulositatem illi inimicus inmiserit] scripulosus sit inimico inmitente EL s. ille i. inmiserit $\mathrm{S}$ perdit $\mathrm{V}$ mercedem] mercem $\mathrm{L}$ operum om. PELS$$
\text { XVIII - MVPELS reprimenda] dormienda S }
$$$$
\text { 1-MVPELS } 1 \text { abba S eius om. E } 2 \text { saepem] -e } \mathrm{M} \text { sep- }
$$
tem $\mathrm{V}$ hortis $\mathrm{L}$ disiecit] disiit $\mathrm{V}$ facit $\mathrm{S}$ hortum] $-\mathrm{o} \mathrm{E} 3$ quod $\mathrm{om} . \mathrm{P}$ postquam] propterquam $\mathrm{S}$ est $a d d . \mathrm{P}$ regressus] reuersus $\mathrm{PEL}$ est add. VE hoc om. VELS senex agnouit] a. s. S. senex om. E agnouit om. V melotam $\mathrm{E} \quad 4$ suum $\mathrm{P}$ ille LS ad] in E propter quod] pro quid $\mathrm{E}$
} 
hoc faceret ut diceret postulabant. Tunc senex: Non ingredior, inquit, in cella hac, nisi prius saepis in loco suo fuerit reuocata. Quo mox perfecto ita regressus est.

2-Quidam frater requisiuit senem: $\mathrm{Si}$ mihi debet paucos nummos frater, iubes repetam eum? Cui senex: Semel tantummodo illi dic cum humilitate. At ille: Quod si semel illi dixero et nihil mihi proderit, quid faciam? Tunc senex: Vlterius nihil illi dicas. Et ille: Et quid faciam quia non possum uincere cogitationem meam nisi illi fuero inportunus? Cui senex: Dimitte cogitationem tuam crepare; tantummodo fratrem tuum ne contristeris, quia monachus es.

3 - Abbas Agathon uolentibus conparare opera manuum suarum cum requie uendebat. Pretium autem erat: cribri quidem nummi centum, sportellae uero ducenti quinquaginta; et uolenti conparare dicebat pretium. Et quicquid illi dedisset suscipiebat tacens nec aliquando dinumerans. Dicebat enim: Quid mihi prodest concertare cum illis, ut illi peccent forsitan et iurantes? Et quando mihi superfuerint nummi, erogo illis fratribus. Sed quia Deus non uult talem eleemosynam a me, neque illi placet ut aliquem permittam in sacramento peccare. Et cum illi frater

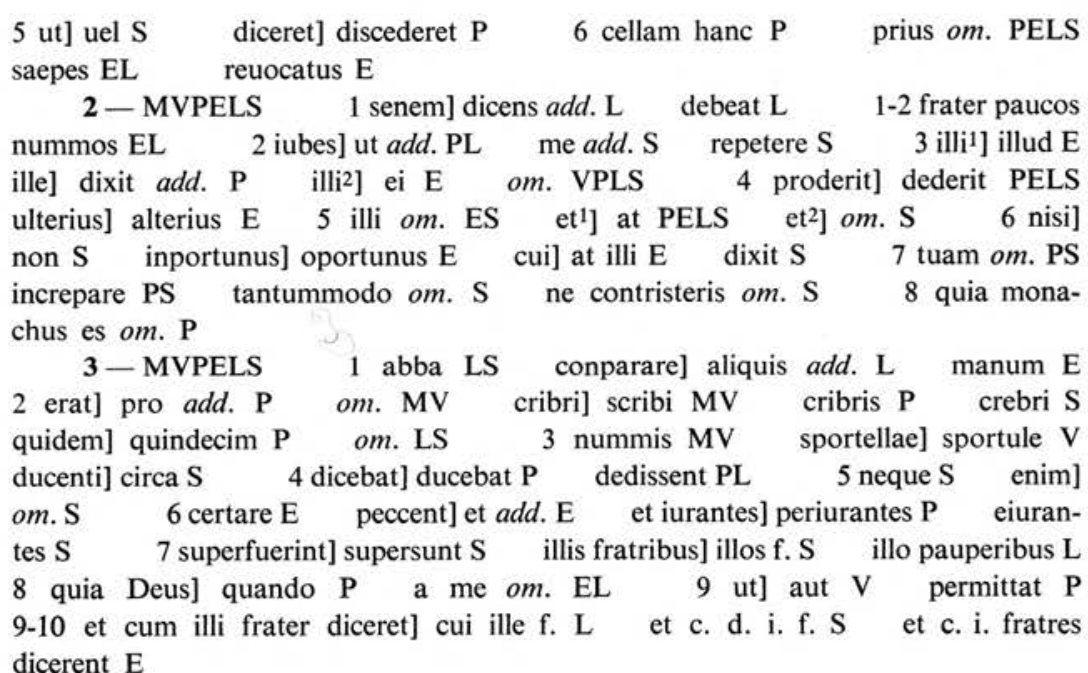


10 diceret: Et panis in cella unde uenturus est? Dicit ei: Quid enim est panis hominis in cella?

\section{XIX - DE VILITATE VESTIS}

1-Abbas Agathon dispensabat semetipsum et in omnibus cum discretione pollebat, tam in opere manuum suarum quam in uestimento. Talibus enim uestibus utebatur ut nec satis bonae nec satis malae cuiquam apparerent.

2-Abbas Arsenius sic ut paene super omnes homines, dum saecularis esset et pretiosis uestibus utebatur; ita constitutus in eremo uiliora uestimenta uti prae ceteris festinabat.

\section{$X X$ - DE ORIGINE IRAE}

1 - Ira per has quattuor res exurgit: Per cupiditatem auaritiae dando et accipiendo, et si quis propriam sententiam amans defendat, et si quis se uult esse honoribus dignum, et si quis doctorem se esse uelit plus omnibus se sapientem sperans. Ira etiam per haec quat5 tuor, humanos sensus obscurat: $\mathrm{Si}$ odio habuerit homo proximum

10 et om. PS panes E cella] tua add. S uenturus est] erit L dicit ei om. PS $\quad 10-11$ quid ... cella] Melius est parum cum timore Domini quam tesauri magni et insatiabiles $\mathrm{L}$ quid etiam, dicit, panis est in cella homini $\mathrm{S}$ 11 enim est panis] p. est e. V e. est ait p. P est om. E in cella hominis P XIX - MVPELS

1 -MVPELS 1 abba ELS dispensauit V et om. S 1-2 cum discretione in omnibus $\mathrm{S} \quad 2 \mathrm{in}^{1}$ ] om. $\mathrm{S}$ opera $\left.\mathrm{E} \quad \mathrm{in}^{2}\right] \mathrm{om} . \mathrm{S} \quad 2-3$ uestimento talibus enim om. $\mathrm{E} \quad \mathrm{nec}^{1}$ ] neque $\mathrm{S}$ bonae nec satis malae] bona nec (neque S) s. mala PELS 4 quemquam L appareret PL

2-MVPELS 1 abba ES sic ut] sunt $\mathrm{S}$ omnes homines] h. o. S omnes om. L 2 et om. PELS 3 uiliori uestimento $\mathrm{P}$ uti] ut S om. V festinauit $E$

XX - MVPELS Contra iram de PS irae om. S

1 -MVPELS 1 ira per] ora propter $\mathrm{S}$ haec PES res om. PS insurgit $\mathrm{V}$ per2] propter $\mathrm{S} \quad 2$ sententiam amans] conscientiam a. se $\mathrm{S}$ 3 dignus E 3-4 doctorem se esse uelit] uult se e. d. S 4 omnibus se sapientem] aliis s. se L omnibus sapientibus P se om. ES speret E etiam om. S hos $\mathrm{V} \quad 5$ sensos $\mathrm{M}$ 
suum, aut si pro nihilo duxerit, aut si illi inuiderit, aut si detractauerit de eo.

Passionis autem huius retributio quattuor modos habet: Primum ex corde, secundum ex facie, tertium ex lingua, quartum ex facto. Si ergo potuerit quis ita portare malum ut non ingrediatur in cor, non peruenit usque ad faciem; si autem uenerit in faciem, custodiat linguam suam ne loquatur illud; quod si locutus fuerit uel hoc custodiat ne reddat in facto, sed mox incidat.

Tres enim gradus sunt in passione irae: nam qui uoluntarie nocetur aut iniuriatur et parcit proximo suo hic secundum naturam Christi est; qui autem nec laedit nec laedi uult hic secundum naturam Adam est; qui uero nocet aut iniuriatur aut calumniam gerit aut usuras exigit, hic secundum naturam diaboli est.

\section{XXI - DE NON RETRIBVENDO MALVM PRO MALO}

1 - Quidam fratres uenientes ad abbatem Antonium postulabant per quem saluarentur audire sermonem. Quibus ille ait: Scripturas audistis? Quae uobis sufficiant scitis. At illi ut ipse quoque aliquid dicere dignaretur instabant. Tunc dicit eis: Dicit euangelium: «Si te percusserit aliquis in dextera maxilla praebe illi et alteram». At illi

XXI, 1 lin. 4-5: Si te... alteram-cf. Mat. V, 39; Luc. VI, 29.

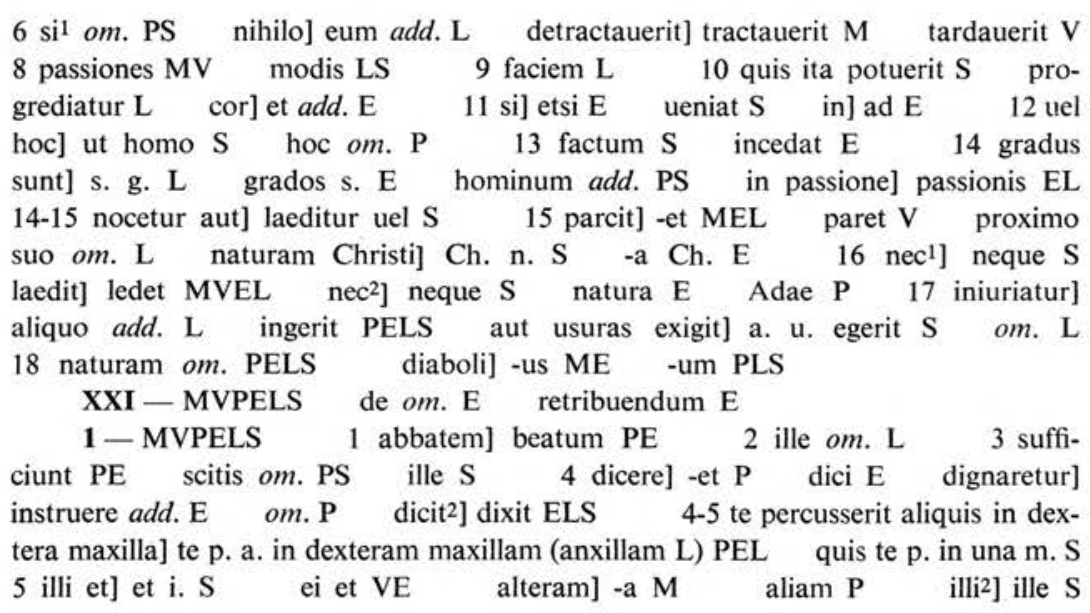


hoc se facere non posse dixerunt. Respondit eis: Si praebere alteram non potestis, uel in illa una iterum si uoluerit feriat. Sed cum nec hoc se posse facere testarentur, dicit eis: $\mathrm{Si}$ ergo nec hoc potestis, ne reddatis pro quod accepistis. Et cum illi idem uerbum quod superius

10 dixerant repetissent, dicit Antonius discipulo suo: Vade, fac illis escas ut comedant; uides enim quod ualde infirmi sunt. Si enim unum non potestis et alterum non uultis, quid a me quaeritis? Necessaria uobis est oratio per quam infirmitas uestra sanetur.

2-Quidam ex fratribus passus ab alio iniuriam uenit ad abbatem Sisoium et contumeliae illi genus exponens addebat: Cupio me uindicare. Senex autem rogabat eum ut relinqueret Deo uindictam. At ille: Non desistam, inquit, nisi me fortiter uindicauero. Cui senex:

5 Quatenus semel hoc statuisti uel oremus. Et exurgens senex, his uerbis coepit orare: Deus, iam non es nobis necessarius ut pro nobis sis sollicitus, quia nos ipsos, sicut iste frater dicit, et uolumus et possumus uindicare. Quod cum frater audisset, ante pedes senis effusus ueniam postulabat, promittens se cum illo cui irascebatur numquam deinceps

10 certaturum.

XXI, 2 lin. 3: Deo uindictam - cf. Rom. XII, 19; Hebr. X, 30.

6 se facere non posse] f. se n. p. P se n. p. f. S altera L 7 in illa una] ille in u. V illam unam PE ut add. EL in om. S uoluerit] noluerit $\mathrm{P}$ feriat] ferat $\mathrm{V}$ ferire PE sustinete (adsustinete E) add. PELS sed] et $\mathrm{P}$ 8 se] ne $M$ om. VE posse facere]f.p.S f. potere $E$ f. non p. dicentes $P$ posse $o m$. L eis om. S nec hoc] haec non S 9 quod $^{1}$ ] quo VPS accipitis ES illi] ille $\mathrm{S} \quad$ nec add. $\mathrm{V}$ 9-10 repetissent quod superius dixerant $\mathrm{S}$ 10 dicit] dixit $\mathrm{E} \quad$ uade] et add. $\mathrm{S} \quad 11$ uidens $\mathrm{E} \quad 12$ a] ad VL om. $\mathrm{P}$ requiritis PELS 12-13 est uobis $\mathrm{S}$

2-MVPELS $\quad 1$ quidam ex fratribus passus ab alio iniuriam] q. ex f. p. $\mathrm{ab}$ aliis i. V quandam enim fratri ab alio iniuriatum L 2 Sisoium] Sisonium $\mathrm{S} \quad$ om. $\mathrm{V}$ contumelia $\mathrm{L}$ illi genus exponens] illius g. e. $\mathrm{P}$ g. illius exprimens $\mathrm{S}$ genus $\mathrm{om}$. $\mathrm{L}$ exponens om. MV addebat] aiebat $\mathrm{P}$ dicebat S cupio] enim add. L 3 autem] uero P 4 fortiter] forte S 5 quatenus] quia $\mathrm{P}$ semel hoc] h. in animo s. EL in animo add. PS 6 non es iam S 7 ipsi PELS sicut] et add. S uolumus] nolumus $\mathrm{V}$ possumus] possimus $\mathrm{V} \quad$ nos add. $\mathrm{P} \quad 8$ audisset frater $\mathrm{E}$ senis] -i E eiusV 8-9 effusus ueniam postulabat] e. iacens u. illi postulabit $\mathrm{L} \quad 9$ promittens] enim add. $\mathrm{L}$ qui $\mathrm{E}$ irasceretur $\mathrm{L}$ 
3-Quidam frater dum ab altero iniuriaretur, uenit et renuntiauit seni. Cui respondit: Satisfac cogitationi tuae, quoniam frater non te uult iniuriari sed peccata tua submittunt illum.

Nam in omni tentatione quae tibi contingit per hominem, ne arguas eum, nisi tantummodo dic: Quia propter peccata mea contingunt mihi haec.

\section{XXII - DE RETRIBVENDO BONVM PRO MALO}

1 - Dicebat frequenter abba Poemen: Malitia malitiam numquam exuperat; sed si quis tibi male fecerit, tu illi bonum reddito, ut per bonitatem uincas malitiam.

2-Quidam frater quantum plus eum aliquis iniuriabatur aut incitabat, tantum magis ille currebat ad eum dicens: Isti sunt qui nobis occasionem praebent ad profectum nostrum; qui autem beatificant nos, conturbant animas nostras. Scriptum est enim: Quoniam hii qui beatificant uos decipiunt uos.

3 - Alter senex si quis detraxisset ei ille festinabat, si uicinus erat, per se ipsum bene illum remunerari. Quod si longius manebat, transmittebat ei munera.

XXII, 2 lin. 4-5: hii... uos - cf. Es. III, 12.

3-MVPELS 1 dum] cum $\mathrm{E}$ iniuriatur $\mathrm{M}$ nuntiauit $\mathrm{S} 2$ cui] ille add. PEL cogitationis $\mathrm{E}$ tuae] et dic add. $\mathrm{L}$ quoniam] quia $\mathrm{S}$ frater] iste add. $\mathrm{L} \quad 3$ te] me $\mathrm{L}$ tua] mea $\mathrm{L} \quad 4$ nam] non $\mathrm{P}$ iam $\mathrm{S}$ et $a d d$. $\mathrm{L}$ contigit VPEL non $\mathrm{S} 5$ quia] qua $\mathrm{L}$ quod $\mathrm{S}$ contingunt] contigit $\mathrm{E}$ contigunt $\mathrm{L}$

XXII - MVPLS om. E Titulus bis inuenitur in $\mathrm{P}$ retribuendum $\mathrm{M}$ bono $\mathrm{P}$

1-MVPELS 1 frequenter om. P abba] -s V om. E malitia malitiam] -am malitiae L malitiam om. P 2 exuperet PL sed om. V male] mala E mali aliquid S redde PES 2-3 per bonitatem] pro bonitate $\mathrm{L}$

2-MVPELS 1 eum] enim $\mathrm{L}$ aliquis om. V iniuriabat $\mathrm{P}$ 2 tanto VPLS illum E 4 quoniam] omnes E $5 \operatorname{uos}^{1}$ ] nos VE uos $\left.^{2}\right]$ nos VE

3-MVPELS 1 ille om. $\left.\mathrm{S} \quad \mathrm{si}^{2}\right]$ ei add. $\mathrm{S}$ uicinus erat] u. ei erat (satis add. P) PEL $\quad 2$ bene illum remunerari] honore $\mathrm{P} \quad$ b. ixiunare $(d u b$.) illum S 


\section{XXIII - DE NON RESISTENDO INIMICIS}

1-Quidam frater interrogabat abbatem Sisoium dicens: $\mathrm{Si}$ latrones aut barbari super me inruerint occidere me uolentes, et ego si praeualere potuero, iubes occidam? Cui ille respondit: Ne facias, sed totum Deo trade. Quicquid enim tibi aduerse contigerit, profitere

5 hoc tibi propter tua euenire peccata. Si quid boni uero fueris adsecutus diuinae dispensationi totum debes adscribere.

2 - Erat quidam eremita magnus in monte qui dicitur Athlibeus et uenerunt super eum latrones. Cum autem ille uocem fecisset, de uicinis locis alii fratres confluentes conprehenderunt eos quos transmissos in ciuitate, iudex misit eos in carcerem. Fratres ergo alii maesti-

5 ficati sunt quia propter ipsos latrones traditi essent et uenientes ad abbatem Poemenem renuntiauerunt ei factum. Qui scripsit ad eremitam dicens: Reminiscere primam proditionem unde facta est et tunc secundam uidebis proditionem. Nisi enim proditus fuisses ab interioribus tuis, secundam proditionem numquam perpetrasses. Quo

10 ille sermone conpunctus, cum esset in omni illa regione nominatus et

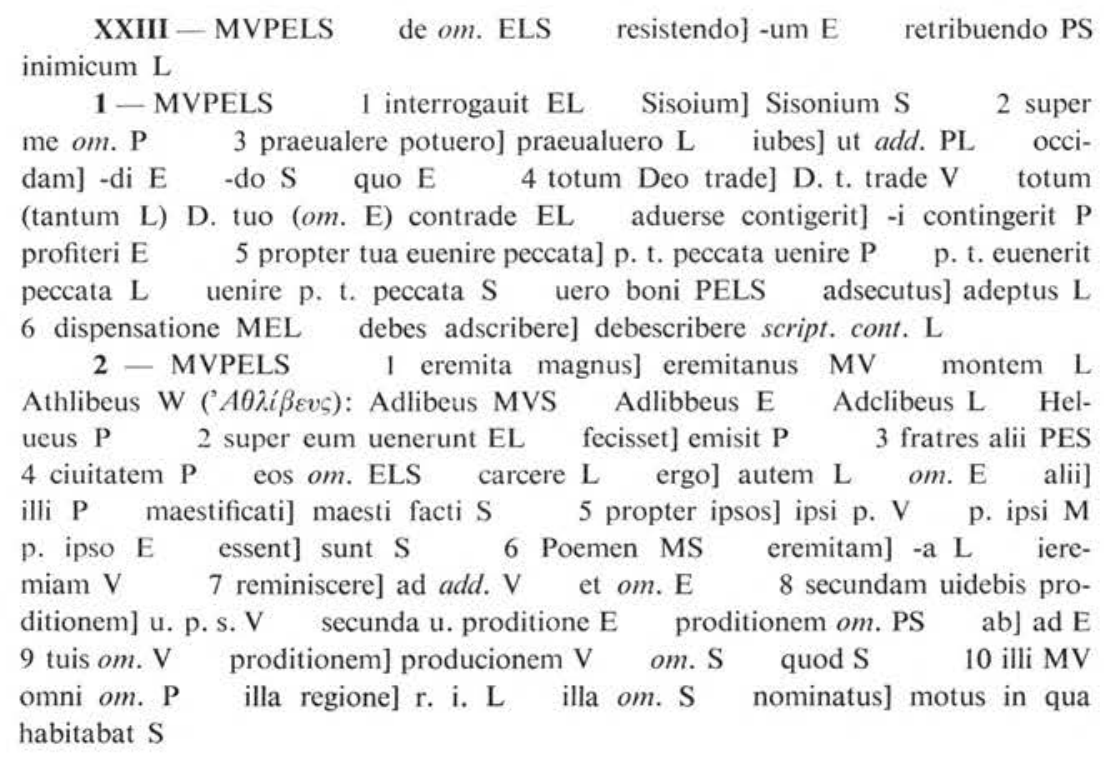


per multum tempus de cella sua non exiens, exurrexit et uenit in ciuitatem et excutiens latrones de carcere, publice liberauit eos.

\section{XXIV - DE PERFECTA PATIENTIA}

1 - Cuiusdam philosophi discipulus peccauit et dum sibi peteret indulgeri, dicit ei philosophus: Non tibi indulgeo nisi his tribus annis portabis onera aliorum. Cui reuerso post tres annos, cum imperata fecisset, dicit ei philosophus: Nec adhuc tibi indulgeo, nisi aliis tribus annis dederis mercedem his qui te iniuriis et conuiciis adfligant. Quod etiam cum ille conplesset, remisso peccato eius, dicit ei magister suus: Veni modo et ingredere Atheniensium ciuitatem ut illic sapientiam possis ediscere. Erat autem illic quidam senex sapientiae studiosus et sedebat ad portam, omnesque ingredientes, experiendi causa, conuiciis adfligebat. Qui cum idem iuueni illi ingredienti faceret, ille exorto cachinno risit. Cui senex: Quid hoc, inquit, est? Ego te, inquit, iniurio, et tu rides? Cui iuuenis ait: Et non uis ut rideam, cum tribus his annis mercedem dederim ut hoc paterer quod hodie gratis accepi? Cui senex: Ingredere ergo ciuitatem quia dignus es. Hoc autem solebat abbas Ioannes refferre et his ipse addebat: Haec est porta Dei per quam patres nostri in multis iniuriis gaudentes ingressi sunt ciuitatem.

2-Quidam frater requisiuit senem dicens: Dic mihi unam rem quam custodiam et saluer per ipsam. Respondit ei: $\mathrm{Si}$ potueris

11 per om. $\mathrm{L}$ tempus multum $\mathrm{S}$ sua om. $\mathrm{P}$ exurrexit et] et surrexit PEL et $\mathrm{om} . \mathrm{S} \quad 12$ ciuitate ME publice $\mathrm{om}$. S

$$
\text { XXIV - MVPELS }
$$

1-MVPELS 1 philosopho $\mathrm{L} 2$ dixit $\mathrm{S}$ his om. $\mathrm{S} 3$ portaueris PELS quo PS reuersus $\mathrm{V} 4 \mathrm{ei} \mathrm{om.} \mathrm{S} \mathrm{neque} \mathrm{S} 5$ iniuriis et conuiciis] i. conuiciisque $P \quad$ i. contumeliis $S \quad o m$. $V$ affligunt $E L$ 5-6 quod etiam cum ille conplesset] quo e. conplesset ille $E$ 6 eius] eis $P$ illo $E$ dixit $\mathrm{S} 7$ modo] ergo $\mathrm{L}$ et om. VL atheniensium] ueniensium $\mathrm{P}$ 8 ediscere] discere VP edicere EL adiscere S quidam om. P sapientia PE 9 ingredientes om. S 10 idem] eadem PS ingredienti] gradiendi $\mathrm{E} \quad$ ille] autem add. EL 11-12 quid hoc ... iniurio om. P 11 hoc inquit est] e. h. i. L h. e. i. et (om. S) ES inquit ${ }^{2} \mathrm{om}$. ELS 12 iniurior S ridam EL 13 his om. PEL dederitus V suscepi $\mathrm{S} 14$ cui] tunc PELS 15 ipsi E quem L 16 ciuitatem] Dei add. PELS 2-MVPLS om. E 2 et] ut $\mathrm{S}$ respondit ei om. $\mathrm{S}$ potuerit $\mathrm{V}$ 
iniuriari et affici conuiciis et portare ac tacere, magna est haec res super alia mandata.

3-Quidam uidens laboriosum portantem in lecto mortuum, dicit ei: Mortuos portas? Si uis melius facere, uiuos porta.

4 - Interrogantibus quibusdam fratribus abbatem Moysen sermonem, ille hortatus est discipulum suum Zachariam ut eis aliquid diceret. Tunc ille pallium suum deposuit sub pedes suos, conculcauit illud et dixit: Nisi qui sic fuerit conculcatus, monachus esse 5 non potest.

5-Abbati Ammoni prophetauit beatus Antonius dicens: Multum habes in timore Dei proficere. Et educens eum de cella, ostendit illi lapidem et dicit ei: Vade et iniuriare hunc lapidem et caede illum. Qui cum fecisset, requirente beato Antonio si ei lapis aliquid respondisset,

5 dixit: Non. Cui beatus Antonius: Ita et tu ad hanc mensuram peruenturus es ut nullam tibi arbitreris iniuriam.

Hic autem Ammon per quattuordecim annos in eremo Sceti, tam diebus quam noctibus orauit Deum ut illi donaret iracundiam uincere.

3 iniuriari et affici conuiciis et portare ac tacere] i. et conuiciis adfligi et p. ac t. P iniurias portare et $t$. et a. c. S 3-4 est haec res super] h. est $r$. $s$. omnia $\mathrm{S}$ 4 alia] omnia $\mathrm{L}$

3-MVPELS 1 laboriosum portantem] alium cum laborem portante L

4-MVPELS 1 item interrogantibus $E$ quibusdam] quidam ex (om. E) ELS abbate E Moysen] Moyse E dic nobis pater alicum add. L 3 suos] et add. PELS 4 illum $\mathrm{S}$ et om. L nisi om. P qui sic] quis $\mathrm{S}$ add. non $\mathrm{PL}$ conculcatus fuerit $\mathrm{E}$

5-MVPELS 1 abbatem Ammon L prophetauit] profuit EL 2 habens L eum] illum $\mathrm{S}$ cella] sua add. LS illi] ei $\mathrm{E} 3$ dixit $\mathrm{S}$ iniuriari E et ${ }^{3}$ ] dicit illi add. S qui om. E 4 lapis aliquid] a. 1. P lapidem a. E 5 dixit] ei add. ES beatus] abba ES abbas PL Antonio $\mathrm{E}$ et om. $\mathrm{S}$ peruentum $\mathrm{S} \quad 6$ ut] et $\mathrm{E}$ tibi arbitreris]

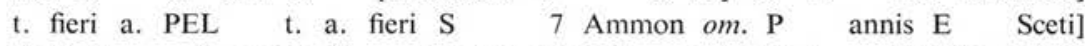
stetit $\mathrm{S} \quad 8$ orabat $\mathrm{S}$ donaret] daret $\mathrm{P}$ ut add. L $8-9$ iracundiam uincere] i. uinceret $\mathrm{L}$ uirtutem uincendi i. $\mathrm{P}$ 
6-Dicebat abba Macarius: Ille uerus est monachus qui se in omnibus uincit. Nam si alium arguens, ad iracundiam moueatur, quis propriam passionem implet? Nec enim ut alterum saluet se debet perdere.

\section{XXV - DE TENTATIONE PATIENTIAE}

1-Quendam fratrem sub praesentia abbatis Antonii alii conlaudabant. Sed cum tentasset eum senex, repperit quod non sufferret iniuriam et dicit ei: Tu quidem, frater, similis es aedificio quod quamuis habeat ingressum ornatum, per posticum tamen a latronibus expoliatur.

2-Quidam ad abbatem Agathonem uenerunt, audientes de eo quod et magnam haberet discretionem et numquam irasceretur. Et uolentes tentare eum dixerunt illi: Tu es, Agathon, superbus et fornicator? At ille dicebat: Ego sum. Cui addebant: Tu es, Agathon, latro et detractor? Et iterum respondit: Ego sum. Dicunt ei tertio: Tu es, Agathon, haereticus? At ille respondit: Non sum. Et coeperunt eum rogare: Quare in illis prioribus confessus es, hunc sermonem non potuisti portare? Dicit eis: Priora quae dixistis adscribo mihi pro iuuamine animae meae; haereticum autem esse diuidi est a Deo et nolo ab eo separari.

6-MVPLS om. E 1 abbas VP est uerus L 2 amoveatur S 3 neque $\mathrm{S}$ enim] conuenit add. $\mathrm{L} \quad$ se] seipsum $\mathrm{L} \quad 4$ debet perdere] perdat $\mathrm{L} \quad$ d. prodere $\mathrm{S}$

XXV - MVPELS

1 -MVPELS 1 quidam $\mathrm{E}$ praesentia] -iam $\mathrm{M}$-ti $\mathrm{E}$ abbatis] beati PE alii om. MV 2 sed cum tentasset eum] s. c. tentassent e. MV om. S reperiit VE 3 dixit PELS 4 habeat om. MV per] et MV 5 expoliatur] expilatur E

2-MVPELS 1 quidam ad abbatem Agathonem uenerunt] q. fratres u. ad a. A. L ad om. E 2 et $^{1} \mathrm{om} . \mathrm{L} \quad 4$ at ille ... addebant $\mathrm{om} . \mathrm{P}$ dicebat om. S cui addebant] c. ille dicebant $\mathrm{E}$ c. etiam illi a. L etiam illi dicebant $\mathrm{S} 5$ latro] flagellator $\mathrm{E}$ et iterum] et ille $\mathrm{P}$ at ille $\mathrm{S}$ ei om. E 6 at ille om. E $\quad 7$ in $\mathrm{om} . \mathrm{S} \quad$ prioribus] sermoniis et add. L es] est et $\mathrm{S} \quad$ hunc] autem $a d d$. PEL 8 dicit] dixit $\mathrm{P}$ adscribi $\mathrm{E} \quad 9$ pro] propter MV iuuamen $\mathrm{V}$ haeretico $\mathrm{S}$ autem esse] e. a. V autem om. E a Deo] ab eo M $10 \mathrm{ab}]$ ad E 
3 - Abbas Moyses, quando factus est in Sceti presbyter coopertus est ab episcopo in ipsa ordinatione pallio albo. Et dicit ei episcopus: Ecce abbas Moyses factus est totus candidus. Erat enim niger in corpore. At ille respondit: Putas, domine pater, sicut de foris albatus 5 sum, ita ab intus aliquando candidus effici possum? Volens autem episcopus tentare eum, dixit clericis: Quando ingreditur ad altare, expellite eum et sequatur unus aliquis ut audiat quae dicit. Cum ergo ingressus fuisset expullerunt eum cum iniuria dicentes: Egredere foras, aethiopus. At ille egressus sibi ipsi dicebat: Bene tibi fecerunt,

10 cinerate, nigricori; cum enim non esses homo, quare ingressus es inter homines?

4-Iterum patres in Sceti uolentes tentare eum, uelut contemnentes eum dixerunt: Quare iste aethiopus ingreditur inter nos? Ille autem audiens tacuit. Postquam uero discesserunt, dicit ei unus: Abbas Moyses, non es conturbatus in uerbo illo? At ille ait: Etsi conturbatus sum, non sum locutus.

\section{XXVI - NON LOQVENDVM IN IRA}

1-Quidam frater requisiuit abbatem Isaac dicens: Abba, quare te daemones ita timent? Respondit senex: Ex quo factus sum mona-

3-MVPELS 1 abba PS et p. corr. L est om. S Sceti] Scito P opertus L 2 est om. P ab episcopo in ipsa ordinatione] in i. o. ab e. EL ab ipso episcopo (om. P) in i. o. PS dicit ei] dixit EL 3 abbas] abba ELS om. P Moysi E factus est totus] f. es t. P t. es f. S candidus] albus $\mathrm{S}$ 4 de foris albatus] de f. dealbatus EL dealbatus de f. S 5 sum om. $\mathrm{S}$ candidus $\mathrm{om}$. $\mathrm{V}$ possim $\mathrm{L}$ autem om. ES 6 ingredietur $\mathrm{V}$ altarem $\mathrm{E}$ 7 eum] illum ELS aliquis] eum $\mathrm{S}$ om. $\mathrm{P} \quad 8$ eum] illum $\mathrm{P}$ dicentes] ei add. $\mathrm{P} 9$ aethiopus] e..iope $\mathrm{E}$ aeziope $\mathrm{L}$ aethiops $\mathrm{PS}$ egressus $\mathrm{om}$. $\mathrm{S}$ ipsi] ipse MV ipso $\mathrm{E} 10$ cinerate] cinerente $\mathrm{PE}$ cinerenti $\mathrm{S}$ nigricori] nigricore $\mathrm{E}$-iori $\mathrm{L}$ nigrae cori $\mathrm{P}$ nigri coloris $\mathrm{S}$ enim] igitur $\mathrm{V}$ ergo EL

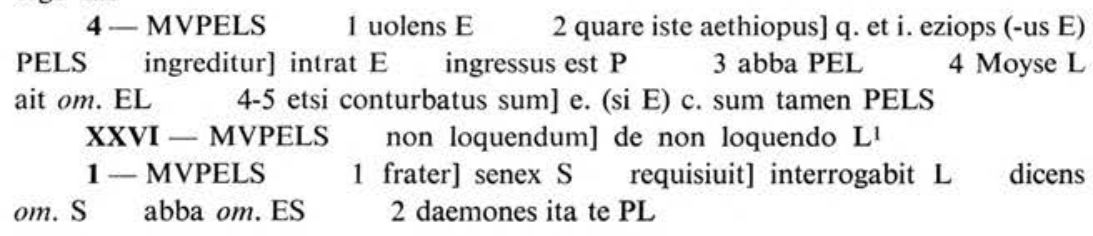


chus, statui apud me ut iracundia mea foris guttur meum non procederet. Et ideo timent me daemones.

2-Cum uenisset quidam de patribus ad abbatem Achilam, uidit eum sanguinem expuentem et requisiuit quid esset. At ille respondit: Sermo erat fratris qui me contristauerat et repugnaui ut non illum dicerem, sed petiui Deum ut tolleretur a me et factus est ille sermo sanguis in ore meo. Et postquam expui illum, requieui; sed et ipsam tristitiam et sermonem illum oblitus sum.

3-Quidam fratres uenerunt ad quendam sanctum senem sedentem in solitudinem et inuenerunt foras cellam eius infantes pascentes pecora et loquentes inter se turpia uerba. Postquam etiam de singulis cogitationibus requirentes acceperunt responsum, dicunt ei: Quemadmodum potes, abba, uoces portare infantum istorum et non praecipis illis ut non ita iocentur? Et dicit eis senex: In ueritate, fratres, plurimos dies habet cogitatio mea uolens illis aliquid dicere, sed redarguo meipsum reputans mihi: Si paruum hoc non porto, quemadmodum si maior mihi tentatio uenerit portabo? Et ideo nihil illis dico, ut fiat mihi consuetudo portandi.

4-Item dixit: Qui linguam suam non tenuerit in tempore irae, nec passiones carnis suae aliquando poterit continere.

3 iracundia mea] -am apud me S 3-4 foris guttur meum non procederet] foras gutturem (-e L) m. (-o L) non p. (-dat E) EL

2-MVPELS 1 uenissent $\mathrm{E}$ de] ex $\mathrm{S}$ abbatem om. $\mathrm{P}$ Achilam] ancillam $\mathrm{V} \quad 2$ quis $\mathrm{PE} \quad 3$ fratris] frater $\mathrm{MV}$ mei add. $\mathrm{P}$ 3-4 repugnaui ut non illum] -bam non eum $\mathrm{E} \quad 4$ dicere $\mathrm{E} \quad$ a] de $\mathrm{E}$ sermo ille $\mathrm{S}$ 5 ore meo] eremo L $\quad 5-6$ requieui sed et ipsam tristitiam et $\mathrm{om}$. L $\quad 5$ sed eras. E et ipsam] etiam $\mathrm{S} \quad 6$ illum om. EL

3 -MVPELS 1 quidam fratres] quibus fratribus $M \quad$ sanctum om. EL 2 solitudine VES inuenerunt] uenerunt $\mathrm{P}$ illum add. $\mathrm{S}$ cellulam $\mathrm{EL}$ 3 inter se] i. se (om. E) aliquotiens PEL uerba om. MV etiam] ergo PELS 4 cogitationibus] suis add. PELS requirentes acceperunt] inquirentes a. V requirentes (om. S) acceperunt (accepissent $\mathrm{P}$ habuerunt $\mathrm{S}$ ) a sene PELS 5 uoces portare] p. u. PEL portare $\mathrm{om} . \mathrm{S}$ et $\mathrm{om}$. P non] nec PEL ne S 6 illis] eis $\mathrm{S}$ iocentur] uocentur EL ei L in ueritate om. S fratres] per add. $\mathrm{V} \quad 7$ habet cogitatio mea] c. $\mathrm{m}$. fuit $\mathrm{V}$ habeo cogitare omnia $\mathrm{P}$ habet om. M sed om. L arguo P 8 paruum] parum MVPL 9 euenerit $\mathrm{P}$ ideo nihil illis] idem $\mathrm{n}$. EL

4-MVPELS 1 item] idem $E$ non tenuerit linguam suam $V$ 2 neque $\mathrm{S} \quad$ carnis suae] cordis sui $\mathrm{L}$ suae om. $\mathrm{S}$ potest $\mathrm{S}$ 


\section{XXVII - QVIA INVIDIA PER PATIENTIAM VINCITUR}

1 - Abbas Ioannes dum sederet inter fratres et singuli eum de propriis cogitationibus inquirerent atque illis singulis responsum daret, quidam senex ex inuidia dicit ei:

Sic est Ioannes quomodo mulier meretrix ornans semetipsam ut 5 congreget sibi amatores. Cui abbas Ioannes: Verum dicis, abba, et non est aliter. Nam et hoc ipsum Deus tibi reuelauit. Respondit illi iterum senex:

Nam et uas tuum, Ioannes, ueneno repletum est. At Ioannes ait illi: Sic est, abba, sicut dixisti; et haec dicis quia tantummodo ea quae

10 de foris sunt uides. Nam si ea quae intra me sunt uideres quantum plus habuisti quid diceres?

Et post hoc quidam ex discipulis eius dicit ei: Non es conturbatus interius in uerbis senis huius? Cui ille respondit: Non. Sed sicut sum de foris ita et sum de intus.

2 - Erat quidam senex in Aegypto et antequam ueniret illic abba Poemen grandem uenerationem habebat ab omnibus. Cum autem abba Poemen de Sceti illic subisset, multi, relicto illo sene, ueniebant ad hunc. Et propter hoc coepit ille inuidiare et detrahere. Quod

\footnotetext{
XXVII - MVPELS inuidiam M per patientiam uincitur] per (om. S) p. (-a LS) u. (-atur PS) PLS

1-MVPELS 1 abba PS sederet] esset $\mathrm{L}$ eum] dum $\mathrm{E} \quad 2$ atque] et $\mathrm{S} \quad$ illis singulis responsum] ille $\mathrm{r}$. omnibus PELS 4 est] hic add. ELS quomodo] sicut $\mathrm{S}$ seipsam $\mathrm{S} 5$ abbas] dicit $\mathrm{P}$ abba MS om. E 6 aliter] alter $\mathrm{P} \quad$ nam] iam $\mathrm{S} \quad$ ipsud $\mathrm{ML} \quad 7$ illi $\mathrm{om} . \mathrm{P}$ iterum] ille add. ES 8 et $o m$. $S$ repletum] plenum $P$ at] et EL 8-9 at Ioannes ait illi] et ille ait $P$ 9 hoc $\mathrm{V}$ ea] illa ELS $10 \mathrm{de} \mathrm{om}$. L nam si ea quae intra me sunt] $\mathrm{n}$. si ea $\mathrm{q}$. intus $\mathrm{s}$. $\mathrm{L}$ iam quae intra me sunt si $\mathrm{S}$ uideres] uides $\mathrm{V}$ uidisses $\mathrm{P}$ 11 haberes $p$. corr. L quod PEL diceres] tantum adhuc dicere debueras add. PS 12 haec PELS quidam ex om. E discipulus E eius] $\begin{array}{lll}\text { suis } \mathrm{P} & \text { dixit } \mathrm{S} & 12-13 \text { conturbatus interius] } \mathrm{c} \text {. abba i. } \mathrm{P} \quad \text { c. i. abba ELS }\end{array}$ 13 uerbo PES cui] tunc S 14 et sum] sum et PEL et om. S 2-MVPELS 1 quidem $M$ et om. MVS 2 grandem uenerationem] g. munerationem E grandi ueneratione p. corr. L omnibus] hominibus L 3 Sceti illic] Scitu illi S subisset] uenisset E uenerunt S 4 hunc] eum L coepit ille] c. ei i. E c. i. ei PS inuidiare] inuidere PES detrahere] detractare $\mathrm{P}$ quo PL
} 
audiens abba Poemen contristatus est et dicit fratribus suis: Quid faciemus quia in tribulatione miserunt nos homines, ut illum senem tamquam sanctum relinquerent et nos qui nihil sumus inspicerent? Quemadmodum ergo sanemus hunc uirum magnum? Venite ergo fratres, faciamus paucas escas et portantes pergamus ad eum et parum uinum ut pariter cum eo gustemus. Forsitan in hoc possumus animum eius placare. Profecti ergo pulsauerunt ostium. Audiens uero discipulus illius senis dixit: Quis est? At illi dixerunt: Dic abbati tuo quoniam Poemen uenit ut benedicatur ab eo. Quod cum ille per discipulum suum audisset, respondit: Dic ei: "Vade hinc, non enim mihi uacat». Illi tamen restiterunt in aestu dicentes: Quia non hinc discedimus nisi digni fuerimus adorare eum. Quorum cum ille humilitatem et patientiam peruidisset, conpunctus aperuit ostium et gustauerunt pariter. Dicit ergo eis ipse senex: In ueritate non sunt ea sola quae audiui a uobis, sed centuplum opera uidi in uos. Et ab illo die amicus est factus.

\section{XXVIII - QVIA OPORTET PRO PACE QVODVIS BONVM CONTEMNI}

1 - Abbas Motoes aedificauit sibi monasterium in loco qui uocatur Heracleona et dum ibi a multis molestaretur in alterum locum transgressus est. Et similiter etiam ibi construxit monasterium. Sed per

5 est om. S suis om. S facimus $\mathrm{E} \quad 6$ nos miserunt $\mathrm{S}$ homines] omnes $\mathrm{P} \quad 6-7$ tamquam] suum $\mathrm{P} \quad 7$ sanctum] senem $\mathrm{V}$ inspicerent] et $a d d$. E 8 ergo sanemus] sanabimus PS e. om. ES hunc uirum magnum] $u$. h. sanctum $P$ 9-10 parum uinum] paruum humum $\mathrm{MV}$ purum u. $\mathrm{P} \quad$ p. uini $\mathrm{S} 10 \mathrm{ut} \mathrm{om}$. E possumus] possimus $\mathrm{L}$ poterimus $\mathrm{S}$ animum] -us MV -am PL 11 placare]-i MV placere E uero] autem $P$ ergo $\mathrm{L} \quad 12$ illius] eius $\mathrm{S} \quad 13$ quoniam] quod $\mathrm{S}$ Pemon $\mathrm{S}$ quo $\mathrm{P}$ 13-14 per discipulum suum] discipulus suus $\mathrm{S} \quad 14$ respondit] dixit $\mathrm{P}$ dicit $\mathrm{E}$ ei] illi $\mathrm{L}$ enim om. L 15 mihi uacat] u. $\mathrm{m} . \mathrm{V} \quad \mathrm{m}$. uacant $\mathrm{S}$ tamen] autem $P$ restiterunt] -erent $V$ retinerunt $L \quad 16$ discedimus] discessimus E decedemus S 17 ostium] intraberunt simul add. L 18 eis] ei E om. LS 19 a] de PELS centuplo MV uobis ELS 20 factus est S XXVIII - MVPELS quia] quod $\mathrm{S}$ quoduis] quamvis $\mathrm{M}$ bono $\mathrm{L}$ 1 - MVPELS 1 abba $\mathrm{S}$ Motoes] Moyses $\mathrm{V}$ in loco qui uocatur] in 1. (-um PEL) q. (-em P) dicitur PELS 2 molestaretur] mostraretur V molestiaretur EL in om. $\mathrm{S} \quad 3$ etiam om. VS 
insidias diaboli quidam frater inuentus est ibi qui per inuidiam semper

5 cum eo iram habebat, propter quod surrexit inde et ad proprium regressus est uicum et fecit sibi illic quoque monasterium et reclusit semetipsum. Post tempus autem aliquantum congregati sunt senes de illo loco unde egressus est deducentes secum etiam illum fratrem cum quo habuerat litem, quatenus rogarent eum et reducerent in monas-

10 terium suum. Postquam autem uicino loco uenerunt tam melotes suas quam illum fratrem ibidem dereliquerunt. Ipsi quoque profecti sunt ad senem et pulsantibus illis, aperta fenestra, respexit eos et cognouit et dicit eis: Vbi sunt melotes uestrae? At illi responderunt ei: Ecce hic in uicino sunt una cum illo fratre qui tecum iram habebat. Hoc

15 postquam senex audiuit et nomen illius agnouit, prae gaudio ostium per quod ingressus fuerat cum secure confregit et egressus cucurrit usque ad locum ubi erat ille frater et prior ipse coepit poenitentiam agere apud eum et amplecti illum, et introduxit illos in cellam suam et per tres dies conuiuatus est cum eis, quod numquam habebat con-

20 suetudinem ut ieiunium solueret. Et surrexit et profectus est cum illis.

2-Quidam frater requisiuit abbatem Eliam dicens: Si contristauero aliquem quemadmodum rogem? Respondit senex: Ex profundo cordis tui cum dolore age poenitentiam apud eum, et uidens Deus propositum tuum satisfaciet tibi.

3-Abbas Agathon solebat dicere: Numquam dormiui litem habens cum aliquo, sed nec permisi aliquem mecum litem habentem dormire, quantum ad uirtutem meam pertinuit, nisi prius cum illo in pace reuerterer.

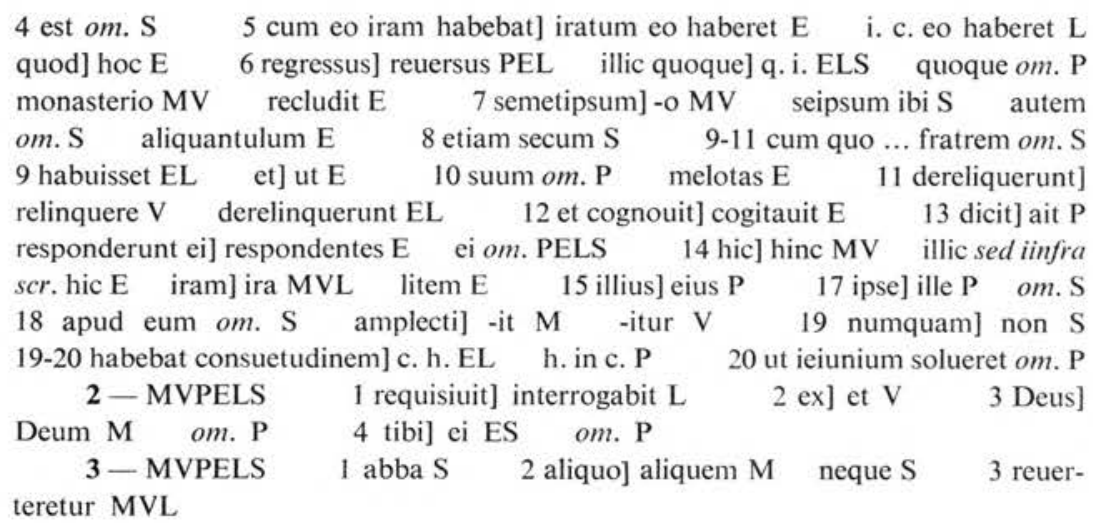




\section{XXIX - DE PERFECTA CONCORDIA}

1-Erant duo senes pariter sedentes in una cella et numquam inter se uel qualemcumque paruam contentionem habuerant. Dicit ergo unus ad alterum: Faciamus et nos unam litem sicut et alii homines. At ille alter dixit: Nescio quemadmodum fit litis. Dicit ei ille: Ecce ego ponam laterem istum in medio et dico quia meus est; et tu dic: «Quia non est tuus, sed meus est». Et ex hoc fit contentio et rixa. Et dum posuissent laterem in medio, dicente uno "quia meus est», ille autem primo respondit: «Ego meum esse spero». Et cum ille alter iterum diceret: «Non est tuus sed meus»; tunc ille respondit: Et si tuum est, tolle illud. Quo dicto non inuenerunt quemadmodum litigarent.

2-Quodam tempore, orante beato Macario uox ad eum de caelo personuit: Macari, necdum ad mensuram duarum mulierum peruenisti quae in proxima habitant ciuitate. Quo audito, senex exurgens, arrepto baculo, in designata ciuitate peruenit. Cumque ostium quaesitae domus atque inuentae pulsasset, egressa una ex illis, cum magna eum exultatione suscepit. Quas utrasque senex conuocatas, ita est adlocutus: Propter uos tantum laborem ueniens ex solitudine longinqua sustinui, ut opera uestra cognoscerem, quae mihi uos condecet enarrare. Cui illae sic responderunt: Crede nobis, sanc-

\section{XXIX - MVPELS}

1 -MVPELS 1 erant] autem add. $\mathrm{V}$ unam cellam PE 2 contentionem habuerant] intentionem $h$. (-runt P) PELS 3 altero $M$ unam] aliquam EL 4 alter] autem add. $\mathrm{V}$ dicit $\mathrm{E}$ quomodo $\mathrm{S}$ lis VS ei om. $\mathrm{S} 5$ ego] enim $\mathrm{P}$ pono $\mathrm{S}$ 5-7 et dico ... medio om. VE 5 dico] dicam L 6 quia om. L 7 deposuissent $\mathrm{S}$ medium $\mathrm{P}$ dicente uno] dicit unus $s$. scr. L $\quad 7-8$ est ille autem] est et $(\mathrm{om}$. S) i. alter PS 8 primus p. corr. L ego] autem add. E ille 2 om. $\mathrm{P}^{8-9}$ alter iterum] i. a. $p$. corr. V 9 iterum om. $\mathrm{L}$ tuum PE meus] meum EL esse afirmo add. P tuum] tuus $\mathrm{S} \quad 10$ illud] illum $\mathrm{L}$ eum PS 2-MVPELS 1-2 de caelo $\mathrm{om}$. $\mathrm{P} \quad 2$ personuit] personauit $\mathrm{P}$ dicens add. L Macharii MV 2-3 peruenisti mulierum L 3 quae] qui $\mathrm{E}$ proxima] -am V pariter add. PELS ciuitatem VEL 4 consurgens $\mathrm{S}$ designata] sibi add. L 5 domus] inuenisset add. $\mathrm{P}$ inuentae] inueniente $\mathrm{E}$ 6 eum exultatione] e. eum VS eum om. PE quas utrasque] quibus utraque $\mathrm{S}$ senex] sene $\mathrm{L} \quad \mathrm{om} . \mathrm{S} \quad$ 6-7 conuocatas ita est adlocutus] -is sic a. est $\mathrm{S}$ 7 ueniensque $L \quad 7-8$ solitudinem longinquam $M \quad$ 8-9 uos mihi $P \quad 9$ narrare E illae sic] s. i. PE sic om. L 
10 tissime pater, quia nec praesente nocte a maritorum lectulis fuimus separatae. Qualem ergo a nobis exquiris operam? Sed senex precibus persistebat ut ei uitae suae ordinem declararent. Cui tunc illae compulsae dixerunt: Noś nulla inter nos sumus parentilitatis adfinitate coniunctae. Contigit autem ut fratribus iungeremur et cum in his

15 quindecim annis in una domo pariter permanentes neque turpe uerbum altera dixit ad alteram neque litem aliquando conmisimus, sed in pace hactenus uiximus et consensu. Tractauimusque pariter, relictis maritis, in congregatione religiosarum uirginum proficisci et multis precibus hoc a coniugibus nostris non ualuimus inpetrare. Quo non adepto

20 inter nos et Deum posuimus testamentum ut usque ad mortem nostram saeculare uerbum non loquamur omnino. Quae cum beatus Macarius audisset dixit: In ueritate non est uirgo neque maritata neque monachus neque saecularis, sed Deus tantum propositum quaerit et spiritum uitae omnibus subministrat.

3-Quidam frater dum esset in coenobio et frequenter ad iram moueretur dixit: Vadam ad solitudinem et cum non habeam cum quo litigem forsitan quiescet a me haec passio. Cum autem egressus mansisset solus in spelaeo, quodam die cum uas aquae replesset et posuisset

5 in terram subito uersatum est. Quod ille secunda uice repleuit et iterum uersatum est. Cumque tertia uice replesset ac similiter con-

10 neque $\mathrm{S} \quad$ a $\mathrm{om} . \mathrm{P} \quad$ lectulis] lecto $\mathrm{EL} \quad \mathrm{om} . \mathrm{S} \quad 11$ qualia $\mathrm{P}$ ergo] enim $L$ a nobis exquiris operam] $n$. opera e. $P$ opera a $n$. e. E opera de n. e. $\mathrm{L}$ exquiris om. S 12 adsistebat $\mathrm{EL}$ illae tunc $\mathrm{ES}$ 13 nullam E sumus om. E parentilitatis] parentilitus $M$ parentele VS parentela $P$ parentalitatis $\mathrm{L}$ adfinitate] adfinitae $\mathrm{E} \quad 14$ et] ut $\mathrm{E}$ in om. PELS 15 quindecim] XII P 16 aliquando] aliquam S 17 et] pari add. $\mathrm{P}$ tractauimusque] tractauimus ut (om. P) $\mathrm{PL}$ pariter om. $\mathrm{P}$ 19 a $\mathrm{om} . \mathrm{S}$ inpetrari MV quo] que $\mathrm{S} \quad 20$ posuimus] statuimus $\mathrm{L}$ ut om. E nostram] ut add. E 21 saecularem $\mathrm{M}$ loqueremur $\mathrm{L}$ qui $\mathrm{E}$ 22 audiuisset $\mathrm{V}$ in ueritate] add. enim $\mathrm{L}$ om. $\mathrm{S}$ neque ${ }^{1}$ ] est add. $\mathrm{S}$ 23 neque] uel S tantummodo PLS propositum] bonum add. L 24 uitae om. E subministret $\mathrm{L}$

3-MVPELS 1 frater] pater $\mathrm{L}$ ad iram] ad ira E ab ira PS ad iracundiam L 2 moueretur] mouebatur E conuerteretur L ad solitudinem et cum] in s. (-e S) et (ut L) cum (quo add. E) PELS 3 litigem] si add. E quiescet] -at $\mathrm{E} \quad$-it $\mathrm{L}$ haec] ista $\mathrm{S} 4$ spelaeo] peleo MV spelunca $\mathrm{S}$ quadam LS et] cum add. L posuit V 5-6 quod ille... est om. PS 6 cum $P \quad$ ac] at $S$ simili $L$ 
tigisset, arrepto uas fregit illud iratus. Cum autem ad se reuersus fuisset cogitauit quoniam ab spiritu est deceptus et dixit: Ecce et solus sum et tamen ab iracundia uictus sum. Reuertar ergo in coenobio quia ubique pugna est et patientia et Dei auxilium. Et ita exurgens reuersus est in locum suum.

\section{XXX - DE PATIENTIA IN LATIS CRIMINIBVS}

1 - Beatus Macarius de semetipso referebat dicens: Dum essem iuuenis et tamen in cella residerem inuitum me tenentes in uico clericum ordinauerunt. Cum autem nolens in uicum alterum refugissem, et quidam mihi saecularis religiosus opere meo uendito ministraret, contigit quandam uirginem per stuprum uentris onus accipere. Quae dum a quo fuisset conprehensa requiritur: Anachoreta, inquit, ille uester hoc facinus in me perpetrauit. Egressi ergo parentes puellae et conprehendentes me, suspendentes in collum meum uasa fictilia et per singulas semitas circumducebant caede mactantes, atque insuper his uocibus insultantes: Hic monachus filiae nostrae uim intulit. Cumque me usque ad necem fustibus paene mulctassent, quidam ex senioribus dixit: Vsquequo hunc peregrinum monachum caede mactatis? Sed et ministranti mihi sequenti ac rubore suffuso, iniurias inrogabant dicentes: Ecce quid fecit is pro quo testimonium perhibebas. Parentes

7 arreptum $\mathrm{V}$ uas] uasculo $\mathrm{P}$ uase $\mathrm{S}$ fregit om. $\mathrm{V}$ illud om. $\mathrm{L}$ 8 quoniam] quod $\mathrm{S}$ est] esset $\mathrm{L}$ dixit] ait $\mathrm{L}$ et ${ }^{2}$ ] hic $\mathrm{E}$ om. PL 9 sum $^{2}$ om. V in om. V coenobium PS 10 pugna] opus add. PELS XXX - MVPELS in latis] inlata $E$ inlati $L$ criminis EL 1 -MVPELS 1 seipso $S \quad 2$ et] sed $P$ tamen] cum V cellula ES inuictum $\mathrm{S} \quad 3$ ordinarunt $\mathrm{L} \quad 3-4$ uicum alterum refugissem et quidam] u. a. (a. u. P) r. (fuissem L) et q. (quendam P) PL 4 meo] modo S 5 quandam] quidam $M$ quendam ELS stuprum] struprum PE truprum $L$ scrupum $S$ uentris] ueneris $P$ quae] quo $L$ quem $S$ 6 quo] quodam $\mathrm{P}$ conprehensa] conpressa $\mathrm{E}$ requireretur PS $p$. corr. E inquit ille] ille inquit illi (om. P) PS 7 uester] uidetur S in me facinus PELS 8-9 et comprehendentes ... semitas om. S 8 suspenderunt PE in om. E collo meo P 9 circumducebant] ducebant me $\mathrm{S}$ caede] corde MV caedentes $P \quad 10$ insultantes] exultantes 11 usque $\mathrm{om} . \mathrm{S}$ paene mulctassent] promultassent $P$ p. mulgarent $L$ p. me mulgassent $E$ 12 hunc] unum $\mathrm{L} \quad 13$ et om. $\mathrm{L}$ ac] hoc $\mathrm{MV}$ atque $\mathrm{S}$ rubore] ruore $\mathrm{E} \quad 14$ quod $\mathrm{P}$ is] hii $\mathrm{L} \quad \mathrm{om} . \mathrm{S}$ pro quo] cui $\mathrm{E}$ perhibeas $\mathrm{S}$ 
15 autem puellae dixerunt: Nulla hunc ratione dimittimus nisi pro alimentis puellae praestandis aliquis pro ipso satisdator accesserit. Quod cum ministranti mihi ut faceret innuissem, interposita me sua fide suscepit. Itaque reuersus sum ad cellulam, quantascumque inueni sportellas ei contribui ut uenditis uictum meae coniugi ministraret. Dicebam

20 autem: Ecce, Macari, inuenisti tibi uxorem. Necesse est ergo amplius operari ut eam ualeas enutrire. Et tam diebus quam noctibus operabar ut ei uictum quotidie ministrarem. Sed quando misere tempus aduenit diebus plurimis cruciata parere non poterat. Quae quid rei esset requisita respondit: Quoniam anachoretae illi causam non habenti

25 crimen inposui. Nam me iuuenis uicinus ille conpressit. Quod cum ille qui mihi ministrabat audisset gaudio repletus aduenit «infelicem illam puellam priusquam fateretur quod tibi calumniam frustra contexuit parere nullatenus potuisset» uociferans, sed et «omnes uicinos uellent uenire et ante conmissi ueniam postulare». Quo ego cognos-

30 cens ne me ipsi homines molestarent, festinus abscedens in Sceti perueni. Haec est causa nostri aduentus in istis locis.

15 autem om. L nulla hunc ratione] -am h. rationem ME nisi] hunc add. S 16 puellae $\mathrm{om}$. MV praestandis] portandis MV praestantiis $\mathrm{P}$ aliquis] alioqum $\mathrm{L}$ ipso satisdator] ipsis sdato $\mathrm{L} \quad 17 \mathrm{cum}$ om. $\mathrm{L}$ administranti $S$ ut faceret innuissem] ut (non P) f. (-ent $S$ ) innuissent PS 18 sum om. PES cellulam] cellam PS cella meam L 19 uenditas EL mei E coniugii V ministraret] -ent E -em PS dicebat E 20 Macharii MVL necesse est] necesses $L \quad 21$ ut eam valeas enutrire] ut eam uales e. V ut u. eam e. S om. L 22 ei uictum quotidie ministrarem] u. administrarem $\mathrm{E}$ misere tempus aduenit] t. parturiendi a. in $\mathrm{P} \quad 23$ cruciata parere non poterat] parere c. n. p. EL c. n. poterat p. S quae] quo $\mathrm{P} \quad 24$ adquisita $\mathrm{E}$ respondit] dicens add. $\mathrm{P}$ anachoreta MVP ille MVL 25 nam] iam S ille uicinus $P$ opressit LS quo $P \quad 26$ mihi om. VE 27 priusquam] pateretur uel add. S quod tibi calumniam] quae t. -a $\mathrm{L}$ contexit $\mathrm{L}$ 28 nullatenus potuisset] non potuisse $\mathrm{P} \quad$ et] ut $\mathrm{S} \quad \mathrm{om}$. $\mathrm{P} \quad 28-30$ uicinos ... ne me om. S 29 uellent] -et MVS -it E uelle P ante] a te PEL conmissi] criminis add. $\mathrm{L}$ postulare] petere $\mathrm{EL}$ quo] quomodo $\mathrm{V}$ quae $\mathrm{PE}$ ego] ergo V $30 \mathrm{ne}$ me] et $\mathrm{E}$ ipsi $\mathrm{om}$. L molestiarent $\mathrm{E}$ abscedens] ascendens $\mathrm{S}$ perueni] et add. PLS 31 hoc $\mathrm{P}$ aduentus in istis locis] in 1. i. a. $\mathrm{S}$ in istius loci aduentum $\mathrm{P}$ in Sciti l. a. E in Scitis 1. a. L 


\section{XXXI - CONTRA SPIRITVM TRISTITIAE QVI DESPERATIONEM FACIT}

1-Abbas Orsisius dixit: Non coctum laterculum si missum fuerit in fundamento prope fluuium, neque uno die sufferre poterit; si autem bene fuerit coctum, permanet sicut lapis. Sic et homo non discoctus neque inflammatus - secundum quod de Ioseph dictum est «Eloquium Domini inflammauit eum»-mox in principio carnalis cogitationis dissoluitur.

2-Quidam frater requisiuit abbatem Poemenem: Quid faciam quoniam tribulor tristitia? Dicit ei senex: Neminem pro nihilo aspicias; nullum condemnes; nulli detrahas et dabit tibi Deus requiem.

3 - Idem requisitus ab altero dicente: $\mathrm{Si}$ peccauero etiam in quocumque minuto peccato et consumet me cogitatio mea et arguet me dicens "quare peccasti?», quid faciam? Respondit senex: Quacumque hora ceciderit homo in culpa et dixerit ex corde: «Deus, peccaui, indulge mihi», mox cessabit cogitationis eius uel tristitiae illa consumptio.

XXXI, 1 lin. 5: Eloquium... eum - cf. Ps. CIV, 19.

XXXI - MVPELS tristitiae om. S

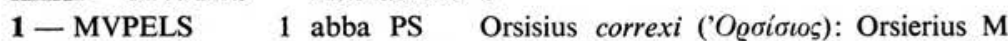
Sisoyus V Omesius E Arsenius PL Aserius S laterculum] laterem $L$ missus $E \quad 2$ fundamentum VPS potest $S \quad 3$ coctum fuerit $\mathrm{S} \quad$ sicut] tamquam PELS 3-4 sic et... inflammatus om. P 3 et $\mathrm{om}$. S non om. L 4 de Ioseph om. E dictum] scriptum P 5 inflammauit] igniuit $\mathrm{P}$ nam nondum coctus neque inflammatus ante mox habet $\mathrm{P}$ prin.cipio carnalis] p. a (om. S) carnalibus PS 6 cogitationis] cogitationibus MS cogitatio $\mathrm{V}$ p. corr. $\mathrm{E}$ desideriis $\mathrm{P}$

2-MVPELS 1 requisiuit] interrogauit $L$ Poemenem] Poemen MVPL add. dicens PL 2 quoniam] quia $\mathrm{S}$ tribulor] conturbor (a add. P) PELS dicit ei senex] dicebat ei ses L 2-3 neminem pro nihilo aspicias om. post senex, sed traiecit post detrahas $\mathrm{S} 3$ Deus] Dominus $\mathrm{L}$

3-MVPELS 1 idem] item ES dicente om. S 2 quacumque E minuto peccato] p. m. $\mathrm{P}$ minimo p. LS me om. $\mathrm{V}$ et om. $\mathrm{S}$ arguit MV 4 homo ceciderit EL culpam EL ex] in E toto add. $\mathrm{L}$ corde] suo add. $\mathrm{L}$ peccaui] tibi add. PELS 5 mox] statim add. $\mathrm{E}$ cessabunt $\mathrm{P}$ cogitationis] -es $\mathrm{PE}$ cogitatio $\mathrm{S}$ eius om. PELS tristitia MVELS illa consumptio] i. (et S) consumatio PS 
4-Dicebat autem abba Poemen de abbate Isidoro quia solus ille se cognouisset. Nam quotiens illi cogitatio sua dicebat «quia magnus es», tunc et ipse respondebat ad se: Numquid talis sum qualis Antonius aut certe abba Pambo uel reliqui patres qui Deo placuerunt?

5 Quotiens haec cogitabat requiescebat. Quando uero inimicus conturbans eum suggerebat ei desperationem et poenas dicens "quoniam post haec omnia in tormenta iturus es», dicebat iterum ipse: Quia quamuis ego in tormenta mittar, tamen uos subtus me inuenio.

5 - Abbati quoque Moysi frequenter apparuerunt spiritus maligni dicentes: Euasisti nobis et nihil tibi possumus facere, quoniam quotiens te per desperationem humiliare uoluerimus exaltaris, quotiens autem exaltare ita humilias ut nullus de nobis accedat ad te.

6- Cum quidam abbatem Sisoium frequenter tali sermone requireret: Quid faciam, pater, quoniam cecidi? - Surge, inquit. At ille: Et surrexi. Et iterum cecidisse professo respondit: Et iterum surge. Cum autem frater frequenter resurrexisse et frequenter cecidisse narraret,

5 eodem uerbo senex utebatur exclamans: $\mathrm{Ne}$ desistas surgendo. Cui frater: Et usquequo possum exurgere, pater, explana. Ait tunc

4-MVPELS 1 abbas $\mathrm{V} \quad 2$ cognouisse $\mathrm{V}$ quotiens] quot $\mathrm{V}$ totiens $\mathrm{S}$ sua cogitatio $\mathrm{L}$ quia] qua $\mathrm{E} \quad 3$ es om. $\mathrm{V}$ et om. S respondebat] -dit $\mathrm{V}$ respondens dicebat $\mathrm{P}$ ad se om. $\mathrm{S}$ sum] ego add. $\mathrm{L} \quad$ om. $\mathrm{S} \quad 4$ Pambo CARW $(\Pi \alpha \mu \beta \omega)$ : Pammo MVPL Pamon ES 5 quotiens] quot $\mathrm{V}$ ergo add. PEL requiescebat $\mathrm{om}$. $\mathrm{P}$ uero] ergo PL 6 suggerens MV 7 post] per $\mathrm{S}$ in tormenta iturus es] i. es in t. S in tormentis i. es et $\mathrm{L}$ ipse] sibi add. L 8 tormentis EL me om. S inuenio] eritis $L$

5-MVPELS 1 quoque $\mathrm{om}$. S 1-2 maligni dicentes] maledicentes $\mathrm{P}$ mali d. E 2 possimus $\mathrm{E}$ quoniam $\mathrm{om}$. L 3 per om. MV desperationem] dispositionem $\mathrm{P}$ exaltare $\mathrm{V}$ quotiens] te add. $\mathrm{P} \quad 4$ ita] tu $\mathrm{P}$ te add. ES humiliabas $\mathrm{V}$ de] ex $\mathrm{S}$ accedebat $\mathrm{V}$

6-MVPELS 1 quidam abbatem Sisoium] q. frater a. Sisonium $\mathrm{S}$ frequenter om. E sermonem L 2 quoniam] quia LS 3 surrexisse PELS cecidisse] quo add. E professo] professus est PLS et ${ }^{2} \mathrm{om}$. PS 4 frater frequenter resurrexisse et] $\mathrm{f}$. frater surrexisse et $\mathrm{S}$ frater surrexisset $\mathrm{E}$ frater $o m$. MV frequenter $\mathrm{r}$. et $\mathrm{om}$. $\mathrm{P}$ frequenter ${ }^{2} \mathrm{om}$. S narrasset $\mathrm{P} \quad 5$ uerbo senex] uero s. ES uero sene L exclamans] clamans S non L 6 et usquequo possum exurgere pater] et (om. E) u. (usque $\mathrm{S}$ ) p. (-mus $\mathrm{S}$ ) surgere p. (om. L) PELS ait om. L 
senex: Vsquequo aut in bono opere aut in malo deprehensus obcumbas. In quo enim opere homo fuerit deprehensus, in eo etiam iudicabitur.

7-Quidam senex tentabatur cogitationibus per annos decem ita ut iam desperaret dicens: Perdidi animam meam; sed quatenus semel perii uel reuertar ad saeculum. Cum autem proficisceretur uenit ad eum uox dicens ei: Decem annis in quibus tentatus es coronae tuae erant. Reuertere ergo in locum tuum et ab omni malo cogitationis tuae liberabo te. Non est ergo bonum desperare se quemquam propter cogitationes; illae enim magis nobis coronas prouident, si utiliter eas pertractantes transierimus.

\section{XXXII - CONTRA SPIRITVM ACEDIAE}

1-Quodam tempore beatus Antonius dum resideret in eremo spiritu tentatus acediae, cogitationibusque diuersis inplicatus, dicebat ad Dominum: Domine, saluari desidero sed cogitationes uariae non permittunt. Quid faciam in tribulatione mea uel quomodo saluari ualeam dignanter ostende. Et post paululum surgens quendam sibi similem conspicatur sedentem torquere funiculum et surgentem ex opere et orantem. Erat autem angelus ad emendationem Antonii

7 aut ${ }^{1}$ om. MV deprehensus] in eo add. E obcumbas] obcubans L obcubas S 8 enim] primus $\mathrm{S}$ opere homo fuerit] h. f. o. E h. o. fuerat $\mathrm{S}$ opere om. L deprehensus] opereensus $\mathbf{L}$ eo] hoc $\mathrm{P}$

7-MVPELS 1 tentabatur] a add. $\mathrm{P}$ de in marg. add. $\mathrm{L}$ per om. P 2 iam om. PS 3 uel om. EL proficisceretur] proficeretur L profisceretur S 4 ei decem annis in quibus] illi d. a. (-i ES) in q. (in q.] inquit P) PELS 5 erant] erunt PEL cogitationes $M \quad 6$ libero $S$ est om. $S$ desperare se] desperasse $\mathrm{V} \quad$ se $o m$. PL 7 enim om. S magis nobis coronas] n. m. c. PE magis coronae $\mathrm{M}$ coronae magis $\mathrm{V}$ praevident MVPE

\section{XXXII - MVPELS}

1 -MVPELS 1 quadam $L$ beatus] abbas ELS abba $P$ resideret] sederet LS 2 inplicatis E 3 Dominum] Deum PES Domine] -us L om. S 3-4 Domine ... permittunt om. V 3 saluare $\mathrm{E}$ non] me add. $\mathrm{L}$ 6 conspicatur] -ciatur V -citur E -ciebat p. corr. L -cit S torquentem $\mathrm{P}$ et surgentem] exurgentem E $7-8$ erat ... destinatus om. P 7 autem om. $\mathrm{S}$ angelus] Domini add. $\mathrm{L}$ 
destinatus, a quo sermonem audiens: «Et tu ita facies, Antoni, et saluaris», summo gaudio cumulatus, accepta confidentia, salua10 batur.

2-Quidam frater ab abbate Achila requisiuit dicens: Quid faciam, pater, quoniam nullam operam facio monachi, sed in neglegentia constitutus, comedo, bibo, dormio et de opera in opera transgredior et de cogitatione in cogitatione et propter hoc contristor et deficior?

5 Cui senex dixit: Tu sede in cella tua et quod potes fac sine turbatione animi et confido in Deum quoniam qui sedet in cella sua propter Deum inuenitur in locum ubi est abbas Antonius.

3-Quidam frater abbatem requirebat Arsenium dicens quia cogitationes meae tribulant taliter suggerentes: "Quoniam non potes ieiunare nec operare, uade et uisita fratres infirmos, et hoc opus est caritatis». Cui senex, tamquam instigationem diaboli cognoscens,

5 respondit: Vade et manduca et bibe et dormi et ne opereris; tantummodo pedem tuum foras de cella tua non efferas. Continentia enim cellae monachum ad ordinem solet bonum uitae deducere.

8 a] uel V faciens PS Anthonii MV et ${ }^{2} \mathrm{om}$. PLS 9 saluaris] saluaberis (ilico add. P) PELS saluabatur] -bitur E saluatur LS saluationis permanebat animo fixus $P$

2-MVPELS $1 \mathrm{ab}$ om. ELS abbate Achila] abba A. V abbatem Achilam MELS 2 quoniam] quia $S$ nulla opera PEL in om. E neglegentiam VL 3 constitutus comedo] contristatus $c$. et $P$ opera in opera] o. in operam VS opere in opere incedo et $\mathrm{P} \quad$ et $^{2} \mathrm{om}$. $\mathrm{P} \quad 4$ cogitatione 2 ] cogitationem VPS deficio PEL 5 dixit om. S quod om. L sine] murmuratione et add. $\mathrm{L}$ turbatione] conturbatione $\mathrm{V}$ perturbatione PELS 6 Deum $\left.^{1}\right]$ meum add. $\mathrm{L}$ quoniam] quod $\mathrm{S}$ om. $\mathrm{V}$ propter] per $\mathrm{E}$ Deum $^{2}$ ] et laborat add. L 7 loco PS abbas] abba PE om. S

3-MVPELS 1 requirebat] requisiuit EL 2 cogitationes] tribulationes $\mathrm{P}$ meae] me add. PE tribulant] me add. $\mathrm{S}$ taliter] alter $\mathrm{E}$ quoniam] quia $S \quad 3$ nec operare] nec operari $V$ nec comparare $E$ corpore $S$ 4 instigationes PLS diaboli] diabolicas P cognoscens] -es $\mathrm{V}$ agnoscens $\mathrm{P}$ 5 et ${ }^{1}$ om. PELS et ${ }^{3}$ om. L 6 tuum om. PES foris $\mathrm{S}$ de om. P cellam P tua om. PLS afferas V continentia] -ae E -am L 7 cellae] cellulae E solet om. P bonum uitae deducere] ducit bonorum uitae P bonae u. d. E 
4- Alter frater requisiuit abbatem Achilam dicens: Cur sedens in cella mea patior acediam? Cui senex: Quia necdum uidisti requiem quam speramus neque tormenta quae timemus. Si enim ea diligenter inspiceres, etiam si uermibus plena esset cella tua usque ad collum, tu tamen in ipsis lateres permanens sine acedia.

5-Dixit quidam senex: Ideo non proficimur quia mensuras proprias ignoramus nec hoc habemus patientiam in opere quod incipimus, sed sine labore uolumus adipisci uirtutem.

De loco in loco, acedia turbante, transimus sperantes quia inueniemus locum ubi non sit diabolus.

In quocumque enim loco fuerit aliquis, si tentauerit aliquid boni facere et non potuerit, ne arbitretur quoniam si alibi transgressus fuerit potest illud proficere, quia sine labore nemo potest adipisci uirtutem, sed et si adeptus fuerit non permanebit in ea. Nam lugentibus et esurientibus promissum est regnum caelorum.

6-Quidam frater cum argueretur cogitationibus ut egrederetur de cella, suggessit abbati. Ille autem praecepit ei: Vade et sede in cella tua et da pignus parieti cellae tuae corpus tuum ut non inde egre-

XXXII, 5 lin. 9-10: lugentibus... caelorum - cf. Mat. V, 3-6.

4-MVPELS 1 abbatem Achilam] ab abbate Achila $\mathrm{P}$ cur] sum $\mathrm{S}$ sedes $\mathrm{V} 2$ cella mea] cellam meam $\mathrm{E}$ et add. $\mathrm{S}$ patior] nocte add. $\mathrm{S}$ acediam] -a EL ac die S 3 quam] quem $\mathrm{E}$ enim om. S ea] et MV om. L 4 cella tua esset plena V 5 tu om. E lateres] laetareris MV -is ELS permanes $\mathrm{L}$

5-MVPELS 1 non om. L proficimur] -imus PL -iemus E -iamur $\mathrm{S} 2 \mathrm{nec}$ hoc habemus] neque haec -amus $\mathrm{S}$ hoc om. $\mathrm{P}$ quo $\mathrm{L}$ 3 sed sine labore uolumus] et s. 1. u. E om. V $4 l^{\left.l o c o^{2}\right]}$ locum PS turbante] perturbante $\mathrm{S}$ perturbat nos et $\mathrm{L} \quad 4-5$ quia inueniemus] q. (non $a d d$. $\mathrm{S}$ ) inuenimus PELS 5 sit] est $\mathrm{E} 6$ quocumque] quo $\mathrm{V}$ fueris $\mathrm{E}$ 7 ne arbitretur] me arbitraretur $\mathrm{V}$ nec a. $\mathrm{E}$ non a. $\mathrm{S}$ quoniam] quia $\mathrm{P}$ quod $\mathrm{S} \quad 8$ illum $\mathrm{E}$ proficere] facere $\mathrm{V}$ adipiscere $\mathrm{M} \quad 9$ et si] si et $\mathrm{S}$ et om. VPE adeptus] cogitationem add. $\mathrm{P}$ eam $\mathrm{P}$ 9-10 nam lugentibus ... caelorum om. E 10 promissum est regnum] promitit Dominus regna $\mathrm{S}$ 6-MVPLS om. E 1 cum] dum $P$ argueretur] urgeretur VS a. a P urgueretur a (om. M) ML 2 de cella suggessit] a cella sua cumque suggessisset $\mathrm{P}$ illi add. $\mathrm{S}$ autem] enim $\mathrm{L}$ et om. $\mathrm{P} \quad 3 \mathrm{da}$ om. $\mathrm{L}$ pignus] pugnos $S$ corpus tuum ut] c. t. da et $L \quad$ c. t. om. $S$ 
diaris. Dimitte enim cogitationem ut cogitet quicquid uult, tantummodo corpus tuum de cella non efferas.

7-Quidam frater cum expetisset sermonem ab abbate Moyse, dicit ei senex: Vade et sede in cella tua; cella enim tua omnia te potest instruere si ibi permanseris.

«Sicut enim piscis ex aqua eductus moritur, ita et monachus si 5 foras cellam suam tardare uoluerit»: hoc enim dicebat beatus Antonius.

Nam si in cella sua sedens monachus, rememoratus fuerit peccata sua, Dominus illi in omnibus adiutor est et non patiatur taedium.

8 - Quidam frater a beato requisiuit Antonio dicens: Quid obseruans Deo placebo? Respondit senex: Quae demando tibi custodi. Quocumque uadis Dominum semper habeto prae oculis et quodcumque opus exerceris sumito ex diuinis Scripturis exempla; et in quocumque

5 loco resideris ne inde citius mouearis, sed patienter in eodem loco consiste. Haec enim tria custodiens saluus efficieris.

\section{XXXIII - CONTRA SPIRITVM VANAE GLORIAE}

1-Quidam frater requisiuit abbatem Poemenem si melius esset remotius ab aliis manere. Respondit senex: Homo si seipsum reprehendet

XXXII, 7 lin. 7: Dominus... est - cf. Gen. XLIX, 25; Ps. XVIII, 15.

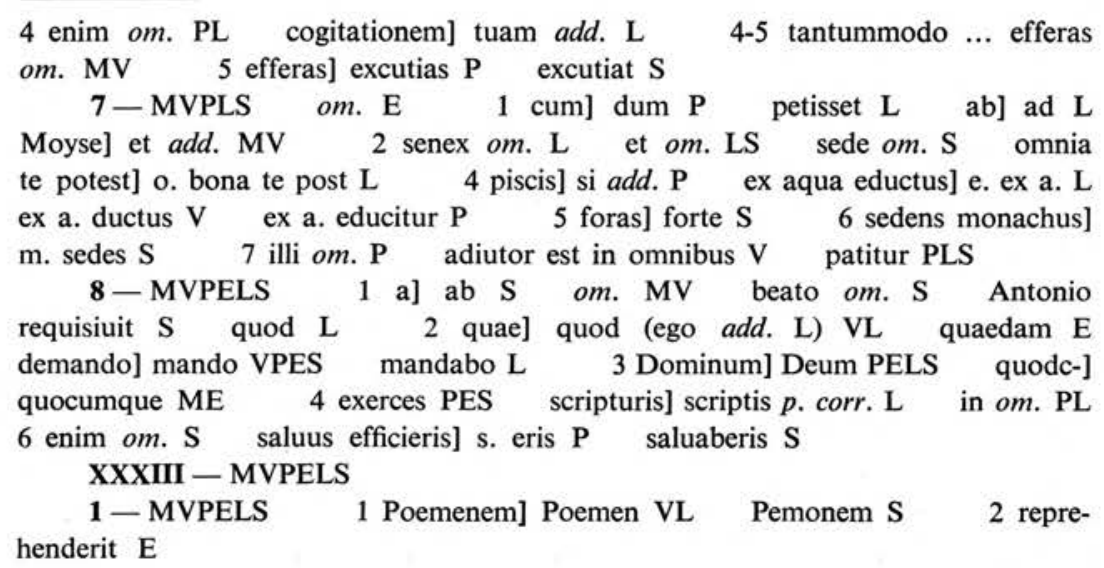


ubique potest persistere; si autem se magnificat, numquam stat. Quicquid enim boni fecerit homo ne exultet in eo quia mox perdet illud.

2-Abbas Macarius si quis illum cum timore uelut sanctum uirum uoluisset adire, suscipiens nullum penitus a sene percipiebat responsum. Si quis uero uelut contemnens eum uerbis talibus conpelleret: «Abba Macari, quando eras camelarius et nitrum furabaris numquid non uapulabas a magistris deprehensus in furto?», libenter ei quicquid requisisset cum gaudio respondebat.

3 - Venit aliquando ad abbatem Zenonem in Syriam aliquis frater aegyptius et coepit cogitationibus propriis accusare praesente sene. Ille autem admiratus audiens dixit: Aegyptii uirtutes quas habent celant et uitia quae non habent manifestant; Syrii autem et Graeci uirtutes quas non habent praedicant et uitia quae habent abscondunt.

4-Quidam senex dixit: Qui ab hominibus amplius honoratur aut laudatur non parum damni patitur; qui autem penitus ab hominibus non honoratur desuper gloriam accipiet.

3 persistere] resistere $\mathrm{E} \quad$ se $\mathrm{om} . \mathrm{L}$ nusquam LS stat] sed add. $\mathrm{E} \quad 4$ quicquid] quod $\mathrm{P}$ bonum $\mathrm{L}$ non $\mathrm{P}$

2-MVPELS 1 abba PES 2 adire] audire MVP adibere L suscipiens om. L penitus] dixit add. S sene] se L percipiebat] recipiebat $\mathrm{E} 3$ uelut] uel $\mathrm{V}$ illum PS contemnens] ut add. $\mathrm{V}$ eum om. $\mathrm{S}$ talibus om. S compellebat L 4 abba Macari] a. Macarii MV abbas Macarius E camelarius] cucumerarius $P$ et nitrum] et nitrium MVE om. S 5 non om. S a magistris om. P furto] -u M -um P enim add. $\mathrm{L} \quad 6$ eis $\mathrm{E}$ requisissent $\mathrm{PE}$

3-MVPELS 1 ad om. M 2 aegyptus L coepit] ex add. V cogitationes proprias PELS accusare] se add. $\mathrm{M}$ praesente sene] praesentem senem L om. MV 3 audiens admiratus PES celant] zelant L 4 habeant L 4-5 et graeci uirtutes quas non habent] u. q. h. et g. S 5 praedicunt $\mathrm{S}$ abscondent $\mathrm{L}$

4-MVPELS 1 hominibus] omnibus EL amplius om. $\mathrm{S}$ honorantur $P$ 2 aut] uel LS laudantur $P$ damnum ES patiuntur $P$ hominibus] omnibus $\mathrm{ME} \quad 3$ honorantur $\mathrm{P} \quad$ gloriam accipiet] gratiam -ent $\mathrm{P}$ 
5-Idem dixit: Sicut fieri non potest ut simul et herba nascatur et semen, ita inpossibile est ut laudem et gloriam saecularium habentes simul etiam et fructum faciamus caelestem.

6-Idem dixit: Sicut thesaurus manifestus minuitur, ita et uirtus deperit publicata; nam sicut cera soluitur a facie ignis, ita et anima per laudem resoluta perdit intentionem suam.

7-Idem dixit: Quando cogitatio uanae gloriae uel superbiae te inpugnant, perscrutare teipsum si omnia mandata Dei seruasti, si inimicos tuos diligis, si gaudes in gloria inimici tui, et contristaris in deiectione eius et si apud te habes quoniam seruus inutilis es et omnibus

5 hominibus plus peccator et neque tunc tamen grande aliquid sapias tamquam aliquod feceris, sciens quod elata cogitatio omnia illa bona dissoluit.

8-Quidam senex cum uenisset ad alterum senem dicit ei: Ego mortuus sum saeculo huic. Cui ille alter: Ne confidas in teipsum donec egrediaris de corpore hoc. Nam etsi tu dicas «quoniam mortuus sum», diabolus tamen necdum mortuus est.

5-MVPELS 1 idem] item PEL sicut] si $P$ simul et herba nascatur] s. (semel E) h. n. (-antur P) PEL 2 saecularem PL 3 simul etiam et] ut simul cum ea $\mathrm{P}$ etiam om. $\mathrm{V}$ et $o m$. $\mathrm{S}$

6-MVPELS 1 idem] item PEL dixit om. $\mathrm{S}$ manifestus minuitur] diminuitur $\mathrm{m} . \mathrm{S}$ ita $\mathrm{om}$. $\mathrm{E}$ et $\mathrm{om}$. $\mathrm{P}$ uirtus] monaci add. L 2 deperiit VEL soluitur] fluit $\mathrm{S}$ a facie] ante faciem $\mathrm{E}$ ita et] et ita $\mathrm{E}$ et $o m$. MV 3 perdit] -et MV -idit P

7-MVPELS 1 idem] item PELS cogitationes P 2 inpugnat LS praescrutare MVPEL 3 tuos om. L diliges $\mathrm{M}$ gloria] gratiam $\mathrm{P}$ gloriam $\mathrm{S}$ et] si non $\mathrm{P}$ deiectione] deictione $\mathrm{V}$ dilectione $\mathrm{P}$ delectione $\mathrm{L}$ deiectionem $\mathrm{S} \quad 4$ eis $\mathrm{E}$ et $\left.{ }^{1}\right]$ ut $\mathrm{L}$ si om. $\mathrm{P}$ quoniam] cum $\mathrm{P}$ quia $\mathrm{S}$ et ${ }^{2}$ ] ut $P \quad 5$ hominibus plus peccator] plus te extimes peccatorem $P \quad$ plus $\mathrm{om}$. V et om. PS tunc om. L sapias] -es M -ens V -is P 6 tamquam] quasi L aliquid PELS quod] quo $\mathrm{V}$ elata] delata $\mathrm{V}$ electa $\mathrm{P}$ illata $\mathrm{S}$ illa bona] b. i. E non add. P 7 dissoluit] -et MVPS -at L

8-MVPLS om. E 1 cum] dum $\mathrm{P} o m$. $\mathrm{S}$ uenit $\mathrm{S}$ dixit $\mathrm{P}$ 2 sum $o m$. $\mathrm{S}$ alter] frater $\mathrm{L}$ non $\mathrm{P}$ te ipso $\mathrm{L} 3$ hoc om. $\mathrm{P}$ quoniam] quia $\mathrm{S} \quad 4$ nondum $\mathrm{V}$ est mortuus LS 
9-Quidam senex cum per quinquaginta annos esset in deserto neque panem gustans neque aquam ad satietatem accipiens, dicebat ipse: Quia occidi auaritiam et uanam gloriam. Quod cum audisset abbas Abraham uenit ad eum et requisiuit si illum sermonem ipse dixisset. At ille confitente dicit ei abba Abraham: Ecce dum per uiam ambulas uides et lapides et fragmenta laterculorum et inter haec massam auri. Ne potest cogitatio tua aurum et illud simile illis aliis iudicare? Dicit ei senex: Non. Sed iterum pugno cum cogitatione mea ut non illud tollam. Cui abbas Abraham: Ecce ergo uiuit auaritia sed ligata est. Item dixit abbas Abraham: Ecce audis de duobus fratribus, unus quidem diligit te et laudat, alter uero te horret et detrahit. $\mathrm{Si}$ utrique uenerint ad te, ne utrosque similiter accipies? Dicit ei senex: Non. Sed iterum pugno ut et illum diligam quem horreo. Cui abbas Abraham: Ecce ergo uiuunt in te passiones adhuc, sed ligatae sunt a sanctis cogitationibus, quae tibi adhuc propter uitam tuam permanent.

10 - Quidam frater requisiuit senem dicens: Si fratri meo dedero panem uel aquam uel aliquid boni fecero et tamen spiritus cenodoxiae sordidat ea tamquam propter hominum laudem haec faciam... Cui

9-MVPELS 1 cum] dum P om. L esset] fuisset $\mathrm{P} \quad$ om. $\mathrm{L}$ deserto] habitans add. L 2 gustauit E accipiens] bibens $\mathrm{S} \quad 2-3$ dicebat ipse] i. dixit V ipse om. PS 3 quod cum] quocum L 4 abba E 4-5 uenit...Abraham om. S 4 si illum sermonem] i.s.si L si om. MV ipse] a se P 5 illo VEL abbas PS 6 uia $\mathrm{E}$ ambulas] uadis L uides et] et u. E uidens P et om. PLS 7 massa E ne potest] p. ne V nec post $\mathrm{P}$ tua om. $\mathrm{S}$ aurum et] et a. P aurum om. EL et om. E illud simile illis] i. similem illis $\mathrm{E}$ illum similem illius $\mathrm{L}$ aliis om. PL 8 iudicare] in decore S ei om. PS sed] si P 9 ut non] ne PELS abba E ergol enim $\mathrm{P}$ adhuc $\mathrm{S}$ om. $\mathrm{E}$ uiuit auaritia] a. $\mathrm{u} . \mathrm{S}$ u. -am $\mathrm{L}$ 10 ligata] delicata $\mathrm{S}$ abbas] abba $\mathrm{E} \quad \mathrm{om} . \mathrm{P} \quad 11$ fratribus] quia add. PES te $1 \mathrm{om} . \mathrm{E}$ te $2 \mathrm{om} . \mathrm{P} 12 \mathrm{ne}$ ] nonne $\mathrm{P}$ non $\mathrm{S}$ accipies]-is $\mathrm{E}$ aspicis $\mathrm{L}$ ei om. PES 13 et om. E horrebam E 14 abbas] senex P abba E ligatae] delicatae $\mathrm{S} 15$ cogitationibus om. ELS qui MLS tibi] mihi $\mathrm{P}$ adhuc] forte ELS om. $\mathrm{P}$ tuam] omnia $\mathrm{S}$

10 - MVPELS 1 quidam frater requisiuit senem] r. s. q. f. S q. fratre r. s. $\mathrm{M}$ dederim $\mathrm{E} 2$ uel $^{2}$ ] et $\mathrm{P}$ fecerim $\mathrm{E}$ et om. $\mathrm{S}$ tamen om. P 3 sordidat ea] sordidet eas (eam S) PS hoc VS faciam] quid faciam add. $\mathrm{P}$ 
senex: Etsi propter laudem hominum haec facias, tamen quae neces-

5 saria sunt proximo numquam neges. Nam duo homines erant in uno uico et unus quidem seminauit alter uero noluit. Et ille qui seminauit fecit fructum parum et ipsum non mundum; ille autem alter nihil omnino fecit quia nihil seminauit. Cum autem famis contigisset, quis ex duobus potuit melius uiuere? Respondit frater: Quia ille

10 qui fecit etsi inmunda potest uiuere. Dicit ei senex: Faciamus et nos aliquanta, etsi inmunda uideantur, tantummodo fame non periclitemur.

11 - Abbas Sisoius cum sedens praesente fratre altero factus in extasi et alterum adesse nesciens suspirasset, coepit poenitere ac dicere: Indulge mihi frater, exposco, necdum me enim monachum cognosco esse qui audiente altero suspiraui.

5 Quotiens autem in oratione stans idem senex manus suas erexisset ad caelum, idem et sensus eius rapiebatur ad caelum, sed cito deponebat manus propterea si alter praesens esset, nec hoc ipsum illi pro laude constaret.

12 - Quidam senex habitabat in inferioribus partibus eremi et sedebat quiescens; unus autem saecularis religiosus ministrabat ei. Contigit autem ut filius saecularis illius infirmaretur. Multis ergo precibus postulabat senem ut ueniret in domo sua et faceret orationem

5 pro infante; et exurgens ambulabat cum eo. Ille autem praecessit et ingressus in domum suam dixit: Venite in occursionem anachoretae.

4 hominum haec] $\mathrm{h}$. hominis $\mathrm{L}$-is haec $\mathrm{S} h$. hoc $\mathrm{V}$ haec om. $\mathrm{E}$ facias] -es $\mathrm{M}$-is $\mathrm{V}$ tamen] ea add. $\mathrm{P} \quad 5$ deneges $\mathrm{P}$ nam] tamen $\mathrm{E}$ 6 quidem] quoque $\mathrm{E}$ noluit] non seminauit $\mathrm{E} \quad 7$ fructum] frumentum EL fragmentum $P$ frugmentum $S$ mundum] mundauit $S$ 7-8 ille autem alter nihil omnino fecit quia nihil seminauit] alter vero n. o. f. q. n. s. S qui autem nihil seminauit nihil colligit EL 8-9 contigisset quis ex] cogi q. ex his $\mathrm{S}$ 9 uiuere melius PS 10 inmunda] -um PEL -o S ei om. ELS faciamus] ergo add. PELS 11 aliquanta] -um $P$-ulum $S$ periclitemur] -s $S$-etur $P$ 11 - MVPS om. EL 1 abbas Sisoius] abba Sisoys $\mathrm{S}$ sederet $\mathrm{P}$ 3 frater mihi $P$ posco $S$ enim me $P \quad 4$ qui] quia $S$ altero] te $S$ suspirauit MP 5 erexit $\mathrm{S} \quad 6$ idem et... sed om. $\mathrm{P}$ et $\mathrm{om} . \mathrm{S} \quad 7$ preterea MS neque $\mathrm{S}$ ipsut $\mathrm{M}$ illi) sibi $\mathrm{P}$

12 - MVPLS om. E 1-2 et sedebat] sedebatque PS 3 illius om. L ergo] autem $\mathrm{P} \quad 4$ precibus $\mathrm{om}$. V postulabat] postulabit ad $\mathrm{L}$ in domo sua] ad domum suam $L$ fecisset $P \quad 5$ infantem $M$ exurgens] senex add. PLS praecessit] ei add. L 6 ingressus in domum suam dixit] i. est in d. s. et d. S dixit uicinis suis $\mathrm{L}$ occursum PL 
Quos cum senex uidisset de longe egressos cum lampadis, sensit quod ad se uenirent et expolians se uestimenta sua misit in flumine et coepit lauare stans nudus. Ille autem qui ministrabat ei uidens erubuit et rogabat homines dicens: Reuertimini, senex enim noster sensum perdidit. Et ueniens ad eum dixit illi: Abba, quid hoc fecisti? Omnes enim qui te uiderunt dixerunt: Quia daemonium habet senex. Cui ille: Et ego hoc uolebam audire.

13 - Cum iudex prouinciae abbatem Moysem uellet adorare, audiens ille fugiebat de loco. Et cum obuiam illi forte fuisset requisiuit iudex ab eo: Dic nobis ubi est cella abbati Moysi. At ille respondit: Quid illum uultis uidere hominem stultum et haereticum? Quod cum audisset iudex ueniens ad ecclesiam retulit clericis dicens: Ego quidem diuersa audiens de abbate Moyse uolui ab eo benedici, sed quidăm nobis obuiam monachus retulit de eo quod esset haereticus. Quod cum audissent clerici contristati coeperunt interrogare qualis esset ille monachus qui hoc ei dixisset. Ille autem respondit: Senex ueterrima habens uestimenta, longus et niger. Et tunc cognoscens ex relatione eorum quod ipse esset, miratus discessit.

14-Quidam iudex uenit uidere abbatem Simeonem. Ille autem audiens subiit in arborem palmae et coepit mundare eam. Cum autem uenissent illi dixerunt: Vbi est anachoreta? At ille respondit: Non est hic, sed discessit. Et ita discesserunt $a b$ eo.

7 quod $\mathrm{L}$ de longe om. $\mathrm{P}$ egressus $\mathrm{P}$ lampadis] lampadibus $\mathrm{S}$ lapidibus $\mathrm{P}$ 8 se] eum L dispolians LS flumen S coepit] ea add. PS 9 ei om. V uidens] eum add. L 10 rogauit PLS homines] omnes VP reuertamini S enim om. S 11 eum] senem L haec S omnes] homines MVL 12 enim] quidem $\mathrm{S}$ uiderant $\mathrm{P}$ quia daemonium habet senex] q. (om. S) -nem h. s. (iste add. S) PS 13 et $\mathrm{om}$. VL

13-MVPELS 1 cum] quidam $a d d . \mathrm{P} \quad 2$ illi forte $\mathrm{om} . \mathrm{S} \quad 3$ abbati] -is VPLS om. E 4 uidere om. P 4-5 haereticum et stultum quo P 5 ueniens ad ecclesiam] uenit ad e. et P 6 Moysi VE uolo P 7 nobis obuiam monachus] n. m. o. L nos obuians $\mathrm{m}$. P quod om. V 8 contristati] -ari $\mathrm{V}$ et add. $\mathrm{E} 9$ ille $^{1} \mathrm{om}$. $\mathrm{P}$ hoc ei] ea $\mathrm{S}$ respondit] dixit PES 10 ueterrimus $S$ longus et niger] longa et nigra $S \quad 11$ ex] de $P$ relatione] religione $\mathrm{E} \quad$ eorum quod ipse esset] e. q. i. esset (quod ipse esset om. S) et LS miratus] admiratus iudex $\mathrm{L}$

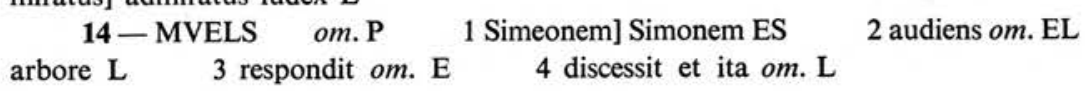


15 - Alia uice uolebat eum uidere quidam ex iudicibus et praecesserunt clerici dicentes ei: Abba, para te, quoniam iudex audiens opera tua uenit a te benedici. Ille autem dixit: Ita faciam et parabo me. Vestitus ergo centonem suum, tollens panem et caseum in manibus

5 suis et ascendens in porta diuaricatis pedibus sedit et coepit comedere. Veniens autem iudex cum officio suo et uidens eum dixit: Iste est anachoreta de quo talia audiebamus? Et contemnens eum ita discessit.

\section{XXXIV - CONTRA SPIRITVM SVPERBIAE}

1-Quidam frater requisiuit senem: Quid est humilitas? Cui senex: Arbor est uitae in altum crescens.

2-Idem dixit: Terra in qua iussit Deus sacrificia sibi offerri humilitas est.

3-Requisitus quidam senex quomodo potest humilitatem anima adipisci, respondit: $\mathrm{Si}$ sua tantummodo mala consideret.

Dicebat autem: Quia profectio hominis humilitas est; quantumcumque enim se deposuerit homo in humilitate, tantum prouehetur 5 in honore.

Sicut enim superbia si ascenderit in caelum usque ad infernum

15-MVLS om. PE 1 alia] a. iterum $\mathrm{L}$ a. item S uolebant MV uidere eum $\mathrm{L}$ iudicibus] ducibus $\mathrm{L} \quad 2$ quoniam] quia $\mathrm{S} \quad 3$ a] ad LS ille... parabo me om. L 4 suum] et add. LS 5 portam S 8 ita $\mathrm{om}$. L

XXXIV - MVPELS

1-MVPELS 1 requisiuit senem quid] r. a sene q. (quod E) PELS est] esset P 2 est $\mathrm{om}$. L excrescens LS

2-MVPELS 1 idem] item PLS p. corr. E sacrificium V 2 humilis L

3-MVPELS 1 quidam senex om. MV animam L 2 respondit] dicebat $\mathrm{S}$ consideret mala $\mathrm{L} \quad 3$ profectio] probatio $\mathrm{E}$ est] quia add. $\mathrm{P} \quad 3-4$ quantumcumque enim] quantum plus $\mathrm{P}$ enim om. $\mathrm{E} \quad 4$ homo om. E in om. L prouehetur] -itur MVP preuetur L 6 enim] autem $\mathrm{L}$ si add. $\mathrm{V}$ si ascenderit] descendit $\mathrm{E}$ in caelum usque] u. ad c. $\mathrm{S}$ de caelo u. E ad] in E 
deducetur, ita humilitas si descenderit usque ad infernum tunc exaltabitur usque ad caelum.

4-Dicebat abbas Motoes: Quantum plus homo se Deo proximauerit, tantum se peccatorem uidebit. Esaias enim propheta uidens Dominum miserum se et inmundum uocauit.

5-Idem dixit: Non sumus hic sine sollicitudine. Dicit enim Scriptura: «Et qui stat uideat ne cadat». In incerto enim nauigamus; et nos quidem quasi in tranquillo mari nauigare uidemur, saeculares uero in periculosis locis. Sed nos quasi in die nauigamus, sole iustitiae inlustrati, illi uero in ignorantia quasi per noctem. Sed frequenter contigit ut saecularis in tenebrosa hieme nauigans, uigilans autem et clamans propriam nauem saluet. Nos autem dum in tranquillo nauigamus saepius ex ipsa securitate neglegimus et perimus, humilitatis gubernaculum relinquentes. Sicut inpossibile est nauem firmam fieri sine clauis, ita inpossibile est aliquem sine humilitate saluari.

XXXIV, 4 lin. 2-3: Esaias... uocauit - cf. Es. VI, 5.

5 lin. 2: Et qui... cadat-cf. I Cor. X, 12.

lin. 4-5: Sole... inlustrati-cf. Ps. XXXVI, 6: et Antiphona maior die 21 Decembris.

7 deducetur] -itur MVP dimergitur L om. E ita humilitas om. L si descenderit usque ad infernum tunc om. EL ad] in P 8 exaltabitur] -atur E enim humilitas add. $\mathrm{L}$

4-MVPELS 1-2 dicebat ... uidebit om. $\mathrm{L}^{3} \quad 1$ dixit PEL abba $\mathrm{P}$ se $o m$. PELS Deo proximauerit] p. D. E D. aproximauerit S 2 peccator $\mathrm{L}$ uidebit] uideat $\mathrm{E}$ euidebit $\mathrm{L}$ a uerbis Esaias enim repetit hanc sententiam $\mathrm{L}^{3} \quad 3$ Dominum] Deum EL se om. $\mathrm{S}$

5-MVPELS Totam sententiam repetit $\mathrm{L}^{3} \quad 1$ idem] item PELS non sumus hic] h. n. s. $\mathrm{L}^{1} \quad$ n. simus h. $\mathrm{L}^{3} \quad 2$ in om. P enim] ergo E 3 quidem quasi] quasi $q$. $V$ quidem quas $\mathrm{L}^{3}$ nauigare uidemur] nauigamus $\mathrm{P} \quad$-ri u. MVLS n. uidemus $\mathrm{E} \quad 4$ sed om. E nos om. $\mathrm{L}^{3}$ diem $\mathrm{E}$ sole] -em $\mathrm{M}$ sol $\mathrm{E}$ iustitiae] iniustitiae $\mathrm{L}^{3} \quad 5$ illustranti V ignorantiam S 6 saeculares MPE hieme nauigans] $\mathrm{n}$. h. S h. nauigantes $\mathrm{P} \quad$ uigilans autem om. $\mathrm{P} \quad 7$ clamans] clamantes $\mathrm{P}$ clamet $\mathrm{EL}^{3}$ ut add. LS saluet] -at eos P 8 neglegimus] -ur M -ximus V 8-9 humilitatis gubernaculum relinquentes] h. (-i $\left.\mathrm{L}^{1}\right)$-a $\mathrm{r}$. (reliquentes $\left.\mathrm{SL}^{1}\right) \mathrm{PSL}^{1} \quad 9$ sicut] autem add. $\mathrm{ESL}^{3}$ enim add. $\mathrm{PL}^{1}$ nauem firmam fieri] fieri $\mathrm{n}$. $\mathrm{f} . \mathrm{S}$ nauim firmam f. V 10 claue $\mathrm{S}$ 
6-Idem dixit: Humilitas nec ipsa irascitur nec alios irasci permittit.

7-Idem dixit: Humilitas est si quando peccauerit in te frater tuus et antequam ille poeniteat indulgeris ei.

\section{XXXV - QVOD PERFECTI NOLINT FACERE MIRACVLA NE EXTOLLANTVR}

1 - Abbas Sisoius cum habitaret in monte in quo erat beatus reclusus Antonius, quidam saecularis ad eum cum paruulo filio percipiendae benedictionis gratia properauit. Contigit autem ut infans ille moreretur in uia; quem pater sine ulla mentis perturbatione subla-

5 tum, cum fide portauit ad senem. Ingressusque cellam tam se quam infantem proiecit in terram ut est moris postulantium benedictionem. Oratione autem facta, exurgens pater egressus est, filii corpusculo derelicto ante pedes abbatis. Quem cum senex adhuc orandi causa iacere speraret: Surge, inquit, fili, et egredere. Defunctum enim esse

10 nesciebat. Confestimque puer exurgens egressus est. Quem cum pater uidisset obstipuit. Regressusque in cellam adorauit senem:

6-MVPLS om. E 1 idem dixit] item d. PS om. MV humilitas nec] neque h. S ipsa om. S nec ${ }^{2}$ ] neque $\mathrm{S} 2$ permittitur $\mathrm{S}$

7 - MVPELS Sententiam repetit $\mathrm{L}^{3} \quad 1$ idem] item PSL ${ }^{1}$ 1-2 peccauerit in te frater tuus] f. t. p. P in te om. PS 2 et $\mathrm{om} . \mathrm{S}$ poeniteat] tu add. $\mathrm{P}$ indulgeris] -seris PS -geas $\mathrm{L}^{1}$

XXXV - MVPELS perfecti] quamuis possint (-unt S) tamen (om. E) add. PELS nolint] -unt PS -ent EL uolunt $\mathrm{V}$ miracula facere PELS ne extollantur om. $\mathrm{L}^{1}$

1 -MVPELS 1 abbas Sisoius] abba Sisonius S montem L in quo] ubi PE $\quad 1-2$ beatus reclusus Antonius] b. A. r. EL inclusus b. A. P 2 ad eum om. PEL paruulo] proprio L filio] ad eum ueniens add. P 3 gratiam M 4 mentis $\mathrm{om}$. S 5 cum fide om. MV cellam] cellula E cellulam LS 6 postulantium] postulauit add. P $\quad 7$ facta exurgens] perfecta e. (om. S) PES est] et add. S om. V 8 ante] ad S abbatis] -i E se proiecit add. S quem] que MEL senex om. L adhuc om. P 9 iaceret E speraret] dixit add. ES senex dixit add. L filii VL et om. P egredere] extrahe $\mathrm{S} \quad 9-11$ enim esse... regressusque om. S 9 esse] senes $a d d$. E 10 puer $\mathrm{om}$. $\mathrm{L} \quad$ est] foras $a d d . \mathrm{L} \quad 11$ regressusque] reuersusque $\mathrm{L}$ in] ad V cellam] -a E et add. S adorauit senem] adorato sene (senem S) PES adorationem L 
tam causam filii quam luctum cum fide proprium enarrauit. Sed senex ualde maestus effectus (nec enim a se quicquam tale factum uolebat audiri) per discipulum suum illi homini ne cui usque ad suum transitum hoc diceret imperauit.

2 - Abbas Nestor dum cum altero fratre ambularent in deserto, uiderunt draconem et fugierunt. Dicit ei ille frater: Et tu times, abba? Cui senex: Non timeo, fili, sed oportuit me fugere quia nisi draconem fugissem cogitationem uanae gloriae non uitassem.

3-Cum quidam saecularis in ecclesiam ueniens ab inmundo spiritu teneretur et omnes orationem fecissent, nullatenus spiritus inmundus egrediebatur ab eo. Dicunt ergo intra se fratres: Quid possumus huic spiritui facere? Nemo illum poterit excutere nisi abba Besarion, sed si dixerimus hoc illi nec ad ecclesiam adquiescet uenire. Sed faciamus taliter: Quomodo ante omnes solet uenire ad ecclesiam hunc qui patitur faciamus sedere et postea dicamus abbati: Suscita, abba, hunc dormientem. Fecerunt ergo ita et ueniente abbate Besarione steterunt omnes in oratione et dicunt ei: Abba, suscita etiam istum qui dormit. Ille autem dixit: Surge et egredere foras. Et mox egressus est $a b$ eo spiritus inmundus et sanus effectus est.

12 causam] etiam L casum PES quam luctum cum fide proprium] q. 1 . cum (om. P) f. propria PEL cum luctu propria fide $\mathrm{S}$ 12-13 senex ualde maestus] sene u. misertus $\mathrm{E} \quad 13$ effectus] est add. L neque $\mathrm{S}$ quicquam] qui quam $\mathrm{E}$ factum om. MV 14 audire MVPL discipulum suum] d. enim s. direxit $\mathrm{L}$ ne cui] nec $\mathrm{L} 15$ hoc om. L dicere E imperauit] impetrauit $\mathrm{V}$

$$
\text { 2-MVPLS om. E } 1 \text { abba S Nestor] Nestoro L Nesteros P }
$$

Neston S altero] alio P ambularet PLS 2 ei om. PS ille] illi S
om. $\mathrm{V} 3$ senex] abba $\mathrm{P}$ draconem om. $\mathrm{S}$

3-MVPELS 1 cum] cui S ecclesia ELS 1-2 spiritu inmundo PE 2 et] cum $a d d$. $\mathrm{E}$ fecissent] pro eo add. $\mathrm{P} \quad 2-3$ inmundus spiritus $\mathrm{S} \quad 3$ egrediabatur L ergo om. PS inter ELS 4 possumus om. P huic spiritui] hoc (huc L) -u EL spiritui om. S illum poterit] p.i. V potest i. PEL i. potest $\mathrm{S}$ abbas $\mathrm{E} 5$ hoc $\mathrm{om}$. $\mathrm{P}$ neque $\mathrm{S}$ adquiescit EL 6 faciemus $\mathrm{S}$ ad ecclesiam uenire PELS 7 huc $\mathrm{L}$ faciamus] eum add. $\mathrm{P}$ 8 abbate] abba L $\quad 9$ orationem E suscita etiam] et suscita S 10 istum] illum V autem] ergo E et ${ }^{1} \mathrm{om}$. PL 11 inmundus spiritus $\mathrm{S}$ factus V 
4-Erat quidam uir habens filium paralyticum in Aegypto et adtulit eum in cella abbatis Besarionis et reliquit eum super ostium plorantem et discessit longe. Coepit ergo infans flere. Cum autem per fenestram senex uidisset eum dixit: Quis te hic detulit? Cui infans

5 respondit: Pater meus detulit me et ipse discessit. Cui senex: Surge et adiungere illum. Et mox sanus effectus, peruenit ad patrem suum.

5-Cum quendam mortuum beatus Macarius suscitasset, ut pecuniam conmendatam sibi pro qua uxor eius et filii in seruitio detinebantur ubi illam posuisset ediceret, discipuli eius prae timore ante pedes ipsius ceciderunt. Quibus senex: Istud propter me factum non 5 recte praesumitis. Nihil enim mihi conlatum est, sed propter uiduam mulierem et paruulos eius Deus indoluit. Hoc namque maius est quod Deus noster animas hominum sine peccato esse desiderat quam mortuum suscitare.

6 - Item dixit: Qui laborat et arbitratur se aliquid facere recipiet hic mercedem suam.

4-MVPELS 1 erat] cum $\mathrm{P}$ uir om. PELS et $o m$. P 2 abbatis om. $\mathrm{P} \quad 3$ ergo] autem E om. $\mathrm{S}$ flere] plorare EL 4 per fenestram senex uidisset eum] s. p. f. u. e. ES p. fenestra s. u. e. L p. f. u. e. s. P eum $\mathrm{om} . \mathrm{V}$ quis] qui $\mathrm{L}$ huc VP 5 detulit] at- PES re- $\mathrm{L} 6$ adiunge $\mathrm{EL}$ illi VPS

5-MVPLS om. E 1 resuscitasset LS ut] et MV 2 comodatam $\mathrm{S}$ seruitium $\mathrm{S}$ detenebantur $\mathrm{L} \quad 3$ illum $\mathrm{P}$ posuissent $\mathrm{V}$ ediceret] et diceret MP diceret $\mathrm{V}$ edicere et $\mathrm{L} 4$ ipsius] eius VS illius $\mathrm{P} \quad$ istum L 5 praesumitis] - mit $\mathrm{S}$-psistis $\mathrm{P}$ enim om. $\mathrm{P}$ mihi $\mathrm{om}$. S sed om. L 6 et $\mathrm{om}$. V paruulos eius Deus indoluit] p. filios e. D. doluit $\mathrm{P}$ maius] malus $\mathrm{ML}$ malum $\mathrm{P} \quad 7$ noster om. $\mathrm{S}$ sine peccato esse desiderat] s. p. d. e. V esse uult sine p. S esse om. L 7-8 quam mortuum suscitare] q. mortuos s. $\mathrm{P}$ om. $\mathrm{L}$

6-MVPLS om. E 1 item] idem LS a uerbis et arbitratur repetit hanc sententiam $\mathrm{L}^{3} \quad 1-2$ recipiet hic] $h$. recipit $\mathrm{P} \quad$ recipit $h . \mathrm{S}$ recepit $\mathrm{h} . \mathrm{L}$ 


\section{XXXVI - DAEMONES HVMILITATE VINCI ET EFFVGARI}

1 - Abbas Macarius dum diluculo palmarum folia portans ad cellam suam reuerteretur, occurit ei diabolus cum falce preacuta uolensque eum percutere et non ualebat. Qui exclamans dixit: Magnam uim a te, Macari, patior, qui cum te cupiam nocere non ualeo. Dum quaecumque tu facis ego magis exuperor: Tu enim ieiunas interdum et ego nullo umquam cibo reficior; tu saepius uigilas, me sopor numquam oppressit; sed una re me uincis ipse profiteor. Cumque ab eo rem ipsam abba Macarius requisisset, respondit: Humilitas tua sola me uincit. Ac sic extendente manus ad orationem beato Macario, spiritus inmundus inter auras euanuit.

2-Quendam ex senibus monachum eremitam homo spiritu malo correptus et spumans fortiter, in maxilla percussit. Senex autem mox praebuit illi et alteram maxillam ut feriret. Diabolus autem non sufferens incendium humilitatis abscessit.

XXXVI, 2 lin. 3: praebuit... alteram - cf. Mat. V, 39; Luc. VI, 29.

XXXVI - MVPELS daemones humilitate uinci et effugari] d. humilitatem uinci (-ient V) et (om. V) e. MV d. cum h. u. et fugari P d. h. (-is E) u. (-it L) et e. (fugari E) EL garri d. humilitatis deuincti fuerunt $\mathrm{S}$

1 -MVPELS 1 abba PS 2 preacutam E 3 percutere eum $S$ et $o m$. PES qui] et $\mathrm{P}$ magna $\mathrm{E} \quad 4$ a te Macari patior] $\mathrm{M}$. a te $\mathrm{p}$. $\mathrm{S}$ a te p. M. L cupio PES 5 exuperor] -em PEL superem $S$ enim om. P ieiunans LS 6 et] at E om. PLS nullum E reficio p. corr. $\mathrm{L}$ saepe PELS me] uero add. PEL sopor numquam] $\mathrm{n}$. sopor (sapor E) ELS 7 sed] in add. P de add. E unam rem PEL ipsum $P \quad 7-8$ ab eo rem ipsam abba Macarius requisisset] ab eo et i. requisisset M. P rem i. a. M. ab eo r. E rem ipsam om. V 8 humilitas]

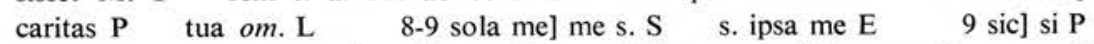
beato Macario manus ad orationem $\mathrm{S} \quad 10$ inter auras] i. aures $\mathrm{V}-\mathrm{om}$. $\mathrm{S}$ euanuit] euasit E

2-MVPLS om. E 1 quidam MVLS 1-2 homo spiritu malo correptus et spumans] hoc $\mathrm{m}$. s. c. et expugnans $\mathrm{S} \quad 2$ maxillam PS 3 et $\mathrm{om}$. PLS alteram] aliam $\mathrm{P} \quad 4$ discessit $\mathrm{P}$ 
3-Quidam dicebat ex patribus: Omnis labor sine humilitate uanus est. Humilitas enim praecursor est caritatis. Et sicut Ioannes praecursor erat Iesu omnes trahens ad eum, ita et humilitas adtrahet ad caritatem, id est, ad ipsum Deum quia caritas est.

4-Abbas Theodorus dum inter alios fratres ad mensam sedens pro caritate reficeret, tacentes monachi calicem suscipiebant non dicentes: «Indulge». Tunc ille: Humilitatis, inquit, signum et nobilitatem suam monachi perdiderunt. In quocumque enim loco ac tempore uel actu

5 ueniam postulare, humilitatis est formula. Hic enim sermo, id est, «indulge», decus est monachi.

\section{XXXVII - QVIA SERMO SVPERBVS ETIAM BONVM HOMINEM MALVM FACIT, SERMO VERO HVMILIS ETIAM DE MALO BONVM FACIT}

1 - Abbas Macarius, dum ad montem Nitriae ascenderet, discipulo suo ut parum praecederet imperauit. Qui dum praeiret obuius est quendam sacerdotem idolorum cursu uenientem et lignum grande portantem. Cui exclamans ait: Quo curris, daemon? At ille iratus

5 tantis eum plagis affecit ut exanimem paene relinqueret et relicto eo iterum currebat. Progressusque parum obuiauit beatum Macarium

XXXVI, 3 lin. 2-3: Ioannes... eum - cf. Mat. III, 1-17; Io. XII, 32.

lin. 4: Deum... est - cf. I Io. IV, 8, 16.

3-MVPELS 1 dicebat] ex fratribus uel add. S 2 uanum E est om. P 2-3 caritatis ... Iesu in marg. scribit $\mathrm{L} \quad 2$ et sicut] s. enim $\mathrm{P}$ 3 erat] est E om. L eum] Deum PS et om. V humilitas adtrahet] h. omnes trahens $\mathrm{P} 4$ Deum] Dominum $\mathrm{E}$ quia] qui $\mathrm{V}$ Deus add. PELS 4-MVPELS 1 abba $S \quad 2$ pro caritate] procaciter $S$ tacentis $S$ 3 humilitas E signum] sinum MV suam om. $\mathrm{P}$

XXXVII - MVPELS etiam om. VL bonum om. M facit malum $\mathbf{M}$ sermo uero... facit $o m$. PL humilis etiam de malo] h. et de $\mathrm{m}$. V h. e. malum $\mathrm{E}$ bonus h. malum $\mathrm{S}$

1 -MVPELS 1 abba S dum] cum PELS 2-3 obuius est] obuiatus est ei $(\mathrm{om}$. S) PS 3 quendam sacerdotem] q. sacerdos $\mathrm{L}$ cuidam sacerdoti $\mathrm{S}$ cursu uenientem] currentem $S \quad 4$ cui exclamans] e. qui $S \quad 5$ affecit ut exanimem] effecit ut e. (-e E) VE 6 beatum] -o E abbatem P abbati LS Macarium] -o ES Mario L 
qui ait ad eum: Salueris, laboratur, salueris. At ille admiratus respondit: Quid in me boni conspexisti ut ita me salutares? Cui senex: Quia uidi te laborantem et in quo curris ignorantem. Cui sacerdos: Et ego, inquit, in salutatione tua conpunctus magni Dei seruum te esse cognoui. Nam alter nescio quis miserabilis monachus occurrens mihi iniuriam fecit, sed ego illi plagis pro uerbis inposui. Tunc tenens pedes beati Macarii proclamabat: Nisi me monachum feceris non desistam. Pergentesque pariter uenerunt ad locum in quo caesus frater $a b$ eo iacebat. Quem utrique tollentes, quoniam gradi non poterat, in ecclesiam detulerunt. Cum autem ceteri fratres uidissent sacerdotem beato Macario comitantem stupefacti monachum eum cum admiratione perficiunt. Ac multi propter illum ex paganis facti sunt christiani. Dicebat ergo abbas Macarius: Sermo superbus et malus etiam bonos uiros conuertit ad malum, sermo autem humilis et bonus etiam malos mutat in melius.

\section{XXXVIII - QVIA HVMILITATE MAGNORVM ET PARVI IVVENTVR}

1 - Cum in Sceti patribus semel a quodam uineae fuissent caricae erogatae, abbati Arsenio ceteri fratres destinare noluerunt timentes

7 ad eum om. S salueris2] salutis $\mathrm{E} \quad$ respondit $\mathrm{om} . \mathrm{S} \quad 8$ quid] enim add. E in om. S salutaris $\mathrm{V}$ quia om. E 9 te laborantem] laborante $\mathrm{S}$ in om. PELS quo] co ML eo V ignorante $\mathrm{V} 10$ ego inquit in salutatione tua conpunctus magni Dei seruum te esse] e. i. in (om. EL) salutatione (-is E) tua (tuae E) c. sum (om. E) magni (-um E) D. s. te (te D. s. L) e. EL in s. t. ego compunctus te e. m. D. s. S 11 cognoui nam] cognosco nam et $\mathrm{E} \quad 12$ iniurias PELS sed ego illi] sed et ego illi (om. S) ES plagis pro uerbis] plagas p. u. L p. u. plagas $\mathrm{P}$ inposui] me posui $\mathrm{V}$ posui $\mathrm{L} 15 \mathrm{ab}$ eo $\mathrm{om}$. EL utrique] utriusque $\mathrm{E}$ uterque $\mathrm{S}$ quoniam gradi] quem (qui $\mathrm{S}$ ) g. (-iri V) VS 16 pertulerunt PELS uiderunt $S 17$ beatum Macarium $P$ eum om. 18 perficiunt ac] proficiunt ac (hanc E) PEL 19 ergo abbas] e. (autem E) abba EL 20 uiros bonos $\mathrm{P}$ ad] in $\mathrm{E}$ autem] uero $\mathrm{E} \quad 21$ bonis $\mathrm{L}$ meliores $\mathrm{V}$ XXXVIII - MVPELS quia] qui in E parui iuuentur] $\mathrm{p}$. iuuantur $\mathbf{P}$ paruuli iuuentur (iuuentus S) ES parba iubenter $p$. corr. L

$$
\text { 1-MVPELS } 1 \text { patribus] partibus } P \text { a] ad } E \text { uineae fuissent] }
$$

binae f. P om. S caricae] -a S calice P et etiam p. corr. L 2 erogati $\mathrm{E}$ fratres] senes PEL senex $\mathrm{S}$ destinari $\mathrm{E}$ 
ne propter paucitatem fecisse ei iniuriam uiderentur. Quod cum beatus Arsenius audisset, noluit in ecclesia in congregatione uenire

5 dicens: Excommunicastis me, ne benedictionem mihi transmitteretis quam Deus fratribus destinauit, quam quidem non eram dignus accipere. Quod uerbum cum plurimi cognouissent, iuuati sunt accepto per humilitatem tanti senis exemplo. Presbyter autem pergens ad eum, datisque illi duabus caricis, sicut et ceteris fratribus, deduxit eum in congre10 gatione cum gaudio.

\section{XXXIX - QVIA VTILITER ALIQVOTIENS IN SORDIDIS COGITATIONIBVS RELINQVIMVR NE EXTOLLAMVR}

1 - Saepe dicebat beatus Antonius: Nisi pistor muli oculos operiret, mercedem suam respiciens ipse consumeret. Ita et nos per dispensationem Dei tegimen accipimus ut ea quae operamur bona non ualeamus intendere, ne nos ipsi beatificantes possimus extollere et mercedem

5 propriam amittamus. Nam et ob hoc quando relinquimur in sordidis cogitationibus haesitantes, ut hoc tantummodo peruideamus, ut nos ipsos nostra sententia condemnemus et ea quae sunt in nobis sordida illud parum bonum opus nostrum in nobis obscurent.

Numquam enim homo bonus est etiamsi bonus esse desideret

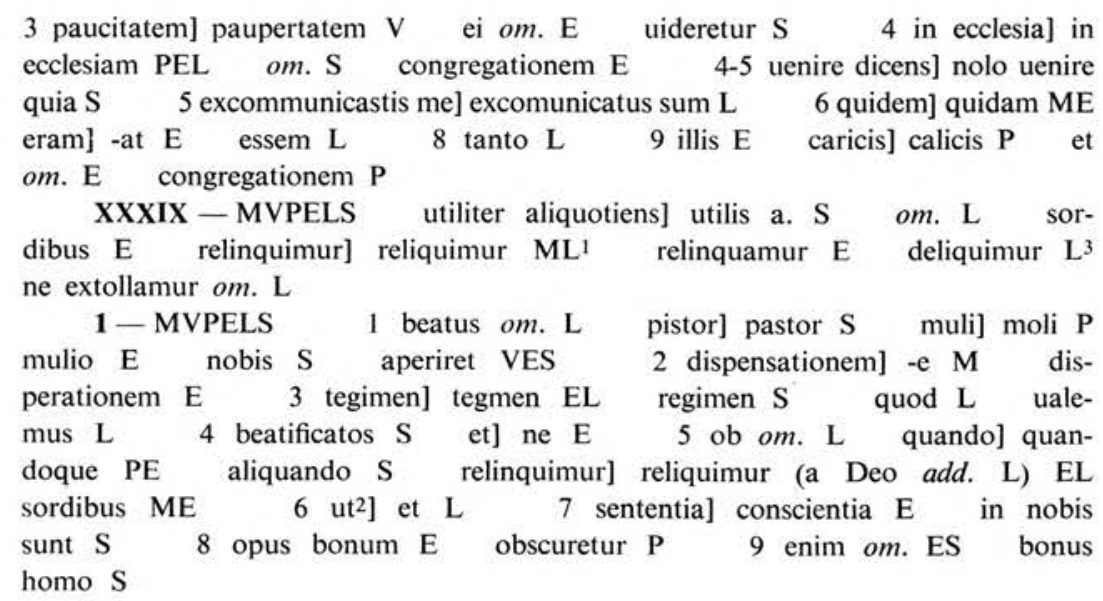


nisi Deus habitauerit in ipso. Quia nemo bonus nisi solus Deus.

Oportet autem ut nos semper ueraciter incusemus.

Quando enim se quisque reprehendit mercedem propriam non amittit.

2-Idem beatus Antonius retulit se uidisse omnes laqueos inimici super uniuersam terram explicitos. Et cum suspirans dixisset: «Quis hos poterit transilire», uocem ad se dicentem audiuit: Humilitas sola pertransit, Antoni, quam nullo ualent modo contingere.

3-Idem dum in cella propria oraret beatus Antonius uenit ad eum uox dicens: Antoni, necdum ad mensuram coriarii istius qui est in Alexandria peruenisti. Quo audito senex consurgens mane, arrepto baculo, ciuitatem festinus aduenit. Cumque ad designatum hominem fuisset ingressus, ille uiso tanto uiro obstipuit. Cui senex: Refer mihi opera tua, quia propter ea relicto deserto ad te hic ueni. Qui respondit: Nescio me aliquando bonum aliquid perpetrasse. Vnde et ex cubili proprio mane consurgens, antequam in opere meo resideam, dico quod omnis haec ciuitas a minore usque ad maius ingrediuntur in regnum Dei propter iustitias suas; ego autem solus propter peccata mea poenam

XXXIX, 1 lin. 10: Quia... Deus - cf. Luc. XVIII, 19.

10 in] cum PE $\quad 11$ autem] enim $\mathrm{P} \quad$ semper om. $\mathrm{S}$ ueraciter incusemus] i. u. $L$ u. concussemus $S \quad 12$ se quisque] se quisquam $E$ quisquam se $S$ 2-MVPELS 1 idem] item PLS retulit se uidisse] retulisse u. MV se u. om. EL 2 explicitos] explicatos LS qui S 3 possit E transilire] transire PL 4 pertransiit VELS quem $\mathrm{L}$ nullo ualent modo] n. m. u. E n. ualet $\mathrm{m}$. $\mathrm{L}$ nullo om. S nullo $\mathrm{m}$. uallent modo V Ordo uerborum qui inuenitur in $V$ erat etiam in $M$, sed primum modo erasum est. 3-MVPELS 1 idem] item PLS cellam propriam L oraret beatus Antonius] b. A. o. P b. o. A. LS 3 Alexandria] -am L. ualle andria $\mathrm{P}$ audiens EL senex] semper $\mathrm{V}$ om. $\mathrm{L}$ consurgens mane] m. c. S surgens E 3-4 baculo ciuitatem festinus] b. in ciuitate f. ELS b. f. in c. P 4 uenit $P$ cum $E$ signatum $S \quad 5$ illo $\mathrm{L}$ obstupuit VPES 6 quia propter] quapropter $\mathrm{S}$ ea relicto om. $\mathrm{S}$ ad te deserto $\mathrm{S}$ hic] huc VP om. ELS perueni ES respondens L 7 aliquando om. $\mathrm{S}$ bonum aliquid] boni a. $\mathrm{P}$ aliquod b. $\mathrm{S}$ et om. PS ex om. L cubile M 8 proprio] meo $S$ resideam] sedeam E 9 ciuitas haec $\mathrm{EL}$ minore] minimo $\mathrm{PE}$ maius] maiorem in marg. $\mathrm{E}$ maximum $\mathrm{P}$ in om. L regno PS 10 ego] ago $\mathrm{P}$ 
heredito sempiternam. Quod uerbum etiam antequam quiescam sero semper ex cordis mei recenseo ueritatem. Quo audiens beatus Antonius respondit: In ueritate, fili, sicut bonus artifex sedens in domo sua cum requie regnum Dei adeptus es; ego autem uelut sine discretione omne

15 tempus meum in solitudine conuersatus et necdum uerbi tui adsumpsi mensuram.

4-Cum quidam frater ad abbatem Sisoium ueniens memoriam suam semper cum Deo permanere dixisset, respondit senex: Non est difficile cum Deo adhaerere memoriam; sed magnum est si te inferiorem totius creaturae respicies.

5 - Idem dixit: Corporalis labor dux humilitatis est.

6-Quidam frater requisiuit abbatem Poemenem dicens: Quid est: «Omnia munda mundis»? At ille dixit: Si quis ad hunc sermonem peruenire potuerit ut eum intelligat, uidebit se minorem esse totius creaturae. Cui frater: Et quomodo possum me uidere minorem ab

5 eo qui homicida est? Respondit senex: Si potuerit homo ad sermonem hunc Apostoli peruenire et uiderit hominem quia occidit, dicit in semetipso: Iste quidem hoc solum peccatum fecit, ego autem omni hora homicidium conmitto, meipsum interficiens.

XXXIX, 6 lin. 2: Omnia munda mundis - Tit. I, 15.

11 uerbum] -o $\mathrm{P}$ uero $\mathrm{E}$ sero] secundo $\mathrm{S} 12$ semper $\mathrm{om}$. PELS meis $\mathrm{E}$ ueritatem quo] u. (-e VP) quod VPLS 13 respondit] dixit $P$ artifex] aurifex PEL sua] tua PES et $p$. corr. L 14 est $\mathrm{S}$ uelut] sicut add. P discretionem E 15 conuersatus] consumpsi P conuersatum S et om. ELS 4-MVPELS 1 Sisoium] Sisogium $\mathrm{P}$ Sisonium $\mathrm{S} \quad 2$ respondit] ei add. E 3 adhaerere] habere EL adhibere S est om. P 4 respicies] -as ELS cognoueris $P$

5-MVPELS 1 idem] item PS est humilitatis $S$

6-MVPELS 2 munda mundis at ille dixit] manda mandis respondit senex $P \quad 3$ peruenire potuerit] pot. peru. $S$ uenire p. $L$ eum] illum $S$ esse om. L 4 cui] qui ille $\mathrm{L}$ possum me videre] me p. u. ELS me u. p. P possem m. u. V minore L 4-5 ab eo om. E 5 est] sum L hominem E 6 uiderit hominem quia] u. (-i L) h. (om. S) qui (alium add. P) PLS occidet $M \quad 6-7$ dicit in semetipso iste] d. ei in s. $S$ in $s$. haec dicat $i$. $P$ 
Et cum frater requireret quomodo hoc posset fieri respondit: Haec sola est hominis iustitia si seipsum reprehendat. Tunc enim iustus est cum sua peccata reprehendat.

7-Quidam frater dixit ad senem: Cogitatio mea dicit mihi: «Bene sum». Respondit senex: Qui non uidet peccata sua semper ille in bonis esse credit; qui autem uidet illa, mille cogitationes ei suadere non possunt quod in bonis sit; scit enim quod uidet. Opus enim labore multo ut se unusquisque consideret, nam neglegentia et relaxatio obcaecat nos.

8-Quidam frater dixit abbati Poemeni: Cogitationes meae non permittunt me mea respicere peccata, sed fratris mei cogunt me cogitare delicta. Respondit abba Poemen de abbate Isidoro referens ac dicens: Dum plangeret abba Isidorus in cella sua et discipulus eius in altera cella sederet, contigit ut illa hora discipulus eius ad illum ueniret qua ille plangebat et requisiuit dicens: Quid plangis, pater? At ille respondit: Peccata mea plango. Cui discipulus: Non habes peccata, pater. At senex: In ueritate, inquit, fili, si peccata mea Deus manifestaret omnibus non solum alii tres et quattuor sufficerent mecum plangere sed pluriores.

9 hoc posset] h. possit $\mathrm{S} \quad$ possit h. P potest haec $\mathrm{E} \quad 10$ sola est] e. s. S est om. L hominis] -i $\mathrm{S}$ omnis MVE si seipsum] ut $\mathrm{s}$. (semetipsum PLS) PELS 10-11 tunc enim... reprehendat om. E 11 reprehendat] condemnat PLS

7-MVPLS om. E 1 dixit] dicit PLS dicit] dic V mihi] quia add. $\mathrm{S} 2$ bene] unde $\mathrm{V}$ bonus $\mathrm{S}$ senex om. $\mathrm{V} \quad 3$ in bonis] bonus $\mathrm{L}$ se $a d d$. PS esse] se $a d d$. L credit] -et MV credidit L illa] -m L mille correxi (cfr. Palladii Lausiaca $X X, 12$ : decem millia cogitationum non possunt suadere quia in bonis est. [PL LXXIV, col. 380]): ille MVL iste PS 4 uidit S 4-5 enim labore multo ut] e. (ergo PS) est ut 1 . m. PLS ut om. PLS 5 unusquisque] quisque PLS 6 obcaecat] excecat $P$

8-MVPELS 1 meae] om. L 2 permittunt me] me p. L mea respicere peccata] p. $\mathrm{m}$. conspicere $\mathrm{S}$ m. p. om. EL peccata om. $\mathrm{P}$ fratres S me om. L 3 delicta] peccata PELS abba] abbas $P$ 4 abbas $\mathrm{P} \quad 5$ sederet] erat MV eius om. PELS qua] quia MV 6 requisiuit] eum add. PLS illum add. E dicens om. S at ille] et senex P 7 non] num $P \quad 8$ at] et $P \quad 9$ omnibus] hominibus ELS et] sed E uel $\mathrm{S}$ quattuor] non add. EL sufficeret VP 10 plures S 
9-Dum sederent fratres prope abbatem Poemenem unus alterum quendam fratrem laudauit dicens: Bonus est ille frater, quoniam mala horret. Cui senex: Et quid est mala horrere? At ille nesciens quid illi responderet petebat dicens: Dic mihi, abba, quid est mala horrere.

5 Cui senex: Ille horret mala qui sua peccata propria horret et omnem fratrem suum beatificat.

\section{XL - QVOMODO VITETVR DETRACTIO}

1-Quidam frater requisiuit abbatem Poemenem dicens: Quomodo potest homo uitare ne loquatur malum de proximo suo? Respondit senex: Ego et proximus meus duae sumus imagines. Cum ergo meam imaginem respexero et reprehendero me, inuenitur imago

5 fratris mei apud me uenerabilis. Quando autem meam laudauero, tunc fratris mei imaginem prauam respicio. Tunc ergo de alio non detraho si semper reprehendero meipsum.

2-Dixit abbas Hyperechius: Melius est comedere carnes et bibere uinum quam comedere carnes fratrum in uituperatione.

Sicut enim susurrans serpens Euam de paradiso excussit, ita qui de fratre suo detrahit non solum suam sed et audientis animam perdit.

9-MVPELS 1 dum] cum PS fratres om. S 2 laudabat P quoniam] qui ES 3 at ille] at (om. EL) illi ELS $3-4$ quid illi] quod ille L 4 responderent $\mathrm{E}$ petebat] -ant $\mathrm{E}$ re- $\mathrm{P}$ dicentes $\mathrm{E}$ mala] magis $\mathrm{E}$ 5 propria om. S 6 suorum $\mathrm{P}$ beatificat] benedicat $\mathrm{V}$

XL - MVPELS

1 - MVPELS 1 Poemen P 2 uitare homo PELS malum om. E 3 duae] duo EL 5 apud me om. MV uenerabilis] -i sed P meam] me ES 6 fratris mei om. $\mathrm{S}$ prauam] paruam EL 7 detraho] detracto PEL semper] et add. S reprehendero meipsum] m. r. V m. reprehendo $\mathrm{S}$

2-MVPELS 1 abba S Hyperechius] Yspiricius MVL Ispiricus $\mathrm{P}$ comedere] manducare $\mathrm{P} \quad 1-2$ et bibere ... carnes om. V 2 carnes fratrum in uituperatione] in u. c. f. PEL $\quad$ c. in u. f. S 3 Eua EL 4 fratri M suo om. E detrahit] detractat PEL suam] sua MV suum P et om. EL perdit] -et MPEL -at V 


\section{XLI - NON DEBERE DE QVOVIS PECCATORE DIIVDICARE NEQVE QVEMQVAM CONDEMNARE}

1-Cuidam patri in solitudine conmanenti presbyter solebat uenire et consecrare oblationem. Quidam autem ueniens ad eum accusauit presbyterum. Cum ergo uenisset ille secundum consuetudinem oblationem consecrare, scandalizatus senex non ei aperuit ostium. Cum autem presbyter discessisset, uox facta est ad solitarium dicens: Tulerunt homines a me iudicium. Et subito factus in extasi uidit lacum aureum et uas aureum et funem aureum et aquam optimam et quendam leprosum haurientem ex laco aquam et transfundentem. Cum autem uellet bibere senex qui hoc uidebat, non bibebat ab eo quod leprosus esset ille qui hauriebat. Et ecce iterum uox ad senem dicens: Cur non bibis ex aqua hac? Qualem causam habet qui haurit? Ille enim tantummodo haurit atque transfundit. Cum ergo in se reuersus fuisset solitarius et habuisset discretionem uisionis, uocauit presbyterum et fecil eum, sicut et prius, oblationem sacrare.

2-Solebat dicere abbas Ioannes: Paruam sarcinam dimisimus, id est, nosmetipsos reprehendere, et grauem portare elegimus, id est, ut nos iustificemus et alios condemnemus.

XLI - MVPELS de om. $M$ diiudicare] iudicari $\mathbf{L}^{1}$ neque quemquam condemnare om. $\mathrm{S}$ quemquam] quendam $\mathrm{M}$ quicquam $\mathrm{V}$ quam $\mathrm{E}$ et p. corr. $\mathrm{L}^{3} \quad$ om. $\mathrm{L}^{1}$

1-MVPELS 1 patri] fratri E conmanenti] uiuenti (solitario add. P) PES 2 et consecrare] ad c. ei L 3 presbyterem $\mathrm{M}$ ergo] autem $\mathrm{PL}$ secundum] ad L 4 consecrare scandalizatus senex] sacrare s. (est add. P) senex (et add. P) PELS 6 homines a me] me omnes homines $\mathrm{E}$ a me h. (inquit add. L) PLS iudicium] meum add. PL 6 factus] est add. VL 7 lacum] locum $\mathrm{E}$ et funem aureum] et f. auream $\mathrm{S}$ om. $\mathrm{E} 8$ laco] lacu $\mathrm{P}$ lacum $\mathrm{S}$ om. E 9 autem] ergo $\mathrm{P}$ haec $\mathrm{S}$ non bibebat] horrebat quidem $\mathrm{P} \quad \mathrm{ab}$ ] ex E om. VP 10-11 uox ad senem dicens] u. (de celo add. E) d. ad s. PEL 11 bibes MVPL hac aqua LS haurit] currit S 12 enim om. $\mathrm{S} \quad$ atque] et $\mathrm{S} \quad 12-13$ in se reuersus fuisset] ad se f. r. L 13 habuisset discretionem] d. dissereret $\mathrm{P} \quad 14$ presbyterem $\mathrm{M}$ 2 - MVPELS
1 solebat] nolebat $P$ abba $S$
2 nosmetipsos repre-

hendere] r. n. S

n. deprehendere $\mathrm{E}$ graue EL 
3 - Facta congregatione semel in Sceti, dum patres de multorum uita et de rebus plurimis loquerentur, abbas Pior tacebat. Postea uero egressus tollens saccum impleuit eum harena et portauit in dorsu suo. Iterum in altero paruo panno misit alteram harenam et portauit

5 ante se. Videntes autem ceteri patres requisierunt ab eo quod hoc esset exemplum. Et respondit dicens: Iste saccus qui habet multam harenam mea peccata sunt quoniam plurimae sunt iniquitates meae; et ecce dimisi ea post dorsum meum nolens illa uidere ut pro ipsis doleam uel plangam; et ecce haec pauca delicta fratris mei ante oculos

10 meos posui et crucior in ipsis condemnans fratrem meum. Sed non oportet sic facere, sed mea magis ante me adducere et de ipsis cogitare et rogare Deum ut indulgeat mihi. Quo audientes patres dixerunt: In ueritate haec est uia salutis.

4-Vnus ex sanctis patribus uidens alium neglegentem, fleuit amare et dixit: Vae mihi quia quomodo iste hodie peccat sic et ego crastino. Et monebat discipulum suum dicens: Quamuis grauiter aliquis te praesente peccauerit ne condemnes eum, sed sic apud te sit 5 tamquam si tu plus pecces de eo, quamuis ille sit saecularis, nisi forte in Deum blasphemauerit quod est haereticus.

5-Abbati Theodoro quidam ex fratribus referebat eo quod unus ex monachis reuersus fuisset ad saeculum. Cui senex res-

XLI, 3 lin. 7: plurimae... meae - cf. Ps. L, 11.

3-MVPELS 1 dum] cum P 2 abbas] Iohannes add. P Pior] Prior MLS postea om. S 3 uero egressus] et e. foras $\mathrm{S}$ harena et portauit] h. (arenam EL) et portabat (eum add. P) PELS 3-4 in dorsu... portauit $o m$. EL dorsu suo] dorso suo et (om. V) VPS 4 portabat PS 5 ab eo quod] ab eo (om. S) quid PS 6 et om. P dicens] senex $\mathrm{P} \quad 7$ quoniam] quia $\mathrm{S} \quad 8$ et $\mathrm{om}$. $\mathrm{E}$ eas $\mathrm{S}$ illa] illas $\mathrm{V}$ ea $\mathrm{S} 9$ uel] et $\mathrm{E}$ aut $P$ haec om. PS 10 meum $\mathrm{om}$. PELS 11 ante $\mathrm{om}$. MV me om. MVS de] in $\mathrm{E} \quad 12$ quod VELS patres] fratres $\mathrm{S} \quad 13$ uia salutis est $\mathrm{V}$

4-MVPELS 1 patribus] fratribus $S$ uidens alium] $u$. alterum PEL uidit fratrem suum $\mathrm{S}$ negligere $\mathrm{V} \quad 2$ quia $\mathrm{om}$. $\mathrm{V}$ quomodo $\mathrm{om}$. $\mathrm{L}$ hodie peccat] p. h. E hodie om. P sic om. V 3 crastino] -a E -am L 3-4 grauiter aliquis te praesente] a. g. te p. E a. te p. g. S 4 peccet EL nec MV 4-5 sic apud te sit tamquam] s. a. te sit quam MV sit a. te sicut $S$ 5 de eo] Deo MP saecularis sit $\mathrm{P} \quad 6$ quod] quia talis $\mathrm{S}$

5 -MVPELS 1 fratribus] patribus PS eo om. L 2 ex monachis] monachus $\mathrm{V}$ 
pondit: In hoc capitulo ne mireris, sed magis stupe si quis potuit inimici dentes atque insidias euadere.

6 - Venit aliquando abbas Isaac in coenobio et uidit illic fratrem neglegentem et iratus iussit eum expelli de coenobio. Dum ergo regrederetur in deserto, uenit angelus Domini et stetit ante ostium cellae eius dicens: Non te permitto ingredi. At ille rogabat ut ei culpa manifestaretur. Et respondit angelus: Deus meus transmisit me dicens: «Vade et dic Isaac: Vbi iubes ut mittamus illum fratrem qui peccauit?». At ille mox egit poenitentiam dicens: Peccaui, Domine, indulge mihi. Et dicit ei angelus: Exurge, indulget tibi Deus, sed ne iterum hoc facias ut quemquam condemnes antequam illum Deus iudicet. «Tulerunt homines a me iudicium meum et non illum mihi permittunt», dicit Dominus. Hoc autem dictum est quia si contigerit de illis perfectis aliquem uel in paruo peccare mox proditur.

7-Quidam anachoreta cum audisset aliquem fratrem ex relatione abbatis sui in coenobio neglegere dixit ipsi abbati: Si quomodo dicis ita uiuit, expelle illum de coenobio foris. Audiens autem hoc abbas Poemen dixit anachoretae illi: Erant duo homines in uno loco et utrisque contigit ut haberent mortuos. Ille autem unus, relicto proprio mortuo in domo sua, noluit eum plangere sed profectus coepit

XLI, 6 lin. 9-10: Tulerunt $\ldots$ permittunt - cf. Ierem. II, 9; Es. LIX, 9.

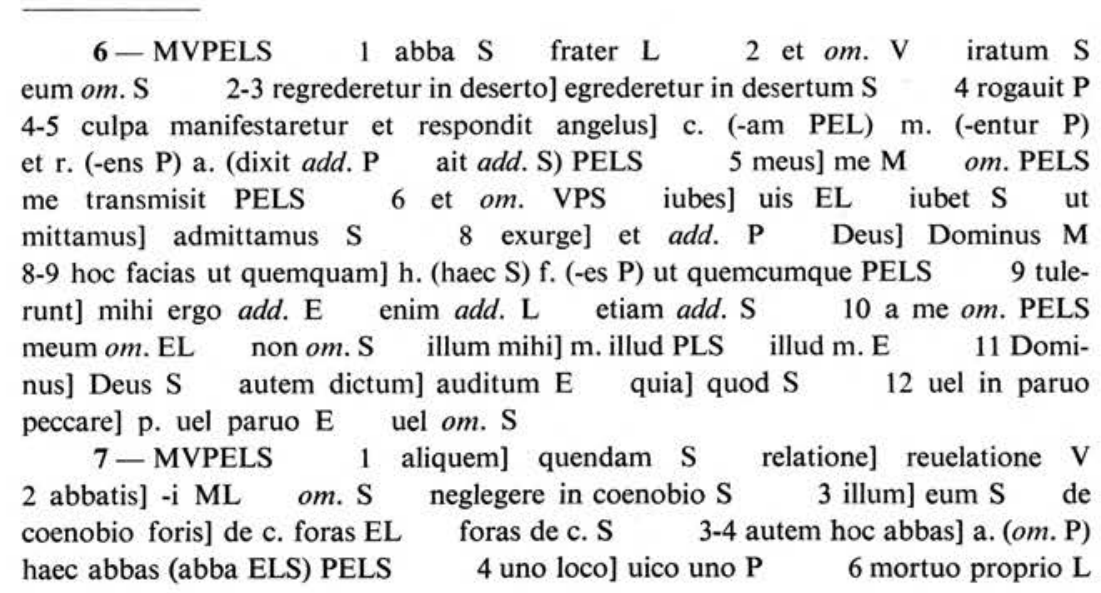


uicini mortuum flere. Quod cum anachoreta audisset, conpunctus in sermone eius et recordatus quod fecerat dixit: Indulge mihi, abba, tu enim de superioribus et caelestibus es, ego autem de inferioribus et 10 terrenis.

8 - Quidam frater, dum neglegenter uiuens, a ceteris fratribus de coenobio fuisset expulsus, ad abbatem Antonium est profectus. Cum autem aliquanto tempore permansisset cum eo, remisit eum in coenobio. At illi noluerunt eum suscipere, sed iterum expulerunt. At ille rursus

5 ad beatum Antonium regressus est dicens: Noluerunt me suscipere, pater. Tunc transmisit ad eos beatus Antonius dicens: Ecce nauis in medio pelago naufragauit et omnem mercedem suam perdidit et uix cum grande labore nauis ipsa peruenit ad litus. Vos autem et id quod saluatum est in litore iterum uultis in mari proicere. Quod

10 cum illi audissent, expulsum fratrem cum gaudio susceperunt.

9 - Contigit fratri culpa in coenobio et dum a ceteris increparetur ad abbatem est profectus Antonium. Et adsecuti eum fratres uolentesque reducere coeperunt exprobrare ei. Ille uero fecisse culpam denegabat. Inuentus est autem ibi abbas Paphnutius, cui cognomen 5 erat Cephalas, qui talem retulit, audita fratrum contentione, para-

7 uicini mortuum] -is (-o L) m. (-o L) VL flere] plangere E 9 autem] quidem $\mathrm{S}$

8-MVPELS 1 uiueret E 2 fuisset $\mathrm{om}$. EL est profectus Antonium PELS 3 aliquanti $\mathrm{L}$ cum eo om. $\mathrm{S}$ in coenobio] ad coenobium PELS 4 iterum expulerunt] e. i. $S$ i. expellerunt $M \quad$ i. eum e. $E$ iterum om. P at] et PS 5 ad beatum Antonium regressus est] ad b. e. r. A. L r. e. ad b. A. S ad beatus Antonius r. e. $M$ ad b. A. e. reuersus $P$ reuersus e. ad b. A. E recipere $P \quad 6$ ecce] dum add. PS 7 pelago naufragauit et] p. (-i S) nauigaret PS mercedem] mercem $S \quad 8$ uix cum grande] $u$. (uis S) cum grandi PS 9 saluatum] sublatum MV iterum] tamen P mare E 10 expulsum] e. (exemplum E) illum PELS fratrem $\mathrm{om} . \mathrm{V}$ gaudio] gratia LS receperunt $P$

9-MVPELS 1 fratri om. S 2 profectus est $\mathrm{P}$ et om. S uolentesque] nolentesque $\mathrm{V} \quad 3$ exprobare $P$ fecisse] fecisset ei $\mathrm{V}$ feces se $p$. corr. L se add. E 4 denegebat] -uit $\mathrm{P}$ negabat $\mathrm{L}$ est om. S autem ibi abbas] a. (om. EL) ibi abba ELS Paphnutius] Paphnuntius PLS cognomen] inquit add. S 5 audita] -am V -um MP contentionem EL 
bolam: Vidi, inquit, in ripa fluminis hominem usque ad genua in limo dimersum. Venientes autem quidam ut eum porrecta manu extraherent, usque ad collum dimerserunt. Tunc abbas Antonius de beato Paphnutio dixit: Ecce homo qui potest animas ex ueritate saluare. Quo fratres illi sermone conpuncti agentes poenitentiam eum qui discesserat ad coenobium reuocauerunt.

10 - Dixit abba Poemen: Si peccauerit homo et negauerit dicens quia non peccaui, ne arguas illum. Nam incidis propositum eius. $\mathrm{Si}$ autem dixeris ei: Ne tribuleris, frater, sed perseuera; si non peccasti ne pecces. Tunc confortas animam eius ad poenitentiam.

11 - Dixit quidam senex: Si uideris aliquem peccantem, ne mittas culpam in eo, sed in illum qui inpugnat eum dicens: Vae mihi quia sicut iste nolens uictus est, sic et ego. Et plange et inquire Dei solacium. Nemo enim uult peccare, sed omnes decipimur.

12 - Quidam Timotheus anachoreta neglegentem aliquem fratrem audiens, interroganti abbati quid illi faceret dedit consilium ut eum expelleret. Cum ergo ille expulsus fuisset, tentatio uenit super Timotheum. Et cum ploraret in conspectu Dei et diceret: Peccaui, miserere mei, uenit ad eum uox dicens: Timothee, ideo tibi hoc uenit quia fratrem tuum in tempore tentationis despexisti.

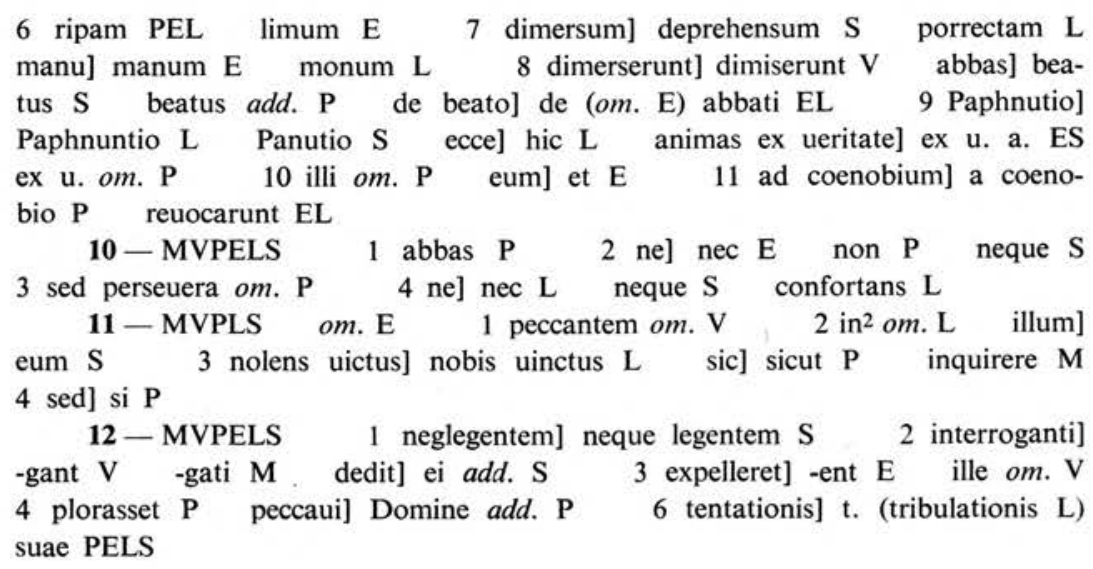




\section{XLII - DE OBOEDIENTIA MONACHORVM}

1-Dixit quidam senex: Grande ornamentum est monachis oboedientia. Nam quicumque eam possederit et ipse audietur et Crucifixo cum fiducia adstabit, quia Dominus noster oboediens fuit usque ad mortem.

2-Quidam pater in extasi positus uidit quattuor ordines ante Deum. Et primus quidem ordo erat hominum infirmantium et gratias agentium Deo; secundus uero erat eorum qui hospitalitatem sectantur et in hoc stant et ministrant; tertius uero illorum qui solitudinem sectan-

5 tur et non uident homines; quartus autem illorum qui propter Deum et oboedientiam subiecti sunt patribus. Erat ergo his tribus hic ordo superior qui oboedientiam exhibebat et utebatur torquem aureum et maiorem gloriam possidebat. Dixit autem senex ei qui sibi hoc in extasi demonstrabat: Quare hic ordo quartus maiorem ceteris gloriam

10 habet? Ille autem respondit ei: Quia hii omnes habent aliquam requiem adimplendo, quamuis in bonis operibus, proprias uoluntates; is uero qui oboedientiam exercet omnes uoluntates suas relinquens totus pendet in patris uoluntate iubentis. Et ideo maiorem gloriam prae ceteris est sortitus.

XLII, 1 lin. 3-4: Dominus... mortem - cf. Philip. II, 8.

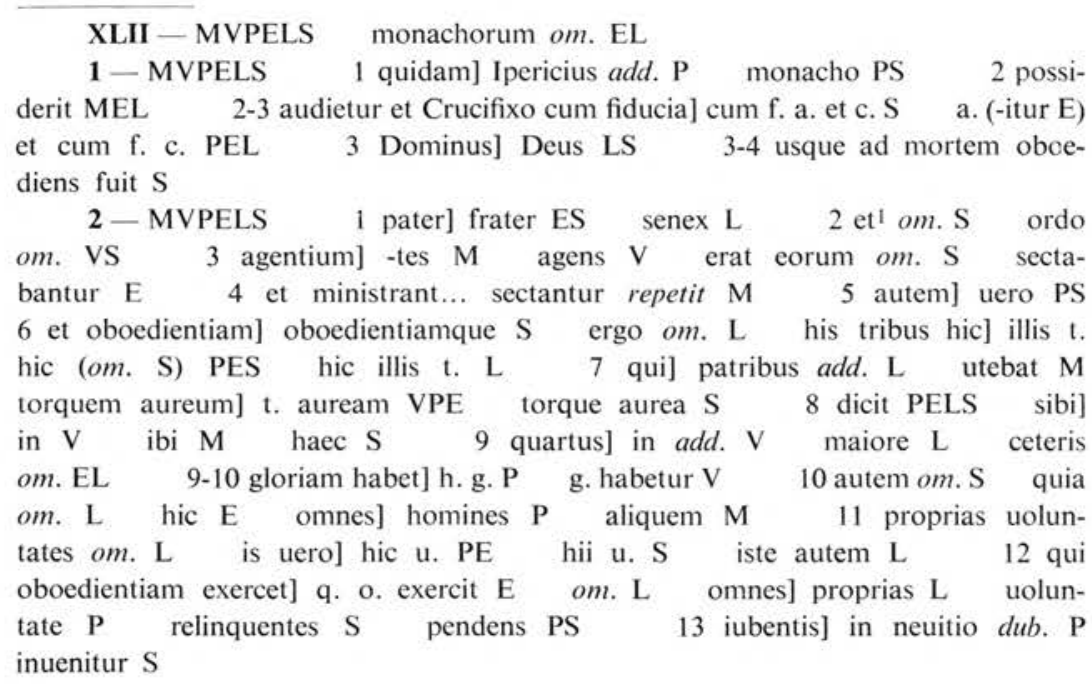


3-Quidam senex dixit: Quia si quis fratri suo iniunxerit causam cum timore Dei et cum humilitate, sermo ille qui propter Deum egreditur conpellit fratrem oboedire et facere quod iniunctum est. $\mathrm{Si}$ autem iubere quis cupiens non secundum Dei timorem, sed ex auctoritate propria fratri uoluerit imperare, uidet Deus absconsa cordis et non illum permittit ut audiat nec faciat quod illi praeceptum est, quia manifestum est opus Dei quod fit propter Deum et manifesta est hominis auctoritas. Quaecumque enim ex Deo sunt a principio humilitatem habent, quae autem ex auctoritate et iracundia uel conturbatione ex inimico sunt.

4-Abbas Arsenius dicebat ad abbatem Danielem: Vade et foue patrem tuum oboediens ei ut pro te exoret cum uadit ad Dominum et bene tibi ex eius oratione contingat.

5-Abbas Siluanus habebat discipulum nomine Marcum cuius oboedientia erat magna et propterea senior diligebat eum. Habebat autem et alios undecim discipulos qui tristabantur pro eo quod illum amplius diligeret. Quod postquam alii senes audierunt, maesti uenerunt ad eum ut ei renuntiarent quia fratres qui cum illo erant contristabantur. Sed antequam illi aliquid faterentur, ipse cum illis ad singulorum cellas profectus unumquemque nomine proprio uocauit dicens: Egredere, frater, quoniam opus te habeo. Et nullus de illis uoluit egredi. Venerunt autem post omnes ad cellam Marci et pulsans ostium uocauit nomen eius. Ille autem mox audita uoce senis egressus est,

3-MVPELS 1 quia] qui $\mathrm{E}$ quod $\mathrm{S} 2$ humilitate] et add. $\mathrm{E}$ 3 compellet PELS 4 cupiens] capiens S timore M $4-5$ auctoritate propria] -em propriam $\mathrm{M}$ uoluntate $\mathrm{p}$. $\mathrm{E} 5$ fratri] suo add. $\mathrm{P}$ uidetur $\mathrm{V}$ 6 nec] neque $\mathrm{L}$ ne $\mathrm{S}$ illi] illic $\mathrm{L}$ ille $\mathrm{S} \quad 7$ est om. $\mathrm{E}$ fit] fiet $\mathrm{P}$ hominis] omnis PELS 8 quaecumque] quicumque $\mathrm{V}$ quaecum $\mathrm{E}$ humilitatem] utilitatem MV 9 qui $\mathrm{V}$ et] uel $\mathrm{S} \quad 10$ inimici $\mathrm{L}$

$$
\text { 4-MVPELS } 1 \text { abba S Danielem] -el MV -lum L et om. S }
$$

2 uadat $\mathrm{V}$ Dominum] caelum $\mathrm{P}$ Deum ELS 3 contigit $\mathrm{E}$

$$
\text { 5-MVPELS } 1 \text { abba } S \text { cui } E 2 \text { propterea] propter hoc } P
$$

eum] et add. E 3 autem] enim V om. EL et om. VPES discipulos undecim $\mathrm{P}$ pro] ab ELS om. $\mathrm{P}$ illum om. $\mathrm{V} \quad 4$ amplius] plus $P$ diligebat $L$ audierunt] cognouerunt $S \quad 5$ ei $\mathrm{om}$. PS 6 aliquid faterentur] a. faceret $\mathrm{V}$ quid $\mathrm{f}$. $\mathrm{L} \quad \mathrm{om} . \mathrm{S}$ ipse] ille $\mathrm{V}$ illis] ipsis $\mathrm{V}$ 7 cellas] est add. EL 8 quoniam] quia $\mathrm{S}$ te opus $\mathrm{P} \quad 9$ pulsans] senex add. PS 10 nomine $\mathrm{V}$ mox] autem add. repetens $\mathrm{S}$ senex $\mathrm{S}$ 
atque $a b$ eo ad ministerium quoddam directus. Tunc dicit senibus: Vbi sunt reliqui fratres? Et ingressi cellam Marci, quoniam scriptor erat, circauit quaternionem quem scribebat et inuenit quod in qua hora uocatus est litteram quam faciebat reliquit mediam ut tantummodo

15 oboedientiam adimpleret. Noluit enim post auditam uocem senis litteram quam coeperat perconplere. Vnde alii senes dixerunt: In ueritate quem tu diligis et nos diligimus quoniam et Deus illum pro sua oboedientia diligit.

6- Iterum dum esset abba Siluanus in Sceti cum aliis senibus, uolens ostendere oboedientiam Marci, propter quod et diligebat eum, uidit suem siluestrem et dicit ei: Vides hunc bubalum, fili? At ille dixit: Video, abba. Et ait illi iterum: Sed et quam bona et recta cornua

5 habet considera! At ille similiter confessus est. Et admirati sunt senes oboedientiam eius.

\section{XLIII - QVIA OBOEDIENTIA DE QVOVIS PERICVLO LIBERAT}

1-Quidam senex solitarius habebat ministrantem sibi manentem in uico. Cum autem ille tardasset et seni necessaria defecissent et

11 atque $\mathrm{ab}$ eo] ab eo om. E om. L ad om. E ministerium] misterium $\mathrm{S}$ quoddam] quondam MV directus] est add. S 12 sunt] illi add. PL reliqui] illi add. $\mathrm{E}$ ingressi] i. in $\mathrm{V}$ ingressus (in add. PEL) PELS cella VE quoniam] qui $S \quad 13$ circauit] circuit $V$ circuiuit $P$ circitauit $S$ quod] quia PL om.S 14 reliquit mediam] m. r.S relinquit media $\mathrm{M}$ mediam (-a EL) dereliquit PEL 15 enim] autem PS 16 perconplere unde] adimplere (conplere ELS) u. illi PELS 17 et $^{1} \mathrm{om} . \mathrm{S}$ quoniam] quia PELS illum] eum ELS 17-18 pro sua oboedientia diligit]d. p.s. o. S p. suam oboedientiam d. L

6-MVPELS 1 dum esset abba Siluanus] abbas S. d. e. E aliis] illis PS 2 quam $\mathrm{S} \quad$ et $\mathrm{om} . \mathrm{S} \quad 3$ suem] bestigiam L uides] uidens $\mathrm{P}$ bubalum] bobalum MV babulum $\mathrm{P}$ fili om. MV 4 et $^{1}$ om. ES ait illi] at ille E et ${ }^{2}$ om. ES et $\left.{ }^{3}\right]$ quam add. PS 5 confessus] confusus P 6 senes] in add. P om. EL oboedientiam] -a P -ae E

XLIII - MVPELS quia] quod $S$ periculo] peccato $P$

1-MVPELS 1-2 manentem in uicol in $\mathrm{u} . \mathrm{m}$. $\mathrm{L}$ manentem om. $\mathrm{E}$ 2 ille tardasset] t. i. V per dies aliquos add. PLS per aliquos dies add. E 
neque quod operaretur haberet neque quod reficeret et propter hoc tristasset, dicit discipulo suo: Vis ire in uico? At ille respondit: Quid iubes faciam. Timebat autem ipse frater accedere ad uicum propter scandalum, sed tamen ut oboediret patri promisit se iturum. Dicit ergo ei senex: Vade et confido in Deum patrum nostrorum quia proteget te $a b$ omni tentatione. Et facta oratione transmisit eum. Cum autem uenisset frater in uico et requisisset quo maneret ille qui ministrabat eis, inuenta domo eius, cum pulsasset ostium contigit ut nemo ex illis inueniretur in domo praeter una filia illius ministrantis. Quae cum aperuisset ostium et frater eam de patre eius requireret cur tot diebus tardasset, illa hortabatur eum ingredi in domum, simul et trahebat. Cum autem ille non adquiesceret, illa inualuit et adtraxit eum ad se. Cum autem uidisset ille quia ad peccatum trahebatur et urguebant eum cogitationes, ingemuit et clamauit dicens ad Dominum: Domine, propter orationem eius qui me misit salua me in hac hora. Et cum haec dixisset subito inuentus est ad fluuium prope monasterium suum. Et reuersus est ad patrem sine macula.

2 - De Ioanne discipulo abbatis Pauli dicebant quia grandem haberet oboedientiam. In loco autem quodam erant sepulcra et fera illic hyena habitabat mala. Cum autem senex in loco illo uidisset fimum boum et opus haberet, dicit discipulo suo: Vade et affer mihi. Cui ille dixit: Et quid faciam, abba, propter hyenam? Senex autem iocans dixit ad

\section{(1)}

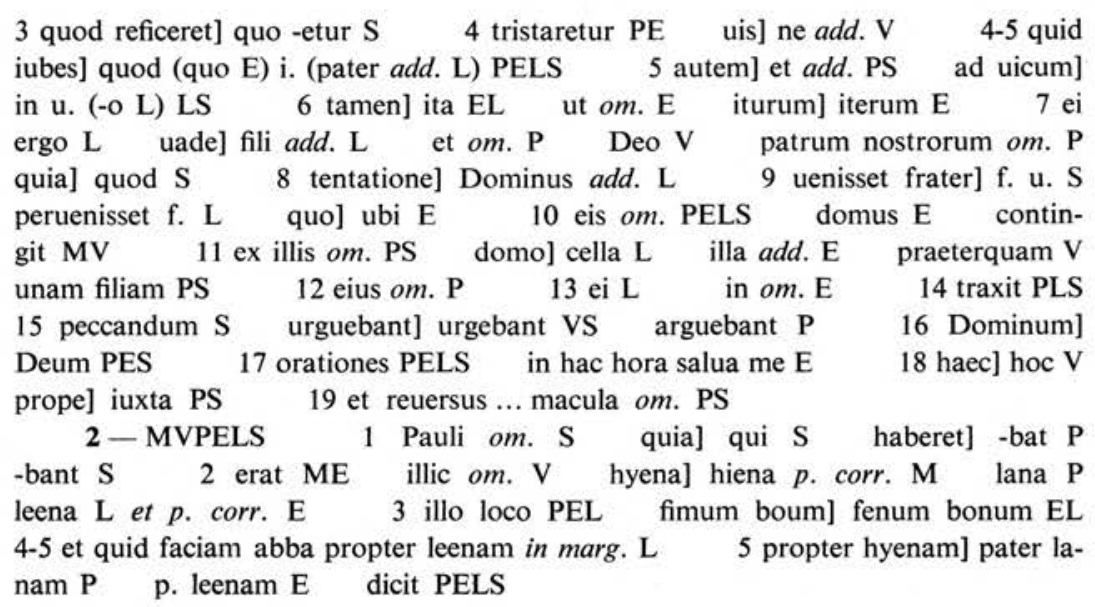


eum: Si uenerit super te, liga illam et adduc huc. Cum ergo isset ibi iam uespere et uenisset super eum hyena, ille secundum sermonem senis uoluit eam tenere. Cum autem illa fugeret, insequebatur eam et dicebat: Abba meus dixit ut te ligarem. Et comprehendit et ligauit

10 illam. Senex autem tristabatur quia tardaret et sedebat expectans eum. Et ecce superuenit ille trahens hyenam ligatam. Videns autem senex admiratus est. Et uolens humiliare eum, ne elatus fieret, caedit eum dicens: Stulte, istum canem miserum, quid hic adduxisti? Et mox soluit eam senex et permisit discedere.

3 - Duo fratres carnales uenerunt in quodam monasterio habitare et unus ex ipsis erat religiosus, alter tamen oboedientiam habens grandem. Cum ergo abbas praeciperet illi: «Fac hoc» et faceret, et iterum «Fac illud» et faceret, et in hoc gloriaretur in monasterio quod

5 talem oboedientiam haberet, inuidit frater eius ille religiosus et dicit intra semetipsum: "Tentabo hunc si habet certam oboedientiam». Et ueniens ad abbatem dicit: Transmitte fratrem meum mecum quoniam necessarius sum in quodam loco. Et dimisit eum. Cum ergo pariter proficiscerentur, uolens tentare eum, cum peruenissent ad flumen in

10 quo erat multitudo crocodilorum dicit ei: Descende in fluuium et

XLIII, 3 lin. 3-4: Fac... faceret - cf. Mat. VIII, 9.

6 super] ad $P$ illam] eam $P$ adduc] affer $E$ huc om. PS isset] iret $S$ esset VP ibi om. S 7 super eum] frater cum V hyena] hiena $p$. corr. M lana $\mathrm{P}$ leena EL 8 tenere eam PELS fugeret] fugiret et $\mathrm{L} \quad 9$ abbas $\mathrm{P}$ apprehendit $S \quad 10$ illam] eam $P$ expectando $S \quad 11$ et ecce superuenit] cum autem superueniens $\mathrm{P}$ hyenam] hienam p.corr. $\mathrm{M}$ lanam $\mathrm{P}$ leenam $\mathrm{EL}$ 12 est] ualde add. $\mathrm{P} 13$ dicens stulte] s. d. S d. stultus L quid hic] cur huc $P$ adducebas PELS 14 eum MVPE permisit] praecipit eam $S$ 3-MVPELS 1 duos $\mathrm{L}$ in quodam monasterio habitare] in $\mathrm{q}$. monasterium h. $\mathrm{P}$ h. in quodquodam monasterium $\mathrm{S} 2$ erat religiosus] e. r. (r. e. EL) ualde (et add. L) PELS tamen oboedientiam habens] h. o. PELS 3 abbas om. P illi om. L hoc] haec S faceret] faciebat P 3-4 et iterum fac illud et faceret $\mathrm{om}$. MV 4 gloriabatur EL monasterium PS 5 inuidit] et uidit $V \quad$ ille religiosus eius $P \quad 6$ hunc] illum $E$ eum $S$ 7 dicit] dicens MV dixit $\mathrm{E}$ ei add. EL transmitite $\mathrm{S}$ quoniam] quia $\mathrm{S}$ 8 necessarius sum] necessarium suum $L$ necarius s. $S$ quidam $E$ ergo] autem $P$ 9 proficisceretur $\mathrm{M}$ uolens tentare eum om. E ad] eum add. L 9-10 in quo] ubi $\mathrm{S} 10$ crocodilorum] corcodrillorum MEL cocodrillorum VPS 
transi. Et descendit ille et uenerunt crocodili et coeperunt lingere corpus eius et non eum nocuerunt. Quod cum uidisset ille dicit ei: Ascende de fluuio ut eamus. Et dum irent inuenerunt corpus mortuum iacentem in uia. Et dicit ille religiosus: Si haberemus aliquid ex ueteramentis mitteremus super illud. Cui frater: Oremus potius ne forte suscitet illum Deus. Et stantibus illis in oratione suscitatus est mortuus et laudauit se ille religiosus dicens: Propter religionem meam suscitatus est hic mortuus. Manifestauit autem Deus patri in monasterio omnia et quemadmodum tentauit fratrem in crocodilis et quomodo mortuus surrexisset. Et postquam uenerunt in monasterio dixit abbas ad illum religiosum: Quare sic fecisti fratri tuo? Quia ecce propter oboedientiam eius surrexit hic mortuus.

11 et ${ }^{1} \mathrm{om}$. E crocodili] corcodrilli ML cocodrilli VPS corcodrillorum $\mathrm{E} 12$ eum] ei $\mathrm{S}$ ille uidisset $\mathrm{S}$ dixit $\mathrm{E} 13$ de om. $\mathrm{L}$ ut] et PELS 14 iacens VPEL uiam V dicet $E$ ueteramentis] uestimentis $P$ 15 illum PE cui frater] et ille alius ait $\mathrm{P}$ potius om. $\mathrm{S}$ ne] si PS om. $\mathrm{P} \quad 16$ suscitet] -at $\mathrm{P} \quad$ est] ille add. EL 17 laudabat $\mathrm{S}$ ille $\mathrm{om}$. $\mathrm{L} \quad 18$ suscitatus est] surrexit ELS hic om. MV patri om. S in monasterio] monasterii $P$ 19 frater E crocodilis] corcodrillis MEL cocodrillis VPS 20 surrexit S monasterium PS 22 hic] et $\mathrm{L}$ om. PES In fine huius capituli legitur in $\mathrm{E}$ (fl. 107r): Finit liber primus. Incipiunt capitula libri secundi. Index capitulorum a I usque ad XLVI in ff. 107r-108v. Sequitur textus cap. I: De caritate... = XLIV sequens. N. B. $-L^{1}\left(f f .3^{\mathrm{r}}-45^{\mathrm{r}}\right)$ XLIII capitulis constituitur. Tituli capitulorum inueniuntur ff. $3^{\mathrm{r}}-4^{\mathrm{r}}$. Expleto textu apophthegmatis XLIII,I (fl. $45^{\mathrm{r}}$ ) in summo $\mathrm{fl.} .45^{\mathrm{v}}$ legitur: Explicit liber primus Geronticon. Item capitulationes ex libro secundo. Capitulatio secundae seriei $\left(f f .45^{\mathrm{v}}-46^{\mathrm{v}}\right)$ ex LVI titulis constat. Textus incipit $\left(\right.$ fl. $\left.47^{\mathrm{r}}\right)$ : Interrogationes et responsiones patrum. I De karitate hoc faciendum alteri quod tibi fieri uis ( $=X L I V$ sequens). Transcriptio huius seriei expletur $f l .94^{\mathrm{v}}$ sine explicit. Sequuntur Sententiae a Martino Dumiense translatae. Tunc Paschasii textus ab initio resumitur (= tertia series) his uerbis (fl. $\left.113^{\mathrm{r}}\right)$ : Incipit capitulatio eiusdem libri, quae ex titulis XXIII conponitur usque ad fl. $113^{\mathrm{v}}$. Illico datur textus (ff. 114 $\mathrm{r}_{\text {- }}$ $-135 \mathrm{v}$ ) qui cum apophthegmate XLIII,3 finit. Statim nuntiatur quarta series (ff. $135^{\mathrm{v}}$ $-142^{\mathrm{v}}$ ) hoc modo: Item capitulationes ex libro secundo, quae XXII titulos habet (ff. $135^{\mathrm{v}}-136^{\mathrm{r}}$ ). Abrupte Paschasii textus secatur in fl. $142^{\mathrm{v}}$ his uerbis: post triginta dies con- (=nostrae editionis $n$. LI,3). Hae quattuor series capitulorum in initio critici apparatus editionis nostrae conlatae sunt. 


\section{XLIV - DE CARITATE: HOC FACIENDVM ALTERI QVOD TIBI FIERI VIS}

1-Quidam ex senibus de Sceti discipulum suum transmisit in Aegypto ut ei camelum deduceret quatenus sportellas quas fecerat portaret in Aegypto. Cum autem deduceret camelum, alter senex obuians eum dicit illi: $\mathrm{Si}$ scissem quando ibas in Aegypto dixeram ut

5 et mihi alterum camelum adduceres. Quod cum ille frater proprio abbati dixisset, dicit ei senex: Vade et duc camelum ad illum alium senem dicens: "Quia necdum parati sumus conple necessitatem tuam et uade cum ipso usque in Aegypto et iterum reduc ad nos camelum ut et nos nostra uasa portemus». Cum ergo haec fecisset frater et

10 isset ad illum senem dicens: Abbas meus dixit: "Quia nos necdum sumus parati, tolle et conple necessitatem tuam», carricauit senex camelum et iuit in Aegypto. Cum autem discarricasset iterum ille frater reducebat camelum et dixit: Ora pro me. Cumque senex requisisset quo pergeret, respondit: In Sceti uado ut etiam nostras sportellas

15 huc afferam. Quod cum audisset senex, conpunctus coepit poenitere, lacrimans et dicens: Indulge mihi quoniam multa caritas uestra fructum meum abstulit.

XLIV - MVPELS alteri om. PS fieri uis] u. f. EL f. non u. V 1-MVPELS 2 Aegyptum ES ei camelum] c. ei $P$ ei om. E quatenus sportelas] q. eum exportellas $\mathrm{S} \quad 3$ portaret in Aegypto] -e in -um S autem deduceret] a. (om. L) adduceret PL 4 obuius E eum dicit] ei d. (dixit S) VS scirem PS ires L Aegyptum S dixeram] tibi add. EL 5 et $\mathrm{om}$. ES quo L 6 dixisset] diceret $\mathrm{E} \quad$ illum] ipsum PS 6-7 alium senem om. PELS parati sumus] paratum (nos add. L) habemus EL complere VS 8 cum ipso usque in Aegypto] in A. c. i E c. i. u. in Aegyptum PS usque om. L ad nos] nobis PELS 9 nostra uasa] nostras sportellas MV haec] hoc VE om. PL fecisset] recessisset L 10 illum] alium add. EL dicens] ait L abba ELS dixit] dicit P nos om. PEL 11 tolle et conple] tollere et portare S et om. P carregauit S 12 iuit in Aegypto cum] i. (abiit P) in -um cum (dum P) PS discarricasset] -ent et (om. L) EL discarreset S 13 reducebat] ducebat $\mathrm{P}$-ceret $\mathrm{E}$ orate MV me] pater add. $\mathrm{E}$ requireret $\mathrm{L} 14$ Sceti] stanti $\mathrm{S}$ etiam om. $\mathrm{P} 15$ afferamus $\mathrm{V}$ poenitere] $-\mathrm{i} \mathrm{EL}$ et $a d d . \mathrm{S} \quad 16$ indulge] -ete $\mathrm{P} \quad$-ite $\mathrm{S}$ quoniam] quia LS 
2-Alter senex cum perfecisset sportellas suas et misisset etiam retinacula earum, audiuit uicinum suum dicentem: Quid faciam quoniam nundina prope est et non habeo unde mittam retinacula in sportellis meis? Et mox egressus dissipauit propria retinacula et adtulit ad fratrem dicens: Ecce ista superflua habeo; tolle et mitte in sportellis tuis. Et ita prae nimia caritate fecit ut fratris quidem opera conplerentur, sua autem inperfecta reliquit.

3-Abbas Ioannes per grandem gratiam caritatis omnem malitiam est oblitus. Hic cum a quodam fratre mutuasset solidum unum et conparasset linum unde operaretur, uenit unus frater petens ei parum linum ut faceret sibi saccum. Dedit ei cum gaudio. Item alter ueniens petens eum linum, dedit illi necnon et aliis plurimis uenientibus et petentibus dedit omnia cum gaudio. Post haec ille qui mutuauerat solidum uenit repetens eum. At ille dixit: Ego uado et affero tibi. Et non habens unde redderet, surrexit et profectus est ad abbatem Iacob ut eum peteret, quatenus redderet illi qui eum mutuauerat. Et dum iret per uiam inuenit solidum iacentem et non eum tetigit. Sed facta oratione reuersus est in cellam. Et cum idem frater ille peteret rationem suam, dixit ei: Vndecumque modo defero illum. Et iterum profectus inuenit solidum ubi antea erat positus. Et facta oratione reuersus est. Et ecce iterum uenit frater ille molestans eum

2-MVPELS 2 eorum MVPES quoniam] quem $\mathrm{L}$ quia $\mathrm{S}$ 3 nundina] -ae $\mathrm{P}$ nunda $\mathrm{E}$ sunt $\mathrm{P}$ in om. $\mathrm{E} 4$ regressus PELS tulit $\mathrm{P} \quad 5$ et om. $\mathrm{P} \quad 6$ ita] ista $\mathrm{L}$ quidem] quidam $\mathrm{V} \quad \mathrm{om}$. $\mathrm{P}$ 6-7 conplerentur sua autem] -etur suam quidem $\mathrm{L}$ autem om. S
3-MVPELS
1 abba $\mathrm{S}$ Ioannes] Persa add. E
2 a om. PS quodam fratre] $q$. fratrem $L$ quidam frater $P$ cuidam fratri $S$ mutuasset] mutasset $\mathrm{E} \quad$ solidum unum] sarculum $\mathrm{S} \quad 3$ operare $\mathrm{L}$ eum $\mathrm{L}$ parum om. MV 4 linum]-i P ligni S 4-5 ut faceret ... linum om. MV 4 saccum sibi S item] iterum PE uenit PS 5 ei PS linum dedit] lignum et d. etiam S pluribus S 5-6 et petentibus om. S 6 omnibus PELS hoc VL cui $\mathrm{S}$ mutuauerit L solidum] s. (sarculum S) unum PS 8 non habens] cum non haberet $p$. corr. E reddere L 9 illi] ei P eum ${ }^{2}$ om. PELS 10 dum om. V solidum iacentem] saculum i. in uia $\mathrm{S}$ eum] illum PELS 11 orationem $\mathrm{L}$ uersus $\mathrm{S}$ in cellam] ad c. (-a E) EL 11-14 et cum ... reuersus est om. $\mathrm{S} \quad 11$ idem] eidem $\mathrm{P} \quad 12$ repeteret PEL post dixit ei (scrip. in marg. inferiori) (fl. 137v) interrumpitur textus mutilatus in $L^{4}$ et in pagina sequenti (fol. 138 legitur sententia XLVI,4 etiam mutila. 12 undecumquam MV defero illum] defer illud E tibi add. P 13 ante VE 
15 pro solido. Tunc senex: Modis omnibus modo uado et affero illum. Et dum proficisceretur in eodem loco inuenit solidum iacentem. Et facta oratione tulit illum et abiit ad abbatem Iacob et dicit ei: Abba, ueniens ad te inueni hunc solidum in uia. Fac ergo caritatem et praedica in ciuitate ne quis perdiderit illum; et si inuentus fuerit dominus eius

20 redde illum. Profectus ergo senex per tres dies praedicauit et nemo inuentus est qui perdidisset illum solidum. Tunc ergo dicit ad abbatem Iacob: Si nemo illum perdidit, redde illum fratri isti quoniam debeo illi; et ueniens ad te mutuari aut certe tollere in caritate et reddere debitum meum inueni illum. Et miratus est senex quemadmodum et

25 debens et inueniens non statim tulit et reddidit nisi et bis reuersus fuisset et tertio praedicasset. Hoc autem eius erat mirabile quia si quis uolebat ab illo aliquid mutuari non dabat per manus suas sed dicebat fratri: Vade et quod opus habes tolle tibi. Et cum reportaret, dicebat: Vade et repone in locum unde tuleras. Si autem nihil detulisset, nihil 30 illi penitus loquebatur.

\section{XLV - DE MANDATIS DEI IN PROXIMO: VT QVOD TIBI VIS FIERI FACIAS ILLI}

1-Quidam frater requisiuit abbatem Poemenem dicens: Quid est fides? Cui senex: In caritate et humilitate semper uiuere et facere bonum proximo suo.

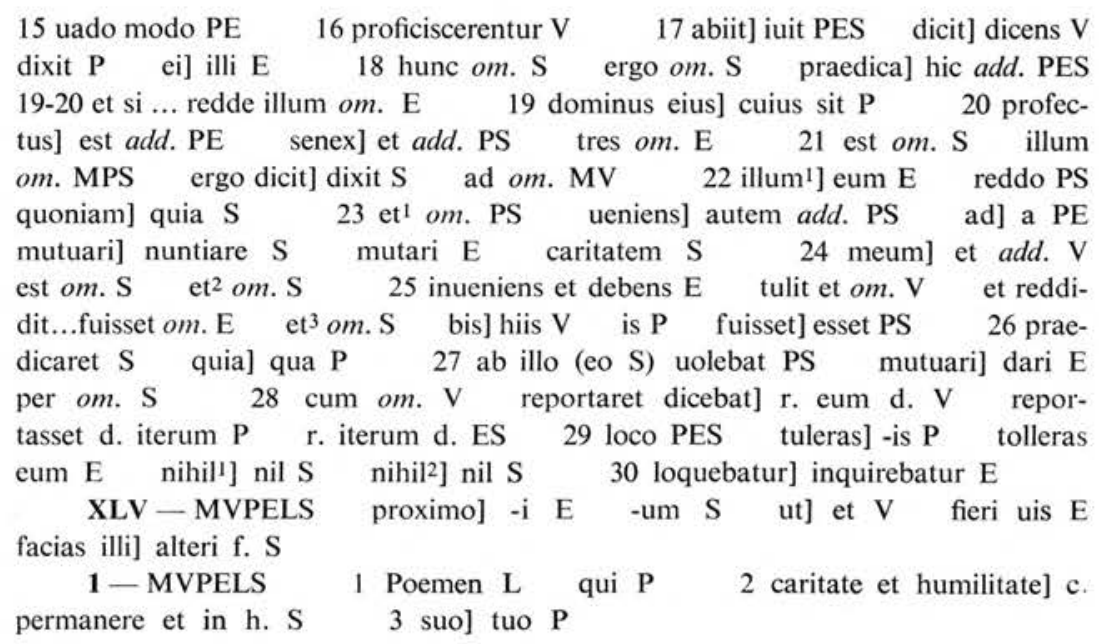


2-Abbas Theodorus cum de opere animae ac manuum loqueretur, quidam frater ex audientibus dicit ad eum: Explana nobis opus animae et opera manuum. Cui senex: Omnia quaecumque pro mandato Dei perficimus in operibus animae reputanda sunt; quae uero pro nostra agimus utilitate seu quolibet modo, haec opera manuum esse noscuntur.

3 - Abbas Apollo si quis eum de fratribus in suo quaesisset opere laborare, mox pergebat cum omni laetitia dicens: Ego cum rege meo Christo uado hodie operare pro anima mea. Haec est enim merces quae animae reputatur.

\section{XLVI - DE VOLVNTATE PROXIMI FACIENDA}

1-Abbas Poemen dicebat: Voluntatem tuam numquam adimpleas, sed magis humilia temetipsum ut facias uoluntatem proximi tui.

2-Idem dixit: Si quis fecerit rem aliquam obtemperans uoluntati suae et res ipsa non est secundum Deum, sed tamen ignorans hoc fecit, potest tamen si ab alio monetur ad uiam Dei peruenire. Qui autem ita propriam tenuerit uoluntatem ut ab altero nihil penitus audire delectet, hic difficile ad uiam Dei peruenit.

\footnotetext{
2-MVPELS 1 abba $\mathrm{S}$ animi MV atque $\mathrm{S} \quad 3$ opus $\mathrm{S}$ pro mandato om. MV 4 reputanda] reportanda E uero $\mathrm{om}$. S 5 seu om. PLS quolibet] quo $\mathrm{E}$ haec] et $\mathrm{P}$

3-MVPELS 1 abba LS de fratribus eum $\mathrm{P}$ opere om. V 2-3 meo Christo] Ch. m. S modo Ch. V 3 operare] -i PS laborare L mercis $\mathrm{L}$

XLVI - MVPELS facienda uoluntate proximi S

1-MVPELS 1 abba S 2 humiliare $\mathrm{L}$ teipsum PELS ut facias uoluntatem proximi tui] et facies u. proximo tuo $\mathrm{E}$

2-MVPELS 1 idem dixit] item d. PL om. MV aliquam] -a L et add.S obtemperauit S uoluntati]-is E -es L 2 et om. PS sed] si S 3 fecit potest] facit p. (post LS) PELS si] sibi L moneatur PELS peruenire] uenire PELS Hic talis potest saluari add. L 4 ita propriam tenuerit uoluntatem] i. p. tenuerit (renuit V) proprietatem MV illum t. ut p. u. iudicet $\mathrm{P}$ ita om. L ut] et E nil S penitus om. EL 4-5 audire delectet] ualet a. E uellet a. PLS 5 difficile] est add. L peruenit] -iet PS peruenire L
} 
3 - Idem abbas Poemen quando uocabatur ut comederet extra uoluntatem suam ibat plorans ne non oboediret fratri suo et contristaret eum. Et dimittens propriam uoluntatem humiliatus sequebatur uoluntatem alterius.

4-Quidam anachoreta sedebat iuxta coenobium multas uirtutes faciens. Et cum aliqui uenissent in coenobio, conpulerunt eum hora non constituta comedere. Et post haec dicunt ei fratres: Contristatus es aliquid, abba, quia extra consuetudinem fecisti? Quibus ille res-

5 pondit: Tunc est mihi tribulatio quando propriam fecero uoluntatem.

5 - Abbas Paphnutius non gustabat uinum aliquando. Semel autem ambulans deuenit super latrones et cum inuenisset eos bibentes cognitus est a principe latronum qui sciebat quod uinum non bibebat. Sed uidens quia esset ex labore itineris fatigatus, impleuit calicem gran5 dem uino et gladium tenens in manu sua dixit seni: Nisi biberis occidam te. Et cognoscens senex quia ex mandato Dei uult facere, uolens eum lucrari, tulit et bibit. Princeps autem latronum coepit dicere: Indulge mihi, abba, quoniam tribulaui te. Cui senex: Confido in Deum meum quia propter hunc calicem facit tecum misericordiam 10 et in praesenti saeculo et in futuro. Dicit ei princeps latronum: Et ego confido in Deum quia ab hac die nemini malum facio. Et sic lucratus est senex omne collegium latronum.

\footnotetext{
3-MVPLS om. E 1 abba S comeret $\mathrm{L} 3$ dimittens] damnans PS 3-4 sequebatur uoluntatem] u. (-e L) s. PLS

4-MVPELS 2 faciebat $P$ uenissent in coenobio] u. (-erunt $S$ ) in -um PS eum] illum S 3 non] nona MVE constituta] consueta PS comedere] incipit iterum textus mutilus in $L^{4}$ hoc VPEL fratres ei $\mathrm{L}$ 4 aliquid $\mathrm{om}$. S $\quad 4-5$ ille respondit] ipse ait $\mathrm{S}$

5-MVPELS 1 abba PS Paphnutius] Paphnuntius EL 2 autem om. EL super] in $\mathrm{S} \quad 3$ est $\mathrm{om} . \mathrm{S}$ sciebat] eum add. ELS uinum non bibebat] u. non biberet ELS non biberet u. $\mathrm{P} \quad 4$ sed] et $\mathrm{S}$ labori $\mathrm{S}$ 5 biberis] hoc add. EL 6 quia] quod $\mathrm{S} \quad 8$ quoniam tribulaui] q. contristaui PE quia consului contribulare $\mathrm{S} 9$ quia] quoniam $\mathrm{L}$ facit] -iet $\mathrm{S}$ fecit P 10 et $^{1} \mathrm{om} . \mathrm{S} \quad$ in $^{1} \mathrm{om}$. V 11 hac die] hanc d. M hodie S nemini] nulli EL memini $\mathrm{S}$ malum] male et $s$. scr. mala $\mathrm{S}$ faciam PE 12 omnem $M$
} 
6-Quidam frater ueniens in Sceti, ut abbatem uideret Arsenium postulabat. Cumque alii fratres ei ut paululum quiesceret suaderent, respondit: Non gustabo panem nisi illum uidere meruero. Tunc unus ex fratribus deduxit eum ad beatum Arsenium. Pulsatoque ostio cellae, suscepti oratione facta consederunt. Cum autem beatus taceret Arsenius, ille qui fratrem deduxerat ait: Ego discedam. Sed et is qui ex desiderio uenerat, quia nihil eo adlocutus fuisset abbas Arsenius, prae uerecundia tacitus, sedens respondit: Et ego quoque tecum, frater, abscedam. Ac sic utrique discesserunt. Postulauit autem ut etiam ad abbatem Moysen qui ex latronibus conuersus fuerat duceretur. A quo susceptus, facta caritate, dimissus est. Frater autem qui eum ad utrosque perduxerat dicit illi: Ecce utrosque quos postulaueras uidisti. Quis tibi plus ex ambobus placet? At ille ait: Mihi interea hic melior uidetur qui nos utrosque et bene suscepit et pauit. Quo sermone conperto, unus ex patribus orauit ad Dominum dicens: Domine, hanc mihi rem precor ostende, quia unus propter nomen tuum omnes homines uidere aut conpellere refugit, alter uero omnibus idem propter nomen tuum communis est. Et ecce in extasi duae illi per fluuium naues ostensae sunt. Et in una quidem uidit spiritum Dei cum silentio et requie una cum beato Arsenio nauigantem, in altera uero uidit abbatem Moysen et angelos mellis ei fauos in ore et dentibus inserentes.

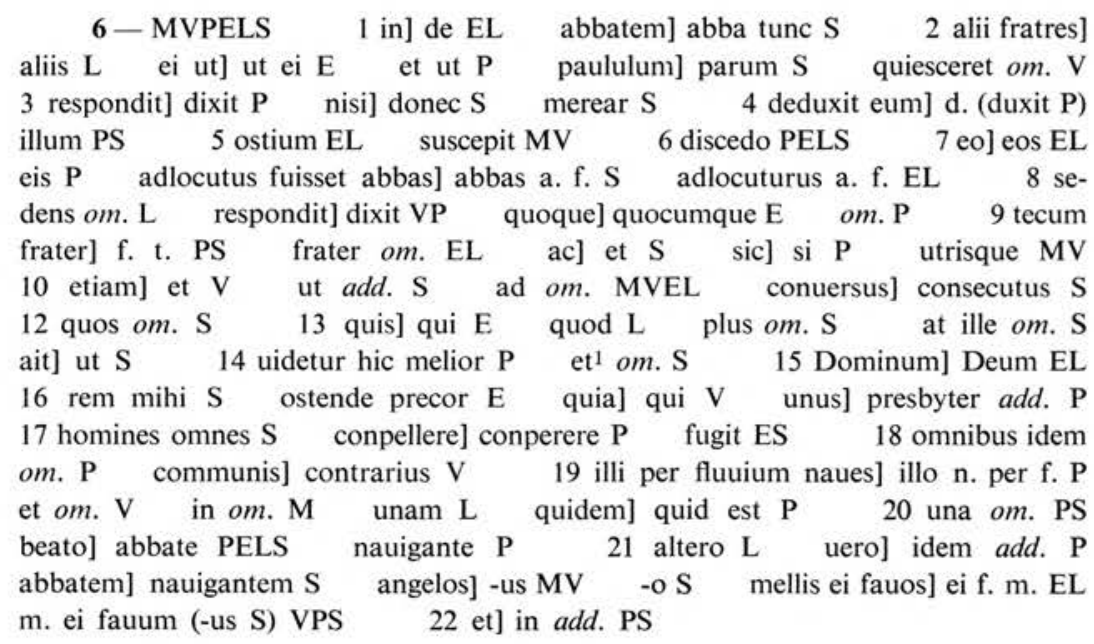


7-Quidam frater requisiuit abbatem Poemenem dicens: $\mathrm{Si}$ uidero fratrem de quo audiui aliquid prauum, nolo illum introducere in cellam meam; si autem bonum uidero exulto cum illo. Putasne bene facio? Cui senex: si facis illi bono aliquid parum boni, duplex bonum cum illo fac altero.

8 - Erant duo fratres et unus ex ipsis senex erat. Qui rogabat iuniorem dicens: Pariter habitemus, frater. Ille autem respondit ei: Ego peccator sum et non poteris habitare mecum, abba. Ille uero rogabat dicens: Possum habitare. Erat autem ille senior mundus et 5 nolebat audire quia monachus habet aliquando cogitationem prauam. Et dicit ei ille iunior: Permitte me hac una septimana et iterum loquimur. Cum ergo post septimanam senex uenisset ad illum, ille uolens experire eum dicit: In grandi tentatione incidi septimana hac, abba. Profectus enim in uico, propter necessitatem meam, peccaui. Et dicit

10 senex: Et uis poeniteri? Cum autem promisisset dicit ei senex: Et ego tecum porto medium peccati illius. Tunc ille frater dixit: Modo possumus pariter permanere. Et manserunt simul usque ad tempus transitionis suae.

\footnotetext{
7-MVPLS om. E 1 abba L Poemen P 1-2 si uidero] tibi dico $S \quad 2$ prauum] parum MV et add. PLS 3 cella mea LS 4 bono] bonum MV aliquid parum] p. (parbum L) a. PLS duplex] est add. S 5 fac cum illo PL

8-MVPELS 1 ipsis om. $\mathrm{L}$ senibus $\mathrm{S}$ 1-2 qui rogabat iuniorem] qui (et EL) rogauit i. (iuueniorem L iuuenem P) PEL 2 autem om. E respondit] dixit $\mathrm{P} \quad$ ei] et $a d d$. $\mathrm{E} \quad 3$ poteris habitare mecum] p. (-tes PES) $\mathrm{m}$. h. PELS 4 rogabat] eum add. $\mathrm{S}$ possum habitare] possumus PELS senior ille $\mathrm{S} 5$ nolebat] eum add. $\mathrm{S}$ monachus habet] $\mathrm{m}$. ille habebat $\mathrm{S}$ aliquando] aliquam de (om. S) ES prauam] paruam MV 6 ei ille iunior] ille i. ei $\mathrm{S}$ ei $\mathrm{om}$. $\mathrm{L}$ hac] ac $\mathrm{P}$ unam septimanam $\mathrm{E}$ loquamur PS 7 ille] uero $a d d$. $\mathrm{E} \quad 8$ experire] $-\mathrm{i} \mathrm{V}$ exire $\mathrm{S}$ dixit $\mathrm{P}$ grandi] -e E -dam L tentationem L incidi] incedi MV cecidi $\mathrm{P}$ septimana hac] h. s. PS -am hanc E abba om. E 9 necessitatem] nessitatem L meam] sic S om. PEL et dicit] et $(o m$. P) d. ei PS 10 et uis ... senex et $o m$. S dicit ei senex et] ait senex PEL 11 ego] enim $a d d$. E dixit $o m$. L 12 possumus] possimus $\mathrm{L}$ ambo add. PS manere PELS
} 


\section{XLVII - NON FACIENDVM ALTERI QVOD TIBI FIERI NON VIS}

1 - Quidam senex dicebat: Quicquid horret homo alii ne faciat. Horres enim si quis detrahit tibi? Tu ne detrahas alterum. Horres si quis tibi calumniam fecerit, si quis contempserit uel iniuriatus fuerit, uel aliquid tibi abstulerit? Et tu siue haec siue alia his similia ne facias alicui. Qui enim hoc uerbum seruauerit, potest illi sufficere ad salutem.

2 - Dicebat abbas Isaac: Scio fratrem aliquem in agro se celantem et uoluit unam spicam comedere et tamen nisi dominum agri requisisset dicens: «Iubes ut tollam unam spicam et comedam», non gustauit. In tantum etiam de hoc minimo timebat ne quasi fraudans alterum peccaret.

3 - Abbas Theodorus quodam tempore cum quidam saecularis ad cellam eius caepas uenditans aduenisset atque ex ipsis uas implesset, dicit senex discipulo suo: Vade, imple illi idem uas frumento et redde. Cum autem duo acerui essent, unus habens frumentum mundius, alter uero sordidius, profectus frater uas ipsum de frumento sordidiore compleuit. Quo uiso senex cum trucido eum uultu respexisset, prae timore cecidit et uas ipsum confregit. Et incuruatus in terra coepit poenitere. Senex autem dixit ei: Exurge frater, nec enim tua culpa

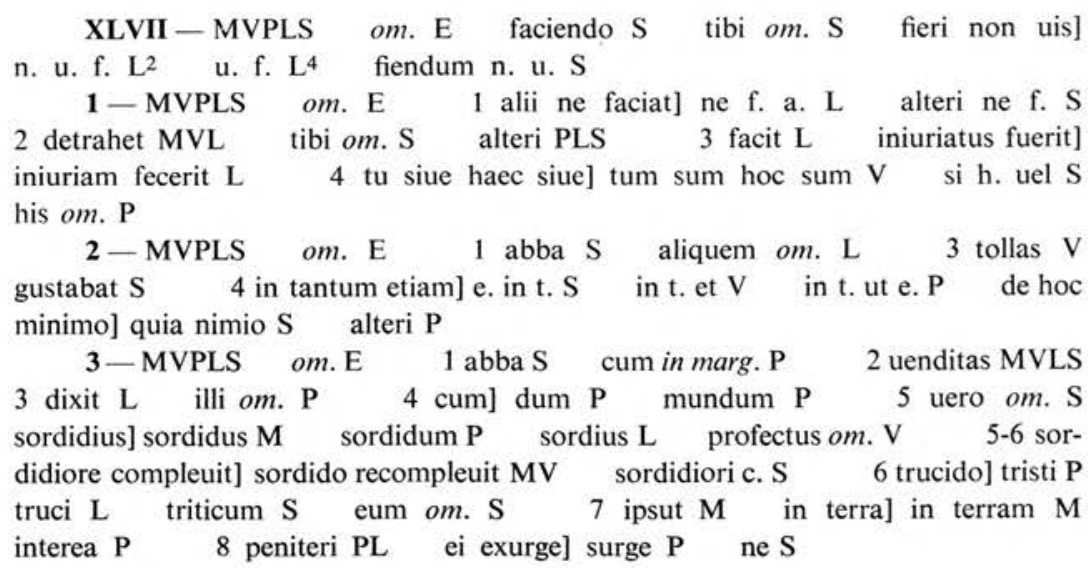


est, sed ego qui tibi praecepi peccaui. Et ingressus ipse sinum suum

10 de mundiori frumento impleuit et caeparum uenditori restituit, sed et ipsas quas uendiderat caepas reddens illi abire permisit.

4-Abbas Or cum discipulus eius Paulus ad conparanda palmarum folia perrexisset et uidisset quod arras praecedentes alii iam dedissent pergebat alibi. Vnus autem ex uenditoribus dixit illi: Tolle haec et operare quia is qui mihi dedit arras uenire tardauit. Quae

5 cum tulisset, remeans ad senem, uerba ei retulit uenditoris. Quae cum senex audisset conplosis manibus ait: Or quod operetur praesenti anno non habeat. Nec eum in cella ingredi permisit, nisi regressus unde tulerat folia portasset.

\section{XLVIII - NON DEBERE FRATRI VERECVNDIAM INCVTERE}

1-Quidam frater abbatem Sisoium requisiuit dicens: $\mathrm{Si}$ dum ambulamus per uiam, itineris nostri monstrator errauerit, non oportet ei dicere? Respondit: Non. Et frater: Dimittimus ergo eum ut nos cogat errare? Tunc senex: Quid ergo adhuc? Et cum baculo tuo

5 debes illi plagas inponere? Cum ergo sciam quosdam fratres ambulantes per noctem, cum is qui eis uiam monstrabat errasset et illi essent undecim atque omnes se errare cognoscerent, tamen statuerunt apud se ne dicerent. Luce autem facta, cum errorem proprium dux itineris cognouisset atque indulgentiam pro itinere acto perperam postularet,

9 sinum] signum $\mathrm{S} \quad 10$ mundiore $\mathrm{L} \quad$ frumento $\mathrm{om} . \mathrm{S} \quad 11$ illi abire] alibi ire $\mathrm{P}$ permisit] promisit $\mathrm{P}$ praecepit $\mathrm{S}$

4-MVPLS om. E 1 abba $S \quad 3$ pergebat] periebat $M \quad$ alibi] alii $\mathrm{V} \quad 3-4$ haec tolle $\mathrm{S} \quad 4$ dederat $\mathrm{L}$ quae] qui $\mathrm{V} \quad 5$ uerba ei retulit] r. ei -um $\mathrm{S}$ quae] qui $\mathrm{V} \quad \mathrm{om} . \mathrm{S} \quad$ 6-7 praesenti anno] presentiam $\mathrm{V}$ presentiam presentiam $M \quad 7$ habeat nec eum in cella ingredi] habet nec (neque $S$ ) eum i. in c. (in -am i.S) LS 8 unde] bene S portasset] re- LS reportaret $\mathrm{P}$ XLVIII - MVPLS om. E incutere] incurrere S

1-MVPLS om. E 1 Sisoium] Sisonium $\mathrm{S} \quad 3$ dicere ei $\mathrm{P}$ non $\mathrm{om}$. S 3-4 dimittimus ergo eum ut nos cogat] diuiratimus (dub.) ut cognoscat S 4 et om. S 5 ambulantes om. V 6 noctem] et add. L is] eum MV his LS eis uiam monstrabat] ei u. de- $\mathrm{P}$ eis $\mathrm{u}$. monstrabant $\mathrm{S}$ errasse P 7 atque] et $\mathrm{P} \quad$ se $\mathrm{om}$. LS cognoscerent] sensissent $\mathrm{P}$-et $\mathrm{S}$ 8 autem om. S 9 perperam] perpetrans MV 
dixerunt omnes: Quia errabamus agnouimus, sed consulentes pudori tuo tacuimus. Quo audiens ille miratus est quia usque ad mortem perseuerassent non loquendo, et largitorem huius patientiae Dominum conlaudauit. Erat autem spatium quod errauerunt duodecim milia.

\section{XLIX - DE NON PRAEPONENDIS DEO PARENTVM AFFECTIBVS}

1 - Abbas Poemen et abbas Anub postquam in deserto uenerunt desiderans mater eorum uidere eos saepe ueniebat ad cellam nec tamen illic eos poterat contemplari. Captato itaque tempore occurit illis cum ad ecclesiam festinarent. Qua uisa, reuersi uelociter ostium cellae clauserunt. Illa autem stans foras cum lacrimis querebatur. Abbas uero Anub ad beatum Poemenem ingressus ait: Quid faciamus de hac anu quae plangit ad ostium? Tunc exurgens abba Poemen uenit ad ostium. Quo non aperto, audiens eam lamentari iugiter, dicit: Cur tantos clamores, cum iam aetate defessa sis et planctus effundis? Illa autem uoce filii cognita amplius exclamauit dicens: Quoniam uos uidere desidero, filii, quid est si uos uidero? Nonne non uestra sum genetrix? Ne non uos his meis lactaui uberibus? Iam omnis ruga-

10 errabamus] errauimus et $\mathrm{S}$ cognouimus $\mathrm{S}$ consulentes] considerantes $\mathrm{P}$ 11 quo audiens ille] quod a. i. (i. a. L) LS quia] qui et $\mathrm{L} \quad 12$ loquendum MV Dominum om. L 13 errauerunt] -at $\mathrm{L}$-ant $\mathrm{S}$ tibus $M$ XLIX-MVPELS praeponendis] posponendis V proponendo S paren1 -MVPELS $\quad 1 \mathrm{abba}^{1} \mathrm{~S} \quad \mathrm{abba}^{2} \mathrm{~S}$ Anub A('Avov́ $\left.\beta\right)$ : Nuph MV Nup $\mathrm{P} \quad$ Nub EL Nubth $\mathrm{S} 2$ desiderans om. S saepe ueniebat uidere eos S 3 illic eos poterat contemplari captato] e. p. (p. e. E) -are c. (capto L) EL 4 uelociter $\mathrm{om}$. EL 5 cellae $\mathrm{om}$. S foris ELS 6 abba PS beatum] abbatem E Poemen L faciemus PELS 7 hac] hanc $M$ haec EL anu] mulier $\mathrm{L}$ anima $\mathrm{S}$ ana $\mathrm{M} \quad 7-8$ tunc... ostium $\mathrm{om}$. $\mathrm{P} \quad 7$ abbas $\mathrm{P}$ 8 quo non] que ne non $\mathrm{L}$ aperto audiens] peraperto $\mathrm{P}$ eam om. $\mathrm{PE}$ lamentari iugiter] i. 1. ELS interlamentans $P$ lacrimari i. $V$ dicit] dicens $E$ ei add. S 9 defessa] defensa MV es L planctus] -os E plactos L plantum tuum $\mathrm{P}$ effundes MV 10 uocem $\mathrm{M}$ cognita fili ELS 10-12 exclamauit... ne non $\mathrm{om} . \mathrm{S} \quad 10$ quoniam] quia $P \quad 11$ desidero uidere $\mathrm{E}$ fili $M$ quid] enim add. PEL nonne non uestra sum] ne non sum $\mathrm{u}$. PE nam non sum ego $\mathrm{u}$. L 12 ne non uos his meis lactaui uberibus] et non uos $1 . \mathrm{h} . \mathrm{m}$. u. L uos om. MV his om. P omnis] -i V -ium PS 
rum contractione repleta sum et audita uoce tua omnia uiscera mea prae desiderio conturbata sunt. Cui Poemen: Hic nos magis an in

15 futuro saeculo uidere desideras? At illa: Quid ergo? Si uos hic non uidero, quasi pro certo illic uisura sum? Sene autem respondente: "Quod si te hic cogere potueris ne nos uideas, illic nos procul dubio peruidebis», tunc illa discessit cum gaudio dicens: Si pro certo uos illic uisura sum, hic uos filii nolo conspicere.

2-Marcus discipulus abbatis Siluani habebat matrem et uenit uidere eum. Egresso autem abbate, postulauit ut diceret filio suo quatenus egrederetur et uideret illum. Ingressus autem senex dicit ei: Egredere ut te mater tua uideat. Ille autem centonem erat uestitus

5 et tamquam ministerium in coquina exhibens totus niger. Et egressus propter oboedientiam quam seni praestabat, clausit oculos suos et dixit: Saluete, saluete. Et neminem de his uidit qui illum quaerebant, sed nec mater eius eum cognouit. Iterum ergo transmisit mater ad senem dicens: Abba, fac egredi filium meum ut eum conspiciam. Tunc

10 senex dicit Marco: Iam antea dixi tibi ut egredereris et uideret te mater tua. At ille respondit: Secundum iussionem tuam egressus sum. Tamen supplico ne mihi iterum semel hoc praecipias ne forte non oboediam. Egressus senex satisfecit matri eius quia ille erat qui ante paululum fuerat egressus. Et dimisit eam.

13 repleta sum]-ae sunt L tua om. S omnis EL 14 an] aut P 16 uideo V pro certo illic] i. p. c. PS illuc p. c. E illuc p. certa L sene autem respondente] senex respondit $P$ senex a. respondit ES 17 hinc S illuc $\mathrm{L}$ nos om. V procul] sine add. E 18 praeuidebis PS 18-19 uos illic] u. illuc PE illuc u. L 19 filii nolo conspicere] fili n. c. MV n. f. c. PL n. c. f. E 18-19 si pro... conspicere] si cum gaudio pro certo uisura sum senex autem respondit sic: Hic igitur nolo nos fili conspicere $\mathrm{S}$

2 -MVPELS 1 abbatis Siluani] S. a. E abbati S. M Siluanus abbati L 2 diceret] educeret MV 3 regrederetur S 4 autem centonem] a. -um P autenem S $5 \mathrm{et}^{2} \mathrm{om}$. PS 7 saluete semel tantum P his] eis $\mathrm{S}$ illum] eum $\mathrm{E} \quad 8$ nec om. V eum] illum $\mathrm{P}$ matrem L 9 egredere EL 10 dicit] dixit ES egrederis V 12 ne mihi iterum semel hoc] nec hoc $\mathrm{m}$. i. S $\mathrm{s}$. hoc om. P 13 oboediam] et add. PLS satisfacit EL 14 eum $P$ 
3-Quidam frater profectus est uisitare sororem suam in monasterio uirginum infirmantem. Illa autem erat fidelis quae numquam uirum uidebat, sed nec fratrem suum uolebat ut inter mulieres alias ingrederetur. Et mandauit ei dicens: Vade, frater, ora pro me et confido quia per gratiam Christi uidebimus nos inuicem in regno caelorum.

4 - Quidam iudex cum uellet uidere abbatem Poemenem et senex non adquieuisset, et uellet iudex per occasionem uidere eum ut benediceretur $a b$ eo, quasi quendam latronem filium sororis eius adprehendit dicens: Quia non illum dimittam nisi forte senex uenerit et rogauerit me pro illo. Soror ergo abbatis Poemenis uenit ad ostium eius plorans pro filio suo. Ille autem non dabat ei responsum. At illa foris clamabat dicens: Ferree, miserere mei, quoniam unigenitus mihi est. Ille autem misit ad eam dicens: Poemen filios non genuit. Quod illa cum audisset discessit. Audiens uero iudex misit dicendo: Quia uel si uerbo mihi praeceperit, dimittam eum. Misit ergo senex et mandauit ei: Discute illum secundum leges, et si dignus est moriatur; si autem dignus non est fac quod uis.

5 - Abbas Iosefel, dum cum aliis senibus ad abbatem Poemenem uenisset, quidam ex parentibus senis adtulit infantem cuius facies per correptionem fuerat deprauata et sedens pater eius cum eo foras monasterium plorabat. Cum autem quidam senex egressus fuisset foras et

3 - MVPELS Hanc sententiam repetit $L^{4} \quad 1$ monasterium E 2 uirginum om. LS quae] et $\mathrm{L}^{2} \quad$ om. $\mathrm{L}^{4} \quad 3$ uiderat $\mathrm{E}$ neque $\mathrm{S}$ uolebat] uidebat $\mathrm{E}$ mulieres alias] a. $\mathrm{m}$. $\mathrm{L}^{4} \quad \mathrm{~m}$. aliunde $\mathrm{P} \quad 4$ et $^{1} \mathrm{om}$. E mandauit ei dicens] -bat d. ei L et ${ }^{2} \mathrm{om}$. P 5 quia per gratiam] in gratia $\mathrm{P}$

4-MVPELS 2 et uellet iudex] i. ut $P$ i. cum $S$ i. ut uel $E L$ uidere eum ut] uideret e. (eum -ret S) et PELS 3 adprehendi S 4 illum dimittam] d. i. P d. om. V 5 abbati MV Poemen P 6 eius] illius $\mathrm{P}$ om. S ei om. S 7 illa] de add. PELS clamat L dicens om. EL miserere] miserere add. repetens $\mathrm{E}$ quoniam] quia PS unigenitus] unicus $\mathrm{PL}$ 8 mihi est] e. $\mathrm{m}$. filius $\mathrm{P} 9$ uero] ergo $\mathrm{P}$ dicendo] ad eam $\mathrm{S}$ dicens $\mathrm{P}$ 10 quia om. PELS mihi uerbo $\mathrm{E}$ ergol ei add. $\mathrm{S} 11$ et $^{1} \mathrm{om}$. MV illum] eum $\mathrm{S}$ est] fuerit $\mathrm{S}$

5-MVPLS om. E 1 abba LS dum] ait S 2 attulerit V 3 fuerat deprauata] d. est S f. om. P cum eo om. S 4 plorans S autem quidam senex egressus fuisset] ergo regressus esset q. s. S 
5 interrogaret eum quare ploraret, tunc ille respondit: Parens sum istius abbatis Poemenis; huic infanti quae tentatio contigerit uides, et timuimus illum hic afferri quia non uult uidere nos. Et nunc si cognouerit quia hic sum adhuc expellet me hinc. Ego autem uidens uos, patres, quia modo ad eum uenistis, praesumpsi uenire hic. Quomodo uis

10 ergo, abba, miserere mei et tolle infantem hunc et fer intus ut oret pro eo. Quem cum senex tulisset et ingressus fuisset in cella, sapienti consilio usus, non eum obtulit primum abbati Poemeni, sed a minoribus fratribus incipiens dicebat eis: Signate infantem facientes orationem. Similiter et per singulos senes. Post omnes detulit eum ad abbatem

15 Poemenem. At ille nolebat eum contingere. Cum autem rogarent eum ut sicut omnes ita et ille oraret, ingemuit et surgens orauit dicens: Deus, sana facturam tuam ne dominetur illi inimicus. Et signauit infantem et mox sanus patri est redditus.

6-Quidam frater requisiuit abbatem Sisoium dicens: Quoniam soror mea mendica est, si quid illi pro caritate praestitero, ne non simile est uelut si ex mendicis uni contribuam? Ait senex: Non est simile quia illuc te facit sanguinis propinquitas declinare.

7 - Cuidam monacho mors nuntiata est sui patris. At ille nuntianti ait: Cessa homo blasphemare; meus enim pater inmortalis est.

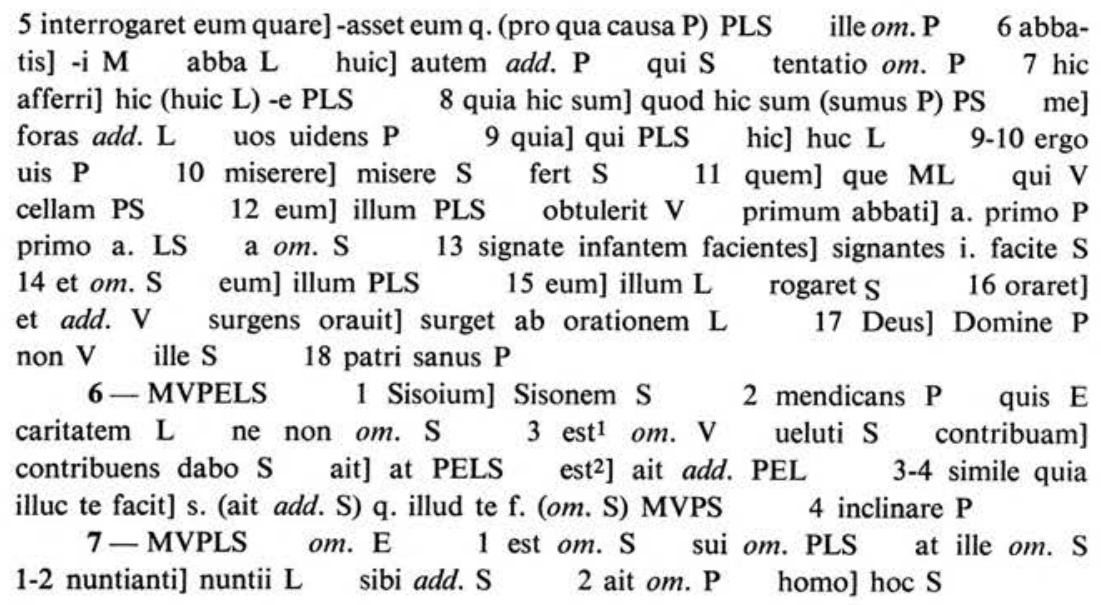




\section{L - DE OBSEQVIIS INFIRMANTIVM VEL IPSA INFIRMITATE}

1-Quidam senex quendam fratrem turbationes noctibus patientem a uisionibus liberauit, infirmantibus cum ieiunio eum ministrare praecipiens. Nullum enim, sic dicens, sicut misericordem eas extinguere passiones.

2-Quidam frater requisiuit a sene dicens: Duo fratres in una sunt cella; et ille quidem unus sex diebus integris ieiunat, ille autem alter infirmo facit obsequium. Cuius ergo maius est opus apud Deum? Respondit senex: Si ille qui ieiunat sex diebus per oculos se suspenderit non erit similis illi alteri in conspectu Dei.

3 - Ioannes minor Thebaeus, discipulus abbatis Ammoe per duodecim annos ipsi seni infirmanti fecit obsequium. Et senex tamen, cum uidisset eum laborantem, numquam illi sermonem placidum locutus est. Cum autem transiret, sedentibus aliis senibus, tenuit manum eius et dicit ei tertio: Salueris, salueris, salueris. Et tradidit eum senibus dicens: Iste angelus est et non homo, qui tot annis mihi infirmanti, nec tamen bonum sermonem audiens, fecit obsequium.

\footnotetext{
L-MVPS om. EL infirmitas S

1-MVPS om. EL 1 quendam] quedam MV noctis $\mathrm{S} \quad 2$ a] in $\mathrm{S}$ infirmitatem MV 3-4 extingueret $\mathrm{P}$

2-MVPELS 1 dum (p.corr.) quidam $\mathrm{L}$ requisit p.corr. $\mathrm{L}$ a sene] senem $\mathrm{P} \quad 2$ cella sunt $\mathrm{S}$ integris $\mathrm{om}$. E ieiunans $\mathrm{L} \quad 3$ alter infirmo] a. ( -i S) -is ( -anti PS) PELS ergo maius est opus] o. m. est P e. o. maior est $\mathrm{E}$ e. est eius m. o. S apud] ante EL 4 si] sed VE diebus per oculos] d. si per oculo $E$ dies p. o. P se suspenderit] se suspenderet MVLS suos penderet $P \quad 5$ illi $o m$. $V$

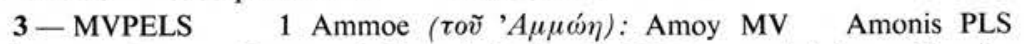
Moisi p. corr. E 2 annos ipsi] annis i. ( -e E) MVE seni infirmanti] enim -ium L obsequium] obedientiam MV et $o m$. PS 3 ille MV 4 senibus aliis $\mathrm{S} \quad 5$ ei om. E 6 iste] autem add. L et om. P non] est add. $\mathrm{E}$ qui] quia $\mathrm{L}$ om. $\mathrm{P}$ tot] quot $\mathrm{P} \quad 7$ neque $\mathrm{S}$ audiens] audieris $\mathrm{P} \quad$ ex ore meo add. $\mathrm{L}$
} 
4-Abbas Agathon ueniens in ciuitate ut opera sua uenundaret, inuenit quendam peregrinum iacentem in angulo portae infirmum nullum habentem qui ei curam adhiberet. Et permansit ibi senex et conduxit cellam et ex opere manuum suarum tam pensionem cellulae

5 persoluit quam infirmo faciebat obsequium. Et permansit ibi mensibus quattuor donec sanaret infirmum et sic in cella sua regressus est.

\section{LI - QVIA INFIRMITAS CORPORIS PROSIT}

1-Quidam magnus senex infirmanti discipulo suo dixit: $\mathrm{Ne}$ contristeris ex infirmitate uel plaga corporis. Summa enim religio est ut in infirmitate quis gratias agat Deo.

$\mathrm{Si}$ ferrum es aeruginem per ignem amittis, si uero aurum es per 5 ignem probatus a magnis ad maiora procedis.

$\mathrm{Ne}$ anxieris ergo, frater. $\mathrm{Si}$ enim te uult Dominus in corpore torqueri, tu quis es qui moleste feras? Sustine ergo et roga eum et quae ipse uult illa concedat.

2-Quidam senex cum frequenter infirmaretur et langueret, contigit ut uno anno nulla ei inualitudo contingeret et propterea flebat et grauiter ferebat dicens: Reliquisti me, Domine, et noluisti me praesenti hoc anno uisitare.

4-MVPELS 1 abba PS ciuitatem VS uenderet PELS 2 anguli MV portae] -a M portu V 4 et om. MVPLS operibus S 5 persoluit] persoluebat $\mathrm{PE}$ solebat $\mathrm{L}$ soluebat $\mathrm{S}$ infirmo faciebat] i. etiam exhibebat $\mathrm{S} \quad 6$ infirmus $\mathrm{P}$ cella sua] cellula sua $\mathrm{P}$ cellulam suam $\mathrm{S}$ regressus] reuersus $\mathrm{E}$ est] in pace $a d d$. PL

LI-MVPELS quia] quod $S$ corpori $S$

1-MVPELS 1 magni senis E suo om. E 2 contristeris] te fili add. $\mathrm{L} \quad 3$ in infirmitate] infirmitas $\mathrm{E}$ agat gratias $\mathrm{S} \quad 4$ amitis per ignem PL 5 approbatus $P$ a] de ES magnis] minimis PS ad maiora] a $\mathrm{m}$. enim L 6 Dominus (Deus P) te uult PELS 7 qui PEL ergo om. S et ${ }^{2}$ ] ut ELS at P 8 ipsa $L$

2-MVPELS 1 cum] dum $\mathrm{S}$ frequenter infirmaretur] i. f. $\mathrm{S}$ f. i. (in add. $\mathrm{P}$ ) corpore PELS et langueret $\mathrm{om} . \mathrm{L}^{2} \quad 2$ ut $\mathrm{om} . \mathrm{S}$ unum annum $\mathrm{P}$ ei inualitudo correxi: eum ualitudo MVPS eum inualido L ualitudo E contingeret] contigeret E contingere LS 3 ferebat] re- E lugebat $\mathrm{L}$ relinquisti $\mathrm{M} \quad 3-4$ me praesenti hoc anno uisitare] hoc p. a. me u. S me praesente h. a. u. MV me praesentem in h. a. u. L 
3-Quidam ex senibus dum langueret solus sedens in cellula et neminem habens qui ei obsequium faceret, exurgens de lectulo quicquid inuenisset in cellula comedebat. Cum ergo sic per multos dies permansisset et nullus ad uisitationem eius ex fratribus aduenisset, post triginta dies conpletos, nemine ueniente, transmisit Deus angelum qui illi obtemperaret. Et post septem dies recordati sunt alii patres de ipso sene et dixerunt ad inuicem: Eamus et uideamus ne forte infirmetur ille senex. Cum autem uenissent et pulsassent ostium recessit angelus. Senex autem clamabat ab intus: Ite hinc fratres. Illi uero frangentes ostium ingressi sunt et requirebant cur sic clamaret. At ille dixit: Triginta dies infirmus fui et nemo me uisitauit; et ecce iam dies septem erant ex quo angelum suum Deus transmisit qui mihi obtemperaret. Cum autem uos uenissetis ad ostium, ille discessit. Et postquam haec dixit pausauit.

\section{LII - DE TRANSITV PERFECTORVM}

1-Quidam senex dum moreretur in Sceti et circumdarent lectum eius fratres et conposuissent eum atque plangerent aperuit oculos suos et risit et iterum risit, risit et tertio. Cum autem rogarent eum fratres dicentes: Dic nobis, abba, cur nobis flentibus ipse risisti? Respondit

3-MVPELS 1 quidam ex senibus dum] q. senex (frater E) cum frequenter infirmaretur corpore et EL cellula] -am P cella EL 2 obsequium ei $\mathrm{V}$ 3 cellula] cella PE sic] hic $\mathrm{P} 4$ adueniret PELS 5 post dies con- explicit truncatus textus $\mathrm{L}^{4}$ conpletos nemine ueniente] c. (complectens $\mathrm{S}$ ) -em uenientem PES angelum] suum add. $\mathrm{P} 6$ illi] ei $\mathrm{E}$ et $\mathrm{om}$. $\mathrm{S}$ post] per $\mathrm{E}$ septem] autem add. S sunt om. S patres] fratres $\mathrm{P} \quad 7$ de ipso sene

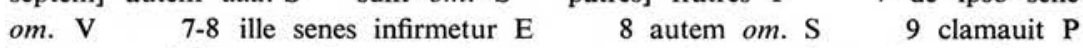
11 me om. MV 12 septem dies $\mathrm{E}$ ex om. $\mathrm{S}$ quo] qua $\mathrm{P}$ quibus $\mathrm{E}$ quod $\mathrm{S}$ angelum suum Deus] D. a. s. PS D. a. E Deus om. M qui] ut S 13 uenistis PE ille] cellulae MV 14 et om. E hoc V pausauit] statim obiit $\mathrm{S}$ in pace add. $\mathrm{P}$

\section{LII - MVPELS}

1-MVPELS 1 circumdassent PLS 2 posuissent $\mathrm{V}$ atque] et PEL aperuit] ille add. PEL 3 et iterum risit] et i. r. aperuit et ELS om. MV risit et (ante tertio)] et $\mathrm{r}$. $\mathrm{E}$ risitque $\mathrm{S}$ eum om. $\mathrm{E} 4$ cur] quare $\mathrm{L}$ nobis $\left.{ }^{2}\right]$ nos $\mathrm{P}$ risisti] rides PELS 
5 eis: Primo risi quia omnes timetis mortem, et secundo risi quia non estis parati, tertio uero risi quia de labore uado ad requiem.

2-Abba Pambo quando uenit ut transiret de corpore, in ipsa hora qua transiret dixit aliis uiris sanctis adstantibus sibi: Ex quo ueni in hunc locum eremi et aedificaui mihi hanc cellulam extra opera manuum mearum nescio me panem gustasse nec poenitui me sermonem quem

5 locutus sum usque ad hanc horam. Et tamen sic uado ad Deum tamquam si nec inciperem colere eum.

3 - Abbas Agathon dum moreretur per tres dies oculos apertos tenuit non eos mouens. Fratres autem tangentes eum dixerunt ei: Vbi es nunc, abba? At ille: In conspectu iudicii Dei sto. Et dicunt ei: Numquid et tu times? Quibus ille respondit: Interea quantum

5 ad uirtutem meam pertinet semper consideraui ut mandata Dei facerem; sed homo sum et unde scio si opera mea Deo placeat? Cui fratres: Et non confidis in opera tua quia secundum Deum est? At ille respondit: Non confido nisi in conspectu Dei peruenero. Aliud est enim iudicium Dei et aliud hominis.

4 - Abbati Sisoio, cum tempus dormitionis aduenisset et multi illic senes alii conuenissent, uiderunt faciem eius fulgore quodam radiante et dicit eis: Ecce abbas Antonius uenit ad nos. Et post parum: Ecce,

5 eis] senex PEL et $o m$. VS 6 tertio uero] et t. PL uero om. ES uado de labore $\mathrm{L}$

2-MVPELS 1 abbas VL Pambo CARW $(\Pi \alpha \mu \beta \omega)$ : Pamon MVPEL Pemen $S$ uenit ut transiret] $u$. hora eius ut $t . P$ ad transitum uenit $\mathrm{L}$ uenit ut $\mathrm{om}$. S 1-2 de corpore in ipsa hora qua transiret] $\mathrm{om}$. PEL 1 in om. S 2 sibi om. S ex quo] ego E 3 hanc om. PL cellam E opera] panem $\mathrm{S} \quad 4$ me sermonem] s. me $\mathrm{V}$ me (om. PS) super s. PELS quem] que $\left.M \quad 5 \mathrm{ad}^{1}\right]$ in ES 6 nec inciperem] n. -im ML $n$. inceperim VS nunc i. $P$ nescirem $S$

3-MVPES om. L 1 abba S 2 ei $\mathrm{om} . \mathrm{V} \quad 3$ Dei $\mathrm{om} . \mathrm{E}$ sto] sum $\mathrm{S} 5$ pertinet $\mathrm{om}$. PES mandata Dei facerem] $\mathrm{m}$. (uoluntatem P) D. f. non timeo PS 6 Deo placeat] D. placeant V D. placet $E$ placent D. P D. placent S 7 confides MVPE quia secundum Deum est] q. s. D. sunt ES om. P at ille] qui P 8 enim est $\mathrm{E} 9$ et om. E hominum $\mathrm{S}$

4-MVPES om. L 1 abba S Sisoio] Sisoyus MV Sisoy E Sisorus $\mathrm{S} 2$ alii $\mathrm{om} . \mathrm{S}$ aduenissent $\mathrm{PE}$ quodam] condam $\mathrm{M}$ 2-3 radiante et dicit eis] -em et d. (-unt S) eis (ei S) PS 3 abba P 
ait, et chorus prophetarum. Et iterum facies eius clariori luce perfusa est et dixit: Beati quoque apostoli adsunt. Visusque est cum quibusdam conloqui. Cum ergo postularent $\mathrm{ab}$ eo patres ut cum quibus loqueretur dixisset: Angeli, inquit, animam meam uenerunt auferre et supplico illis ut paululum me pro poenitentia agenda sustineant. Dicunt autem ei patres: Tu non indiges poenitentiam, abba. At ille respondit: In ueritate uobis dico quia adhuc nec principium me arripuisse poenitentiae reminiscor. Ex quo dicto senserunt quod esset in timore Dei perfectus. Tunc in splendore solis eius effigie relucente dicit ad eos: Videte, uidete, quia uenit Dominus. Et in hoc sermone, reddito spiritu, omnis locus ille grato odore repletus est.

5 - Beatus Arsenius, cum tempus eius ut migraret de hoc saeculo proximaret, dicebat ad discipulos suos: Nemo super me faciat caritatem nisi solam oblationem; ego autem si feci per caritatem inuenio illam.

Turbatis autem discipulis eius quasi iam tempore propinquante, dicit eis: Necdum uenit hora mea. Cum autem uenerit non tacebo. Sed tamen stabitis mecum in diuino iudicio ante tribunal Christi, si alicui de meo corpusculo aut rebus aut reliquias dederitis. Illis autem respondentibus «et quid faciemus, pater, quia nescimus hominem sepelire?», respondit: Numquid nescitis funem in pedibus meis mittere et ita ad montem trahere?

\footnotetext{
4 ait] uenit $\mathrm{P} \quad$ et chorus prophetarum] c. p. (p. c. S) ES eius om. $\mathrm{P}$ clarior V 5 uisus $\mathrm{S} 6$ ergo] autem $\mathrm{S}$ patres $\mathrm{om} . \mathrm{S} \quad 7$ eloqueretur $\mathrm{S}$ dixisset] ediceret (et diceret $\mathrm{E}$ ) at ille PES dixissent $\mathrm{V}$ inquit $\mathrm{om}$. $\mathrm{S}$ uenerunt animam meam $\mathrm{S} \quad 8$ illis] eis $\mathrm{P}$ me ut paululum $\mathrm{S}$ poenitentiam agendam MV 9 autem om. E indiges] agere add. PE poenitentia S 10 dico uobis $\mathrm{V}$ adhuc om. $\mathrm{S} 11$ poenitentiae] remissionem add. E senserunt] superserunt $d u b . \mathrm{V} \quad 12 \mathrm{in}^{2} \mathrm{om}$. PE eius $\mathrm{om}$. VES effigia M relucentem E 13-14 in hoc sermone reddito spiritu] hoc s. dicto reddidid spiritum et $\mathrm{S}$

5-MVPES om. L 1 beatus] abba $\mathrm{S}$ eius] aduenisset add. PE om. V migratus $\mathrm{V} 2$ proximaret $o m$. PE ad discipulos suos] discipulis suis $\mathrm{S} \quad 3$ per om. PES inueniam $\mathrm{S} \quad 5$ turbatis autem discipulis eius] t. (-i PE) a. (om. S) d. (-i PE) e. (e. d. S) PES quasi] quia si V 6 dixit E autem] ante $\mathrm{M}$ om. E 8 alicui de meo corpusculo aut rebus aut reliquias dederitis] alicui (om. PS) de m. c. a. r. alicui (om. E) uelut reliquias dederitis (-ratis S) PES 10-11 in pedibus meis mittere et ita] in p. meis $\mathrm{m}$. ( $\mathrm{m}$. in p. meis E) et ita me PE
} 
Pili autem oculorum eius ex iugi fletu ceciderunt.

Nam omne tempus uitae suae sedens et operans pannum habebat in sinu suo propter lacrimas defluentes ex oculis eius.

15 Dum ergo moreretur coepit flere. Et cum fratres eum requisissent dicentes: Quid fles, pater? Numquid et tu times? Ait: In ueritate timeo et iste timor qui nunc mecum est semper in me fuit ex quo factus sum monachus.

Cum autem uidisset abbas Poemen quia transiit dixit: Beatus es, 20 abba Arseni, quia te in hoc saeculo planxisti. Qui enim se hic non planxerit, illic in perpetuo lugebit. Aut hic ergo ex uoluntate aut illic pro tormentis, inpossibile est hominem non plangere.

\section{LIII - DE TIMORE DEI}

1 - Abba Pambo requisitus a fratre quemadmodum anima resisteret et Deum timere nollet respondit: Anima quidem uult timere, sed necdum tempus est. Timor enim Domini perfectio est.

2-Quidam frater a sene requisiuit dicens: Quemadmodum timor Dei uenit in anima? Et senex ait: Si quis prius humilitatem possederit ut neminem condemnet et nihil habeat, tunc uenit timor Dei in anima.

12 ex iugi fletu ceciderunt] ex i. f. ceciderant nam ES ceciderant ex i. f. P 13 nam] et add. $\mathrm{P} \quad$ omni tempore $\mathrm{P} \quad 14$ sinu] signu $\mathrm{S} \quad 15$ fratres eum] e. f. alii PES 16 ait] ille respondit PES 17 est mecum $P \quad 19$ abba ES quia transiit] q. transit $\mathrm{E}$ quod -iret $\mathrm{S} \quad 20$ abba Arseni] abbas A. (-ii V) MV quia] qui PE saeculo] sic add. PE enim se hic] e. h. se P h. se etiam S 21 illic in perpetuo] i. (illuc S) in -um PS 22 hominem] omnem E non $\mathrm{om}$. M

LIII - MVPS om. EL

1-MVPS om. EL 1 Pambo RW $(\Pi \alpha \mu \beta \omega ́)$ : Pammon MVS Pammos $\mathrm{P}$ anima om. V $3 \mathrm{est}^{2} \mathrm{om}$. P

2-MVPS om. EL 2 Dei uenit] Domini u. $(\mathrm{om}$. S) PS 3 possiderit MVP et nihil habeat] et ut $\mathrm{n}$. h. P om. S 4 animam $\mathrm{P}$ 
3-Quidam frater requisiuit abbatem Poemenem dicens: Quid faciam, pater, quoniam insensata est anima mea et non timet Deum? Dicit ei senex: Vade et iunge te cum homine timente Deum et ab eo inquire quod ille timet et tu doctus incipies timere.

\section{LIV - DE LACRIMIS VEL LVCTV}

1-Quidam frater requisiuit senem dicens: Quemadmodum desiderat anima lacrimas sicut de senibus audio et non ueniunt ad me et ideo contristatur cor meum? Cui senex: Post quadraginta annos filii Israel ingressi sunt in terram repromissionis. Lacrimae ergo sunt terra repromissionis et per multos labores perueniuntur ad illam; et si semel aliquis ingressus fuerit illic, iam proelium non timebit. Sic autem uult Deus ut semper anima tribuletur et desideret ingredi in terram illam repromissionis.

2-Quidam senex uidit fratrem ridentem et dicit ei: Praesente caelo et terra, totius uitae nostrae rationem reddituri sumus, et tu rides?

Sicut enim umbram corporis nostri ubique portamus ita planctum et conpunctionem ubicumque sumus a nobis derelinquere non debemus.

3-MVPS om. EL 2 quoniam] quia $\mathrm{S} \quad 3$ te om. S hominem timentem $\mathrm{M} \quad \mathrm{ab}$ eo] ob hoc $\mathrm{V}$ ab illo $\mathrm{S} 4$ inquire om. MV qui $\mathrm{S}$ illum $\mathrm{S}$ et $\mathrm{om}$. $\mathrm{S}$ doctus incipies] edoctus incipias $\mathrm{S}$

LIV - MVPELS lacrimans $L$ uel] et $E$

1-MVPELS 2 desiderat anima] a. d. S a. mea d. V audio] audeo $\mathrm{L} \quad 3$ post] per MVPE 4 annis EL filii Israel ingressi sunt] filios I. i. s. $M$ i. s. f. I. S promissionis S 4-5 lacrimae ergo sunt terra repromissionis] 1. ergo (quae S) s. terra (-m M) r. (promissionis S) MS om. EL 5 et $\mathrm{om} . \mathrm{S}$ per $\mathrm{om}$. P perueniuntur] -itur VPS peruenerunt $\mathrm{E}$ perueniunt L 6 illas PLS si] quis add. E aliquis om. $\mathrm{S}$ illic ingressus fuerit $\mathrm{S} \quad 7$ autem] enim $\mathrm{P}$ anima] autem $\mathrm{S}$-am $\mathrm{L} \quad 8$ in om. $\mathrm{S}$ 2-MVPELS 1 dixit $\mathrm{P} 2$ et terra] et om. $\mathrm{E}$ om. $\mathrm{S}$ totus $\mathrm{L}$ 4 umbra MPEL nostri corporis V 5 conpunctiones ELS a nobis derelinquere] a n. (a n. om. P) relinquere PELS 
3-Quidam frater dum peteret ab abbate Poemene instructionis audire sermonem, respondit senex: Rem quam quaeris, principium eius patres nostri luctum posuerunt. Luctus enim duplex beneficium est quia non tantum operatur sed etiam seruat.

4-Beatus Athanasius episcopus rogauit aliquando abbatem Pambo ut de eremo descenderet in Alexandriam.

Qui descendens cum aliis fratribus, cum uidisset saeculares dicit eis: Surgite et salutate monachos ut benedicamini; frequenter enim 5 isti cum Deo loquuntur et os illorum sanctum est.

Et cum uidisset mulierem mimam in ciuitate, plorabat grauiter. Et requisierunt eum adstantes cur plangeret. At senex dixit: Duae me res ad lacrimas conpulerunt: una quidem perditio illius mulieris; secunda uero quia ego tantam curam non habeo placendi Deo quan10 tam habet haec mulier ut hominibus turpibus placeat.

\section{LV - DE POENITENTIA}

1-Quidam frater requisiuit abbatem Poemenem dicens: Quid est poenitentia? Cui senex: Poenitentia peccatorum est ulterius non peccare.

Haec enim uox ad hominem semper clamat usque ad ultimam 5 respirationem: «Hodie conuertimini».

LV, 1 lin. 5: Hodie conuertimini - cf. Ps. XCIV, 8 .

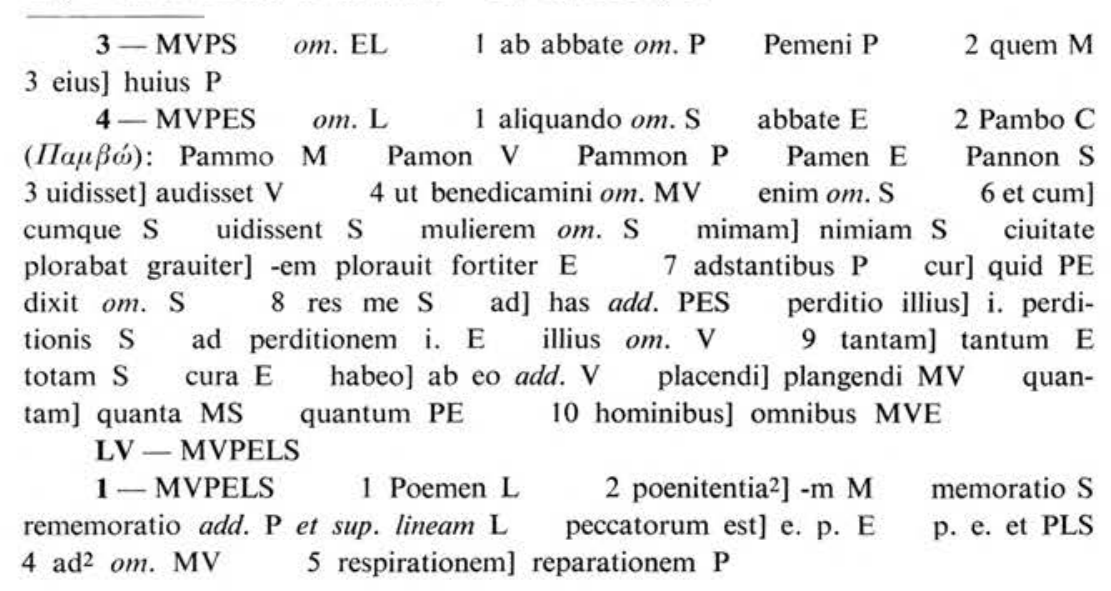


2-De quodam sene dicebatur quia quotiens illi sua cogitatio dicebat «Dimitte hodie et cras poenites», respondebat: Non, sed hodie debemus poeniteri et cras Dei uoluntas fiat in nobis.

3 - Idem dixit: Omni uespere et omni mane debet homo rationem contra semetipsum ponere dicens: Videamus quid hodie fecimus ex his quae Deus non uult et quid ex his quae uult impleuimus. Sic enim secum pertractans in omni uita sua et poenitentiam agere inuenitur et Deo adhaerere.

Et ob hoc sicut nemo potest nocere eum qui iuxta imperatorem est, sic nec diabolus illum potest laedere cuius anima semper adpropinquat Deo, quia ipse dixit: Adpropinquate mihi et adpropinquabo uobis. Cuius autem sensus huc atque illuc diuertitur, inueniens tempus inimicus facillime animam illius in diuersas passiones inducit.

4-Dixit abba Poemen: Volo magis hominem post peccatum suum poenitentem quam hominem neque peccatum intellegentem neque poenitentem. Ille enim semper in cogitatione sua se peccatorem dicens, humilis est; ille autem habet cogitationem quia homo iustus sit, et non est.

LV, 3 lin. 8-9: Adpropinquate... uobis - cf. Iac. IV, 8.

2-MVPLS om. E 2 poenites] se iterum add. $\mathrm{P}$ ipse iterum add. LS respondebat] repraehendebat $\mathrm{S}$ non sed] nos et MV 3 penitere LS et] ut PS Dei uoluntas fiat] f. u. D. L Dei om. V Dei sup. lin. $\mathrm{M}$

3-MVPLS om. E 1 idem] item PL 1-2 rationem contra] r. (orationem P) intra PLS 2 seipsum V componere PLS quod L 2-3 fecimus ex his quae] ex his f. q. (quod P) PLS 3 quae $^{2}$ ] quod P om. S impleamus MV 4 secum om. V tractans $V$ inuenimur $P \quad 6$ ob om. MV ei VS imperatorem] -e $\mathrm{L}$ enim add. p. corr. $\mathrm{M}$ dignus add. $\mathrm{P} \quad 7$ potens $\mathrm{L} \quad 8$ quia] quoniam $\mathrm{S}$ et] ego add. $\mathrm{S} \quad 9$ autem sensus] enim s. (-um P) PL 10 diversis passionibus $\mathrm{P}$ inducet PL

$$
\text { 4-MVPES om. L } 2 \text { neque] post } \mathrm{S} \text { peccatum] nec add. } \mathrm{S}
$$

om. V 3 neque poenitentem ille] nec p. tunc ille et $\mathrm{S}$ semper in cogitatione sua] in c. sua s. P semper om. S peccatorem se S 4 dicens] iudicans E 4-5 sit iustus PES 5 et non est om. PES 
5-Quendam senem miles quidam requisiuit dicens: Suscipit Deus poenitentem, abba? Cui senex: Dic mihi, carissime: si rupta fuerit parum clamis tua, numquid proicis illam? Cui miles respondit: Non, sed sarcio illam et iterum utor. Dixit ei senex: Si tu ergo uesti5 mentum tuum parcis et uteris eum, Deus propriae facturae non parcit? Et his uerbis iuuatus est miles.

6-Abbas Ioannes hanc similitudinem dicebat de anima poenitentiam adpetente: Quaedam meretrix erat in ciuitate multos habens amatores. Veniens autem iudex ad eam dixit illi: Sponde mihi continentiam et ego te in uxore recipiam. Illa uero spondente, accepit eam

5 et duxit in domum suam. Amatores autem eius priores, quaerentes eam dicebant: Iudex intulit eam in domum suam et si profecti fuerimus ad ostium eius et senserit, puniet nos; sed uenite post ostium, sibilemus ei et cognoscens illa uocem sibili nostri descendet ad nos et ita nos sine culpa reperiemur. Illa autem postquam sibilum audiuit, consignans

10 aures suas, in interiori cubiculo confugit et clausit ostium.

5-MVPES om. L 1 quendam senem miles quidam requisiuit] quidam $\mathrm{m}$. r. quendam s. $\mathrm{P}$ quendam senex $\mathrm{m}$. quidem $\mathrm{r}$. MV 2 poenitentiam PE rupta] rapta S 3 parum] rarum $S$ clamidis M 4 sarcio] -or $\mathrm{S}$ sortio $\mathrm{E}$ illa $\mathrm{S}$ utor] uteor $\mathrm{M}$ ea $(-\mathrm{m} \mathrm{E})$ add. PES dicit PES ei] autem $V \quad 5$ parcis] sarces $P$ sartis $E$ sarcis $S$ et uteris eum Deus] et u. eo D. $\mathrm{V}$ et $\mathrm{u}$. ergo D. quomodo $\mathrm{P}$ ut utaris ex eo D. S propriae facturae non parcit] n. parcit p. f. S p. f. n. parcet $P \quad 6$ his] istis $S$ 6-MVPES om. L 1 abba $\mathrm{S}$ anima]-am $\mathrm{M}$-i $\mathrm{P} \quad 2$ adpetente] $-\mathrm{m} \mathrm{M}$ adpenitentem PE erat $\mathrm{om}$. E habuit E 3 iudex ad eam] ad e. i. E ad eam om. S dicit E 4 uxorem PES spondentem E 4-5 eam et duxit in domum suam] eam uxorem $\mathrm{E}$ et d. eam in domo sua $\mathrm{S}$ 5 eius om. P quaerebant $\mathrm{S} \quad 6$ dicentes $\mathrm{S}$ intulit eam in domum suam] tulit eam in domo sua ES 7 puniet nos sed uenite] nos p. sed ueniente $\mathrm{V}$ ostium] et add. E 8 ei] illi ES illam V descendit V ita et E 


\section{LVI - QVOMODO PER POENITENTIAM VNO DIE POTEST HOMO RECONCILIARI DEO}

1 - Abbas Sisoius frequenter de poenitentia hunc solebat replicare sermonem: Si uoluerit homo, a mane usque ad uesperum potest ad diuini praecepti peruenire mensuram, hoc est, si pro transactis peccatis lugendo poeniteat et ne ulterius delinquat inter se et Deum statuat testamentum.

2-Quidam ex patribus de aliquo referebat episcopo eo quod audisset duos ex plebe sua uiros nimiae inpuritatis adulteros. Rogauit ergo Deum ut si ita esset agnosceret. Cum ergo post oblationem consecratam unusquisque ad communionem accederet per singulorum facies intellegebat et animos. Peccatores autem facies nigras inspiciebat ut carbones et oculos sanguine repletos; alios uero uidebat clara facie et uestibus albis. Cum autem corpus Domini suscepissent, in quorundam uultibus lumen, in quorundam uero flamma uidebatur. $\mathrm{Vt}$ autem cognosceret de illis quorum crimina audiebat, communionem eis ipse porrexit. Et uidit unum ex eis clara facie et honorabile albisque uestibus circumdatum, alterum uero nigrum et horribile uultu. Et postquam diuini mysterii gratiam susceperunt, illum lux quaedam inlustrauit, illum uero alium quasi flamma succendit. Orauit ergo episcopus Deum de singulis quae ei ostensa fuerant edoceri. Adstans

LVI - MVPELS uno] omni E potest homo reconciliari Deo] de Deo reconciliatur $\mathrm{S}$ p. h. reconciliare Deo $\mathrm{L}$

1 -MVPELS 1 Abbas Sisoius] abba Sisonius S 1-2 solebat replicare sermonem] sermone s. r. L 2 mane] me S 3 pro] post $\mathrm{S} \quad 4$ peccatis om. MV et ne ulterius] et (ut $a d d$. P) u. non PL 5 statuet S

2-MVPES om. L 1 patribus] fratribus $\mathrm{P} \quad 2$ ex plebe sua duos E 3 ergo] itaque $\mathrm{E}$ ita] ergo add. $\mathrm{P}$ cognosceret $\mathrm{S} \quad 4$ ad communionem] om. V sup. lin. M accederet] et add. E 5 intellegeret $\mathrm{E}$ et om. PE peccatorum PES 6 carbo PS uero] autem S 7-8 in quorundam uultibus lumen] in q. u. flame 1. S om. P 8 in quorundam uero flamma om. S uidebat PS 9 agnosceret $\mathrm{E}$ audierat PS 10 eis $^{1}$ ] illis $\mathrm{P} \quad$ ipse] in se $\mathrm{V}$ om. $\mathrm{P}$ eis $\left.{ }^{2}\right]$ his $\mathrm{E}$ clara om. $\mathrm{P}$ et om. P honorabile] -em V -i PS 10-11 albisque uestibus] uultu S nigrum et horribile uultu] $\mathrm{n}$. et horribilem (horribiliorem $\mathrm{S}$ ) uultu (-m V) VES horribili et nigro uultum $\mathrm{P} \quad 12$ diuinam $\mathrm{P} \quad$ mysterii $\mathrm{om}$. PS susceperunt] -rant $\mathrm{P} \quad$ perceperunt $\mathrm{E} \quad 13$ flammam $\mathrm{V} \quad 14$ quae ei ostensa] quae o. ei $\mathrm{P}$ eis quae o. $\mathrm{P}$ fuerat $\mathrm{M}$ 
15 autem angelus Domini dixit ei: Omnia quae de ipsis audisti uera sunt. Sed ille unus adhuc in sordibus suis permanet et in uoluptate peccandi. Ideo illum nigra facie et flamma succendi uidisti. Ille autem alter similis quidem illi erat sicut audieras, sed ideo illum clara facie inlustrari uidisti quia recordatus de his quae prius fecit et renuntians illis

20 operibus cum lacrimis et gemitibus Dei misericordiam postulauit, promittens ut si praeterita illi fuissent remissa peccata ulterius ad ea numquam rediret. Et ideo prioribus criminibus deletis ad hanc gratiam quam uidisti peruenit. Cum autem episcopus de gratia Dei miraretur eo quod non solum de tormentis tam turpis uitae hominem

25 liberum statuerit, sed etiam tanto honore decorauerit, respondens angelus dixit: Bene miraris; homo enim es. Nam Dominus noster ac uester naturaliter bonus et humanus est cessantibus a peccatis. Petentibus enim semper confessionem non solum tormenta peccati dimittit sed honore efficit dignos. Sic enim Deus dilexit homines ut

30 unigenitum filium suum pro peccatoribus destinaret et pro ipsis daret ad mortem. Qui ergo dum inimici eius essent, mori pro ipsis elegit, quanto magis quando illius proprii fiunt. Hoc ergo scias quoniam nullum peccatum humanum bonitatem Dei uincit si tantummodo per poenitentiam unusquisque ea quae prius fecerit aboleuerit mala. Mise-

35 ricors enim Deus et infirmitatem generis uestri scit et passionum fortitudinem et diaboli uirtutem uel malitiam. Et cadentibus omnibus

LVI, 2 lin. 29-31: Sic... mortem - cf. Jo. III, 16.

lin. 31-32: dum... fiunt $-\mathrm{cf}$. Rom. V, 10.

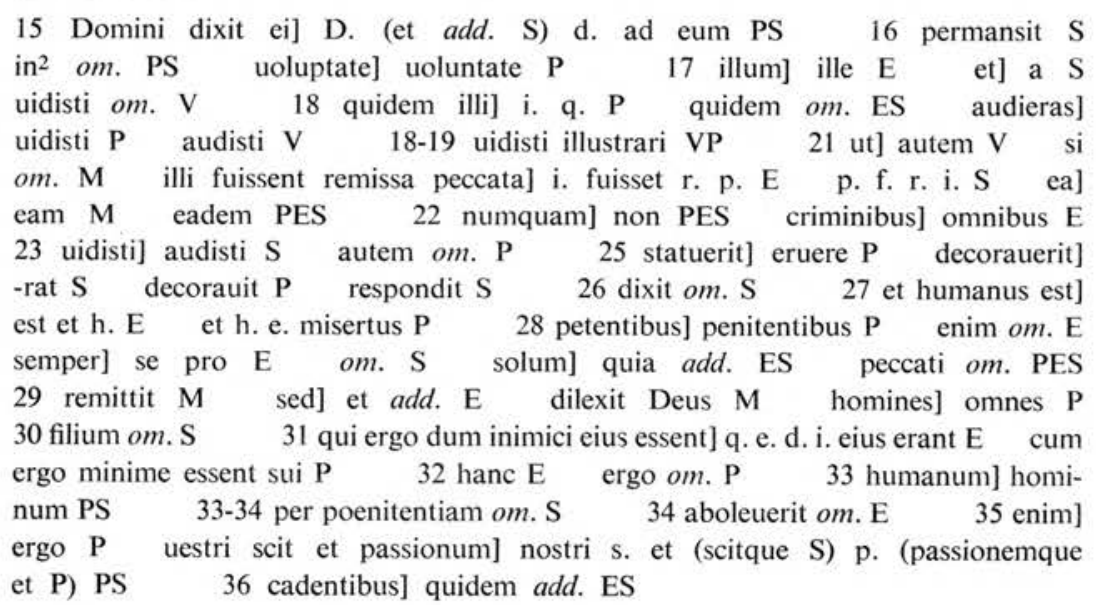


in peccato tamquam filiis indulgens sustinet emendationem; poenitentibus uero tamquam languidis conpatitur et mox soluens peccata eorum iustorum illis etiam praemia tribuet. Audiens uero haec episcopus miratus est et glorificauit Deum.

3-Abbas Paulus Simplex habebat hanc gratiam ut ingredientes in ecclesiam senes aspiceret et ex ipsa facie eorum uniuscuiusque cogitationes seu malae essent seu bonae sentiret. Cum ergo uenissent ad ecclesiam et ingrederentur, senex uidit eos clara facie et laeta anima ingredi et angelos eorum cum gaudio pariter cum ipsis. Vnum autem uidit nigrum et nebulosum habentem corpus et daemones hinc atque inde trahentes eum ad se, misso freno in naribus eius, et angelum eius sanctum de longe sequentem tristem. Beatus ergo Paulus coepit flere et pectus suum tundere, sedens ante ecclesiam, propter eum quem talem uiderat. Omnes autem alii senes uidentes eum sic flentem coeperunt rogare ut si quid in illis uidit manifestaret aut cum eis ingrederetur in congregatione. Ille autem noluit ingredi, sed semper fleuit propter eum quem sic uiderat. Post paululum autem, cum absoluta congregatione discederent, iterum omnium uultus circuminspiciebat si tales egrederentur quales ingressi sunt. Et uidit illum quem antea uiderat $\begin{array}{lcccc}37 \text { filius V } \quad \text { sustinens P } & 38 \text { soluet E } & 39 \text { illis etiam praemia tribuet] e. } \\ \text { illis p. (om. V) t. (-it P) VP } & \text { uero haec] h. u. E } & \text { u. hoc V } & \text { autem S } & \text { om. P } \\ \text { episcopus] sanctus } \text { add. S } & 40 \text { glorificabat ES } & & & \end{array}$

3-MVPELS 1 abba ES ut] et EL 2 ecclesia M senes] senex $\mathrm{S}$ om. $\mathrm{P}$ aspiceret om. $\mathrm{V}$ ex om. VP facies $\mathrm{P} \quad 3$ malae essent seu bonae] mala e. s. bona $S$ b. e. s. malae (-a L) EL uenissent] ueniret populus $\mathrm{P} \quad 4$ ingredierentur $\mathrm{M}$ senes MVEL animi $\mathrm{M}$ 5 ingredientes $P$ et om. P angelorum E 6 et nebulosum habentem corpus et om. V 6-7 daemones hinc atque inde trahentes] t. d. h. a. i. V d. hinc (hic L) atque (ac S) i. trahentes (tractantes P) PLS 7 eum om. P 7-8 sanctum eius PE 8 ergo] autem PS 9 quem] qui L 10 alii om. S flentem] flere $\mathrm{V}$ coeperunt] eum add. S. 11 rogare] eum add. EL si quid in illis uidit manifestaret] si quid (quidem $M$ quis E) in (om. E) i. u. m. ME ea quae uiderat $\mathrm{m}$. eis $\mathrm{P} \quad 12$ congregationem $\mathrm{S}$ flebat PELS 13 paulum $\mathrm{S}$ autem] uero $\mathrm{P} \quad 13 \mathrm{cum}$ ] quam $\mathrm{E}$ om. $\mathrm{P}$ congregatione] cum omnes add. $\mathrm{P} 14$ discederent] -et VS descenderent $\mathrm{P}$ iterum omnium uultus circuminspiciebat] similiter eos inspexit $\mathrm{P} \quad$ i. o. u. circumspiciebat (conspiciebat E) ELS si] utrum V om. M 15 ingrederentur $\mathrm{S}$ illum om. V ante $\mathrm{S}$ uideret $\mathrm{E}$ 
nigrum et nebulosum egressum de ecclesia clara facie, candido corpore et daemones de longe sequentes eum, sanctum autem angelum eius prope eum hilarem et gaudentem super eum nimis. Tunc Paulus exurgens cum gaudio, uociferatur benedicens Deum ac dicens: Quanta

20 misericordia et bonitas Dei est! Quanta miseratio eius est! Et ascendit in loco altiori et magna uoce dicebat: Venite et uidete opera Dei; uenite et uidete quemadmodum Deus homines uult saluos fieri et ad agnitionem ueritatis uenire. Venite, adoremus eum dicentes: Quia tu solus potes peccata tollere. Cum autem omnes conuenissent, exposuit

25 eis Paulus quae uidisset antequam ingrederentur in ecclesiam et postea. Et petebat illum fratrem quem sic uidisset ut ei manifestaret cogitationes suas uel quemadmodum tantam commutationem Deus illi donasset. Ille uero ante omnes coepit referre dicens: Ego homo sum peccator et in multis temporibus istis semper fornicationi fui deditus.

30 Ingressus autem nunc in ecclesiam Dei, audiui uerba Esaiae prophetae, magis autem Dei per ipsum loquentis: «Lauamini, mundi estote et tollite malitias de animabus uestris ante conspectum oculorum meorum, discite bene facere et quaerite iudicium, et si fuerint peccata uestra ut coccinum sicut nix dealbabuntur; et si uolueritis et audieritis me

35 bona terrae comedetis». Ego autem fornicator, conpunctus in hoc

LVI, 3 lin. 21: Venite... Dei-cf. Ps. XLV, 9.
lin. 22-23: Deus... uenire $\mathrm{cf.}$ I Tim. II, 4.
lin. $23:$ Venite adoremus - cf. Ps. XCIV, 6.
lin. 24: solus... tollere - cf. Marc. II, 7.
lin. 31-35: Lauamini... comeditis - Is. I, 16-19.

16 facie] et add. S candidoque $\mathrm{L} \quad 17$ autem] uero $\mathrm{P} \quad 18$ eum] illum $\mathrm{S} \quad 19$ uociferatur] -abatur $\mathrm{E}$ uociferebatur $\mathrm{L}$ ac dicens quanta] atque d. quam S 20-21 est et ascendit in loco altiori et] est (om. L) -ens in 1. a. (a. 1. EL) PELS 21 uenite et uidete opera Dei] om. PEL 22 Deus homines uult] D. u. h. V omnes u. P omnes h. D. u. E u. D. omnes h. L omnes h. u. D. S agnitionem] cognitionem ES 24 potes om. $\mathrm{V}$ tollis $\mathrm{V} 25$ eis] eos $\mathrm{S}$ priusque $a d d$. dub. $\mathrm{S}$ 25-26 Paulus... uidisset ut $\mathrm{om}$. S 25 uiderat $\mathrm{P}$ ingrederetur VPE in om. E ecclesia M et postea] et quae p. PEL om. V 26 petebant $\mathrm{E}$ uiderat $\mathrm{P}$ eis $\mathrm{E}$ manifestare S 27 illi Deus S 28 uero ante omnes] autem omnibus P 30 nunc om. PS ecclesia MS Dei om. L uerbum P 31 Dei] de L Deus P per om. L loquentem P lauamini] leuamini V om. PES et om. L 32 malitiam E conspectu MEL 33 et $^{1}$ om. ES 34 ut] tamquam PELS sicut] quasi $V$ tamquam E albabuntur P 35 comedetis] manducabitis $\mathrm{E}$ 
sermone prophetae et ingemescens intra pectus meum, dixi ad Dominum: «Domine, tu es qui uenisti saluare peccatores. Haec ergo quae nunc per prophetam promisisti, opere conple in me indignum et peccatorem. Ecce enim amodo profiteor tibi et ex omni corde meo confiteor quia ulterius hoc malum non faciam, sed renuntio omni iniustitia et amodo seruio tibi in conscientia munda. Ab hoc die ergo, Domine, et $a b$ hac hora suscipe me poenitentem et adorantem te et renuntiantem omnibus peccatis. Iuraui etenim et statui apud me seruare omnes iustificationes tuas». Sub hac ergo sponsione egressus sum de ecclesia: statui apud me nihil de prioribus peccatis ulterius facere. Omnes ergo senes audientes exclamauerunt una uoce ad Dominum dicentes: Quam magnificata sunt opera tua, Domine! Omnia in sapientia fecisti!

\section{LVII - QVIA ET IN PROPOSITO POENITENTIAE SI TRANSEAT HOMO TAMEN SVSCIPITVR}

1 - Quidam frater uenit ad abbatem Poemenem dicens ei quod grandem tentationem passus esset. Et respondit senex: Fuge de loco illo quantum tribus diebus ac noctibus ambulare potes et fac annum

LVI, 3 lin. 43-44: seruare... tuas - cf. Ps. CXVIII, 8.

lin. 47-48: Quam... fecisti - cf. Ps. CIII, 24.

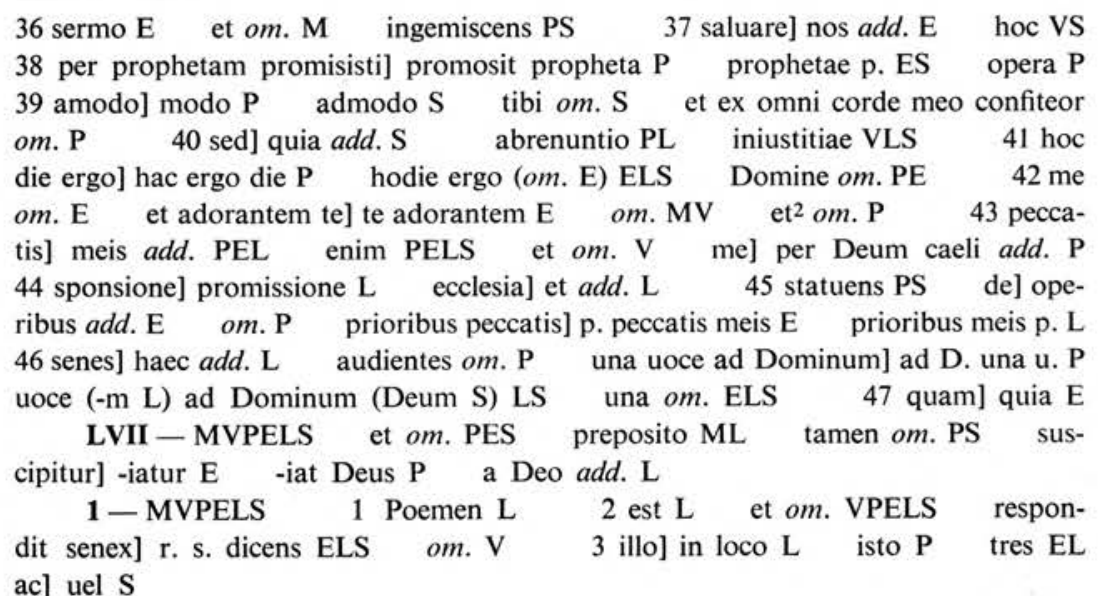


integrum ieiunans usque ad noctem. Cui ille: $\mathrm{Si}$ mortuus fuero ante5 quam annus transeat, quod de me fiet? Dicit ei abba Poemen: Confido in Domino quia si cum tali proposito a me fueris egressus ut hoc perficias, etiam si mox mortuus fueris suscipitur poenitentia tua apud Deum.

2 - Quidam frater sedebat in cella in Aegypto in magna humilitate praecipuus. Habebat autem sororem in ciuitate meretricem, quae multis animabus perditio fuerat. Frequenter ergo insultabant senes illi fratri et uix potuerunt eum suadere ut ueniret ad eam quatenus

5 per admonitionem suam posset peccatum quod per eam fiebat euincere. Dum autem ueniret ad locum, quidam ex notis uidens eum, praecessit et nuntiauit illi dicens: Ecce frater tuus uenit ad te. Illa autem prae gaudio, relictis amatoribus suis, quibus ministrabat, capite discooperto ad occurrendum fratri egressa est. Dum autem tentaret eum amplecti,

10 dicit ei: Soror mea carissima, parce animae tuae, quoniam propter te multi perierunt. Et quemadmodum poteris sufficere amara illa aeterna tormenta? Illa autem contremescens dicit ad eum: Et scis, frater, quia erit mihi salus uel amodo? Cui ille: Si uolueris est salus. Illa autem iactans se ad pedes fratris petebat ut eam secum duceret in 15 deserto. Cui frater: Vade et cooperi caput tuum et sequere me. Cui

4 ieiunans usque ad noctem] i. (-una E) u. ad nocte EL cui] tunc $\mathrm{P} 5$ quid PELS fiet] sit $\mathrm{S}$ abba Poemen] abbas Poemenem V 6 in Domino] in Deum ES om. $\mathrm{P} \quad$ si cum tali proposito a me] dum in t. p. $\mathrm{P}$ si cum a me t. p. S fueris] fieris $\mathrm{L} \quad 6-7$ egressus... fueris $o m$. $\mathrm{P} \quad 6$ egressus] segregatus $\mathrm{E}$ agressus $\mathrm{S} \quad 7$ proficias $\mathrm{L} \operatorname{mox}$ om. E tua om. E 2-MVPELS 1 in cella in Aegypto] in c. (-am L) in (om. L) Ae. (-um E) EL in $^{3}$ om. PE humilitate] utilitate MV 2 sororem in ciuitate] in c. s. P s. in ciuitatem E 3 ergo insultabant senes] s. insultabant S 4 illi fratri] illi alii fratres $\mathrm{P}$ eum om. $\mathrm{S}$ suadere] -i MV persuadere PEL 5 posset] posse $\mathrm{P} \quad$ om. $\mathrm{L} \quad 6$ notis] nostris $\mathrm{E}$ noctis $\mathrm{S} \quad 6-7$ praecessit et] et illi praecedens $\mathrm{S} \quad 7$ illi] sorori $\mathrm{L}$ om. $\mathrm{S}$ autem om. PE 8 decooperto E 9 currendum E eum amplecti] e. (eam S) complecti PELS 10 ei] ea $\mathrm{L} \quad 10-11$ quoniam... perierunt om. $\mathrm{L} \quad 10$ quoniam] quia $\mathrm{S}$ 11 perierunt] pereunt PES 11-12 sufficere amara illa aeterna tormenta] sufferre a. i. ae. t. (t. ae. E) PES a.i. ae. t. sufferre L amara om. MV aeterna om. MV 12 autem om. V contremiscens P dixit L 13 erit] est PELS amodum MV cui] at $\mathrm{L}$ salus $\mathrm{om}$. S 14 fratris] eius PE $15 \mathrm{et}^{1} \mathrm{om}$. PE operi MV 
illa: eamus, ait. Oportet enim mihi deformari inter homines nudo capite ambulantem quam in officina peccati me iterum ingredi. Dum autem pariter ambulassent monebat eam ad poenitentiam. Videns autem quia quidam obuiarent sibi, dicit ei: Quoniam necdum omnes sciunt quod soror mea es, parum de uia secede donec transeant. Et post transgressos illos uocat eam: Eamus, soror, uiam nostram. Illa autem non respondente, perquirens inuenit eam mortuam et uestigia pedum eius plena sanguine. Erat enim discalceata. Cum autem senibus renuntiasset factum, contendebant inter se de saluatione eius. Manifestauit autem Deus uni seni de ipsa: «Eo quod nulla illi cura fuit de corporali re, sed et uulnus proprium neglexit, neque suspirauit in tam grandi plaga, propterea suscepi poenitentiam eius».

3-Quidam ex patribus referebat eo quod aliquis frater, uolens discedere in solitudine, a matre propria prohibebatur. Ille uero dicebat: Saluare uolo animam meam. Cum autem non potuisset retinere mater, dimisit eum. Ille uero ueniens in solitudine per neglegentiam omnem uitam suam consumebat. Contigit autem ut mater eius moreretur, et post aliquod tempus factus ipse infirmus et raptus est in extasi ad iudicium et inuenit ibi matrem suam cum his qui iudicabantur. Illa

16 illa om. E eamus ait] a. e. $\mathrm{E}$ e. inquit frater $\mathrm{L}$ ait om. $\mathrm{P}$ me VPE deformare E 17 ambulare E quam in officina] quia in mofficina V me iterum] mei i. (atrium S) PELS 18 ambularent PELS monebat] autem add. P 19 autem om. S quia] qui L quidam] quidem ME quedam $\mathrm{L}$ dixit $\mathrm{P}$ quoniam] quia $\mathrm{S}$ omnes] homines MV 20 quod] quia $S$ secede] recede $E \quad 21$ post transgressos illos uocat] transgressis illis u. (-auit P) PE eam] frater add. $\mathrm{L}$ uia nostra $\mathrm{M}$ 22 non respondente] $n$. respondentem $L \quad$ r. minime $S$ perquirens inuenit eam] p. eam i. illam S 23 autem] frater ille add. $\mathrm{P} \quad 24$ senibus] om. V sup.lin. M intra $\mathrm{L}$ saluatione] salutatione $\mathrm{V} \quad 25-26$ illi cura fuit] c. i. f. E c. f. ei S 26 re] ire $\mathrm{V}$ et uulnus proprium] in $\mathrm{u}$. p. se ipsam $\mathrm{P}$ et om. $\mathrm{S}$ nec $\mathrm{S}$ 27 grandi plaga propterea suscepi] g. (-e L) plaga (dolore $\mathrm{P} \quad$ corporis add. L) p. suscepit (om. V) Deus VPEL

3-MVPELS 1 quidam] frater add. $\mathrm{P}$ patribus] fratribus VS 2 solitudinem PES propria] ire add. $\mathrm{S}$ uero] autem $\mathrm{L}$ ad eam add. $\mathrm{P}$ 3 uolo] desidero $\mathrm{E}$ potuisset] eum add. $\mathrm{L}$ retinere mater] $\mathrm{m}$. $\mathrm{r}$. E r. illum m. P 4 solitudinem PELS 4-5 omnem uitam suam consumebat] o. u. s. consumabat ME consumauit o. u.s.S 5 contingit V autem om. S eius] sua $\mathrm{L} \quad 6$ aliquod tempus] t. a. PES $t$. aliquid $L$ factus] est add. PE est et $a d d$. $\mathrm{L}$ et raptus] raptusque EL et om. PS est om. $\mathrm{S} \quad$ extasi] -im ductus $\mathrm{P} \quad 7$ iudicium] uenit add. S ibi om. PELS 
autem cum uidisset eum obstipuit dicens: Quid est hoc, fili, et tu in hoc loco es condemnatus? Et ubi sunt uerba illa quae solebas dicere:

10 «Saluare uolo animam meam»? Erubescens ergo in quibus audierat nihil habebat quid responderet. Et ecce uoce facta ut hic reuocaretur, tamquam altero iussu ex coenobio frater transiret, reuersus ad se haec ipsa quae cognouerat adstantibus nuntiabat. Ad confirmationem sane uerborum suorum conpulit ut aliquis de adstantibus ad coenobium

15 iret et uideret si transiret frater eiusdem nominis de quo audierat. Et qui profectus est inuenit ita. Ipse uero postquam sanus effectus est, reclusit se et sedit cogitans de salute sua, poenitens et lacrimans super his quae fecit prius in neglegentia. Tanta autem erat eius conpunctio ut cum multi eum rogarent paululum requiescere ne forsitan 20 noxium aliquid pateretur per incessantem fletum, ille nolebat dicens: $\mathrm{Si}$ matris meae inproperium non portaui quemadmodum praesente Christo et angelis eius in diem iudicii aut inproperia aut poenam portabo?

4-Quaedam fuit meretrix nomine Taisis tantae pulcritudinis ut paene multi propter eam, uenditis substantiis suis, ad ultimam peruenirent paupertatem, sed et litibus amatorum inter se consertis, fre-

8 uidisset] iudicasset $\mathrm{P}$ obstipuit] obstupuit VP stupuit S est hoc] h. e. E hoc om. P et tu om. L 9 loco] saeculo ductus P deductus add. ELS condemnatus om. L illa uerba PEL dicere] quoniam add. PEL quia add. S 10-11 audierat nihil habebat quid] a. $\mathrm{n}$. habens quid (quod P) PS audiebat stabat $\mathrm{n}$. habens quod EL 11 et om. P ecce] subito add. P uoce facta] f. u. P uox f. V uox f. est L u. altera f. $\mathrm{S}$ ut] cum $\mathrm{S} \quad 12$ tamquam altero iussu] t. (in add. V) a. iusso MV frater transiret] fratre (-em E) transire MVPES haec] ex P 13 nuntiabat] referebat PELS confirmatione ML 14 suorum om. V aliquis de] a. (-i ES -id L) ex PELS 14-15 ad coenobium iret] i. ad c. E ad c. irent S 15 et uideret om. P transiret frater eiusdem] transit f. e. (eius P) PE nomine MV 16 et $\mathrm{om} . \mathrm{P} \quad$ est $\mathrm{om} . \mathrm{P} \quad 17$ et sedit $\mathrm{om} . \mathrm{S}$ et lacrimans] et cogitans de salute sua perlacrimans $\mathrm{S} \quad 18$ his] ipsud $\mathrm{E}$ in neglegentia tanta] in (om. L) -am t. (-i M) MVL 18-19 erat eius conpunctio] e. erat c. (compassio E) EL 19 rogarent paululum requiscere] $r$. (ut add. PE) p. -eret (requisce V) VPES forsitan] forsan V forte E 20 incessante fletu M 21 inproperium] imperium $\mathrm{S}$ praesente] Domino Iesu add. L 22 die S aut $^{1} \mathrm{om}$. PE inproperia] inpropria $\mathrm{M}$ in opprobria $\mathrm{V}$ poenam correxi: poena MV tormenta PELS

4-MVPES om. L 1 tantae] cui tantae inerat P 2 uenerunt E 3 amatorum inter se consertis] i. se c. amatores sui (amatoribus suis P) PE a. in se confertis $\mathrm{S}$ 
quenter sanguine iuuenum puellae limina replebantur. Quae cum abbas Paphnutius conperisset, sumpto habitu saeculari et uno solido, profectus est ad eam in quadam Aegypti ciuitate, deditque ei solidum quasi pro mercede peccati. At illa accepto pretio: Ingrediamur, inquit, domum. Cumque illum ingressum ut lectum pretiosis stratum uestibus conscenderet inuitaret, dicit ad eam: $\mathrm{Si}$ est interius cubiculum in ipso eamus. Illa autem dixit: Est quidem, sed si homines uereris nec in hoc exteriori cubiculo ullus ingreditur, si uero Deum times non est locus quod diuinitatis eius oculis abscondatur. Quod cum audisset senex, dicit ei: Et scis esse Deum? Cum autem illa respondisset et Deum se scire et regnum futuri saeculi necnon et tormenta peccatorum, dicit ei: Si ergo haec nosti, cur tantas animas perdidisti ut non solum pro tua sed et pro illorum reddita damnatione damneris? Quod cum Taisis audisset, prouoluta ad pedes senis, cum lacrimis exorabat dicens: Scio esse poenitentiam, pater, et confido remissionem te orante sortiri. Tantum peto tribus horis indutias et post hoc quocumque iusseris ueniam et quodcumque praeceperis faciam. Cumque locum illi abbas constituisset quo uenire deberet, illa discedens, collectis omnibus quaecumque ex peccato susceperat, perlatisque in medio ciuitatis, ignem populo expectante adposuit clamans: Venite omnes qui peccastis mecum et uidete quomodo ea quae mihi contulistis exuram. Erat autem

4 sanguinem ES $\quad 4-5$ limina replebantur quae cum abbas] limine r. (quandam E) Ae. c. (c. Ae. S Ae. -em MPE) d. (-it V) MVPES 7 pretio] dixit add. $\mathrm{P}$ inquit] in add. PES om. $\mathrm{P} \quad 8$ cumque illum ingressum] quae cum illa ingressa P ut] ad PE stratum om. V 9 conscendere PE interius om. $\mathrm{V}$ in] ad $\mathrm{P}$ ipso] - am V -um $\mathrm{P} \quad 10$ quidem] quodam $\mathrm{S}$ homines] omnes $\mathrm{M}$ omnes add. $\mathrm{V}$ nec om. $\mathrm{S} 11$ cubilo $\mathrm{P}$ ullus ingreditur si uero Deum times] nullus i. si u. (autem P) D. (Dominum P) PES 12 quodi1 $^{1}$ qui VS oculi $M$ abscondatur] -antur M -amur PE 13 dixit ES ei] ad eam $P$ et ${ }^{1}$ om. P Deum om. S cum autem illa respondisset om. V 13-14 et Deum se scire] se D. nosse E 15 ei] ad eam $P \quad$ hoc $V \quad 16$ sed et pro illorum] et $\mathrm{om}$. E om. S reddita damnatione damneris] r. ratione damneris (damnaberis S) ES damnatione eris punienda $P \quad 17$ prouoluta ad pedes senis om. $E$ 18 pater om. $\mathrm{P}$ orantem $\mathrm{E} \quad 19$ indutias] indutus $\mathrm{M}$ induceris $\mathrm{V}$ haec S 20 uenio $P$ quaecumque $P$ locum illi abbas] a. 1. i. V illi $o m$. S 21 deberet illa discedens] d. (debeat S) i. descendens PES 22 perlatisque] prolatisque $\mathrm{S}$ paratisque $\mathrm{V}$ medio ciuitatis] mediam ciuitatem PE media ciuitate $\mathrm{S} \quad 23$ expectantes $\mathrm{M}$ subposuit PES 
25 pretium rerum librarum auri quadringentarum. Quae cum omnia conbussisset, in loco quo abbas ei constituerat perrexit. Quam ille repperto uirginum monasterio in cellula illic parua concludens, ostium cellae plumbo signauit, paruamque reliquit fenestram per quam illi uictus modicus inferretur. Iussitque ei diebus omnibus parum panis

30 et paululum aquae a ceteris ministrari. Cum autem, ostio plumbato, discederet, ait ad illum Taisis: Quo iubes, pater, ut aquam meam effundam? At ille respondit: In cella, sicut es digna. Cumque iterum quemadmodum deberet orare requireret, dixit ei: Non es digna nominare Deum neque in labiis tuis nomen diuinitatis eius adducere, sed nec ad cae-

35 lum manus expandere quoniam et labia tua iniquitate plena sunt et manus tuae sordibus inquinatae. Sed tantummodo sedens contra Orientem aspice, hunc sermonem solum frequenter iterans: Qui plasmasti me, miserere mei. Cum ergo tribus annis ita fuisset inclusa, condoluit abbas Paphnutius et mox profectus est ad abbatem Antonium ut ab

40 eo requireret si remisisset illi Deus, si non. Cum ergo peruenisset et totam illi causam subtiliter narrasset, conuocatis discipulis suis, abbas Antonius praecepit ut illa nocte omnes uigilarent et in oratione persisterent singillatim, quatenus uni alicui ex his declararet Deus causam pro qua abbas Paphnutius ueniret. Cum ergo ita singuli secessissent

45 atque incessanter orarent, abbas Paulus Maior, discipulus beati Antonii, uidit subito in caelo lectum uestibus pretiosis adornatum, quem tres

25 pretium om. S rerum om. PE librarum] autem add. V quadringentorum VE 26 conbussisset] conbursisset $V$ consurnasset $E$ consumpsisset $P$ quo abbas ei constituerat] q. (quem E) a. c. ei PE ei om. S 27 repperto uirginum monasterio] r. m. u. P u. m. r. S illuc $\mathrm{E}$ concludens] conclusit $\mathrm{P}$ claudens $E \quad 28$ fenestram] fenestrelam $P$ fenestellam $E$ illi] ei PE 29 modicum E diebus omnibus] o. diebus (-erum E) PE parum] paris E 30 aquae $\mathrm{om} . \mathrm{S} \quad$ ministrare PE 31 Taisis] transire $\mathrm{S} \quad 32$ at ille $\mathrm{om}$. P digna es PES 33 quemadmodum deberet orare requireret] q. Deum d. o. (rogare S) r. (om. PS) PES 34 nec P adducere] dicere P nec] neque $\mathrm{S}$ ad] in $\mathrm{P} \quad 35$ expandere] expandas $\mathrm{P}$ extendere $\mathrm{E}$ quoniam] quia $\mathrm{S}$ et ${ }^{1} \mathrm{om} . \mathrm{S}$ sunt plena PE manibus $\mathrm{V} 36$ inquinatae] iniquitate $\mathrm{S}$ sedens] sta P 37 aspice] et add. P itera P 39 est om. E 40 requireretur V $\mathrm{si}^{2}$ ] aut $\mathrm{E} \quad 40-41$ peruenisset et totam illi] -ent et $\mathrm{t}$. i. E uenisset et $\mathrm{t}$. illam $\mathrm{S}$ et om. V 41 causam] clausam M subtili V enarrasset PE abba E 42 nocte illa ut $\mathrm{E}$ orationem $\mathrm{S} \quad 43$ singillatim] singulatim $\mathrm{M}$ quatenus] qualiter $\mathrm{P} \quad$ uni alicui ex his] unicuique ex his (ex h. om. P) PE u. ex h. a. S declarasset $P \quad 44$ ueniret] -isset $S$ uenerat $P E$ ita singuli] s. i V i. se s. E 45 atque] et PE 46 caelum $S$ uestibus pretiosis] p. u. PE pretiosis om. V que $\mathrm{M}$ 
uirgines clara facie custodiebant. Cum ipse diceret: «Non est alterius haec gratia nisi patris mei Antonii», uox ad eum facta est: Non est tui patris Antonii, sed Taisis meretricis est. Quod cum mane facto abbas Paulus retulisset, cognita Dei uoluntate, abbas Paphnutius discessit. Et profectus ad monasterium in quo fuerat reclusa, ostium quod obstruxerat dissipauit. Illa uero petebat ut adhuc ita permaneret inclusa. Cum uero aperuisset eius ostium dixit ei: Egredere, quoniam remisit tibi Deus peccata tua. Illa respondit: Testor Deum quia ex quo hic ingressa sum, ex omnibus peccatis meis quae feci uelut sarcinam et statui ante oculos meos et sicut non discedit anhelitus ex naribus meis una hora, sic non discesserunt peccata mea ab oculis meis, sed flebam semper illa conspiciens. Cui abbas Paphnutius respondit: Non propter poenitentiam tuam remisit tibi Deus, sed quia hanc cogitationem habuisti semper in animo. Et cum eam inde eduxisset, quindecim dies superuixit tantum et pausauit in pace.

\section{LVIII - DE ORATIONE}

1 - Cum quidam frater quemadmodum oraret beatum Macarium requisisset, respondit illi: Non sunt necessaria uerba superflua, sed extendere manus ac dicere: Deus, quomodo uis; Domine, sicut tibi placet. Si autem pugna in te uenerit, dicendum est: Deus, auxiliare.

47 cumque PES est om. ES $47-48$ alterius haec gratia] h. g. a. E g. a. P 48 patri $\mathrm{E}$ facta est om. $\mathrm{P} \quad$ est $^{2}$ ] om. $\mathrm{V}$ inquit add. $\mathrm{P} \quad 49$ patris tui $\mathrm{S}$ mane] magne $\mathrm{S} \quad 50$ cognitam $\mathrm{M}$ uoluntate] -em $\mathrm{E}$ reuelatione $\mathrm{P}$ 51 inclusa PE 52 dissipabat $\mathrm{S}$ ita om. S 53 uero aperuisset] ergo aperuit $\mathrm{S}$ eius] om. PE ei ostium dixit $\mathrm{E} \quad 54$ quoniam] quia $\mathrm{S}$ dimisit $\mathrm{P}$ tibi om. V Deum] Deus V 55 quia om. E quae om. ES 56 sarcina $\mathrm{E} \quad \mathrm{et}^{1} \mathrm{om} . \mathrm{P}$ discedat $\mathrm{V} \quad$ ex] a $\mathrm{S}$ de PE 57 discedunt $\mathrm{S}$ 58 semper illa] super illam E 59 propter poenitentiam tuam remisit tibi Deus] r.t. D. propter p.tuam S tuam om. MV 60 in animo semper S 61 eduxisset] extraxisset $\mathrm{S}$ et $\mathrm{om} . \mathrm{S}$

\section{LVIII - MVPELS}

1-MVPLS om. E 1 frater quemadmodum oraret] patres q. -ent PLS 2 requisisset respondit illi] -ent (perquisissent P) r. illis PLS superflua om. MV 3 Deus quomodo uis] q. u. D. P $\quad$ D. q. tu u. L 3-4 sicut tibi placet] sic t. placeat $P \quad 4$ in te uenerit] interuenerit PLS Deus auxiliare] a. D. S

D. indulge, D. respice, D. succurre add. L 
5 Ipse enim nouit quae nobis expediant et faciat nobiscum misericordiam suam.

2-Idem dixit: Saepe petitionem nostram Deus utiliter differt, aliquotiens alia ex aliis praestans; et his quae praestat prouocat petentem ut persistat.

3-Abbas Ioannes dicebat: Similis debet esse monachus homini sedenti sub arbore grande qui respiciens feras diuersas et serpentes uenientes ad se, cum non potuerit eis resistere, subit in arbore et saluatur. Ita et monachus sedeat in cella sua et respiciens prauas cogitationes

5 inimici uenientes super se, cum non potuerit eis resistere, confugiat per orationem ad Deum et saluatur.

4 - Idem dixit: Similis debet esse monachus homini habenti a sinistra parte ignem et ad dexteram aquam. Quotiens enim succensus fuerit ignis, tollet de aqua et extinguet illum. Sic oportet et monachum facere omni hora, ut quando cogitatio succensa fuerit ab inimico, tunc 5 aquam orationis fundat et extinguat illam.

LVIII, 1 lin. 5: Ipse $\ldots$ expediant - cf. Luc. XII, 30; Mat. VI, 28.

lin. 5-6: faciat... suam. Expressio facere nobis misericordiam saepius occurrit in Vulgata, ex. g. Tob: VIII, 18; XII, 6; XIII, 8.

5 quae nobis expediant et faciat] q. (quod L) n. e. (-unt PL) et -it (-iet P) PLS 2-MVPLS om. E 1 idem] item PL differret P 2 qui MVL petentem] poenitentiam MV

3-MVPELS 1 abba S 1-2 debet esse monachus homini sedenti] e. d. m. h. (homo L) sedente EL 2 grandi $P \quad 3$ subit in arbore et saluatur] subiit in a. (-em E) et (ut E) s. (-etur E) ELS 4 respiciat $P$ fugat $\mathrm{E} 6$ per orationem ad Deum] super o. ad D. MV ad D. per o. E saluabitur $\mathrm{E}$

4-MVPels 1 idem] item PL 2 dextera M 2-3 quotiens... aqua $\mathrm{om} . \mathrm{V} 2 \mathrm{enim}$ si $\mathrm{P}$ succensus] $-\mathrm{um} \mathrm{M}$ incensus $\mathrm{L} \quad 3$ ignis] -em M -e P tollat E extinguat E illum] illud EL om. P et ${ }^{2}$ $\mathrm{om}$. $\mathrm{S} 4$ cogitatione $\mathrm{P}$ succensus $\mathrm{P}$ fuerit] uenerit $\mathrm{E} \quad 5$ aquam om. $\mathrm{P}$ orationis] -es $\mathrm{P}$ ab oratione $\mathrm{E}$ fundat] ef- (Deum add. L) PELS extinguat illam] -gat (-guit P) illum VP 


\section{LIX - ORATIO PRAEFERENDA OPERI}

1-Abbas Agathon cum tempus uenisset psallendi dimittebat operam suam, etiamsi parum esset inperfecta. Nec enim propter operam manuum ordinem religionis patiebatur infrangi.

\section{LX - AB OPERE AD ORATIONEM TAMQVAM AD REQVIEM VENIENDVM}

1 - Abbas Ammon uenit ad abbatem Achilam et inuenit eo quod per noctem grandem funiculum operatus esset et requisiuit eum: Pater, dic nobis sermonem aliquem. At ille hoc tantum respondit: Ego a uespere usque modo uiginti ulnas funiculi operatus sum et in veritate non indigeo, sed propterea laboro ex omni uirtute mea, ut ad orationem tamquam ad requiem ueniam. Et ita iuuatus ille discessit.

\section{LXI - EX EO QVOD EX OMNIBVS VIRTVTIBVS ORATIO MAIOREM LABOREM HABEAT}

1-Abbas Agathon cum requireretur quae esset maior uirtus in uita hominis maiorem laborem habens, respondit: Ego ita suspicor

\footnotetext{
LIX - MVPELS oratio] de oratione $\mathrm{S}$ praeferenda] proferenda ME perenda $\mathrm{L}$

1-MVPELS 1 abba $S$ cum] dum $P$ psallendi uenisset $S$ 2 esset inperfecta] e. et (om. M) -am MV neque $\mathrm{S} \quad 3$ operam manuum] opera $\mathrm{m}$. suarum PELS ordine MV religionis] Dei add. $\mathrm{L}$ infringi PELS

LX - MVPLS om. E ab opere ad orationem tamquam ad requiem] ab o. t. ad r. ad orationem $\mathrm{P}$ de o. et oratione t. ad r. L ueniendum] ueniendo $P$ uenire $L$ est $u$. $S$

1-MVPLS om. E 1 abbas Ammon] abba Erimon S Achilam] ancyllam $\mathrm{V}$ eo quod] eum qualiter $\mathrm{S} 2$ noctem grandem] $\mathrm{n}$. (-e M) grande MV esset] fuisset PLS 3 hoc tantum om. V ego a om. S 4 admodo L 5 omni] uoluntate uel add. S 5-6 ut ad... ueniam om. S 6 et om. V ita om. L ille] illa V uirtutibus add. P

LXI - MVPELS ex ${ }^{1}$ om. PELS laborem] uirtutem E habet $\mathrm{L}$ 1-MVPELS 1 abba $\mathrm{S}$ requireretur] -ret $\mathrm{S}$ ab eo add. $\mathrm{P}$ 2 hominis] aut quale opus add. $\mathrm{P}$ maiorem laborem habens om. $\mathrm{L}$
} 
quia non sit maior labor quam Deum orare. Quia quotienscumque homo uoluerit orare festinant inimici inpedire eum, scientes quia non

5 aliunde sic confunduntur quomodo per orationem. Quamcumque autem uitam elegerit homo et in ea permanserit requiem possidebit. Orare autem usque ad ultimam uitam inpedire nituntur daemones et ideo resistere illis labor est fortis.

Resistentibus enim daemonibus et prohibentibus orare, contra

10 stantibus autem hominibus et certantibus in oratione peruenire, in utrisque non parua pugna consistit. Contendite ergo, filioli, in orationibus uestris fugare contrarios et malignos daemones.

\section{LXII - VBIQVE ORATIO PRAEMITTENDA PROPTER INSIDIAS ET SECVNDO ET TERTIO}

1 - Abbas Zenon dum esset in Sceti egressus est nocte de cella sua et errauit et tres dies noctesque ambulans cecidit fatigatus usque ad mortem. Et ecce stetit ante eum infans habens panem et uas aquae et dicit ei: Exurge et comede. At ille surrexit et orauit, sperans esse 5 phantasma. Cui infans: Bene fecisti quod orasti. Modo ergo surge et comede. Cui abbas Zenon non adquieuit nisi secundo et tertio orasset. Et cum ille conlaudaret, iam tunc surrexit et comedit. Post

\footnotetext{
3 labor] uirtus $\mathrm{P} \quad 3-4$ quia... orare $\mathrm{om}$. LS quotienscumque] quocumque $\mathrm{V}$ quotiens cum $\mathrm{E} \quad 4$ uoluerit homo $\mathrm{P}$ scientes] eum add. $\mathrm{S}$ non] numquam $\mathrm{P} \quad 5$ confunduntur] -antur $\mathrm{L}$-itur ES daemones add. $\mathrm{P}$ quamcumque] quacumque $\mathrm{M}$ quia cumque $\mathrm{L} \quad 6$ uita $\mathrm{ML}$ homo] in Deo add. P et] si PE 7 nituntur] conantur S 9 enim om. P daemoniis $\mathrm{L}$ orare] e add. $\mathrm{P}$ 9-10 contra stantibus autem hominibus et] contristantibus (c. astantibus V) a. h. (omnibus EL) et (om. E) VELS 10 in oratione peruenire] perueniens in $\mathrm{o} . \mathrm{P}$ in $\mathrm{o}$. prae- $\mathrm{E} \quad 11$ parua] praba $\mathrm{L}$ pugna om. MV 12 fugare] $-\mathrm{i} \mathrm{E}$ fugere $\mathrm{S}$ contrariis $\mathrm{L}$ et] uarios add. dub. S malignos] spiritus add. $\mathrm{P}$
LXII - MVPELS ubicumque E insidias et secundo] i. diaboli (om. P) et (om. S) bis PS
1 -MVPELS I abba S est] de add. V om. S 2 et errauit] orauit $\mathrm{S}$ et tres dies noctesque ambulans cecidit] tribus diebus et tribus noctibus perambulans ceciditque $\mathrm{P} \quad 4$ ei om. E surge LS at ille om. S 5 phantasma] nia dub. S quod] quia VS ergo om. S exurge E 6 abba L $\quad 7$ oraret E in uerbo orasset explicit mutilus textus Paschasii in codice $\mathrm{M}$ cum] Deo add. $\mathrm{L}$ 
hoc dicit ei infans: Quantum ambulasti, tantum longe es a cella tua; sed surge et sequere me. Et mox inuentus est ante cellam suam. Dicit ergo ei senex: Ingredere in cella mea et fac nobiscum orationem. Et ingresso sene in cella ille non conparuit.

\section{LXIII - DE IVGITATE ORANDI}

1-Quidam frater requisiuit senem ut ei sermonem diceret per quem possit Christum adipisci. Cui senex: Labor et humilitas et oratio sine cessatione possident Christum. Omnes enim sancti a principio usque ad finem per haec tria saluati sunt. Nam requies et uoluptates et iustificatio propria inpedimenta sunt animae. Omnes enim paene per ea pereunt.

2-Quidam abbas qui habebat monasterium in Palestina mandauit beato Macario episcopo Cypri: Quia orationibus tuis non negleximus regulam, sed tertiam et sextam et nonam facimus. Ille autem reprehendit eos mandans: Manifesti estis eo quod neglegitis et uacatis $\mathrm{ab}$ oratione aliis horis. Verus enim monachus sine cessatione aut orationem aut decantationem psalmorum semper habet in corde.

8 haec $\mathrm{S} \quad$ ei $\mathrm{om} . \mathrm{P} \quad 9$ sed $\mathrm{om} . \mathrm{V}$ ante] in S 10 ergo ei] e. illi $\mathrm{L}$ ei e. $\mathrm{S}$ ergo om. $\mathrm{P}$ ingredere in cella mea et fac] i. (mecum add. S) in -am meam et $\mathrm{f}$. (dic $\mathrm{S}$ ) PES nobiscum] mecum $\mathrm{S}$ nobis $\mathrm{E} \quad 11$ ingressus senex $\mathrm{E}$ in cella] in cellam suam (om. P) PS et add. V om. L ille] uero add. $\mathrm{P}$ infans add. $\mathrm{L}$ om. $\mathrm{E}$

LXIII - VPELS Quia M a medio apophthegmatis praecedentis mutilus est non amplius de eo loquemur.

1 -VPELS 1 senem] a sene (dicens add. E) PELS 2 possit Christum] Ch. p. S -et Ch. P cui senex om. L 3 possident] -et E enim add. S omnes] homines $\mathrm{V}$ enim om. S 4 principio] et add. $\mathrm{P}$ ad] in $\mathrm{L}$ 5 uoluptates] uoluntas E uoluntates L animae om. ES 6 ea] haec L eam $\mathrm{E}$ perierunt $\mathrm{P}$

2 -VPELS 1 qui habebat] habens PS qui eras. E 2 quia orationibus tuis] o, t. pater (om. S) PS negleximus] negligimus $\mathrm{P}$ neglegimus $\mathrm{L}$ 3 sed] secundum $\mathrm{S} \quad \mathrm{et}^{1} \mathrm{om}$. PS 4 eo quod] q. non L neglegitis] -istis EL neglexistis S 4-5 et uacatis ab oratione] et (non add. S) uacastis (uagastis P) ab (om. S) o. (-i S aut decantatione add. P) PES 5 monachus] est qui add. L 6 oratione $\mathrm{V}$ decantationem]-e V decantatio $\mathrm{L}$ habetur $\mathrm{V}$ 


\section{LXIV - QVOD IVGITAS ORANDI PROPOSITVM DIABOLI INPEDIAT}

1-Temporibus Iuliani imperatoris, quando ad Persidam est profectus, unum ex spiritibus inmundis transmisit Iulianus in Occidentem ut ei responsum quoddam inde refferret. Cum autem ipse diabolus quem Iulianus miserat uenisset in locum in quo monachus

5 nomine Publius maneret, perstitit ibi per decem dies inmobilis non ualens progredi ulterius eo quod monachus non cessabat ab oratione nec die nec nocte. Et reuersus ad Iulianum sine effectu, cum requisitus $\mathrm{ab}$ eo fuisset cur tardasset, respondit: Ego et tardaui et sine effectu ueni; decem enim diebus permansi obseruans Publium monachum si

10 forte cessasset ab oratione ut ego transirem, sed ille non requieuit et ego inpeditus reuersus sum sine effectu. Tunc inpius Iulianus iratus dixit: Quia reuertens faciam uindictam. Et intra paucos dies occisus est. Vnde ex his unus qui cum eo fuerant profecti, conpunctus omnia sua erogauit pauperibus et uenit ad senem illum a quo factus est mona-

15 chus, uenerabili fine discessit.

LXIV, 1 lin. 13-14: omnia $\ldots$ pauperibus - cf. Mat. XIX, 21; Marc. X, 21; Luc. XVIII, 22.

\footnotetext{
LXIV - VPELS iugitas eras. E

1 - VPELS 1 ad Persidam] in P. (-diam S) PS 2 inmundis] malignis PELS Iulianus in Occidentem] in Occidente E 3 ei] eis E om. S responsum quoddam inde referret] r. q. (quidam E condam L) i. referret EL i. r. ferret $\mathrm{S} 4$ Iulianus $o m$. PELS loco PELS 5 maneret perstitit ibi per] manebat p. (persistit E peresistit L praestitit S) ibi (-dem L) per (om. PEL) PELS 6 ulterius] anterius VELS cessaret $P \quad 7$ die nec nocte] d. (-em E) nec (neque S) n. (-em E) ES reuersus] est add. E effectu cum] affectu cum (-que L) VEL 7-8 requisitus ab eo] requireretur ab eo ubi $P$ 8 affectu VEL 9 enim om. PE dies P Publicum L 9-10 si forte cessasset] quotiens (ne ES ut L) f. cessaret PELS 10 ut] et $P$ pertransirem E requieuit] quieuit (orans add. L) PELS 10-11 et ego] tunc ergo $P$ 11 affectu VEL 12 reuertens faciam uindictam et] r. $f$. in illum u. $P$ si reuersus fuero $\mathrm{u}$. huic monacho restituens dabo sed Domino ordinante $\mathrm{L}$ paucos] autem add. P 13 ex his unus] unus princeps ex his L unus om. PES fuerant profecti conpunctus] f. (erant L) p. (praefecti E) c. unus (om. L) PEL 14 quo] enim add. L est om. PES 15 uenerabili fine discessit] -e fide usque in finem d. ad Deum L u. f. d. (decessit E) (in pace add. P) PE
} 
2-Abbas Daniel de beato referebat Arsenio eo quod sabbatorum die uespere, solem relucentem post dorsum suum dimittebat in oratione persistens, extendensque manus ad caelum non desistebat orare nisi altero die sol iterum oculos eius surgens implesset.

Ceteris autem noctibus peruigilans, prope diluculum cum uellet parum pro naturae fragilitate quiescere, dicebat somno: Male serue, ueni. Moxque sedens et parum claudens oculos exurgebat.

\section{LXV - QVIA ET MANDVCANDO POTEST ORARE}

1 - Dum fratres in ecclesia facta caritate comederent et loquerentur inter se, iratus abbas Esaias presbyter de eodem loco Pelusio dixit illis: Tacete, fratres. Scio enim unum fratrem comedentem nobiscum et bibentem calices quantos et nos et tamen oratio eius ascendebat in caelum ante conspectum Dei sicut ignis.

2-Aliquando cum fratres in caritate comederent, unus risit in mensam. Quod cum uidisset abbas Ioannes plorauit dicens: Quid putas habet frater ille in corde suo qui risit cum magis debuit orare et plangere tamquam agapem comedens?

2-VPES om. L 1 abba PS referebat Arsenio] A. dicebat P eo om. V 2 solem relucentem] s. lucentem $\mathrm{P}$ sole lucente p. corr. E sole reluscente $\mathrm{S} \quad 2-3$ orationem $\mathrm{S} \quad 5$ nocte $\mathrm{P}$ diluculo $\mathrm{P} \quad 7$ moxque sedens et parum claudens oculos exurgebat] mox s. (quiescens P) et p. c. (ut p. claudas S) o. e. (-ens S) PS

homo add. S
LXV - VPELS
et] in $V$
om. S
manducandum L
potest]

1 - VPELS 1 dum] cum quidam (om. S) PS in ecclesia fratres L 1-2 loquerentur inter se iratus] col- i. se beatus $S \quad 2$ abbas $\mathrm{om}$. E Pelusio] Peludio V 3 illis om. P scio enim unum fratrem om. V enim] ego add. $\mathrm{PE} \quad$ unum] ego quidem add. $\mathrm{S}$ comedentem] manducantem L 4 quantos et nos] q. (-is E) nos PE ascendet $\mathrm{E} \quad 5$ in] ad $\mathrm{S}$ conspectu PL sicut] fuit $\mathrm{S}$

2-VPELS $\quad 1 \mathrm{in}^{2}$ ] ad P 2 uidisset] audisset $P \quad 3$ ille frater $\mathrm{S}$ qui] quia $\mathrm{P}$ debuerat $\mathrm{L} \quad 4$ tamquam] quam $\mathrm{L}$ agapem] aquam et panem $\mathrm{S}$ comedere $\mathrm{L}$ 


\section{LXVI - QVOMODO SINE CESSATIONE ORETVR}

1-Quidam fratres cum ad abbatem nomine Lucium uenissent, requisiuit eos senex dicens: Quod soletis manibus uestris operari? At illi dixerunt: Nos nihil manibus operamur, sed secundum quod dicit Apostolus sine cessatione oramus. Quibus senex: Non manducatis?

5 At illi professi sunt. Et dicit eis: Quando ergo comeditis, quis pro uobis orat? Et iterum requisiuit eos dicens: Numquid non dormitis? Cumque illi se dormire dixissent, dixit eis: Quando ergo dormitis quis orat pro uobis? Et non inuenerunt quid responderent ei. Tunc dicit eis: Indulgete mihi quoniam non facitis sicut dicitis. Ego autem

10 dicam uobis quemadmodum manibus meis operans sine cessatione oro. Sedeo de mane et pauca palmarum folia infundo et facio inde funiculum dicens: Miserere mei, Deus, secundum magnam misericordiam tuam et secundum multitudinem miserationum tuarum dele iniquitates meas. Et numquid non est istud oratio? Cumque illi annuerunt,

15 dixit: Quando per omnem diem operatus fuero orans, plus minusue facio nummos sedecim. Et ex ipsis duos nummos do ad ostium et reliquum comedo. Quando autem comedo aut dormio tunc ille pro me orat et ita sine cessatione adimpleo orationem meam.

LXVI, 1 lin. $\quad 4:$ sine $\ldots$ oramus - cf. I Thes. V, 17.

lin. 12-14: Miserere... meas - cf. Ps. L, 3 .

\footnotetext{
LXVI - VPLS numerum et titulum capituli om. E

1-VPELS 1 cum ad abbatem nomine Lucium] dum ab abbate Lucio $\mathrm{V}$ ad a. $\mathrm{n}$. Lucidum $\mathrm{L}$ uenissent] ad- PS -erunt et $\mathrm{L}$ 2 quid PLS operare E 3 operamus E $3-4$ sed secundum... oramus om. E 3 secundum] sicut PS quod $\mathrm{om}$. PS 5 at] et $\mathrm{S}$ eis] illis $\mathrm{S} \quad 6$ iterum $\mathrm{om} . \mathrm{S}$ dicens om. PELS 7 illis L dixit] dicit PELS 8 ei responderent $\mathrm{P} \quad 8-9$ tunc dicit eis om. LS indulgete] i. (-ite ELS) ergo PELS quoniam] quia PS 10 dico $\mathrm{E}$ quemadmodum] sum add. S manibus meis om. S operans] et add. S 11 sedeo de mane et pauca] s. (sed eo VL) enim (om. V) $\mathrm{m}$. (usque ad uesperum add. E) et p. (quidem $a d d$. L) VPELS infundo] findo $\mathrm{P}$ infido $p$. corr. $\mathrm{L}$ facio] ex add. ELS 12-13 pro magnam misericordiam tuam habet etc. S 13-14 pro dele iniquitates meas habet etc. S 14 meas om. L et om. E istud] ita P illi om. S annuerent ELS 15 diem] dicit $\mathrm{V}$ minusue] minus $\mathrm{ES}$ manus $\mathrm{P}$ minus quod $\mathrm{L} \quad 16$ ipsos $\mathrm{L}$ duos nummos] nummis d. $\mathrm{P} \quad$ ostium] petenti add. PELS et ${ }^{2} \mathrm{om}$. E $17 \mathrm{reli}^{-}$ quos PS autem] ergo (aut add. EL) PELS 17-18 ille pro me orat] illi pro me orant $\mathrm{P} \quad 18$ sine $\mathrm{om}$. L
} 


\section{LXVII - CONSTRINGENDA VAGATIO OCVLORVM NE ABSTRAHATVR SENSVS AB ORATIONE}

1-Abbas Siluanus dum sederet in montem Sina, discipulus eius Zacharias ad quoddam ministerium proficiscens dicit ei: Abba, dimitte aquam in horto ut adaquetur quia ego ad responsum uado. Ille autem cooperuit faciem suam dum adaquaret et nihil aliud praeter uestigia sua uidebat. Contigit autem quendam fratrem conspicere eum eadem hora de longe et postquam reuersus in cella, uenit ad eum et coepit ab eo postulare dicens: Dic mihi, abba, quare faciem tuam cooperuisti et ita adaquabas hortum? Respondit senex: Fili, ne uiderent oculi mei arbores et sensus meus alienaretur ab opere quo erat intentus.

\section{LXVIII - DE FIDVCIA PERFECTORVM IN ORATIONE}

1 - Abbas Macarius dum semel de Sceti portans sportellas quas texuerat graderetur uiae labore defessus, resedit et dixit: Deus, tu scis quia amplius non ualeo ambulare. Et mox inuentus est ad fluuium unde adhuc multis habebat interuallis.

2-Abbas Sisoius cum quodam tempore discipulus eius Abraham tentatus fuisset ab spiritu, manus extendit ad caelum dicens: Deus,

\footnotetext{
LXVII - VPELS de constringenda E uagatio] uagatione PE om. L abstrahantur $\mathrm{E}$ ab oratione $\mathrm{om}$. $\mathrm{L}$

1 -VPELS 1 abba S monte PS Sina] Sinay E 2 quoddam] condam E ministerium] monasterium VPES dicit ei] dixit abbati $P$ om. S abba om. PS 3 responsum uado ille autem] responsionem u. i. uero E 4 et dum adaquaret (adaquaretur PS) PELS aliud $\mathrm{om}$. E praeter] propter $\mathrm{S} 5$ uidebat] -atur $\mathrm{V}$ uideret $\mathrm{E}$ 5-6 conspicere eum eadem hora] eadem h. c. e. PEL eadem h. om. S 6 postquam] est add. PS reuersus in cella] regressus in c. (-am PS) PELS 7 tuam om. E $7-8$ cooperuisti et ita adaquabas] c. (operuisti S) ut ita -ares PS 8 respondit senex om. S fili $\mathrm{om}$. E 9 meus] meos L opere quo erat] o. (-ibus P) orationis (om. P) q. (quibus P) e. (-am PL) PELS

LXVIII - VPELS perfecta V in oratione om. E 1-VPELS 1 abba PS 2 texerat E uia PLS 3 ad] ante L 4 habuerat $\mathrm{S}$ interuallis] -ibus $\mathrm{V}$ inter ualens $\mathrm{S}$

2-VPELS 1 abbas Sisoius] abba Sisonius $\mathrm{S}$ eius] abba add. E 2 ab] a $\mathrm{V}$ tetendit PELS dicens om. V Deus] Domine $\mathrm{E}$
} 
uis, non uis, non desistam nisi eum sanaueris. Et confestim spiritu discedente sanatus est.

3 - Abbas Ammon ueniens in deserto ad lacum, uolens haurire aquam, uidit basiliscum et iactans se in faciem dixit: Domine, aut ego moriturus sum aut iste. Et mox basiliscus per uirtutem Dei dissipatus est.

4-Discipulus abbatis Besarionis nomine Dulas referebat eo quod dum pariter ambularemus per uiam iuxta litus maris contigit me sitire. Et dixi seni: Sitis me macerat. Qui facta oratione iussit me de mari aquam tollere et bibere. Quam cum bibissem et dulcissimam

5 reperissem, uasellum quod mecum fortasse portabam impleui. Quod ut uidit senex ait ad me: Quare implesti? At ego: Indulge mihi, abba, timeo ne forte etiam in ante sitiam. At senex respondit: Indulgeat tibi Deus, quia hic et ubique Deus est et potest tibi dulcem aquam praestare.

3 uis $\left.{ }^{1}\right]$ uis aut add. P om. S non desistam om. V 3-4 spiritus discedens $P$

3-VPLS om. E 1 Ammon] Annusio $S$ in deserto] in desertum $\mathrm{L} \quad \mathrm{om} . \mathrm{S}$ uolens] uolensque $\mathrm{S}$ om. $\mathrm{P} \quad 2$ basilicum $\mathrm{S}$ faciem] suam add. S Domine] Deus $\mathrm{L}$ aut ego] ante hic $\mathrm{P} \quad 3$ basilicus $\mathrm{S}$ Dei $\mathrm{om}$. V

4-VPELS 1 discipulus abbatis Besarionis] d. abbati B. V a. B. d. S nomine $\mathrm{om} . \mathrm{V}$ Dulas $(\Delta o v \lambda \tilde{a} \varsigma)$ : Dulus VPELS 2 dum om. $\mathrm{S} 3$ sitiri $\mathrm{P}$ qui] cum $\mathrm{P}$ quid $\mathrm{E}$ quod $\mathrm{S} 4$ aquam de mari $\mathrm{P}$ et bibere om. $\mathrm{S}$ cum] tulissem et add. S 5 uascellum $\mathrm{S}$ quod mecum fortasse] q. m. forte $\mathrm{E}$ fortem q. m. L fortasse om. PS quod ${ }^{2}$ quem $\mathrm{E} \quad 6$ ait] dixit P quare implesti] uas aquam (aqua $\mathrm{P}$ aquae $\mathrm{S}$ ) add. PES om. $\mathrm{L}$ at] et $\mathrm{P}$ 7 etiam om. PS in om. ELS ante sitiam] antea s. PE antiscitiam L at] et $\mathrm{P}$ respondit] mihi (dicens add. $\mathrm{S}$ ) add. PELS indulgeat] inquit add. $\mathrm{S}$ 8 Deus] Dominus $\mathrm{P}$ inquit add. EL ubique] usque $\mathrm{S}$ tibi dulcem aquam] ibi d. a. $\mathrm{V}$ dulcedinem aquae tibi $\mathrm{E}$ tibi $\mathrm{om} . \mathrm{S} 9$ praestare] Potens est Dominus in omni loco seruis suis reficere add. L 


\section{LXIX - QVIA ORATIO VIRI PERFECTI ETIAM MORTVIS PROSIT}

1-Abbas Macarius dum ambularet in deserto caput mortui cuiusdam pronum inuenit in terra. Quod postquam cum baculo suo conuertit uocem uisum est emittere. Quod senex quisnam esset interrogat. At ille respondit: Ego quidem princeps eram sacerdotum idolorum ex gentibus quae hoc loco habitant; tu autem Macarius es spiritu diuino repletus. Quacumque hora misertus eorum qui in poena sunt pro his oraueris, consolationem aliquam consequuntur. Cui senex: Et quae est consolatio uel quae poena? Responde! At ille altius ingemescens: Quantum, inquit, caelum distat a terra, tantum ignis altus est, in quo medio sumus a pedibus usque ad caput undique perfusi. Nec cuique licet faciem alterius intueri, sed facies nostrae dorso coniunctae sunt. Cum autem oras pro nobis ex parte nos uidemus alterutrum et hoc nobis pro consolatione constat. His auditis lacrimas senex effudit dicens: Vae die illa in qua homo mandatum Dei transgressus est. Et iterum ab eo si esset altera poena maior requirit. Cui ille respondit: Est poena maior. Sunt enim alii a nobis multo inferius. Cumque qui essent illi senex interrogasset, ille respondit dicens: Nos quidem qui Deum non nouimus misericordiam

\footnotetext{
LXIX - VPLS om. E quia om. P prodest P

1 -VPLS om. E 1 abba PS desertum S 1-2 cuiusdam mortui $\mathrm{S} 2$ pronum] -i $\mathrm{V}$ om. $\mathrm{P}$ cum om. PLS 3 uocem uisum est] $\begin{array}{llll}\text { u. uisus e. } V & \text { u. e. uisus } P & \text { u. e. uisum } L & \text { uisum e. u. } S \text { emit- }\end{array}$ tere] Hic sanctus Macharius caput mortui pro poena interrogat add. $\mathrm{P}$ quod] at PS interrogat] -asset $\mathrm{L}$-auit $\mathrm{S} \quad 5$ ex gentibus] gentilium $\mathrm{P}$ et $\mathrm{g}$. L gentilibus $\mathrm{S}$ quae] qui in PLS habitabant $\mathrm{P}$ es Macarius PLS 6 quacumque] autem add. PL 7 his] eis PLS aliquam consequuntur] a. -antur $\mathrm{L} \quad$-entur a. $\mathrm{S} \quad 8$ respondit $\mathrm{V} \quad 9$ ingemiscens PS distat om. V 10 igni $p$. corr. L 11 nec cuique] necuiquam L ne c. $\mathrm{S}$ nostrae] a add. $\mathrm{P} 12$ dorso] deorsum $\mathrm{S}$ sunt coniunctae $\mathrm{L}$ 13 hoc om. P his auditis] insuaditis dub. P 14 lacrimans PS senis L effudit] effundit $\mathrm{L}$ om. $\mathrm{S}$ dixit $\mathrm{S}$ die illa] dies i. P dies ille $\mathrm{L}$ diei illi $\mathrm{S}$ in $\mathrm{om}$. $\mathrm{L}$ quo $\mathrm{S} \quad 15$ iterum] senex add. $\mathrm{P} \quad 15-16$ ab eo si esset altera poena maior requirit] requirens ab eo si e. a. p. m. V ab eo si (om. P) esset (est P) a. p. m. inquirit (om. P) PS 16 cui ille respondit] ille dixit P poena $\mathrm{om}$. P enim $\mathrm{om}$. PS a $\mathrm{om}$. S 17 multum L qui essent illi senex interrogasset] q. e. i. s. -aret $\mathrm{S} \quad$-aret q. e. $\mathrm{P} \quad 17-18$ respondit dicens] dixit $\mathrm{P}$ addidit d. LS 18 quidem $\mathrm{om}$. PS cognouimus PLS
} 
quamcumque sortiti sumus. Illi uero qui agnitum negauerunt ineffa-

20 bilibus poenis subtus nos constituti torquentur. Quibus beatus Macarius auditis, capite altius terrae defosso, discessit.

\section{LXX - DE REVELATIONIBVS}

1-Quidam frater requisiuit a sene dicens: Quemadmodum quidam dicunt quia uidemus uisiones angelorum? Respondit: Beatus est qui peccatum suum semper intendit et uidet.

2-Cum quidam fratres ad beatum Antonium pergerent, uolentes $\mathrm{ab}$ eo inquirere si phantasmata quae uidebant inpulsu daemonum cernerentur, habebant secum asinum quem in uia contigit mori. Cum ergo peruenissent ad senem dicit eis: Quomodo defunctus est asellus uester in uia? At illi a quo hoc cognouisset interrogabant. Quibus

5 senex: Daemones mihi ostenderunt. Tunc illi responderunt: Et nos propterea uenimus requirere si phantasias quas uidemus et saepe contingunt per daemones nuntiantur. Quibus senex satisfecit quod friuola ista non aliunde nisi per daemones declarentur.

\section{LXXI - DE INPVGNATIONE DAEMONVM}

1 - Quidam frater requisiuit a sene dicens: Cur, abba, a daemonibus inpugnamur? Respondit: Quoniam arma nostra proiecimus, id est, patientiam, humilitatem, oboedientiam et penuriam.

19 quamcumque sortiti sumus] quantumque (quantulumque L) sortimur PLS agnitum] cognitum $\mathrm{P}$ Deum $a d d$. $\mathrm{L}$ ineffabilis $\mathrm{L} 20$ Macarius] his add. $\mathrm{L}$ 21 caput $\mathrm{S}$ terrae om. $\mathrm{P}$ fosso $\mathrm{S}$

$$
\text { LXX - VPLS om. E }
$$

1 - VPLS om. E 1 a sene] senem P 2 quidam dicunt quia uidemus] d. q. quia u. (-imus PL) PLS 3 est] autem V peccatum suum semper intendit] p. suum s. (s. p. suum S) -et LS

$$
\text { 2-VPLS om. E } 2 \text { requirere PLS phantasma L } 3 \text { asel- }
$$
lum $\mathrm{P}$ contingit VL cumque $\mathrm{P} \quad 4$ ergo om. $\mathrm{P}$ defunctus] mortuus $\mathrm{P} 5$ hoc $o m . \mathrm{S} 6$ daemones] inquit add. $\mathrm{S}$ mihi] inpugnant $a d d . \mathrm{P}$ inquit add. $\mathrm{L}$ tunc illi responderunt om. $\mathrm{P}$ nos] inquiunt add. PS 7 inquirere $\mathrm{P}$ phantasmas $\mathrm{L} \quad 8$ quod] quia $\mathrm{S} \quad 9$ declarantur LS LXXI - VPELS inpugnatione] pugnatione V -tio $\mathrm{L}$ 1 - VPLS om. E requisitus $\mathrm{V}$ seni $\mathrm{L} \mathrm{a}^{2}$ ] Dei $\mathrm{S} 2$ proicimus PS 3 patientiam] et add. $\mathrm{P} \quad$ oboedientiam et penuriam om. $\mathrm{P}$ 
2-Quidam frater abbatem Sisoium requisiuit dicens: Putas, abba, sic nos persequitur diabolus sicut et antiquos? Respondit: Modo magis homines aetatis nostrae persequitur quia adpropinquante poenarum tempore conturbatur.

$\mathrm{Nec}$ tamen infirmos, quos dignatus adpetere, quos uoluerit cito subuertit, sed fortes magis et magnos adgreditur.

3 - Abbas Poemen requisitus ab abbate Abraham quemadmodum nos daemones inpugnant, respondit senex: Daemones nobiscum non pugnant quia uoluntates eorum facimus, sed nostrae nobis uoluntates daemones factae sunt et tribulant nos. Nam uis scire cum quibus daemones pugnauerunt? Pugnauerunt cum abbate Moyse et similibus eius. Nos autem uoluntates nostri cordis inpugnant.

4-Cuidam fratri requirenti abbatem Achilam quemadmodum aduersum nos possunt daemones, respondit senex: Per uoluntates nostras. Et adiecit dicens: Ligna Libani dixerunt: "Quam grandia et alta sumus et paruissimum ferramentum incidit nos! Nihil ergo ei demus ex nobis et non nos poterit incidere». Venerunt ergo homines et fecerunt in securi manubrium ex ipsis lignis et ita inciderunt ea. Ligna ergo sunt animae, securis diabolus, manubrium uoluntates nostrae. Per malas ergo uoluntates nostras incidimur.

2-VPLS om. E 1 abbatem Sisoium requisiuit] a. Sisonium r. S r. a. S. L 2 sic] modo add. PL nos persequitur] p. n. PL n. modo p. S et $\mathrm{om}$. PLS respondit $\mathrm{om}$. L 3 magis modo P 3-4 adpropinquante poenarum tempore] -ant $\mathrm{p}$. eorum tempora et $\mathrm{P} \quad 4-5$ conturbatur nec] -antur nec (neque S) PS 5 quos $^{1}$ ] quosque LS om. P dignatus adpetere quos uoluerit] -atur a. q. ubi u. PL $\quad$-antur a. q. ut uoluerint $\mathrm{S} \quad 6$ subuertent $\mathrm{S}$ sed... adgreditur $o m$. V

3-VPLS om. E 1 abba PS requisiuit $P$ ab abbate] abbatem PL 2 daemones om. L nobiscum om. S 3 nobis om. L 5 pugnauerunt $^{2} \mathrm{om}$. S Moyse] Macario add. P simili L 6 uoluntates] -em PS eius add. V cordis nostri S inpugnat $\mathrm{L}$

4-VPELS 1 cuidam] quidam VPL fratri] frater $V$ fratres $P$ requirenti] cum requirerent $P$ abbatem] -e VE -i L Achilam] -a V -llem S Ancillam L 2 daemones] praeualere $a d d$. PLS 3 Libani] semetipsis add. P granda L 4 incidet ELS ergo om. PL 5 demus ex nobis] ex n. d. ei $\mathrm{S}$ et] ut $\mathrm{S}$ ne $\mathrm{E}$ nos poterit incidere] n. p. incidire $\mathrm{E}$ poterint i. nos L nos om. V uenerunt] posuerunt L 6 et fecerunt $o m$. L in om. P secure EL ea om. PS 7 ligna] sic add. S diabolum $\mathrm{L} \quad 8$ ergo] uero $\mathrm{P}$ enim $\mathrm{L}$ 


\section{LXXII - DE PVGNA COGITATIONVM}

1 - Idem dixit: Non pro eo quod ingrediuntur cogitationes in nobis ob hoc iudicamur, sed quia ipsis cogitationibus utimur. Malum est enim ex cogitationibus naufragari et bonum est ex cogitationibus coronari.

2-Quidam frater dixit seni: Nihil uideo pugnae in corde meo. Cui senex: Tu quadriportium es et qui uult ingreditur et egreditur per te; tu autem non sentis. Si autem habes ostium et clauseris illum et non permiseris per eum ingredi malas cogitationes, tunc uides eas

5 de foris stantes et pugnantes.

3-Quidam frater requisiuit senem dicens: Quid faciam quoniam plurimae sunt cogitationes meae et nescio qualiter pugnem aduersus eas? Cui senex: Aduersus omnes non tenes pugnare, sed aduersus unam. Omnes enim cogitationes unum caput habent. Opus est

5 ergo ut scias quale caput est et aduersus ipsum caput debes confligere et aliae humiliabuntur.

Sicut enim solet in bello contingere ut ubi uiderint fortem ex aduersariis et ipsi alterum eligunt fortiorem, et si potuerit percutere caput ceteri fugiunt et debellantur; sic ergo et cogitationes unum caput habent:

LXXII - VPLS om. E pugna] purgatione S

1 -VPLS om. E 1 idem dixit] item d. PS d. quidam senex L 2 Corruptio textus in $\mathrm{V}$ liquet etiam e punctuatione, nam scribit utimur male. utimur] naufragari add. L male $\mathrm{V} \quad 3$ ex om. V naufragari et bonum est] -are et cum V

2-VPLS om. E 1 senis L pugna L 2 quadriportium] quadriportis $\mathrm{P}$ quadri potius $\mathrm{S}$ egreditur] regreditur PS 3 autem om. L habes ostium om. V clausis V illum] eum V illud $\mathrm{S} \quad 4$ per eum om. V 5 inpugnantes $\mathrm{S}$

3 -VPELS 1 senem] a sene E quoniam] quia LS 2 plures $\mathrm{P}$ sunt om. S 3 non tenes] ne tentes PELS 4 opus] quid E 5 caput ${ }^{1}$ om. PELS aduersum $\mathrm{P}$ 6-7 et aliae humiliabuntur sicut enim] et (tunc add. PS) a. -antur s. e. (sic et P) PELS 7 ut] et VS et sed p. corr. ut E ubi] ut S nisi per comp. V 8 et $^{1} \mathrm{om}$. PS ipsi] ipse S om. E alterum] alium $\mathrm{L} \quad$ eligant $\mathrm{P} \quad$ sup. fortiorem script. est similiter in cod. E caput] eius add. ELS aduersus ipsum solum add. P 9 ceteri fugiunt et om. P bellantur $\mathrm{S} \quad \mathrm{et}^{2} \mathrm{om}$. PLS 
siue de gastrimargia siue de auaritia siue peruagatione de loco in loco uel ceteris rebus. Et si a principio non cognoueris caput ipsum et expuleris a te, decipient te in aliis subsequentibus cogitationibus et fallent te. Quia dum ipsum caput coeperit inpugnari, mouet ceteras passiones ut faciat hominem de aliis in aliam errantem falli. Si uis ergo uincere passiones, caput cogitationum semper obserua et cum deprehenderis quale est ipsum, aduersus illud solum proeliare.

4-Abbas Poemen requisiuit aliquando abbatem Ioseph dicens: Quid faciam quando passiones mihi adpropinquant? Resistam illis an permittam illas ingredi in corde meo? Cui senex: Permitte eas ingredi et pugna cum ipsis. Cum ergo reuersus abba Poemen sederet in cella, alter ex fratribus veniens ab eodem sene Ioseph, dixit abbati Poemeni: Fui ad senem Ioseph et interrogaui eum de passionibus cordis si eas intrare permitterem. Et dixit mihi: Ne permittas eas penitus adpropinquare tibi, sed mox eas incide. Quod cum audisset abba Poemen quia illi aliter dixisset quam sibi, exsurgens perrexit ad eum dicens: Ego tibi, abba Ioseph, sic credidi quomodo Deo et dixi tibi omnes cogitationes meas et tu alteri fratri aliter respondisti quam mihi. Cui senex: Numquid nescis quia te diligo? Et cum ille profi-

10 auaritia] uarilia $\mathrm{V}$ siue peruagationel s. de p. (uagatione S) PS in loco] ad locum (-o L) PELS 11 ipsut EL et ${ }^{2} \mathrm{om}$. PL 12 a te decipient] antequam decipiaris $\mathrm{P}$ a te et $\mathrm{d} . \mathrm{V}$ a te decipiet ES te2] om. $\mathrm{P}$ et add. $\mathrm{L}$ cogitationibus] irrepunt te add. P 13 fallet ES te om. E quia] qui $\mathrm{P}$ ipsum caput coeperit inpugnari] i. (-ud L) caput c. (-ris E) -are EL 14 passiones] cogitationes L 14-15 ut faciat... passiones om. E 14 ut faciat] et facit PL hominem] -es $\mathrm{P}$-e L aliis in aliam errantem] a. (-a V) in alia (-as P) e. (-es P) VP 14-15 uis ergo uincere passiones] e. uis u. cogitationes PLS 15 cogitationum] tuarum add. $\mathrm{S}$ semper $\mathrm{om} . \mathrm{S} \quad 16$ qualis $\mathrm{V}$ ipsum] ipsum (-ut EL) caput PELS illud] ipsum PS illum E solum] semper L

$$
\text { 4-VPES om. L } 1 \text { abba PS aliquando om. S } 2 \text { quando] }
$$
quia $P \quad 3$ an] non $V$ illas] eas ES corde meo] domum meam $E$ 4 ipsis] eis $P$ cum ergo] cumque $S \quad 5$ cella] sua add. ES ab eodem sene] ad e. (eundem PS) senem PES 5-6 Joseph dixit... interrogaui eum om. P 5 Joseph om. S 5-6 dixit abbati Poemeni fui ad senem Joseph om. V 6 interrogauit $\mathrm{V} \quad 7$ si] ut $\mathrm{V}$ permitterem] -et requisisset (om. P) PS et om. PS mihi] ei PS penitus om. P 8 adpropinquare] intrare E 9 illi] alteri add. $\mathrm{P} \quad$ exurgit $\mathrm{V} \quad 10$ abba om. $\mathrm{S} 12$ cui senex om. $\mathrm{S}$ diligo te PS 12-13 profiteretur] proficisceretur S 
teretur adiecit senex: Ego tamquam mihi ipsi sic tibi dixi. Etenim si semel ingressae fuerint passiones et coeperimus cum eis pugnare 15 probabiliores nos faciunt. Ideo ergo tibi sic dixi: Nam sunt alii quibus non debent adpropinquare passiones sed mox debent recidi.

5 - De quodam sene referebant patres eo quod in cella sua sedens diceret: Ite a me longe; tu uero ueni ad me, amice. Et cum requisitus esset a patre cum quo ita loqueretur, respondit: Malas cogitationes expellebam et bonas inuitabam.

6-Abbas Ioseph requisiuit abbatem Sisoium dicens: Per quantum tempus debet homo passiones cordis excidere? Respondit senex: Tempora uis huius rei cognoscere? Cum autem ille annuisset, respondit: Quacumque hora in corde tuo ingressae fuerint passiones, 5 eadem hora illas si potueris abscide.

7 - Abbas Siluanus requisitus ab aliis patribus per quam uitam adeptus fuisset tantam prudentiam, respondit: Numquam dimisi morari cogitationem in corde meo quae Deum prouocaret ad iram.

8-Quidam ex senibus sedens in Thebaida in spelaeo habebat unum discipulum probatum. Erat autem consuetudo seni monendi

\footnotetext{
13 ipsi om. S

13-14 etenim si semel] si enim s. PE

si s. etiam $\mathrm{S}$

14 fuerunt $P$

14-16 cum eis... non debent om. S

15 sic om. V

nam] si add. $\mathrm{P}$

16 passiones sed] sed $\mathrm{om}$. $\mathrm{P}$

om. S

debent $^{2}$ ] debebant $\mathrm{V}$

recedere $\mathrm{E}$$$
5 \text {-VPS om. EL } 1 \text { patres] fratres } \mathrm{S} \quad 2-3 \text { requisitus esset a patre] }
$$

perquisitus e. (fuisset S) a fratre PS 4 et $\mathrm{om}$. $\mathrm{S}$

$$
\text { 6-VPLS om. E } 1 \text { abba PS Sisonium S } 2 \text { passiones cordis }
$$

excidere] p. c. abscidere $P$ a se excidere passiones $L \quad 3$ tempora uis huius rei cognoscere] uis h. r. c. causam? P ille om. P annueret S 4 passiones] cogitationes $\mathrm{L} \quad 5$ illas si potueris] i. si potes $\mathrm{PL} \quad$ si potes $\mathrm{i} . \mathrm{S}$

7-PLS om. VE 1 abba $\mathrm{S}$ uitam] uiam $\mathrm{S}$ 2-3 morari cogitationem]-es $\mathrm{m}$. $\mathrm{P} \quad \mathrm{m}$. cogitationes $\mathrm{S} 3$ prouocaret] -ent $\mathrm{P}$ prouocant $\mathrm{S}$ 8 -VPES om. $\mathrm{L} 1$ ex senibus] senex $\mathrm{S}$ sedebat $\mathrm{P}$ in Thebaida in spelaeo] idem in s. $\mathrm{P}$ in $\mathrm{s}$. in Thebaide $\mathrm{E}$ in Thebaide in $\mathrm{s}$. $\mathrm{S}$ habebat] uero add. $\mathrm{P} \quad 2$ proba- in $\mathrm{P}$ tota pars exterior deficit in fol. LXIV, quod praecisum est, et ideo in unaquaque linea aliqua uerba desiderantur usque ad finem huius apophthegmatis.
} 
discipulum et post admonitionem, facta oratione, dimittebat eum dormire. Contigit autem ut quidam religiosi saeculares uenirent ad senem. Quos cum ille sermonibus instruxisset ac dimisisset, sedit iterum uespere secundum consuetudinem monens fratrem et dum loqueretur subito obdormiuit. Ille autem discipulus permansit usquequo expergefieret senex et faceret ei secundum consuetudinem orationem. Cumque per aliquas horas sederet et ille non expergefieret, per cogitationes suas frequenter admonitus est quatenus ipse iret et requiesceret priusquam dimiteretur. Sed ille restitit cogitationi et permansit. Cumque iterum argueretur non discessit. Et septies cogitatio illi institit. Tamen ille semper permansit. Post hoc autem cum nox paene finiretur, expergefactus senex inuenit eum sedentem prope se et dicit ei: Vsque modo non discessisti? At ille: Non, inquit, quia non me dimiseras. Cui senex: Cur me, inquit, non expergefaciebas? At ille ait: Non fui ausus ne aliquem tibi laborem incuterem. Exurgentes ergo et facientes matutinos, post consuetas orationes a sene dimissus est. Dum autem sederet senex, factus in extasi uidit quendam monstrantem sibi locum gloriosum et sedem in eo et super sedem septem coronas. Requirit autem monstrantem sibi cuius essent haec. At ille respondit: Discipuli tui-locum quidem et sedem ex quo discessit de saeculo Deus illi donauit, septem autem has coronas hac nocte promeruit. Quod cum audisset senex miratus extimuit. Et uocans

3 discipulum] suum add. $\mathrm{E}$ probatum add. $\mathrm{S}$ oratione] spiratione $\mathrm{S}$ 4 religiosi saeculares] religiosus et quidam saecularis $V$ uenissent $E$ 5 quos] quod $\mathrm{E}$ quem $\mathrm{S}$ ille $\mathrm{om} . \mathrm{S} \quad 6<$ monen $>$ tem $\mathrm{P} \quad 6-8 \mathrm{mo-}$ nens... consuetudinem om. V 6 et om. P dum] cum S 8 expergesceret PS et] ut $\mathrm{S}$ orationem om. S 9 cumque] dum P dum ergo ES sederet] cederet $\mathrm{V}$ non] sed V spergefaceret $\mathrm{S} \quad 11$ ille restitit] i. (illi S) resistit ES 12-13 cumque... permansit om. E 12 iterum argueretur] i. (igitur S) urgeretur PS et] per add. S 12-13 illi institit] inmittunt $\mathrm{V}$ i. insistit $\mathrm{S} \quad 13$ permansit semper $\mathrm{S}$ haec $\mathrm{S}$ cum] iam add. ES 14 finiretur] fuisset $\mathrm{P}$ expergefactus] expertus PES eum om. V sedentem prope se] se sedentem $V \quad$ p. se s. $S \quad 15$ inquit] non fui ausus $P \quad 16$ non me dimiseras] me n. d. $\mathrm{P}$ me om. $\mathrm{S}$ cui senex om. $\mathrm{V}$ 16-17 cur me... ait om. $\mathrm{P} \quad 16$ inquit me $\mathrm{S}$ non om. $\mathrm{E}$ expergescere faciebas $\mathrm{E}$ 17 ait om. ES non fui ausus] timui P excuterem V 19 extasim S 20 sedem] sedentem VP 21 requisiuit $\mathrm{P} \quad$ se $\mathrm{E} \quad 22$ at $\mathrm{om}$. V 22-23 discesserit PS 23 donauit] concedet P -abit S 23-24 septem... promeruit om. E 23 septem autem has] has septem $S \quad 24$ miratus extimuit] admiratus e. (extitit E) PE 
25 ad se fratrem requisiuit quid illa nocte fecisset. Ille autem dicebat: Indulge mihi, abba, quia nihil feci. Sperans autem senex quia per humilitatem non confiteretur, dixit: Non tibi indulgeo nisi mihi dixeris quid feceris aut quid cogitaueris hac nocte. Ille uero cum nihil sibi esset conscius, quid diceret dubitabat. Postea tamen ait: Nihil feci,

30 abba, nisi forte septies inpugnatus a cogitatione ut discederem, antequam me dimitteres non discessi. Sensit ergo senex quia quotiens contra cogitationem repugnauit totiens et coronatus est. Et hoc quidem ipsi non dixit. Aliis autem dicebat: Quia et pro paruis cogitationibus Deus coronas largitur. Et referens factum discipuli dicebat:

35 Bonum est si semetipsum quis cogat. Sic enim scriptum est: Quia uiolenti diripiunt regnum caelorum.

\section{LXXIII - DE RESERANDIS COGITATIONIBVS CVM OMNI OPERE}

1-Abbas Antonius dicebat: Si posset fieri, quot passos ambulat uel quot guttas aquae bibit frater in cella sua debet senioribus declarare ut si non delinquit in ipsis agnoscat.

Dicebat autem: Vidi monachos qui cum labore magno ceciderunt

5 in cordis elatione uenientes. Spem enim suam in opere proprio tam-

LXXII, 8 lin. 36: uiolenti... caelorum - cf. Mat. XI, 12.

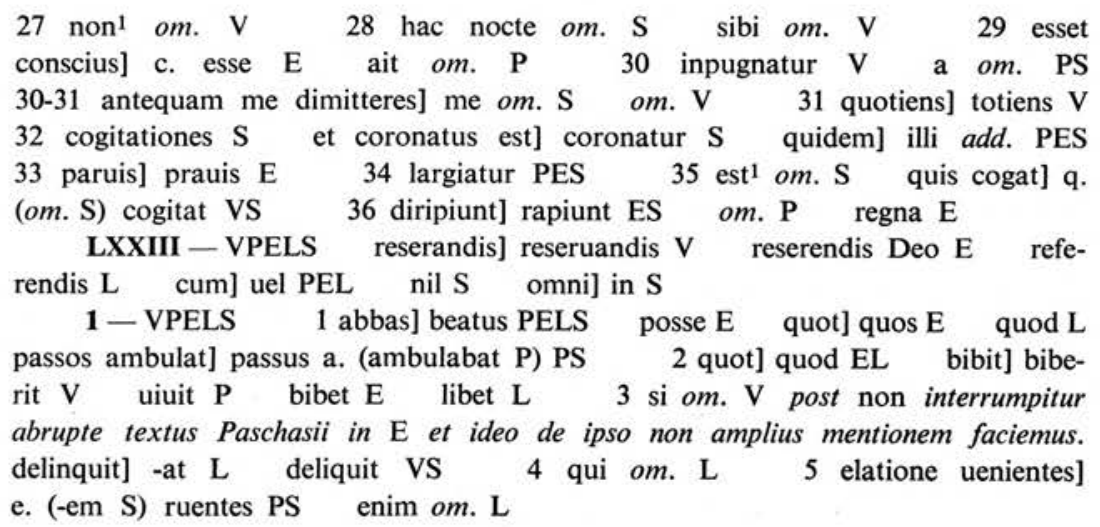


quam Deo placituri ponebant, cuius mandata transgressi sunt dicentis: Interroga patrem tuum et dicet tibi, seniores tuos et adnuntiabunt tibi.

2-Solebat etiam referre quod quidam frater locum quietum et satis uacuum in solitudine reperisset. Cumque abbatem suum ut illum dimitteret postularet dicens: «Spero in Deum et in orationes tuas quia potero ibi laborare», noluit eum penitus relaxare dicens: Scio ex ueritate, fili, quia et multum poteris laborare, sed quia non sunt illic proximo seniores quibus operam tuam manifestes si reuera placet Deo et quia confides quod opus monachi per te ualeas explicare, et laborem tuum perdes et sensum.

3-Dicebat etiam abba Poemen: In nullo homine sic gaudet inimicus quomodo in illo qui non uult cogitationes suas manifestare.

4-Quidam frater inpugnatus est a cogitatione et exurgens per noctem profectus est ad quendam senem et dixit ei cogitationem suam. Quem senex monuit et dimisit. Reuersus ergo in cella sua, iterum coepit inpugnari et iterum profectus est ad senem et monitus iterum reuersus est ad cellam. Et ecce iterum inpugnabatur et iterum reuertebatur ad senem. Decies ipse profectus est ad senem et dicit ei senex:

LXXIII, 1 lin. 7: Interroga $\ldots$ tibi-cf. Deut. XXXIII, 7.

6 placituri] placatim $\mathrm{P}$ proponebant $\mathrm{P}$ cuius] qui senis PLS dicentis] -em V -es LS 7 patrem tuum et dicet] parentes tuos et adnuntiabunt P adnuntiabunt tibi] docebunt te PS

2 -VPLS 1 solebat] nolebat $P$ etiam] autem $V$ enim $P$ quietum om. $\mathrm{P} 3$ Deum] meum add. $\mathrm{L} 4$ laborare] abba $a d d . \mathrm{P}$ et add. $\mathrm{L}$ eum] enim V om. L 5 et om. PS laborare] et opus monachi exercere add. $\mathrm{L} 6$ illic] in add. PELS opera tua $\mathrm{P}$ reuera] opera $\mathrm{S}$ uera $\mathrm{L}$ 7 placet] -ent $P$-eret $S$ quia confides quod] c. quia q. $V$ quia q. c. $L$ per te ualeas] per te potes $\mathrm{L}$ preualeas $\mathrm{S}$ 7-8 explicare et] exercere et $(\mathrm{om}$. S) PLS 8 et sensum perdes $S$ 3-VPLS 1 etiam] enim $P$ homini $P$ sic] se $V$
4-VPLS 1 inpugnatus est] inpugnabatur $L$ et om. V 1-2 per noctem] nocte L 2 ei om. P cogitationes suas] cogitatione L 3 ergo om. S cellam suam PS 4-5 et monitus... cellam om. P 6 ipse] enim PL ergo $\mathrm{S}$ profectus est ad senem] p. ad s. e. $\mathrm{L}$ ad s. p. e. S senex om. S 
Semper uenit, frater, et renuntia mihi, quia nihil sic daemonem inpugnatorem contristat quomodo manifestare opera eius et nihil sic illum laetificat quomodo abscondi cogitationes eius.

5-Abbas Poemen, dum esset iuuenis, profectus est ad quendam senem longe a se manentem requirere eum de tribus quibusdam cogitationibus suis. Cum ergo uenisset ad senem, unam ex illis oblitus est et mox reuersus est ad cellam suam. Et postquam misit clauem

5 ut ostium aperiret iterum rememoratus est cogitationem quam uolebat requirere et dimissa claue ad senem reuersus est. Cui ille: Festinasti, frater, redire? At ille retulit ei: Quia postquam misi clauem in ostio rememoratus sum sermonem quem quaerebam et non aperui cellam, sed reuersus sum ad te. Erat autem spatium inter utrasque cellas 10 grande ualde.

6-Quidam frater requisiuit senem dicens: Quales cogitationes debeo habere in anima mea? Cui senex: Omnia quaecumque cogitat homo a caelo et in terra uanitas est; qui autem permanet in memoria Christi, hic solus in ueritate est.

7-Quidam frater dixit ad senem: Ecce, abba, frequenter interrogo senes ut dicant mihi de salute animae meae et quae dixerint mihi nihil ex ipsis retineo. Cur ergo uel interrogo eos nihil faciens? Totus enim sum inmundus. Erant enim illic duo uasa uacua. Et dicit ei

5 senex: Vade, affer unum ex illis uasis et mitte aquam et laua illud et effunde aquam et pone id in locum suum. Fecit ergo sic et semel et

7 nuntia L $\quad 7-8$ inpugnantem $\mathrm{S} \quad 8$ manifestare opera] manifestatio operum PS illum] eum S om. L 9 quomodo abscondi cogitationes] q. (sicut S) absconsio cogitationum PS

5 -VPLS 1 abba $S \quad 2$ a] ad $\mathrm{V}$ requirere] ut requiret $\mathrm{S}$ quibus V $4 \mathrm{et}^{2} \mathrm{om}$. L 5 est $\mathrm{om}$. L $5-6$ uolebat requirere] oblitus fuerat ei $P \quad 6$ et dimissa] amissa $L$ ad senem reuersus est] r. ad s. e. L r. e. ad s. PS ille festinasti] illi festinanti S 7 redire ] uenire P om. L ostium PS 8 quem quaerebam] quam requirebam L 9 inter utrasque] i. utrisque $\mathrm{L}$ intrasque $\mathrm{S}$

6-VPLS 2 quaecumque] quae $L \quad 3$ a] in $P$ in terra] infra PLS 3-4 qui autem... est om. V 4 hiis $\mathrm{S}$

7-VPS om. L 1 dixit om. V 2 dixerint] -unt $\mathrm{S} 3$ cur] cum $\mathrm{S}$ uel om. S eos] illos et (om. S) PS facio P 4 enim] autem PS dixit eis V 5 uade] et add. PS 6 id in locum sum] illud in loco suo PS 
bis et dicit ei: Vtrumque affer simul. Et cum adtulisset dicit ei senex: Quod est mundius ex utrisque? Cui frater: Vbi aquam misi. Tunc senex: Sic est et anima. Quamuis enim nihil retineat ex his quae interrogat, tamen plus mundatur ab illo qui non interrogat.

8-Quidam senex erat in Sceti, laboriosus quidem corpore, non tamen diligens in cogitationibus. Venit ergo ad abbatem Ioannem requirere eum de obliuione. Et audiens ab eo sermonem, dum reuerteretur oblitus est. Et iterum reuersus requisiuit eum et similiter oblitus est. Et sic frequenter faciens semper obliuiscebatur quod audiebat. Semel ergo cum obuius fuisset abbatem Ioannem dicit ei: Abba, oblitus sum quod mihi dixeras, sed ne inportunus tibi essem ideo non ueni. Cui abbas Ioannes: Vade et incende lucernam. Et cum incendisset iterum dicit ei: Affer alias lucernas et incende ex ipsa. Cum autem ita fecisset dicit ei: Numquid aliquid laesa est lucerna quia de illa alias incendisti? Cumque ille renueret dicit: Et sic Ioannes. Etsi omnes qui in Sceti commanent ueniant requirere me, non mihi impediunt a gratia Christi. Quotienscumque ergo uis ueni sine discretione. Et ita per utrorumque patientiam Deus obliuionem abstulit ab illo sene.

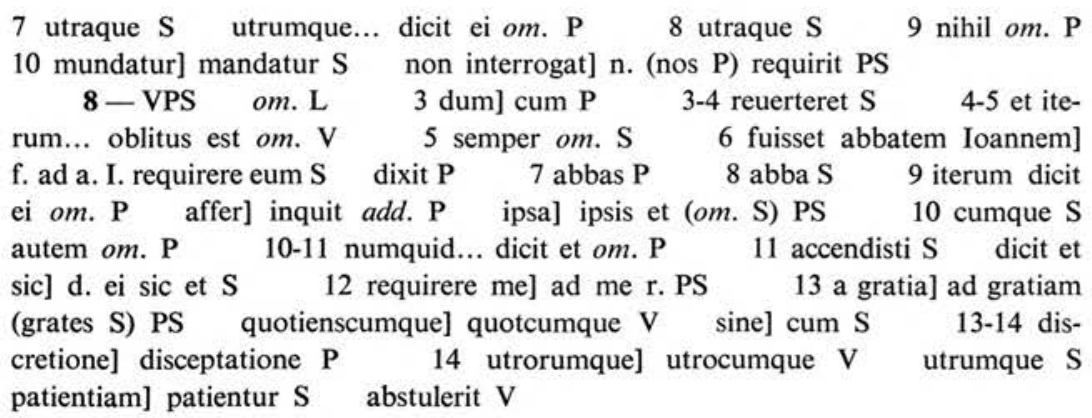




\section{LXXIV - DE DISCRETIONE}

1-Quidam ex senibus dicebat: Quando cooperuerit homo oculos animalis tunc in machina conuertitur. Sin autem non fuerint operti oculi eius non facile flectitur. Sic et diabolus. Si potuerit operire oculos hominis qui discretionem non habet, humiliat eum in omni

5 peccato; si autem per discretionem inluminati fuerint oculi hominis, cito potest ab illo discedere.

2-Abbas Poemen dixit: Est homo portans omni tempore securem et tamen non potest deponere arborem. Et est alter sciens quemadmodum inciditur et paucis plagis potest deponere arborem. Securis ergo discretio est, quam si quis habuerit potest euadere insidias inimici.

\section{LXXV - QVIA NON NOCEANT QVAEDAM HIS QVI DISCRETIONEM HABENT}

1-Abbas Isaac uenit ad abbatem Poemenen et uidit eum super pedes suos aquam mittentem et tamquam habens fiduciam dixit ei: Quare quidam sic dure corpus suum tractauerunt? Cui abba Poemen: Nos non didicimus corpus sed passiones extinguere.

Dumque hoc loqueretur audiuit abbas Isaac gallum cantantem

\section{LXXIV - VPLS}

1-VPLS 1 cooperuerit] cooperit $\mathrm{P}$ operuerit $\mathrm{L}$ aperuerit $\mathrm{S}$ 2 animales $\mathrm{V}$ in machina] in -am $\mathrm{P}$ inicianam dub. S $2-3$ sin autem... flectitur om. L 2 aperti VP $\quad 3$ oculos V aperire VP 4 humiliat eum] -auit enim $\mathrm{V} \quad 5$ fuerint inluminati $\mathrm{S}$ hominis] eius $\mathrm{L}$

2-VPLS 1 abba PS dixit] dicit $\mathrm{S}$ om. $\mathrm{V}$ portans omni tempore] omne tempus p.S 2 arborem deponere PLS et ${ }^{2}$ om. P 3 incidatur LS 4 ergo] est $\mathrm{V}$ om. $\mathrm{S}$ est discretio $\mathrm{S}$ habuerit potest] h. facilius p. (-erit S) PLS

LXXV - VPLS quia] quod S non om. S noceant] -cet $\mathrm{L}$-cent $\mathrm{S}$ 1-VPLS 1 abba PS Poemen VL 2 et om. V tamquam] tantam $\mathrm{P}$ tamen $\mathrm{L}$ fiduciam habens $\mathrm{S} 3$ quidem $\mathrm{V}$ dure corpus suum tractauerunt] c. tuum $\mathrm{t}$. dire $\mathrm{S}$ abbas $\mathrm{L} 4$ non om. $\mathrm{V}$ didicimus CA (Pallad. Laus. XX, 4 b: sumus docti [PG LXV, Poemen 184 (col. 368)] $\hat{\varepsilon} \delta \delta \delta \dot{\alpha} \chi \theta \eta \mu \varepsilon v)$ : dicimus VPLS extinguere] occidere PLS 5 hoc loqueretur] h. (haec S) loquerentur PLS 
et dixit ei: Sunt et ista hic, abba? At ille respondit: Quid me cogis loqui? Tu et similes tui audierunt haec. Qui autem sapit nihil istorum aut audiuit aut curat.

\section{LXXVI - DE MORTIFICATIONE}

1-Quidam frater requisiuit abbatem Moysem dicens: Quemadmodum se potest homo mortificare? Dicit ei: Nisi se quis arbitratus fuerit habere iam triennium in sepulcro, ad hunc sermonem pertingere non potest.

2-Idem dixit: Ille monachus potest tamquam mortuus huic saeculo esse, qui duas res horruerit, id est, carnis suae requiem et uanam gloriam.

3-Quidam senex dixit: Tunc erit monachus liber ab omnibus cum in uno opere tantum intentus est, id est, bonum.

Quando enim bonam operam exercet, ueniens diabolus locum non inuenit et discedit. Si autem malum opus exercet, ueniens frequenter spiritus Dei et uidens malum opus non accedit sed recedit. $\mathrm{Si}$ tamen requisitus fuerit, cito reuertitur.

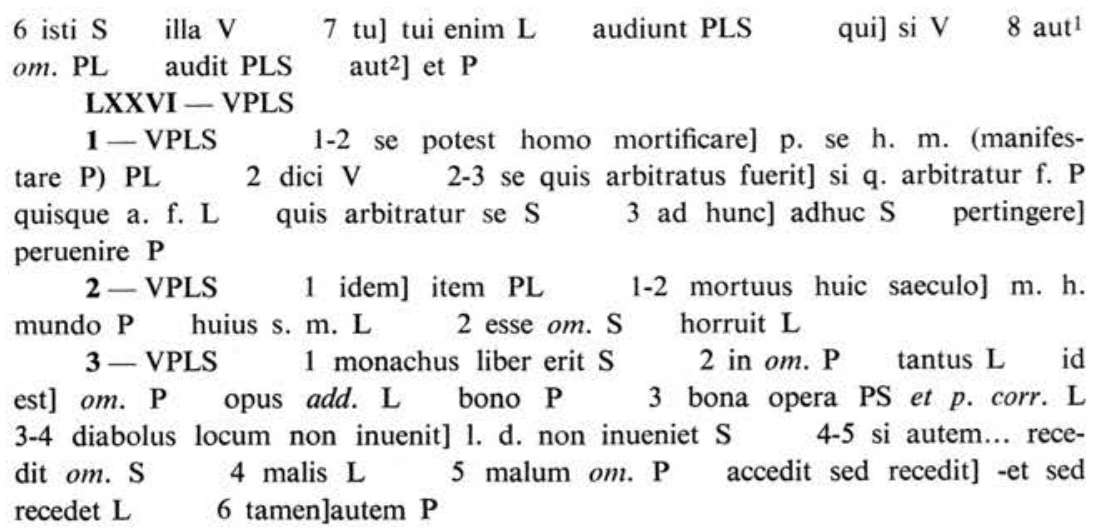


4-Quidam senex dixit: Horre uentrem tuum et necessitates huius saeculi et honorem, et tamquam absens de hoc saeculo requiem possidebis.

5-Idem dixit: Monachus debet sibi requiem conparare, id est, ut mundum contemnatur, etsi corporalem iacturam sustineat. Nam si adhuc ipse alios repreherdit, necdum potest mortificationis requiem possidere.

\section{LXXVII — DE PERSEVERANTIA}

1-Abbas Antonius dixit: Si monachus paucis diebus laborat et iterum relaxatur et rursus laborat et deinde neglegit, hic nihil agit nec enim patientiae perseuerantiam possidebit.

2-Abbas Motoes dixit: Si leuem operam tamen perseuerantem desiderat Deus in monacho, quam a principio grandem quae cito dimittitur.

3-Quidam ex senibus a quodam requisitus est fratre dicente: Quemadmodum non debemus, pater, scandalizare aut a proposito nostro deficere cum aliquos uidemus ad saeculum reuertentes? Respondit: Canes uenaticos debemus respicere quemadmodum unus ; leporem aspiciens persequitur; illi uero alteri tardiores tantummodo canem uident et quidam ex his cupiunt adiungere eum; alii uero fatigati

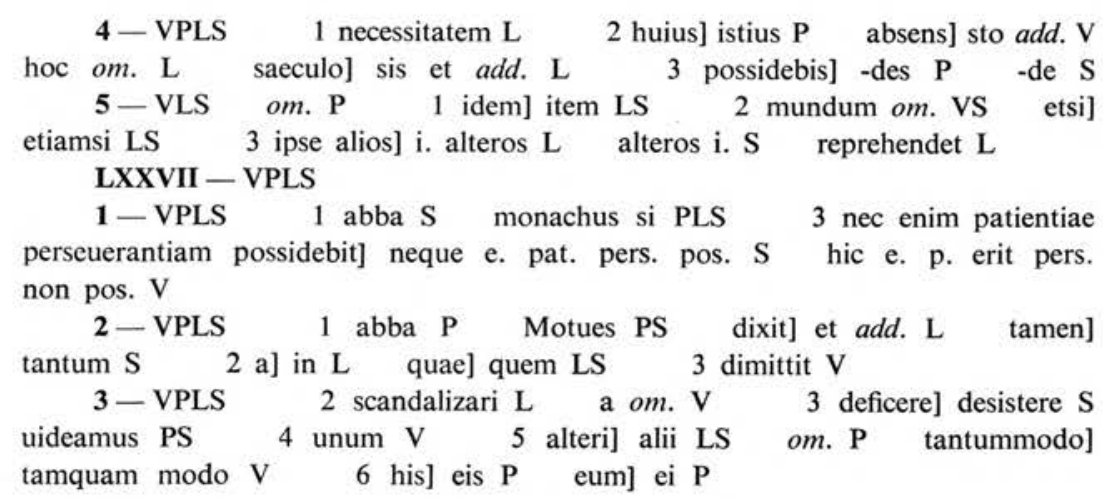


redeunt retrorsum. Ille uero qui uidit usque tunc insequitur usquequo pertingat in nullo penitus inpeditus $a b$ his qui remeauerunt. Sed neque scopulis neque siluis praepeditur; spinas quoque transilit et frequenter $a b$ his laesus tamen non cessat. Sic et qui Christum sequitur, incessanter cruci eius permanet, omnia scandala quaecumque ueniunt ille transiliens usquequo perueniat ad eum qui pro nobis est crucifixus.

\section{LXXVIII - DE LABORE SANCTORVM}

1-Quidam senex dixit: Vsque tunc laborat homo usquequo possideat Christum. Qui autem illum semel adeptus fuerit iam non laborat. Permittitur tamen laborare ut rememorans tribulationem laboris undique semetipsum custodiat, timens ne tantos labores amittat. Nam et filios Israel ideo Deus per desertum quadraginta annis circumduxit ut rememorantes uiae tribulationem nollent redire retrorsum.

2-Quidam frater requisiuit senem: Quemadmodum laborantium patrum est gratia? Et dixit senex: Quoniam qui adhuc laborant postulantes de remissione peccatorum antequam perueniat in eos gratia quae portet laborem ipsorum, illi pallidi et in labore sunt; super quos uero ex priori patientia iam gratia Christi peruenit, isti florent; exultantis enim animae facies clara est. Sicut autem sol cum nubes non habet

LXXVII, 3 lin. 12: qui... crucifixus - cf. Galat. III, 1.

7 illi $\mathrm{L} \quad$ uidit usque tunc] uidet $\mathrm{u}$. $\mathrm{t}$. $\mathrm{V} \quad$ u. t. uidet $\mathrm{P}$ uidet $\mathrm{u}$. ad nunc $\mathrm{L}$ usquequo] usque $\mathrm{V} \quad 8$ pertingat] pergat $\mathrm{V}$ inpeditur $\mathrm{P} \quad$ ab his] aliis $\mathrm{P}$ remeauerunt] remanserunt $P$-rant $S \quad 9$ spinas] spinasque $P$-is $S$ quoque] quousque $\mathrm{L} \quad 10 \mathrm{ab}$ his om. P 12 illi LS transilens L perueniens $\mathrm{V}$

\section{LXXVIII - VPLS}

1-VPLS 1 quidam senex dixit om. P laboret $\mathrm{L} 2$ qui] cum $\mathrm{P}$ illum semel] s. i. LS illum om. P 3 remorans $\mathrm{L} \quad 5$ et $\mathrm{om}$. S Deus om. $\mathrm{P} \quad 6$ uiae] uiam et $\mathrm{P}$ nollens $\mathrm{V}$

2-VPS om. L 1-2 laborantium... adhuc om. P 2 gratiam S quoniam qui] quae quia $\mathrm{S} \quad 2-3$ laborant postulantes] -at postulante $\mathrm{V}$ 3 peccatorum] respondit senex add. $\mathrm{P}$ eo $\mathrm{V} 4$ oportet VP labore ipsorum] laboris eorum $P$ illi] isti PS 5 exultantes VS 6 animae facies] f. a. $\mathrm{P}$ a. facie $\mathrm{S}$ est $\mathrm{om}$. $\mathrm{S}$ autem] enim $\mathrm{P}$ 
lucet, quando uero nubibus cooperitur tunc pallescit, sic et anima donec passiones eam obscurant pallescit. Quae autem iam per gratiam munda est, ita est sicut scriptum est: Magna est gloria eius in 10 salutari tuo.

3-Item dixit: Quamuis laborent hic sancti uiri attamen et aliquam requiem habent, quoniam liberi sunt de cogitatione huius mundi.

\section{LXXIX - QVARE MODO LABORANTES TALEM GRATIAM NON ACCIPIVNT SICVT ANTIQVI}

1-Quidam frater requisiuit senem dicens: Quemadmodum nunc laborantes in conuersationibus uiri non accipiunt gratiam sicut antiqui? Cui senex: Tunc caritas erat et unusquisque proximum suum sursum trahebat. Nunc uero postquam caritas refrixit, singuli

5 proximos suos ad inferiora deducunt et ideo gratiam non sortimur.

\section{LXXX - VTRVM SCIANT VIRI SANCTI QVANDO VENIT IN EIS GRATIA DEI}

1 - Quidam frater requisiuit senem dicens: Putas, abba, cognoscunt sancti quando uenit super eos gratia Dei? Respondit senex: Non semper. Nam cuiusdam magni senis discipulus dum peccasset in

LXXVIII, 2 lin. 9-10: Magna... tuo - Ps. XX, 6.

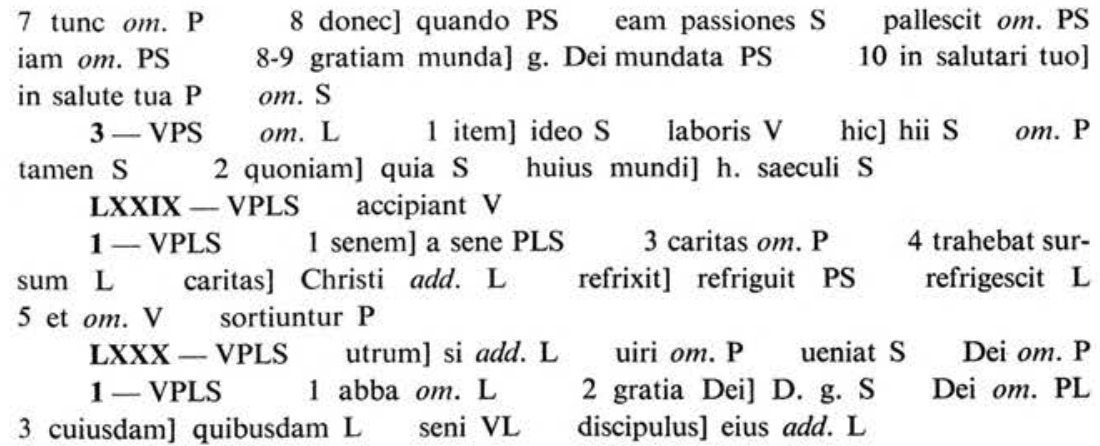


aliqua re dixit ei senex cum clamore: Vade et morere. Et mox cecidit et defunctus est. Quod cum senex uidisset, cum timore et humilitate multa rogauit Deum dicens: Domine Iesu, suscita eum et iam ulterius sine consideratione non loquar. Et mox surrexit frater.

2 - Idem amma Sarra, dum ambularet per uiam, paruulum riuum transiliuit. Saecularis autem quidam uidens eam risit. Illa uero nesciens quia gratia Dei uenerat super ipsam dixit saeculari: Tace, rumparis. Et conuersa uidit intestina eius dirupta. In tremore ergo conuersa, orauit dicens: Iesu meus, resuscita illum et ulterius talem sermonem non loquar.

\section{LXXXI - DE EXHORTATIONE ET DOCTRINA}

1 - Interroganti cuidam abbatem Poemenem de duritia cordis, respondit senex dicens: Natura aquae mollis est et lapidis dura. $\mathrm{Si}$ autem frequenter stillet aqua super lapidem, stillando perforat illum. Sic et uerbum Dei molle est, nostrum autem cor durum. Homo ergo frequenter audiens uerbum Dei, dat locum timori Dei ut ingrediatur in eo.

2-Quidam senex dixit: Homo qui secundum Deum est aut debet cum fide doceri quae nescit aut quae scit aperte ostendere. Si autem neutrum uult, cum possit, insanus est.

4 ei om. S mox om. L 6 Deum] Dominum L eum] illum PLS ulterius] amplius $\mathrm{S} \quad 7$ et mox surrexit frater om. L

2-VPS om. L 1 idem] item PS amma Sarra] amassarra VP per om. V uia $\mathrm{V}$ paruum $\mathrm{S} \quad 1-2$ riuum transiliuit] riuulum transiuit $\mathrm{P}$ 3 quia] quod $\mathrm{S}$ ipsam] illam $\mathrm{S} \quad 4$ eius om. $\mathrm{S} \quad 5$ meus] mi $d u b . \mathrm{P}$ LXXXI - VPLS

1-VPLS 1 interrogauit quidam $S$ abbati $V$ Poemenem] Poemen $\mathrm{L} \quad \mathrm{om} . \mathrm{V} 2$ senex $\mathrm{om} . \mathrm{P}$ natura aquae... dura $\mathrm{om} . \mathrm{P}$ aquae] atque $\mathrm{S}$ mollis] mobilis $\mathrm{V}$ lapis $\mathrm{LS} 3$ super lapidem] supra petram $\mathrm{L}$ stillando] stillando add. repetens $\mathrm{L} \quad 4$ et om. L ergo] igitur $\mathrm{P}$ om. S 5 timori] ad timorem $\mathrm{L}$ Dei ${ }^{2}$ ] sui $\mathrm{P}$ Deo $\mathrm{V}$

2-VPLS 1 dixit] ait $\mathbf{P} 2$ cum fide om. $\mathbf{P}$ doceri] confiteri P 
3-Quidam ex patribus dixit: Periculosum est si is qui actualem uitam non egit alterum docere incipiat. Sicut enim si quis domum habens ruinosam et peregrinos in ea suscipiens casu eos occidat, sic et hii sunt qui non prius se firmiter aedificantes alios perdunt uenien5 tes ad se.

4-Dixit abbas Poemen: Homo qui docet et non facit quae docet similis est fonti alto qui omnium quidem res lauat et omnes satiat potu, se autem ipsum curare non potest, sed habet intra se inmunditiam et sordes.

5-Idem dixit: Doce animam tuam seruare quae lingua tua alios docet.

\section{LXXXII - QVIA DOCTRINA ET SINE VERBO OPERE SOLO CONFERTVR}

1-Abbas Isaac dum esset iuuenis sedebat cum abbate Cronio et numquam illi dixit ut aliquam operam faceret. Sed ipse erat senex tremulus et per se surgebat et aquam ad manus uel bibere tam illi quam omnibus porrigebat. Fuit autem idem abbas Isaac similiter ad abba5 tem Theodorum sed nec ipse aliquid illi imperauit, sed per se ponebat

3-VPLS 1 periculosum] periculo $\mathrm{S}$ enim add. $\mathrm{P}$ auctualem $\mathrm{L}$ 2 incipiatur L enim om. S 2-3 domum habens] d. habet (-eat L) PL habet d. S 3 ea] eam $\mathrm{P}$ eos] eius VS 4 et om. L se prius S aedificantes firmiter $\mathrm{L} \quad 4-5$ ad se uenientes $P$

4-VPLS 1 abba LS homo] quidam add. S quae docet om. $\mathrm{P}$ 2 potum L 3 ipsum $\mathrm{om}$. S inmunditiam] as PS -ae L

5-VPLS 1 idem] item PLS

LXXXII - VPLS quia] et add. V et om. PS opere solo] s. o. S solo om. V confertur (cfr. in capitulatione $\mathrm{M})$ : confirant $\mathrm{V}$ continetur PLS

1 -VPLS 1 abba PS Cronio (Koóvlos): Coronio VPS Eronio $L \quad 2$ sed ipse erat senex] i. uero s. e. PS 3 bibere] uel repetens $\mathrm{S}$ 4 idem om. PS 5 sed $^{1}$ ] et $\mathrm{L}$ nec] neque $\mathrm{P}$ illum $\mathrm{V}$ imperauit] -bat PS et p. corr. sup. lin. L sed per se] per se enim P sed ipse $\mathrm{L}$ per se etiam $\mathrm{S}$ 
mensam et dicebat: Frater si uis comedere, ueni et manduca. Ego autem dicebam illi: Abba, ego ueni ad te ut iuuares me; et quare mihi non dicis ut aliquid faciam? Senex autem semper tacebat. Propter quod profectus est abbas Isaac et retulit aliis patribus. At illi uenientes dixerunt abbati Theodoro: Iste frater uenit ut a sanctitate tua aliquid instrueretur; et quare non illi dicis ut faciat aliquid? Quibus respondit senex: Numquid princeps coenobii sum ut aliquid praecipiam? Ego interea nihil illi dico; si uult quod uidet me facere, faciat et ipse. Et ab illo tempore anticipabat abbas Isaac et quicquid facturus erat senex praeocupabat. Senex autem quicquid faciebat semper tacebat. A quo etiam et hoc beatus Isaac didicit, ut quicquid faciebat faceret tacens.

\section{LXXXIII - FORTIOREM ESSE SCIENTIAM EXPERIMENTO OPERVM QVAM LECTIONEM}

1 - Abbas Arsenius cum quendam senem de cogitationibus propriis aliquando requireret, alter frater dixit ei: Quemadmodum tu tantarum litterarum tam in graeco quam in latino sermone doctrina adeptus ab hoc rustico interrogare aliquid non fastidis?

Cui Arsenius: Graecas quidem me litteras ac latinas plurimas legisse conmemini; istius autem senis adhuc alphabetum me nec adtigisse profiteor.

6 mensam om. V et dicebat] dicebatque V ueni om. S ego] ille PS 6-7 ego autem dicebam illi om. V 7 dicebam illi] dicebat ei PS ego abba S iuuares me] iuuarem te V 9 est om. V abba $\mathrm{S}$ uenientibus $\mathrm{S}$ $10 \mathrm{a} \mathrm{om} . \mathrm{S}$ tua] ut $a d d . \mathrm{L}$ aliquid $\mathrm{om}$. PS 11 quare] qua $\mathrm{V}$ illi non PLS 11-12 senex respondit $L \quad 12$ sum coenobii PLS 12-13 ut aliquid... interea om. $\mathrm{P} 13$ uidet me facere] uidit me facit $\mathrm{L} \quad 14$ anticipabatur $\mathrm{P}$ abba S senex om. $P \quad 15$ quicquid faciebat] quod cum faceret $P$ 15-16 a quo etiam] acceptum $P \quad 16$ hoc] iste $S$ om. V beatus] abbas PLS didicit om. $\mathrm{V}$ quicquid] quid $\mathrm{V}$ faciebat] facere $\mathrm{L}$ om. $\mathrm{S}$ taceret $\mathrm{S}$ LXXXIII - VPLS scientiam] sapientiam L

1-VPLS $\quad 1$ abba S cogitationibus] uestris aliter add. S 2 aliquando] aliquam S om. V alter frater om. V tu om. S 3 doctrinam $P \quad 4$ hoc rustico] h. r. sene PL h. sene r. S fastidis] fastidiis V fastidias $\mathrm{L} \quad 5$ me quidem $\mathrm{L}$ atque $\mathrm{S} \quad 6$ autem $\mathrm{om}$. S senis adhuc] a. s. S adhuc om. $\mathrm{L}$ neque $\mathrm{S}$ 6-7 adtigisse] attingas se V 
2-Abbas Euagrius abbatem requirebat Arsenium dicens: Cur nos ex tam multis lectionibus nullam ualuimus possidere uirtutem, isti uero rustici tantam uirtutum indolem et scientiam sunt adepti? Cui beatus Arsenius: Nos ex saeculari scientia nihil potuimus adipisci, 5 hii uero uirtutum scientiam ex propriis laboribus didicerunt.

\section{LXXXIV - DE SCRIPTVRIS DIVINIS}

1 - Idem abbas Arsenius numquam ullam quaestionem de Scripturis spiritualibus proponebat sed nec propositam, cum certe posset, uolebat exsoluere nec ad aliquem cito litteras destinabat.

2-Quidam frater requisiuit a sene dicens: Si contigerit mihi alicubi ut loquar, de quibus rebus iubes ut loquar: de Scripturis an de sermonibus patrum? Cui senex respondit: Si tacere non potes uel sermones patrum loquere. Nam de Scripturis loqui periculosum est.

3-Quidam philosophus beato dixit Antonio: Quomodo toleras, pater, ea quae ex uoluminibus Scripturarum est consolatione fraudari? At ille: Meus, inquit, liber natura factorum est et adest cum uoluero legere Dei sermones.

2-VPLS 1 Euagrius] Macarius $\mathrm{P}$ Euagus $\mathrm{S}$ Arsenius $\mathrm{L}$ 2 tam multis] tantis L 3 tantam] tantorum L tam S uirtutum] uerborum $L$ uirtutem $P$ indolem] in Dei laudem $P$ e $S 4$ scientiam L potuimus] ualuimus $\mathrm{L}$ possumus $\mathrm{S} 5$ hic $\mathrm{P}$ uirtutem $\mathrm{L}$ scientia $\mathrm{S}$ laboribus] operibus $\mathrm{P}$ didiscerunt $\mathrm{V}$

$$
\text { LXXXIV - VPLS }
$$

1-VPLS 1 idem] actem dub. S om. P abbas] beatus $\mathrm{L}$ abba $S$ nunquam ullam] nullam umquam PLS 2 nec] neque $S$ praepositam VL cum certe posset] cum c. possit LS om. V 3 exsoluere] excutere $\mathrm{S}$ nec] neque $\mathrm{S}$ ad aliquem] aliqui $\mathrm{L}$ ad $\mathrm{om}$. $\mathrm{V}$

2-VPLS 1 a sene] senem P 2 alicubi ut loquar] ut 1. alicui $L$ alicui ut $1 . \mathrm{S}$ iubes] me add. $\mathrm{P} \quad 3$ patrum] quid faciam $a d d$. $\mathrm{L}$ respondit om. PLS tacere non] sciri V 4 Scripturis] scriminibus legitur in S qui om. reliquia uerba huius apophtegmatis.

3-VPS om. L 1 -2 quidam... uoluminibus om. S 1 Antonio dixit $P \quad 3$ meus inquit] melius $V \quad$ factorum] fictorum $V \quad 4$ legere] punctum add. $\mathrm{P} \quad$ sermones] sunt add. $\mathrm{P}$ 


\section{LXXXV - NIHIL LOQVENDVM CVRIOSIS DE SCRIPTVRARVM QVAESTIONIBVS}

1-Quidam anachoreta cum uenisset ad abbatem Poemenem, suscepit eum senex cum laetitia et cum se alterutrum amplexissent residerunt et coepit anachoreta de Scripturis et de rebus caelestibus loqui. At uero senex uertit faciem suam ad alteram partem et nullum illi dedit responsum. Ille uero uidens quod non loqueretur cum eo, tristis egressus est et dicit discipulo eius: Sine causa tanti itineris laborem subii et ueni ad hunc senem qui mecum loqui non patitur. Ingressus autem discipulus abbatis Poemenis dixit ei: Propter te uenit hic homo magnus, tantam gloriam in suis locis habens, et tu non uis loqui cum ipso? Respondit senex: Ille de superioribus est et caelestia loquitur; ego autem de inferioribus sum et terrena uix loquor. Si mihi locutus fuisset aliquid de passionibus animae, forsitan et ego respondissem illi; si autem de caelestibus, ego me nescire confiteor. Egressus ergo discipulus dicit anachoretae: Senex iste noster non uult de Scripturis loqui, sed si quis ei de passionibus locutus fuerit, respondet illi. At ille conpunctus in hoc sermone ingressus ad senem dixit ei: Quid faciam, abba, quoniam passiones cordis mei dominantur mihi? Tunc respexit eum senex gaudens et dicit ei: Modo bene uenisti. Aperi ergo os meum et imple id bonis tuis. Et ex hoc sermone iuuatus anachoreta dixit: Haec est uera uia. Et agens gratias reuersus est in regionem suam.

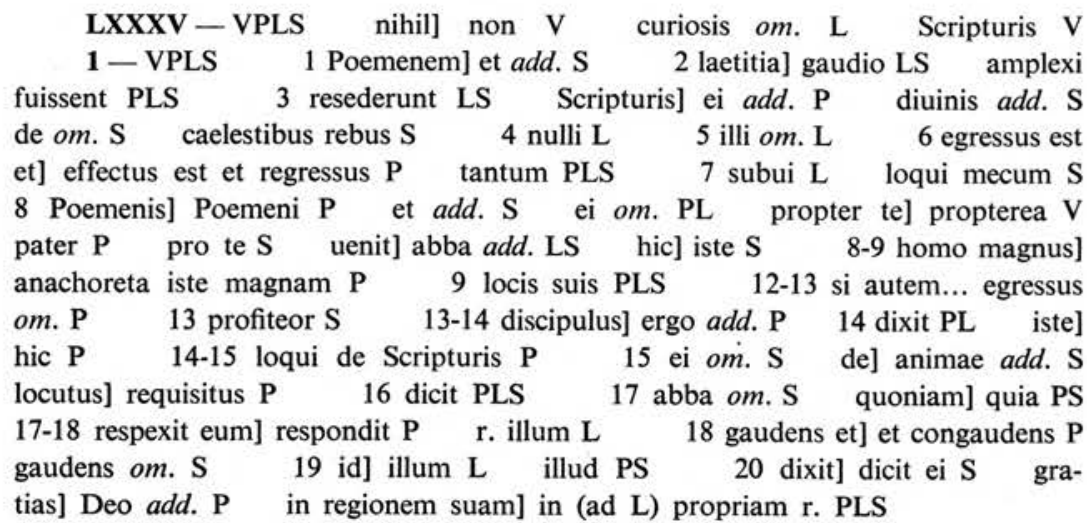


2-Quidam frater cum ad abbatem Theodorum uenisset, tribus diebus ibi permanens et nullum responsum ab eo accipiens, egressus est tristis. Dicit ergo ei discipulus suus: Abba, quare non illi dixisti sermonem? Et ecce tristis egressus est. Cui senex: In ueritate nihil

5 illi dicebam quia negotiator homo est et in aliorum uult glorificari sermonibus.

\section{LXXXVI - DE CVRIOSITATE VITANDA}

1-Quidam senex dixit: Non oportet monacho requirere qualiter ille aut quemadmodum ille. Per interrogationem enim abstrahitur ab oratione in detractiones et uerbositates. Vnde nihil melius quam tacere.

2-Quidam frater requisiuit a sene dicens: Si uenerit aliquis frater sermones mihi de foris inferens alienos, iubes ut dicam illi quatenus mihi illos non afferat? Respondit senex: Nihil dicas illi, quia nec nos potuimus hoc obseruare. Cauendum ergo ne forte dicentes 5 proximo «hoc ne facias», nos idem postea faciamus. Cui frater: Quid ergo oportet facere? At senex: Si uoluerimus, inquit, tacere, exemplum sufficit proximo.

2-VPLS 1 frater] senex $\mathrm{V} \quad 2$ ibi permanens diebus $S \quad$ ab eo responsum $\mathrm{S}$ recipiens $\mathrm{P}$ egressus] reuersus $\mathrm{S} 3$ ergo om. $\mathrm{P}$ ei] ex V illi $\mathrm{L} \quad$ om. $\mathrm{S}$ discipulis suis V 3-4 quare non... egressus est] hic anachoreta nihil ei locutus es et maerens abscedit P 3 dixisti illi S 4 cui senex om. VS 5 homo negotiator S et om. S in om. PS $5-6$ glorificare sermonem $P$

\section{LXXXVI - VPLS}

1-VPLS 2 enim om. S 3 ab oratione] ob o. ceciditur L detractionem $\mathrm{P}$ nihil] est add. PLS et post est habet punctum $\mathrm{S}$ melius] est tacere add. S 4 quam om. $\mathrm{P}$ tacere] loqui $\mathrm{S}$

2 -VPLS 1 fratrem L 2 frater $\mathrm{om}$. S 3 illos mihi L afferatur $\mathrm{P} 4 \mathrm{nec}$ ] neque $\mathrm{S}$ hoc om. $\mathrm{P}$ obseruare cauendum] seruare (o. $\mathrm{P}$ ) c. est PLS ergo om. P forte] te add. S dicente LS 5 proximo hoc] h. p. V p. haec S 6 at] et PL uoluerimus] noluerimus L tacere] facere $\mathrm{L} \quad$ exemplum] solum add. $\mathrm{P} \quad 7$ sufficiat $\mathrm{S}$ proximo om. $\mathrm{L}$ 


\section{LXXXVII - DE CONTENTIONIBVS EVITANDIS}

1-Quidam senex dixit: Si quis tecum aut de Scripturis aut de quacumque causa locutus fuerit ne contendas cum eo. Sed si quidem bene dicit, consenti; si uero male, dic illi: Tu scis quomodo loquaris. Haec obseruans et humilitatem possidebis et odium euitabis.

Nam si persistas contendens et uis defendere sermonem tuum nascitur inde scandalum. Frequenter enim dum laudas alterum fit etiam ex iustificatione contentio. De quacumque ergo re, si grauiter contenderis nullo modo requiem possidebis.

2-Quidam frater requisiuit abbatem Pambo si bonum esset laudare proximum. Respondit senex: Melius est tacere.

\section{LXXXVIII - DE SILENTIO}

1-Abbas Agathon per tres annos misit lapidem in ore suo silentium affectans.

2-Quidam frater requisiuit a sene dicens: Vsquequo est seruandum silentium? Respondit: Vsquequo interrogeris. Scriptum est enim: Antequam audias ne loquaris. Nam et qui loquitur sermonem bonum, nisi prius considerauerit quod se iuuat ipse sermonem loqui non debet. In omni enim loco si taciturnus fueris requiem possidebis.

LXXXVII - VPLS contentionibus] conceptionibus S uitandis VP 1 -VPLS 3 bene dicit] benedicet $\mathrm{V}$ uero] locutus fuerit add. $\mathrm{P}$ dic illi om. S scis quomodo loquaris] facias q. loqueris $\mathrm{S} \quad 4$ haec] enim add. PLS uitabis S 5 persistas] perstans VS consistas $\mathrm{P}$ defendere] contendere $\mathrm{V} \quad 6$ inde] michi $\mathrm{S}$ enim] autem PLS alter V 7 etiam ex iustificatione] autem ex iustificationem L

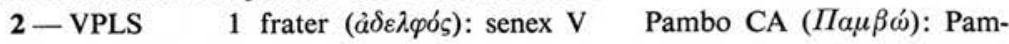
mon V Poemen sed p. corr. Pammo L Poemen P Poemenem S 2 tacere] quam laudare aut detuperare $a d d . \mathrm{L}$

LXXXVIII - VPLS

1 - VPLS 1 abba $\mathrm{S}$ suo om. S

2-VPLS 1 requisiuit a sene om. S 1-2 usquequo est... respondit $\mathrm{om} . \mathrm{V} 2$ usquequo] usque $\mathrm{P} \quad 3$ et $\mathrm{om} . \mathrm{S} \quad 4$ iuuat] iubet $\mathrm{L}$ ipse om. S sermo VPL $4-5$ non debet loqui S 5 taciturnus] tacitus $\mathrm{S}$ 
3-Abbas Euagrius a quodam fratre requisitus est per quem possit saluari sermonem. At ille respondit: Si saluari desideras, in quocumque loco perrexeris ne anticipes loqui nisi fueris ab altero requisitus.

Sed magis stude silentium; de nullo esto sollicitus; adtende meditationi tuae cum timore Dei tam exurgens mane quam uespere et inpiorum inpetus non timebis.

4 - Item abbas Euagrius cum, facta pro quodam capitulo congregatione, locutus fuisset dicit ei presbyter: Scimus, abba Euagri, quia si esses in regione tua et episcopus esses et multorum caput; nunc autem hic uelut peregrinus sedes. Quo sermone ille conpunctus et

5 in nullo penitus contristatus, caput concutiens atque in terra respiciens, digito suo scripsit: In ueritate sic est; tamen semel modo locutus sum; secundo hanc culpam sibi non adgregabit Euagrius.

5- Beatus Arsenius saepe hunc solebat iterare sermonem: Saepe me locutum fuisse poenitui, at uero tacuisse numquam.

6- Beatus Antonius discipulo suo solebat hoc dicere: Si affectaueris silentium non arbitreris te exercere uirtutem, sed indignum te proloqui confitere.

LXXXVIII, 4 lin. 6-7: semel... adgregabit - cf. Iob XXXIX, 35.

3-VPLS 1 abbas Euagrius] abba Euagius $S$ fratre] fratrem $L$

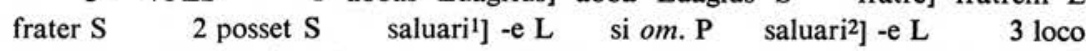
om. P 4 quaesitus $\mathrm{S} \quad 5$ silentium] et add. L ullo $\mathrm{S}$ esto] eloquio $\mathrm{S}$ esse VL meditationis L 6 uesperum V et om. S 7 inpiorum inpetus] $i$. inpetu $V$ inpetus malus $L$

4-VPLS 1 item] idem LS abbas Euagrius] abba Euagius $\mathrm{S}$ $\begin{array}{lll}\text { facto } L & 1-2 \text { pro quodam capitulo congregatione] p. q. cartula c. } P & \text { c. p. q. }\end{array}$ capitulo $\mathrm{S} 2$ scimus] sumus $\mathrm{S}$ abbas $\mathrm{V} \quad$ Euagii $\mathrm{S} \quad 3$ esses $^{1}$ ] esset $\mathrm{S}$ et $o m$. S esses ${ }^{2}$ ] esset $\mathrm{S} \quad 4$ hic om. PS conpunctus] est add. $\mathrm{P} \quad 5$ in nullo penitus contristatus] ullo penitus contristatur $\mathrm{S}$ atque in terra respiciens] a. in terram r. P om. L 6 in ueritate sic est om. P modo semel S 7 culpam sibi non] s. c. n. $\mathrm{P}$ c. n. s. $\mathrm{S}$ adgregabit CA: adgregauit VPL agrauauit $\mathrm{S}$

5 -VLS om. $\mathrm{P} \quad 1$ solebat iterare hunc $\mathrm{S} \quad 2$ poenitui] poenitum $\mathrm{V}$ poenituit $\mathrm{S}$ at] ad $\mathrm{L}$

6-VPLS 2 ne PLS 2-3 indignum te proloqui] dignum te non loqui $\mathrm{L} \quad 3$ profitere $\mathrm{S}$ 
7-Cum quidam frater beato Sisoio dixisset: «Volo animam meam saluare» respondit: Qua ratione possumus animam nostram saluare, cum lingua nostra aperto ostio saepe prosiliat?

8-Quidam fratres, uolentes in Sceti ad beatum Antonium proficisci, ascenderunt in nauem cum quibusdam. Ignotus quidam senex ingressus ad praefatum patrem pergere cupiebat. Sedentes autem fratres uaria loquebantur inter se tam de Scripturis quam de sermonibus patrum. Senex uero semper tacebat. Sed postquam ad beatum Antonium perrexerunt, dicit eis abbas Antonius: Bonum comitem, fratres, inuenistis hunc senem. Et conuersus ad eum: Tu quoque, inquit, abba, cum quibus uenires, bonos socios inuenisti. Cui senex ille respondit: Boni quidem sunt, sed atrium illorum ostium non habet et qui uult ingreditur in eorum stabulum et soluit asinum et quo uult proficiscitur. Hoc autem dicebat quia quicquid illis uenisset in labiis loquebantur.

9-Abbas Poemen dixit: Est homo qui silentium affectat, sed cor eius multos condemnat. Iste talis multum loquitur. Et est alter qui de mane usque ad uesperum loquitur et tamen, quia sine iuuamine non loquitur, silentium magnum studet.

7 -VPLS 1 beato] abbati PLS Sisoio] Sisoium L Sisoni S 2 respondit] senex $a d d$. $S$ rationem $L \quad 2-3$ animam nostram saluare] s. a. $\mathrm{n}$. $\mathrm{L}$ animas nostras s. S 3 linguam nostram $\mathrm{L}$ prosiliet $\mathrm{L}$

8 -VPLS 2 Punctum habent post nauem PLS, post ignotus $\mathrm{V}$ quibusdam ignotus quidam] quibus q. i. (i. q. L) PLS 3 cupiebant L 4 inter se uaria loquebantur PLS de 2 om. L 6 perrexerunt] -xit et illi S ei VL abbas] beatus $P \quad 7$ et conuersus ad eum om. V 9 atrium] auris V non habet ostium LS 10 ingredi VS eorum om. LS stabulum] ingreditur add. S soluit] -et L soluens PS et ${ }^{3} \mathrm{om}$. PS 11 haec S quicquid] in add. $\mathbf{L}$

9-VPLS 1 est homo] extimo quia $\mathrm{P}$ affectat] quidem add. PLS 3 qui de] qui quidem a $\mathrm{S}$ uesperam LS quia om. $\mathrm{S}$ iuuamine] iuramine $\mathrm{S} \quad 4$ non om. $\mathrm{S}$ magnum] multos $\mathrm{V}$ iste add. $\mathrm{L}$ 


\section{LXXXIX - DE PEREGRINATIONE}

1-Dixit quidam senex: Peregrinatio quae propter Deum fit bona est si habuerit et silentium. Nam fiducia peregrinatio non est.

2-Abbas Arsenius solebat dicere: Peregrinus monachus in aliena terra nullius causae mediator accedat et quietem poterit adipisci.

3-Abbas Pambo dicebat: Sicut apis quocumque uadit mel operatur, ita et monachus quocumque pergit, si propter opus Dei perrexerit, dulcedinem bonorum operum potest efficere.

4-De abbate Megethio maiore dicebant patres quia egrediebatur de cella sua et cum ueniebat ei cogitatio ut relinqueret locum non reuertebatur in cellam, quia nec habebat ex saeculi huius instrumentum nisi forte unam acum unde palmarum folia finderet et in dies 5 tres paruulos funiculos operabatur quantum sibi ad escam sufficeret.

\section{XC - DE FVGIENDO HONORE CLERICATVS}

1-Abbas Theodorus, dum esset in Sceti diaconus ordinatus, nullatenus permanere acquiescebat, sed multis locis fugiebat. Et

\section{LXXXIX - VPLS}

1-VPLS 2 bona est si habuerit et silentium] si h. s. b. e. PL nam fiducia peregrinatio non est] $\mathrm{n}$. f. iam non est p. PS om. L

$$
2 \text {-VPLS } 1 \text { abba S } 2 \text { aliena terra] aliam terram } \mathrm{L} \text { nullus } \mathrm{V}
$$
causa $\mathrm{P}$ mediator] meditator $\mathrm{S}$

3-VPLS 1 abba S Pambo CARW $(\Pi \alpha \mu \beta \omega)$ : Pammon VPLS 2 pergit] -eret $\mathrm{V} \quad 3$ operum potest efficere] actuum p. e. (officere L) PLS

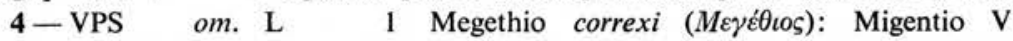
Iesion $\mathrm{P}$ Migezio $\mathrm{S}$ quia] qui $\mathrm{V} \quad 2$ ueniret $\mathrm{P} \quad 3$ in cellam] in cella $\mathrm{P}$ om. $\mathrm{V}$ ex] res $\mathrm{P}$ de $\mathrm{S}$ saeculi huius] h. s. $\mathrm{S}$ huius om. $\mathrm{V}$ instrumentum W: instrumento VPS 4 finderet] findebat $p$. corr. $\mathrm{P}$ fundebat $\mathrm{S}$ in dies] inde $\mathrm{P}$ in die $\mathrm{S}$

$$
\text { XC - VPLS }
$$

1 -VPLS 1 abba $S$ diaconus] dicens $\mathrm{V}$ decanus $\mathrm{S} 2$ nullatenus om. $\mathrm{S}$ acquiescebat] quiescebat $\mathrm{S}$ fugiebat] quiescebat $\mathrm{S}$ 
iterum senes reducebant eum dicentes: Ne derelinquas locum tuum. Quibus ille ait: Permittite me deprecari Deum si me iubet ministrare locum meum. Et orauit sic: Domine, si uoluntas tua est ut in ordinatione mea persistam, ostende mihi. Et ostensa est illi columna ignea a terra usque ad caelum pertingens. Et uox ad eum: Theodore, si potes fieri sicut columna ista, uade et ministra. Quod ille audiens, ultra nullatenus acquieuit. Sed cum uenisset in ecclesiam, deprecabantur eum ut si non ministraret uel calicem teneret. Qui non acquieuit dicens: Si mihi amplius de hac re uerbum feceritis, discedo hinc. Et sic eum dimiserunt.

2-Abbas Isaac audiens quia presbyterum eum patres uellent facere in Sceti, fugit in Aegyptum et ingressus in agrum latuit inter herbas. Contigit autem ut et patres qui eum sequebantur in eodem agro requiescerent quia iam nox erat et dimiserunt asinum suum ut pasceretur. Ille autem in pascendo peruenit ad locum ubi latebat abbas Isaac. Et mane facto, quaerentes asinum, inuenerunt et senem et admirati sunt. Cum autem uellent eum ligare, dicit eis: Iam non fugio quia scio hoc ex iussione Dei esse et quocumque fugero ad hoc peruenturus sum.

3-Abbas Motoes uenit aliquando de loco qui uocatur Ragitam in partibus Gebalonis. Erat autem cum eo etiam discipulus eius. Videns autem illum episcopus loci ipsius, tenens eum, inuitum presbyterum fecit. Et dum pariter comederent, dicit ei episcopus: Indulge mihi, abba, scio enim quia hanc causam nolebas, sed ego a te benedici desiderans hoc praesumpsi. Cui senex, pro humilitate ait: Et mea

3 locum]ordinem $\mathrm{L} \quad 4$ permitte $\mathrm{V}$ deprecare $\mathrm{L}$ ministrare] $-\mathrm{i}$ LS in add. $\mathrm{P} \quad 5$ loco meo $\mathrm{S}$ est $\mathrm{om} . \mathrm{S} \quad 8$ fieri] figi $\mathrm{S}$ et uade $\mathrm{S}$ 9 nullatenus] non $\mathrm{S}$ deprecabatur VS 10 ministrabat PLS 11 discede V 2 -VPS om. L 1 abba S patres] senes S 2 agro S 3 et om. PS sequebantur eum P 4 quiescerent $\mathrm{P}$ iam om. $\mathrm{S} \quad 5$ in om. PS 6 abba $\mathrm{S} \quad 8$ fugio] fugiero $\mathrm{P}$ haec $\mathrm{S}$ 3-VPS om. L 1 abba S Motoes (cfr. XXVIII, 1 et sim.): Moroes V Motues PS uocabatur P Ragitam] Ragitano V 2 Gebalonis] Iebalonis V Gebulonis P etiam om. S 3 illum episcopus loci ipsius] eum e. i. 1. S 4 dum] cum $\mathrm{P} \quad 5$ enim om. $\mathrm{P}$ a om. P 
cogitatio parum uolebat; sed in hoc laboro quia diuidi ab eo fratre qui mecum est nolo et solus non sufficio orationes meas implere. Dicit ei episcopus: Si scis eum esse dignum, ordino ego et illum. Respondit

10 abbas Motoes: Si quidem dignus sit nescio, unum autem scio quia de me melior est. Ordinauit autem et illum. Vtrique tamen ita permanserunt usque ad finem suum ut ad altare quantum ad oblationem sacrandam pertinet numquam accederent. Vnde dicebat senex: Confido in Deo meo quia non habeo grande iudicium propter ordinationem

15 hanc quia oblationem non mihi praesumpsi offere. Nam ordinatio illorum est qui sine culpa sunt; ego autem me bene cognosco.

\section{XCI - DE STVLTITIA PERFECTORVM}

1 - Cum quidam praesente Ammone episcopo negotium dicerent, ille non intendit in uerbis eorum. Vnde quaedam mulier dixit ad proximam suam: Iste senex stultus est. Ille autem audiens dixit ei: Quantos labores sustuli in solitudine, mulier, ut hanc stultitiam conse5 querer! Et modo propter te uis eam hodie ut amittam?

\section{XCII - DE QVIETA VITA}

1-Abbas Poemen dixit: Homo qui iuxta carnales aliquos actus est, similis est uiro stanti prope lacum altissimum. Quando enim

\footnotetext{
7 a S eo om. S 8 nolo om. $\mathrm{V}$ et] quia $\mathrm{S} \quad 9$ ego et] et ego $\mathrm{S}$ ergo eum et V 10 abba PS Motoes: Moroes V Motues PS sit] ego add. $\mathrm{S} \quad$ nescis $\mathrm{V} \quad 10-11$ de me melior est] $\mathrm{m}$. est me $\mathrm{S} \quad 11$ utroque $\mathrm{V}$ 12 quantum] quam $\mathrm{V} \quad 13$ pertinet $\mathrm{om}$. $\mathrm{P} \quad 15$ ordinatio] hic, inquit add. $\mathrm{P}$ XCI - VPLS

1-VPLS 1 episcopo] episcopus ad V 2 non om. V in om. S dicit PLS 4 sustuli in solitudine mulier] $\mathrm{m}$. sustuli (sustinui L) in s. PL mulier om. S sequerer $\mathrm{V} \quad 5$ modo propter te uis] ideo $\mathrm{p}$. te uix $\mathrm{S}$ eam hodie ut] ut e. h. PL hodie illam S amittam] admittam VS Sapientiam enim huius mundi stultitia est apud Deum add. $\mathrm{L}$$$
\text { XCII - VPLS }
$$

1-VPLS 1 abba S 1-2 iuxta carnales aliquos actus est] i. c. a. est actus $\mathrm{P}$ prope est a carnales a. actos $\mathrm{L} \quad 2$ simile $\mathrm{L}$ lacum] locum $\mathrm{V}$ quando enim] quem cum $\mathrm{L}$ enim om. $\mathrm{S}$
} 
uoluerit inimicus, facile eum mittit in lacum. Qui autem longe est a carnalibus desideriis, similis est uiro stanti longe a lacu, quem cum uoluerit inimicus trahere in lacum non inuenit quia longe est. Dum autem trahit mittit Deus adiutorium suum et liberat eum. Bonum est fugere a conuersatione carnali.

2-Abbas Motoes dicebat: $\mathrm{Si}$ quis uult habere requiem habitet in deserto; aut si in deserto non uult, inter plurimos habitet fratres. Quicumque enim uenerit, ab illis aliis suscipietur et ille habet requiem. $\mathrm{Si}$ autem in loco fueris nominato et non susceperis hominem, contristatur cogitatio tua; inter plurimos autem, uoluntatis tuae sensus, dum absconditur, requiescit.

3-Quodam tempore iudex de regione illa in qua habitabat abbas Poemen, unum hominem comprehendit. Et uenerunt petentes senem ut pergeret ad iudicem et excuteret eum. At ille dixit: Tres istos dies date mihi indutias et sic uenio. Per illos ergo tres dies orauit abbas Poemen dicens: Domine, ne mihi des hanc gratiam ut me petente dimittatur ille homo. Nam non me dimittunt hic residere quietum. Venit ergo post tres dies ut iudicem postularet. At iudex ait: Pro latrone me uenisti rogare, abba? Ille autem gauisus quod ei ad primum sermonem non praestitisset, reuersus est.

3 eum om. S 4 longe stanti PLS lacu] loco V laco L 5 in] ad PS inuenit] ualebit L 6 trahet VPL adiutorem S 7 est] ergo add. PLS fugire $\mathbf{P}$

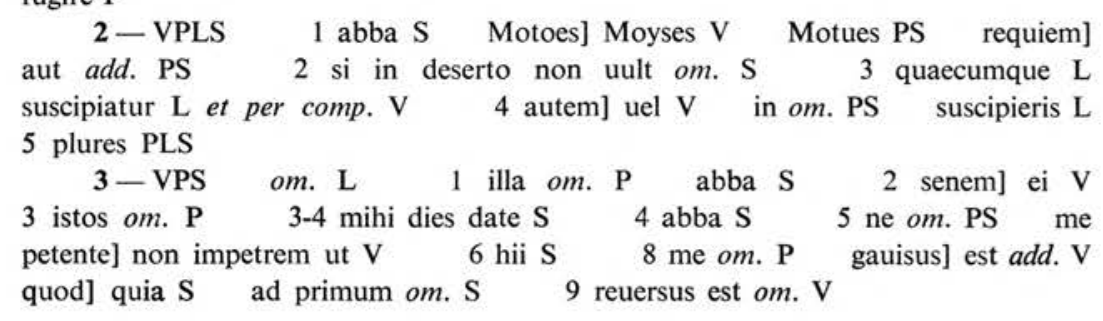




\section{XCIII - DE EREMO ET QVARE FVGIANT HOMINES AD EREMVM VEL IN SOLITVDINEM}

1-Beatus Antonius dicere solebat: Qui sedet in deserto tribus proeliis caret, id est, uisus, auditus et detractionis, et ad unum tantummodo opus cordis intertus est.

2 - Abbas Aion beatum Macarium postulabat ut ei sermonem diceret per quem possit saluari. Cui senex: Fuge, inquit, homines. At ille requisiuit dicens: Et quid est homines fugere? At senex respondit: Fugere homines est sedere in cella sua et pro peccatis iugiter 5 lamentari et quod super omnes uirtutes est tam linguam coercere quam uentrem.

3-Abbas Arsenius, dum adhuc saecularis esset et in palatio moraretur, orauit ad Deum dicens: Domine, uiam mihi per quam saluer ostende. Et audiuit uocem dicentem sibi: Arseni, fuge homines et salueris.

5 Cum ergo in solitudine recessisset et eundem sermonem orasset, audiuit sibi rursum uocem dicentem: Arseni, fuge, tace, quiesce. Haec enim sunt principia salutis.

4 - Item abbas Arsenius ab abbate Marco requisitus est aliquando cur fugeret homines. At ille respondit: Scit Deus quia diligo homines, solitudine $\mathrm{L}$

XCIII - VPLS fugiant] -iantur L -iunt $\mathrm{S}$ ad erenum uel om. PLS

1-VPLS 2 proeliis om. V caret] cadet $\mathrm{V}$ uisus auditus et

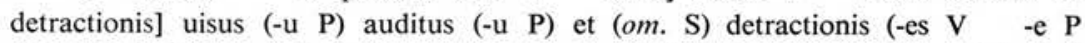
-ibus L) VPLS 3 tantummodo opus cordis] tantum o. cor $\mathrm{S}$ intentus] intendens $\mathrm{L}$ intentum $\mathrm{S}$ est om. $\mathrm{L}$

2-VPLS 1 abba S Aion correxi ('Aï $\mathrm{S}$ ): Salon V Sisoio L Saion PS postulauit L 3 est om. S 3-4 at senex respondit fugere om. S 3 at] tunc L 4 sua om. PLS 5 lamentare $\mathrm{V}$ uirtus $\mathrm{V}$ quam] et $\mathrm{S}$ 3 -VPLS $\quad 1$ abba S esset et] esset dum V om. S 2 Deum] Dominum L 3 Arsenii V 4 et] ut P salueris] -aris L saluus eris S 5 solitudinem PS 6 audiuit sibi rursum uocem] a. s. sursum u. V rursum (-us PL) a. u. s. (s. u. L) PLS Arsenii V tace] et add. S

4-VPLS 1 item abbas] idem a. (abba S) LS ab] ad L Marco] Macario VP Macarius L 
sed cum Deo pariter et hominibus esse non possum. Supernae enim multitudines ac uirtutes unius sunt uoluntatis; homines uero et multas habent uoluntates et uarias. Et ob hoc Deum relinquere et cum hominibus esse non possum.

5 - Quidam fratres dum linum ex Thebaida pergerent conparare, dixerunt: Per ocasionem beatum uideamus Arsenium. Quod cum ingressus ad eum Daniel discipulus eius nuntiasset, praecepit ut pro qua causa illic aduenissent de Alexandria ab eis requireret. Cum ergo renuntiasset quod propter linum pergerent conparandum, respondit Arsenius: Ergo faciem meam non uidebunt, quia non propter me, sed propter suum opus aduenerunt. Vade itaque et susceptis eis fac obsequium et dimitte eos dicens: Quia senex non potest uobis occurrere.

6-Cum quidam ad eundem beatum Arsenium ex fratribus uenisset uolens uidere eum, pulsauit ostium. Abbas autem Arsenius sperans suum esse discipulum aperuit ei, sed postquam alterum conspexit, mox se in terram proiecit in faciem. Illo autem ut surgeret postulante, respondit: Non hinc exurgam nisi discesseris. Ac per multas horas rogatus non adquieuit corpus adtolere usquequo discederet ille qui uenerat.

7-Quotienscumque autem in ecclesia cum aliis patribus idem beatus Arsenius conuenisset post columnam sedebat ne aut ipse alterius aut alter illius faciem possit inspicere.

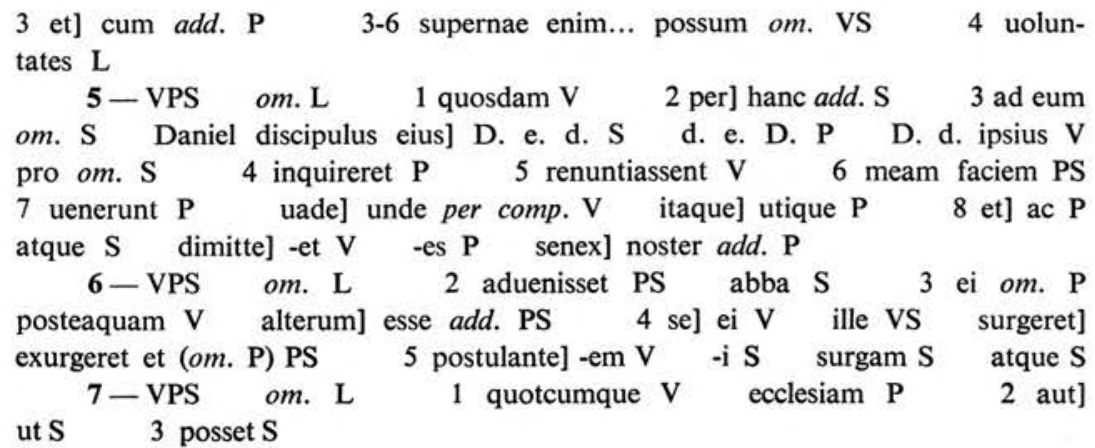


8-Cum ad eundem beatum Arsenium Theophilus uenisset episcopus cum iudice Alexandriae ciuitatis et postularet episcopus aliquem $a b$ eo audire sermonem, parum primum conticiscens, ait: Quod enim dixero custoditis? Quod cum utrique etiam grate respon5 dissent, addidit: Quocumque audieritis Arsenium, illic nullatenus accedatis.

9 - Item cum eum uolens archiepiscopus adorare, misisset nuntium ut id ipsum ei nuntiaret, mandauit ei: $\mathrm{Si}$ ueneris aperio tibi, si autem tibi et omnibus, si autem omnibus ultra hic non sedebit Arsenius. Quod cum audisset episcopus incepto abstitit ne eum cogeret 5 de loco ipso discedere.

10 - Abbas Besarion, dum ambularet cum discipulo suo per eremum, uenerunt ad quandam speluncam et ingressi ibi inuenerunt fratrem sedentem et funiculum operantem, qui neque respexit eos neque salutauit eos neque aliquid locutus est eis. Dicit ergo abbas Besarion ad

5 discipulum suum: Eamus hinc quia non uult hic senex loqui nobiscum. Et profecti sunt ad abbatem Ioannem. Cum autem reuerterentur, uenerunt ad eandem speluncam. Et dicit abbas Besarion: Ingrediamur iterum ad hunc senem ne forte uel modo persuadet illi Deus ut loquatur nobiscum. Et cum ingressi fuissent inuenerunt corpus tantummodo

\footnotetext{
8-VPLS 1 Arsenium om. S 1-2 episcopus uenisset L 2 iudice] iudex L -em S Alexandriae] Alexandrinae S et postularet] et postulasset $\mathrm{P}$ expostularet $\mathrm{S} \quad 3$ aliquem om. $\mathrm{S}$ parum] parumper PS conticiscens] tacens $\mathrm{P} \quad 4$ quod enim] quid ergo si $\mathrm{L}$ custodietis $\mathrm{S}$ utriusque $\mathbf{L}$ etiam $\mathrm{om}$. $\mathrm{S}$ grate] gratanter $\mathrm{P}$ respondissent] suscepissent $\mathrm{L}$ responderent $P \quad 5$ quocumque] quodcumque VS quodcum $\mathrm{L}$ illuc $\mathrm{PL}$ 9-VPLS 1 item] idem $L$ eum uolens archiepiscopus adorare] u. arch. a. eum et L misit P 2 id om. LS ipsud L ei ${ }^{1}$ om. P 2-3 si autem] nam si P 3 si autem omnibus] si a. et o. P om. L sedebit] sedet $\mathrm{L}$ residebit $\mathrm{S} 4$ incepto] in cethy $\mathrm{S}$ abstitit] astitit VS adstitit $\mathrm{L}$ nec $\mathrm{V}$ eum om. $\mathrm{S}$ cogerent $\mathrm{P} \quad 5$ ipso] suo $\mathrm{L}$ 10 -VPLS 1 abba $S \quad 2$ quendam $L \quad 3$ qui neque] cumque $S$ qui nec $\mathrm{P} \quad 4$ eos] illos $\mathrm{S}$ om. $\mathrm{PL}$ nec $\mathrm{P}$ ergo om. $\mathrm{S}$ abba $\mathrm{S}$ 5 hinc om. V hic om. L 6 reuerterentur] reuersi fuissent PL 7 abba S 8 senem ne forte uel modo] fratrem ne (si P) f. uel m. (m. nil S) PS persuadet] imperet $\mathrm{L}$ imperat $\mathrm{P}$ suadet $\mathrm{S} 9$ corpus tantummodo] tantum corpus $\mathrm{S}$
} 
mortuum. Et dicit discipulo suo: Veni, frater, conponamus illud quia propterea hic nos Deus direxit. Cum autem sepellirent, inuenerunt quia mulier esset et admirati sunt et dixerunt: Quemadmodum et mulieres conluctantur et uincunt daemonem! Et glorificantes Deum qui est omnium protector recesserunt inde.

11 - Beatus Macarius aliquando narrabat dicens: Venerunt ad me quondam iuuenes duo et unus quidem iam aetate plena, alter uero adhuc incipiente barbitio. Qui cum ignorantes me ipsum interrogarent, «ubi est abbatis cella Macarii», atque a me cur eum requirerent rogarentur «opera, inquiunt, eius magna et uitam praeconabilem cognoscentes uidere eum summo desiderio festinamus». Cumque ego me ipsum esse quem quaererent profiterer, mox meis pedibus prouoluti ut mecum illos habitare permitterem postulabant. Quos ut uiderem uelut ex diuitiarum opulentiis delicatos non posse mecum illos residere respondi. «Et si hic, inquiunt, tecum manere non possumus, alio tamen nos proficisci definita semel sententia mentis inpellit». Quo ego audito coepi intra me ipsum ita reputare: Si illos hinc abegero scandalum patiuntur; cum enim labor ipse conpellat eos hinc fugere, cur de mea murmurent uoluntate? Tunc dico illis: Venite, construite uobis cellulam si potestis. At illi locum sibi demonstrari tantummodo

10 dicit] abbas Bessarion add. $\mathrm{L}$ frater] ut $\mathrm{P}$ et add. $\mathrm{L}$ illum $\mathrm{V}$ 11 hic nos Deus] n. h. D. P D. n. in hunc locum S direxit] transmisit PLS 12 sunt et om. S 13 et ${ }^{1}$ om. S daemones PLS 14 est omnium] in omnia bona $P$

11 - VPLS 1 aliquando] de semetipso $\mathrm{L}$ narrauit $\mathrm{P}$ dicens] aliquando add. L uenerunt] aliquando add. $\mathrm{P} \quad 2$ quondam om. $\mathrm{P}$ iam aetate plena] i. p. aetas $\mathrm{L}$ i. pleno $\mathrm{P}$ iam aetate om. $\mathrm{S}$ 3 incipiente] -enti $\mathrm{P}$-ebat $\mathrm{L}$ barbitio] superbiciae $\mathrm{S}$ om. $\mathrm{L}$ ignorantes me ipsum interrogarent] interrogantes me ipsum et ab te requirerent $L$ i. me ipso int. V 4 esset LS eum om. V 6 summo] nimio S ego] ergo $\mathrm{S} \quad 7$ profiteret $\mathrm{S}$ pedibus] genibus $\mathrm{P} \quad 8$ illos] -is $\mathrm{L}$ eos $\mathrm{S}$ ut $^{2}$ ] cum PLS 9 opulentiis] -tius V -tis L -tia S illos] illic PS illi $\mathrm{L} \quad 10$ respondit $\mathrm{V}$ hoc $\mathrm{V}$ alii $\mathrm{L} \quad 11$ nos] non $\mathrm{V}$ semel $\mathrm{om}$. $\mathrm{S}$ mentis] nostrae add. $\mathrm{L}$ inpelli $\mathrm{S}$ quod $\mathrm{L} 12$ ego] ergo $\mathrm{V}$ tali add. $\mathrm{L}$ coepi intra me ipsum ita reputare] c. inter me i. ita r. S intra me i. c. r. dicens $\mathbf{P}$ intra me i. r. c. $L$ abegero GRB: abiero $V$ abire permisero PL abigero $\mathrm{S} 13$ ipse om. $\mathrm{L}$ conpellebat $\mathrm{L}$ hic $\mathrm{V} 14$ cur] cum $\mathrm{S}$ murmurent uoluntate] -arent uoluntatem $\mathrm{L}$ dicit $\mathrm{V} \quad 15$ cellam PS demonstrare $\mathbf{L}$ tantummodo om. $\mathrm{S}$ 
poposcerunt. Quibus ego alueolum cum secure et saccum plenum farinibus cum modico sale contradidi et petram ostendi durissimam qua incisa sibi habitaculum praepararent, quod lignis adlatis de palude contegerent. Arbitrabar autem ego confestim illos pro iniuncto labore 20 discedere. At illi interrogauerunt me quid illic solebant alii fratres operari. Respondi ego: Funiculum. Et sublatis foliis principium illis textus ostendi, quem ministratori dari pro pane recipiendo commonui. Et ita discessi. Illi uero cum summa patientia quae fuerant eis a me imperata fecerunt; ac per tres annos ad me nullatenus acces-

25 serunt. Et quia alii de longinquis regionibus uenirent ad me, illi uero nec a me aliquid requirerent nec ad alios propinquarent, non leuiter admirabar, uidens eos tantum in ecclesia oblationem cum silentio in oratione percipere. Desiderans ergo scire conuersationem eorum, septimana integra ieiunans, rogaui Deum ut mihi opera eorum digna-

30 retur ostendere. Et post hoc, profectus ad eos pulsaui ad ostium, quo aperto tacentes adorauerunt utrique; et postquam facta ex more oratione, consedi. Ille autem maior innuit minori et egressus est foras; sedebat ipse torquens funiculum nihil loquens omnino. Hora uero nona, pulsato ostio minor ingressus est; et maiore iterum innuente

35 egressus cibum quod reficeremur excoxit; eodemque nutu iussus, mensam cum tribus paximatiis adposuit tacensque stetit. Quibus

16 poposcerunt] -cunt $\mathrm{L}$ poscunt $\mathrm{P}$ ego] ergo $\mathrm{L}$ alueolum cum] malleo locum L 17 farinibus VU: panibus PLS tradidi $P$ 18 qua incisa] quia in scisa $\mathrm{V}$ sibi habitaculum] h. s. L habitacula $\mathrm{S}$ adlatis] et latis V ablatis $\mathrm{S} \quad 19$ contegerent] contexerunt V contegunt $\mathrm{S}$ arbitrabam $\mathrm{S}$ autem om. $\mathrm{S}$ confestim om. $\mathrm{S}$ iniuncto] hoc (om. S) sibi add. PLS 20 discederent L illi interrogauerunt] ille rogauerunt $\mathrm{S}$ solebant alli fratres] solent a. f. $\mathrm{P}$ solerent a. $\mathrm{f}$. L fratres solent $\mathrm{S} 21$ operare $\mathrm{L} \quad$ ego] illis add. PL foliis] palmarum add. $\mathrm{P}$ 22 illis] illi L illius S ministratoribus PLS 23 commonui] comoui V illi] ibi V fuerunt $P \quad 24$ a me om. L imperata] impetrata V ac] atque $\mathrm{S} \quad$ successerunt $\mathrm{V} \quad 25$ uenerunt $d u b . \mathrm{S} \quad 26 \mathrm{nec}^{1}$ ] neque $\mathrm{S}$ aliquid om. S nec ad alios] neque ad illos S 27 admirabar] ego add. L tantam P oblationem] -e L tantum add. V 27-28 cum silentio in oratione om. L 28 percipere] praeciperet $\mathrm{V} \quad 30$ haec PS $\mathrm{ad}^{2} \mathrm{om}$. PLS 31 quo aperto tacentes] quod cum a. tacente $\mathrm{V}$ utrique] utrumque $\mathrm{V}$ utriusque $\mathrm{L}$ 31-32 more oratione] memoratione S 32 autem om. PLS minore L 33 foris L sedebat] -bant V autem add. PLS 34 uero om. L ostio] atque aperto add. PLS maiorem S innuente] immunte $d u b . \mathrm{S} \quad 35$ quod reficeremur] quo r. (-entur S) PS 36 tribus paximatiis] paxomaziis (paxomatiis P) t. PLS 
ego dixi: Surgite, comedamus. Quo facto et adlato uasculo quo aquam solebant portare, potauimus. Ablata autem mensa, cum uesperesceret dicunt mihi: Discedis? At ego illic me requiescere uelle respondi. Mattam ergo mihi in uno angulo conlocauerunt et ipsi in altero angulo, quasi quieturi, zonas suas et analabios posuerunt. Cum autem quasi ad dormiendum se proiecerunt, iterum rogaui Deum ut mihi eorum operam declarasset. Et ecce ueluti dissipato tecto lux clara cellulam quasi medius dies impleuit, quam tamen illi non senserunt. Sed postquam arbitrati sunt me dormire, surgentes, cinxerunt se atque ad caelum manus extenderunt. Quos quidem ego quae facerent intuebar, illi autem me uidere non poterant. Et ecce uidi tamquam muscas daemones uenientes et in illius minoris ore atque oculis residere uolentes. Sed angelus Domini romphaea ignis armatus tam illum circumdabat quam daemones abigebat. Ad maiorem autem accedere non audebant. Prope diluculo uero se in eodem stratu proiecerunt et ego uelut expergefactus exurgo. Quod cum illi etiam fecissent, ille maior hunc mihi sermonem est locutus: Vis, pater, psalmos duodecim decantemus? Ac me consentiente minor ille frater quinque psalmos senis uersibus decantauit et unum alleluiaticum. Et per singulos uersus fax ignis de ore eius egressa ascendebat ad caelum. Idem et maior cum decantaret, quotiens ad psallendum labia deduceret, uelut funiculus ignis ex ore eius tendebatur ad caelum. Post quos ego quoque aliquantulum decantaui. Et egrediens ut pro me orare dignarentur expetii.

37 surgite] et add. S et om. PLS 38 portare] potare $\mathrm{P}$ potari L mensam $\mathrm{L} \quad$ uesperasceret $\mathrm{S} \quad 39$ illuc $\mathrm{L}$ requiescere uelle] $\mathrm{u}$. $\mathrm{r}$. $\mathrm{S}$ r. uel $\mathrm{V}$ 40 mattam] martam V mihi in uno angulo conlocauerunt] $\mathrm{m}$. in $\mathrm{u}$. a. collocarunt LS in $\mathrm{u}$. a. collocarunt $\mathrm{m}$. $\mathrm{P} \quad 41$ quietum $\mathrm{P}$ analabios GB (ảvåáßovs): amnabolios $\mathrm{V}$ anelabios $\mathrm{P}$ anoboladios $\mathrm{L}$ amilabios $\mathrm{S}$ 41-42 quasi ad dormiendum se] ad d. se q. S 42 proiecissent PLS iterum] ego add PLS rogaui Deum] D. oraui S 42-43 eorum operam declarasset] eorum (om. P) opera declararet PL declararet o. e. S 43 uelut L tectu V 46 quos] cum $\mathrm{L}$ quidem ego quae] ego quid $\mathrm{S} \quad 48$ ore atque oculis] o. et ore S ore usque o. L 49 circumdabat $\mathrm{om}$. L 50 daemones] homines S daemonum L abigebat] abiebat V ambigebat LS 51 diluculum PL stracto S 52 illi etiam] et illi S 52-53 sermonem mihi S 53 locutus est PLS duodecim psalmos S 54 atque S uersibus] uiribus S 55 alleluiaticum] alleluia $P$ allaticum $S$ per $o m$. L uersos $L \quad 56$ ore] est add. V eius egressa] e. eius V eius om. S ad] in L 57 labia] labra P funiculum V 58 ex ore eius] ex o. e. similiter PL om. S tendebatur] tenebatur $\mathrm{V}$ quos] hos $\mathrm{L}$ quoque om. S 59 expeti VL 
60 Illi uero tacentes meis sunt pedibus prouoluti. Et cognoui quoniam maior quidem esset in timore Dei perfectus; minorem uero adhuc daemones inpugnarent. Post paucos autem dies, maiore fratre recepto, tertio die et minor est assecutus.

\section{XCIV-QVIA IN SOLITVDINE AB OMNI STREPITV SVMMVM DEBEAT ESSE SILENTIVM}

1 - Abbas Arsenius dum ad aliquos fratres uenisset multae ibi erant arundines, quas cum uentus agitaret, facto sono, dixit Arsenius: Quid iste est terraemotus? Ventus, inquiunt, calamos hos concutit. Quibus Arsenius ita respondit: $\mathrm{Si}$ quis in solitudine residens Deum

5 orat cantante passere auscultat, iam non potest eandem intentionem mentis ad requiem custodire. Vos autem uicino terraemotu si potestis in requiem sedere satis admiror.

\section{XCV - QVAE SIT OBSERVANTIA EREMITAE}

1-Abbas Moyses ad solitarios solebat proferre sententias dicens: Quattuor sunt principales obseruantiae, id est, tacendi, seruandi mandata Dei, humiliandi semetipsum et angustia paupertatis. Tres autem has uirtutes homo difficile possidet, id est, ut semper lugeat, ut semper suorum memor sit peccatorum et omni hora ponat sibi ante oculos mortem.

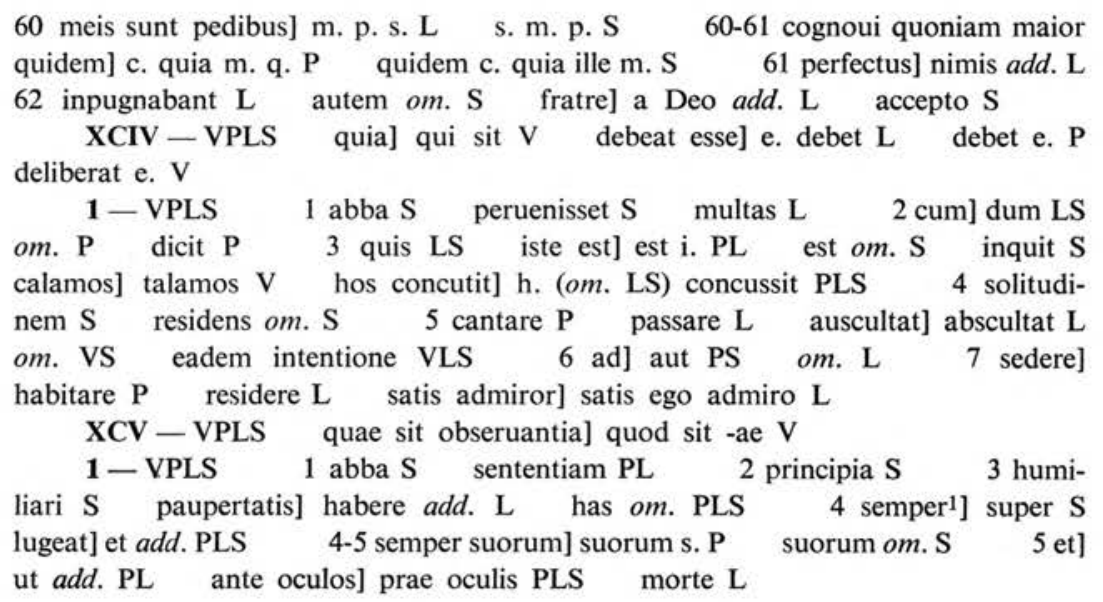


2-Beatus Antonius solebat dicere: Patres antiqui egressi sunt in deserto et ipsi sani effecti sunt medici et reuersi alios sanauerunt. Ex nobis autem si quem egredi contigerit in deserto, antequam ipsi sanemur, curam aliis adhibemus et reuertitur ad nos infirmitas nostra et fiunt ultima nostra peiora prioribus. Propter quod dicitur nobis: Medice, tibi prius curam inpendito.

3-Sancti patres prophetauerunt aliquando de ultima generatione, ex quibus unus uitae praecipuae nomine Ischyrion dixit: Nos quidem mandata Dei implemus. Requirunt illum alii patres: Quid hii qui post nos futuri sunt facient? At ille respondit: Media forte conplebunt. Et iterum requirunt eum: Post hos autem qui ueniunt, quid sunt facturi? Et respondit: Homines generationis illius mandatorum Dei opera non habebunt. Veniet autem super eos tentatio et qui inuenti fuerint in illa tentatione probati et de nobis et de patribus nostris meliores existent.

\section{XCVI - DE COENOBIO: QVOMODO IN EO VIVENDVM SIT}

1-Cum quidam frater abbatem requisisset Agathonem dicens: Quia uolo manere cum fratribus, dic mihi, abba, quemadmodum habitem cum ipsis? Respondit ei senex: Obserua hoc prae omnibus, ut

XCV, 2 lin. 4-5: reuertitur... prioribus - cf. Mat. XII, 45.

lin. 6: Medice... inpendito - cf. Luc. IV, 23.

\footnotetext{
2-VPLS 2 desertum S effecti] facti add. PLS et reuersi alios sanauerunt $\mathrm{om}$. L 3 quem] quidem $\mathrm{L}$ egredi] aegritudo $\mathrm{V}$ contigerit] contingerit $\mathrm{P}$ atigerit $\mathrm{S}$ desertum $\mathrm{S} 4$ alii $\mathrm{V}$ adhibemus] -eamus $\mathrm{L}$ adiuuemur $\mathrm{P} \quad 5$ fiunt] fiet $\mathrm{L} \quad 6$ curam tibi prius $\mathrm{S}$ inpedito $\mathrm{V}$ 3 -VPLS 1 aliquando] alii $\mathrm{V}$ om. $\mathrm{L} 2$ unus om. $\mathrm{P}$ Ischyrion] Exquirio $\mathrm{P}$ Isquirio $\mathrm{L}$ Esquirio $\mathrm{S}$ nos] non $\mathrm{V} \quad 3$ adimplemus $\mathrm{S}$ illum] eum $S \quad 4$ futuri] facturi $S \quad 5$ requisierunt $S$ uenerint $S \quad 6$ respondit] dicit $\mathrm{S}$ homines] -is $\mathrm{V}$ omnes $\mathrm{L}$ generationes PL illis $\mathrm{S}$ 7 autem om. L 8-9 et de nobis et de patribus nostris] de p. nostris (om. P) et de n. PL 9 existunt PL q. in c. $\mathrm{S}$

XCVI - VPLS de coenobio quomodo in eo] de c. q. in eum L de

1-VPLS 1 abbate $L$ requisiisset $S$ Agathon $L \quad 2$ quemadmodum om. $\mathrm{S} \quad 3$ ei om. $\mathrm{P}$ haec $\mathrm{S}$ ut] non $\mathrm{V}$
} 
qualis primo die ingredieris apud ipsos talis etiam reliquos peragas 5 et cum quiete adimplebis peregrinationem tuam. Custodi autem ne quando fiduciam loquendi assumas.

2-Idem abbas Agathon, dum cum beato Macario habitaret, dicit ei abba Macarius: Quare mecum sic habitas tamquam cum extraneo? Respondit abba Agathon: Cur sic dixeris miror. Frequenter enim, aliquo peregrino praesente, fiduciam loquendi assumo, quod tecum 5 mihi non licet habitanti.

Graue enim malum est et paene omnibus peius fiducia, quae genitrix est omnium paene malorum. Monacho autem non dicam inter alios, sed nec in cella propria licet habere fiduciam.

Fiducia enim et risus igni sunt similes calamos consumenti.

3-Abbas Poemen abbatem Nestorem sedentem in coenobio requisiuit dicens: Vnde adeptus es hanc uirtutem, frater, ut quotienscumque tribulatio contingit in coenobio ne loquaris neque mediator accedas? Et cum nollet dicere, postea, conpulsus a sene, dixit: Indulge 5 mihi, abba, quoniam in principio, quando ingressus sum in coenobio dixi cogitationi meae: "Ecce tu et hic asinus unum estis. Sicut enim iste asinus uapulat et non loquitur, iniuriatur et nihil respondit, ita ergo esto et tu». Nam sic dicit psalmus: «Vt iumentum factus sum apud te, et ego semper tecum».

XCVI, 3 lin. 8-9: Vt iumentum... tecum - cf. Ps. LXXII, 23.

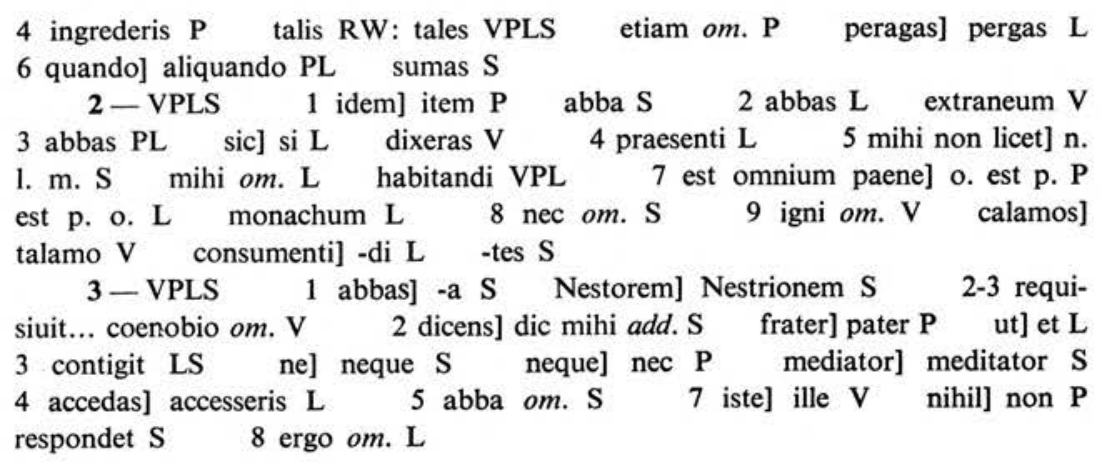


4-Cum aliquando Mazices superuenientes in Sceti multos ex patribus occidissent, abba Poemen, una cum alio abbate seniore sibi, nomine Anub, et cum aliis quinque fratribus, fugiens inde uenit in locum qui dicitur Terenutidis et inuenerunt ibi templum desertum et manserunt in eo hii septem pariter, donec cognoscerent ubi mansuri essent in Aegypto unusquisque. Dicit ergo abba Anub qui erat senior: Septimana hac unusquisque requiescat apud se et alter ad alterum non loquatur. Cum autem sic facerent, erat in templo statua cuiusdam idoli. Abba uero Anub exurgens mane lapidabat eam; et uespere perueniens dicebat ad eam: Peccaui, indulge mihi. Et per totam septimanam similiter fecit. Die ergo sabbati cum pariter conuenissent, dicit abba Poemen: Quod uoluisti hac tota facere septimana, ut homo fidelis idolo diceres: «Indulge mihi»? Dicit ei senex: Numquid uel lapidabat idolum homo fidelis in facie? Sed hoc propter uos feci. Dicite ergo mihi: Numquid quando ego idolum lapidabam locutum est idolum aut iratum? Et iterum quando indulgentiam petebam conturbauit se aut gloriatum est? Cui abba Poemen: Non, inquit. Tunc senex ait: Fratres, ecce septem sumus. Si uultis ergo ut pariter maneamus, sicut idolum istud, nec quando iniuriatur aliquis irascatur nec quando ueniam petitur glorietur; sin autem ita non uultis, unusquisque quo uult uadat. At illi proicientes se in terram spoponderunt

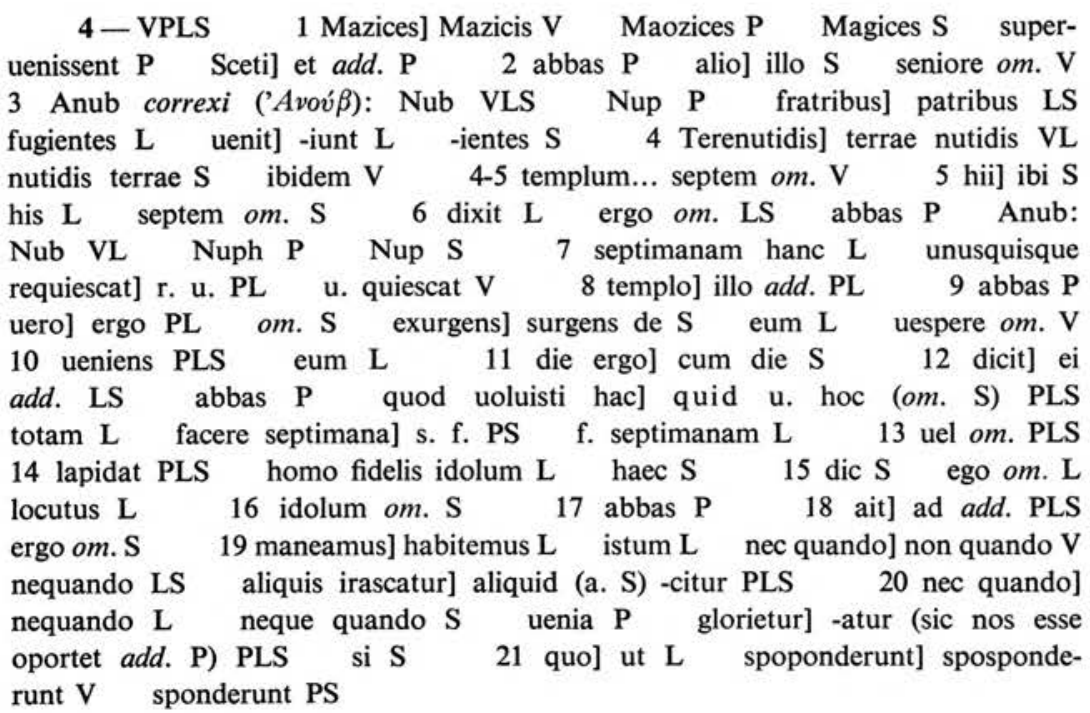


se ita facturos et sic permanserunt per multos annos; unum ex ipsis facientem dispensatorem; quicquid autem positum esset in mensa reficiebant, nullo dicente aut: «Affer nobis aliud» aut: «Hoc nolo comedere».

Quattuor siquidem horis dormiebant in nocte et quattuor psallebant et quattuor operabantur. In die uero usque ad sextam operabantur; deinde uero usque ad nonam legebant, findentes folia palmarum; et post hoc uictum sibi praeparabant.

\section{XCVII - NON DEBERE DE COENOBIO IN COENOBIO MVTARI}

1-Quidam senex dixit: $\mathrm{Si}$ in coenobio permanes, ne mutes locum; noceberis enim non leuiter. Sicut auis cubans super oua, si frequenter exurgat putrida ea facit, ita et monachus mortificat fidem de loco in loco transgrediens.

$5 \quad$ Et sicut arbor fructum afferre non poterit frequenter transplantata de loco in loco, sic nec monachus poterit fructum caelestem afferre frequenter de loco in loco transgrediens.

\section{XCVIII - QVI SVNT SIMILES VNIVS MERITI FRATRES}

1-Quidam frater requisiuit abbatem Poemenem dicens: Qui sunt unius meriti fratres? Respondit senex: Si fuerint tres simul,

22 unum] autem add. L 23 facientem] facientes (sibi add. L) PLS positum] ponitum PS per. comp. V esset om. S mensam PL 24 affers S hoc om. V 26 et quattuor psallebant om. S 27 in die uero usque ad sextam operabantur] operabantur om. S om. V 28 uero om. PL fidentes S 29 haec $\mathrm{S}$

XCVII - VPLS coenobio 2 ] -um PLS mutare L

1 -VPLS 1 permanens VS 2 noceberis] -bis $\mathrm{S}$ nocueris $\mathrm{L}$ cumbans L 2-3 frequenter exurgat] f. de nido exurget L 4 locum PS transgressus LS 5 potest PLS 5-6 frequenter transplantata de loco in loco] f. $t$. de 1 . in locum $S$ de 1 . in 1 . f. $t$. PL 6 neque $S$ caeleste V 7 loco $^{2}$ ] locum $\mathrm{S}$

XCVIII - VPLS quod V sint $\mathrm{S}$ similes unius meriti] u. m. s. P unius meriti om. V fratres om. P

1 - VPLS 1 abbatem Poemenem] ab abbate Poemene P 2 fratres] similes $\mathrm{P}$ senex om. S simul] uel V 
unus quidem in omni uerbo uel opere quiescens, alter autem infirmans et gratias agens, tertius uero cum munda conscientia obsequium faciens, hii tres unius operis sunt.

\section{XCIX - QVALIS DEBET ESSE GENERALIS OMNIVM VITA}

1-Abbas Poemen requisitus a quodam: "Quomodo debeat homo uiuere christianus?», respondit dicens: Sicut Daniel propheta aduersus quem non est inuenta accusatio nisi in sola puritate cordis permanens quam in Dei cultu semper exhibuit.

Iniuriari autem aut mentiri aut periurare alienum a christiano est.

Per has autem quattuor res anima maculatur, id est, si amicitiam quis cum potentibus habuerit concupiscentias carnales studens, uel si de proximo suo detractauerit, uel si per ciuitatem ambulans oculos suos non custodierit et si quamcumque notitiam cum muliere habuerit.

2-Beatus Arsenius referebat eo quod dum propria resideret in cellula uocem sibi dicentem audiuit ut egrederetur foris propter opera hominum contemplanda. Et egressus uidit quendam hominem aquam de puteo haurientem atque in uaso forato mittentem, de quo aqua egrediens fundebatur in puteum. Et iterum parum progrediens uidit alium aethiopem ex lignis a se concisis sarcinam facientem, quam cum tentans inportabilem sentisset alia iterum super eam ligna congessit.

\footnotetext{
4 agens] Deo add. PL 5 hii tres unius operis sunt] hii t. unus operis meriti sunt $\mathrm{L}$ om. V 
Similiterque tentando, cum nec mouere sarcinam potuisset, tamen addere alia ligna non desistit. Et iterum parum progressus Arsenius

10 uidit ante portam ciuitatis duos iuuenes sedentes in equis, qui lignum longum transuersum portantes a latere, ingredi non poterant ciuitatem. Lignum enim quod ita gestabant non eos permittebat intrare. Sequi autem uel humiliare se alter alteri non ualebant; et ita foras portam manserunt utrique. Ille igitur qui hoc beato monstrabat Arsenio

15 dicit ei: Hunc quem prius uidisti aquam haurire et uaso forato rursus effundere, homo est faciens eleemosynam, bonum opus nitens efficere, sed quia in aliis operibus iniquitates saepe conmittit, propter haec mala id etiam parum boni coinquinans perdit. Illum autem quem uidisti ligna concidere et grauem sarcinam additis semper aliis facere

20 grauiorem, homo est in peccatis plurimis constitutus qui, pro poenitentia, aliud super peccatis suis peccatorum onus augmentat. Hos uero quos transuerso ligno retinentes in ciuitate non posse ingredi conspexisti, isti sunt qui iugum cum miserabili uidentur ferre superbia et alter alteri humiliare se noluerunt ut per haec emendati uiam Christi

25 humilem sequerentur, atque ideo extra regnum Dei tam hii quam illi remanserunt.

8 nec mouere sarcinam] neque s. m. S 9 alia ligna addere PL desistit VU: destitit PLS 10 in] qui S qui om. S 11 a] e L 12-13 sequi autem] sed neque autem cum litura super neque autem $L \quad$ s. aut $S \quad 13$ uel] et $L$ om. $\mathrm{S}$ se om. $\mathrm{P}$ ualebant] uolebant $\mathrm{S}$ p. corr. $\mathrm{L}$ alleuant $\mathrm{P}$ foris $\mathrm{S}$ portam] portare $\mathrm{V}$ porta $\mathrm{S} 14$ remanserunt $\mathrm{S}$ utrique] utriusque sed p. corr. uterque L haec PLS monstrabat Arsenio] A. m. S monstrauit A. L 15 uaso] uase $\mathrm{L}$ uasse $\mathrm{S}$ forato] ferrato $\mathrm{S}$ rursum PLS 17 iniquitatem PLS 18 id] illud PLS perdit] perdidit $\mathrm{P}$ illud add. S 19 concidere] concindere $S$ additis] addidit $L$ addendo $P S$ semper aliis] super $P$ om. LS 20-21 pro poenitentia aliud] per -am ad V 21 super VU: semper PLS augmentant $\mathrm{L} \quad 22$ qui $\mathrm{P}$ retinentes in ciuitate] -e in ciuitatem PLS 23 iugum cum miserabili] c. m. i. S cum miserabili cum litura et supr. script. legis diuinae L ferre] cum add. sup. lin. L superbia] -am V -ae S 24 se humiliare PLS ut per] super S hoc PLS 


\section{C-NON LOQVENDVM DE SCRIPTVRIS SANCTIS NISI INTERROGATVS}

1-Interrogauit frater senem dicens: Si legi aliquod capitulum, uis ut exponam illud? Respondit: Scriptum est: $\mathrm{Si}$ quis respondit priusquam audiat, insipientia et inproperium est illi. Si ergo interrogaris, dic; si uero non, tace.

2-Abbas Alonius dum ministraret cum diligentia senibus, laudauerunt singuli diligentiam eius. Ille autem nihil respondit eis. Dicit ei unus: Quare non respondisti senibus cum te laudarent? Respondit Alonius: Si respondissem illis eram quasi suscipiens laudem eorum.

3 - Conuenerunt aliquando patres conquirentes secum de Melchisedec et obliti sunt uocare abbatem Coprem. Postea autem uocantes eum interrogauerunt pro eodem capitulo. Ille autem percutiens os suum tertio, dixit: Vae tibi, Copres, quia quae tibi mandauit Deus illa desisti agere et quod non quaerit a te haec scrutaris. Audientes hoc patres recesserunt unusquisque in locum suum.

4-Dixit abbas Poemen: Recede ab omni contentioso in disputationibus.

Anima enim recedens ab humanis confusionibus et conturbationibus circumdat illam spiritus Dei.

C, 1 lin. 2-3: Si quis... illi-cf. Prou. XVIII, 3; Eccli. XI, 8.

$$
\text { C-VPS om. } \mathrm{L} \text { de non loquendo } \mathrm{S} \text { sanctis] sacris } \mathrm{P} \text { interrogat } \mathrm{S}
$$

1-VPS om. L 2 ut om. S illum V scriptum est om. V 3 priusquam] antequam $\mathrm{S}$ ergo] uero $\mathrm{V}$ om. $\mathrm{S} \quad 3-4$ interrogat $\mathrm{V}$

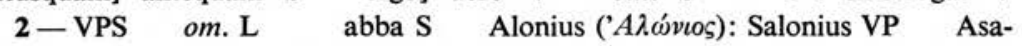
lonius S cum diligentia] diligenter PS 2 eius] illius PS eis] illis PS 4 Salonius VPS

$$
\text { 3-VPS om. L } 1 \text { de] pro PS } 3 \text { interrogauerunt pro eodem] i. }
$$
eum pro quodam S 3-4 suum os PS 5 illa desisti VU: dimisisti illa PS quaeris $\mathrm{V}$ a] ad $\mathrm{S}$ haec] hoc PS 6 hoc] haec PS

4-VPS om. L 1 abba $S$ Poemen recede ab omni] Poemenius secede ab homine $\mathrm{P}$ contentioso] contentione $\mathrm{V}$ intentioso $\mathrm{P} \quad 3$ confusionibus] contentionibus PS 4 illa V 
5 - Venerunt aliquando fratres ad beatum Antonium qui uolens eos probare interrogauit eos aliqua uerba de Scripturis. Illi autem secundum sensum suum reddit unusquisque responsum. Dixit autem ad abbatem Ioseph (erat enim cautus): Tu quid dicis? Ille autem 5 dixit: Nescio. Dicit autem abbas Antonius: Ecce iste inuenit uiam. Hoc autem dixit ut ostenderet non debere aliquem praesumere suo sensu de sanctis proloqui Scripturis.

6-Interrogauit frater senem dicens: Qualem mensuram iubes in loquendo ut teneam? Respondit: Si fuerint sermones tui otiosi, dimitte illos; si autem sunt boni qui aedificent, da locum bonis et loquere. Tamen uel si boni sunt non facias moras in sermonibus tuis, sed cele5 rius abscide et habebis requiem.

7-Perrexerunt duo fratres ex diuersis cellulis ad unum sanctum senem in Sceti sedentem. Dixit autem unus ex illis: Abba, omne uetus Testamentum et nouum memoriter didici. Respondit ei senex: Implesti aerem uerbis. Alter autem dixit: Ego uero uetus et nouum

5 Testamentum scripsi et apud me habeo. Respondit et huic senex: Et tu similiter fenestras tuas implesti chartis.

\footnotetext{
5 -VPS om. L 1 beatum] abbatem PS 2 ille $\mathrm{S} \quad 3$ reddidit $\mathrm{S}$ 4 enim] autem $P \quad 5$ dicit] dixit $P$ abba $S \quad 6$ haec $S$ non debere aliquem] et ideo habere a. V a. n. d. S

6-VPS om. L 1 item interrogauit P fratrem senex V 1-2 in loquendo iubes P 2 respondit $\mathrm{om}$. S tui $\mathrm{om}$. PS otiosi] occisi P 3 sint $\mathrm{S} \quad 4$ moram $\mathrm{S}$

7-VPS om. L 2 abba om. S 3 et nouum testamentum P didisci V ei senex om. PS 4 implesti] te add. V uero om. PS 5 testamentum om. P et ${ }^{2}$ om. PS huic om. P senex] dixit $\mathrm{V}$ ut hic add. $\mathrm{P} \quad 6$ similiter om. $\mathrm{P}$ fenestras tuas implesti] i. fenestris tuis $\mathrm{V}$
} 


\section{CI - DE SENTENTIIS SEPTEM QVAS LOCVTVS EST ABBAS MOYSES AD ABBATEM POEMENEN}

1- Haec sunt quae si quis aut in coenobio aut in solitudine uel in ipso saeculo positus custodit, poterit saluari:

In primis sicut scriptum est, debet homo diligere Deum ex tota anima et ex tota inteligentia sua.

Secundum debet homo diligere proximum suum sicut seipsum. 5

Tertium debet homo mortificare semetipsum ab omni malo.

Quartum non debet homo diiudicare fratrem suum in aliqua causa.

Quintum non debet homo malum facere alicui in aliqua causa.

Sextum debet homo priusquam exeat de corpore mundare semetipsum ab omni inquinamento carnis et spiritus.

Septimum debet homo cor contritum et humiliatum habere, quod ille potest implere qui semper sua peccata et non proximi considerat.

CI, lin. 3-4: debet... sua - cf. Mat. XXII, 37.

lin. 5: debet... seipsum - cf. Mat. XXII, 39.

lin. 7: non debet... diudicare $\ldots$ causa - cf. Mat. VII, 1; Luc. VI, 37.

lin. 8: non... malum... causa - cf. I Pet. III, 9; I Thes. V, 15.

lin. 11: cor... humiliatum - cf. Ps. L, 19.

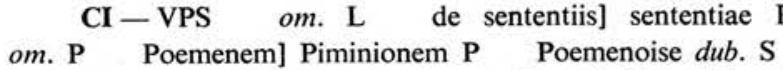

1-VPS om. L 1 ante haec habet: Abbas Moyses locutus est ad abbatem Piminionem de septem sententiis dicens $P$ quae] quia $V$ aut ${ }^{1}$ om. PS 2 ipso] isto $\mathrm{V}$ ponitus $\mathrm{S}$ custodiat PS saluari] se saluare $\mathrm{S} \quad 3-4$ in primis... sua $\mathrm{om}$. V 4 inteligentia] diligentia $P \quad 5$ secundum $\mathrm{om}$. VS 6 tertium $\mathrm{om}$. VS mortificare semetipsum] m. (-i P) seipsum PS 7 quartum $\mathrm{om}$. VS iudicare P in aliqua causa $\mathrm{om}$. PS 8 quintum $\mathrm{om}$. VS in aliqua causa] malum V 9 sextum om. VS 9-10 seipsum PS 12 septimum $o m$. VS homo cor contritum] h. semper cor c. (c. cor P) PS 12 qui] quisquis $P$ et $o m$. PS considerat] Finiunt rubricae de Vitis Patrum. Deo Gratias add. P Sine explicit Paschasii, sequuntur sententiae Martino explicite tributae in VS 

APPENDIX 


\section{SIGLA ET MANV SCRIPTI}

L - Londinensis, Brit. Mus. add. 30855, saec. XI.

G - Stutgartensis, Bibl. Region. Theol. 303, saec. VIII-IX (Germanus).

H - Bruxellensis, Bibl. Reg. Belg. 8216-18, saec. Ix (Hunus).

R - Rotomagensis, Bibl. Mun. 1375, saec. XI.

W - Wiesbaden, Bibl. Region. 8, saec. xv.

F - Vienensis, Bibl. Nat. Austriae 386, saec. XII (Francus).

B - Bruxellensis, Bibl. Reg. Belg. 8372, saec. XII.

T - Einsiedeln, Bibl. Monast. 246, saec. xI (Transalpinus).

$\mathrm{X}-$ Parisinus, Bibl. Nat. lat. 10840, saec. XI.

Z-Monachensis (in Bauar.), Bibl. Region. lat. 17139, saec. XII. 
APOPHTHEGMATA QVAE IN QVIBVSDAM MANV SCRIPTIS PERMIXTA CVM PASCHASII TEXTV INVENIVNTVR, SED VT SPVRIA EXISTIMANDA SVNT

App. 1-Dicebat quidam ex patribus: Omne quodcumque asperum aut graue pro Deo sustinens ne manifestes illud hominibus et perdas mercedem tuam, sed soli Deo sint cognita qui uidet in occulto a quo et retributionem tui operis expectes.

App. 2-Sanctus Hilarion dixit: Ille bene dispensat qui pro Christo sibi nihil reseruat.

App. 3-Dixit senex: Quaecumque pro timore Dei eleemosynam erogaueris ne cum duritia aut cum asperitate illud porrigas, sed cum hilaritate animi et uultu placido pauperem intuere et sic eum ab te et honorifice adtole, sciens enim quia munus pauperi gazophilacium Christi est. Hilaremque datorem diligit Dominus.

App. 4-Interrogauit frater quendam senem dicens: Dic mihi, pater, qualem mensuram debeo haberi in id quod de donis Domini in cella habentur? Cui senex respondit: Periculosum est seruienti Deo auaritiam studere. Sed si uis requiem habere, ne thesaurizes tibi aliquid ante tempus neque plus quam expedit congreges, sed plus de caelestia quam de terrena esto sollicitus, sicut ipse Dominus dixit: Vbi enim est the-

App. 1 Inuenitur tantum in $\mathrm{L}^{1}\left(f l .8^{\mathrm{v}}\right)$ in initio capituli $\mathrm{VI}$ : De toleranda penuria, ante Pasc. VI, 2 (VI, $\left.1 \mathrm{om} . \mathrm{L}^{1}\right)$.

App. 2 Inuenitur tantum in serie media contaminata (Lib. VII) post XIV, 6. Edimus lectionem codd. RWF 2 nihil sibi $\mathrm{F}$

App. 3 Inuenitur tantum in cod. $\mathrm{L}^{1}\left(f l .16^{\mathrm{v}}\right.$ ) in initio capituli XVII: Non debere scrupulosum esse in largiendo. (XVII, $1 \mathrm{om}$. $\mathrm{L}^{1}$ )

App. 4 Inuenitur tantum in cod. $\mathrm{L}^{1}\left(\right.$ fol. $\left.16^{\mathrm{v}}-17^{\mathrm{r}}\right)$ in initio capituli XVIII: De 
saurus tuus, ibi et cor tuum erit. Quoniam qui thesaurizat nescit cui ea congregat, qui uero erogat sine dubio lumen ante se mittit. Et ideo nihil utilius credimus quam de donis Domini semper largire.

App. 5-Dicebat autem discipulis suis: Vestis quoque sit monachi quae nuditatem et frigorem repellat, non inditi coloris qua iactantia elationis aut in uanitate anima fluctuet.

App. 6-Sanctus Hilarion abbas dixit: Maledictus homo qui prius escam carnalem quam spiritalem quaesierit; quicquid agat oportet semper in animo bona meditari.

App. 7 - Abbas Paulus Simplex dum quendam infirmum restaurare uellet, in oratione et ieiunio persistens dixit: Vere hodie non manducabo panem nisi eum sanaueris. Et statim omnis febricitas ab infirmo discessit.

App. 8- Fuerunt et alii similiter septem probatissimi uiri qui in ea eremo quae Sarracenis est contigua habitabant, cellulis quidem haud longe a se diuisis, sed uinculo caritatis conexi, quorum unus uocabatur Petrus, alius Stephanus, tertius Ioannes, quartus Georgius, quintus Theodorus, sextus Felix, septimus Laurus. Hi ergo in sterili ac uastissima solitudine et paene hominibus inhabitabili commorantes, semel sibi

reprimenda auaritia (XVIII, 1 om. $\left.\mathrm{L}^{1}\right) \quad 9$ lumen correxi: lamea dub. $\mathrm{L}^{1}$

App. 5 Inuenitur in serie breui post XIX, 1 (quod de Agathone agit) unde ad mediam seriem contaminatam (Lib. VII) transiit. Editum est a Rosweydo (cf. PL LXXIII, coll. 1064-1065). Utimur mss. GHR 2-3 qua iactantia] quae i. (-am H) HR 3 anima fluctuet] a. (-ae R) -etur HR

App. 6 Inuenitur tantum in serie breui post LXIII, 1. Edimus textum mss. GHB 2 agat] agit homo (om. H) HB

App. 7 Inuenitur tantum in serie media contaminata (Lib. VII) post LXVIII, 2. Sequimur lectionem mss. RWF 3 manduco W

App. 8 Inuenitur in mss. seriei uulgatae libri III Vit. Patr. In editione Rosweydi n. 200. Edimus textum mss. TXZ 1 et om. $Z$ similiter om. $\mathbf{Z}$ 3 haud] aut $X \quad$ sed om. $Z \quad 6$ in sterili] horribili $Z \quad 7$ sibi] ibi $Z$ 
in septimana uidendos se praebebant. Sabbatorum namque die hora diei nona, conueniebant singuli de suis locis ad locum sibi condictum, deferentes unusquisque si quid inuenire poterat. Et unus quidem deferebat nuces, alius lactorones, alius dactylos, alius ficus, alius herbas usibiles, id est, lapsanium, pastinacas, $\uparrow$ scariuitas et petroselinum. Iste quippe erat perpetuus eorum uictus; panem namque et oleum uel potum extra usus habebant; tantummodo enim supradictis herbis et pomis sustentabantur. Vestimentum eis palma solummodo praebebat; aqua in locis illis minime inueniebatur, neque enim aliter potabantur quam exeuntes mane ac discurrentes per diuersas herbas colligebant rorem qui affluentissime ibi cadit et inde tantummodo bibebant. Cumque, ut diximus, in unum conuenirent locum, agentes Deo gratias sumebant cibum. Post refectionem uero usque ad uesperum sedentes, meditabantur de Scripturis sanctis. Non enim discurrebat inter eos saecularis fabula, non cura saeculi, non actio terrenarum rerum, sed solummodo collatio spiritalis, regni caelestis desiderabilis commemoratio, futura beatitudo, gloria iustorum, poena peccatorum, sanctorumque omnium quies qui iam inter beatas paradisi sedes laetantur. Haec commemorantes suspirabant ex immo pectore et flebant uberrime. Cumque per totam noctem

9 die $\mathrm{om} . \mathrm{X} \quad$ diei $o m . \mathrm{T} \quad 10$ deferens $\mathrm{Z} \quad 11$ poterant $\mathrm{Z}$ lactorones] lactucas $T \quad 12$ alius $\left.^{2}\right]$ aut $T \quad$ ficos $Z \quad 13$ pastenacas XZ scariuitas et petroselinum] p. cariuitas $X \quad$ s. et petriscillum $\mathrm{T}$ carisitas et petrischilia $\mathrm{Z}$ Ad hanc crucem soluendam legimus hoc apophthegma in omnibus manu scriptis nobis notis $e$ saeculis XI, XII et XIII, scilicet 16, praeter tres textus nostri. Ecce lectio eorum et numerus codicum: scariuitas 2 , scarauitas 4 , scarauitos 2 , scaruitas 2, cariuitas 2, caruittas 1 , caricas 2, caruncas 1; petriscillum 1, petrischillum 2 , patrischillum 1 , petrisilum 3 , petricillos 2 , petroscillo 1 , petrosillum 1 , petrosilium 1 , petrosilinum 3 , petrosinilum 1 . De petroselino cf. M. H. da Rocha Pereira, Notes lexicographiques sur le «Thesaurus Pauperum» in ALMA, XXIV (1954) p. 259.15 extra usus] exosos $\mathrm{X}$ tantum $\mathrm{X} \quad 17$ eis palma solummodo praebebat] eorum $\begin{array}{llll}\text { palma p. s. } Z & 18 \text { aliter] alter } X & 19 \text { colligentes } Z & 20 \text { qui] }\end{array}$ quia $X Z$ ibi om. $X \quad 21$ locum conuenirent $Z \quad 22$ Deo] Domino $T \quad 23$ uesperam $X \quad 25$ terrenarum actio $Z$ 28 requies TZ 29 ex $\mathrm{om}$. X 
uigiles permanerent celebrantes Domino laudes, die dominico hora nona loquendi secum et uidendi se terminum capiebant. Rediebat enim unusquisque ad cellulam suam, in qua solus soli Deo diebus noctibusque uacabat. In his igitur studiis eos positos Sarraceni late per eremum discurrentes reppererunt et irruentes super eos de eremo eiecerunt atque ligantes eos pedibus suspenderunt, multisque iniuriis affectos, ad extremum focum subtus eos de herbis amarissimis congesserunt, ubi incredibiliter cruciati lumina oculorum ex amaritudine fumi amiserunt. Et postquam multis tormentis eos afflixerunt, semiuiuos dimiserunt. Ex quibus unum nouimus in quodam loco plurimum postea superuixisse tempus; ceteri uero ubinam fuerint deuoluti penitus ignoramus.

33 rediebat] redibat $X \quad$ rediebant $Z \quad$ cellam $Z \quad 34$ noctibusque uacabat] ac noctibus uacabant $Z$ igitur] ergo $Z \quad 38$ focum] ignem $\mathrm{X} \quad 40$ admiserunt $\mathrm{Z} \quad 42$ plurimo $\mathrm{X}$ tempus] tempore $\mathrm{X}$ temporis $\mathrm{Z}$ 


\section{B I B L I O G R A F I A}

Ali (M. Said) - Gramática histórica da lingua portuguesa, S. Paulo, 1966.

Amaral (Dom António Caetano do) - Vida e opúsculos de S. Martinho Bracarense, Lisboa, 1803.

AmÉlineAu (E.) - Monuments pour servir à l'histoire de l'Égypte Chrétienne. Texte copte et traduction française in Annales du Musée Guimet, XXV (1894), Paris.

- Saint Antoine et les commencements du monachisme chrétien en Égypte, Bibliothèque de la Propagande, Bruxelles, 1914.

Antolín (P.e Guillermo)-Estudios de códices visigodos. Códice a. II. 9 de la Biblioteca del Escorial in Boletin de la Real Academia de la Historia, LIV (1909), Madrid.

AvgvstinI (S. Aurelii) - Confessionum libri XIII (...) studio Josephi Capello, Taurini, 1948.

BaIlly, (A.) - Dictionnaire grec-français, Paris, 1950.

BARDY (Gustave) - La question des langues dans l'Église ancienne, I, Paris, 1948.

BARLOW (Claude W.) - Martini episcopi Bracarensis opera omnia, New Haven, 1950.

BASTIAENSEN (A.A.R.) - Le cérémonial épistolaire des chrétiens latins in Graecitas et Latinitas Christianorum Primaeua. Supplementa, Fasc. II, Nouiomagi, 1964.

Batlle (Dom Columba Maria) - Contribució a l'estudi de Pascasi de Dumi i la seva versió de «Verba Seniorum» in Estudis Romànics, Instituto d'Estudis Catalans, Barcelona, VIII (1961).

Bernardes (P. e Manuel) - Nova Floresta, I, Porto, 1909.

Bidez (J.) - DrachmanN (A.B.) - Emploi des signes critiques (nouv. edit. par A. Delatte - A. Severyns), Bruxelles, 1938.

BLAISE (Albert) - Dictionnaire latin-français des auteurs chrétiens, Turnhout, 1954.

BLATT (F.) - Remarques sur l'histoire des traductions latines in Classica et Mediaeualia I (1938), Copegnague.

Boaventura (Manuel de) - Subsidios e achegas para o estudo filológico de dois vocábulos da toponimia portuguesa: Dume e Panóias in Bracara Augusta VIII (1957). 
Bousset (Wilhelm) - Apophthegmata. Studien zur Geschichte des ältesten Mönchtums, Tübingen, 1923.

ButLer (Cuthbert) - The Lausiac History of Palladius, I, Cambridge, 1898.

Carnandet (Ioannes) - Acta Sanctorum, Octob. t. IV, Parisiis et Romae, 1866.

CASSIANvs (Ioannes) - Collationes in Patrologia Latina, vol. LXXIII.

Chaine (M.) - Le texte originel des apophtegmes des Pères in Mélanges de la Faculté Orientale (Université Saint-Joseph, Beyrouth), V (1912).

Colunga (A.) - Turrado (L.) - Biblia Sacra iuxta Vulgatam Clementinam (...), Matriti, 1946.

Corbet (P.B.) - La règle du Maítre (Le problème de l'édition), Bruxelles, 1953.

CоRominas (J.) - Diccionario crítico etimológico de la lengua castellana, Madrid, 1954.

Costa (P. e Avelino de Jesus da) - S. Martinho de Dume, Braga, 1950, separata de Bracara Augusta II (1950).

Cotelier (J.B.) - Ecclesiae Graecae monumenta, t. I, Paris, 1677.

CoutınHo (I. Lima) - Gramática histórica, Rio de Janeiro, 1968.

DAIN (A.) - Les manuscrits, Paris, 1964.

Dante (Alighieri) - La Divina Comedia, Inferno, Torino, 1888.

Delehaye (H.) - L'oeuvre des Bollandistes à travers trois siècles (1615-1915), Bruxelles, 1959.

Devoto (G.) - Storia della lingua di Roma, Bologna, 1940.

Díaz (Manuel Caetano Díaz y) - Index Scriptorum Latinorum Medii Aeui Hispanorum, Madrid, 1959.

DionisIvs (Exiguus) - Opera in Patrologia Latina, voll. LXVII e LXXIII.

DörRIE (H.) - Passio SS. Machabaeorum. Die antike lateinische Übersetzung des IV Makkabäerbuches, Göttingen, 1938.

Draguet (R.) - Les apophtegmes des moines d'Égypte. Problèmes littéraires in Bulletin de la Classe de Lettres et des Sciences Morales et Politiques, Académie Royale de Belgique, Bruxelles, XLVII (1961).

- À la source de deux apophtegmes grecs (PG 65, Jean Colobus 24 et 32) in Byzantion, XXXII (1962).

DUFRESNE (Ch. - (Du Cange) - Glossarium ad scriptores mediae et infimae Graecitatis, Lugduni, Anissonii, 1688.

_- Glossarium mediae et infimae Latinitatis, Parisiis, 1840.

Ellebracht (M. P.) - Remarks on the vocabulary of the ancient orations in the Missale Romanum, Nijmegen-Utrecht, 1963.

Enciclopedia Cattolica, Città del Vaticano, 1951.

Enciclopédia (Grande -) Portuguesa e Brasileira, vol. XX, Lisboa, 1945. 
Engels (Louis) - Fiducia dans la Vulgate in Graecitas et Latinitas Christianorum Primaeua. Supplementa, Fasc. I (1964). Nouiomagi. Fasc. III (1970).

Erasmvs - Apophthegmatum opus, Parisiis, 1532.

ERnout (A.) - MeIllet (A.) - Dictionnaire étymologique de la langue latine, Paris, 1959.

Festugière (A.-J.) - Les moines d'Orient, I, Culture ou Sainteté, Paris, 1961.

Figueiredo (C.) - Novo dicionário da lingua portuguesa, Lisboa, 1949.

Fliche (A.) - Martin (V.) - Histoire de l'Église, III, Paris, 1939.

FLoReZ (H.) - España Sagrada, t. XV, Madrid, 1759.

Fontaine (Jacques) - Isidore de Seville, Traité de la nature, Bordeaux, 1960.

ForCellini (Aegidius) - Totius latinitatis lexicon, Prati, 1858-1860.

France (Anatole) - Thais, Paris, 1890.

FRÄNKEL (Hermann) - Einleitung zur kritischen Ausgabe der Argonautika des Apollonius, Göttingen, 1964.

GaIET (Al.) - L'exploration des nécropoles gréco-bizantines d'Antinoë et les sarcophages de tombes pharaoniques de la ville antique in Annales du Musée Guimet, XXX (1903), Paris.

GARNEFELD (G.) - Elucidationes sacrae in quinque libros de imaginibus antiquorum eremitarum, Coloniae, 1621.

Gembloux (Sigeberto de)-De Scriptoribus Ecclesiasticis in Patrologia Latina, t. CLX.

Gemoll (Wilhelm) - Das Apophthegma. Literar-historische Studien, Wien, 1924.

GiUfFridA (P.) - Lanx Satura. Miscellanea Philologica, Università di Genova, 1963.

Glorieux (Mgr. P.) - Pour revalorizer Migne. Tables rectificatives in Mélanges de Science Religieuse IX (1952), Cahier supplémentaire, Lille.

Goubert (P.) - Bizance et l'Espagne Wisigotique in Études Byzantines II (1944), III (1945), IV (1946), Bucarest.

Grandgent (C.H.) - Introducción al latin vulgar, (trad. F.B. MolL), Madrid, 1952.

Groningen (B.A. van) - Traité d'histoire et de critique des textes grecs, Amsterdam, 1963.

GUY (P. Jean-Claude) - Remarques sur le texte des apophthegmata patrum in Recherches de Science Religieuse, XLIII (1955), Paris.

- Note sur l'évolution du genre apophtegmatique in Revue d'Ascétique et de Mystique, XXXII (1956), Toulouse.

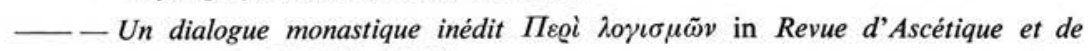
Mystique, XXXIII (1957).

— L L collation des douze anachorètes in Analecta Bollandiana, LXXVI (1958), Bruxelles.

_- Les apophthegmata patrum in Théologie de la vie monastique, Paris, 1961. 
GuY (P. ${ }^{\mathrm{e}}$ Jean-Claude) - Recherches sur la tradition grecque des «apophthegmata patrum", (Subsidia Hagiographica n. 36) Bruxelles, 1962.

HaAdsma (R.A.) - Nuchelmans (J.) - Précis de latin vulgaire, Groningen, 1963.

HAlKIN (F.) - Bibliotheca Hagiographica Graeca, tt. II et III, Bruxelles, 1957.

Hausherr (Irenée) - Penthos. La doctrine de la componction dans l'Orient chrétien, Roma, 1944.

Havet (Louis) - Manuel de critique verbale appliquée aux textes latins, Paris, 1911.

Herman (Joseph) - Le latin vulgaire, Paris, 1967.

Heussı (K.) - Der Ursprung des Mönchtums, Tübingen, 1936.

Hofmann (J. B.) - El latin familiar (trad. J. Corominas), Madrid, 1958.

Hofmann (J.B.) - Szantyr (A.) - Lateinische Syntax und Stilistik, München, 1965.

HOPHNER (Th.) - Uber die koptisch-saidischen Apophthegmata Patrum Aegyptiorum und verwandte griechische, lateinische, koptisch-boharische und syrische Sammlungen in Akademie der Wissenschaften in Wien. Philosophisch-historische Klasse. Denkschriften, LXI (1919), Wien.

HoPPE (Heinrich) - Griechisches bei Rufinus in Glotta, XXVI (1938), Göttingen.

HoppenBrouwers (H.W.F.M.) - La plus ancienne version de la Vie de S. Antoine par S. Athanase, Utrecht-Nijmegen, 1960.

- Conuersatio. Une étude sémasiologique in Graecitas et Latinitas Christianorum Primaeua. Supplementa, Fasc. I, Nouiomagi, 1964.

JANSON (T.) - Latin prose prefaces. Studies in literary conventions (Acta Vniversitatis Stockholmiensis, Studia Latina Stockholmiensia, XIII), Stockholm-Göteborg-Uppsala, 1964.

JAEger (H.) - Mag̣ộoía et fiducia. Étude spirituelle des mots in Studia Patristica, I (1957).

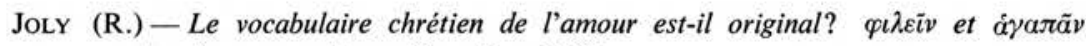
dans le grec antique, Bruxelles, 1968.

JONES (H.S.) - A greek-english lexicon, Oxford, 1966.

Kuenne (O.R.) - A study of the Thais Legend, Philadelphia, 1922.

LAMPE (G.W.H.) - A patristic greek lexicon, Oxford, 1968.

LeCLeRQ (Dom Jean) - Le genre epistolaire au Moyen Age, Lyon, 1946.

_-Études sur le vocabulaire monastique du Moyen Age, Roma, 1961.

- _ Eremus et eremita. Pour l'histoire du vocabolaire de la vie solitaire in Collectanea Ordinis Cisterciensium Reformatorum, XXV (1963), Westmalle.

- Otia monastica. Études sur le vocabulaire de la contemplation au Moyen Age in Studia Anselmiana, LI (1963) Roma.

Lewis (Ch. T.) - Short (Ch.) - A latin dictionary, Oxford, 1962. 
LINNÉR (Sture) - Syntaktische und lexikalische Studien zur Historia Lausiaca des Palladios, Upsala, 1943.

LÜвKE (W. Meyer-) - Romanisches etymologisches Wörterbuch, Heidelberg, 1968.

LuNDSTRÖм (Sven) - Übersetzungstechnische Untersuchungen auf dem Gebiete der christlichen Latinität, Lund, 1955.

MAAS (Paul) - Textkritik, Leipzig, 1960.

Macedo (F. Newton de)-O dominio germânico, in História de Portugal, Barcelos, 1938.

Machado (J. Pedro) - Dicionário etimológico da língua portuguesa, com a mais antiga documentação, Lisboa, 1957.

Madoz (J.) - Martín de Braga. En el XIV centenario de su advenimiento a la Peninsula (550-1950) in Estudios Eclesiásticos XXV (1951).

- Citas y reminiscencias clásicas en los padres españoles in Sacris Erudiri V (1953), Steenbrugge.

Manvtivs (Paulus) - Apophthegmatum ex optimis utriusque linguae scriptoribus libri VIII, Venetiis, 1590.

Marouzeau (Jules) - Traité de stylistique latine, Paris, 1946.

Martinho (S. - de Dume) - Sententiae Patrum Aegyptiorum in Patrologia Latina, vol. LXXIV.

MARTINS (P. e Mário) - Correntes de filosofia religiosa em Braga dos séculos IV a VII, Porto, 1950.

— - Pascásio dumiense, tradutor in Brotéria LI (1950), Lisboa.

MASSENET - Thaïs, 1894.

MAURer (Th. H.) - Gramática do latim vulgar, Rio de Janeiro, 1959.

MeERShoek (G.Q.A.) - Le latin biblique d'après Saint Jérôme, Nijmegen-Utrecht, 1966.

Mendieta (E. Amand de)-Eustathius, Berlin, 1958.

Meyer (R.T.) - Lexical problems in Palladius' Historia Lausiaca in Studia Patristica I (1957).

Migne (J.-P.) - Patrologia Graeca, t. LXV.

- Patrologia Latina, tt. LXXIII et LXXIV.

Mohrmann (Christine) - Études sur le latin des chrétiens, I, Roma, 1958.

- The latin of Saint Patrick, Dublin, 1961.

Mørland (H.) - Die lateinischen Oribasiusübersetzung, Oslo, 1932.

NASCENTES (Antenor) - Dicionário etimológico da lingua portuguesa, Rio de Janeiro, 1932.

NaU (F.) - Histoire de Tais. Publication de textes grecs inédits et de divers autres textes et versions in Annales du Musée Guimet, XXX (1903), Paris, 


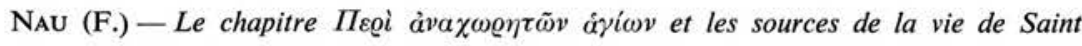
Paul de Thèbes in Revue de l'Orient Chrétien, X (1905), Paris.

- Notes sur le texte originel des apophtegmes des Pères, in Revue de l'Orient Chrétien, XVIII (1913).

_- Histoire des solitaires égyptiens, in Revue de l'Orient Chrétien, XII (1907); XIII (1908); XIV (1909); XVII (1912); XVIII (1913).

NiermeYer (J.F.) - Mediae latinitatis lexicon minus, Leiden, 1965.

Nunes (José Joaquim) - Compêndio de Gramática histórica, Lisboa, 1930.

Palladivs - Heraclidis eremitae Paradisus in Patrologia Latina, vol. LXXIV.

- - Palladii Lausiaca, ibidem.

Pasquali (Giorgio) - Storia della tradizione e critica del testo, Firenze, 1934.

Pelagivs-Ioannes - Verba Seniorum in Patrologia Latina, vol. LXXIII.

Pereira (F. M. Esteves) - A vida de S. Paulo de Tebas, Lisboa, 1903.

- A Vida de Santo Abunafre Lisboa, 1905.

Pereira (Maria Helena da Rocha) - Notes lexicographiques sur le «Thesaurus Pauperum» in Archiuum Latinitatis Medii Aeui, XXIV (1954), Paris.

PIDAl (R. Menendez) - Historia de España, tomo III, España Visigoda (414-711), Madrid, 1940.

Proclvs - Oratio de Deipara in Patrologia Latina, vol. XLVIII (translatio M. Mercatoris).

RaHLfS (Alfred) - Septuaginta, id est Vetus Testamentum graece (...), Stut tgart, 1935.

Ramalho (Américo da Costa) - Recensões a Giovanni Pico della Mirandola, Carmina Latina e a Propercio, Elegias in Humanitas XVII-XVIII, (1965-66), Coimbra.

ReIs (Neves) - A influência do povo na formação da linguagem in Boletim da Sociedade de Lingua Portuguesa V (1954), Lisboa.

Ribeiro (Mário de Sampaio) - Thais, Lisboa, 1951.

RoHLFs (G.) - Sermo uulgaris latinus, Tübingen, 1956.

Rosweydv (H.) - Vitae Patrum. De uita et uerbis seniorum siue historiae eremiticae libri $X$, Antuerpiae, 1628.

SALonius (A.H.) - Vitae Patrum. Kritische Untersuchungen über Text, Syntax und Wortschatz der spätlateinischen Vitae Patrum, Lund, 1920.

SIEGMUND (P. Albert) - Die Überlieferung der griechischen christlichen Literatur in der lateinischen Kirche bis zum zwölften Jahrhundert, München-Pasing, 1939.

Simonetri (Manlius) - Tiranii Rufini opera, Turnholti, 1961.

SLeUMER (A.) - Kirchenlateinisches Wörterbuch, Limburg a. d. Lahn, 1926. 
Soares (Luis Ribeiro) - A linhagem cultural de S. Martinho de Dume, I - Fundamentos, Lisboa, 1963.

SOCII BOLLANDIANI - Catalogus codicum hagiographicorum latinorum bibliothecae Ambrosianae ciuitatis Mediolanensis, Bruxellis, 1892.

_ Bibliotheca Hagiographica Latina Antiquae et Mediae Aetatis, 2 voll., Bruxellis, 1898-1901.

STÄHLIN (Otto) - Editionstechnik, Leipzig, 1914.

Stephano (H.) - Thesaurus graecae linguae, Parisiis, 1831 ss.

URbel (Dom Justo Perez de) - Los monjes españoles en la Edad Media, I, Madrid, 1945.

_ - San Martín y el monaquismo in Bracara Augusta VIII (1957).

VÄÄNÄNEN (V.) - Introduction au latin vulgaire, Paris, 1963.

Vasconcelos (José Leite de) - Vida de Tarsis in Revista Lusitana XI (1908), Lisboa.

VERMEUlen (A.J.) - Le développement sémasiologique d'ėuqúveı et la fête de l'Épiphanie in Graecitas et Latinitas Christianorum Primaena. Supplementa, Fasc. I, Nouiomagi, 1964.

WAGNER (Monica) - Rufinus, the translator, Washington, 1945.

WeIngarten (H.) - Der Ursprung des Mönchtums im nachconstantinischen Zeitalter, Gotha, 1877.

WHITE (E.) - The monasteries of the Wâdi 'n Natrun. Part II. The history of the monasteries of Nitria and Scétis. New York, 1932.

WILmarT (A.) - Le recueil latin des apophtegmes in Revue Bénédictine XXXIV (1922), Maredsous.

ZöCKLER (O.) - Askese und Mönchtum, Frankfurt a. M., 1897. 



\section{OBSERVAÇÕES SOBRE VOCABULÁRIO}

\section{LATIM}

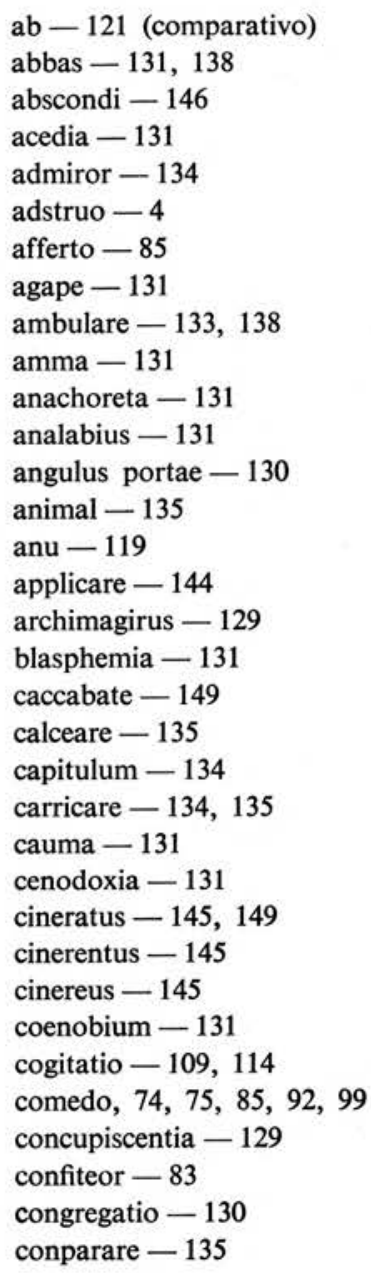

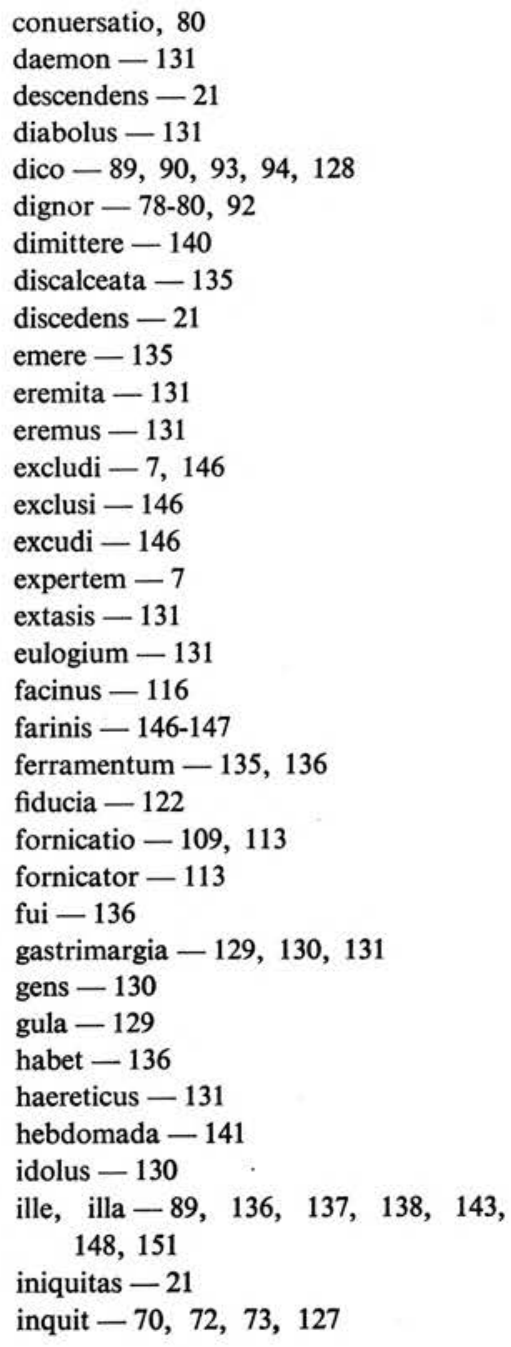




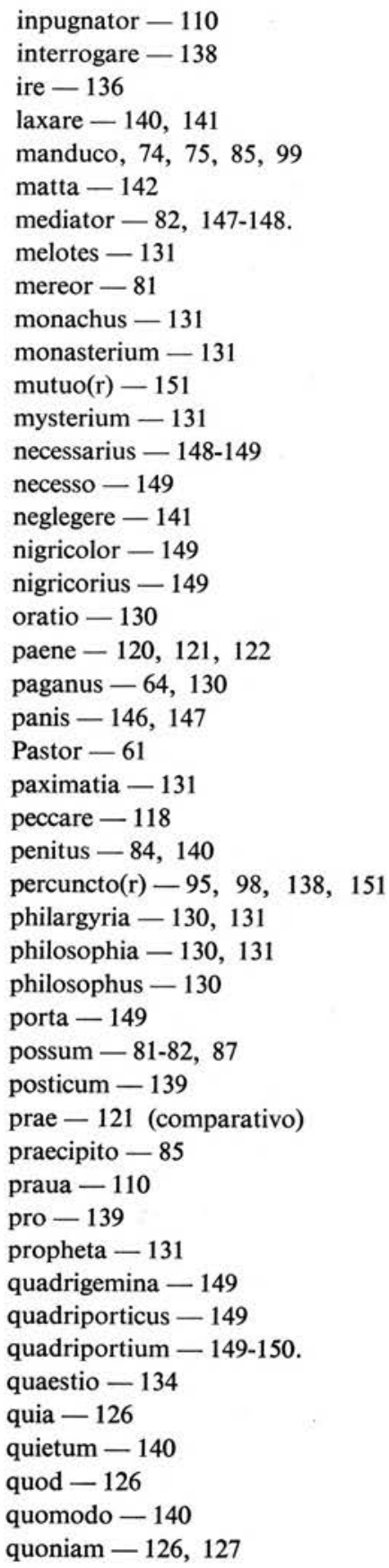

relaxare $-140,141$

religiosus -130

remuneror(r) -151

renitentem -150

renitenter -150

renito(r) $-150-151$

renitui $-150-151$

renituissem $-7,150-151$

renuo -150

requirere -138

retexebat -142

sapientia -130

sapientiae studiosus -130

scilla -131

septimana $-80,141$

si $-95,97,98$,

super - 121 (comparativo)

teneo $-141,142$

terraemotus -142

texebat -142

uado -136

uel -92

uenter -129

uerbum -6

ueteramentarius -151

ueteramentum -151

uetula -119

unus, a, um $-77,80,142,143,144$

\section{GREGO}

$$
\begin{aligned}
& \text { àvaлаи́онає }-82 \\
& \text { d่vé } \mu \eta-124 \\
& \text { à } \pi \varepsilon \lambda \theta \circ \tilde{\sigma} \sigma \alpha-21 \\
& \text { aัอขov-147 }
\end{aligned}
$$

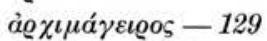

$$
\begin{aligned}
& \text { à } \sigma \tau \eta \tau \dot{\eta} \varsigma-130 \\
& \beta a \sigma \tau \tilde{a} \xi \alpha \iota-77
\end{aligned}
$$

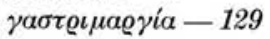

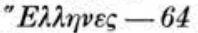

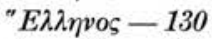

$$
\begin{aligned}
& \dot{\varepsilon} \mu \pi \underline{\eta} \theta \omega-129 \\
& \ddot{\varepsilon} \xi \iota \varsigma-101
\end{aligned}
$$

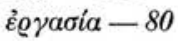

$$
\begin{aligned}
& \text { ย้อ } \chi \varepsilon \tau a-87
\end{aligned}
$$



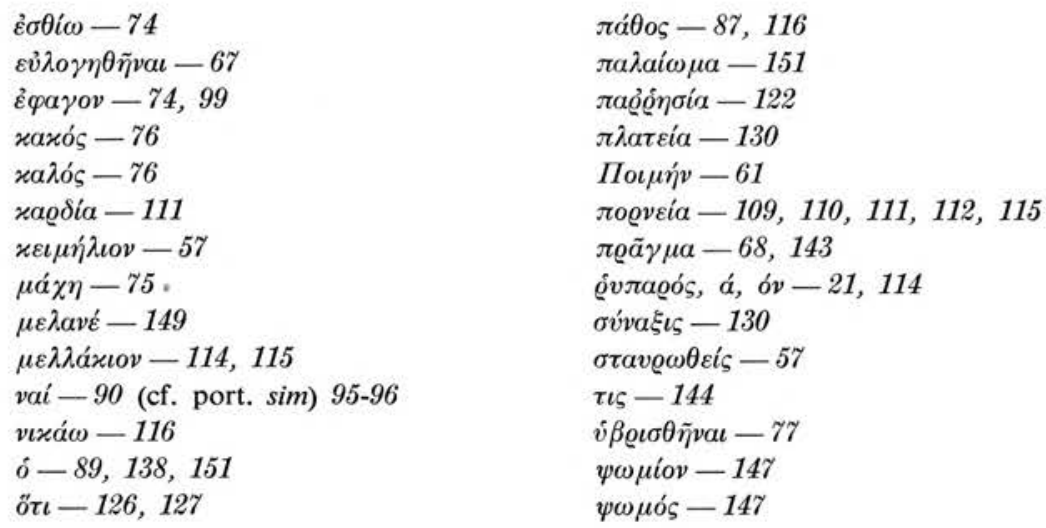



\section{INDICE ONOMÁSTICO}

\section{I}

\section{GERAL}

Agostinho (S.) - 131 .

AlI (M. Said) -132 .

Amaral (A. Caetano do) $-8,12$.

AmÉlineau (E.) - 34, 35.

ANTóNIO (Nicolau) - 15 .

ANTOLín (P.e Guilherme) - 30, 31, 33.

APULEIO - 150.

BaILLY (A.) - 133.

BARBER (E.A.) - 133.

BARDY (Gustave) - 24, 65.

Barlow (C.W.) - 12, 15, 26, 27.

BASTIAENSEN (A.A.R.) -3 .

Batlle (D. Columba Maria) - 12, 13, $14,15,29,30,31$.

BENTO (S.) -16 .

Bernardes (P. ${ }^{e}$ Manuel) -34 .

BIDEZ (J.) - 154 .

BIVAR - 15 .

BLAISE (Albert) - 133, 148.

BLATT (F.) -65 .

Boaventura (Manuel de) -13 .

Bolandistas (= Socii Bollandiani) $6,18,19$.

Bousset (Wilhelm) $-35,37,38,40$, $60,85$.

ButLer (Cuthbert) - 36, 37.

CARNANDET (Ioannes) - 18 .

CASSIANo (João) - 42, 131.

Castro, (P.e Cristóvão de) -25.

Chaine (M.) - 35 .

Cí́CERo - 98.

Colunga (A.) - 129 .

CORBET (P.B.) -154 .
Corominas (J.) - 132, 133, 136, 142.

Costa (P.e Avelino de Jesus da) - 12.

Cotelier (J.B.) - 39, 41, 54, 81, 84, $132,142$.

Coutinho (I. Lima) - 132.

DAIN (A.) -154 .

DANTE - 18 .

Delatte (A.) - 154 .

Delehaye (H.) -6 .

Devoto (G.) - 131 .

Díaz (Manuel Caetano Díaz y) - 30, 39.

Dionísio (o Exíguo) - 18, 19, 20, 21, $22,23,24$.

DörRIE (H.) -65 .

Drachmann (A. B.) -154 .

Draguet (R.) - 35, 40, 41.

Dufresne (Ch. (Du Cange) ) - 133, $136,145$.

ELLEBRACHT (M.P.) -78 .

ENGELS (L.) - 122.

ERASMO - 34.

ERNOUT (A.) - 132.

Festugière (A.-J.) - 108.

Figueiredo (C.) - 133.

Fliche (A.) -35 .

FLOREZ (H.) - 8, 12, 15.

FONTAINE (Jacques) - 154, 155.

ForCELLINI (Aeg.) - 132, 150.

FORTUNATO (Venâncio) - 12 .

France (Anatole) - 18 .

FRÄNKEL (Hermann) - 154 .

GaIET (Al.) - 18.

GARNEFELD (G.) - 8, 14.

Gembloux (Guiberto de) - 145 .

Gembloux (Sigeberto de) $-8,9,10$, $11,13,14$. 
Gemoll (Wilhelm) - 34 .

GIUFFRIDA (P.) -3 .

GLORIEUX (Mgr. P.) -8 .

Gomes (Dom António Ferreira) - 13.

GouberT (P.) - 17.

GRANDGent (C.H.) - 132 .

GRONINGEN (B. A. van) -154 .

GuY (P. e Jean-Claude) - 25, 28, 29, $36,38,39,40,41,85$.

HAADSMA (R.A.) - 132.

HALKIN (F.) - 16, 20.

HAUSHERR (Irenée) - 130 .

HAVET (Louis) - 154.

Hélia (Santa) - 30, 31, 32, 33.

HeRACLIDIS -42 .

Herman (Joseph) -135 .

Heussi (K.) - 34 .

HINNEBUSCH - 15 .

HoEsCh (David) -28.

HOFMANN (J.B.) - 130, 132.

HOPFNER (Th.) $-35,37$.

HOPPE (Heinrich) -130 .

HOPPENBROUWERS (H.W.F.M.) - 65, 80.

JANSON (T.) -3 .

IERSEL (B.M.F. van) -155 .

JAEGER (H.) - 122.

JERÓNIMO (S.) - 131 .

JoÃo (Subdiácono S.E.R.) - 8, 13, $25,29,30,37,38,40,42,54,55$, $56,57,61,63,66,68,70,79$, $80,86,91,92,93,103,104,113$, $118,120,130,132,133,140,143$, $144,145,146,147,149$.

JoLY (R.) -130 .

JoNeS (H.S.) - 133.

KUeHNE (O.R.) -18 .

Labriolle (P. de) -35 .

LAMPE (G.W.H.) - 64, 124, 129, 133.

LeClercQ (Dom Jean) - 3, 130.

LEWIS (Ch. T.) - 133, 155.

LIDDEL (H.G.) - 133.

LINNÉr (Sture) - 129.

LÜBKE (W. Meyer-) - 133, 139, 142.

LUNDSTRÖM (Sven) - 65 .

MaAs (Paul) -154 .

MACEDO (F. Newton de) - 17.
Machado (J. Pedro) -133.

MADOZ (J.) - 3, 12.

Manúcio (Paulo) - 34 .

MARTIN (V.) - 35 .

Martinho (S. - de Dume) - 1, 3, 4, $5,8,9,10,11,12,13,15,16$, $17,23,25,26,27,29,30,31,32$, $36,38,42,59,60,61,86,87,88$. (Cf. também Índice onomástico II).

Martins (P.e Mário) - 7, 12, 13, 17, $27,28,130,134$.

Marouzeau (J.) - 130 .

MASSENET - 18 .

MAurer (Th. H.) - 132 .

MÁximo (Valério) - 34.

MeERshoek (G.Q.A.) - 65 .

Meillet (A.) - 132.

Mendieta (E. Amand de) -154 .

Mercator (Mário) - 23.

Meyer (R.T.) - 130.

Migne (J.-P.) - 6, 39.

Mohrmann (Christine) - 3, 131.

Moll (F.B.) - 132.

MøRLAND (H.) -65 .

NASCENTES (A.) - 133.

$\mathrm{N}_{\mathrm{AU}}$ (F.) $-18,20,24,35,36,39$, $40,41,54,55,56,59,60,69,70$, $74,75,76,77,83,84,85,88$, $96,99,100,101,104,105,109$, $110,112,114,115,116,117,124$, $126,127,132,135,138,141$, $143,148,149,151$.

Niermeyer (J.F.) -133.

Nuchelmans (J.) -132 .

Nunes (J.J.) -132.

PACómIo (S.) - 18.

PALÁdIO - 42, 106, 127, 129, 133.

Pascásio (S. -, de Coimbra) - 14.

Pascásio (de Dume) - fere passim.

Pasquali (Giorgio) - 154.

PASTOR (Feliciano) - 23.

Pelágio (Diácono S.E.R.) - 8, 13, 15, $16,25,29,30,37,38,40,41$, $54,55,56,57,58,59,60,61$, $62,64,65,67,69,70,71,72,73$, $74,75,76,77,78,79,81,82$, 
$83,84,85,89,90,94,95,96$, $97,98,99,100,101,102,104,105$, $107,108,109,110,111,112,113$, $114,115,116,117,118,119,120$, $121,122,123,124,125,126,127$, $128,129,132,133,134,135,136$, $137,138,139,140,141,142,143$, $144,145,147,148,149,151$.

Pereira (F. M. Esteves) - 35.

Pereira (Maria Helena da Rocha) $-339$

Peres (Damião) -17 .

PIDAL (R. Menendez) -17.

Plauto - 98.

Plutarco - 34.

PROCLO - 23.

Radberto (S. Pascásio) -- 14.

RAHLFS (Alfred) - 129.

Ramalho (Américo da Costa) - 18.

ReIS (Neves) - 12.

Ribeiro (Mário de Sampaio) - 18 .

ROHLFS (G.) - 132 .

Rosweydus (Heribertus) $-5,6,8$, $8,13,14,16,18,19,25,26,27$, $28,29,30,36,37,38,40,41$, $42,74,88,94,131,148$.

RUFINO - 130, 131.

SAlonius (A. H.) - 5, 28, 29, 38, 39. ScotT (R.) - 133.

SEVERYNS (A.) -154 .

Sevilha (Santo Isidoro de) -12 .

SHORT (Ch.) - 133, 155.

Siegmund (P. Albert) - 24.

SIMONETTI (Manlius) - 154 .

Sleumer (A.) - 133 .

SMARAGDUS -8 .

SOARES (Luís Ribeiro) $-8,9,12,13$, $14,15,16,27,28$.

Sócrates (filósofo) -4 .

Sócrates (historiador) -74 .

Soeiro (Cónego) - 12.

Solinvs - 149 .

STÄHLIN (Otto) - 154 .

Stephano (H.) -133.

SZANTYR (A.) -130 .

TEODósio - 121.

Tours (S. Gregório de) -12 .
TuRrado (L.) - 129 .

Urbel (Dom Justo Perez de) - 6, 8, 12, 15, 17, 29.

VÄÄNÄNEN (V.) - 132.

Vermeulen (A. J.) - 130.

WAGNER (Monica) - 65 .

Weingarten (H.) - 34.

WhITE (E.) - 34 .

Wilmart (Dom A.) $-25,28,29,30$, $42,59$.

ZÖCKLER (O.) - 34 .

II

\section{PERSONAGENS MENCIONADAS}

DE PASCÁSIO OU NO ESTUdO

DOS SEUS LUGares ParaleloS

N. B. - Esta lista não inclui os nomes constantes do quadro sistemático de paralelos (pp. 43-53), que é por si mesmo um indice de fácil consulta.

Abraham (abbas) - 98, 112, 113, 118, 171, 219, 287, 291.

ABRAHAM (patriarcha) -191 .

ACHILAS - 97, 101, 105, 114, 203, 214, 215, 281, 291.

ADAM - 195 .

AgATHON - 113, 121, 122, 189, 190, 193, 194, 201, 206, 260, 262, 281, $311,325,326$.

AION - 318 .

Alonivs - 331 .

AMMOES - 259 .

АмMON - 105, 125, 126, 200, 281, 288, 316.

Antonivs (et port. Antão) - 16, 66, $79,83,90,91,99,100,101,102$, $110,111,131,186,195,196,200$, $201,212,213,214,216,224,230$, $231,232,238,239,262,278,279$, $290,296,302,308,312,313,318$, $325,332$. 


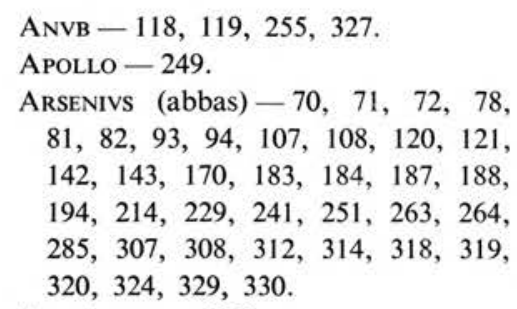

Athañasivs - 266 .

Besarion - 92, 93, 225, 226, 288, 320.

Betimes - 106.

COPRES - 134, 331.

Cronivs - 306 .

DANIEL (abbas) - 94, 139, 241, 285, 319.

DANIEL (propheta) - 166, 329.

Dioscorvs - 106.

DVLAS - 92, 288.

ELIAS - 183, 206.

ESAIAS (abbas) - 285 .

EsAIAS (propheta) - 223, 272.

Eva - 234.

EVAGRIVS - 73, 74, 82, 308, 312.

EvLOGIVs - 141, 172, 173.

FeLIX -338 .

Georgivs - 338 .

HILARION $-337,338$.

HYPERECHIVS - 56, 57, 81, 234.

IACOB -247248.

IOANNES (abbas) - 64, 199, 320.

IOANNES (Colobus) - 113, 176, 204, 235, 268, 280, 285, 299.

IOANNES (Constantinopolitanus) - 172 .

IOANNES (discipulus Pauli) -243.

IOANNES (Thebaeus) -259 .

IOANNES (Persa) - 137, 143, 247.

IOANNES (praecursor) -228 .

IOANNES (uir probatissimus) - 338 .

IOSEFEL -257.

IOSEPH (abbas) - 87, 88, 95, 136, 168 , 172, 173, 293, 294, 332.

IOSEPH (patriarcha) -211 .

IsAAC $-202,237,253,300,306,307$, 315.

ISCHYRION -325 .

IsIDORVS - 212, 233.

ISRAEL - 265, 303.
IVLIANVS -284.

LAVRVS - 338 .

LAZARVS - 191.

Lvcivs - 89, 286.

MACARIVS (abbas) - 62, 63, 76, 79, $80,84,86,97,103,116,120,122$, $123,142,146,174,180,188,190$, $201,207,208,209,210,217,226$, $227,228,229,279,287,289,290$, $318,321,326$.

MACARIVs (episcopus) - 283.

MADIANITAE - 179.

MarCIANVS -64 .

MARCVS - 119, 241, 242, 256, 318.

MARIA - 175, 176.

MARTHA - 176.

MARTINvs (Dumiensis episcopus) 164, 165.

MATOES - 139.

MAZICES - 172, 327.

Megethivs - 312 .

MelChiSedeC - 134, 331.

Mотоеs - 205, 223, 302, 315, 316, 317.

Moyses - 25, 26, 27, 28, 71, 139, 145, $149,164,177,185,200,202,212$, $216,221,251,291,301,324$, 333.

NABUZARDAN $-128,129,171$.

NESTOR - 225, 326.

Poemen (et PASTOR) - 25, 61, 64, 83, $106,110,111,118,119,128,136$, $137,144,164,167,171,177,178$, 179, 182, 197, 198, 204, 205, 211, $212,216,233,234,237,239,248$, $249,250,252,255,256,257,258$, $264,265,266,267,273,274,291$, $293,297,298,300,305,306,309$, $313,316,317,326,327,328,329$, $331,333$.

NISTEROO - 148.

$\mathrm{OR}-254$.

ORsisivs - 211 .

РАмво (abbas) - 58, 95, 166, 212, 262, 264, 266, 311, 314.

PaPhNVTIVS - 238, 239, 250, 277, 278, 279. 
Paschasivs (Dumiensis) - 159, 165.

Pavlvs (apostolus) - 113, 178.

Pavlvs (discipulus Or) -254.

Pavlvs (Galata) - 189.

Pavlvs (magnus) - 142, 243.

Pavlvs (simplex) - 271, 272, 278, 279, 338.

Petrvs - 338 .

PIOR - 236.

PVBLIVS - 284.

SARRA - 305.

SARRACENI - 338, 340.

Satanas - 171, 177.

SERAPION - 74 .

SilvanVs (abbas) $-16,96,119,137$, $168,175,176,192,241,242,256$, 287, 294.

SIMEON - 221.

SYNCLETICA - 123.

Sisorvs - 66, 68, 73, 74, 86, 87, 88, $98,118,166,171,196,198,212$, $220,224,232,254,258,262,269$, 287, 291, 294, 313.

SOCRATES -165 .

STePHanVS - 338 .

TAISIS $-18,19,20,22,23,24,40$, 276, 277, 278, 279.

TheODORVS (Phermensis) - 90, 101, $127,134,147,174,175,188,228$, $236,249,253,306,307,310,314$, 315.

THEODORvs (uir probatissimus) 338.

THEOPENTVS $-180,181$.

THEOPHILVS $-183,320$.

TIMOTHEVS -239 .
ZACHARIAS - 137, 168, 175, 192, 200, 287.

ZENON - 170, 217, 282.

III

\section{GEOGRÁFICO}

(SÓ DO TEXTO DE PASCÁSIO)

Aegyptus - 190, 204, 226, 246, 274, 277, 315, 327.

Alexandria - 183, 231, 266, 319, 320.

Athlibeus - 198 .

Canopo - 183.

Cyprus - 283.

Gebalon - 315 .

Heracleona - 205.

Hierusalem - 171 .

Libanus - 291 .

Nitria - 228 .

Palestina - 170, 283.

Panepho - 168, 172.

Pelusium - 172, 285.

Persida -284 .

Ragitam - 315 .

Roma - 184 .

Sceti - 172, 200, 202, 204, 210, 229, $236,242,246,251,261,282,287$, $299,313,314,315,327,332$.

Sina $-175,287$.

Syria -217 .

Terenutidis -327 .

Thebaida -294319 . 



\section{ÍNDICE GERAL DO TOMO I}

\section{INTRODUÇÃO}

CAP. I - PASCÁsIO, SÚBdITO DE S. MARTINHO DE DUME

Pág.

1 - O prefácio de Pascásio, dedicado a S. Martinho de Dume . 1

2 - Autenticidade do prefácio e da tradução de Pascásio . . . 5

3 - O tradutor das "Sententiae Patrum Aegyptiorum» não é Pascásio, mas sim Martinho, bispo de Dume . . . . . 8

4 - Opiniões diversas sobre Pascásio. Apreciação . . . . . . 12

5-O tradutor da «Vita Taisis» é Pascásio e não Dionísio, o Exíguo . . . . . . . . . . . . . . . . . . 18

6 - $\mathrm{O}$ autor de uma das traduções das «Sete sentenças do abade Moisés» é Pascásio, e não S. Martinho de Dume . . . . 25

7-A tradução «De meditationibus duodecim anachoretarum» não é de Pascásio . . . . . . . . . . . . . . . . . . .

8 - Não passa de uma conjectura sugestiva dizer-se que a «Vita sanctae Heliae» e o seu prefácio são um original latino de Pascásio . . . . . . . . . . . . . . . .

CAP. II - PASCÁSIO E OS APOTEGMAS DOS PADRES DO DESERTO

1 - Os apotegmas como género literário . . . . . . . . 34

2 - Em busca do texto grego de Pascásio . . . . . . . . . 38

3 - Quadro dos apotegmas de Pascásio e dos seus lugares paralelos................. . . 43

CAP. III - APRECIAÇÃo DE PASCÁSIO COMO TRADUTOR

I - Notas prévias. . . . . . . . . . . . . . . . . 54

II - Aspectos do texto grego e da tradução de Pascásio. . . . . 55

1 - Apotegmas que poderiam passar de Pascásio para as colecções gregas . . . . . . . . . . . . . . 55

2 - Há casos em que Pascásio é mais literal que Pelágio-João. $\quad 56$

3 - Coincidências literais entre Pascásio e Pelágio-João . . 57

4 - Comparação do grego com três traduções latinas . . . 59 
5- Possíveis retoques do original grego de Pascásio para coincidir com o título do capítulo . . . . . . . . . .

Pág.

6-Apotegmas passados do discurso directo para o indirecto.

7 - Selecção só de elementos de interesse moral . . . . .

III - Técnicas de tradução de Pascásio

1 -Tradução literal artística . . . . . . . . . . . 65

2-Artifício na distribuição das palavras . . . . . . . 70

3 - Uso e posposição de inquit . . . . . . . . . . . . . 72

4 - O processo da uariatio . . . . . . . . . . . . . . . 74

5 -Criação de hendíades. . . . . . . . . . . . . . 76

6-Perifrases com dignor. . . . . . . . . . . . . . . . . 78

7 - Expressões alongadas com valor enfático . . . . . 81

a) - Mereor + infinitivo . . . . . . . . . . . . 81

B) - Possum + infinitivo . . . . . . . . . . 81

$\gamma)-$ Confiteor + infinitivo. . . . . . . . . . . . . 83

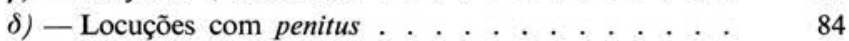

ع) - Outras perifrases expressivas . . . . . . . 85

8 - Formas de concisão narrativa . . . . . . . . . . 88

a) - Elipse do verbo ao introduzir uma resposta . . . 88

$\beta$ ) - Mudança do discurso directo para o indirecto . . 90

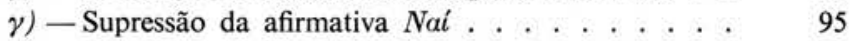

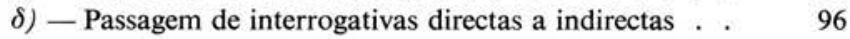

ع) — Omissão de palavras repetidas no grego . . . . . 98

५) - Redução de hendiades a uma só palavra . . . . 101

$\eta)$ - Encadeamento de várias frases por subordinação. 101

9-Introdução do discurso directo . . . . . . . . . . . 104

10 - Tradução ad sensum . . . . . . . . . . . . . . . . 106

11 - Supressão de «palavras feias» . . . . . . . . . . . 108

12 - Eufemismos vários . . . . . . . . . . . . . . . . 115

13 -Delicadeza de sentimentos. . . . . . . . . . 118

IV - Reservas à tradução de Pascásio . . . . . . . . . . . . . 122

1 - Dificuldade de compreensão. . . . . . . . . . . . 122

2 - Automatismos de tradução . . . . . . . . . . . . . 126

3-Pleonasmos . . . . . . . . . . . . . . . . . . . . . 128

4-Helenismos. . . . . . . . . . . . . . . . . . . . . . . . 129

5 -Vulgarismos de feição romanizante. . . . . . . . . . 132

6 -Inovações linguísticas . . . . . . . . . . . . . . . . 144

$\mathrm{V}$ - Nota final. . . . . . . . . . . . . . 152

CAP. IV - OBSERVAÇÕES SOBRE A NOSSA EDIÇÃo DE PASCÁSIO . . . . . . 154 


\section{INDICE GERAL}

Paschasi DVmiensis Translatio

Pág.

Liber Geronticon. De octo principalibus uitiis. . . . . . . . . . . . . .

APPENDIX

Apophthegmata Paschasio non tribuenda . . . . . . . . . . . .

Bibliografia. . . . . . . . . . . . . . . . . 341

Índice de palavras comentadas. . . . . . . . . . . . . . 349

Índice onomástico

I-Geral . . . . . . . . . . . . . . . . .

II - Personagens mencionadas no texto de Pascásio ou no estudo dos seus lugares paralelos . . . . . . . . . . . 355

III - Geográfico (só do texto de Pascásio) . . . . . . . . . . . 357

Índice geral do Tomo I. . . . . . . . . . . . . . . . . . . . . 359 

IMPRESSÃO:

Simốes \& Linhares, Lda.

Av. Fernando Namora, n. ${ }^{\circ} 83$ - Loja 4 3000 COIMBra 
A Versão Latina por Pascásio de Dume dos Apophtegmata Patrum publicada pela primeira vez em 1971, veio disponibilizar para a comunidade científica a verdadeira obra de Pascásio, porque de facto o texto que na edição de Rosweydus havia sido apresentado resultou como uma colecção resumida e imperfeita dos apotegmas de Pascásio, sob o título Exhortationes Sanctorum Patrum tam Graecorum quam Aegyptiorum (PL 73: 68).

O texto completo, traduzido por Pascásio, só foi dado pela primeira vez a ler na editio princeps e tem mais do dobro dos capítulos e com o texto original muito aperfeiçoado, apresentado na Universidade de Coimbra em Novembro de 1971, com o seu verdadeiro título que é Liber Geronticon. De Octo Principalibus Vitiis, de graeco in latinum translatum a Paschasio.

Tendo esta tradução sido elaborada entre 550 e 556, data da chegada de Martinho à Galécia e da sua elevação a bispo, verifica-se que Pascásio é praticamente contemporâneo de Pelágio e João, os outros principais tradutores latinos dos Apotegmas gregos. 